\author{
UNIVERSIDADE DE SÃO PAULO \\ ESCOLA DE COMUNICAÇÕES E ARTES \\ DOUTORADO EM MEIOS E PROCESSOS AUDIOVISUAIS
}

GEÓRGIA CYNARA COELHO DE SOUZA

\title{
PARA VER E OUVIR: \\ A MÚSICA DE ANDRÉ ABUJAMRA \\ NO CINEMA BRASILEIRO
}


GEÓRGIA CYNARA COELHO DE SOUZA

\section{PARA VER E OUVIR: A MÚSICA DE ANDRÉ ABUJAMRA NO CINEMA BRASILEIRO}

Tese apresentada à Escola de Comunicações e Artes da Universidade de São Paulo para obtenção do título de Doutora em Meios e Processos Audiovisuais.

Linha de Pesquisa: Comunicação e Cultura Audiovisual

Orientador: Prof. Dr. Eduardo Vicente 
Autorizo a reprodução e divulgação total ou parcial deste trabalho, por qualquer meio convencional ou eletrônico, para fins de estudo e pesquisa, desde que citada a fonte.

Catalogação na Publicação

Serviço de Biblioteca e Documentação

Escola de Comunicações e Artes da Universidade de São Paulo Dados inseridos pelo(a) autor(a)

Souza, Geórgia Cynara Coelho de

Para ver e ouvir:: A música de André Abujamra no cinema brasileiro / Geórgia Cynara Coelho de Souza. -- São Paulo:

G. C. C. Souza, 2018 .

268 p.: il. + inclui pendrive.

Tese (Doutorado) - Programa de Pós-Graduação em Meios e Processos Audiovisuais - Escola de Comunicações e Artes / Universidade de São Paulo.

Orientador: Eduardo Vicente

Bibliografia

1. cinema brasileiro 2. trilha sonora 3. trilha musical 4. composição musical 5. André Abujamra I. Vicente, Eduardo II. Título.

CDD 21.ed. - 791.43

Elaborado por Sarah Lorenzon Ferreira - CRB-8/6888 
SOUZA, G. C. C. Para ver e ouvir: a música de André Abujamra no cinema brasileiro. 2018. 268 f. Tese (Doutorado em Meios e Processos Audiovisuais) - Escola de Comunicações e Artes, Universidade de São Paulo, São Paulo, 2018.

Tese apresentada à Escola de Comunicações e Artes, da Universidade de São Paulo, para obtenção do título de Doutora em Meios e Processos Audiovisuais.

Aprovado em:

Banca Examinadora

Prof. Dr. Eduardo Vicente

Instituição: Universidade de São Paulo Julgamento: Assinatura:

Prof. Dr. Eduardo Simões dos Santos Mendes Instituição: Universidade de São Paulo Julgamento: Assinatura:

Prof. Dr. Claudiney Rodrigues Carrasco Instituição: Universidade de Campinas Julgamento: Assinatura:

Prof. Dr. Irineu Guerrini Júnior Julgamento: Assinatura:

Instituição: Faculdade Cásper Líbero

Prof. Dr. Lisandro Magalhães Nogueira Instituição: Universidade Federal de Goiás

Julgamento: Assinatura: 


\section{AGRADECIMENTOS}

À Força Maior que reconheço como Deus, que está em mim e em todos que permanecem ou passaram pelo meu caminho.

À minha família, Apolo e Tieta, por todo o profundo amor multiplicado.

Aos meus pais Raimundo e Stella, irmã Priscila, irmão Dênis, tios, primos e avós, sempre tão presentes na vida e no coração.

Ao Edu, meu orientador, pela delicadeza, presteza, confiança, carinho e presença.

Aos professores da banca, que tão generosamente contribuíram para os caminhos deste trabalho: Edu Mendes, Irineu Guerrini Júnior, Ney Carrasco e Lisandro Nogueira.

Aos professores da ECA-USP, ou que por lá passaram, com quem tive o prazer de conviver: Irene Machado, Henri Gervaiseau, Mateus Araújo, Rosana Soares, Wânia Storolli, Leonardo de Marchi, João Godoy e Robert Stam. E aos colegas de ECA, pelas trocas e convivência.

A Maria Elisa Muntaner, Kátia Soubihe Abutara e Maria Raquel Arcuri, amorosas guias do meu autoconhecimento, durante e além desses quatro anos.

Ao meu companheiro Gustavo Machado, pela presença e apoio.

Às minhas irmãs de vida, Lian Tai, Júlia Lemos e Maria Cristina, por todas as luzes, sombras e sonhos compartilhados.

Aos belos e inspiradores encontros acadêmicos, técnicos, filosóficos, poéticos, criativos, críticos e casuais com aqueles que compartilharam coração, casa, conhecimento e risadas: Paula Lunna, Ana Minehira, Mariana Gabriel, Lillian Bento, Heitor Augusto, Léo Bortolin, Tide Borges, Rémi Stengel, Guido Beremblum, Bernardo Marquez, Joice Scavone, Ariel Henrique, Julian Ludwig, Kira Pereira, Eliezer Oliveira, Marcelo Birck, Geraldo Ribeiro, Roberto Gervitz, Fábio Camarneiro, Marcus Neves, Tony Berchmans, Débora Vieira, René Paris, Norton Ferreira, Gustavo Granadeiro, Rafael Ventuna, Leo Leal, Leo Santana, Gisela Dias, Diana Santos, Jonas Dantas, Cynthia Magalhães, Roberta Arcoverde, Tatiane Marinho, Fernanda Budag, Sílvia Dantas, Fernão de Paola, Rafael Durão, Rafael Gallo, Gustavo Nascimento, Brisa Dultra, Ana Luiza Pereira, Débora Opolski, Flora Guerra, Frederico Mucci, Henrique Vieira, Rafael Costa, Lucas Caminha, Nélio Costa, Maurício Domene, Rodrigo Carreiro, Guilherme Maia, Marina Mapurunga, Miguel Hernández, José María Serralde Ruiz, Irene Soria, Miriam Biderman, Maria Muricy.

Aos queridos amigos em Goiânia, Rafael Parrode, Marcelo Ribeiro, Rodrigo Cássio, Joelma Paes, Larissa Mundim, Reginaldo Mesquita, Enilson Macedo, Éveri Sirac, Marcos Henrique, Fabrício Guimarães, Lidiane Satie, Luciana Carneiro.

Aos maravilhosos professores Ana Paula Ladeira Costa, Thaís Oliveira, Wélbia Dias, Sandro de Oliveira, Marcelo Costa, Rafael de Almeida e demais colegas docentes e servidores do curso de Cinema e Audiovisual da Universidade Estadual de Goiás, pelo encorajamento, inspiração, amizade e generosidade. 
A todos os meus alunos, que me nutrem diariamente com o entusiasmo e o frescor de suas descobertas.

A Rose Mendes, meticulosa revisora desta tese.

Aos entrevistados Márcio Nigro, Lulu Camargo, Anna Muylaert, Aluizio Abranches, José Joffily, Maurício Pereira e Juliano Becari.

A André Abujamra, pelo tempo, carinho e confiança.

Ao Estado de São Paulo, financiador desta pesquisa, por meio do processo $\mathrm{n}^{\mathrm{o}}$ 2014/04399-8, Fundação de Amparo à Pesquisa do Estado de São Paulo (FAPESP / CAPES). As opiniões, hipóteses e conclusões ou recomendações expressas neste material são de nossa responsabilidade e não necessariamente refletem a visão da FAPESP. 
Para meu filho Apolo, meu maior mestre, que desenhava na lousa durante as aulas do doutorado e enchia de carrinhos os corredores do CTR. 
Eu não guardo nada, mas eu guardo som. André Abujamra 


\section{RESUMO}

SOUZA, G. C. C. Para ver e ouvir: a música de André Abujamra no cinema brasileiro. 2018. 268 f. Tese (Doutorado em Meios e Processos Audiovisuais) - Escola de Comunicações e Artes, Universidade de São Paulo, São Paulo, 2018.

O presente trabalho visa investigar a contribuição do compositor, instrumentista, ator e artista multimídia André Abujamra ao cinema brasileiro no que tange à composição de trilhas sonoras musicais e à articulação destas com os filmes a que se dirigem. A ideia foi abordar o percurso do artista no cinema a partir de sua estreia em longas-metragens ficcionais, no início da Retomada do cinema brasileiro (1995), buscando a relação entre seu processo criativo, a diversidade de referências musicais e a atuação multifacetada no campo das artes para verificar as características de sua assinatura musical cinematográfica. Neste sentido, fizemos o exercício de uma análise fílmica com foco no som e em suas articulações com a imagem, relacionando a música de André Abujamra tanto a outros elementos sonoros constituintes dos filmes de que participa como compositor - canções preexistentes, ruídos, diálogos, efeitos de silêncio e outros -, quanto aos diversos elementos visuais - fotografia, planos, movimentos de câmera, cenários, montagem e outros. Almejamos, ainda, conhecendo a trajetória de Abujamra e as relações extrafílmicas entre sua música e os diferentes contextos e condições de composição e produção musical para discos e filmes, compreender o lugar do compositor no processo de realização cinematográfica no Brasil. Propomos uma análise estética e contextual das obras cinematográficas ficcionais em longa-metragem com trilha musical assinada por Abujamra, articulada à sua biografia e às formulações teóricas brasileiras e estrangeiras relacionadas ao som e à música de cinema.

Palavras-chave: Trilhas musicais. Cinema brasileiro. Audiovisual. Música. André Abujamra. 


\begin{abstract}
SOUZA, G. C. C. Watching and listening: André Abujamra's music in brazilian cinema. 2018. 268 f. Tese (Doutorado em Meios e Processos Audiovisuais) - Escola de Comunicações e Artes, Escola de Comunicações e Artes, Universidade de São Paulo, São Paulo, 2018.

This study aims to investigate the contribution of the composer, instrumentalist, actor and multimedia artist André Abujamra to brazilian cinema, in reference of the composition of musical soundtracks and its articulation with films they were created for. It was intended to approach the artist's career in film from his debut in fictional feature films at the beginning of 'Retomada' of brazilian cinema (1995), looking for the relationship between the creative process, the diversity of musical references and multifaceted activities in the arts, to verify the characteristics of his film scoring signature. It was an exercise of a film analysis focused on sound and its joints with the image, by relating André Abujamra scores both to other sound elements of the films in which he participates as a composer - pre-existing songs, noises, dialogues, silence effects and others - and to the various visual elements of those films photography, plans, camera movements, scenarios, film editing and others. From knowing Abujamra's carreer and extra-filmic relations between his music and the different contexts and conditions of composition and production for records and films, this study also aims to understand the place of the composer in the filmmaking process in Brazil. It proposes an aesthetic and contextual analysis of fictional feature films whose scores are signed by Abujamra, linked to his biography and Brazilian and foreign theoretical formulations about film sound and music.
\end{abstract}

Keywords: Film score. Brazilian cinema. Audiovisual. Music. André Abujamra. 


\section{LISTA DE FIGURAS}

Figura 1 Caracterização grotesca da personagem Maria Luíza de Parma............... 26

Figura 2 O escocês (Brent Hieatt) descreve o Brasil a Yolanda (Ludmila Dayer)... 27

Figura 3 Caracterização de Carlota Joaquina na infância........................................ 29

Figura 4 Elementos visuais da sequência remetem à cultura espanhola.................. 30

Figura 5 Dom João dá boas-vindas à princesa................................................... 31

Figura 6 Carlota Joaquina se decepciona ao conhecer Dom João........................... 31

Figura $7 \quad$ Corte portuguesa apresentada na sequência do jantar............................... 32

Figura $8 \quad$ Casamento de Carlota Joaquina e Dom João............................................. 33

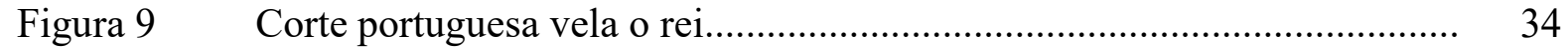

Figura $10 \quad$ Carlota Joaquina tenta consumar seu casamento..................................... 35

Figura 11 Pesadelo da rainha diagnosticada como louca......................................... 36

Figura 12 Carlota 'salva' o pênis de madeira do fogo enquanto a corte foge............. 37

Figura 13 Carlota Joaquina com seu amante, Fernando Leão.................................... 38

Figura 14 Corte portuguesa vela a rainha Dona Maria Louca no Brasil, sob o sorriso de Carlota................................................................................. 39

Figura 15 Expressão de Dom João ao descobrir uma das traições de Carlota............ 40

Figura 16 Carlota lança ao mar os sapatos com que pisara no Brasil....................... 41

Figura 17 Suicídio de Carlota por envenenamento.................................................. 41

Figura 18 Carlota cospe de desprezo pela ideia de fugir para o Brasil...................... 43

Figura 19 Créditos a André Abujamra no filme...................................................... 43

Figura $20 \quad$ André Abujamra e Maurício Pereira em Os Mulheres Negras.................. 45

Figura $21 \quad$ Karnak em uma de suas várias formações.................................................. 46

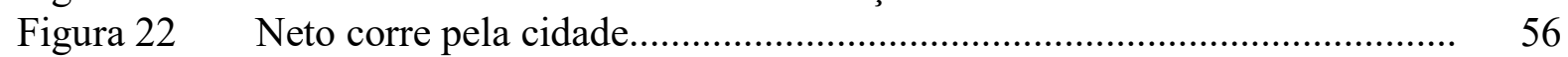

Figura 23 Créditos a André Abujamra e Arnaldo Antunes no filme......................... 57

Figura $24 \quad$ Neto é submetido ao eletrochoque....................................................... 59

Figura $25 \quad$ Noite de amor entre Neto e Leninha..................................................... 60

Figura 26 As mãos de Neto sentem as palavras da canção de Antunes na parede.... 62

Figura 27 Fusão de imagens de Neto e do pátio do manicômio.................................. 63

Figura $28 \quad$ Imagem fixa em preto e branco da mãe de Neto.......................................... 63

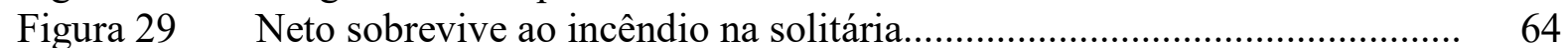

Figura $30 \quad$ Neto entorpecido para sempre, ao lado do pai............................................ 65

Figura 31 Tim Burton e Danny Elfman: mais de 30 anos de parceria...................... 89

Figura 32 Co-diretor Dan Quitério e o compositor Jay Rothman durante a sessão de spotting do filme In-Kind.................................................................. 94

Figura 33 Compositor John Williams grava a trilha musical de Star Wars - O

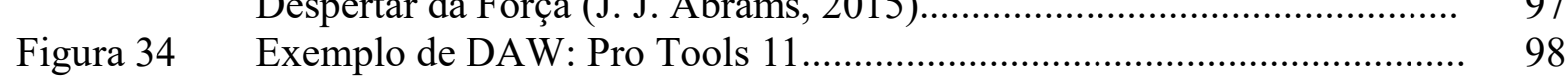

Figura 35 Gravação MIDI no Pro Tools.................................................................. 99

Figura 36 Exemplo de sintetizador digital: Arturia CS 80 ..................................... 100

Figura 37 Exemplo de sampler digital: Steinberg HALion....................................... 101

Figura $38 \quad$ Exemplo de sessão de mixagem de trilha musical.................................... 104

Figura $39 \quad$ Interface do Notator Logic...................................................................... 115

Figura $40 \quad$ Renato Lemos rege músicos na gravação da trilha de As três Marias....... 120

Figura 41 André Abujamra acompanha a gravação da música de As três Marias...... 120

Figura 42 Gilberto Gil gravando vozes para trilha de Cafundó................................. 122

Figura 43 Ao lado de Renato Lemos, André Abujamra conversa com os músicos durante sessão de gravação da trilha de Carandiru.................................. 129

Figura 44 Renato Lemos rege os músicos na gravação da trilha de Carandiru.......... 129 
Figura 45 Agradecimento ao Sabiá Laranjeira, último nome da segunda coluna da esquerda para a direita, nos créditos finais de Carandiru.

Figura 46 André Abujamra como recepcionista de hotel em Castelo Rá-Tim-Bum, o filme. saúvas

Figura 50

Flashback sobre a saia transparente, ao som de trilha orquestral... Nino escreve em seu livro, motivado a salvar os tios Victor e Morgana...

Figura 63

Figura 64

Figura 65

Figura 66

Figura 67

Figura 68

Figura 69

Figura 70

Figura 71

Figura 72

Figura 73

Figura 74

Figura 75

Figura 76

Figura 77

Figura 78

Figura 79

Figura 80

Figura 81

Figura 82

Figura 83

Figura 84 Figura 85 Figura 86
Baile do alinhamento dos planetas, ao som do 'tema de Nino'.

O primeiro feito de Nino como bruxo é destacado pela Ópera Arepó

Da lareira, Morgana e Victor, transformados em marionetes, cantam a

Ópera Arepó e distraem Dr. Abobrinha

Tema de Losângela é apresentado antes que ela revele sua face.

Arpejos enfatizam a revelação da identidade de Losângela.

Losângela reouve seus poderes ao som de seu tema musical.

Ao som de seu tema, Dr. Abobrinha é expulso do castelo no início do filme

Novo prefeito, Dr. Abobrinha surpreende bruxos sem poderes.

Mau, Sujo e Feio conversam com Nino, ao som de seu próprio tema.

Victor explica o alinhamento dos planetas a Nino.

Alinhamento dos planetas e dos temas de Nino e do castelo (Ópera Arepó).

Gralha, cujo som sinaliza a chegada de Losângela

Roberto tenta se suicidar.

Roberto conhece Margueritte.

Em flashback, Roberto conta, à sua maneira, como foi parar na Febem....

Visão idealizada de Cabelinho de Fogo por Roberto

Roberto pergunta pelo nome dos objetos em francês.

Relato 'colorido' de Roberto acerca dos personagens de sua infância

Propaganda da Febem acalenta sonho da mãe de que Roberto se torne doutor.

Febem, na imaginação de Roberto.

Dona Judith, a professora de Educação Física da Febem, na visão de Roberto.

Meninos correm em sua primeira fuga da Febem.

Roberto fala sobre sua turma como se fosse um time de futebol. Imaginação de Roberto, sob efeito do thinner.
164

166

167

168

169

170

171

172 
Figura 87 Roberto corre em direção ao mar pela primeira vez, ao som da música-

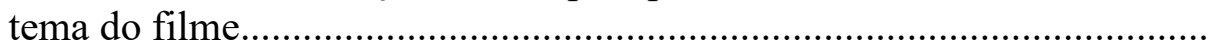

Figura 88 Visão amadurecida do jovem Roberto, que reencontra seu antigo bairro, ao som do tema do filme....

Figura 89 Reencontro de Roberto com sua mãe biológica..................................... 200

Figura 90 Roberto, personagem que inspirou o filme, conta histórias na rua............ 201 


\section{SUMÁRIO}

1 INTRODUÇÃO.

2 A MÚSICA DO CINEMA BRASILEIRO A PARTIR DOS ANOS DE 1990.

2.1 A RETOMADA DO CINEMA BRASILEIRO E A ESTREIA DE NOVOS DIRETORES E COMPOSITORES.

2.1.1 Carlota Joaquina, princesa do Brasil (Carla Camurati, 1995).

2.2 ANDRÉ ABUJAMRA: DA COXIA DO TEATRO À MÚSICA PARA CINEMA

2.2.1 Equipe, parceiros e estrutura de trabalho

2.3 SOM, MÚSICA, RUÍDO: AS INFINITAS POSSIBILIDADES COMPOSICIONAIS NA ERA DIGITAL.

Bicho de Sete Cabeças (Laís Bodanzky, 2001)

CANÇÕES PREEXISTENTES: UMA TRADIÇÃO ATUALIZADA......

TEMAS ORIGINAIS: INSPIRAÇÃO HOLLYWOODIANA, TIMBRES REGIONAIS E A RECORRENTE SUBSTITUIÇÃO DA ORQUESTRA POR SAMPLERS.

3 O COMPOSITOR NO PROCESSO DE REALIZAÇÃO CINEMATOGRÁFICA.

3.1 MÚSICA DE CINEMA: DA NEGOCIAÇÃO AOS CRÉDITOS.

3.2 VOZES DE EXPERIÊNCIA: A TRILHA MUSICAL, SEGUNDO COMPOSITORES E DIRETORES

3.3 'EQUALIZAÇÃO' DE EXPECTATIVAS: PROCESSOS DIALÓGICOS

ENTRE COMPOSITOR E DIRETOR.

3.3.1 Primeiro encontro entre músico e cineasta: o início do processo................... 92

3.3.2 Decupagem, composição e apresentação das ideias ao diretor......................... 94

3.3.3 Gravação e mixagem......................................................................................

4 ENTRE A "LIBERDADE" E O DESAPEGO: O PERCURSO DE ANDRÉ ABUJAMRA COMO COMPOSITOR DE MÚSICA PARA FILMES.

4.1 SONS EM IMAGENS E IMAGENS EM SONS: PROCESSO CRIATIVO E MÚSICA PARA CINEMA.

4.1.1 A criação musical no cinema.

4.4 A COLABORAÇÃO QUE EXTRAPOLA A MÚSICA.

5 MÚSICA DE CINEMA E MÚSICA DE DISCO: EM BUSCA DE UMA ASSINATURA MUSICAL CINEMATOGRÁFICA DE ANDRÉ

5.1 CAMINHOS METODOLÓGICOS E COMPOSIÇÃO DO CORPUS DE ANÁLISE

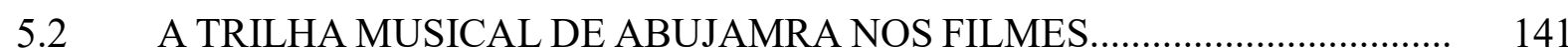

5.2.1 Um copo de cólera (Aluizio Abranches, 1999)................................................... 142

5.2.2 Castelo Rá-Tim-Bum, o filme (Cao Hamburger, 1999)................................ 159

5.2.3 O contador de histórias (Luiz Villaça, 2009)................................................. 181 
REFERÊNCIAS..

ANEXOS.

ANEXO A - Pendrive com discos e filmes com músicas de André Abujamra... 218

APÊNDICES.

219

APÊNDICE A - Lista de filmes brasileiros de ficção em longa-metragem com trilhas musicais de André Abujamra, por ordem cronológica.

220

APÊNDICE B - Entrevista com o compositor André Abujamra.

222

APÊNDICE C - Entrevista com o compositor e produtor musical Márcio

Nigro.

APÊNDICE D - Entrevista com o compositor e produtor musical Lulu

Camargo...

APÊNDICE E - Entrevista com a diretora Anna Muylaert.

APÊNDICE F - Entrevista com o diretor Aluizio Abranches............................. 260

APÊNDICE G - Entrevista com o diretor José Joffily

APÊNDICE H - Entrevista com o ex-integrante da banda Karnak, Juliano

Beccari.

264

APÊNDICE I - Entrevista com o integrante da banda Os Mulheres Negras, Maurício Pereira 


\section{INTRODUÇÃO}

"Fazer música para cinema é fazer cinema". Quando o compositor e produtor musical mexicano Leonardo Heiblum proferiu esta frase, em tom categórico, durante uma das sessões extraordinárias da Cátedra Ingmar Bergman sobre composição de música para cinema (Cidade do México, 2015), refletimos sobre as possíveis implicações desta aferição. Para ser cinema é desejável que a música que o compositor faz para o filme seja criada a partir do conhecimento experimentado da linguagem cinematográfica para além da sincronia rítmica entre a música e a montagem. Tal estofo demanda um tempo dedicado a leituras; construção de repertório e vocabulário fílmicos; vivências dentro e fora da sala de cinema; convívio com diretores, montadores, editores de som, produtores e outros profissionais participantes do processo de realização cinematográfica.

O músico brasileiro contemporâneo que compõe para filmes tem esse tempo? Existe o interesse e a organização, por parte do compositor, para que esse tempo de estudo seja criado, antes do primeiro contato com um novo filme e após a finalização de sua trilha musical? E da parte dos profissionais que, em geral, lidam diretamente com o músico durante a feitura de um filme, existe uma bagagem musical - ou, ao menos, uma curiosidade que resulte em pesquisa prévia - que permita uma comunicação entre o diretor e o compositor que vá além de vagas metáforas, com algum vocabulário - musical e fílmico - compartilhado? O diretor, que realiza sua visão artística em fotografia, atuação, roteiro, cenografia, figurino, tem tempo para compreender, transmitir e realizar seu ponto de vista cinematográfico por meio da música? Até que ponto o músico está envolvido com a equipe de um filme durante o seu trabalho de composição - e até que ponto quer/pode estar?

Tais questões se aprofundaram ao longo de nossa temporada de dois anos na cidade de São Paulo, para a primeira metade do doutoramento, quando surgiu o convite para compor a música de um documentário paulistano em longa-metragem - Minha avó era palhaço (Mariana Gabriel e Ana Minehira, 2016). Diante da oportunidade de compreender, do lugar do compositor, esse processo e da possibilidade do desenrolar empírico de questões, até então, teoricamente formuladas, aceitamos o convite.

Entre março e novembro de 2015, do primeiro contato com a direção até a mixagem final do filme, as experiências por que passamos, conciliadas com os estudos e eventos acadêmicos para a elaboração desta tese, levaram-nos à compreensão do prazer e das dificuldades de se abrir esse tempo de mergulho e criação musical a partir de um projeto cinematográfico de proporções maiores, em relação aos que já havia participado em minha 
cidade natal, Goiânia, capital de Goiás. Além do tempo de criação, tomadas de decisões e realização do diretor, existem os tempos do montador, do editor de som, do compositor, dos músicos intérpretes e outros. E existe outro que surge a partir da orquestração de todos esses tempos, que é o tempo do filme, a razão de ser da articulação entre todos os seus elementos visuais e sonoros, a síntese disponível para o espectador.

Viver, de dentro, o tempo de realização desse filme como compositora - e não como analista, função que exercemos de forma mais ou menos sistemática há, pelo menos, 11 anos proporcionou-nos um olhar, cremos, mais amadurecido e crítico sobre o objeto desta pesquisa: a obra musical do compositor, instrumentista, ator e artista multimídia André Abujamra para o cinema brasileiro.

O primeiro contato com André Abujamra foi pela televisão, no final da década de 1990, quando a dupla Os Mulheres Negras não existia mais. Era uma apresentação do Karnak, em um programa da TV Cultura. Chamou-me a atenção a quantidade de músicos, o figurino e aquela figura teatral e carismática que parecia ser uma liderança na banda.

Foi por meio da tela de cinema que aconteceu nosso segundo contato com o artista, no lançamento de Durval Discos (Anna Muylaert, 2003), durante uma mostra de cinema, em Goiânia. Ao término da sessão, nossa inquietação e mal-estar vinham da perturbação e do desconcerto diante daquele filme que começara tão leve, conduziram-nos por caminhos que pareciam surreais e se despediram de forma triste e melancólica. A partir da trilha musical de Abujamra para esse projeto passamos da espectatorialidade inquieta à pesquisa de som e música de cinema, com ênfase na produção brasileira.

A presente tese é um dos desdobramentos da pesquisa que realizamos na dissertação do Mestrado em Comunicação na Faculdade de Comunicação e Biblioteconomia da Universidade Federal de Goiás (Facomb/UFG), intitulada Riso, desespero, exílio e loucura: a canção popular brasileira em 'Terra estrangeira' e 'Durval Discos' (2012). A dissertação teve como objeto de estudo a aderência da canção popular brasileira ao cinema, especialmente nos filmes do corpus de análise, inserindo-a no contexto de produção e reflexão sobre as trilhas sonoras do cinema brasileiro da atualidade e das pesquisas sobre som no cinema realizadas no País. Esta dissertação deu sequência ao trabalho monográfico de conclusão do curso de graduação em Comunicação Social - Habilitação: Jornalismo, também pela UFG, com o título O resgate do vinil (ou o personagem 'invisível') em Durval Discos (2005), quando investigamos a possibilidade de a música se comportar como um personagem naquele filme.

Após a defesa da dissertação, em junho de 2012, obtivemos a aprovação do projeto de pesquisa Música para ver e ouvir: a contribuição musical de André Abujamra ao cinema 
brasileiro, na Universidade Estadual de Goiás (UEG), onde desde 2009 atuamos na docência, ministrando aulas de Produção Sonora no curso de Bacharelado em Cinema e Audiovisual - e, mais recentemente (desde 2016), no curso de Pós-graduação Lato sensu em Cinema e Audiovisual: Linguagens e Processos de Realização. Desenvolvido ao longo do ano de 2013, o projeto de pesquisa nos auxiliou nas primeiras reflexões que nos levaram ao Doutorado.

O desenvolvimento desta pesquisa buscou investigar, a partir da Retomada da realização cinematográfica brasileira, a existência de traços comuns às obras musicais de André Abujamra para filmes, compostas para atender a especificidades narrativas diversas e em diferentes contextos e condições de realização. Em que medida o trânsito de certos elementos harmônicos, melódicos, rítmicos e procedimentos composicionais entre diferentes trilhas musicais para filmes guardam relação com a vida do artista, sua obra discográfica e suas experiências sonoras ao redor do mundo? Uma vez constatada a recorrência de tais elementos - que foram identificados a partir de análise fílmica, investigação biográfica e da audição da discografia do artista - e considerando as condições de composição e produção da música para cinema em cada caso, é possível falar em uma assinatura musical cinematográfica de André Abujamra e pontuar suas características?

O propósito desta pesquisa foi o de analisar a relação estabelecida entre a música de Abujamra, os demais elementos sonoros - ruído, diálogos, efeitos e outros - e os elementos visuais nos filmes dos quais ele participa como compositor, investigando as possibilidades estéticas e narrativas do uso da trilha musical e como ela interfere na totalidade fílmica. Pretendíamos abordar o percurso musical do artista no cinema nacional, notadamente em filmes de ficção em longa-metragem, verificando a relação entre seu processo criativo, o processo de realização cinematográfica e a existência de uma assinatura musical estabelecida ao longo de sua carreira. Formulações teóricas de autores nacional e mundialmente consagrados foram fundamentais no exercício de uma análise fílmica que se detivesse mais atentamente à trilha sonora, percebendo suas dinâmicas na relação com o visual. Pretendíamos, ainda, estabelecer as aproximações entre as linguagens musical e cinematográfica, considerando também as relações extrafílmicas entre a música composta por Abujamra para cinema e o contexto de composição e produção de discos do artista.

Graças aos esforços de teóricos estrangeiros e de alguns pesquisadores dos países de língua portuguesa - no Brasil: Fernando Morais da Costa, Irineu Guerrini Júnior, Claudiney Carrasco, Eduardo Santos Mendes, Luiz Adelmo Manzano, João Godoy, Suzana Reck Miranda, Eduardo Vicente, entre outros -, o som e a trilha musical são objetos em conquista de valorização no âmbito dos estudos cinematográficos, de modo que os elementos visuais 
prevalecem soberanos como objetos dos trabalhos acadêmicos sobre cinema no Brasil. Nesse contexto, o presente trabalho buscou perceber, de forma aprofundada, a relação intrínseca música-imagem-vida de André Abujamra presente em suas composições para cinema nos últimos 20 anos desta arte no Brasil.

Uma possibilidade de análise que teve como ponto de partida esta relação entre a música, em suas formas audível e visível, ao mesmo tempo e porque volta seu olhar para um presente e um passado recente de ricas referências, pode culminar tanto na ênfase em outra chave de fruição e pensamento para a análise fílmica, tendo o som e a música como eixo - a partir do deslocamento do modelo tradicional, centrado na imagem visual - quanto em novas perspectivas para o uso da trilha sonora no cinema contemporâneo. Acrescente-se o caráter multidisciplinar desta pesquisa, que buscou um diálogo entre as áreas da Comunicação, Cinema, Música e Artes, a partir do qual desejamos contribuir para o atual pensamento sobre o cinema feito no Brasil.

É importante destacar o ineditismo desta pesquisa na área do cinema no Centro-Oeste brasileiro, especialmente no estado de Goiás, onde a formação em som e trilha musical em Cinema e Audiovisual ainda é um grande desafio dos poucos professores e cursos existentes nesta área ${ }^{1}$. Até o momento, esta pesquisa é a única em Goiás a tratar deste tão importante tema de nossa cultura - a música de um compositor vivo e em plena produção no cinema nacional contemporâneo. E a única no Brasil a abordar, especificamente e em profundidade, a trajetória musical cinematográfica de André Abujamra. Desejamos que este feito possa contribuir para o reconhecimento do trabalho do artista também em âmbito acadêmico, bem como para inserção e consolidação de Goiás na geografia do pensamento sobre som e música de cinema no País.

Esperamos, ainda, contribuir para o crescente reconhecimento da importância da música no cinema brasileiro, especialmente nos filmes em que ela dialoga com a imagem e com os demais elementos sonoros; para o entendimento de que, desde a sua composição até as telas, o sentido da trilha musical está na relação entre o que se ouve e o que se vê; e para a identificação das estratégias narrativas da linguagem musical no contexto das duas últimas décadas do cinema nacional. Esperamos que a ampliação da compreensão da música nesse contexto amplie as possibilidades de pesquisa sobre as intersecções entre as produções cinematográfica e musical recentes no cenário nacional.

\footnotetext{
${ }^{1}$ Até o momento, os três únicos cursos superiores em Cinema e Audiovisual existentes no Centro-Oeste brasileiro são, do mais antigo ao mais recente: na Universidade de Brasília (UnB), Universidade Estadual de Goiás (UEG) e no Instituto Federal de Educação, Ciência e Tecnologia - Goiás (IFG).
} 
Estruturado em cinco capítulos, incluindo esta introdução, o texto se inicia (capítulo 2) com um panorama da música no cinema brasileiro a partir da década de 1990 (Retomada) até os dias atuais, buscando iluminar os diversos papéis assumidos pela trilha musical em diferentes narrativas fílmicas no conturbado cenário político e econômico neoliberal da época. Abordando a estreia de então novos diretores e compositores, analisamos o filme Carlota Joaquina, princesa do Brasil (Carla Camurati, 1995), considerado o marco inicial da Retomada - e o longametragem ficcional de estreia tanto da diretora Carla Camurati quanto de André Abujamra como compositor. Na análise mostramos o clima de desconfiança, traduzido em linguagem cinematográfica, que ronda a produção de cinema no Brasil e como a música colabora com a carnavalização proposta pelo filme.

Com o auxílio de Gallo (2015), falamos também sobre as mudanças na produção musical em decorrência do advento e popularização das tecnologias digitais sonoras, ampliando as possibilidades de composição, reduzindo os custos de produção, modelando o perfil empreendedor de novos compositores e aproximando o score de outros sons, como o ruído e os diálogos - característica que ressaltamos com a análise do filme Bicho de sete cabeças (Laís Bodanzky, 2001). Recorremos ao trabalho de Silva (2009) para falar sobre outra característica notável das trilhas sonoras dos filmes do período: a atualização do uso tradicional de canções preexistentes, que apresentam uma maior integração à narrativa e uma articulação mais complexa com outros elementos cinematográficos. Também no segundo capítulo abordamos brevemente a composição de trilhas musicais originais - assunto a ser tratado com profundidade no capítulo seguinte -, a mistura de instrumentos regionais e linhas executadas por músicosintérpretes 'reais' a timbres artificiais 'virtuais', criados em softwares de computador e disponíveis em livrarias de áudio.

O terceiro capítulo trata do lugar compositor musical no processo de realização cinematográfica: o compositor como autor; quando ele é inserido na equipe; e com que outros profissionais do filme, em geral, ele interage diretamente. Destacamos o relacionamento dele com o diretor cinematográfico e como seu trabalho - cujas etapas são aqui explicitadas - se integra ao conjunto de procedimentos sonoros e visuais até a finalização da obra. Para tanto, recorremos a diversos compositores e diretores brasileiros, de diferentes gerações, sobre como a música original é e/ou deveria ser abordada no cinema e os desafios desta comunicação (diretor-compositor) em um contexto no qual, em espaços legitimados de formação em Cinema ou Música, este diálogo é inexistente, incipiente ou não tão estimulado.

No quarto capítulo trabalhamos na reconstituição da trajetória artístico-musical de André Abujamra, a partir de aspectos de seu processo criativo - com inspiração em sonoridades 
de países distantes, idiomas estrangeiros, na prática do candomblé e outras religiões, e em artistas que admira, do rock à música erudita - rememorando seu trabalho pop experimental com Maurício Pereira na dupla Os Mulheres Negras; a diversidade e densidade sonoras das composições da banda Karnak; sua carreira solo; passando pela sua atuação como criador de música para espetáculos teatrais, programas televisivos e peças publicitárias audiovisuais. Destacamos sua atuação como compositor de trilhas musicais originais para cinema, por meio da exposição de como é o trabalho do artista em termos de envolvimento, criação, parcerias, organização, tecnologias e execução.

O quinto capítulo apresenta os caminhos metodológicos para este estudo, pautado por pesquisas biográficas, bibliográficas, entrevistas e análise fílmica. Com a justificativa da composição do corpus para esta análise, estudamos mais três longas-metragens de ficção cuja música original é creditada a Abujamra - Um copo de cólera (Aluizio Abranches, 1999) ou a ele em coautoria com compositores parceiros - Lulu Camargo, em Castelo Rá-Tim-Bum, o filme (Cao Hamburger, 1999), e Márcio Nigro, em O contador de histórias (Luiz Villaça, 2009). Buscamos ainda aproximações e distanciamentos entre os recursos musicais utilizados pelo compositor em diferentes filmes e situações de composição (solo e coautoria) - para atender a demandas estético-narrativas específicas - e fonogramas de seus discos, em busca de uma possível assinatura musical cinematográfica do artista.

Além da conclusão deste estudo - que reúne, de forma reflexiva, as características das composições de Abujamra para cinema -, trazemos uma entrevista com o próprio compositor, concedida especialmente para esta pesquisa (APÊNDICE B), as obras fílmicas aqui analisadas e a discografia do artista (ANEXO A). E ainda entrevistas com alguns diretores e músicos que trabalham ou trabalharam com Abujamra (APÊNDICES C, D, E, F, G, H e I).

A análise de filmes brasileiros com composições musicais de André Abujamra e da relação destas com o processo criativo e a vida de um dos artistas mais ativos, inventivos e multifacetados da música brasileira para cinema pretende contribuir para a elevação da importância da música brasileira em filmes, especialmente nos quais ela dialoga com a imagem e com os demais elementos sonoros; para o entendimento de que o significado da música também está na relação entre o que se escuta e o que se vê; e para a identificação das estratégias narrativas da linguagem musical no contexto das duas últimas décadas do cinema brasileiro, considerando a vasta trajetória musical de Abujamra. Esperamos que a ampliação da compreensão da música nesse ambiente enriqueça e amplie a possibilidade de pesquisas sobre as intersecções entre a produção cinematográfica e musical brasileira recente. 


\section{A MÚSICA DO CINEMA BRASILEIRO A PARTIR DOS ANOS DE 1990}

Os anos de 1990 são conhecidos, nos estudos de música no cinema, pela pluralidade de sonoridades em convívio. Música pop, canções populares, timbres regionais, arranjos orquestrais, samplers e loops eletrônicos passaram a estar mais acessíveis ao compositor por meio do intercâmbio cultural possibilitado pela mundialização da cultura, da globalização econômica e do avanço das tecnologias de produção e reprodução sonoras.

Estratégias de mercado e inovações de linguagem atualizaram as formas de aderência entre som e imagem no cinema ao redor do mundo, ao mesmo tempo em que borraram os limites definidores dos elementos sonoros. Manipulado digitalmente, o ruído se tornou componente musical; a música nem sempre é reconhecível como uma construção tonal, codificada e previsível; falas, som direto e trechos descartados de áudio são distorcidos, reorganizados e aproveitados em trilhas sonoras.

Por outro lado, a qualidade do som digital também modificou os processos de produção de scores, inclusive das trilhas orquestrais tradicionais, 'corrigindo' desvios de afinação por meio de plugins, ou ainda amenizando as imperfeições da performance do músico real por meio da eficácia técnica dos instrumentos virtuais, interferindo em sua expressão.

Sobre a diversidade que marca as trilhas musicais cinematográficas dessa década, afirma Berchmans (2006):

\footnotetext{
Os novos recursos técnicos dos anos 80 deixaram de ser novidade e passaram a se integrar com a instrumentação orquestral nas suas mais variadas formas. Além disso, na música popular, a grande mistura de estilos e o vale-tudo no caldeirão de influências nas novas composições forneceram mais cores e texturas sonoras para a música de cinema (BERCHMANS, 2006, p. 143).
}

Tais processos, observa este autor, não foram desencadeados nos anos de 1990. Ao longo de todo o século XX movimentos como o futurismo, o atonalismo, o serialismo e a música dodecafônica, bem como o expressionismo, a arte abstrata, o surrealismo, o dadaísmo e a pop art, buscavam novas formas de perceber o mundo para além do conforto das armaduras tonais, do realismo visual, dos instrumentos e matérias-primas convencionais e dos tradicionais, e em constante sofisticação, artifícios do cinema clássico narrativo.

Traçamos aqui um panorama da música no cinema brasileiro a partir da década de 1990 até os dias atuais na busca por evidenciar os papéis desempenhados pela trilha musical em diferentes narrativas fílmicas. Trata-se de uma reflexão localizada sobre a ampliação e flexibilidade das possibilidades composicionais trazidas pelo uso da tecnologia sonora digital, 
a consequente diluição das fronteiras entre música e ruído e a convivência entre uma diversidade de sonoridades organizadas em canções preexistentes e trilhas musicais originais. Tal diversidade é considerada por Freire (2009) como um traço fundamental do cinema feito no Brasil, importante para a compreensão do próprio País e de seus contextos de produção cinematográfica.

\begin{abstract}
A história da música no cinema brasileiro não é simplesmente o estudo de um aspecto secundário dos filmes brasileiros, mas, pelo contrário, é um passo essencial para entendermos inclusive o que há de Brasil (ou dos Brasis) em nosso cinema. Talvez a marca maior do que chamamos geralmente sem muita preocupação de cinema brasileiro esteja mais na multiplicidade do que "ouvimos" do que no que "vemos" nas telas. Afinal e contas, nunca é demais ressaltar o apelo à música nacional nos mais variados momentos e circunstâncias na história do cinema brasileiro, com as mais distintas finalidades (identificação popular, viabilidade comercial, projeto político, afinidade estética etc.) (FREIRE, 2009, p. 10).
\end{abstract}

Para compreender as relações estabelecidas entre a música e os demais elementos cinematográficos nas narrativas fílmicas a partir do período conhecido como a 'Retomada' do cinema brasileiro, é necessário contextualizar: a) as condições de produção de cinema do período posterior à extinção da Embrafilme e de outros órgãos culturais federais do Brasil no governo de Fernando Collor; b) o pessimismo inicial e o reaquecimento da produção de filmes a partir da segunda metade dos anos de 1990 - época marcada pela globalização da economia e pela mundialização da cultura; as relações comerciais e artísticas entre música e cinema no Brasil; c) o surgimento da Globo Filmes no final da década de 1990 e seus desdobramentos políticos, econômicos e estéticos.

A hipótese é a de que há certa economia nos usos da música no cinema brasileiro contemporâneo - economia diferente da percebida na música dos filmes dos anos de 1960, que tinham, na precariedade de recursos, um componente fundamental de seu manifesto estético e político diante do cenário efervescente da época. Tal característica, no presente, resulta não apenas de restrições orçamentárias, acesso a novas tecnologias ou contextos específicos de produção, mas, sobretudo, está coerente com propostas estéticas plurais que refletem a possibilidade de diálogo com a tradição musical cinematográfica mundial e a busca constante tanto pelo amadurecimento da linguagem do cinema quanto pelo maior alcance de público. 
No Brasil o cinema da primeira metade da década de 1990 sofreu com a extinção da agonizante Embrafilme - produtora e distribuidora estatal do cinema nacional que já estava em crise desde a década de 1980 -, do Conselho Nacional de Cinema (Concine) - órgão normativo e fiscalizador do mercado nacional de cinema - e com a redução do Ministério da Cultura a secretaria pelo governo Collor. Isso diminuiu drasticamente a produção no período, uma vez que o Estado, até então o principal fomentador do cinema brasileiro mediante políticas de incentivo, distanciou-se dessa função, deixando o cinema, bem como qualquer produto da indústria cultural, ao sabor do mercado econômico liberal.

Segundo Carrasco (2009), essa época tem sido pouco abordada pela teoria e crítica cinematográficas - talvez pela produção quantitativamente pouco expressiva, mas que aponta para uma busca intuitiva do novo - em um contexto de convivência entre forças da tradição mercadológica do cinema de entretenimento e da ruptura com o comercial ('cinema de autor').

Trata-se de uma produção não uniforme, cunhada em um período de transição em que convivem manifestações diversas e nem sempre congruentes. Ao mesmo tempo, ela carrega a efervescência de uma geração, ou melhor, da convivência de gerações em busca de novos caminhos, [...] que presenciaram o esgotamento de vários modelos até então tidos como a alternativa possível de futuro, mas que por sua própria força, adquirida em anos de intenso envolvimento ideológico, agonizam lentamente [...]. Trata-se, portanto, de um momento da cultura brasileira repleto de experiências em busca de alternativas para a construção expressiva de um modelo de futuro, de novas poéticas (CARRASCO, 2009, p. 97-98).

Até que os incentivos estatais para a produção cinematográfica fossem reestabelecidos em novas bases após o impeachment de Collor (1992), houve um trânsito de realizadores para a televisão, como Cacá Diegues ${ }^{2}$ e Jorge Furtado ${ }^{3}$, numa tentativa de se manterem em atividade. Paralelamente, na área publicitária surgiram diretores cuja carreira em pouco tempo incluiu o cinema, como Fernando Meirelles e Afonso Poyart. Outros poucos diretores, entre eles Walter Salles, continuaram produzindo, por vezes em coprodução internacional, em escala reduzida.

O filme Terra estrangeira (Walter Salles e Daniela Thomas, 1996) traz, em sua narrativa, esse momento de desesperança dos brasileiros com o País, ao mesmo tempo revelando,

\footnotetext{
${ }^{2}$ Em parceria com a TV Cultura, Cacá Diegues produziu o telefilme Veja esta Canção (1994), por exemplo.

${ }^{3}$ Veterano em curtas-metragens - Temporal (1984), O dia em que Dorival encarou a guarda (1986), Barbosa (1988), Ilha das Flores (1989), Memória (1990), Esta não é a sua vida (1991), Veja bem (1994), etc. -, o realizador gaúcho Jorge Furtado, entre 1993 e 2000, foi roteirista das minisséries Agosto (1993) e Memorial de Maria Moura (1994); da série A comédia da vida privada (1995); diretor e roteirista do especial Anchietanos (1997); e roteirista das minisséries Luna caliente (1999) e A invenção do Brasil (2000). Após esse período, prosseguiu como diretor e roteirista de séries televisivas, conciliando esta atividade com o início e desenvolvimento de sua carreira cinematográfica em longas-metragens.
} 
esteticamente, o pessimismo inicial que se apossou dos profissionais do cinema durante este ‘limbo’ da produção nacional. Segundo Oricchio (2003):

\begin{abstract}
Terra Estrangeira, o segundo longa-metragem de Walter Salles (e o primeiro em codireção de Daniela Thomas), fala basicamente da sensação de perda da nacionalidade em um momento de grande decepção política. Trata-se, para o diretor, de um trabalho de luto, prévio e necessário para o reencontro com o país, que iria acontecer no filme seguinte, Central do Brasil. [...] Em filigrana com a trama policial, opera nele a interminável questão da identidade brasileira, sua relação com o Outro e consigo mesmo, os limites entre sentir-se estrangeiro em sua própria pátria e na dos outros. É um filme de fronteiras e lugares estranhos e deve ser assim, porque fala de um país alheado e estranho a si mesmo (ORICCHIO, 2003, p. 70-71, grifos do autor).
\end{abstract}

Somente com o encaminhamento de uma política cultural baseada em incentivos fiscais, chancelada pela Lei do Audiovisual (8.685/93), o País teve condições de retomar o ritmo de sua produção cinematográfica. O que exigiu, dos cineastas e do Estado, novas formas de se relacionar política e economicamente com o cinema (MARSON, 2009). A segunda metade da década ficou conhecida como o período da 'Retomada do cinema brasileiro'.

Importante ressaltar que a Retomada não caracteriza um movimento ou ciclo específico, coeso e claramente delimitável na história do cinema brasileiro; tampouco há consenso quanto à utilização desse termo para designar o período a partir do qual foi possível o reaquecimento da produção cinematográfica nacional. Nagib (2002) argumenta que a Embrafilme, após o fechamento, teve seus recursos rateados com o Prêmio Resgate do Cinema Brasileiro, por meio do qual os realizadores puderam, concomitantemente, retornar à execução de seus projetos acumulados, paralisados e/ou novos, após os anos de baixíssima atividade. Dinâmica que, sob a perspectiva desta autora, pode ter sido interpretada equivocadamente como um boom.

Esteticamente, a Retomada é conhecida, segundo Xavier (2003), pela diversidade decorrente da fragmentação intelectual, esvaziamento de projetos e despolitização, acompanhados por uma profunda indagação sobre as identidades brasileiras no mundo globalizado. Para Xavier (2000), o cinema brasileiro do período segue duas tendências principais de enredo: a) a revelação do fracasso por meio de personagens ressentidos e b) redenções moralistas a partir de uma abordagem humanista e melodramática dos males do mundo.

Ainda em termos narrativos, há o resgate, segundo Silva (2009, p. 218), de temas tradicionais do cinema brasileiro, “[...] como a volta de clássicos motivos da representação do popular (a favela, o sertão, o carnaval, o futebol e outros), sem rígidas leituras das manifestações culturais regionais" e a aposta "[...] em adaptações literárias, cinebiografias e comédias de costumes". 
O que seria o Brasil e o cinema brasileiro é uma das perguntas que o cinema nacional passou a se fazer, como se fizera antes - com a diferença de que as causas políticas e as tomadas de posição não estavam mais polarizadas como nos anos de 1960 e 1970. Pelo contrário, apresentavam-se diluídas no labirinto global de instabilidades, dúvidas e desconfianças das utopias perdidas após a queda do Muro de Berlim (1989) e o fim da Guerra Fria, com a extinção da União Soviética (1991).

\footnotetext{
Essa variedade da oferta, que não é apenas de gêneros, mas de estilos, [...] refletiria também a típica fragmentação mental do homem dos anos 1990. Com o chamado "fím das utopias", cada qual se sentiu liberado para estabelecer a própria agenda de prioridades. De uma maneira deliciosamente livre e confusa, o criador pode optar entre expressar seus fantasmas pessoais, divertir o público ou preocupar-se com a questão social do país (ORICCHIO, 2003, p. 30).
}

Oricchio (2003) reforça o caráter plural da produção cinematográfica brasileira do período menos como opção estética e mais como consequência desse 'caminhar no escuro', na dependência de editais de fomento, em nome da busca por quaisquer condições de realização, tendo, à disposição, a tecnologia digital e uma vastidão planetária de repertórios culturais. $\mathrm{O}$ diretor Fernando Meirelles atribui essa pluralidade à forma descentralizada de financiamento dos filmes, via editais de fomento: "O fato de milhares de cabeças decidirem o que deve ser produzido, e não um 'comitê central', como foi na época da Embrafilme, possibilita termos a produção que temos hoje" (MEIRELLES, 2012 apud BALLERINI, 2012, p. 91).

Essa multiplicidade de caminhos, segundo Miranda (2009), reflete-se na música de cinema, na qual se percebe a continuidade do uso da canção popular no filme - talvez de modo menos recorrente e mais preocupado com sua aderência à narrativa fílmica -, convivendo com arranjos orquestrais, timbres locais, ruídos, vozes e recursos eletrônicos.

Ao mesmo tempo, constata Gallo (2015), provavelmente nunca na história do cinema brasileiro houve tantos compositores de música de cinema em atividade concomitante no País, marcados por um perfil majoritariamente empreendedor. Em geral, são músicos multitarefa, conhecedores da tecnologia digital e gestores de sua própria estrutura de trabalho, que centralizam a responsabilidade pela música original em todas as etapas de sua produção; compositores que iniciam suas carreiras na indústria fonográfica e estreantes no cinema a partir da Retomada e atualmente em atividade. São atuantes também na televisão, na publicidade, nos palcos, entre outros espaços, convivendo com gerações anteriores de compositores para cinema. Entre os principais nomes figuram Antônio Pinto, Beto Villares, Eduardo Bid, Plínio Profeta, 
Marco Antônio Guimarães, David Tygel, Mu Carvalho, Lívio Tragtenberg, Ed Côrtes, Berna Ceppas e André Abujamra.

Abujamra compôs sua primeira trilha musical para longa-metragem a convite da diretora também estreante em longas, Carla Camurati, no filme Carlota Joaquina, princesa do Brasil. Considerado como o marco inicial da Retomada, a obra é analisada a seguir com o intuito de demonstrar não apenas a pluralidade de recursos musicais e sonoros, mas o tom cômicocarnavalesco da relação entre imagem e som, na busca pela compreensão de nossas identidades e (des)crenças: o que é ser brasileiro e fazer cinema no Brasil a partir dos 1990?

\subsubsection{Carlota Joaquina, princesa do Brasil (Carla Camurati, 1995)}

Tendo ultrapassado a marca de um milhão de espectadores - em contraste radical com o irrisório quantitativo da produção e da bilheteria do cinema brasileiro nos anos Collor ${ }^{4}$, o que torna compreensível a impressão de boom do cinema brasileiro considerada por muitos a partir de então -, o filme Carlota Joaquina, princesa do Brasil (Carla Camurati, 1995), foi uma das produções financiadas pelo Prêmio Resgate do Cinema Brasileiro, em conjunto com o patrocínio direto de empresas privadas. O primeiro longa-metragem de Carla Camurati é uma ficção farsesca sobre a chegada da corte portuguesa ao Brasil, sob o ponto de vista estereotipado de um europeu (Brent Hieatt), cuja voz é o eixo narrativo e o principal ponto de redundância (intencional, provocadora de humor) entre som e imagem.

Utilizando-se da licença do olhar estrangeiro, grande parte dos elementos cinematográficos parece contribuir para a estereotipização/ridicularização dos personagens e da história. Os excessos na atuação e na caracterização dos personagens, derivados do teatro Maria Luíza de Parma, mãe de Carlota, tem dentes de pérola (FIGURA 1); a protagonista é conhecida como a criança mais feia da corte; o figurino - princesa predominantemente em vermelho, perucas enormes e várias camadas de roupa da realeza em ambiente tropical; a maquiagem e a cenografia exageradas, as cores vivas na fotografia, os ruídos em alta intensidade - arrotos, flatulências, roncos, vômitos, mastigação e outros, que demonstram a 'educação' da corte portuguesa; os barulhos de insetos que nos fazem sentir a 'terra de monstros tropicais ameaçadores' onde os portugueses acreditam estar; o turbilhão de palavrões proferidos

\footnotetext{
4 Segundo dados presentes em Marson (2009), foram produzidos, no Brasil, sete filmes em 1990, oito em 1991, três em 1992, quatro em 1993 e sete em 1994.
} 
sobretudo pela protagonista e a mistura da música pomposa dos europeus com os batuques africanos e indígenas dos nativos -, são recursos que, ficcionalmente, desconstroem a idealização dos primeiros capítulos da História do Brasil. E que, ao mesmo tempo, demonstram, em tom grotesco, o pessimismo, a desconfiança e a 'perda da inocência' (XAVIER, 2001) que matizam a atividade cinematográfica nacional nos anos de 1990.

Essa tensão com a metrópole real ou idealizada (Portugal, depois Inglaterra, depois França, agora Estados Unidos) parece ser um dos nossos traços definidores. Ajudanos a entender em parte o sucesso de farsas históricas como Carlota Joaquina, ou a mini-série da TV Globo $O$ quinto dos infernos, que bebe na mesma fonte (ORICCHIO, 2003, p. 33, grifos do autor).

Figura 1 - Caracterização grotesca da personagem Maria Luíza de Parma

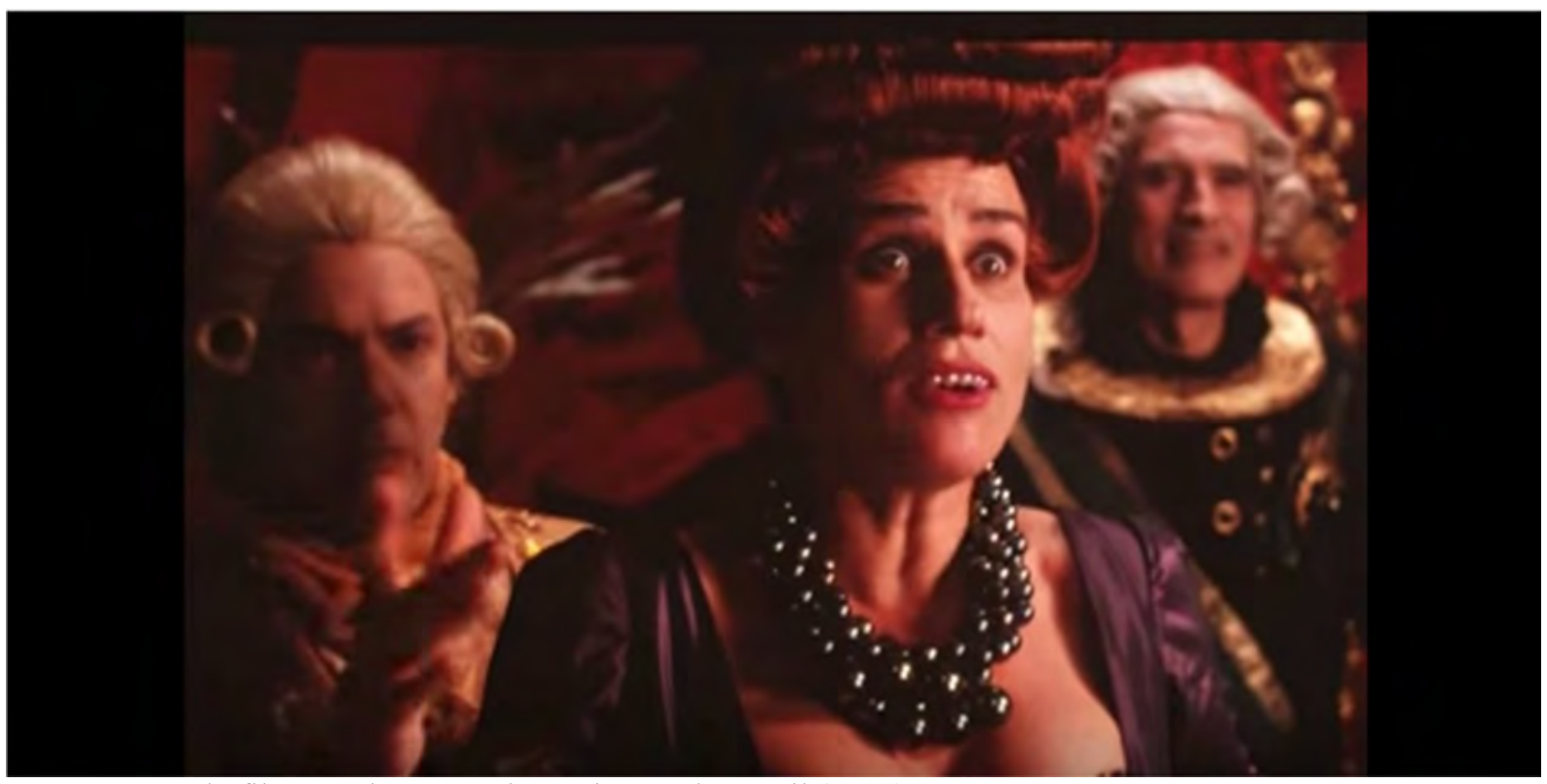

Fonte: Frame do filme Carlota Joaquina, princesa do Brasil (1995).

A estrutura do filme tem como eixo a narração a partir do olhar de um escocês, que conta, à pequena Yolanda (Ludmila Dayer), as peripécias da vida de Carlota Joaquina. Tal recurso é eficaz ao imprimir um tom anedótico/cômico à narrativa. No início, o escocês pega uma garrafa no mar contendo a mensagem de que "o Brasil é perigoso por causa de suas borboletas gigantes que chupam o cérebro dos humanos" (FIGURA 2). A dupla atuação da atriz mirim como a menina que ouve a história e a protagonista quando 'infanta' reforçam a ideia de que se trata de uma versão fantasiosa, em que a criança se imagina na própria história a ela contada.

Figura 2 - O escocês (Brent Hieatt) descreve o Brasil a Yolanda (Ludmila Dayer) 


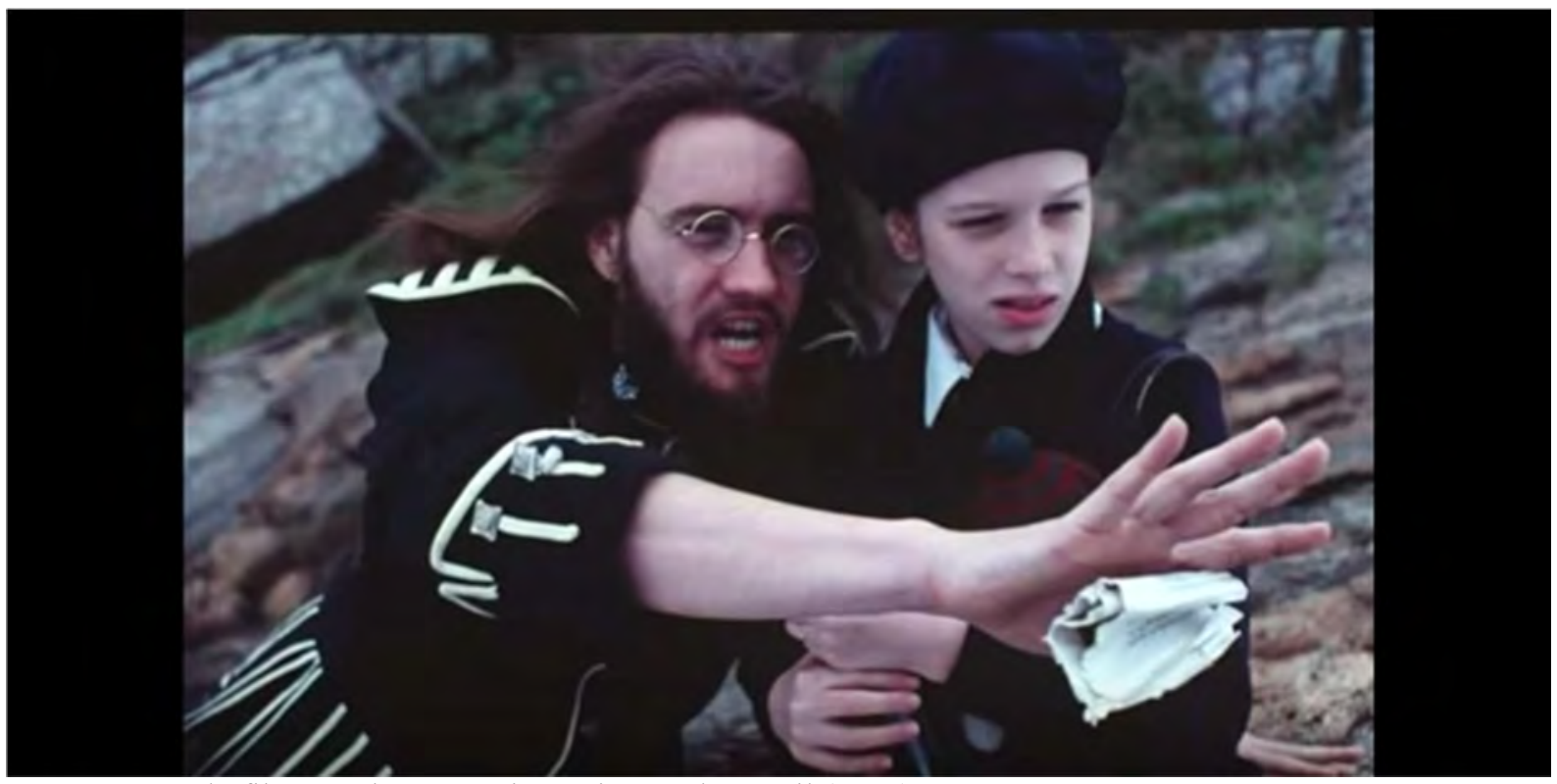

Fonte: Frame do filme Carlota Joaquina, princesa do Brasil (1995).

Ouvinte das indagações de Yolanda, o estrangeiro, em voz in ou over ${ }^{5}$, além de narrar a vida da princesa, desde a infância na corte espanhola até a movimentada vida adulta no Brasil, intervém com comentários, em seu inglês com sotaque escocês, enquanto ambos contemplam o mar europeu. O tom didático e redundante da narração em relação à imagem ou aos diálogos entre os personagens históricos, notável em várias passagens, também colabora para a sátira.

Este foi o primeiro longa-metragem de André Abujamra como compositor, e sua trilha musical cumpre papel importante no enredo, em diálogo com os excessos observados na linguagem. Como observaremos na análise fílmica a seguir, ela, além de localizar a narrativa no tempo e no espaço, revela o estado interno dos personagens e fornece elementos de ironia e de humor por meio do contraste ou do reforço excessivo em relação à imagem. Assim ocorre também com as demais peças musicais preexistentes utilizadas no filme.

$\mathrm{Na}$ primeira sequência há um solo de gaita de fole ${ }^{6}$, acompanhado de uma base eletrônica de cordas, sobre diferentes planos do mar, contextualizando poeticamente a história no período das grandes navegações. Sobre a música entra uma voz over masculina que fala, em

\footnotetext{
${ }^{5}$ Segundo Chion (2004), voz in é aquela que intervém na imagem, demonstrando sua materialidade em relação ao espaço narrativo ao ser associada a um rosto ou a um corpo; enquanto a voz over, conhecida no Brasil como 'a voz de Deus', é a voz 'sem corpo' que comenta ou informa o espectador. Conforme Bordwell e Thompson (2013), o equivalente ao som/voz in de Chion seria o som/voz on (on-screen, cuja fonte aparece na tela). O sentido do som/voz over é abordado por ambos os autores, com a diferença de que adquire uma especificidade maior em Bordwell e Thompson (não diegético) em contraposição ao som diegético off (off-screen), enquanto Chion trata os sons off (tradução francesa) e over (tradução americana) como similares e referentes a sons sem correspondência corpórea na imagem, diegéticos ou não (definição mais abrangente).

${ }^{6}$ Em entrevista concedida por Abujamra ao SESC TV (2013), ele conta que fizera uma gravação em Portugal, de um marinheiro tocando gaita de fole, e experimentou timbres em conjunto, o que originou a peça em questão.
} 
espanhol, sobre o mundo misterioso que o além-mar reserva. A presença do timbre da gaita de fole - instrumento popular na Escócia, na Irlanda, em Portugal e em outros países onde é presente a tradição musical celta, situa geográfica e culturalmente a narrativa, que se desenrola, nas sequências seguintes, a partir da versão de um escocês.

A harmonia tonal crescente em modo maior da música, agregada ao som das ondas quebrando nas rochas e à voz motivadora do desbravador espanhol, cria a atmosfera de que uma grande aventura está em curso - eloquência romântica que será quebrada ao longo do filme por meio da apresentação de personagens grotescos e/ou desprovidos de coragem que em nada lembram os 'heróis do descobrimento'. Ainda na abertura, o som do mar é substituído por música percussiva, que adere ao tema de abertura em menção à cultura dos povos africanos colonizados por Portugal, matriz fundamental da cultura brasileira.

Quando o narrador introduz a história de Carlota Joaquina a Yolanda, o nome da princesa é pontuado pela entrada da trilha orquestral de Abujamra. $\mathrm{O}$ uso de cordas e metais, o andamento alegre e o modo menor inspiram uma atmosfera, ao mesmo tempo, de realeza e de fantasia, convergente com a imaginação de Yolanda - que passa a se ver como Carlota Joaquina criança. Quando a princesa é apresentada, está vestida em vermelho - como passará a maior parte do filme -, dançando flamenco, em postura altiva (FIGURA 3). A música, então, adquire frequências mais agudas, demonstrando a aparição de novas informações na imagem e a já forte personalidade da pequena Carlota.

Figura 3 - Caracterização de Carlota Joaquina na infância 


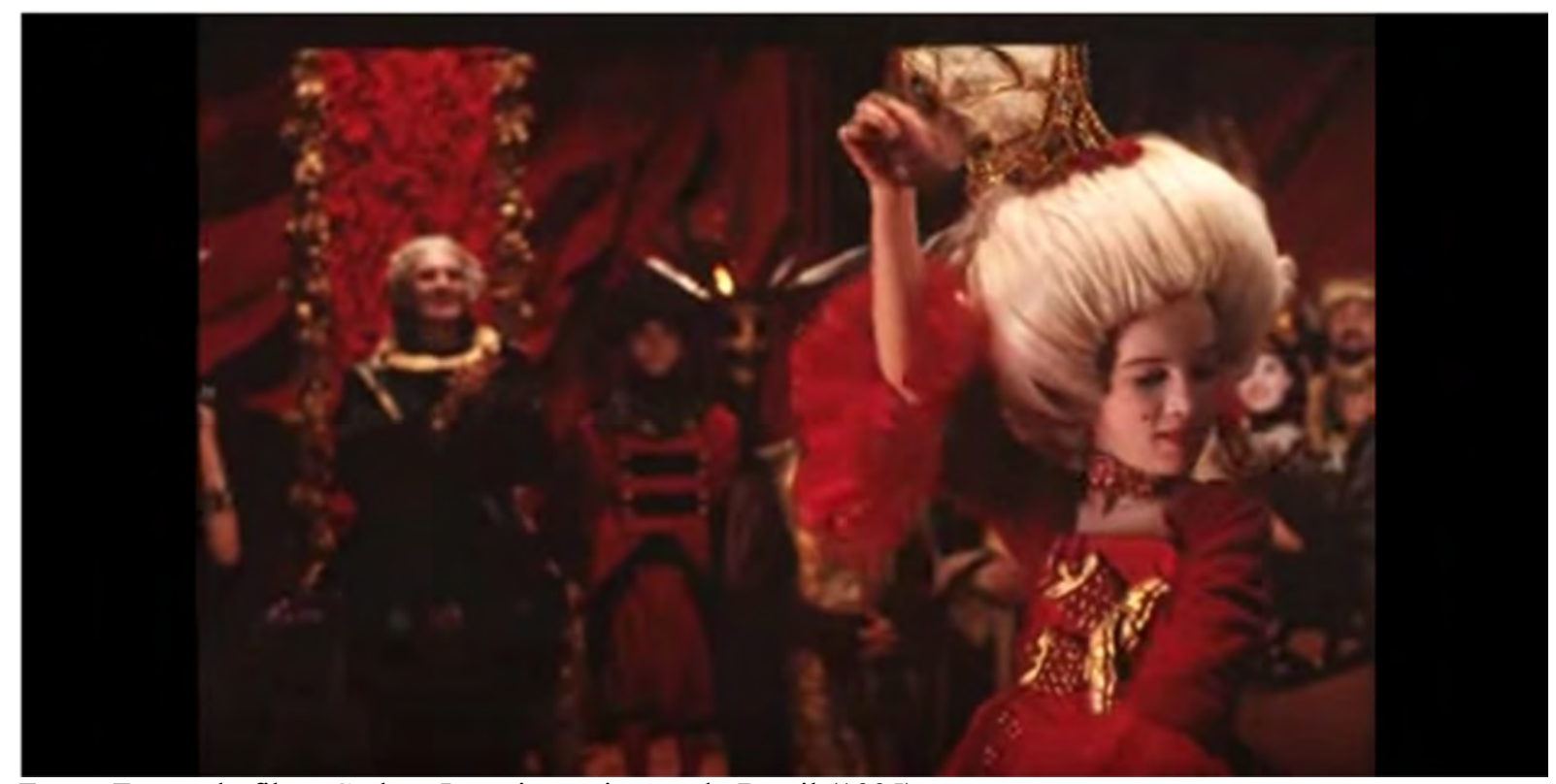

Fonte: Frame do filme Carlota Joaquina, princesa do Brasil (1995).

A música flamenca chega até o espectador pela primeira vez por meio da imagem: a personagem se movimenta tocando castanholas (cujo som não é ouvido), rodeada pela câmera, enquanto o que se ouve é a continuação da trilha original e a voz do narrador informando, em over, o cenário político que envolvia o reino espanhol. Após esta intervenção, a música extradiegética de Abujamra dá lugar ao som diegético das guitarras flamencas, sobre imagens de violões ornamentados e, em sequência, sendo tocados por músicos, sob a reação animada da corte (som direto). As castanholas que não soavam no início da sequência são finalmente ouvidas, com sincronia imperfeita em relação aos gestos da princesa. A câmera revela a corte num giro pelo salão, aplaudindo Carlota ao final da dança.

Diante dos elogios aos dotes artísticos e à inteligência princesa, o narrador intervém de forma redundante, reforçando que 'ela sabia tudo', ao que se segue um 'ohhhh!' exageradamente reverberado dos presentes, também redundante, em alta intensidade e em várias alturas e tempos diferentes. Não se ouve a voz da princesa, que ainda fala. À manifestação espontânea da corte se seguem aplausos; a câmera continua girando e mostrando ora a brilhante princesa, ora seus súditos a admirá-la. O exagero sonoro desta cena, em artifícios e reforço de sentido, demonstra a postura crítica e bem-humorada adotada pela diretora em todo o filme.

Após este parêntese sonoro, nova música de Abujamra, de sonoridade notadamente hispânica - presença da castanhola, contratempos rítmicos, palmas e sapateado dos dançarinos reforçando o andamento -, é ouvida a partir da continuidade da festa. Não se ouvem o som ambiente e as vozes, a não ser na música, quando esta aumenta de intensidade, acompanhada 
pela evolução da dança e da câmera na mão. A música fica ainda mais intensa ao sofrer modulação (mudança de tom). Os demais membros da corte começam a dançar quando a instrumentação se adensa em textura e vozes líricas surgem em vocalização, enquanto a princesa passeia pelo salão. Nesta sequência de mais de dois minutos, a cultura tradicional da realeza espanhola é conhecida, sobretudo por meio da trilha musical original do filme e dos elementos visuais que a ela remetem (dança, figurino, objetos de cena) (FIGURA 4). "Tinha bastante coisa de orquestra, bastante coisa tradicional espanhola [...]. Fiz uma pesquisa bem grande de música erudita daquela época, [...] e tentei 'abujamrar”” (ABUJAMRA, 2013).

Figura 4 - Elementos visuais da sequência remetem à cultura espanhola

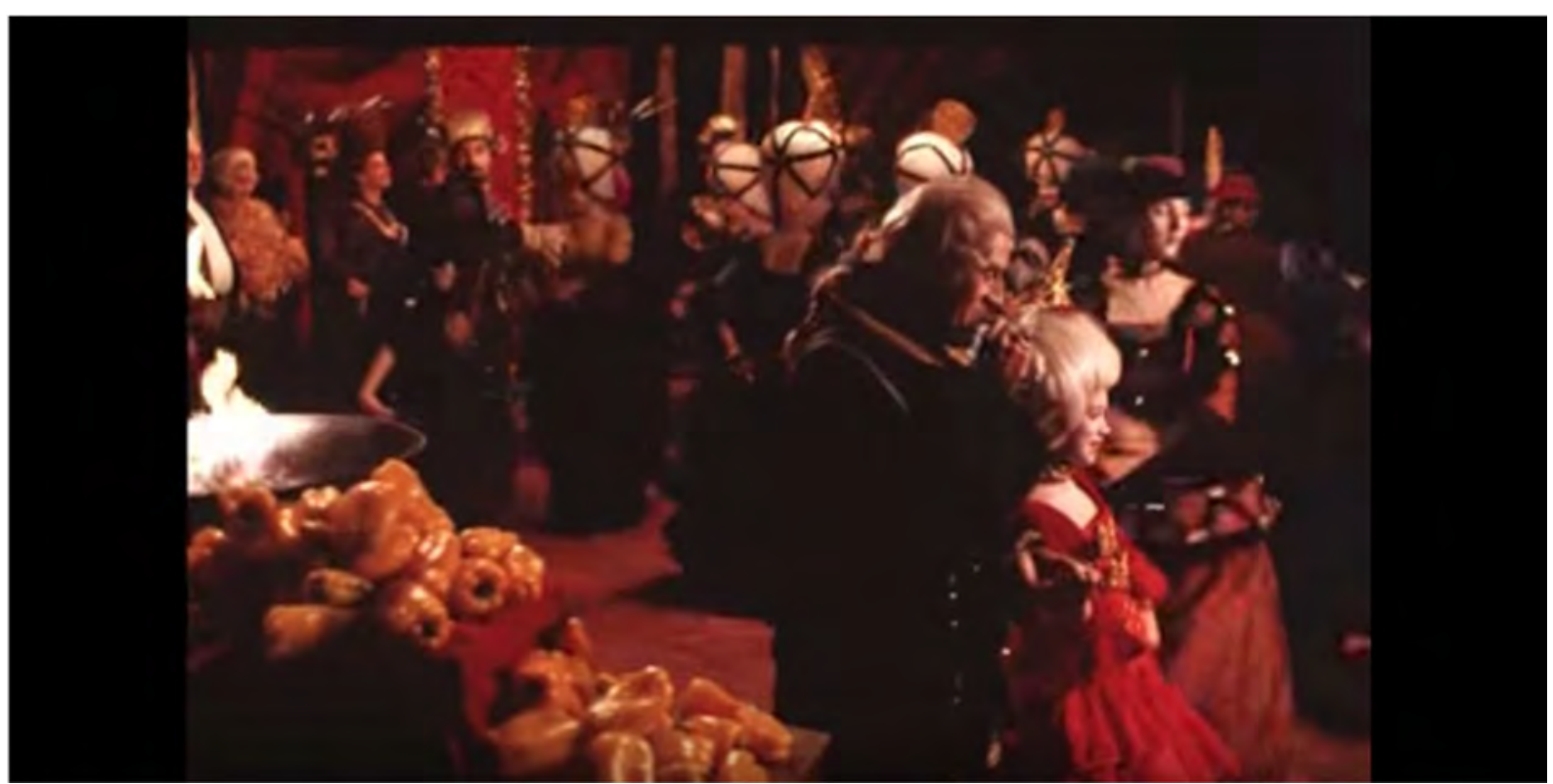

Fonte: Frame do filme Carlota Joaquina, princesa do Brasil (1995).

O trabalho do compositor também pode ser ouvido na sequência da despedida de Carlota da Espanha, a caminho de Portugal para se casar, ainda criança, com o príncipe Dom João (Marco Nanini). Ao mesmo tempo melancólica e de caráter marcial, a trilha sugere a inevitabilidade da 'missão' a ser cumprida pela princesa; as frequências agudas dos instrumentos de sopro e de cordas podem ser uma referência à infância e, as graves, às precoces obrigações adultas da vida real. A música a acompanha durante a despedida do avô e toda a viagem de carruagem até seu triste destino.

Trombetas extradiegéticas soam quando o cocheiro anuncia a presença de Dom João. A formalidade da breve inserção musical contrasta com a feiura da cabeça do príncipe adentrando a carruagem para dar boas-vindas (FIGURA 5). 
Figura 5 - Dom João dá boas-vindas à princesa

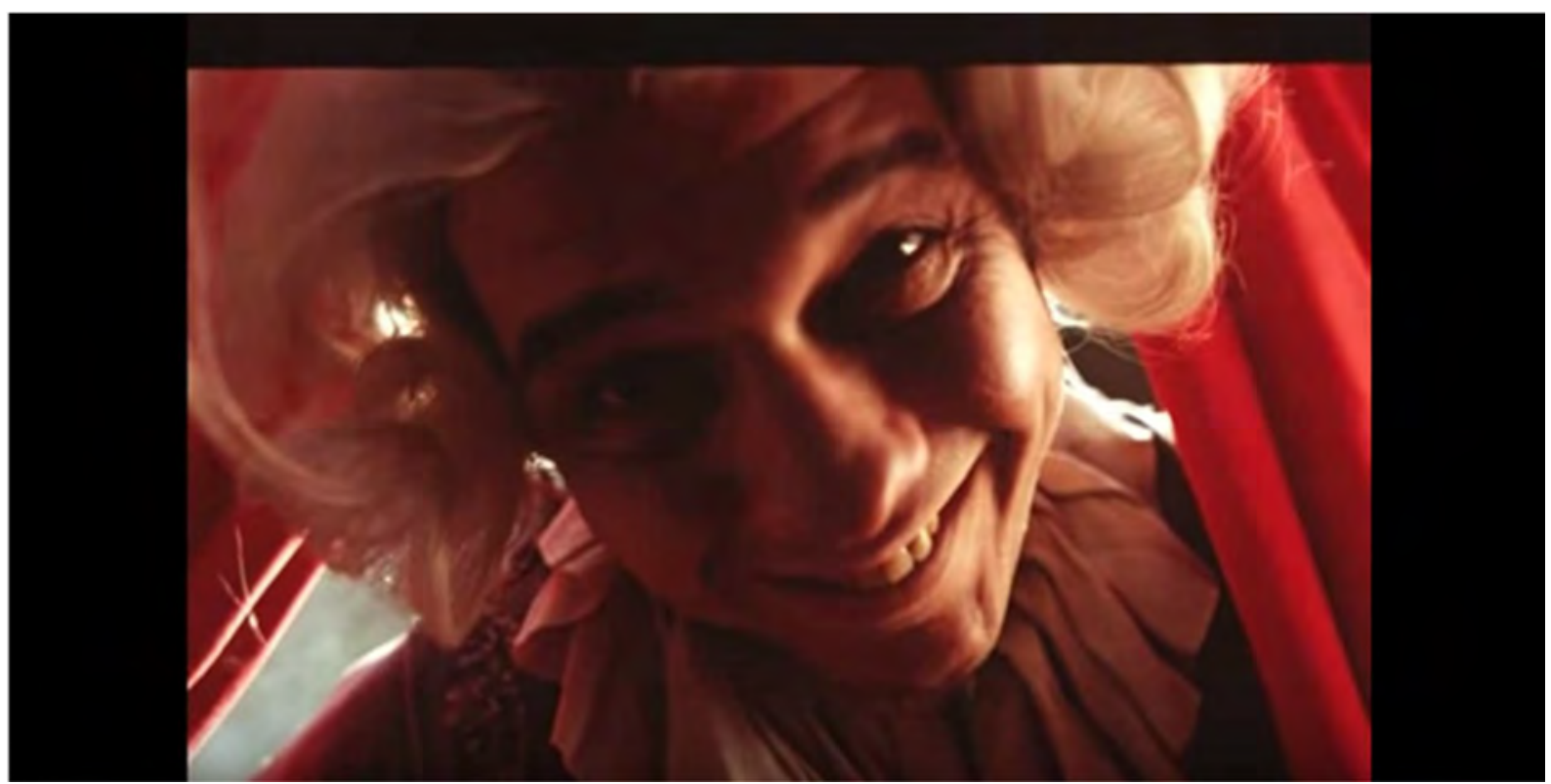

Fonte: Frame do filme Carlota Joaquina, princesa do Brasil (1995).

Ele aparece com a voz desacelerada e reverberada (que destaca sua torpe figura), enquanto ela, sorrindo com os dentes podres, contempla o noivo, decepcionada e com vontade de voltar para a Espanha (FIGURA 6).

Figura 6 - Carlota Joaquina se decepciona ao conhecer Dom João

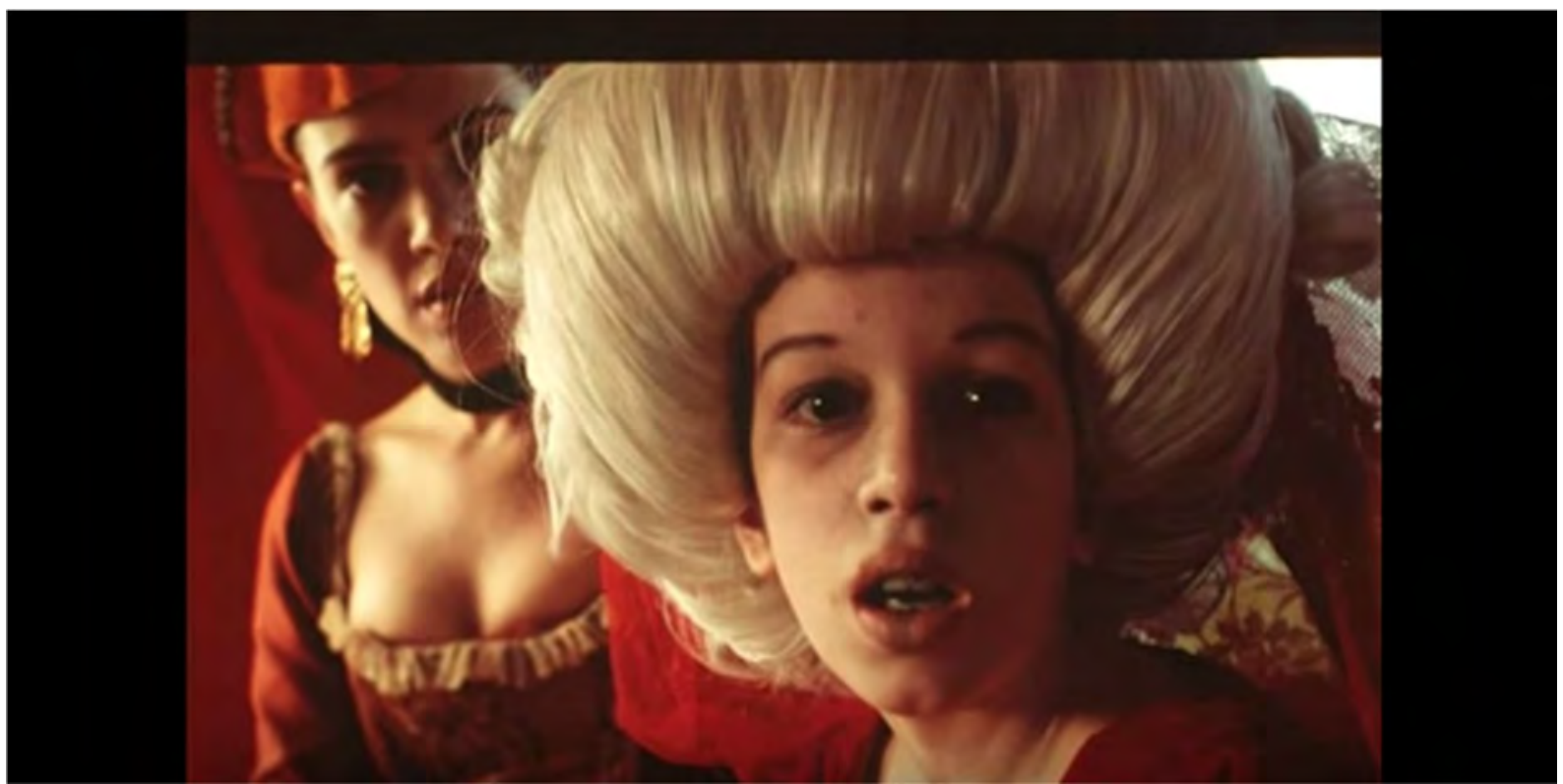

Fonte: Frame do filme Carlota Joaquina, princesa do Brasil (1995).

No entanto, esperava-a um quarto cheio de pompas e presentes da corte, com destaque para a inesperada presença de um pônei vivo. A ausência de música neste ponto, combinada às 
pausas entre as lentas falas em espanhol da princesa e sua ama Francisca (Bel Kutner) e com a grotesca imagem de um pônei no quarto real gera um estranhamento, assim como o fato de a menina falar palavrão (“carajo, Francisca!”).

A voz do narrador retorna e, com ela, a música extradiegética - desta vez com menos texturas e em um andamento mais lento, com solo de clarineta e harmonia em cordas suaves (violino, viola, violoncelo) sobre imagens da corte portuguesa. O narrador fala sobre a recepção à princesa e às diferenças entre os reinos. Ao contrário da corte espanhola, representada por muita música, dança e festejos alegres, a portuguesa é representada por um grupo triste e sussurrante à mesa - o que é justificado pelo narrador pelo fato de o rei de Portugal estar à beira da morte -, acompanhado por um pequeno conjunto de músicos que 'anima' o jantar com uma performance não sincronizada à música que se ouve (FIGURA 7).

Figura 7 - Corte portuguesa apresentada na sequência do jantar

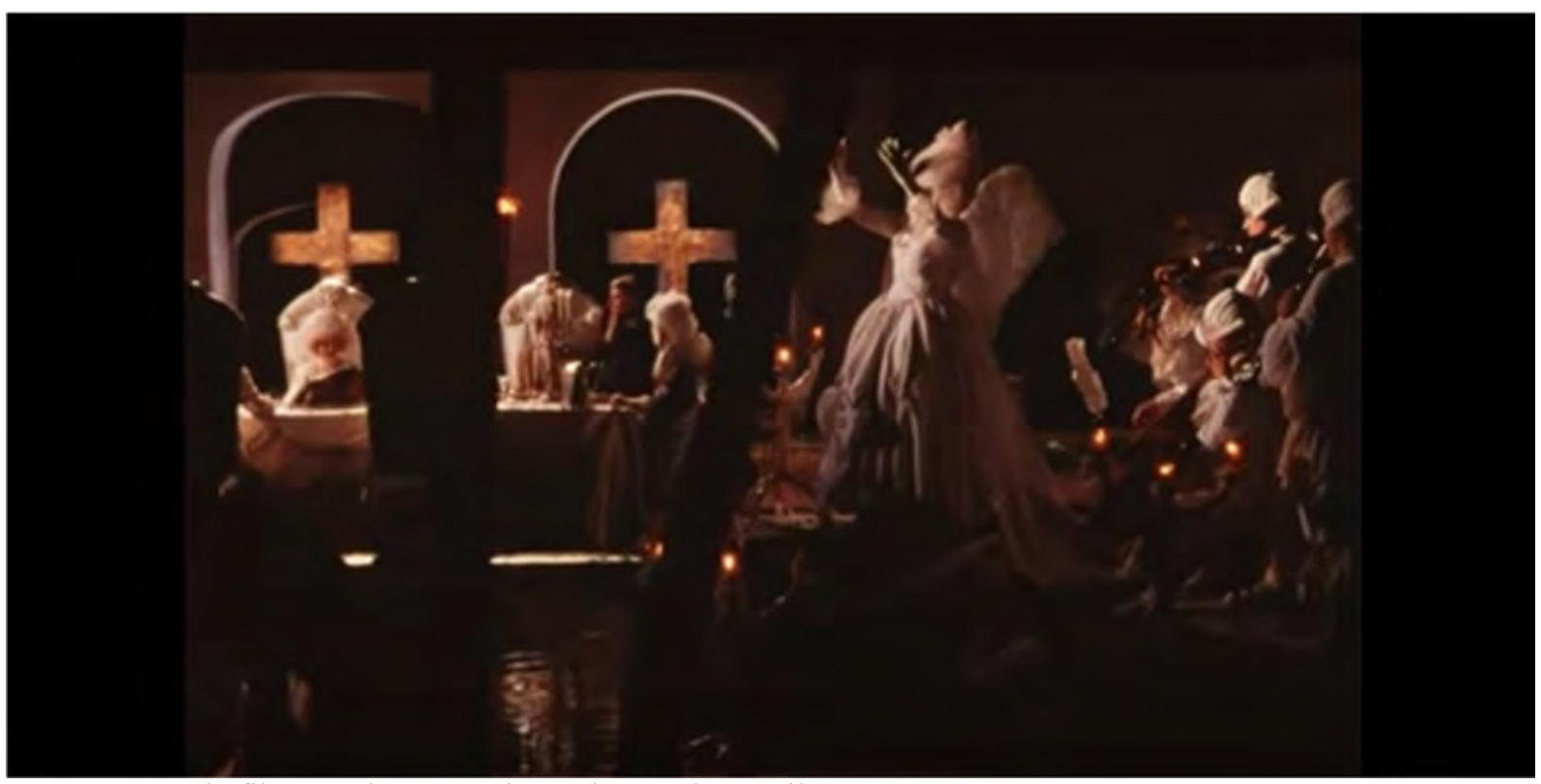

Fonte: Frame do filme Carlota Joaquina, princesa do Brasil (1995).

Considerando os sons de talheres, mastigação, deglutição, escarros, arrotos e flatulências inseridos na cena, o som mais entusiasmado é o do marreco que foge de alguém ao lado da mesa. A trilha aglutina esses e outros sons intensos de pássaros, em ironia construída no contraste com a suavidade da música em relação à imagem e aos demais elementos sonoros, apesar de a cena se passar no salão de jantar (interna). Em determinado momento a música cessa e, após uma pausa, volta a soar do início, como um loop, demonstrando o tedioso, grotesco e triste cotidiano da corte portuguesa.

A música prossegue quando Dona Maria, rainha de Portugal, aparece vestida de anjo, 
com ares de louca, ao redor dos músicos (clarinetista, violinista, violoncelista). A imagem revela as fontes sonoras que justificam a trilha musical como diegética. A suavidade dos instrumentistas, todos com figurino branco, contrasta com a cena grotesca e a representação bizarra da corte.

Em nova sequência, ouve-se a tradicional Marcha nupcial de Mendelssohn, em alta intensidade. No primeiro plano, em frente à cama onde está o rei moribundo e a rainha, o padre celebra o casamento de Carlota e Dom João (FIGURA 8).

Figura 8 - Casamento de Carlota Joaquina e Dom João

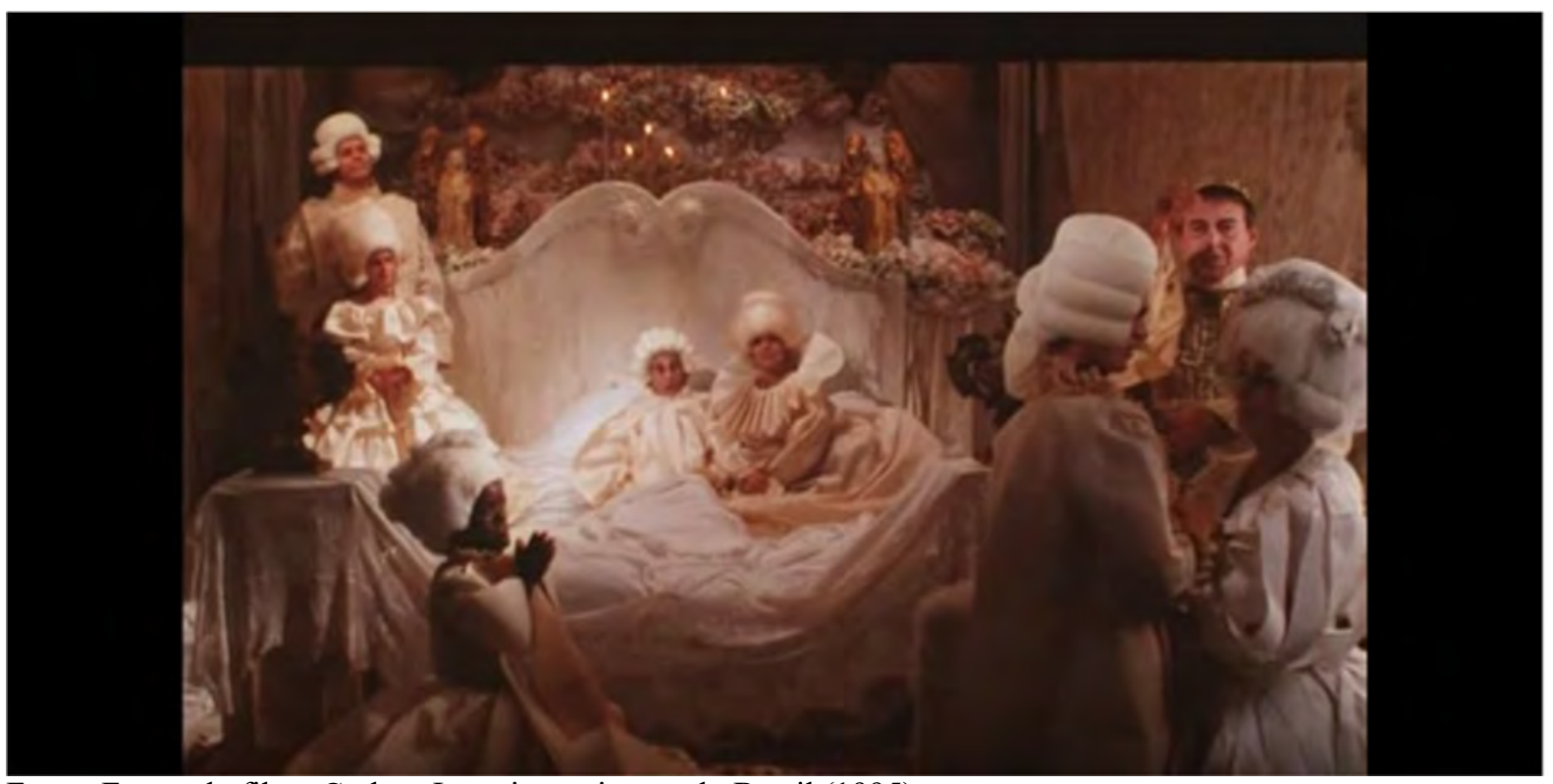

Fonte: Frame do filme Carlota Joaquina, princesa do Brasil (1995).

Apesar de o jovem casal estar mais próximo à tela, é o casal deitado sobre a cama que chama a atenção. Outro elemento interessante é que não somente a princesa, mas todos no quarto estão de branco, assim como são os lençóis e os outros objetos de cena. A câmera deixa os recém-casados para fechar o plano (zoom in) no casal idoso na cama e logo faz um movimento ascendente, mostrando as flores claras e a imagem de Cristo nu carregando sua cruz. A imagem fica centralizada na tela ainda acompanhada pela Marcha nupcial, que colabora para a morbidez e ironia da cena, assim como a intervenção seguinte da pequena Yolanda na narração do escocês, em tom didático, provando que, apesar da pouca idade, sabe o que acontece quando se casa: “o homem introduz seu pênis na vagina da mulher”. Ao que o narrador responde: "Yes! Yes! Yes, Yolanda...", aludindo a uma relação sexual, ação presente em diversas ocasiões na narrativa e que contribui para o estereótipo do Brasil como um país 'quente'. 
A cruz que finaliza a sequência do casamento de Carlota abre uma sequência posterior, desta vez com o som grave de um sino, anunciando a morte do rei. Os elementos da cena, completamente brancos para o casamento, aparecem manchados de preto, uma forma também grotesca de demonstrar o luto da corte, em contraste com a alegria mórbida do casamento (FIGURA 9).

Figura 9 - Corte portuguesa vela o rei

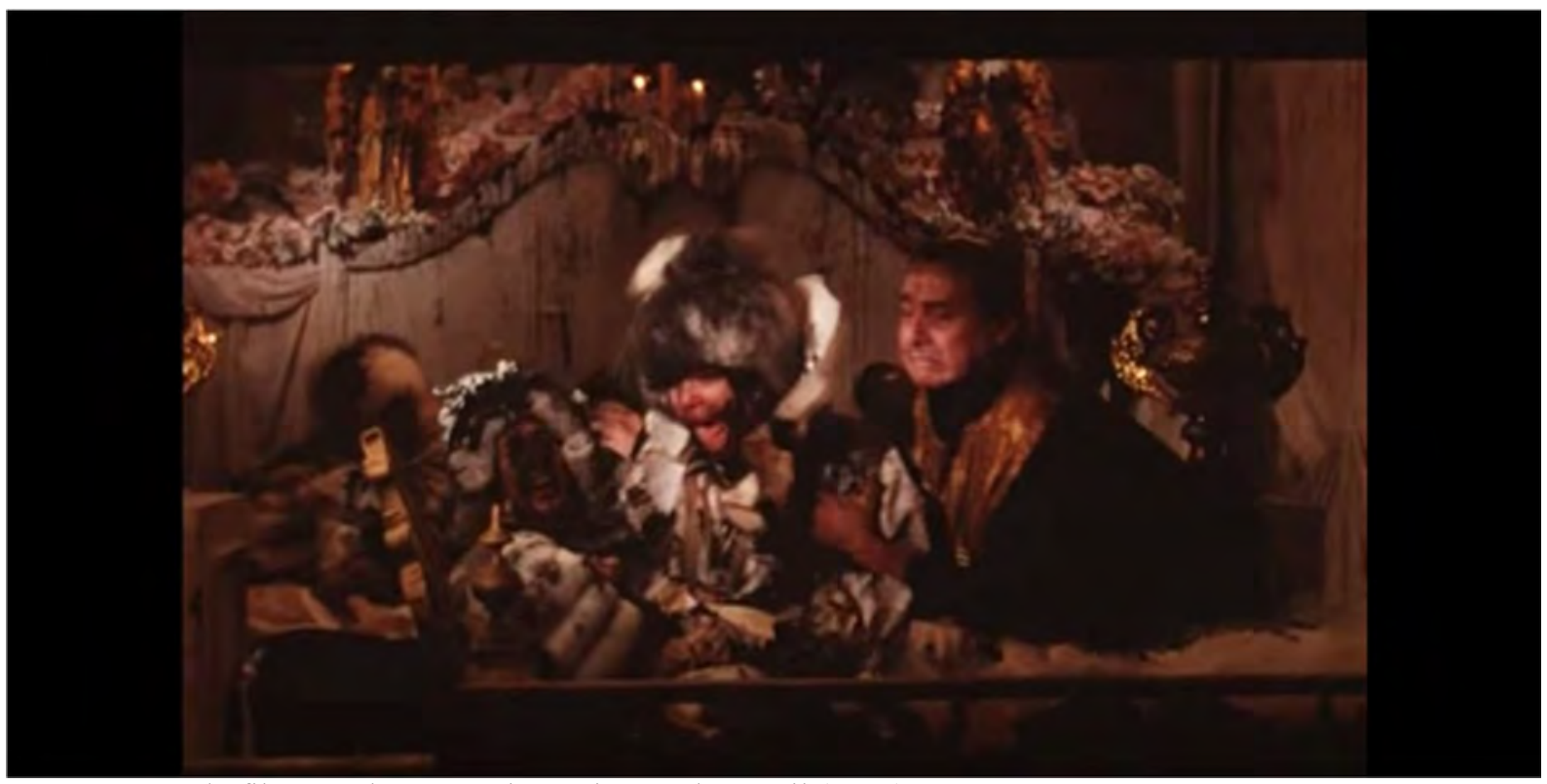

Fonte: Frame do filme Carlota Joaquina, princesa do Brasil (1995).

A música extradiegética que acompanha a cena é orquestral, densa e grave, e soa em segundo plano, atrás dos gritos desesperados da rainha Maria I. A música aumenta de intensidade quando a rainha acompanha a procissão de cruzes com os membros do clero, todos de preto (câmera na mão, imagens de brasões e de Jesus amarrado a cordas), e sai em fade out quando um novo plano mostra o quarto de Carlota, onde ela e a ama brincam encenando um animado teatro de fantoches em meio ao luto geral (humor).

A música flamenca reaparece no quarto da princesa. Carlota dança para alegrar a rainha louca, que entra gritando no aposento alegando estar sendo perseguida. Uma ama toca violão; a outra dança com a menina, tocando castanholas. Aqui a sonoridade hispânica diegética serve ao humor, por contrastar com o luto pela morte do rei e com a loucura da rainha, além de reforçar a forte personalidade da princesa, cujas vontades não poderiam ser contrariadas, sob pena de violentas punições. Um padre interrompe a música diegética, alertando sobre a doença da rainha, e com ela sai rezando, seguido dos fiéis. Tal interrupção também gera comicidade, demonstrando uma divergência de valores entre os desejos da jovem realeza e a austera tradição 
religiosa portuguesa. Quem vence é a princesa, que ordena às amas que continuem a música.

Outra passagem com presença marcante da música hispânica se dá quando Carlota, agora mulher (Marieta Severo), aparece em vestido vermelho, sedenta para consumar o casamento com Dom João. Sua falta de beleza é demonstrada pelo excesso de maquiagem e adereços e pela construção da personagem como um todo. Ela está na penumbra do quarto atrás das cortinas e em primeiro plano e, quando se move em direção à cama, onde Dom João reza (humor), soa uma trombeta, como se estivesse a anunciar um acontecimento importante. Inicia-

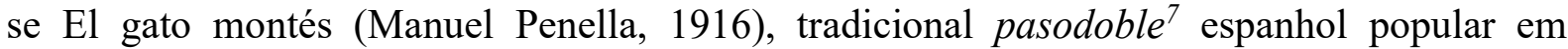
touradas, enquanto o príncipe se cobre, com medo da princesa, cujo figurino lembra a capa de um toureiro (FIGURA 10).

Figura 10 - Carlota Joaquina tenta consumar seu casamento

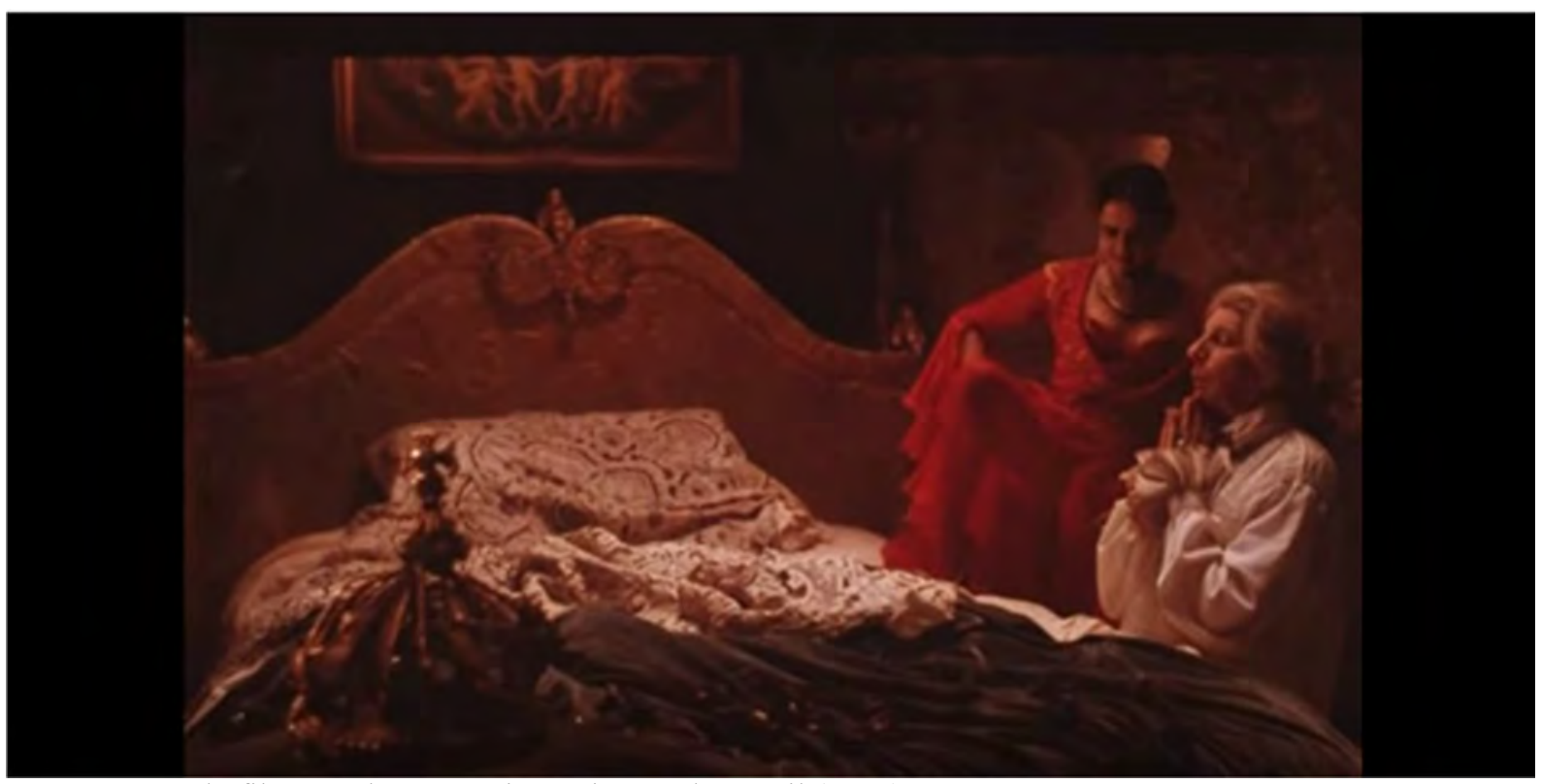

Fonte: Frame do filme Carlota Joaquina, princesa do Brasil (1995).

Carlota aparece, aqui, associada ao touro: a delicadeza e candura esperadas de uma princesa são substituídas pela brutalidade dos gestos e da voz, postura autoritária, sede de sexo e por um vocabulário rico em palavrões. Volta o narrador, enquanto se sucedem imagens de Carlota com seus inúmeros amantes e, em sequência, de seus nove filhos de vários pais.

A trilha original de Abujamra volta a ser ouvida após a voz over do narrador e a junta médica internacional diagnosticarem, de forma redundante, a loucura da rainha, que se encontra deitada, com olhar distante. Vozes femininas que lembram um ritual soam em uma base grave

\footnotetext{
${ }^{7}$ Estilo musical e dança de origem espanhola surgido no século XVI, popular em touradas e desfiles militares.
} 
de sintetizador, com alguns elementos oscilantes, em intensidade crescente - efeito destoante da ambientação histórica e cultural promovida por outros cues da trilha musical original inspirada na música erudita europeia. Na imagem, vê-se um pesadelo da rainha, diante de uma aranha, enquanto a música que representa sua loucura é intensificada (FIGURA 11).

Figura 11 - Pesadelo da rainha diagnosticada como louca

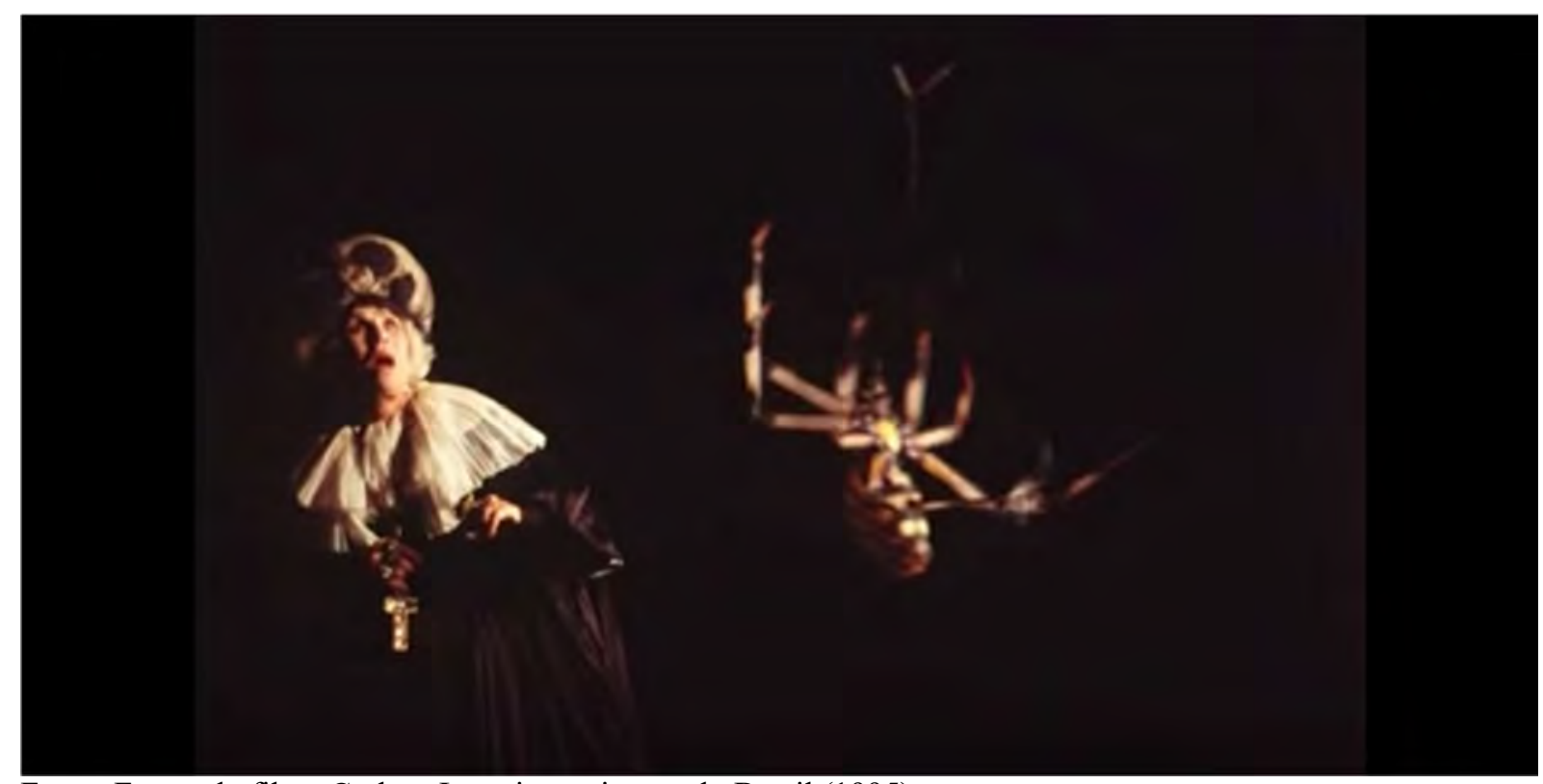

Fonte: Frame do filme Carlota Joaquina, princesa do Brasil (1995).

A trilha é cortada bruscamente junto com a imagem, para mostrar Dom João chorando diante da notícia de que se tornaria o príncipe-regente de Portugal, informação dada pelo narrador. Choro e voz do narrador alternam-se em primeiro plano, evidenciando a covardia de Dom João diante das mais sérias questões do reino.

Nova peça orquestral - Šárka (1875), do compositor tcheco Bedřich Smetana -, com violinos agudos e harmonia tensa em modo menor, é ouvida após a aparição de uma manchete de jornal ('França e Espanha dividem Portugal'), seguidas de imagens do planejamento da fuga da família real portuguesa para o Brasil, simultaneamente ao avanço das tropas de Napoleão, devido ao relacionamento de Portugal com os ingleses, inimigos da França.

Durante os preparativos para a fuga se ouve a Sinfonia $\mathrm{n}^{0} 25 \mathrm{em}$ sol menor (1773), de Mozart, densa peça orquestral em cordas, enquanto Carlota queima suas correspondências com os amantes - à exceção de um pênis de madeira (humor e contraste com a tensão da música) (FIGURA 12).

Figura 12 - Carlota 'salva' o pênis de madeira do fogo enquanto a corte foge 


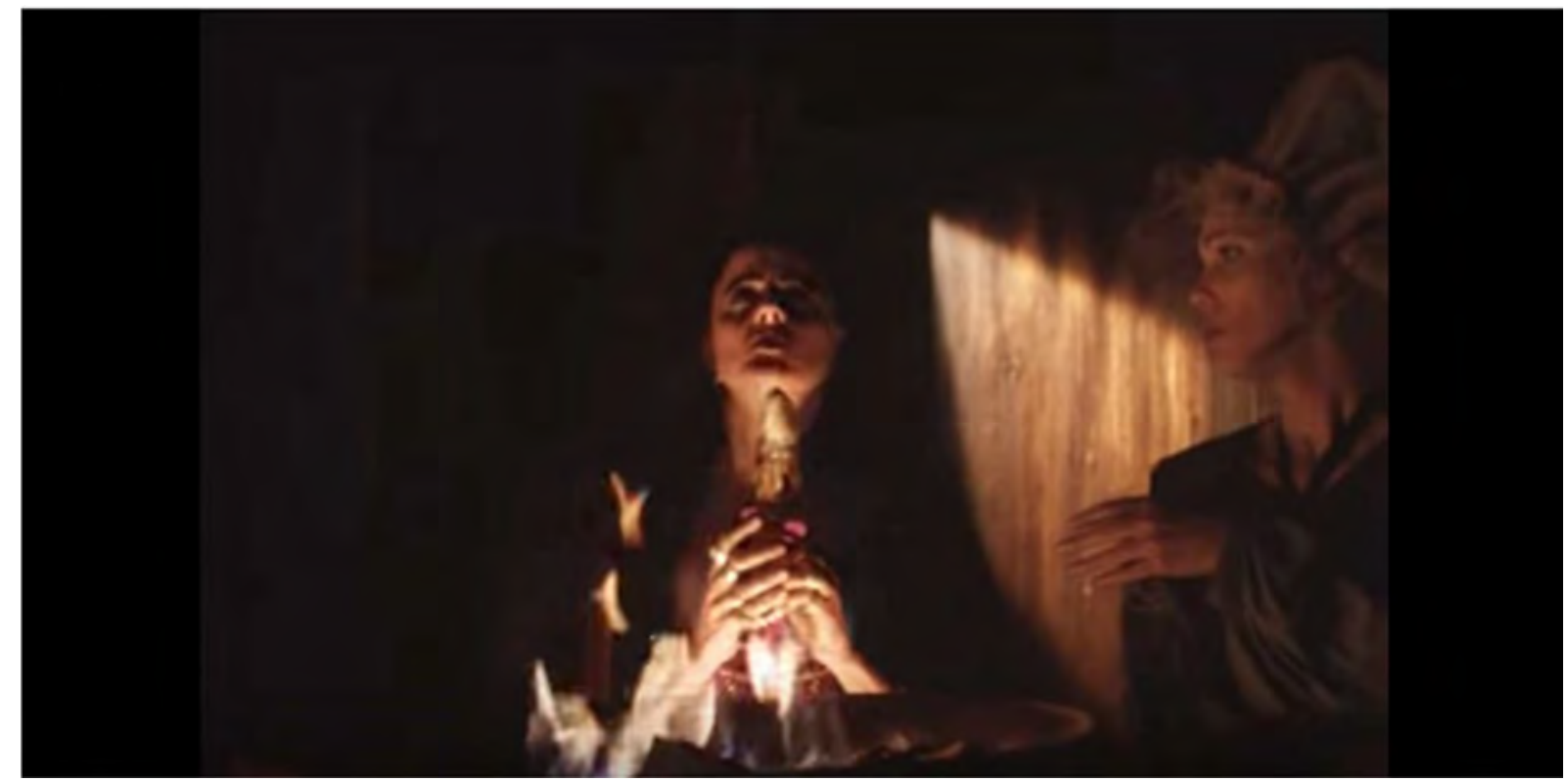

Fonte: Frame do filme Carlota Joaquina, princesa do Brasil (1995).

Raios excessivos no céu escuro e chuvoso aparecem em sincronia com o som exagerado de um trovão, após a menção do narrador (humor pela redundância). A mesma peça de Mozart adquire um ar mais leve com harmonia em modo maior, contrastante com a gritaria e a confusão (ruídos em segundo plano) entre os portugueses que ficam no País, revelados em sua correria pela câmera na mão. A música torna a ficar tensa, como no início da sequência, e tem sua dinâmica desacelerada quando a câmera revela a rua menos movimentada, ao amanhecer.

Quando o narrador se refere ao 'Brasil' como destino da fuga, surge um mapa e uma música grandiloquente, com ares marciais e frequências graves, em modo menor, representando a misteriosa e rica colônia e a saga da família real portuguesa até lá. Carlota xinga para o nada, enquanto Dom João vomita, nauseado, como muitos, com o balanço do navio. A chegada ao Brasil é pontuada sonoramente pelo som de um berimbau - referindo-se à Bahia e à herança cultural africana, em contraste com a aversão de Carlota por negros (informada pelo narrador); pelo ressoar dos sinos e por cânticos de Ave Maria. As sonoridades representativas da Igreja Católica no Brasil são ouvidas misturadas aos sons dos atabaques dos africanos das ruas, demonstrando o sincretismo religioso e cultural da colônia.

Um serviçal toca, no cravo, a peça Fantasia $n^{0}$ 2, de autoria do Padre José Maurício Nunes Garcia (música diegética), enquanto Dom João come. Carlota entra no salão dando a notícia do reconhecimento da corte espanhola ao seu direito às terras do Rio da Prata. Além de ambientar a cena, a música situa o período histórico do Brasil por meio da figura de seu compositor, carioca mulato que atuou no Brasil como mestre da Capela Real sob o reinado de 
Dom João VI, e da Capela Imperial, sob a liderança de Dom Pedro I. Bruscamente a música é substituída pelos gritos de Dom João com Carlota, dizendo que eles não têm dinheiro para expandir seus domínios e que não quer que ela se mude para Buenos Aires com os filhos deles.

Outro momento musical importante é o encontro de Carlota com o seu último e mais querido amante, o negro brasileiro Fernando Leão (Norton Nascimento). Ao som de Tico-tico no fubá (Zequinha de Abreu, 1917) em frequências agudas de flauta, cordas e piano, harmonia orquestral e ritmo percussivo, os dois têm uma tórrida tarde de amor: aqui, Portugal e Brasil literalmente se misturam (FIGURA 13).

Figura 13 - Carlota Joaquina com seu amante, Fernando Leão

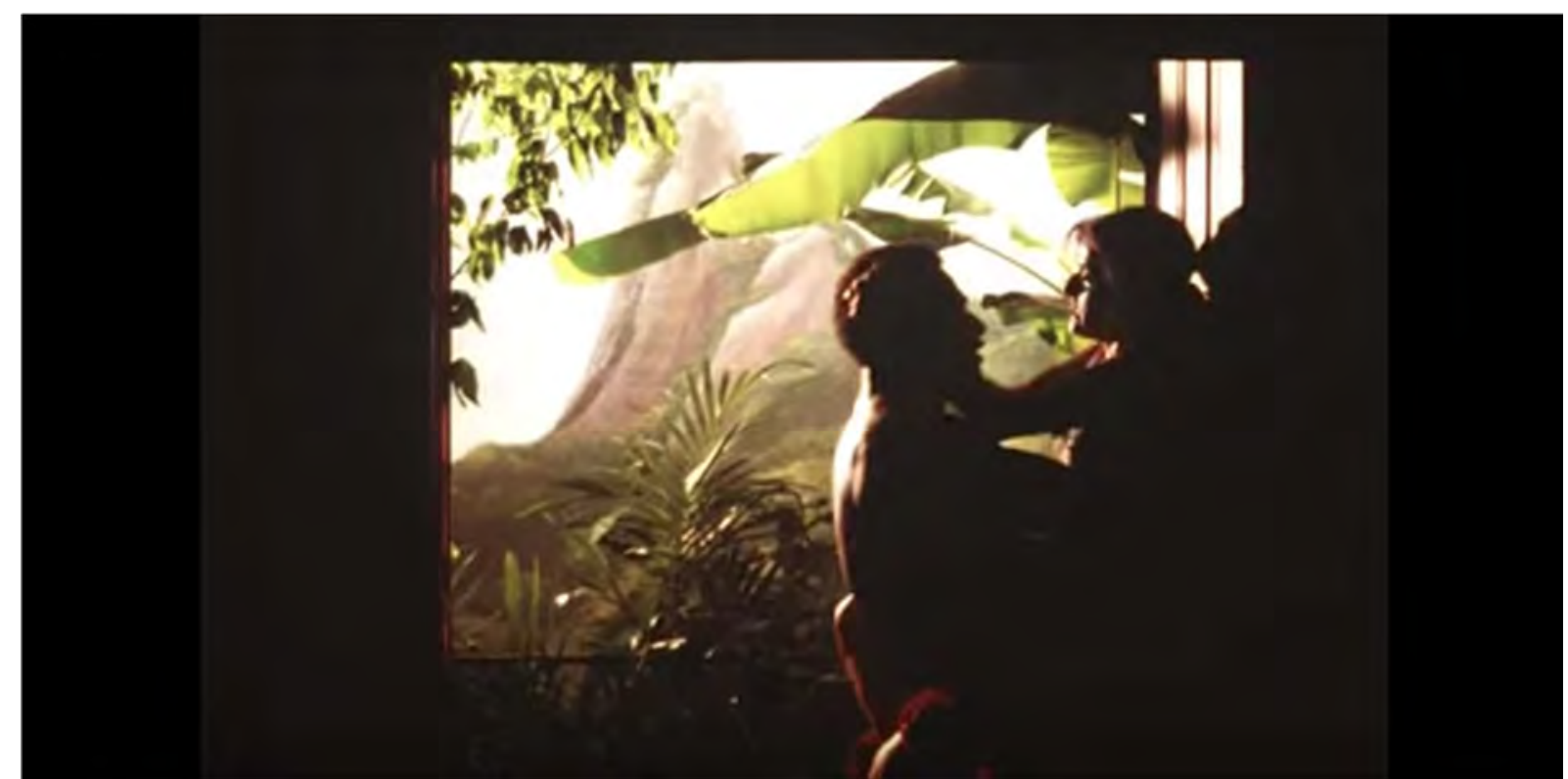

Fonte: Frame do filme Carlota Joaquina, princesa do Brasil (1995).

Destaque para o som excessivamente intenso de pássaros, em primeiríssimo plano sonoro, indicando a exuberância natural do Brasil - que emoldura o quadro e a paixão proibida da princesa. Além da música e do gorjeio dos pássaros, os gemidos de Carlota compõem a trilha sonora da sequência. Em outra cena, enquanto ela lê a carta do amante, o excesso de sincronia entre Tico-tico no fubá - com arranjo de metais e pizzicatos ao violino - e o gorjeio dos pássaros no ritmo da música provocam humor pela revelação da construção de linguagem.

Sons percussivos situam a presença de negros e índios na colônia, seja carregando Dona Maria Louca pela praia, seja nas rodas de capoeira pelas ruas. A morte de Dona Maria é pontuada pela música extradiegética em frequências graves de cordas, em tom solene e fúnebre, enquanto Dom João abraça a mãe, que para de gritar em meio à procissão, com o olhar vago. Ruídos de batida de coração se unem à trilha original de Abujamra. Em outro plano, a rainha 
louca aparece de pé, com expressão perturbada, cobrindo os olhos com as mãos cheias de anéis. Surge um ruído agudo de vozes desconectadas da música, como se fossem ouvidas por ela. As batidas do coração param, confirma o médico. Ouvem-se, então, ruídos de sinos e choro dos presentes, juntamente com a música. O clima triste da trilha sonora contrasta com a expressão alegre e ambiciosa de Carlota, que, enfim, assumirá o trono (FIGURA 14).

Figura 14 - Corte portuguesa vela a rainha Dona Maria Louca no Brasil, sob o sorriso de Carlota

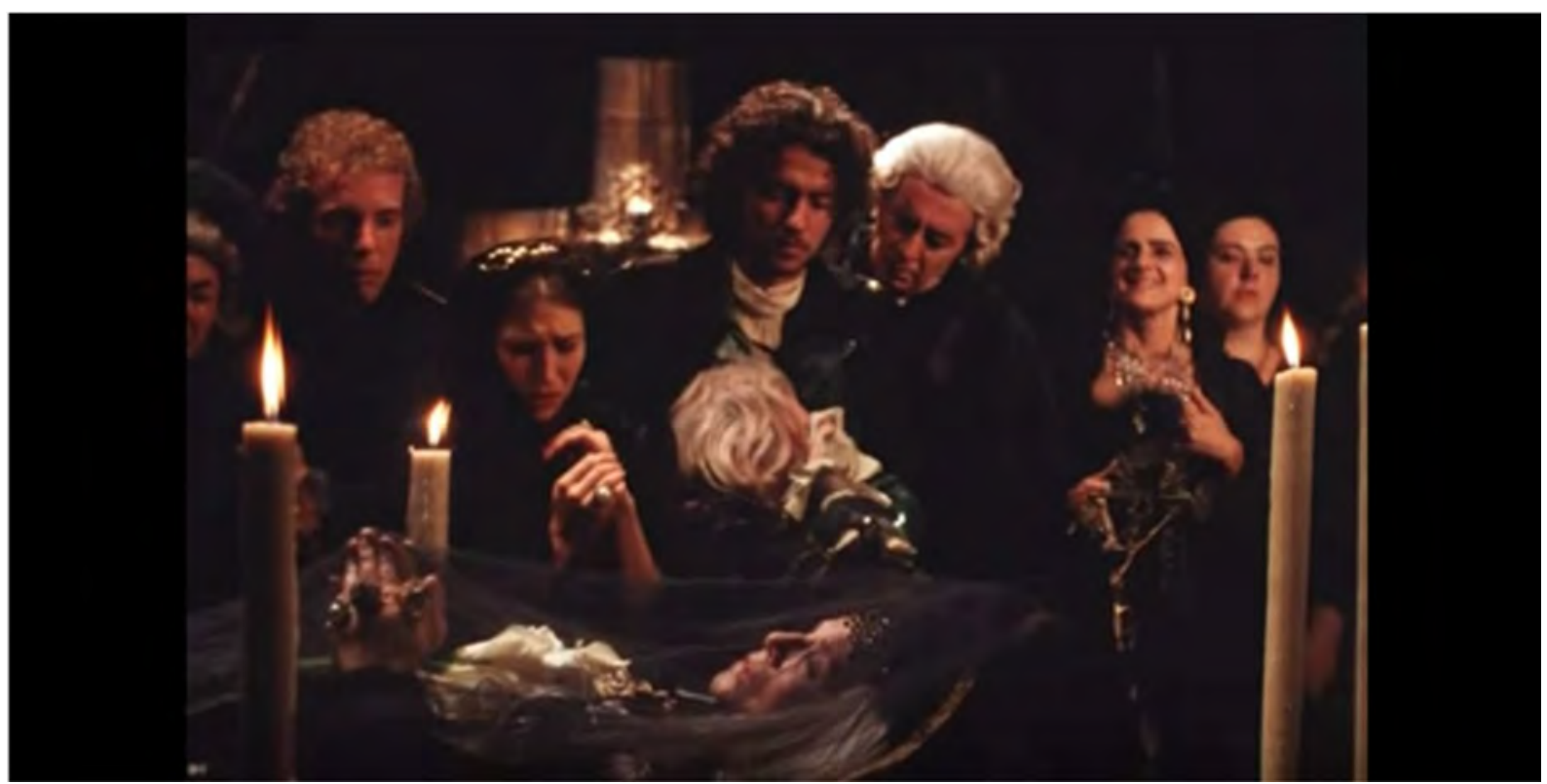

Fonte: Frame do filme Carlota Joaquina, princesa do Brasil (1995).

Diante do luto da corte, Fernando, amante de Carlota, demonstra seus pêsames ao rei, tratando-a com indiferença. Soa, fora da diegese, España cañi (Pascual Marquina Narro, 1921), peça instrumental flamenca que se tornou um ícone da música tradicional espanhola, enquanto Carlota vai atrás do amante como um touro enfurecido. Enquanto o povo chora a morte de Dona Maria, o pasodoble prossegue, confirmando a supremacia das vontades da futura rainha. A música cessa em fade out quando Dom João flagra Carlota declarando seu amor a Fernando; e o diálogo soa cada vez mais reverberado, demonstrando sonoramente o choque do rei pela tardia descoberta da traição. Na imagem, tem-se o close up da expressão de assombro de Dom João, cujo rosto é rodeado pelo escuro, até o fade out (FIGURA 15).

Figura 15 - Expressão de Dom João ao descobrir uma das traições de Carlota 


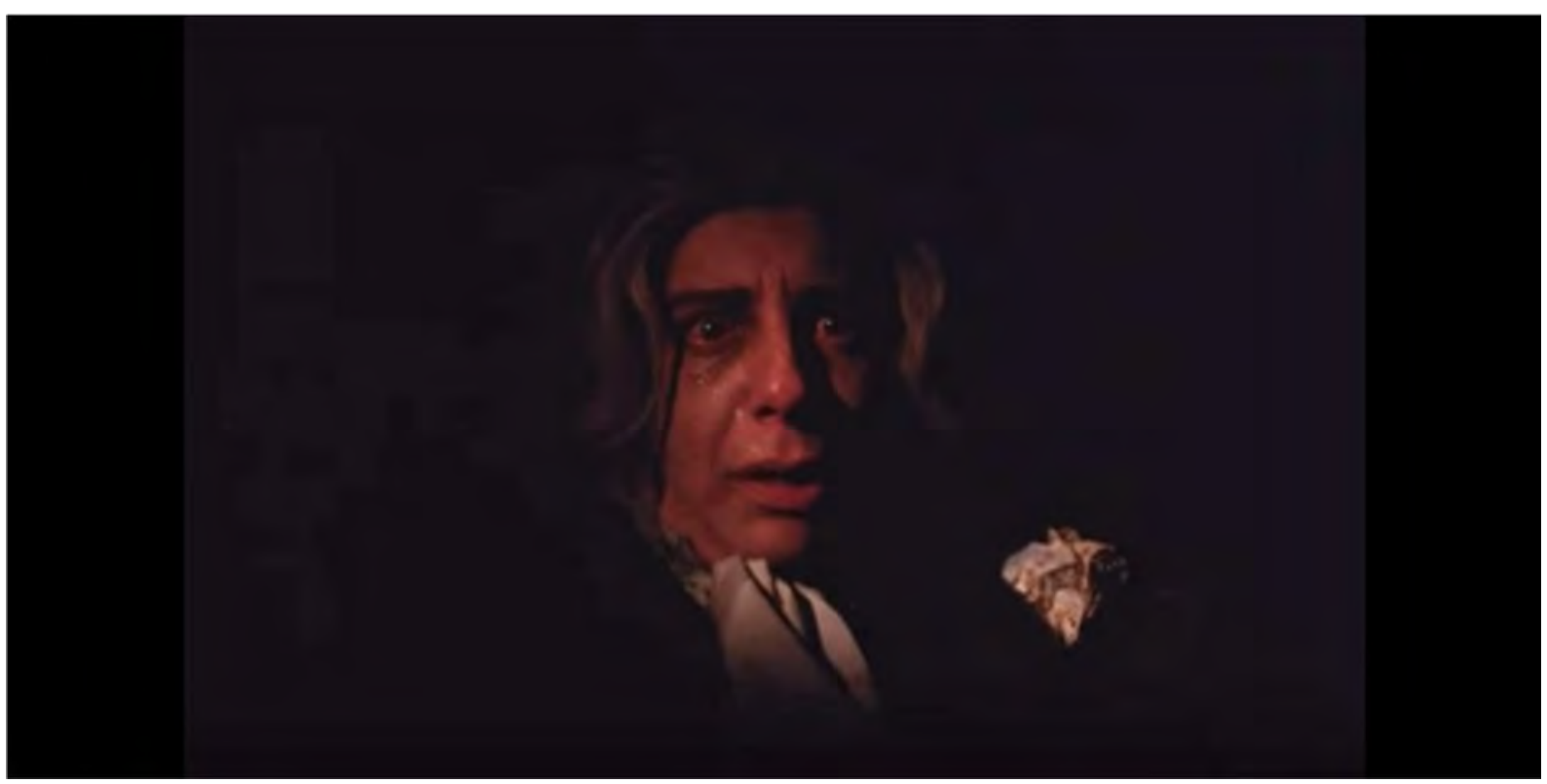

Fonte: Frame do filme Carlota Joaquina, princesa do Brasil (1995).

O fade in para o rosto do rei, sorrindo na sequência seguinte, provoca humor pela montagem. A imagem clareia e Dom João nomeia Fernando presidente do Banco do Brasil, em uma estratégia para mantê-lo ocupado e longe de Carlota.

Trilhas musicais também se fazem presentes na coroação do rei (sonoridade marcial); na tristeza de Dom João ao voltar para Portugal (valsa triste); no afundar dos sapatos de Carlota no oceano, em seu retorno de navio à Europa, devido ao desprezo por ter pisado em terras brasileiras (dedilhados em harpa sobre imagens dos sapatos que se acumulam no fundo do mar) (FIGURA 16).

A trilha musical em harpa prossegue enquanto o narrador conta o desfecho de Carlota que se envenena, exilada nas ruínas de seu próprio palácio na Espanha - e se adensa com metais quando a taça cai e ela começa a engasgar, enquanto a imagem é desfocada e o som de seus gritos são reverberados, sugerindo o suicídio (FIGURA 17). A música continua quando o narrador e Yolanda se levantam, ao final do filme. Ele conta que Dom João morreu no meio de uma sopa de frango, supostamente envenenada (humor). Os dois se despedem da praia, vão embora e a música do início do filme ressurge com a cartela de créditos.

Figura 16 - Carlota lança ao mar os sapatos com que pisou no Brasil 


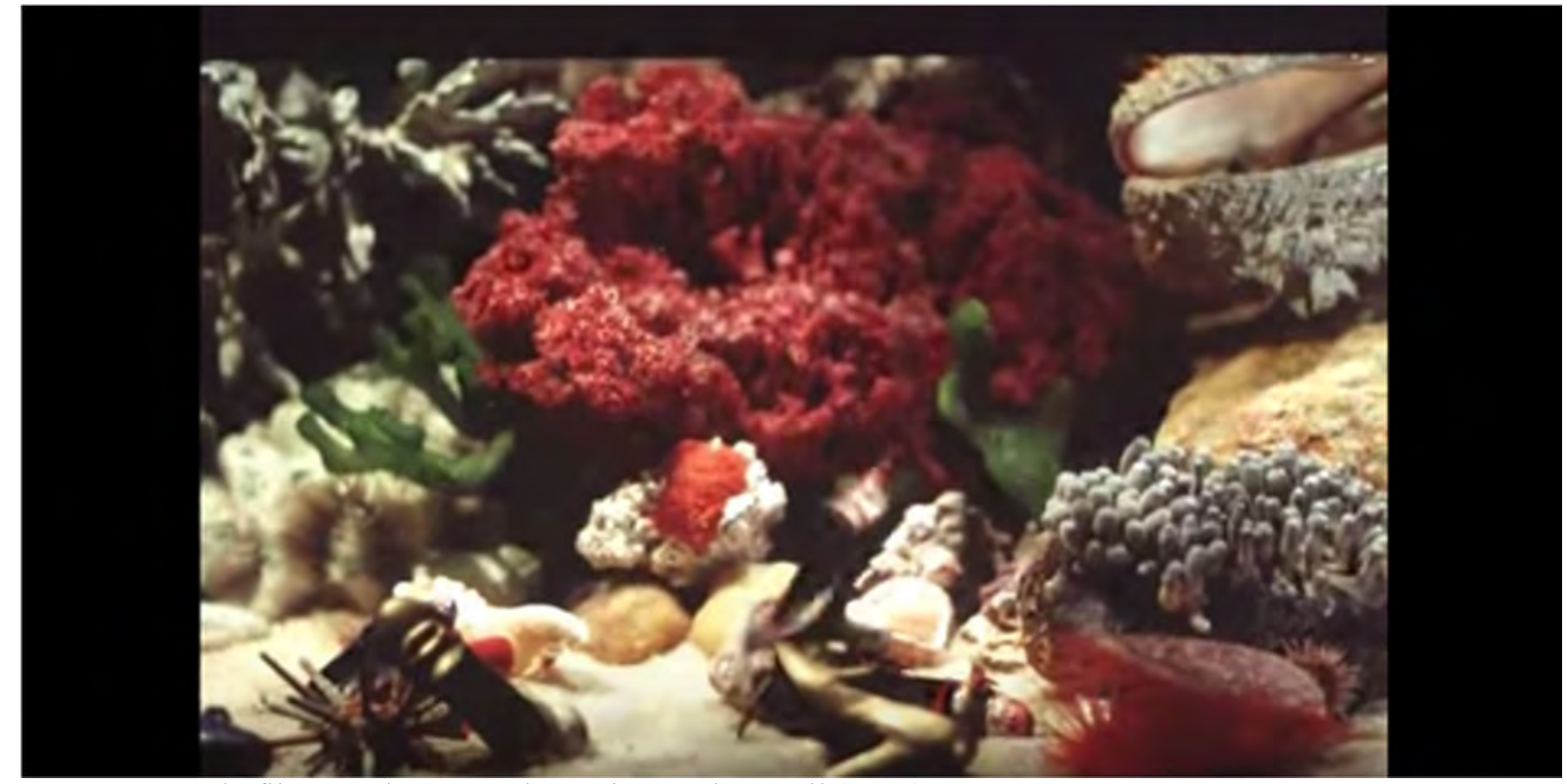

Fonte: Frame do filme Carlota Joaquina, princesa do Brasil (1995).

Figura 17 - Suicídio de Carlota por envenenamento

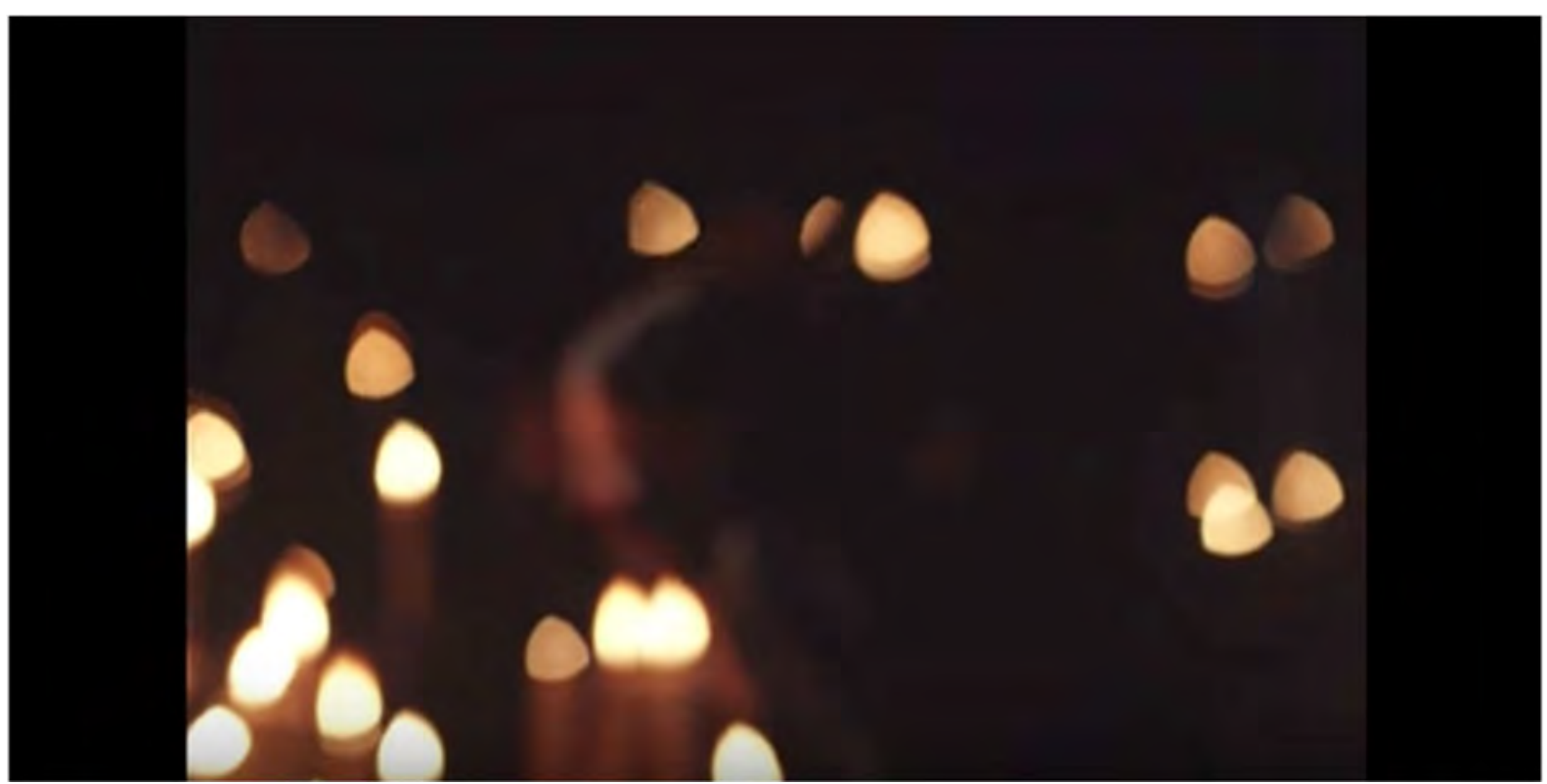

Fonte: Frame do filme Carlota Joaquina, princesa do Brasil (1995).

"Na história, quanto mais se lê, menos se sabe, porque cada um tem sua versão". Esta fala do narrador escocês justifica a abordagem crítica e cômica da diretora Carla Camurati na realização de Carlota Joaquina. O humor provocado pelos estereótipos relacionados ao Brasil permeia, de forma irônica, as indagações extrafílmicas sobre o que é ser brasileiro e fazer arte/cinema no país a partir dos anos 1990, lidando com o fim das utopias, a mundialização da cultura (ORTIZ, 1994) e as incertezas de um país aberto à globalização, no entanto, reticente quanto ao fomento do cinema dentro e além de suas fronteiras. 
Aqui, o europeu vê o Brasil como uma terra misteriosa, cheia de animais peçonhentos e ameaçadores nas ruas - como nos desenhos distribuídos aos conselheiros reais pela rainha Dona Maria; como a terra em que as mulheres imitam o turbante de Carlota, ignorando o fato de que o motivo do adereço era a infestação de piolhos; como o lugar em que os colonos são felizes ao ter suas casas confiscadas para o estabelecimento da corte portuguesa - uma vez que o que vem de fora é sempre melhor e mais atraente; onde a corrupção, a omissão e a conveniência podem transformar personagens preguiçosos e inertes em heróis da independência.

A instância sonora cumpre um papel relevante na construção do perfil do colonizador, seja por meio da representação dos hábitos grotescos da corte portuguesa - sob a forma ruidosa de arrotos, flatulências, vômitos e outros -, seja por meio da redundância - som de bomba explodindo enquanto Dom João lê a carta de advertência de Napoleão Bonaparte - ou dos exageros em sua amplitude - sons intensos de gemidos no sexo; insetos, pássaros e outros bichos, que exaltam os instintos que aproximam homens e mulheres dos outros animais e a fauna e flora brasileiras, ao mesmo tempo em que lembram o ouvinte de que o som e o filme como um todo são representações, visões/audições possíveis do Brasil.

Carlota é a personagem por meio da qual se questiona o papel da mulher na sociedade brasileira desde os tempos da colônia. Ela monta a cavalo, fuma charuto, fala palavrões, enfrenta os homens da corte, tem vários amantes, grande apetite sexual e faz valer suas vontades menos razoáveis. Assim como a imagem - excesso de pelos, vestido vermelho e maquiagem exagerada, o som também colabora para o perfil incomum da princesa no filme, por meio da entonação agressiva de falas malcriadas, dos ruídos que pontuam seus gestos - de gemidos sensuais e golpes mortais de tridente a rugidos de leão e relinchos de cavalo, passando pelo ato desacelerado de cuspir de desprezo ao deixar clara sua recusa em fugir para a colônia (FIGURA $18)$.

O único comportamento que mais a aproxima do estereótipo da mulher comum é o gosto por sapatos - do qual ela abdica, jogando ao mar todos aqueles com as quais ela pisou em terras brasileiras. Dom João, no entanto, é retratado como um bobo da corte, sempre com uma coxa de frango à mão, pulando amarelinha fora do castelo ou apresentando semblante perdido nas reuniões com os conselheiros reais, mas que demonstra alguma esperteza ao conseguir afastar os amantes de Carlota com títulos de nobreza e tarefas reais de grande responsabilidade.

Figura 18 - Carlota cospe de desprezo pela ideia de fugir para o Brasil 


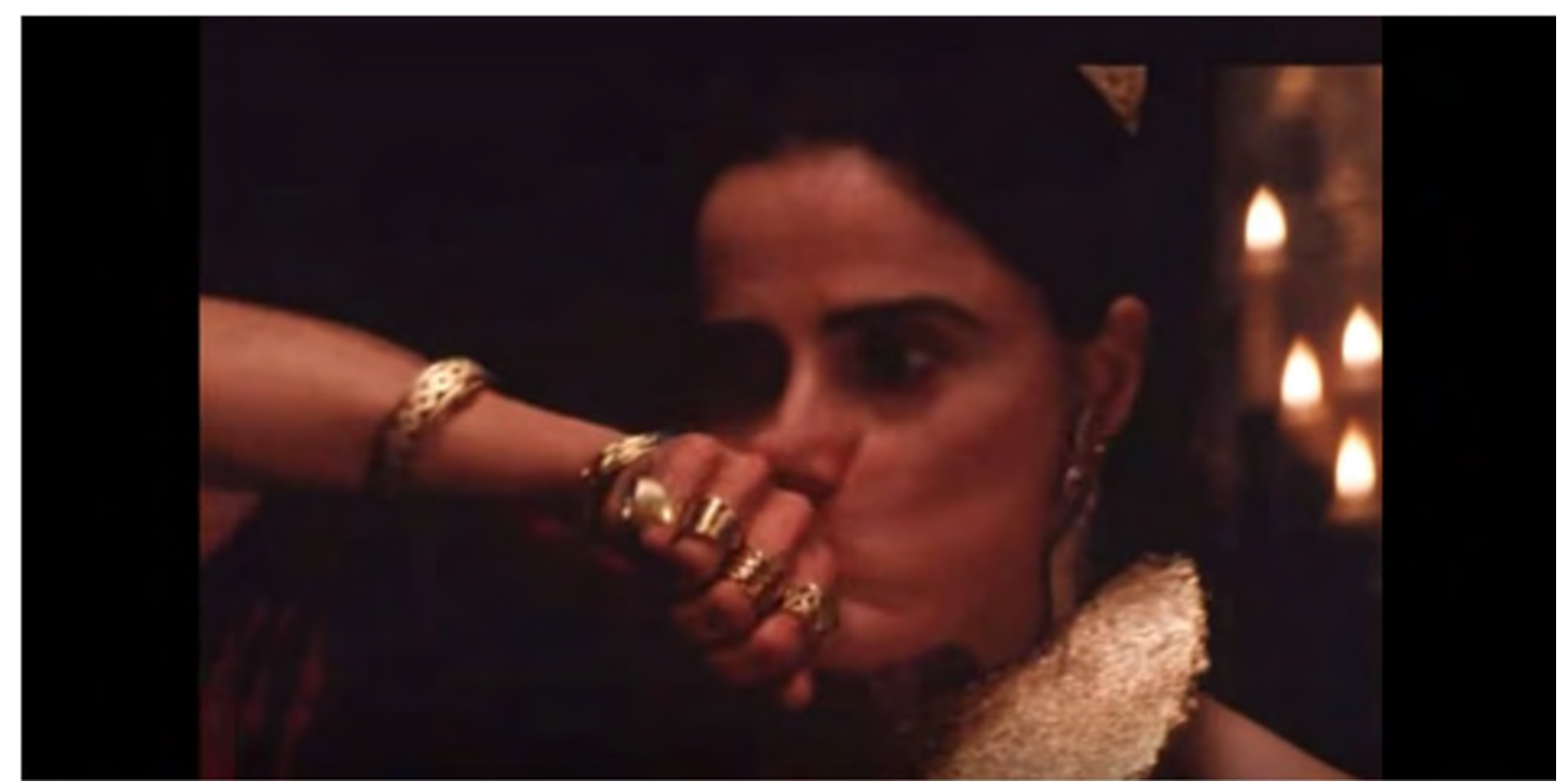

Fonte: Frame do filme Carlota Joaquina, princesa do Brasil (1995).

Composta por peças preexistentes e originais de Abujamra (FIGURA 19), a trilha musical do filme, além de localizar e apresentar sonoramente Espanha, Portugal e as matrizes culturais brasileiras, gera atmosferas e estímulos para a ação - como a dança nos festejos da corte espanhola e o clima de tourada em cenas de sexo envolvendo Carlota. E revela o estado psicológico dos personagens - como a loucura da rainha Dona Maria e os pesadelos de Dom João.

Figura 19 - Créditos a André Abujamra no filme

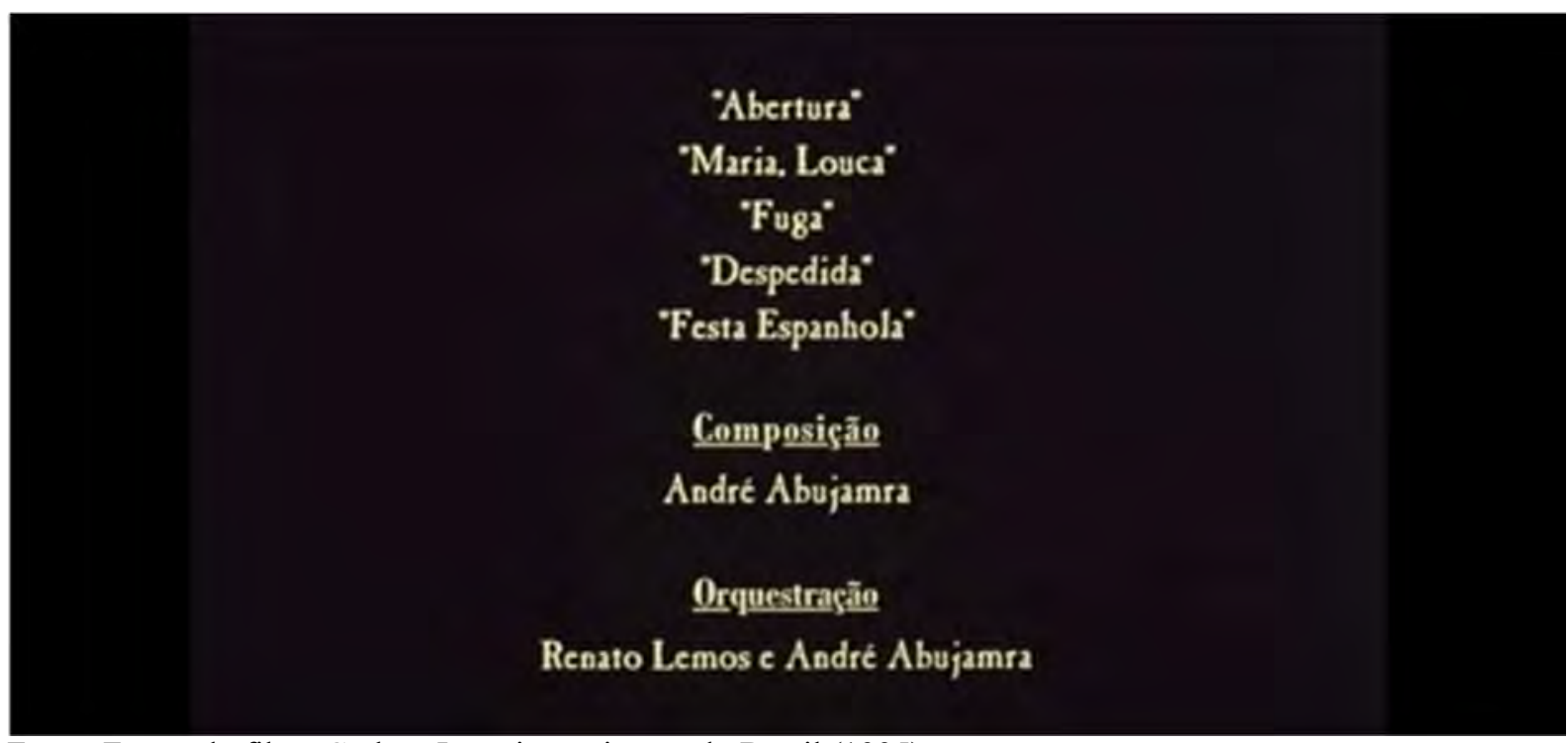

Fonte: Frame do filme Carlota Joaquina, princesa do Brasil (1995).

Além disso, a música está presente na caracterização dos personagens, por meio do 
flamenco dançado por Carlota, da presença da cantora francesa Noemi (amante de Dom Pedro) na história, do serviçal que toca cravo para o rei. Cumpre também a função de hierarquizar personagens e situações: os anúncios reais são feitos com o rufar de tambores e o soar de trombetas; a música erudita soa nos espaços e em ocasiões restritas à realeza, enquanto a música popular soa nas ruas ou quando representantes do povo se relacionam com a nobreza.

Sonoridades hispânicas são utilizadas pelo compositor no filme de forma tradicional, em termos musicais. No entanto, na relação com a imagem, tais sonoridades contribuem para um tratamento não tradicional deste período da História do Brasil, por meio da acidez, da ironia e da crítica contidas no humor.

A desenvoltura de Abujamra na utilização de tecnologias digitais de gravação de áudio possibilita a convivência, em um filme histórico, de sonoridades analógicas (como a gaita de fole gravada em Portugal e a própria gravação da orquestra) e digitais (como timbres sintetizados e simulações de reverberação) - combinação que se tornou recorrente no cinema brasileiro a partir de então. A seguir, é traçado um breve perfil do compositor, revelando sua trajetória nas artes até o ingresso na área cinematográfica e a presença das principais características apresentadas pelos compositores de música para cinema a partir da segunda metade da década de 1990, analisadas neste capítulo.

\subsection{ANDRÉ ABUJAMRA: DA COXIA DO TEATRO À MÚSICA PARA CINEMA}

O cantor, compositor, multi-instrumentista e ator André Cibelli Abujamra nasceu em 15 de maio de 1965, em São Paulo (SP). Filho do dramaturgo, ator, diretor de teatro e apresentador de televisão Antônio Abujamra, ele teve, no seio familiar, seu primeiro contato com a arte. $\mathrm{Na}$ década de 1980 ele formou, juntamente com o músico Maurício Pereira, a banda Os Mulheres

Negras (FIGURA 20), que criava canções pop-rock experimentais com letras irreverentes, instrumentos eletrônicos e uma diversidade de referências. A dupla lançou os discos Música e ciência (1988) e Música serve para isso (1990); separou-se em 1991, teve seus discos relançados em CD em 2005 e retornou à atividade em 2010, em Curitiba (PR).

Figura 20 - André Abujamra e Maurício Pereira em Os Mulheres Negras 


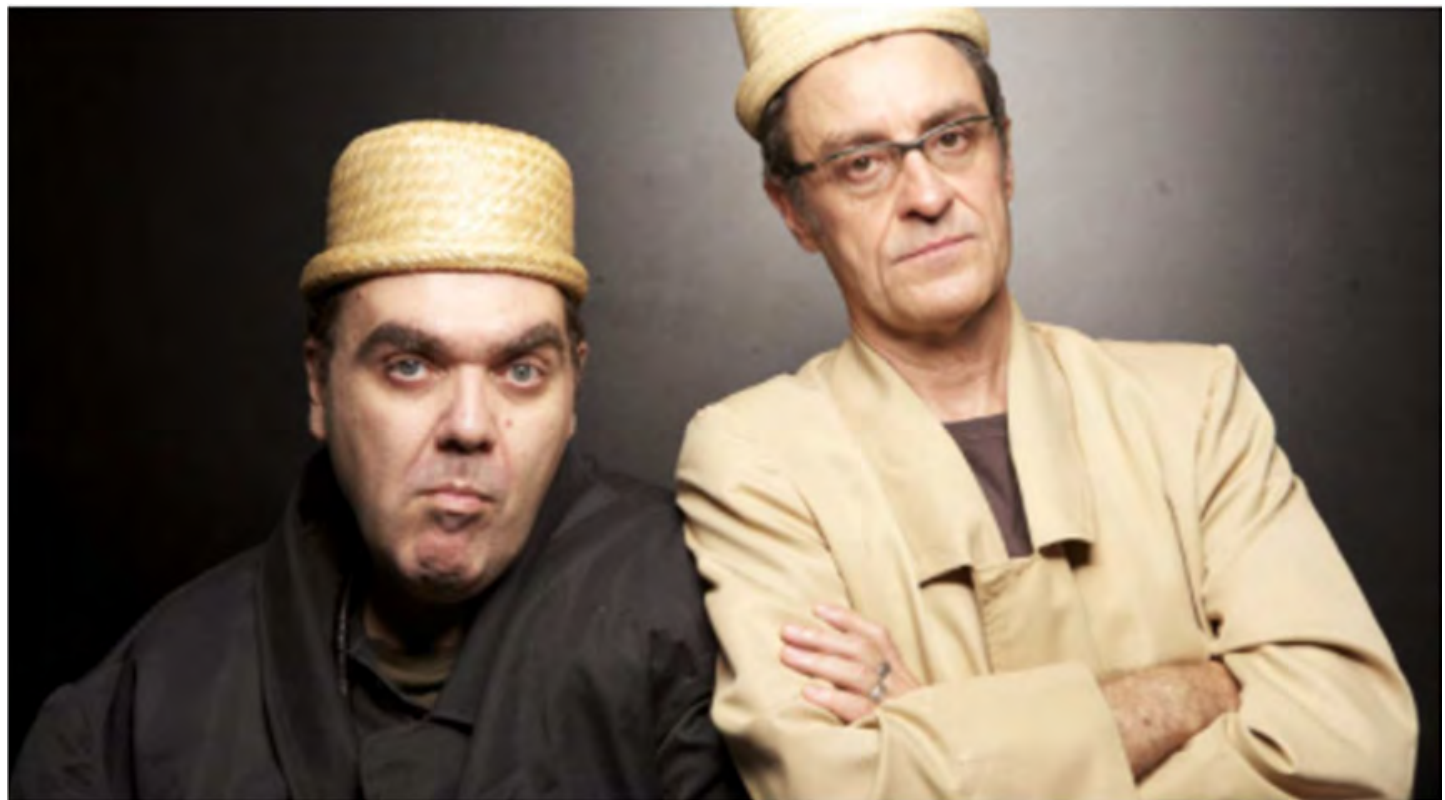

Fonte: Site Curitiba Cultura. Disponível em: $<$ https://www.curitibacultura.com.br/noticias/sesi-musicaapresenta-os-mulheres-negras>. Acesso em: 20 jan. 2018.

Em 1992, após uma viagem ao Egito ${ }^{8}$, Abujamra materializou a influência de antigas e novas sonoridades na Karnak, banda formada também por Lulu Camargo (teclados), Eduardo Cabello (guitarra), Hugo Hori (backing vocal, saxofone), Kuki Stolarski (bateria), Marcos Bowie (backing vocal) e Serginho Bartolo (baixo) (FIGURA 21). O grupo lançou os discos Karnak (1995), Universo umbigo (1997) e Original (1997), voltados para o mercado fonográfico europeu, e Estamos adorando Tokio (2000).

Em carreira solo, o compositor lançou O infinito de pé (2004), Retransformafrikando (2007), Mafaro (2010), O homem bruxa (2015) e Omindá (2018), discos que evidenciam a diversidade de influências do artista e a incorporação de sonoridades de várias regiões do mundo em sua obra musical.

Figura 21 - Karnak em uma de suas várias formações

\footnotetext{
${ }^{8}$ Em entrevista para o site UOL Viagens, de 2006, Abujamra contou ao repórter: "[No Egito] Eu estava andando em um táxi quando escutei uma música que achei bacana. Acabei por comprar a fita do taxista e usei um pedacinho no disco. Até hoje não sei o que é". Disponível em: <http://viagem.uol.com.br/famosos/somparaviagem/2006/07/08/ult3825u9.jhtm>. Acesso em: 13 set. 2013.
} 


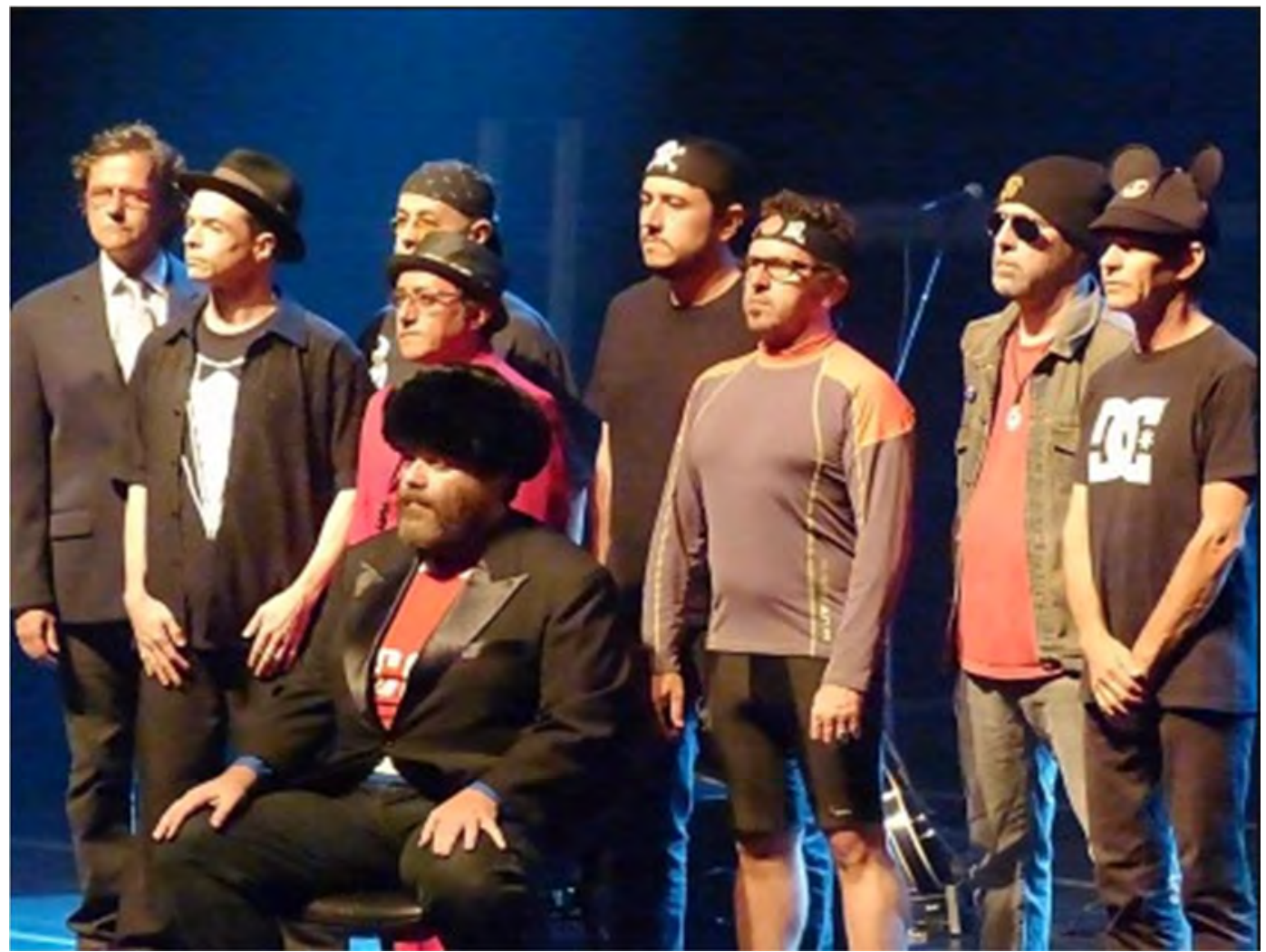

Fonte: Site Tropicália MPB. Disponível em: $<$ http://www.tropicalia.be/site/2014/01/o-mundo-multicolorde-karnak/>. Acesso em: 20 jan. 2018.

Abujamra começou sua carreira de trilhas musicais no teatro, o que foi facilitado pela proximidade familiar com o ambiente. "Eu nasci no teatro. A minha mãe me dava de mamar na coxia do teatro. Então, como eu já nasci músico, eu fiz muita trilha de teatro, peça infantil, de espetáculos grandes. E aí, partir para a televisão foi uma coisa super natural.” (ABUJAMRA, 2016).

Na televisão o compositor assinou as trilhas musicais da minissérie Sampa (Rede Globo, 1988), dos seriados Castelo Rá-Tim-Bum (Cao Hamburger, TV Cultura, 1994), Disney Club (Cao Hamburger, SBT, 1997), Carandiru, Outras Histórias (Hector Babenco, Rede Globo, 2005) e Teatro e Circunstância (Sebastião Milaré, SESC TV, 2008), além de sua participação semanal como músico no palco do recente programa Agora é Tarde (Danilo Gentili, Rede Bandeirantes, 2014).

No cinema iniciou seu percurso compondo músicas para os curtas-metragens da diretora Anna Muylaert, com quem foi casado, e dos amigos dela (Beto Brant e Francisco César Filho, entre outros). "Eu era fã da musicalidade dele e pela nossa proximidade desenvolvemos muita coisa juntos. Começamos um trabalho meu que se chamava 'trash video', onde ele fazia a 'trash trilha', que foi o marco inicial do trabalho dele com sampler" (MUYLAERT, 2014). 
Muylaert namorava Abujamra quando ela era estudante do curso de Cinema da Escola de Comunicações de Artes da Universidade de São Paulo, entre 1980 e 1984, o que facilitou a entrada do músico no ambiente cinematográfico universitário do qual emergiriam os diretores estreantes em longas-metragens a partir dos anos de 1990 no cinema brasileiro. "Ganhei um prêmio em Gramado [Melhor Música, 1992] com o filme da Anna, As rosas não calam [Ana Muylaert, 1992], fiz muita trilha sonora de curta. Foi daí que veio a minha história com o cinema" (ABUJAMRA, 2016).

Na década de 1990 Abujamra assinou ainda as músicas dos curtas-metragens: Hip Hop SP (Francisco César Filho, 1990), Atrás das grades (Paolo Gregori, 1993), Instruções para dar corda no relógio (Eliane Coster, 1995) e A origem dos bebês segundo Kiki Cavalcanti (Anna Muylaert, 1995). Na década seguinte, já concomitante às composições para longas, criou as trilhas musicais para os curtas: O tempo dos objetos (Bruno Carneiro, 2001), O. D. Overdose Digital (Marcos DeBrito, 2007), JLG/Pg (Paolo Gregori, 2008), O divino, de repente (Fabio Yamaji, 2009) e Bartô (Onon e Gunter Sarfert, 2010).

A estreia do compositor em longas-metragens se deu a partir de um convite da então diretora estreante Carla Camurati, durante um show da banda Os Mulheres Negras no Espaço Off, em São Paulo, para que ele fizesse a música de Carlota Joaquina, princesa do Brasil (1995). Segundo ele, a cineasta já o conhecia por trabalhar com Anna Muylaert e seus amigos na composição de trilhas musicais para curtas. De acordo com informações do Internet Movies Database (IMDb) (C1990), entre 1990 e 2017 André Abujamra compôs músicas para 34 filmes em longa-metragem ${ }^{9}$. Como compositor, nesse mesmo período o artista se dedicou ainda a trilhas sonoras para televisão e publicidade - é o criador da trilha de abertura do programa

\footnotetext{
${ }^{9}$ São eles: Praça Paris (Lúcia Murat, 2017); Bem casados (Aluizio Abranches, 2015); Trinta (Paulo Machline, 2014); Minutros atrás (Caio Sóh, 2013); 2 coelhos (Afonso Poyart, 2012); Amanhã nunca mais (Tadeu Jungle, 2011); Harlistas: an american journey (documentário mexicano de Alfredo De Villa, 2011); Do começo ao fim (Aluizio Abranches, 2009); A raça síntese de Joãosinho Trinta (documentário de Giuliano Cedroni e Paulo Machline, 2009); O contador de histórias (Luiz Villaça, 2009); Alphaville - Do lado de dentro do muro (documentário de Luiza Campos e Gustavo Ribeiro, 2009); Encarnação do demônio (José Mojica Marins, 2008); Caixa preta (Marcel Izidoro, 2008); Achados e perdidos (José Joffily, 2007); Querô (Carlos Cortez, 2007); Yellow (Alfredo De Villa, México, 2006); Os 12 trabalhos (Ricardo Elias, 2006); Cafundó (Paulo Betti e Clovis Bueno, 2005); Bem-vindo a São Paulo (documentário de Leon Cakoff, Wolfgang Becker, Renata de Almeida, Maria de Medeiros, Hanna Elias, Amos Gitai, Mika Kaurismäki, Jim McBride, Phillip Noyce, Ming-liang Tsai, Andrea Vecchiato, Caetano Veloso e Yoshishige Yoshida, 2004); Vozes inocentes (Luis Mandoki, México, 2004); De passagem (Ricardo Elias, 2003); O caminho das nuvens (Vicente Amorim, 2003); Carandiru (Hector Babenco, 2003); Durval Discos (Anna Muylaert, 2003); As três Marias (Aluizio Abranches, 2002); Bicho de sete cabeças (Laís Bodanzky, 2001); Domésticas (Fernando Meirelles e Nando Olival, 2001); Nem gravata, nem honra (documentário de Marcelo Masagão, 2001); Nós que aqui estamos por vós esperamos (documentário de Marcelo Masagão, 2000); Castelo Rá-Tim-Bum, o filme (Cao Hamburger, 1999); Um copo de cólera (Aluizio Abranches, 1999); Ação entre amigos (Beto Brant, 1998); Os matadores (Beto Brant, 1997); e Carlota Joaquina - princesa do Brasil (Carla Camurati, 1995).
} 
Provocações, da TV Cultura, à época apresentado por seu pai, Antônio Abujamra -, e também à atuação, tanto na televisão quanto no cinema.

\subsubsection{Equipe, parceiros e estrutura de trabalho}

Ao longo de sua carreira como compositor musical de cinema, André Abujamra trabalhou com diversos diretores, em diferentes condições orçamentárias e estruturais, e firmou parcerias com vários músicos brasileiros para a criação e produção de suas trilhas. Dentre as parcerias de destaque está a do artista com o compositor, guitarrista e produtor Márcio Nigro, estabelecida desde o filme Encarnação do demônio (José Mojica Marins, 2008).

Nigro possui, segundo Abujamra, um traço complementar ao seu no trabalho de composição: ao mesmo tempo em que apresenta um perfil autoral, ele apresenta habilidade ao trabalhar com músicas de referência. "Eu não tenho [esse talento]. Não me peça pra fazer uma música parecida com aquilo. Eu me dou muito mal quando tenho que fazer uma coisa parecida com outra" (ABUJAMRA, 2016). Além das parcerias em trilhas cinematográficas produzidas na Omin Estúdios (home studio e empresa de Abujamra) - também em O contador de histórias (Luiz Villaça, 2008), Amanhã nunca mais (Tadeu Jungle, 2011) e 2 coelhos (Afonso Poyart, 2012) - Márcio Nigro ${ }^{10}$ é sócio dele e do empresário Marcos Naza, na Mondo, produtora de áudio voltada exclusivamente para o mercado publicitário, com sede na Cinecolor Digital, em São Paulo.

Também trabalham esporadicamente na Omin Estúdios os músicos/compositores Meno del Picchia, Eron Guarnieri, Marcos Bowie, Mano Bap, entre outros integrantes da banda Karnak e amigos. Os convites para colaboração são feitos por Abujamra de acordo com as características que a trilha musical demanda. "Mas basicamente eu gosto de fazer tudo, eu sou 'meio gordinho' nessa situação", revela o artista, demonstrando um perfil centralizador da responsabilidade por todo o processo de produção de trilhas, comum aos compositores a partir da década de 1990 (ABUJAMRA, 2016).

Antes da Omin, Abujamra foi sócio da ex-produtora do Karnak, Belma Ikeda, na Bell e Bull Produções Artísticas. Ikeda assina, com o artista, a produção executiva das trilhas musicais de As três Marias (Aluizio Abranches, 2002), O caminho das nuvens (Vicente Amorim, 2003), Cafundó (Paulo Betti e Clovis Bueno, 2005) e do filme mexicano Voces inocentes (Luis

\footnotetext{
${ }^{10}$ Nigro assina, sozinho, a composição da música de É proibido fumar (2009), dirigido por Anna Muylaert.
} 
Mandoki, 2005). Outras produtoras recorrentes nos créditos finais de filmes com música de autoria dele são: A voz do Brasil, onde costuma gravar orquestra; Estúdio Job, onde foram gravadas e/ou mixadas as trilhas de Carlota Joaquina, princesa do Brasil (Carla Camurati, 1995), Os matadores (Beto Brant, 1997) e Ação entre amigos (Beto Brant, 1998); e Nigro Music, estúdio de Márcio Nigro, onde foram gravados trechos da trilha de Encarnação do demônio (José Mojica Marins, 2008) e toda a música de O contador de histórias (Luiz Villaça, 2009). O Mosh Studio aparece nos filmes com trilha do compositor apenas uma vez, como o espaço de gravação da música de Um copo de cólera (Aluizio Abranches, 1999) ${ }^{11}$.

A partir dos anos 2000 o artista resolveu assumir-se como empresário e montou sua própria estrutura de trabalho. Anonimato Estúdios, A Bull Studios, Abujamra Studio e Abujamra Music Station foram os nomes anteriores dados ao estúdio/produtora do compositor, onde foram gravadas as músicas de Bicho de sete cabeças (Laís Bodanzky, 2001), As três Marias (Aluizio Abranches, 2002), Carandiru (Hector Babenco, 2003), Durval discos (Anna Muylaert, 2003), O caminho das nuvens (Vicente Amorim, 2003), Cafundó (Paulo Betti e Clovis Bueno, 2005) e Voces inocentes (Luis Mandoki, 2005) ${ }^{12}$. Com tantos nomes diferentes para chancelar seus projetos musicais para cinema, é possível perceber como o próprio Abujamra define seu trabalho de maneiras diversas, adotando diversas identidades institucionais em parceria com amigos ou em trabalhos solo.

No Anonimato Estúdios ele ainda contratava outros profissionais para compor uma equipe fixa; a partir do momento em que seu empreendimento assumiu outros nomes, as relações de trabalho passaram a ocorrer sem vínculo empregatício (free lance), esquema atualmente em funcionamento na Omin, que opera em um dos cômodos da casa do artista, em Santa Cecília, São Paulo. Na Omin foram gravadas as músicas de Achados e perdidos (José Joffily, 2005), Do começo ao fim (Aluizio Abranches, 2009), 2 coelhos (Afonso Poyart, 2011) e Trinta (Paulo Machline, 2014) ${ }^{13}$.

Transitam ainda, nos créditos de filmes com música de Abujamra, o produtor musical Pena Schmidt, o maestro Renato Lemos (orquestração) e seus parceiros de Karnak e Mulheres Negras. Além disso, o resultado do trabalho do compositor no cinema brasileiro se evidencia pelas parcerias dele com alguns diretores por mais de um longa-metragem. É o caso de Beto Brant, Aluizio Abranches, Ricardo Elias e Anna Muylaert.

O compositor é conhecido pelo seu amplo repertório de sonoridades, acumuladas ao

\footnotetext{
${ }^{11}$ Conforme os créditos finais dos filmes citados.

${ }^{12}$ Idem.

${ }^{13}$ Ibidem.
} 
longo de muitas viagens pelo mundo, o que possibilita uma grande multiplicidade de caminhos a seguir, a partir dos diálogos com os diretores, das particularidades de cada projeto e dos recursos disponíveis para tanto. A versatilidade de André Abujamra é notada não apenas em suas composições musicais para cinema, mas também pela variedade de maneiras como atua na área. São diversas as formas como o artista aparece creditado por suas participações musicais em filmes: como compositor de música original; arranjos; orquestração; regência; diretor e produtor musical; execução de instrumentos musicais como teclados, samplers, voz, midi, guitarra e percussão; mixagem; e autor de música preexistente.

\subsection{SOM, MÚSICA, RUÍDO: AS INFINITAS POSSIBILIDADES COMPOSICIONAIS NA ERA DIGITAL ${ }^{14}$}

Conhecido pela aleatoriedade e indefinição de seus elementos (RODRÍGUEZ, 2006), o ruído, seja natural ou humano (MARTIN, 2003), pode imprimir verossimilhança, quando intencional (ruídos provenientes do som direto ou foley/ruídos de sala sincronizados à imagem), ou, ao contrário, um caráter expressivo que rompa com o realismo e/ou agregue informações à narrativa (um grito fora de quadro, efeitos sem fonte visível ou ruídos de uma fonte sonora invisível 'a' sincronizados à imagem de uma fonte 'b'). Quando não intencional, é considerado erro, perturbação, som indesejado - convergente com Schafer (1992) - e, portanto, algo que precisa ser controlado ou eliminado, sob o 'risco' de se revelar o aparato cinematográfico ao espectador e interferir em sua fruição.

O diálogo entre música e ruído é contemporâneo à construção da linguagem cinematográfica. Nos primeiros anos do século XX o Futurismo italiano de Marinetti propunha uma concepção de música que exaltasse os novos sons da modernidade, das máquinas industriais e do movimento acelerado das cidades, em detrimento da música erudita tradicional. O cinema clássico-narrativo, no entanto, não integrou de pronto as sonoridades incomuns à sua gramática, pois precisava da música erudita para se legitimar perante a elite. Em cinematografias como a russa e a alemã, por outro lado, há sonoridades precursoras da música concreta dos anos de 1950 já em filmes da década de 1930 (Dziga Vertov, Walter Ruttmann), conforme o estudo de Lucentini (2014).

No cinema brasileiro a diluição das fronteiras entre ruído e música é notável a partir dos

\footnotetext{
${ }^{14}$ As informações técnicas contidas neste trecho trazem a situação das tecnologias digitais de produção e reprodução sonora até o momento de redação e defesa desta tese (2018).
} 
anos de 1960 e 1970, com o cinema novo e o cinema marginal, em filmes de Glauber Rocha, Nelson Pereira dos Santos, Júlio Bressane, Ozualdo Candeias e Rogério Sganzerla. Um dos ruídos que se destacam em películas nacionais na década de 1960, por exemplo, é o som do carro de boi em Vidas secas (Nelson Pereira dos Santos, 1963), filme no qual uma certa melodia decorrente do atrito da roda e o ritmo arrastado, característicos daquele meio de transporte, adquirem importância narrativa em suas relações com a imagem.

De fato, no debate sobre trilha sonora, o período que envolve os anos 1960 e 1970 rompe com as fronteiras entre o ruído e a música, com ruídos que passam a ocupar o lugar da música [...]. Também o uso do silêncio passa a ganhar novas tonalidades na experiência com o som no cinema, emoldurando planos, cenas, gestos da interpretação de atores, entre outros procedimentos dramatúrgicos, em particular nos filmes de Júlio Bressane e Ozualdo Candeias, como já analisou Fernando Morais da Costa (2008) (CARVALHO, 2009, p. 93).

Essa dinâmica adquiriu novas nuances a partir da Retomada, quando o Brasil reuniu condições para iniciar a reestruturação técnica dos processos cinematográficos sobre as bases da tecnologia digital. Em um contexto de maior liberdade de manipulação, o ruído reafirmou seu potencial narrativo na relação com a imagem.

Deste modo, há um tratamento diferenciado para a trilha musical, com a elaboração planejada de uma sonoridade ruidosa [...], sem o uso de temas musicais que acompanham o crescendo dramático da estória e sim a criação de temas de ruídos que se articulam com as imagens visuais (SILVA, 2009, p. 230).

Contribuíram, para o momento favorável, a globalização, o liberalismo econômico do governo Collor, o consequente acesso facilitado a produtos culturais, aparelhos eletrônicos e às novas tecnologias de produção audiovisual, além da popularização da rede internacional de computadores, da implantação de novas políticas públicas de fomento à produção cinematográfica pós-Collor e da gradual reconquista do público brasileiro após certa 'queda em descrédito’ do cinema nacional no período de declínio da Embrafilme. Foi possível, então, com o som digital, reduzir a distância, ou mesmo equiparar a qualidade técnica do som dos filmes brasileiros àquela apresentada por produções internacionais, tendo como principal referência o cinema de entretenimento norte-americano. Ao mesmo tempo, reduzindo os custos referentes a equipamentos e infraestrutura profissionais, em comparação aos demandados pela tecnologia analógica.

Da Retomada em diante o Brasil conheceu os gravadores digitais (DAT - digital audio tape), cuja aceitação, segundo Da-Rin (2005), significou a ruptura com mais de três décadas de captação analógica de som. Essas mudanças foram acompanhadas pela adoção da edição sonora 
não-linear informatizada em substituição à moviola, mesa manual onde se manipulavam os rolos de filme, de duas em duas pistas (edição não-linear física); e pela mixagem multipista digital. Desde a edição não-linear digital é possível a audição simultânea de mais de duas pistas de áudio e a edição não destrutiva de cada uma dessas várias pistas, preservando o registro sonoro original. Todas essas mudanças levaram ao surgimento da função do sound designer (desenhista ou projetista de som) nos créditos dos filmes realizados no País ${ }^{15}$.

A deterioração decorrente da geração de cópias do registro analógico não existe no som digital, uma vez que este, consistindo em informação numérica, pode ser replicado e transmitido infinitamente, conservando a mesma qualidade do primeiro arquivo. Tal fato amplia a capacidade operacional dos profissionais de som na pós-produção, que passam a ter a opção de enviar, receber e manusear os arquivos sonoros remotamente. Também se torna possível gravar e guardar os registros digitais em discos rígidos cada vez menores e com maior capacidade de armazenamento, em substituição aos numerosos rolos de fita magnética, e, paralelamente, manipular o áudio por meio de softwares instalados no computador.

Sistemas digitais de reprodução sonora, como o Dolby Digital ${ }^{16}$, passaram a ser instalados nas salas de cinema, garantindo uma melhor qualidade de som, com aumento do espectro dinâmico e maior imersão do espectador na exibição, enquanto o som multicanal ocupou o ambiente doméstico com os home theathers. Em casa ou na sala de cinema o espectador tornou-se mais exigente em suas experiências sonoras e audiovisuais.

Ao abordar a questão tecnológica do som no cinema brasileiro, Vieira (2001) analisa uma das tendências da produção de buscar 'internacionalizar' a estética dos filmes para atingir novos públicos:

Estamos diante de um cinema que exibe um total domínio não apenas da técnica sempre elogiável na medida em que [sic] materializam valores por toda a vida cobrados do cinema brasileiro, em especial com relação ao som e à cor - mas também da narrativa mais clássica, produzindo filmes que se querem internacionais e

\footnotetext{
15 Segundo Costa (2008), o papel do 'desenhista de som' é coordenar todo o som de um filme, da concepção à finalização, responsabilizando-se pelo trabalho de todos os profissionais envolvidos nas diferentes etapas deste processo - elaboração do conceito, captação, edição e mixagem. Esta função foi criada por Walter Murch no final da década de 1970, nos Estados Unidos, quando ele assinou seu trabalho em Apocalypse now (Francis Ford Copolla, 1979) como sound designer. Murch creditava ali o planejamento e gerenciamento do som do filme, que nortearia seu trabalho com mais de 100 pistas sonoras naquele projeto, algo inovador e complexo para os padrões hollywoodianos de então. No Brasil, apesar de a função do sound designer ainda não se encontrar plenamente consolidada, é possível apontar a atuação de alguns profissionais de referência, como Luiz Adelmo Manzano e Eduardo Santos Mendes.

${ }^{16}$ O sistema Dolby Digital foi inaugurado comercialmente em Batman returns (Tim Burton, 1992), apresentando seis canais independentes de áudio: cinco para frequências médias-graves, médias e agudas e um para o reforço de frequências mais graves (subwoofer), formando o sistema 5.1. Isso permitiu aos espectadores ouvir uma melhor resposta de frequências sonoras nas salas de exibição e ter uma experiência imersiva mais intensa proporcionada pela estereofonia quadrifônica, ampliando as possibilidades criativas do sound design no cinema.
} 
populares, ou melhor, "globalizados" ao condensar temas locais, históricos ou tradicionais, dentro de uma estética "internacional" (VIEIRA, 2001).

Simultaneamente à busca dessa 'estética internacional', Vieira, citado e corroborado por Costa (2008), vincula o uso do som digital à maior recorrência de associações criativas entre sons e imagens, antecipadas aqui e ali a partir da década de 1960 com o Cinema Novo e o Cinema Marginal.

[...] sons que deixam de ter a textura usual, naturalista, do som direto, para se tornarem distorcidos, ou se multiplicarem, simulando para o espectador a percepção alterada do personagem [...]. Filmagens em locação nas metrópoles serão facilmente invadidas pelo imenso nível de ruídos cotidianos (COSTA, 2008, p. 228-229).

Por outro lado, observa Costa (2008), os parâmetros naturalistas e hiper-realistas na relação entre som e imagem foram mantidos no cinema brasileiro dos anos de 1990 e 2000 com o objetivo de facilitar a comunicação com o público. Além disso, o autor elenca conquistas técnicas e estéticas que alteram as bandas sonoras dos filmes brasileiros de então, como a maior qualidade da captação, finalização sonora e exibição; o tratamento mais elaborado de ruídos e sons ambientes e a maior frequência do uso do silêncio como elemento narrativo.

Quanto à música, as limitações técnicas de gravação sofreram grande redução, atraindo tanto compositores quanto músicos autodidatas, de ocasião ou aspirantes a profissionais. Ao mesmo tempo, as possibilidades criativas de composição se abriram em diversidade, complexidade e dramaticidade, com as sonoridades disponíveis por meio das ferramentas digitais de produção, viabilizando, inclusive, simulações de peças orquestrais " [...] gravadas e processadas com uma alta qualidade de resolução, em uma estrutura bastante enxuta" (GALLO, 2015, p. 59).

Em um curto espaço de tempo, constata Vicente (2014), áreas de conhecimento antes consideradas distantes da composição musical - informática, engenharia eletrônica, o próprio domínio técnico da produção e finalização de áudio e até a fluência no inglês - passaram a demandar uma grande e constante atenção dos músicos, cada vez mais pressionados a atualizar tanto seus conhecimentos quanto sua estrutura de produção; a exercer funções antes delegadas a outros profissionais - assumindo, muitas vezes, a responsabilidade por todas as etapas da produção, da composição à mixagem - e a gerir, de forma cada vez mais autônoma, seu próprio negócio. 
lógica produtiva do que de idealizadores individuais que incorporaram a lógica produtiva da indústria ao seu fazer artístico. E acumulando frequentemente os papéis de engenheiro de gravação, produtor, arranjador, divulgador, empresário etc. (VICENTE, 2014, p. 258).

Em um espectro mais amplo, essas novas demandas dizem respeito, segundo Mannis (2012), às transformações do ofício do compositor musical, sobretudo a partir do século XX, no sentido de ampliar suas funções para além da escuta e da criação.

O ofício de compositor expandido se caracterizaria então por uma acumulação gradativa de novas atribuições, aglutinadas ao redor da composição, tal qual um cacho, um cluster, compreendendo variada paleta de atividades, todas unificadas pelo princípio da invenção sonora, como: criação, produção e realização nas artes e no entretenimento; gêneros híbridos (escultura sonora, poesia sonora, poesia vídeosonora, música-vídeo, vídeo-música, arte sonora, paisagem sonora, rádio arte, acústica arquitetural, cine-instalação-sonora-interativa, ambientes de imersão); integração, transmissão e provimento de conteúdos (incluindo fornecimento de streaming e acesso a repositórios organizados); conforto ambiental e design sonoro aplicados também a marketing e publicidade (sound business, sonic branding) (MANNIS, 2012, p. 199-200).

A expansão do ofício leva o compositor, por um lado, à busca de outros saberes; por outro, a uma maior autonomia profissional e, consequentemente, à aposta simultânea em diferentes frentes de produção sonora e musical - tais como: trilhas musicais cinematográficas, gravação de foley e dublagem, licenciamento de músicas, locução e jingles para peças publicitárias, gravação e produção de discos, aluguel de equipamentos e locação do estúdio próprio para registros audiovisuais.

Vicente (2014) chama a atenção para o fato de que este processo foi iniciado ainda no final da década de 1980, com a popularização do uso dos sintetizadores e das baterias eletrônicas na produção musical.

Sem desconsiderá-los também como uma importante fonte de novas sonoridades e recursos expressivos para artistas e bandas, queria enfatizar aqui um aspecto menos visível de sua utilização: o de que, dentro de uma lógica de redução dos custos da produção musical, eles permitiam a substituição de músicos reais por trilhas sintetizadas, diminuindo o dispêndio com cachês e horas de estúdio (VICENTE, 2014, p. 138).

A racionalização da produção resultante das práticas possibilitadas pela tecnologia digital provoca, além do provimento de timbres e ferramentas mais acessíveis aos compositores - não havendo, em tese, a necessidade de contratar outros músicos, grandes estúdios ou locar equipamentos caros para gravar -, a exclusão daqueles que não conseguem adquirir, acompanhar e/ou dominar as novas ferramentas, pondera Gallo (2015). Dentre estas, até o 
momento de redação desta tese, estão o MIDI (musical instrument digital interface), sintetizadores, samplers, instrumentos virtuais e processadores de efeitos manipulados, em conjunto com gravações de fontes externas e de forma independente e simultânea, em softwares que funcionam como estações de trabalho de áudio digital (DAW ou digital audio workstation).

Ao mesmo tempo em que promove a redução de custos e a facilidade logística pela maior mobilidade, chegando a dispensar, em muitos casos, a materialidade de fontes sonoras, dos equipamentos de manipulação e de suportes analógicos de registro, a produção musical em plataforma digital demanda capacidade de armazenamento e processamento da informação numérica - as combinações de 0 e 1 do código binário da linguagem na qual são programados os aparelhos digitais -, além da preocupação com a resolução (qualidade) do som - dada por taxa de amostragem - e da precaução de se fazer cópias de segurança dos arquivos.

\footnotetext{
Uma vez gravados os instrumentos 'reais', estes não precisam mais estar presentes toda vez que a música for executada no restante do processo criativo [...]. Por outro lado, é absolutamente imprescindível manter cópias de segurança (backup) de tudo que é gravado (MATOS, 2014, p. 192-193).
}

Para a produção musical em cinema e audiovisual, as DAWs oferecem ainda a possibilidade de interação em tempo real com a imagem digital, permitindo sua sincronização frame a frame com o som, por meio de sua inserção no arquivo do projeto em uma pista de vídeo paralela à dos elementos sonoros e musicais, e, assim, otimizando o tempo de trabalho do compositor. Um exemplo de destaque criativo do som a partir das possibilidades da tecnologia digital é o filme Bicho de sete cabeças (2001), dirigido pela diretora então estreante em longas-metragens Laís Bodanzky. O processo de enlouquecimento de Neto (Rodrigo Santoro), separado da família e de si mesmo por um abismo irreversível, é demonstrado, entre outras escolhas de linguagem, pela utilização densa, distorcida, ruidosa e não realista do som em várias sequências. A música eletrônica de Abujamra dialoga, em termos narrativos, com as canções de Arnaldo Antunes, cuja voz é distorcida e utilizada pelo compositor da trilha musical.

\subsubsection{Bicho de sete cabeças (Laís Bodanzky, 2001)}

Em Bicho de sete cabeças a densidade e a agressividade das texturas visuais e sonoras da cidade - ruído, rock e música eletrônica - evidenciam uma relação íntima do jovem protagonista Neto (Rodrigo Santoro) com as ruas por onde corre, os prédios que picha, o beco 
onde encontra seus amigos, o quarto onde constrói seu mundo adolescente, lugares em que ele se refugia e busca sua identidade (FIGURA 22).

Figura 22 - Neto corre pela cidade

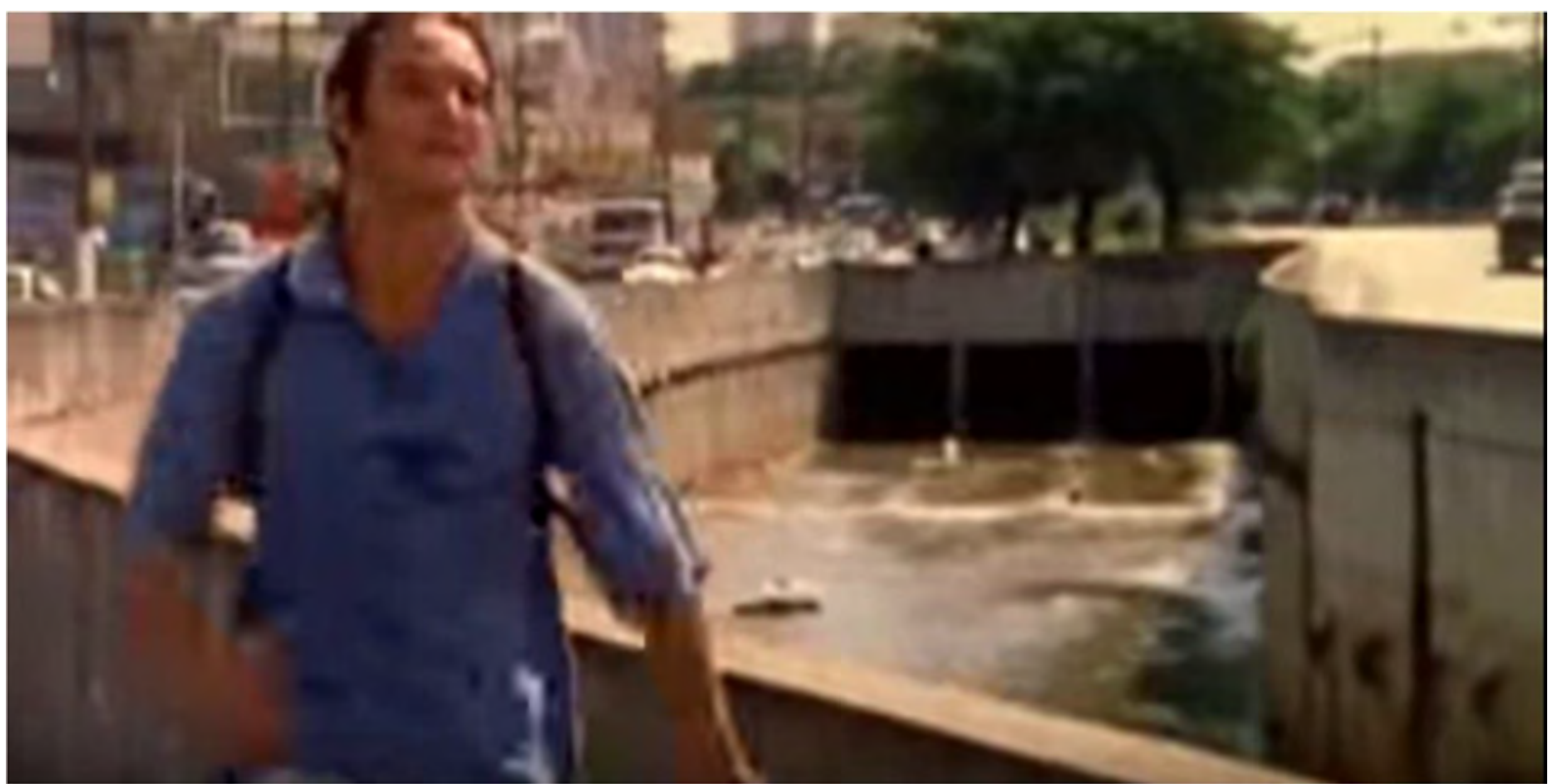

Fonte: Frame do filme Bicho de sete cabeças (2001).

Tal intimidade com a crueza do ambiente urbano marginal contrasta com a distante relação do personagem com a mãe, Meire (Cássia Kiss), e com o pai, Wilson (Othon Bastos) figura conservadora, autoritária e ausente, principal responsável pela falta de diálogo na família e pelos traumas de Neto ao longo da trama.

Ao descobrir que o filho é usuário de drogas, Wilson interna-o à força em um hospital psiquiátrico. O desespero e a resistência de Neto, que quer resgatar sua liberdade, são interpretados pelos enfermeiros como um comportamento agressivo característico de dependentes químicos. A equipe do hospital encobre o desinteresse do doutor Cintra (Altair Lima) e os maus tratos aos internos ante as famílias engordando-os e acalmando-os com remédios, o que gera ainda mais indignação em Neto e a adoção de procedimentos cada vez mais agressivos pelos enfermeiros. O processo de enlouquecimento de Neto, separado da família e de si mesmo por um abismo irreversível, é demonstrado, entre outras escolhas de linguagem pela diretora Laís Bodansky, pela fotografia, cenografia, montagem, interpretação dos atores e utilização densa, ruidosa e não realista do som em várias sequências.

A trilha musical de Bicho de sete cabeças participa ativamente da narrativa, imprimindo ritmo à imagem e delimitando espaços internos e externos aos personagens. Em relação aos diálogos e ruídos, a economia na inserção da música evidencia as demais ocorrências de som, 
de modo que aquela avança ou recua na medida em que alguma outra situação sonora se torna importante. A música não só fornece pistas narrativas ao espectador - seja por meio das letras das canções, das composições ruidosas de André Abujamra associadas à loucura - como conduz a história e promove a continuidade rítmica entre planos e sequências, em consonância com as funções exercidas pela música no cinema clássico narrativo, apontadas por Gorbman (1987).

A música de Abujamra e as canções de Arnaldo Antunes e outros artistas guardam entre si uma relação de complementaridade. Elas são utilizadas com economia, de modo a se contrapor aos momentos de textura sonora menos densa (prevalência do som ambiente em detrimento da fala) e, assim, valorizar sua inserção na trama (FIGURA 23).

Figura 23 - Créditos a André Abujamra e Arnaldo Antunes no filme

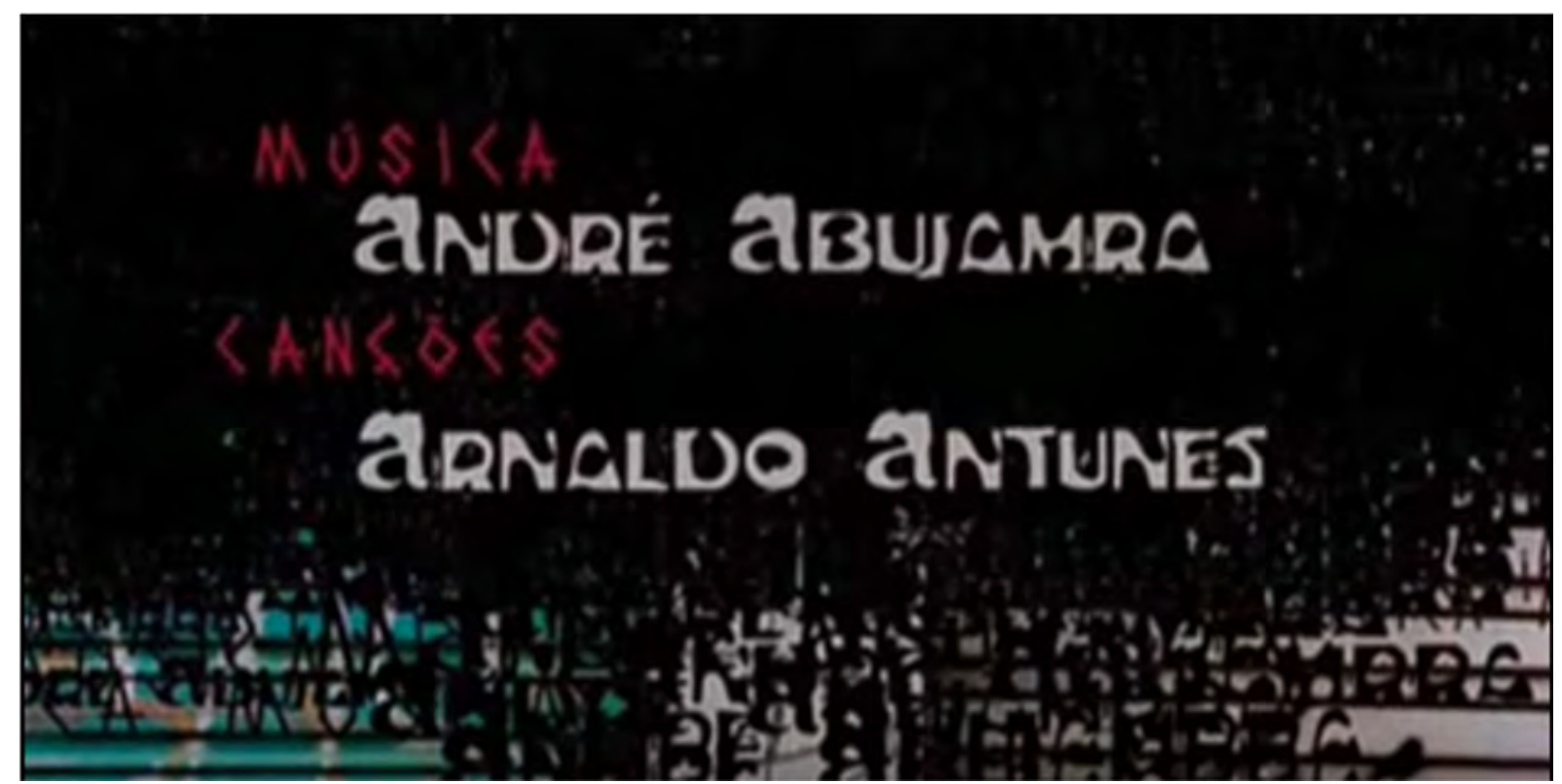

Fonte: Frame do filme Bicho de sete cabeças (2001).

A fragmentação da montagem vai ao encontro do concretismo poético e da voz grave e áspera de Antunes e do ritmo frenético do ambiente urbano frequentado por Neto, sublinhado pela densidade de ruídos e distorções da trilha musical original. Dentro ou fora da diegese, música instrumental, canção e efeitos de silêncio respondem tanto pela intensificação da tensão quanto pela evidência da loucura/apatia desenvolvida gradativamente por Neto, cujo vão esforço de conhecer a si mesmo e de experimentar a adolescência dá lugar a uma delirante, poética e quase perdida luta contra a apatia, provocada por um estado forçado e prolongado de torpor.

Conforme o conceito de valor agregado de Chion (1993), sequências de fuga, maus tratos e algazarra se tornam mais potentes com a presença do som sincronizado e da música, 
que, assim como os movimentos dos personagens na imagem, imprime ritmo e agilidade às cenas. A trilha musical original de Abujamra revela, ainda nos créditos iniciais, a violência psicológica de que trata o filme. O correr de Neto pela cidade, seja depois de uma discussão com o pai, seja tentando fugir da polícia após a pichação de edifícios, tem sua dimensão ampliada pelo predomínio de frequências graves, pelas batidas eletrônicas em alta velocidade e pela presença da guitarra distorcida - cuja melodia sombria remete à relação de Neto com a frieza do ambiente urbano. Ao longo do filme os ruídos sonoros da trilha encontram os ruídos visuais dos muros pichados, da sujeira da cidade e da degradação dos pacientes confinados em condições desumanas no hospital psiquiátrico.

As composições de Abujamra oscilam entre o tonalismo e o atonalismo, dada a combinação ou sequenciação de linhas melódicas simples com texturas sonoras densas e de origem não convencional. Sons metálicos e intermitentes sugerem atritos ao mesmo tempo irregulares e constantes e geram desconforto no espectador, cuja audição é culturalmente marcada pela tradição tonal ocidental.

Viajante e sensível a sons singulares de diversas origens, Abujamra tem seu trabalho marcado pela experimentação proporcionada pela tecnologia digital, de infinitas possibilidades de manipulação. Essa é a marca sonora dos delírios de Neto e de sua relação com o ambiente do hospital psiquiátrico e as pessoas que ali sobrevivem.

Em algumas sequências em particular essa utilização subjetiva do som e sua integração com a música original se fazem evidentes: quando Neto é capturado após uma tentativa de fuga e levado pelos enfermeiros para a sala de choque, a respiração ofegante, o debater-se e o choro do protagonista contrastam com a impessoalidade das expressões vocais e corporais dos enfermeiros e do médico - o que é sublinhado pela ausência de música (FIGURA 24).

No instante do choque, uma nova gama de sons metálicos e graves da trilha original vem à tona e acompanha Neto até o final da película, como uma 'cicatriz sonora' dos pesadelos vividos e internalizados. Na análise de Costa (2008):

\footnotetext{
A junção de ruídos provenientes da ação e matéria musical também amplifica a tensão [...] em especial na cena em que Neto (Rodrigo Santoro) toma eletrochoque. Os sons da máquina se unem à voz do diretor do manicômio, distorcida, reverberante, para tornarem-se todos elementos da colagem que inclui a música de André Abujamra, momento de destaque da elaborada edição de som, a cargo de Silvia Moraes (COSTA, 2008, p. 227).
}

Figura 24 - Neto é submetido ao eletrochoque 


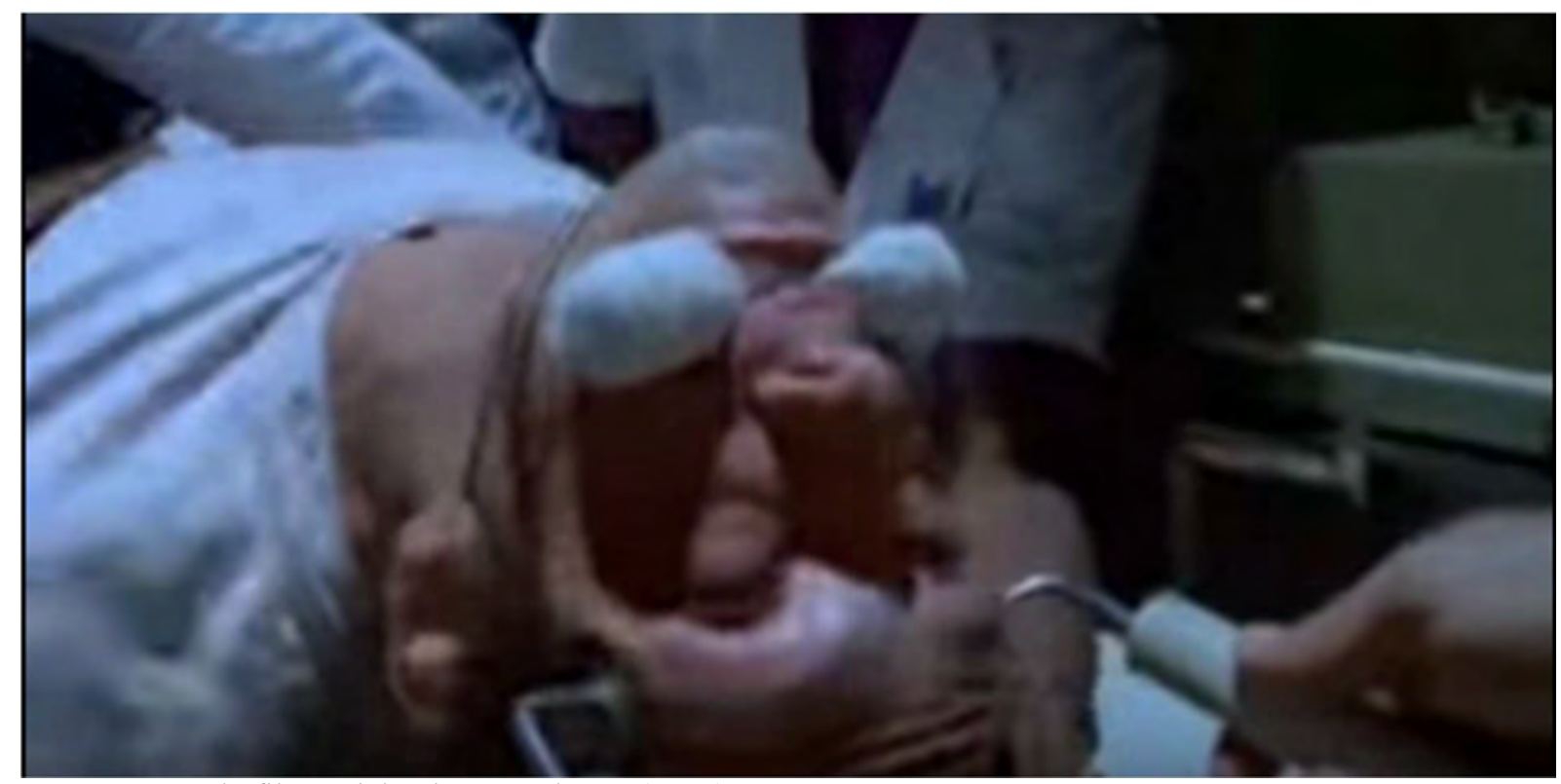

Fonte: Frame do filme Bicho de sete cabeças (2001).

Pequenos fragmentos da composição original - desta vez, em frequências agudas passam, então, a substituir as vozes dos personagens que se relacionam com Neto após sua primeira saída do hospital - o que é percebido pela sincronia entre o movimento das bocas dos personagens e a ocorrência do som distorcido. Isso ocorre apesar de o som ambiente prosseguir audível. Outra situação sonora subjetiva se dá com a audição fragmentada da música que toca no discman de Neto - interrompida sempre que ele tira os fones de ouvido. Fragmentos sonoros dialogam com fragmentos de imagem, os movimentos de câmera na mão e os jumpcuts ${ }^{17}$, também quando da lembrança do pai, reforçando a ideia de que a experiência do choque e tudo o que a precedeu deixaram marcas irreparáveis na vida do rapaz. É possível perceber o processo de desumanização do personagem, que vai se tornando mais um ser apático a vagar pelo hospital.

As canções em Bicho de sete cabeças se referem aos delírios de Neto, aos lugares por ele frequentados, às companhias de que desfruta. Para ambientar o lugar em que Neto encontra os amigos e caracterizar esse universo adolescente urbano, por exemplo, são utilizadas canções de rap (O caminho das pedras - banda Zona Proibida) e punk rock nacional (Satélites - banda Infierno). Mas a maioria das canções do filme é creditada a Arnaldo Antunes. Estas composições surgem em momentos-chave da narrativa e convidam o espectador a uma experiência sinestésica. De acordo com Caznok (2003), a linguagem musical, por si só, já aponta a necessidade de indiferenciação (não separação dos sentidos) na experiência auditiva,

\footnotetext{
${ }^{17}$ Tipo de corte que promove a desestabilização e a descontinuidade de uma cena ao serem excluídos vários de seus frames.
} 
uma vez que ela é, ao mesmo tempo, melodia (audição), textura (tato) e movimento (visão). Desse modo, quanto maior a indiferenciação de sentidos ao assistir ao filme, maior a fruição do espectador.

No único momento de leveza entre Neto e o pai, durante um jogo do Bragantino, a canção Fora de si, de Arnaldo Antunes, dá o tom do jogo, tanto pontuando a vibração da torcida e a paixão do brasileiro pelo futebol quanto anunciando, sutilmente, tudo o que acontecerá com Neto: "Eu fico louco / eu fico fora de si / eu fico assim / eu fico fora de mim". Quando Neto viaja com um amigo para Santos a ambientação da praia ganha novos contornos com a canção Dinheiro (Arnaldo Antunes e Jorge Benjor), com um ritmo próximo ao reggae, reforçando o caráter descontraído da viagem.

Quando Neto está na casa de Leninha - mulher que conheceu em um bar em Santos -, no momento em que os dois personagens começam a trocar olhares (FIGURA 25), a fotografia de cores quentes se une à canção $\mathrm{O}$ seu olhar (Paulo Tatit e Arnaldo Antunes) para revelar a visão subjetiva de Neto, que volta de ônibus para casa mirando o céu, entrecortado pelas lembranças daquela noite de amor: "O seu olhar lá fora / O seu olhar no céu / O seu olhar demora / O seu olhar no meu".

Figura 25 - Noite de amor entre Neto e Leninha

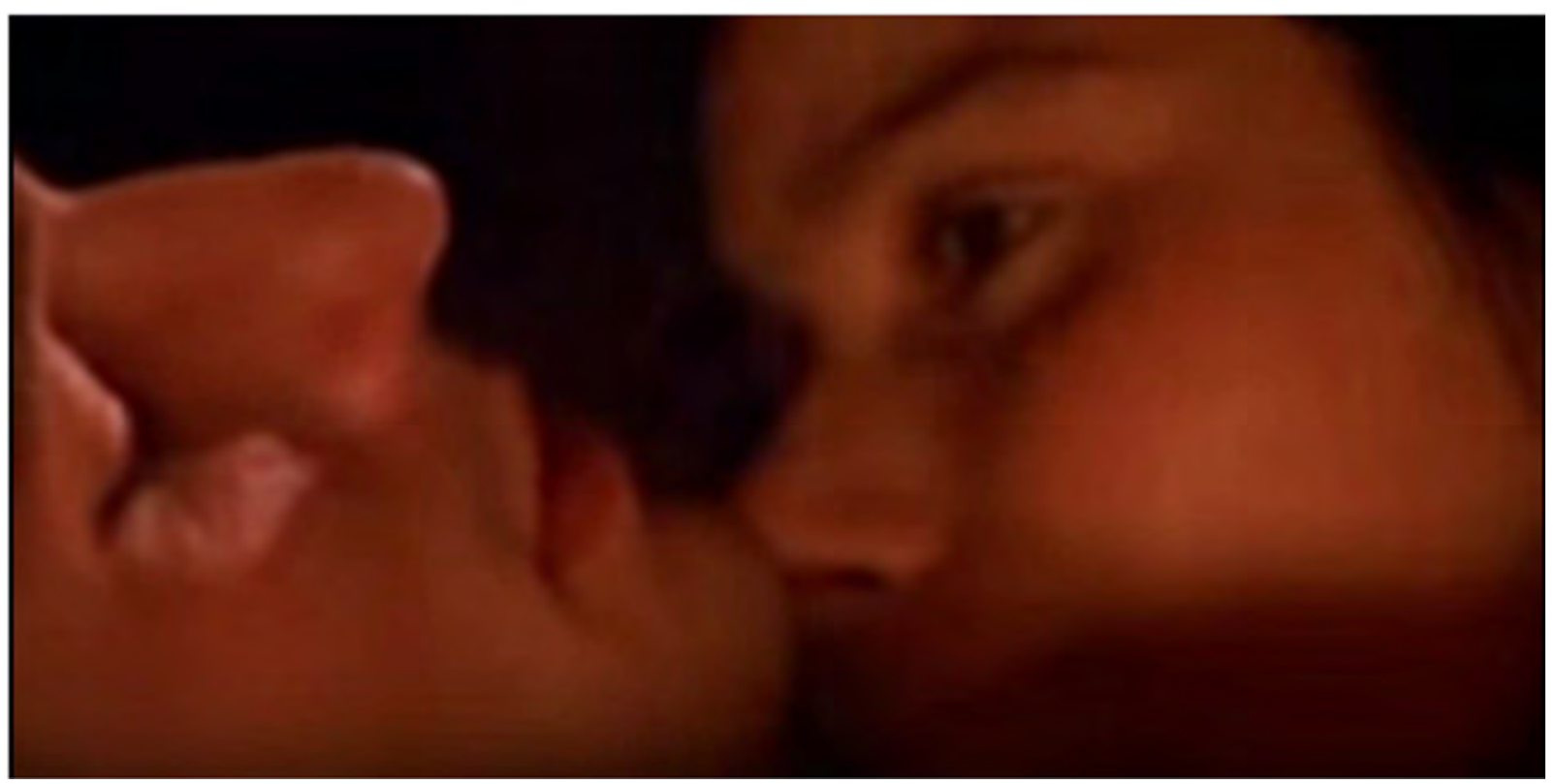

Fonte: Frame do filme Bicho de sete cabeças (2001).

O tom profético do uso da canção no filme também está na interpretação da voz trêmula de um louco, sem acompanhamento instrumental e dentro da diegese, de Quem vem pra beira do mar, de Dorival Caymmi: “Quem vem pra beira da praia, meu bem, não volta nunca mais / 
A onda do mar leva / A onda do mar traz". A música sintetiza a ideia de que a experiência no manicômio faria com que Neto nunca mais 'voltasse para casa' - alusão à apatia e à loucura demonstradas pelo personagem a partir do internato e às ruidosas e distorcidas cicatrizes sonoras que também pontuam a impossibilidade de retorno.

Esse sentimento de ausência, presente em cada interno do hospital, tem seu correspondente, na imagem, nas distorções do quadro, nos desfoques e movimentos irregulares de câmera, e, no universo das canções da trilha musical, em Carnaval (Arnaldo Antunes) - que se inicia no filme com a cena do médico bebendo despreocupadamente seu whisky e termina com os loucos, que simultaneamente circulam pelo pátio: “árvore / pode ser chamada de / pássaro / pode ser chamado de / máquina / pode ser chamada de / carnaval / carnaval / carnaval".

Um dos momentos mais marcantes da canção no filme, no entanto, ocorre quando um dos internos mais velhos do hospital diz: "A gente até precisa fingir que é louco sendo louco, fingir que é poeta sendo poeta" (BOLOGNESI, 2001) ${ }^{18}$. Ele convida Neto a ler as palavras gravadas na parede, que correspondem à letra da canção $O$ buraco do espelho (Edgard Scandurra e Arnaldo Antunes). A câmera passeia pelas palavras (FIGURA 26), enquanto a música, 'recitada' por Antunes em um ritmo compatível com o movimento da imagem, revela a prisão definitiva de Neto no universo da loucura e o perigo iminente da morte: "o buraco do espelho está fechado / agora eu tenho que ficar aqui / com um olho aberto, outro acordado / no lado de lá onde eu caí".

Figura 26 - As mãos de Neto sentem as palavras da canção de Antunes na parede

\footnotetext{
${ }^{18}$ Menção ao roteiro de Bicho de sete cabeças, de autoria de Luís Bolognesi.
} 


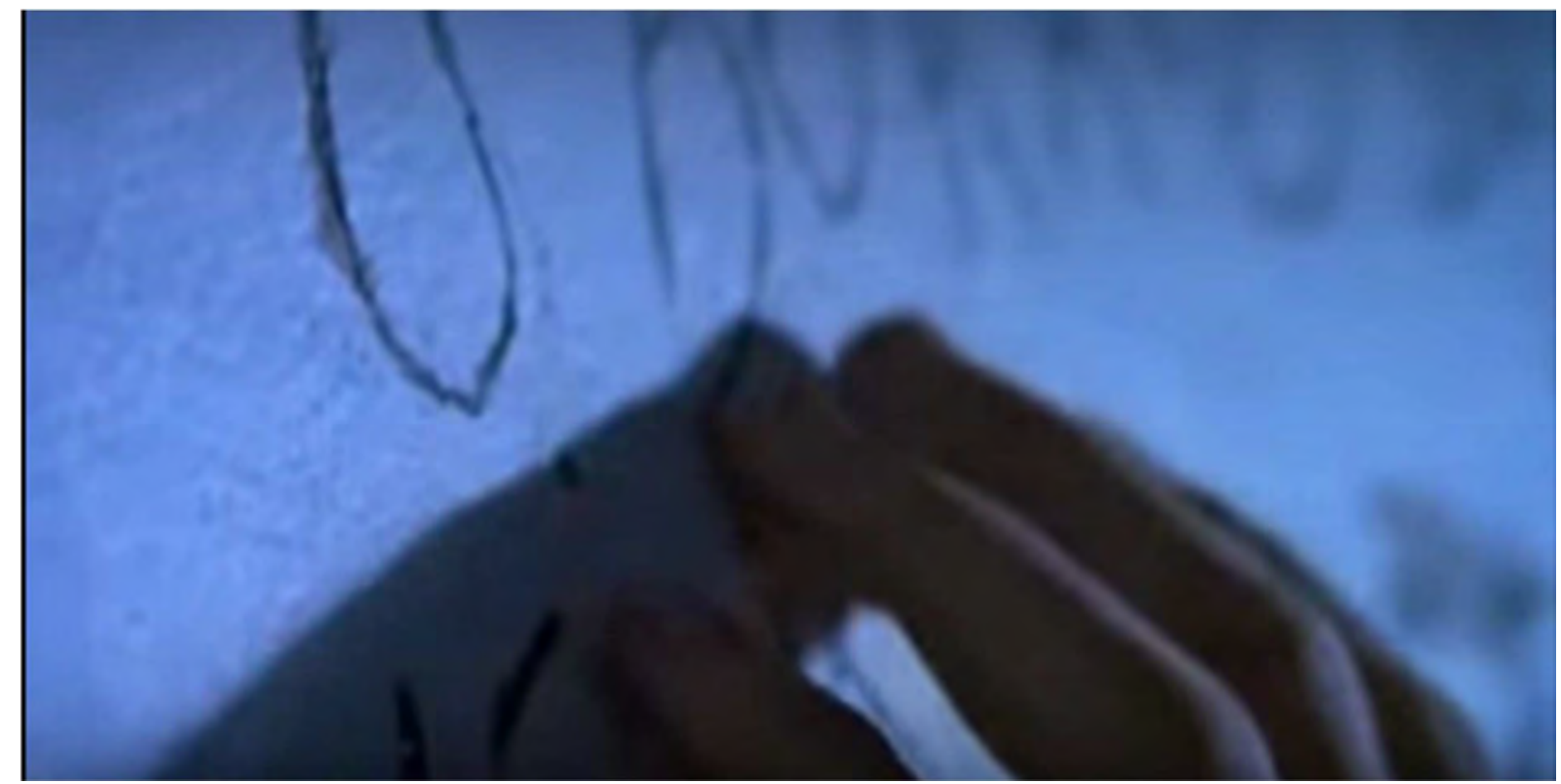

Fonte: Frame do filme Bicho de sete cabeças (2001).

A entoação grave e solene de Antunes por meio da canção, acompanhada do dedilhado da guitarra em uma linha melódica distorcida, revela-se uma extensão da fala do personagem. As imagens igualmente distorcidas da parede se misturam às imagens fixas (FIGURA 27) e em preto e branco da mãe de Neto, em casa, sofrendo com a ausência do filho (FIGURA 28).

Depois de voltar para casa carregando suas marcas, o personagem, após perder o controle em uma festa, é novamente internado, desta vez em outro hospital psiquiátrico, onde é constantemente desafiado pela agressividade do chefe dos enfermeiros. O som e sua espacialidade são importantes para demonstrar a sensação de prisão de Neto na solitária, cubículo escuro para onde é levado devido a seu 'mau comportamento'. Da segunda vez em que ele é preso na solitária tenta suicídio incendiando o lugar, para desespero do amigo Bil.

Figura 27 - Fusão de imagens de Neto e do pátio do manicômio 


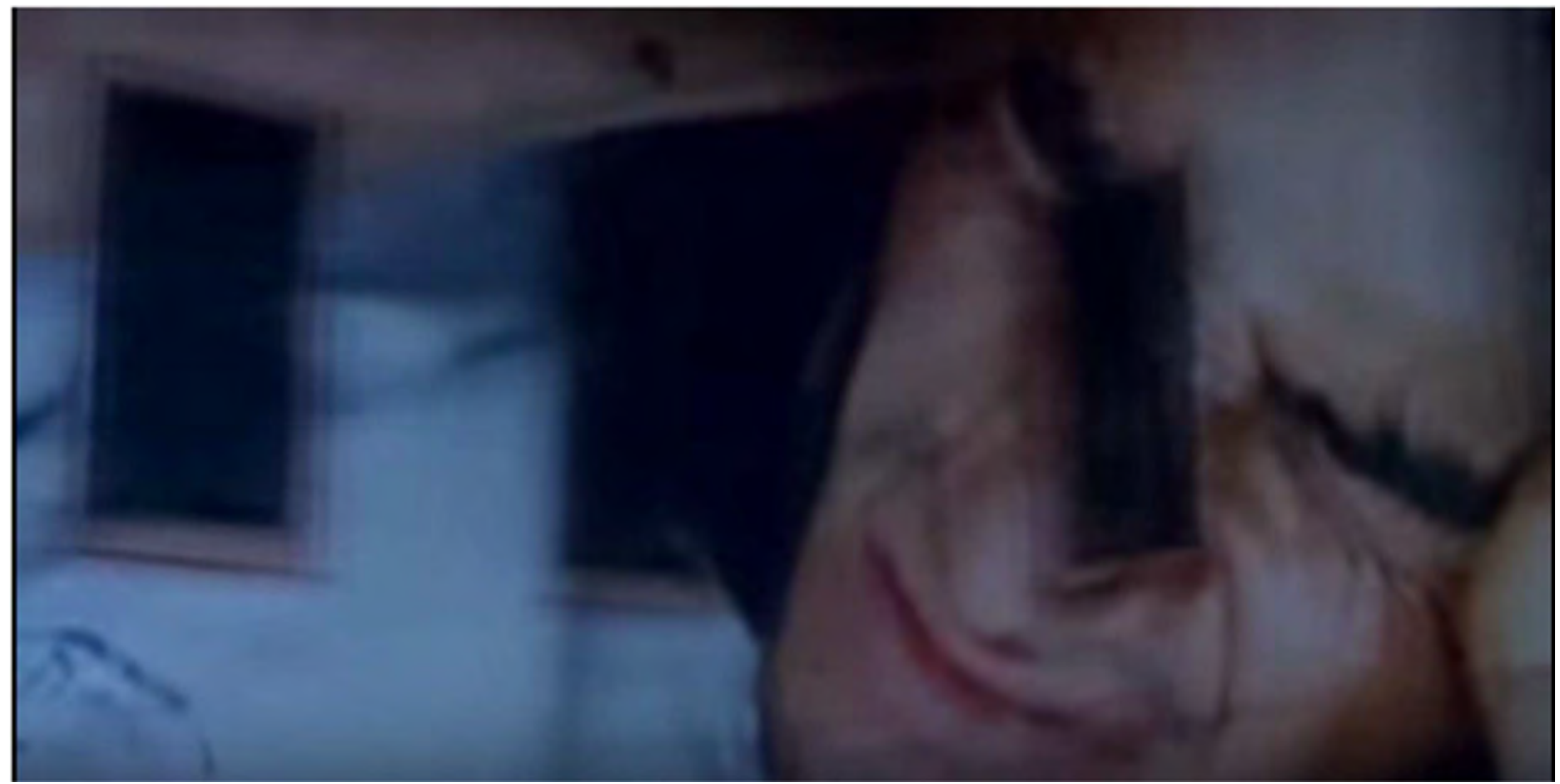

Fonte: Frame do filme Bicho de sete cabeças (2001).

Figura 28 - Imagem fixa em preto e branco da mãe de Neto

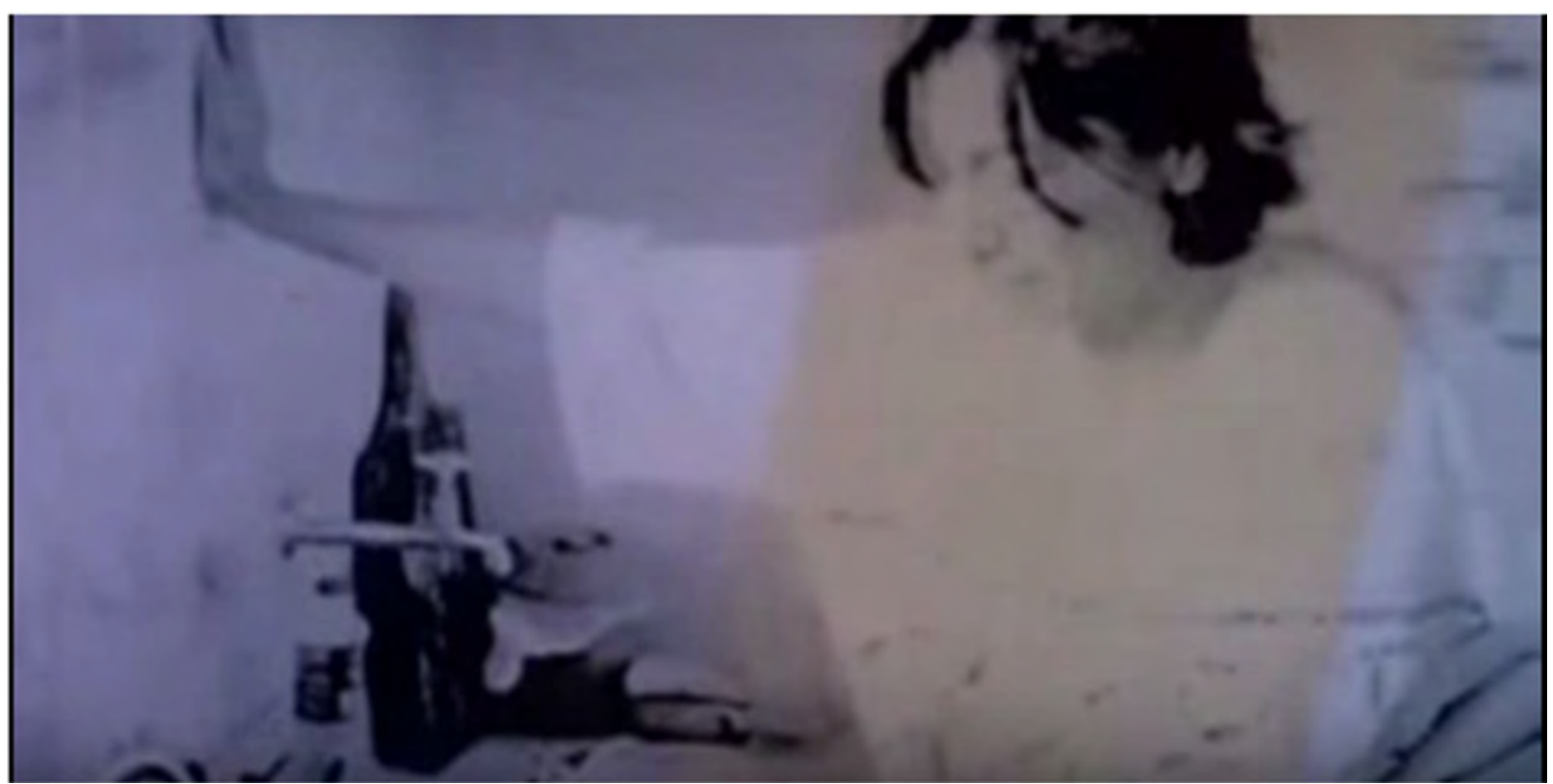

Fonte: Frame do filme Bicho de sete cabeças (2001).

Quando a porta se abre e Neto, enfim, consegue respirar (FIGURA 29), pode-se ouvir, então, a canção que dá nome ao filme - Bicho de sete cabeças (Zé Ramalho, Geraldo Azevedo e Renato Rocha), interpretada por Zeca Baleiro -, que marca o renascimento do personagem, a possibilidade de recomeço, apesar das cicatrizes e do ressentimento pelo pai: "Não dá pé / Não tem pé, nem cabeça / Não tem ninguém que mereça / Não tem coração que esqueça / Não tem jeito mesmo / Não tem dó no peito / Não tem nem talvez ter feito / O que você me fez desapareça / Cresça e desapareça...”. 
Figura 29 - Neto sobrevive ao incêndio na solitária

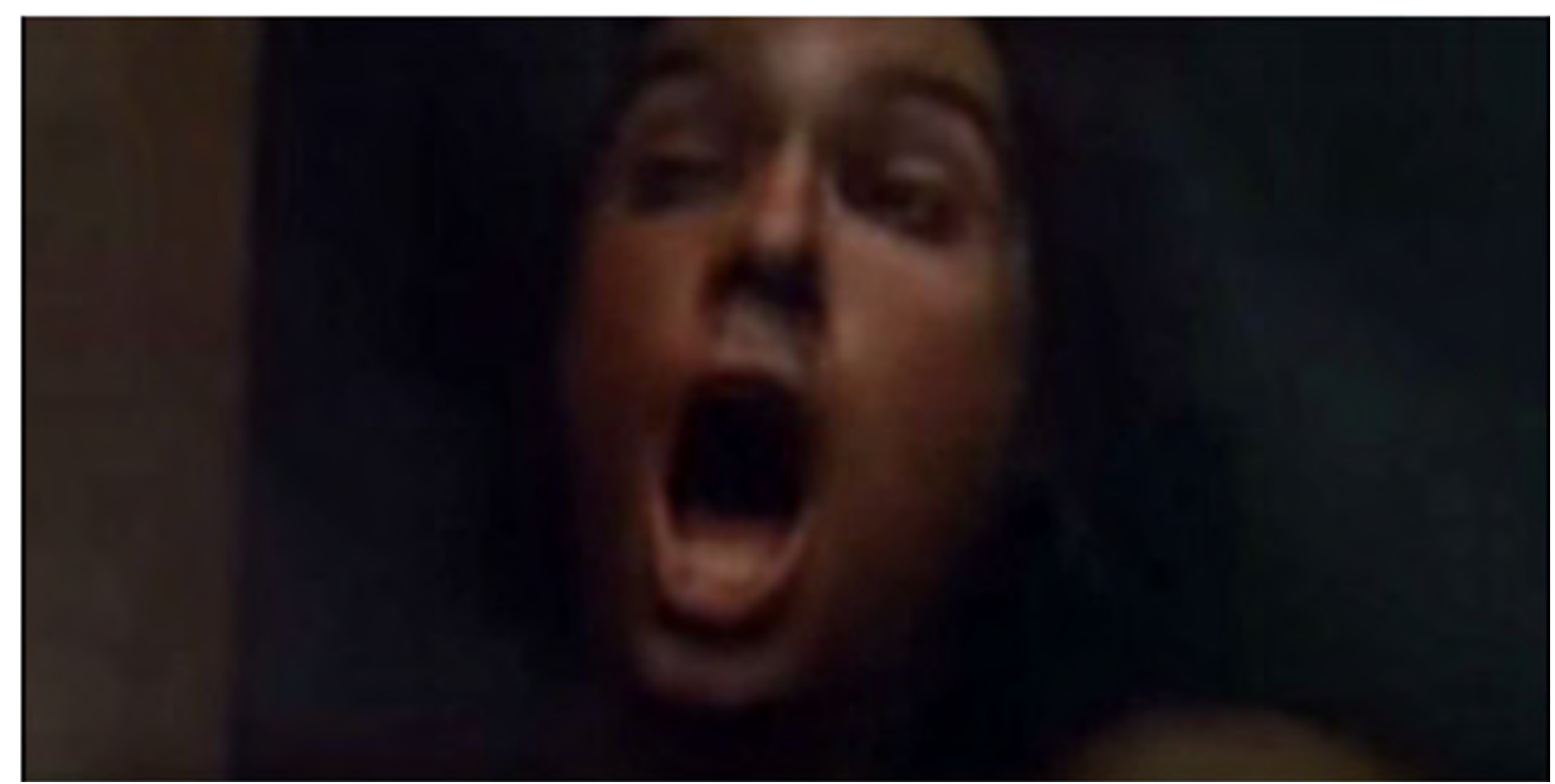

Fonte: Frame do filme Bicho de sete cabeças (2001).

A canção embala a saída de Neto do hospício, paralela à cena do pai que, em lágrimas, lê a carta do filho - a mesma da cena inicial do filme. A sequência descendente de notas do refrão, repetida e superposta às estrofes da canção, remete ao triste final do personagem (FIGURA 30) e conclui o ciclo narrativo com o lirismo e a melancolia de uma resignada aceitação do destino.

Especialmente em se tratando da canção-tema - que só é ouvida ao final do filme -, a música se configura também como um significante independente de emoções, uma vez que, independentemente da existência da obra cinematográfica, o espectador-ouvinte nutre sentimentos e interpretações prévias em relação à canção, ressignificada por Laís Bodansky para finalidades narrativas específicas.

Figura 30 - Neto entorpecido para sempre, ao lado do pai 


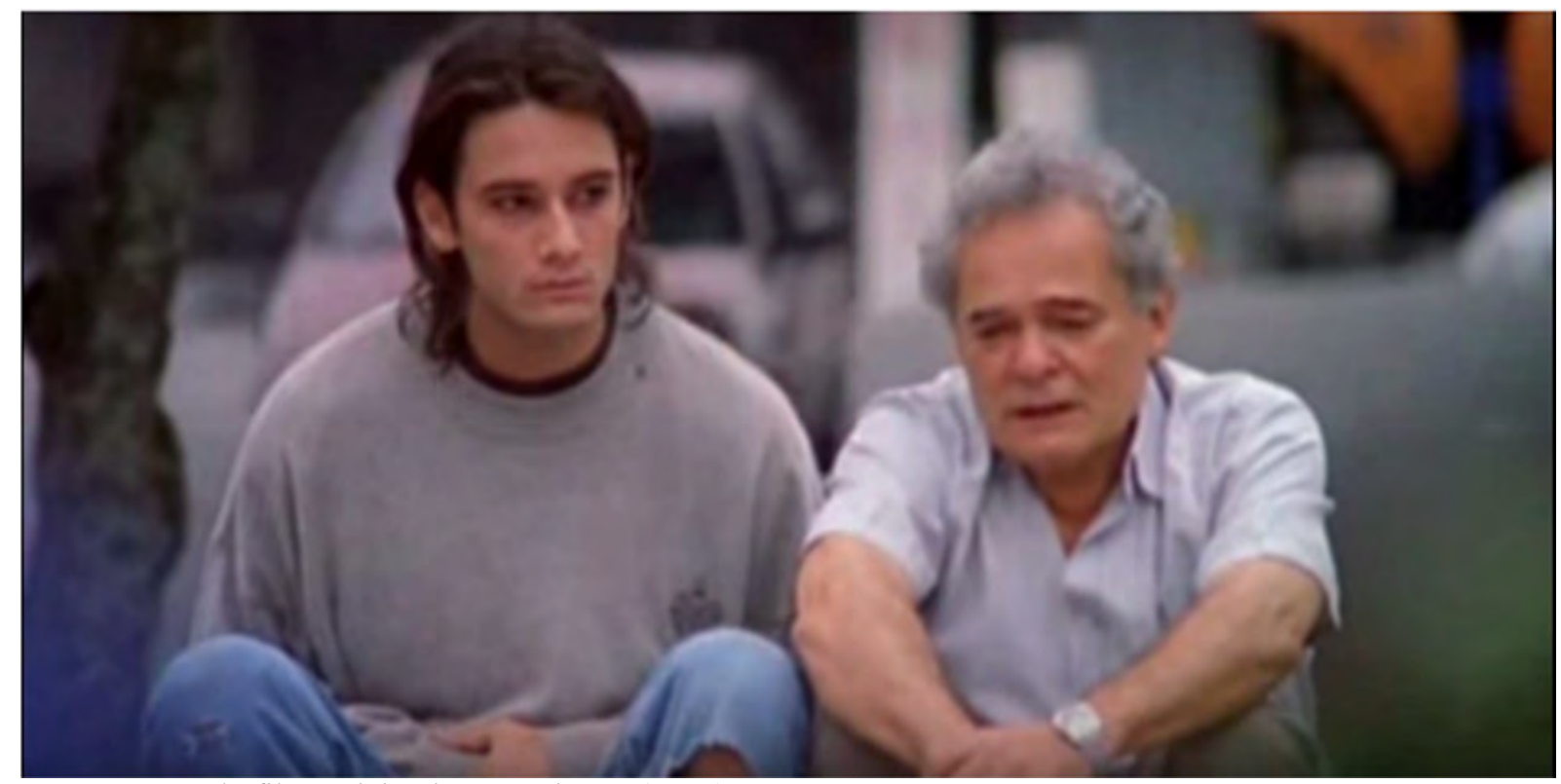

Fonte: Frame do filme Bicho de sete cabeças (2001).

É importante destacar que o diálogo sonoro entre a música original de Abujamra e as canções, em especial as de Arnaldo Antunes, é anterior à demonstração nesta análise. Durante a produção da trilha musical o compositor efetivamente trabalhou com a voz de Antunes, que, na realidade, era o artista cotado pela diretora para assinar a música do filme.

99\% das vezes eu não converso [com as canções preexistentes dos filmes]. Teve um filme em que eu conversei, que na verdade foi o que eu ganhei mais prêmios até hoje, que é o Bicho de sete cabeças, que quem foi convidado pra fazer a trilha foi o Arnaldo Antunes. E ele falou: "cara, eu não consigo fazer trilha sonora". Mas a Laís [Bodanzky] amava as músicas dele. Então ele me indicou pra fazer e a gente já fez... eu já fiz alguns filmes em que eu usei o Arnaldo. [...] Eu peguei as masters do Arnaldo Antunes, fui pro estúdio e tirei só a voz dele. E eu fiz os remix da voz dele com a minha música, então esse [Bicho de sete cabeças] foi o único filme em que eu tive essa participação mesmo. (ABUJAMRA, 2016).

O gosto de Laís Bodanzky pelas músicas de Antunes, a indicação de Arnaldo Antunes para que Abujamra fizesse a música do filme, o diálogo artístico entre os músicos e o próprio momento de dificuldades pessoais que Abujamra declara ter vivido na época (vide capítulo 4) propiciaram a oportunidade de uma efetiva integração, em nível de produção, da música original com as canções - algo não recorrente no processo de composição para cinema ${ }^{19}$. Como resultado, score e canções se alimentam mutuamente, estas emprestando à música original o gesto vocal marcante de Arnaldo Antunes e o lirismo verbal de seu texto, e aquele fornecendo

\footnotetext{
${ }^{19}$ Em geral, a seleção de canções preexistentes não passa pelo compositor de música original de um filme, ficando a cargo do editor musical ou, se não há este profissional na equipe, do próprio diretor. A criação e produção da música original é um processo paralelo e um não interfere no outro.
} 
tanto as bases sonoras - harmônicas ou distorcidas - para voz e palavra quanto os alicerces narrativos fundantes da unidade sonora do filme.

\subsection{CANÇÕES PREEXISTENTES: UMA TRADIÇÃO ATUALIZADA}

A presença de canções extradiegéticas em Bicho de sete cabeças é uma demonstração de que a canção popular, presente desde os primórdios do cinema brasileiro, tem sua inserção nos filmes atualizada a partir dos anos de 1990; menos vinculada à propagação de ideais nacionalistas, como entre os anos de 1930 a 1960, e mais comprometida com a universalidade e a densidade dramática das narrativas fílmicas. Importante lembrar que, antes e para além das possibilidades político-ideológicas ou narrativas, desde os anos de 1930 até hoje a inserção da canção também se relaciona à afirmação comercial do cinema nacional - no início, em constante diálogo com o rádio e seu elenco; com o passar do tempo, em sua relação com a indústria fonográfica, a televisão e, mais recentemente, a internet.

Com sua pregnância na memória, capacidade de síntese e manutenção narrativa, a articulação entre a estabilização conduzida pela música e a instabilidade provocada pela enunciação oral (TATIT, 1997), além de contribuir para a identificação do ouvinte e a venda de um produto, demonstra a complementaridade e adaptabilidade da canção a diferentes contextos, meios de comunicação e outras linguagens artísticas ao longo da vida cultural brasileira.

Enquanto microestrutura tonal exemplar, a canção potencializa a circularidade e a dinâmica de antecipações estabelecidas pelo encadeamento harmônico em que se sustenta a melodia e, por conseguinte, a própria letra (VALVERDE, 2008, p. 275).

A melodia incorporada pela palavra e entoada pela voz do intérprete, acompanhada por uma harmonia em um determinado ritmo e obedecendo a certa dinâmica, aliada ao contexto histórico, social e cultural em que a canção nasce e se desenvolve, ao encontrar uma sequência fílmica, transforma e é transformada por ela. Afirma Wisnik (2004, p. 199): “[O uso da música] [...] envolve poder, pois os sons passam através da rede das nossas disposições e valores conscientes e convocam reações que poderíamos talvez chamar de sub e hiperliminares".

Canções preexistentes são ressignificadas quando convivem com a imagem e outros elementos sonoros em relação, ao mesmo tempo em que podem ativar, no espectador, memórias e narrativas particulares construídas em experiências passadas de escuta. Canções originais 
deslocam a palavra falada, instável, descontínua e passível de esquecimento, para o canto geralmente estruturado em estrofes e refrão -, aumentando seu poder de reforço, contraste ou acréscimo de informações à narrativa fílmica e sua 'audibilidade' (atenção) por parte do espectador em relação a outros elementos sonoros, como a trilha musical instrumental.

Conforme pesquisado anteriormente (SANTANA, 2012), no final do século XIX, antes mesmo do som sincronizado à imagem, as canções dos primeiros centros urbanos brasileiros já eram sugeridas em filmes. Costa (2008) chama a atenção para as cenas posadas que sugerem acompanhamento musical nos primeiros filmes rodados no Brasil, como Dança de um baiano (1899) e Maxixe de outro mundo (1900), realizados por Afonso Segreto, além dos filmes com temática sacra projetados durante a semana santa e dos títulos de carnaval, como o documentário Carnaval na Avenida Central (Paschoal Segreto, 1906). Desde o início da história do cinema brasileiro, portanto, a música popular se encontra relacionada a filmes, evidenciando os traços culturais do povo em seus festejos, danças e preferências musicais - seja no acompanhamento das sessões, seja na sala de espera, em apresentações durante os intervalos ou antes da primeira exibição.

Assim como em outras cinematografias, notadamente a americana, as canções no cinema brasileiro também se alinham, desde os primórdios, a estratégias comerciais. As canções de carnaval, por exemplo, popularizavam-se no cinema e circulavam também no circo, teatro de revista, boates, rádio e nas gravações em discos, contribuindo para as vendas destes, relata Macario (2009) - circulação ampliada com a atual audição via streaming e o licenciamento ou venda de fonogramas pela internet, conjugados com a contratação de shows, venda de discos (físicos ou no formato de arquivos digitais), divulgação em rádios e programas de televisão (a partir dos anos de 1950). Confirma Vicente (2014, p. 31): "Verificou-se, ainda, [nos anos 1980, no mundo] um nível inédito de integração entre som e imagem simbolizado pelo uso intensivo do videoclipe e pela vinculação de músicas e artistas a produções cinematográficas".

Além disso, até hoje é comum a inserção de canções durante os créditos iniciais e/ou finais de filmes nacionais e estrangeiros, aliada tanto aos repertórios coletivos construídos culturalmente pelo espectador/consumidor quanto às estratégias promocionais de grandes gravadoras (até a metade de anos de 1990) e artistas autônomos, selos independentes e/ou grandes conglomerados de comunicação - que incorporaram, a seu modo, funções de produção/gravação e lançamento/circulação, atributos da indústria fonográfica antes de seu declínio com a popularização da tecnologia digital e da internet, a partir da segunda metade da década. Sobre a canção neste novo cenário, completa Silva (2009): 


\begin{abstract}
A musicalidade dos sons e dos arranjos, a poesia das letras e a entonação da voz, criadas de maneira inventiva ou ligeira, tornam-se parte da expressão cultural brasileira contemporânea. Dinamicamente, ao sabor da criatividade e das intenções mercadológicas de seus agentes, as composições e canções atuais, que se renovam com o uso dos meios eletrônicos e digitais sem perder a valorização da palavra falada, migram para as trilhas musicais do cinema brasileiro (SILVA, 2009, p. 216).
\end{abstract}

Dentro de um contexto de globalização da economia e mundialização da cultura fenômenos interligados que consistem, respectivamente, na complexificação das relações de produção e consumo advindas da internacionalização da dinâmica econômica e na ‘desterritorialização' e diluição das fronteiras simbólicas das culturas nacionais, que convivem e se influenciam mutuamente em esfera global (ORTIZ, 1994) - a canção popular brasileira atualiza seus gestos e aglutina elementos da música pop internacional às diversas referências locais, da música caipira ao maracatu. Essa aglutinação de referências globais e locais converge com a busca de identidades e a vontade de internacionalização do cinema brasileiro a partir da Retomada, que utiliza a canção tanto como estratégia de promoção e visibilidade - assim como a canção faz uso do cinema - quanto como elemento narrativo articulado aos outros sons e à imagem.

\footnotetext{
Além das imagens, o cinema também é feito de som. Um som que já não é mais menosprezado e que chama a atenção do espectador com suas trilhas abertas à articulação do uso de canções na elaboração de roteiros e propostas de direção cinematográficas (SILVA, 2009, p. 248).
}

Uma função desempenhada pela canção no cinema brasileiro atual apontada por Silva (2009) é a localização da narrativa em uma ou diferentes épocas, como ocorre com as diversas paisagens sonoras ao longo do tempo na comunidade de Cidade de Deus (Fernando Meirelles e Kátia Lund, 2002); ou na reconstituição sonora da Lapa carioca do final da década de 1930 em Madame Satã (Karim Aïnouz, 2002), por meio de canções de Noel Rosa, Francisco Alves, Lamartine Babo, entre outros compositores populares; no contexto radiofônico de sambas e marchinhas dos anos de 1930 e 1940 que conduz a trilha musical de Cinemas, aspirinas e urubus (Marcelo Gomes, 2005).

Quanto à atribuição de funções narrativas e expressivas a canções em articulação com o roteiro e a proposta de direção cinematográfica, Silva $(2009$, p. 233) destaca a presença musical do movimento manguebeat encabeçado por Chico Science na canção Sangue de bairro presente em Baile perfumado (Lírio Ferreira e Paulo Caldas, 1997) e na música Tempo amarelo, composta pela Nação Zumbi e que pode ser ouvida em Amarelo manga (Cláudio Assis, 2002). 
Outra articulação recorrente ocorre em filmes cuja produção está vinculada à televisão. As comédias, filmes infantis, aventuras e outras produções realizadas pela Globo Filmes - braço cinematográfico das Organizações Globo criado em $1998^{20}$-, por exemplo, conjugam a alta codificação narrativa das canções - mudança de núcleo dramático, reforço da imagem em cenas de amor e outros - com a vinculação a objetivos mercadológicos, demonstradas pela presença de cantores nacionais e internacionais de grande visibilidade na mídia e pela venda de coletâneas de 'trilha sonora' - tal como ocorre na produção e na divulgação de telenovelas. Já em Castelo Rá-Tim-Bum, o filme (Cao Hamburger, 1999), conforme veremos no capítulo 5, a música-tema de André Abujamra - transformada em canção original para o baile da família Stradivarius no filme - segue as convenções já consagradas na série televisiva homônima, exibida na TV Cultura entre 1994 e 1997, o que acarreta certa previsibilidade do tema musical.

Quando apartada do caráter previsível conferido pelos procedimentos televisivos, a canção pode adquirir grande força na narrativa cinematográfica se transformada em tema. Seja nos créditos iniciais, seja sugerida e desenvolvida ao longo da narrativa, ela pode anunciar o curso da história a ser contada, dar pistas sobre os personagens, enfim, sintetizar/apresentar o filme em poucos minutos. Em Durval Discos (Anna Muylaert, 2003), por exemplo, a versão com ares de surf music de Os Mulheres Negras para Mestre Jonas (Sá, Rodrix e Guarabyra, 1973) apresenta Durval e seu mundo analógico particular (a ‘baleia') de forma enigmática, por meio de alegorias.

No entanto, as interferências externas e a pressão dos clientes para a 'conversão' de Durval à tecnologia digital vão minando a estabilidade e previsibilidade do 'lado A' do filme marcado pela sonoridade do vinil - e conduzindo às incertezas do 'lado B' - caracterizado pela perda do controle e das múltiplas possibilidades.

\subsection{TEMAS ORIGINAIS: INSPIRAÇÃO HOLLYWOODIANA, TIMBRES REGIONAIS E A RECORRENTE SUBSTITUIÇÃO DA ORQUESTRA POR SAMPLERS}

No tocante a temas originais, o cinema brasileiro contemporâneo, em geral, faz um uso tradicional da trilha musical, tendo como referência o cinema clássico de Hollywood e sua música orquestral extradiegética - aqui substituída, em grande medida, por samplers e

\footnotetext{
${ }^{20}$ Maior conglomerado de comunicação do Brasil, que, desde 1998, já atuou em 175 produções cinematográficas no País.
} 
instrumentos virtuais, com a colaboração eventual de músicos 'reais', dependendo do orçamento disponível para a música na pós-produção - e as funções usualmente cumpridas pela música segundo Gorbman (1987). Para esta autora, a trilha musical pode promover a unidade de um filme, por meio do desenvolvimento de temas musicais e suas variações, e ser 'invisível', quando a fonte da música é extradiegética, não constando na imagem. Ela também pode se constituir como pista narrativa, caso forneça informações importantes para a compreensão da história pelo espectador - como a indicação de pontos de vista e a caracterização de lugares e personagens.

No cinema clássico narrativo americano a música também pode ser inaudível ou imperceptível, se não for percebida de maneira consciente pelo espectador ${ }^{21}$, uma vez subordinada a imagens e diálogos.

\begin{abstract}
Entre os compositores brasileiros que seguem esta linha na produção recente do cinema brasileiro, pode-se destacar David Tygel, com exceção de seu trabalho para o filme For all - O trampolim da vitória (1997), dirigido por Luiz Carlos Lacerda e Buza Ferraz, no qual Tygel mistura Gershwin com forró, Andrews Sisters com os Cariocas, entre os seus temas originais (SILVA, 2009, p. 228).
\end{abstract}

Assim como a exceção de David Tygel em For all, Silva (2009) elenca outros compositores que aliam, em sua música para cinema, timbres orquestrais - reais e/ou sintetizados, compostos por músicos que não necessariamente possuem formação originalmente erudita; e regionais - agregando sonoridades de instrumentos populares como pandeiro, viola caipira, rabeca, zabumba e outros do repertório cultural popular brasileiro. É o caso de Antônio Pinto, em sua trilha para Central do Brasil (Walter Salles, 1998), com a colaboração de Jacques Morelembaum, e Abril despedaçado (Walter Salles, 2001), com a participação de André Abujamra, Ed Cortes e Belo Villares, entre vários outros compositores. Conhecido mais pela sua influência pop e de world music, Abujamra, por vezes, conta com a parceria de orquestradores para concretizar suas trilhas - como ocorreu em Castelo Rá-TimBum, o filme (Cao Hamburger, 1999) e em Carandiru (Hector Babenco, 2003), ambos orquestrados por Renato Lemos.

Em Castelo Rá-Tim-Bum, o filme a música-tema original composta por Abujamra e Lulu Camargo, além de ser transformada em canção (Ópera Arepó), é desdobrada em diversas variações orquestrais para ambientar a história da tradicional família de bruxos Stradivarius -

\footnotetext{
${ }^{21}$ A possível 'inaudibilidade' da música, conforme proposto por Gorbman (1987), depende do nível de percepção desta pelo espectador em meio aos demais elementos sonoros. Quanto maior o repertório musical e cinematográfico deste, mais aguçada tende a ser a percepção da presença da música.
} 
que mora em um castelo no meio da cidade de São Paulo. A obra conserva as características musicais e o didatismo presentes na trilha sonora da série televisiva na qual se baseia, Castelo Rá-Tim-Bum, criada por Flávio Souza e Cao Hamburger, diretor do filme. Altamente codificada, ela apresenta frequências agudas e ritmo veloz em momentos de alegria; acompanha os momentos de medo e mistério com notas graves e ritmo lento; entre outros procedimentos a serem analisados nesta pesquisa (capítulo 5).

Em Carandiru (Hector Babenco, 2003) o peso da narrativa ficcional inspirada no relato de Dráuzio Varela sobre o massacre do Carandiru condiz com a música em tom menor, de sons graves e andamento lento, o que confere gravidade e um tom solene ao conjunto audiovisual. É como se a composição de Abujamra, sincronizada a cenas de extrema violência, funcionasse como uma 'câmera lenta'. A trilha original, tendo sua primeira parte (cordas e madeiras) como representação sonora da memória (passado) e da busca (futuro) da liberdade, contrapõe-se à sua própria segunda parte (guitarras com slider e percussão), que constata a inevitabilidade do tempo presente, e ao som do filme, cuja ruidagem hiper-realista criada na pós-produção (foley) evidencia a sensação de aprisionamento.

Outras possibilidades da música original percebidas por Silva (2009) a partir da década de 1990 dizem respeito à atuação de compositores estrangeiros em filmes nacionais, como Philip Glass, autor da música de Jenipapo (Monique Gardenberg, 1995); e Zbigniew Preisner, compositor parceiro do diretor Kristof Kieslowski e autor da trilha de Coração iluminado (Hector Babenco, 1998), em uma aproximação estratégica com a música do cinema internacional. Silva (2009) também aponta o movimento inverso, no qual a música brasileira torna-se um chamariz para o público internacional.

Filmes de Bruno Barreto [...] trazem a música popular brasileira descaradamente para agradar o público internacional e, em sua maioria, nas versões instrumentais ou em inglês, como em $O$ que é isso companheiro? (1997), com música de Stewart Copeland, e em Bossa Nova (2000), com música original de Eumir Deodato, trilha adicional de Marcelos Zarvos e supervisão musical de Alan Palanker (SILVA, 2009, p. 228).

Verificamos, portanto, uma convergência entre a maior parte das trilhas musicais originais do cinema brasileiro da Retomada em diante e os princípios de utilização da música no cinema clássico narrativo americano, apontados por Gorbman (1987) ainda no final da década de 1980. Essa aproximação, temperada com timbres do repertório popular brasileiro e alimentada pelo trânsito de profissionais entre cinema e televisão e pela crescente acessibilidade à tecnologia digital de produção musical/audiovisual, evidencia a tendência à 
internacionalização dos modos de produção e consumo de grande parte dos filmes nacionais contemporâneos, em conjunto com fórmulas dramáticas que têm, em Hollywood, sua referência principal, não apenas em termos narrativos, mas também de atualização estética e tecnológica de som e imagem.

Ao longo deste capítulo percebemos como as transformações econômicas, políticas, tecnológicas e estéticas pelas quais passou o cinema brasileiro a partir da década de 1990 afetaram a música deste cinema e suas relações com a instância visual. O inicial desamparo do cinema pelo próprio Estado brasileiro - no intervalo entre a extinção da Embrafilme (1990) e outros órgãos vinculados à atividade cinematográfica e a criação da Lei do Audiovisual (1993) - revelou uma drástica redução da produção, que tem, na economia liberal implantada por Collor para o cinema, uma das origens da precariedade de condições com a qual a década de 1990 se iniciou para os realizadores.

Por outro lado, é notável que a pluralidade de timbres, texturas, formas de manipulação e reorganização de sons por meio da tecnologia digital se tornou possível com o barateamento de equipamentos importados mediante a abertura propiciada pelo liberalismo econômico. $\mathrm{O}$ que, por sua vez, estimulou a estreia de novas gerações de cineastas e compositores - vindos das artes, da publicidade, da indústria fonográfica e televisão, entre outros - marcadas pela postura empreendedora, pela detenção dos meios de produção, pelo contato com a tecnologia e pela vontade/necessidade de equiparação técnica, possível a partir de então, entre o cinema brasileiro e o internacional.

Ballerini (2012) afirma que a 'revolução digital', em conjunto com as leis de incentivo à produção cinematográfica, promoveu as bases para o surgimento de novos cineastas no século XXI e, por consequência, para uma diversidade nunca antes vista - pluralidade esta considerada pelo autor a principal tendência do cinema brasileiro contemporâneo. "Assim, na impossibilidade de rotular o cinema da Pós-Retomada, ele se define como o cinema da diversidade, sem diretrizes, sem um posicionamento político, econômico, social e cultural único, englobando tanto bons filmes como produções precárias” (BALLERINI, 2012, p. 80).

Sobre essa diversidade, que permite e estimula a convivência entre antigos e novos procedimentos e estéticas audiovisuais, Costa (2008) sintetiza, em relação ao som do cinema brasileiro contemporâneo:

Se por um lado, no cinema brasileiro produzido entre os anos 1990 e a primeira década de 2000 grande parte das relações entre sons e imagens é ainda baseada na manutenção dos parâmetros naturalistas que facilitam a comunicação direta com o público, ou no hiper-realismo que deles adveio, por outro, há conquistas técnicas, bem como outras estéticas sonoras, que merecem atenção renovada. A relação com a 
música popular, tão cara à história do cinema brasileiro, permanece, embora traga questões diversas daquelas suscitadas em momentos anteriores. A voz over continua sendo uma opção à narrativa baseada nos diálogos. A língua falada nas telas reproduz com maior propriedade a riqueza do idioma falado no país. Alguns desses parâmetros dão continuidade a conquistas antigas. Há, ao mesmo tempo, êxitos mais recentes, como o grande refinamento quanto ao tratamento dos ruídos e sons ambientes. $\mathrm{O}$ uso do silêncio como elemento que pode contribuir para a narrativa parece disseminar-se. O senso comum que tanto dificulta as relações entre o público de cinema no Brasil e o som de seus próprios filmes dá sinais de enfraquecimento, em resposta às melhorias técnicas na captação, na finalização e na exibição. As funções dentro das equipes de som expandem-se, provocando a esperança de um pensamento maior sobre o som dos filmes dentro do próprio processo de criação, embora modelos contrários a essa expansão, assim como problemas estruturais antigos em todas as cadeias do processo, permaneçam. Segue o trabalho para que também ouvir os filmes seja tarefa tão prazerosa quanto importante (COSTA, 2008, p. 240).

A expansão das equipes cinematográficas de som e uma compreensão mais alargada de seus processos e funções se relacionam à busca de se pensar o cinema conectado ao ascendente mercado audiovisual brasileiro e a outras mídias atuantes neste mercado - lugar onde jovens recém-graduados em cinema em cursos técnicos e superiores de todo o País ingressam anualmente para trabalhar com som, muitas vezes já trazendo consigo uma sólida formação técnica, histórica e estética (DA-RIN, 2005). Conforme Ballerini (2012, p. 80): “[ ...] pensar no cinema industrialmente, conectado à televisão, publicidade, internet etc. Essa é a grande exigência que se faz ao cineasta do século 21 , constituindo uma tarefa não muito árdua para as novas gerações". Percebemos, também na música e nos filmes a que elas se destinam, uma maior preocupação com a distribuição, comercialização e comunicação com o público - o que se tornou mais sistematizado com a criação da Globo Filmes, braço cinematográfico da Rede Globo, em 1998.

Canções são inseridas nos filmes com finalidades que vão além da comercial, articuladas às narrativas ora de forma mais sofisticada em termos dramáticos que em décadas anteriores, ora mais televisiva, quando voltadas para o entretenimento. Sobre a atual relação entre cinema e televisão/publicidade no Brasil e suas consequências, analisa Ballerini (2012):

Com o lançamento de Cidade de Deus, em 2002, falou-se muito sobre a "invasão" do cinema pela estética publicitária ${ }^{22}$. E com o advento da Globo Filmes, passou-se a falar em "invasão televisiva". O fato é que o cinema mundial sempre se comunicou com outras artes, como a literatura e o teatro, por exemplo. Agora, a influência vem principalmente da televisão e da publicidade, no que se refere à construção

\footnotetext{
22 Nesse contexto, a pesquisadora e crítica de cinema Ivana Bentes cunhou a expressão 'cosmética da fome', resgatando, por comparação, o manifesto Estética da fome, de Glauber Rocha, que foi um dos grandes princípios norteadores da produção do Cinema Novo: utilizar a precariedade como possibilidade estética para o filme. A 'cosmética' presente nos filmes brasileiros dos anos 2000 se refere à tendência, segundo Bentes (2007), de se produzir filmes cujo caráter conservador é ‘maquiado' por uma altíssima qualidade técnica, conquistando o público e convertendo-se em algumas das maiores bilheterias do cinema brasileiro a partir de então. Cidade de Deus seria o exemplo inaugural deste tipo de produção.
} 
fotográfica, ritmo, narrativa, etc. Portanto, não há nada de novo nessa intercomunicabilidade; as influências podem ser tanto positivas quanto negativas, tudo depende do talento do cineasta e de sua equipe. Mas uma coisa é certa: a comunicação entre as linguagens publicitária, televisiva e cinematográfica contribuiu para que surgissem propostas estéticas e narrativas totalmente díspares no novo milênio, tornando o cinema brasileiro imune a qualquer rotulação (BALLERINI, 2012, p. 79).

Enquanto ruídos passam, por vezes, a ser componentes musicais, atuando no sentido de alimentar ou superar a sincronia realista com a imagem, música e silêncio passam a valorizarse mutuamente por meio da economia de seu próprio uso pelos compositores, com a anuência dos diretores. No entanto, na análise de Silva (2009), não se verificam grandes inovações quanto ao panorama das composições musicais para cinema, em termos de estética e funcionalidade.

Ao investigar a diversidade dos filmes de ficção, realizados a partir dos anos 90, além de algumas contribuições de novas sonoridades e performances de intérpretes da música popular brasileira, o que mais nos chama a atenção é como o panorama de trilhas musicais do cinema brasileiro não mudou substancialmente, prevalecendo antigas parcerias entre compositores e diretores, a presença de consagrados cancionistas, as trilhas voltadas para o público internacional (SILVA, 2009, p. 223224).

A grande inovação da música brasileira de cinema a partir da Retomada talvez esteja mais claramente vinculada às mudanças estruturais no processo de composição e no perfil de compositor que elas passam a demandar - o 'compositor-empreendedor' -, relacionadas à adoção irreversível da tecnologia digital de produção sonora. Como vimos, ela estimulou o surgimento de um grande número de novos compositores, entre eles André Abujamra, cada qual com seu repertório, bagagem, metodologia e estrutura de trabalho, o que contribui para a consolidação da pluralidade e da convivência entre tradição e inovação como as principais características das novas partituras do cinema brasileiro contemporâneo. 


\section{O COMPOSITOR NO PROCESSO DE REALIZAÇÃO CINEMATOGRÁFICA}

Este capítulo contextualiza o compositor no processo de realização cinematográfica, revelando quando ele é inserido na equipe; com que outros profissionais do filme, em geral, ele interage diretamente; quais são as principais etapas de seu trabalho; enfim, como ele integra sua trilha musical ao conjunto de procedimentos sonoros e visuais do cinema até a finalização da obra.

O relacionamento entre o compositor e o diretor cinematográfico é abordado de forma especial, buscando a compreensão de como se desenvolve a comunicação para a criação, desenvolvimento e inserção da música do filme. Para isso, citamos diversos compositores e diretores brasileiros, de diferentes gerações, falando sobre os desafios deste relacionamento e sobre como a música original é e/ou poderia ser abordada no cinema, sobretudo em um contexto no qual, em espaços legitimados de formação em Cinema ou Música, este diálogo é inexistente, incipiente ou não tão estimulado.

\subsection{MÚSICA DE CINEMA: DA NEGOCIAÇÃO AOS CRÉDITOS}

Até que o nome do compositor da trilha musical apareça nos créditos de um filme é comum que boa parte da ideia original do compositor tenha sido alterada a partir das sugestões do diretor e/ou do produtor. Isso acontece porque, no cinema, a música é funcional; não é a obra final e não constitui uma obra de arte independente, lembra Giorgetti (2008). Sendo um dos elementos sonoros que comporá, juntamente com os demais sons e elementos visuais, a narrativa fílmica, a música já nasce com várias referências - o roteiro, a fotografia, por exemplo - e colaborações - do produtor, do editor de som, do montador e, principalmente, do diretor, que assume a responsabilidade pelas decisões artísticas.

As demandas do processo de composição musical, assim como outras no cinema, em geral, superam o conhecimento do diretor. Este passa, então, a liderar uma equipe de especialistas em cada área da realização cinematográfica, cada qual com sua experiência e potencial para dar, ao filme, sua contribuição técnica e criativa. Para que o conceito estéticonarrativo idealizado pelo diretor esteja, de alguma forma, presente no filme, este precisa estabelecer com cada profissional uma comunicação clara e fluente. De acordo com Berchmans (2006), essa clareza no diálogo com o compositor, aliada à compreensão da linguagem musical 
e sua importância por parte do diretor, tende a contribuir para a construção de uma relação intrínseca entre a música e o filme.

\begin{abstract}
No processo de composição musical, grande parte da responsabilidade artística de uma obra está nas mãos do diretor. [...] Quanto mais o diretor conhece e entende o poderoso recurso que tem nas mãos, mais possibilita, direciona e permite um uso criativo e inteligente da música em seu filme (BERCHMANS, 2006, p. 22).
\end{abstract}

Assim sendo, é com a orientação principal do diretor - cujo objetivo é concretizar sua ideia por meio do trabalho de diferentes profissionais - que ocorre a criação da música pelo compositor, a qual é passível de ajustes até o momento da finalização. Portanto, embora a assinatura da música original de um filme seja atribuída ao compositor, ela é proveniente de um conceito estabelecido por outrem, a partir do qual o músico compõe e passa, em última instância, pelos ajustes operados pelo profissional finalizador da trilha sonora do filme na mixagem final. Que é quando a música se une às demais camadas sonoras da obra e são tomadas as últimas decisões sobre volume, equalização, espacialização e outras- processo que, via de regra, prescinde da presença do compositor.

Há, neste processo, uma constante negociação entre a "liberdade" criativa do músico e o projeto artístico do diretor, na qual interferem aspectos como a notoriedade artística, o conhecimento técnico, as relações políticas e interpessoais estabelecidas na área cinematográfica e a capacidade de argumentação de um e de outro. Ao mesmo tempo, como vimos, o ofício de compositor vem sendo transformado e expandido desde o início do século XX, agregando, além da criação musical, atividades vinculadas à: física, psicoacústica, informática, curadoria de conteúdos, produção e outras que surgem conforme as necessidades do compositor em cada projeto.

É importante ressaltar que os estudos sobre a autoria no cinema são historicamente vinculados ao papel do diretor. Este conceito é questionado nos estudos cinematográficos contemporâneos devido ao fato de que a visão romantizada do autor - artista cuja obra, completamente imbuída da originalidade de estilo e resultante de sua "liberdade" criativa, é descolada do contexto histórico, econômico, social e cultural onde ela é idealizada e concretizada e de todas as limitações, condições e imprevistos que este contexto pode oferecer - remonta a um discurso de legitimação do cinema [notadamente o norte-americano, conforme Buscombe (2004)] como arte e expressão pessoal do diretor, em revistas de crítica de cinema de circulação mundial, desde o início dos anos de 1950. 
Naquele período, e ainda hoje, o produtor é figura central na indústria cinematográfica ocidental, especialmente na norte-americana; no entanto, diretores como John Ford, Orson Welles e Alfred Hitchcock se consagraram como exceções no contexto hollywoodiano de 'filme de produtor'. Publicações como os Cahiers du Cinéma - um dos principais veículos de análise e crítica cinematográfica, surgido em 1951 - foram determinantes nessa afirmação da preponderância da expressão artística do diretor sobre a viabilização econômica do filme pelo produtor.

Desde os primeiros números, discutiam-se diretores de Hollywood como Welles, Ford e Lang. Os Cahiers não queriam só elevar o status do cinema em geral, mas do cinema americano em particular, alçando seus diretores à categoria de artistas (BUSCOMBE, 2004, p. 282).

Ainda de acordo com Buscombe (2004), os Cahiers du Cinéma sempre mencionaram uma politique des auteurs, cuja tradução 'teoria do autor' é atribuída a Andrew Sarris, no ensaio Notes on the Auteur Theory in $1962^{23}$. Seria por meio da autoria que, conforme desejavam os críticos dos Cahiers, o cinema poderia sair da condição de produto de entretenimento da indústria cultural para se estabelecer como obra resultante da criatividade de um artista. Esta exaltação do diretor-autor no cinema como o grande indicativo de valor de um filme tem suas origens na teoria artística romântica.

Em Cultura e Sociedade: 1780-1950, Raymond Williams descreve que no período romântico a teoria estética chegou a ver o artista como essencialmente oposto à sociedade, realizando a expressão pessoal em um ambiente hostil e valorizando-a ainda mais por isso (BUSCOMBE, 2004, p. 288, grifos do autor).

A partir da vinculação de textos a uma individualidade no período romântico, afirma Jost (2009), a figura do autor aparece na cultura. Tal atribuição se mostra arriscada no cinema, devido à própria natureza híbrida da linguagem cinematográfica, cuja realização depende de procedimentos e saberes múltiplos e coletivos e, antes, de um contexto que a estimule.

A importância desse contexto é resgatada posteriormente por Bordwell (2008), que defende os recursos humanos e materiais disponíveis, os modos e as condições de produção especificamente as situações nas quais o diretor se vê confrontado a tomar decisões diferentes do que planejara originalmente - como fatores determinantes da estética de uma obra cinematográfica, sendo o diretor seu principal agente viabilizador, e não o motivo absoluto da existência da obra.

23 'Notas sobre a teoria do autor em 1962', tradução nossa. 
Ao mesmo tempo, pondera Jost (2009), o conceito de autoria 'humanizaria' o cinema, antes popularizado pela inovação mecânica do aparato.

\begin{abstract}
Tendo entrado naturalmente na era da reprodutibilidade, ele [o cinema] é, sobretudo, e antes de tudo, uma arte da mecânica no sentido próprio, de forma que lhe faz falta de início esta humanidade que lhe conferiria o pleno valor de artefato e que facilitaria a transfiguração do filme em obra (JOST, 2009, p. 13).
\end{abstract}

De acordo com as leis de propriedade intelectual vigentes atualmente na Europa e na América Latina, em uma peça audiovisual são considerados autores o diretor, o roteirista e o compositor da trilha musical original. Mais especificamente no Brasil, a lei de direitos autorais (Lei n 9.610, de 19 de fevereiro de 1998), em seu Capítulo II, artigo $16^{\circ}$, traz o seguinte texto: "São co-autores da obra audiovisual o autor do assunto ou argumento literário, musical ou lítero-musical e o diretor" (BRASIL, 1998) ${ }^{24}$.

O fato de, no Brasil, diretores, roteiristas e compositores serem considerados coautores legais de um filme, ao mesmo tempo em que constitui uma proteção dos seus direitos como criadores, não significa, como rezava o ideal romântico de autor, que não estejam suscetíveis às diversas condições de realização - de situações de baixíssimo orçamento àquelas estruturadas dentro dos grandes conglomerados midiáticos; que não sejam influenciadas pela política - historicamente baseada em editais de fomento à produção; pela economia - do advento da tecnologia digital tornada acessível com a globalização aos gargalos da distribuição e exibição; pelo contexto socio-histórico e cultural em que surgem - mundialização da cultura e do acesso à informação.

A globalização da economia e a mundialização da cultura, por princípio, já complexificam a questão da autoria, uma vez que se vive o compartilhamento global de tecnologias, estéticas, imagens e sons remixados, muitas vezes sem que as fontes da informação-matriz sejam conhecidas ou reveladas. Isso sem mencionar o impacto das soluções criativas de profissionais como fotógrafos, captadores de som, editores de som e imagem e outros não considerados coautores de obras audiovisuais pela legislação. Prova disso são os relatos do compositor André Abujamra sobre os processos de composição musical para diversos filmes, como veremos no capítulo 4.

\footnotetext{
${ }^{24}$ Em complementação a essa, o parágrafo sexto da Lei $\mathrm{n}^{\circ} 12.853$, de 14 de agosto de 2013, dispõe sobre a necessidade de uma entidade arrecadadora "[...] dos direitos relativos à execução ou exibição pública, imediatamente após o ato de comunicação ao público, relação completa das obras e fonogramas utilizados, e de [...] torná-la pública e de livre acesso, juntamente com os valores pagos, em seu sítio eletrônico ou, em não havendo este, no local da comunicação e em sua sede" (BRASIL, 2013).
} 
Há que se recordar que o reconhecimento da autoria de um compositor musical é anterior ao cinema - como comprovam Bach, Mozart, Beethoven, Wagner, Brahms, entre tantos outros célebres criadores de música sinfônica erudita legitimados pela crítica e pelo público das salas de concerto. Mannis (2012) problematiza esta concepção de autoria por ineditismo, legitimidade social e posse de um conhecimento privilegiado, quando analisa a questão do lugar do performer frente ao do compositor de uma obra, por exemplo.

\begin{abstract}
Nos primórdios, quem cantava ou tocava, necessariamente inventava o que executava. Invenções se salientando sobre as demais, foram repetidas. E assim, músicas foram reproduzidas (copiadas, imitadas) por terceiros. Os mais destacados inventores de músicas não passaram a ser denominados compositores? Aqueles que reproduziam o que apre(e)ndiam, inventando sua realização, não foram chamados de intérpretes ou performers? E a sistemática dessa classificação não acabaria provocando ambiguidades e equívocos, como o de que a "simples" interpretação de uma obra já composta (publicada) seria uma mera reprodução da mesma, não caracterizando invenção musical, nem havendo em jogo processo criativo, sendo estes, próprios (e exclusivos) do compositor? (MANNIS, 2012, p. 202-203).
\end{abstract}

Ou seja, antes mesmo da existência do próprio cinema e, consequentemente, da figura do compositor de música para filmes, já havia fissuras profundas no pensamento musical tradicional do Ocidente quanto à autoria, segundo as quais os compositores se tornavam, em uma visão idealizada, criadores únicos e absolutos de suas obras, restando aos performers um secundário e distorcido papel de leitores de partituras e reprodutores de peças concebidas pelos primeiros, seja qual fossem os meios. Sobre uma suposta 'aura' de divindade do compositor no século XIX, sublinha Mannis (2012):

O compositor, também levado pelo vórtice da consagração, era visto rodeado por uma aura. Na passagem ao século XX "suas" músicas puderam ser reproduzidas, distribuídas e comercializadas através de modernos meios e mídias. Novos negócios surgiram, com impacto no setor artístico. O valor da aura do artista foi mantido, porque todos a admiram, todos a querem consigo (MANNIS, 2012, p. 204).

Para os compositores vindos da Europa para a América do Norte, exilados ou como imigrantes durante a Segunda Guerra Mundial e que, nos Estados Unidos, lograram, depois de algum tempo, estabelecerem-se como músicos de cinema, o desafio do reconhecimento da autoria adquiria mais uma camada: a tarefa de se firmar em um ofício complexo e carente de reconhecimento em um país estrangeiro, ao mesmo tempo acompanhando uma mudança gradativa da compreensão do cinema pelo público - que passaria de divertimento 'vulgar' a arte e entretenimento industrial. Nos primeiros anos de composição musical original para filmes sentiram o peso desse contexto - da atuação isolada de compositores de diferentes origens em 
busca de legitimação e da falta de reconhecimento da música como elemento narrativo importante no cinema - os hoje consagrados Max Steiner e Dimitri Tiomkin e, posteriormente, Franz Waxman, Miklós Rózsa e Bronislau Kaper, entre outros. Basta lembrar que o primeiro estudo analítico e em profundidade sobre as possíveis funções da trilha musical no cinema clássico narrativo hollywoodiano - Unheard melodies: narrative film music, de Claudia Gorbman - data de 1987.

Buscaram reconhecimento também os compositores populares, muitas vezes provenientes da indústria fonográfica - onde a autoria é limitada, sobretudo, pelos interesses das gravadoras - do rádio e da televisão, cuja notoriedade e visibilidade midiática colaboraram com sua inserção profisssional como autores de música para cinema - como Danny Elfman, vocalista da banda Oingo Boingo, por exemplo. Não sem sofrer a oposição de compositores veteranos $^{25}$, esse movimento, segundo Wierzbicki (2009), além do fator lucratividade e publicidade historicamente vinculados à relação entre as indústrias fonográfica e cinematográfica, possui outras camadas, como os fatores estéticos envolvidos em cada narrativa fílmica em particular e o surgimento dos movimentos contraculturais a partir dos anos de 1960. Esse contexto histórico aproximou o jazz, o rock e outros gêneros musicais do cinema, bem como tantas outras influências, na moda, no comportamento e em outros aspectos da vida da juventude urbana da época.

Perdura a necessidade de revisão da ideia romântica de autoria, 60 anos depois, em um contexto em que, paradoxalmente, há uma compreensão consolidada da performance como criação artística e a existência de redes de colaboração cada vez mais densas, híbridas e fluidas entre compositores e outros artistas no compartilhamento de sonoridades diversas, no cinema e em quaisquer outras linguagens.

\footnotetext{
Com o colapso dos antigos modelos de negócios, [...] no que diz respeito às artes e aos artistas, nos encontramos diante de uma estrutura social e econômica estagnada há praticamente um século, profundamente arraigada em modelos quase obsoletos, em extinção. Há um elefante na sala [propriedade intelectual individual] porque a casa do compositor foi construída a seu redor. E pela janela observa-se grande movimentação (MANNIS, 2012, p. 205).
}

\footnotetext{
${ }^{25}$ Wierzbicki (2009, p. 191-192) elenca os três principais fatores da 'infiltração' da música popular no cinema, segundo o compositor de música sinfônica para filmes David Raksin: vender discos - angariando publicidade para o filme -; mostrar-se a um público 'demograficamente definido'; e a busca por uma suposta 'atualização' de diretores e produtores experientes em uma área com cada vez mais jovens profissionais atuantes. Pontuando também a resistência de Bernard Herrmann a esse fenômeno, o autor afirma que Raksin e Bernstein chegam a sugerir que a entrada da música popular no cinema nos anos de 1960 se deveu, em primeira instância, à "[...] ignorância, mau gosto e comercialismo grosseiro por parte de diretores e produtores cinematográficos" (WIERZBICKI, 2009, p. 192, tradução nossa).
} 
Todas as instâncias de criação visam a uma finalidade única, que é o filme, e, nesse percurso, o que é filmado não corresponde exatamente ao conceito idealizado pelo diretor, tampouco ao último tratamento do roteiro, assim como a trilha musical, em geral, não coincide com a ideia original apresentada pelo compositor ao diretor. Sobre a relação destes em específico, faz-se necessário conhecer as diferentes perspectivas criadoras, pautadas na formação, nas experiências profissionais e na construção de seus repertórios cinematográficos e musicais, para entender como a compreensão da música no cinema por cada um deles pode interferir na escolha do compositor pelo diretor, na aprovação da trilha musical e, por fim, no impacto da narratividade do conjunto som-imagem no espectador.

Neste ponto, é importante ressaltar, em consonância com Mannis (2012), que a criação sonora não é uma atividade específica e reservada ao compositor; o que o difere dos demais artistas potencialmente inventores de sonoridades é a transformação de sua sensibilidade de escuta em estéticas e técnicas específicas de criação, registro e reprodução de som. Eis o que o torna apto a, conforme o citado autor, estabelecer " [...] elos entre os mundos sonoro e extrasonoro (associações, correlações simbólicas, sensitivas, sensuais e emocionais), agregando à produção qualidades estruturais e formais enriquecidas por múltiplas leituras e significações” (MANNIS, 2012, p. 203).

Somente a partir de saberes e práticas mais abertos à complexidade trazida pela questão da autoria no cinema se poderá 'libertar' o compositor tanto de seus resquícios de ideal romântico quanto de uma persistente frustração relacionada ao caráter funcional de sua música no cinema; bem como aproximá-lo de outras esferas de produção sonora cinematográfica, como o sound design.

\subsection{VOZES DE EXPERIÊNCIA: A TRILHA MUSICAL, SEGUNDO COMPOSITORES E DIRETORES}

O processo de composição da trilha musical varia tanto quanto o de realização cinematográfica, em função dos contextos político, econômico, cultural, social, tecnológico etc.; das necessidades técnicas e estéticas específicas de cada filme e dos métodos e estilos de cada diretor.

Ocorre que a criação musical exige um conhecimento técnico que, salvo exceções, foge à seara do diretor, fazendo com que, por vezes, não haja muito controle sobre a trilha musical. Matos (2014) aponta as lacunas na formação superior em Cinema no Brasil quanto à 
composição e produção musical como um dos agravantes dessa dificuldade de comunicação entre diretor e compositor.

Entre todos os aspectos da produção de um filme, a música é, quase sempre, o que mais foge ao controle do diretor, já que, além de não fazer parte dos cursos regulares para cineastas - pelo menos com a mesma profundidade e o mesmo detalhamento dos cursos de música -, é uma forma de expressão sutil, sem uma correspondência material ou visível como são o figurino, o cenário, a maquiagem, a performance dos atores, a luz, a fotografia etc. (MATOS, 2014, p. 270-271).

Já do ponto de vista específico da área musical, Mannis (2012) aponta o engessamento dos currículos tradicionais na formação dos compositores também como um fator de distanciamento de outras possibilidades de criação interartística:

Que se reflita sobre a formação dos compositores, pois estranhamente insiste-se, ainda na atualidade, em se manter grades curriculares aprisionadas, enrijecidas e antiquadas para 'nobres criadores musicais' (MANNIS, 2012, p. 206).

Devido a essa lacuna na formação superior no País, tanto da falta de abordagem da música nos currículos dos cursos de Cinema quanto do cinema nas matrizes curriculares dos cursos de Música, em níveis de graduação e pós-graduação ${ }^{26}$, é na atuação profissional que compositores e diretores passam a compreender os papéis que a música pode exercer no filme ${ }^{27}$. Comentários acerca deste assunto, por diretores e compositores de diferentes gerações do cinema brasileiro, são elencados a seguir para que se possa compreender como eles se colocam neste relacionamento ainda desafiador no processo de realização cinematográfica no País.

\footnotetext{
${ }^{26}$ As exceções são os cursos de Graduação em Música Popular, da Universidade de Campinas (Unicamp), que desde 1991 oferece disciplinas específicas sobre trilha sonora (Trilhas Sonoras I e II), e o Bacharelado em Música da Universidade Federal do Espírito Santo (UFES), cuja matriz curricular de 2010 já oferece a Habilitação em Composição, com ênfase em Trilha Musical. Muitos músicos atuantes no cinema brasileiro contemporâneo também têm a oportunidade de investir na formação específica em composição de trilhas musicais para cinema viajando para o exterior para aulas presenciais, participando de cursos online oferecidos por instituições com tradição na área - como a Berklee College of Music, ou ainda frequentando oficinas e cursos livres sobre o assunto, já oferecidos nas principais capitais brasileiras.

${ }^{27}$ Uma das primeiras exceções no Brasil é o maestro e pianista Antonio Remo Usai, conhecido por ser um dos primeiros compositores no país a ter formação específica de música para cinema. Autor de mais de 140 trilhas musicais para filmes brasileiros, o filho de imigrantes italianos foi encorajado pelo contato com os mestres Cláudio Santoro, Léo Peracchi e Guerra-Peixe, que também tinham destacada atuação no cinema nacional. Usai vendeu seu jipe foi para os Estados Unidos estudar música e composição de trilha musical no curso de cinema da Califórnia do Sul, onde foi aluno de Miklos Rózsa, importante compositor musical em Hollywood. Como consequência do alto investimento, Usai tornou-se um dos compositores mais importantes do cinema brasileiro a partir dos anos de 1960, tendo assinado a música de filmes como Assalto ao trem pagador (Roberto Farias, 1962) e de Mandacaru vermelho (1960) e Boca de ouro (1962) - estes últimos, dirigidos por Nelson Pereira dos Santos. O percurso de Remo Usai como compositor de música para filmes foi estudado por Eikmeier (2010) e narrado no documentário Remo Usai - um músico para o cinema (Bernardo Uzeda, 2008).
} 
O compositor e professor Eugênio Matos $^{28}$ reflete sobre o comportamento da música extradiegética - aquela exterior ao universo diegético - no cinema em seu encontro com os demais elementos imagéticos e sonoros que, por sua vez, buscam, na diegese, emular certa verossimilhança com a realidade. Nessa situação, a origem desconhecida (ou não pertencente à diegese) e o compromisso facultativo com tal simulação da realidade permitem à música extradiegética tonalizar, com maior liberdade, o conjunto audiovisual, expandindo suas possibilidades sensoriais, emocionais e semânticas.

Enquanto atores, cenários, iluminação, efeitos sonoros e figurino têm, de modo geral, o objetivo de simular a realidade, a música surge como algo inusitado, estranho mesmo a essa realidade. [...] De certa forma, e com exceção das situações em que ocorre de forma diegética, a música entra na estória com uma "atitude" no mínimo especial em relação aos outros ingredientes do audiovisual (MATOS, 2014, p. 47).

Em pensamento convergente se encontra o veterano cineasta Nelson Pereira dos Santos $^{29}$, diretor de filmes brasileiros importantes, do Cinema Novo em diante. Ao defender a música no cinema como elemento expansivo das possibilidades da imagem, ele confirma, do ponto de vista da direção cinematográfica - ou seja, do lugar de fala de quem precisa orquestrar todos os componentes da linguagem para realizar um filme -, a música não como um elemento submisso à imagem, mas sim como um recurso chave na complexificação da experiência audiovisual.

Não se pode subordinar música, que é uma linguagem muito mais poderosa, mais comunicativa, à imagem, que é burra, é concreta, copo é copo, gente é gente. A música não, ela tem condições de alargar o universo afetivo, intelectual, sentimental, e não apenas de ficar atrás do filme (SANTOS, 2001 apud GUERRINI JÚNIOR, 2009, p. $6)$.

No entanto, o exagero, na intensidade e na recorrência da música, afeta a relação entre som e imagem, cujo equilíbrio só pode ser alcançado a partir das demandas estéticas e narrativas específicas de cada filme. Uma vez desestabilizada esta relação fundante da linguagem, a

\footnotetext{
${ }^{28}$ Eugênio Matos é compositor de trilhas musicais para cinema e televisão, formado em Composição para Cinema e TV pela Universidade da Califórnia (UCLA) e graduado em Música pela Universidade de Brasília (UnB). Mestre em Composição pela Universidade Estadual de Campinas (Unicamp), além de compositor, atua como professor da Escola de Música de Brasília. É responsável pelas trilhas musicais dos documentários em longa-metragem O Brasil na batalha do Atlântico (Erik de Castro, 2012), Juruna, o espírito da floresta (Armando Lacerda, 2008) e Senta a pua! (Erik de Castro, 1999), além do longa de ficção Federal (Erik de Castro, 2010), entre outros trabalhos em curta-metragem.

${ }^{29}$ O diretor Nelson Pereira dos Santos é graduado em Direito pela Universidade de São Paulo, fundador do curso de Cinema da Universidade Federal Fluminense (UFF), instituição onde é professor. Entre as obras mais conhecidas de sua filmografia (28 filmes) estão: Rio, 40 graus (1955), Rio, Zona Norte (1957), Mandacaru vermelho (1961), Vidas secas (1962), Fome de amor (1968), Como era gostoso o meu francês (1971), Tenda dos milagres (1977), Memórias do cárcere (1984) e A terceira margem do rio (1994).
} 
narrativa fílmica é enfraquecida e sua existência como obra de arte é passível de questionamento, conforme pondera o cineasta Ruy Guerra ${ }^{30}$ :

\begin{abstract}
Você pode esmagar uma imagem com a música. Pode transferir tudo para a música, e a imagem ser um suporte daquela música. Pode haver um momento em que você possa fazer essa transferência de uma forma específica e válida, mas aí já foi filmado nesses termos. Ou foi pensado na montagem. Mas quando a música é um substitutivo total da imagem, não vale a pena fazer um filme. É melhor fazer um concerto [...] (GUERRA, 2001 apud GUERRINI JÚNIOR, 2009, p. 6).
\end{abstract}

O uso da música no cinema demanda, portanto, uma economia; um equilíbrio de forças entre som e imagem e seus elementos constitutivos. Todos estes têm, como função primordial, servir ao filme; e não seria diferente com a música, mesmo com todo o seu poder autônomo. Considerando-a como um dos vários elementos da linguagem cinematográfica, ela deixa de ser uma obra de arte em si para prestar suporte narrativo, estético e dramático ao filme, não se submetendo, entretanto, à instância visual. Sobre tal economia, Ruy Guerra analisa a necessidade da música como algo de certo modo subjetivo e imprevisível.

A música de filme é assim. Às vezes está tudo certo, mas se tirar também está certo. Então a música não serve para aquela cena. É uma química extremamente imprevisível, e que não pode ser trabalhada na racionalidade da palavra (GUERRA, 2001 apud GUERRINI JÚNIOR, 2009, p. 201).

Em consonância, Guilherme $\mathrm{Vaz}^{31}$ - compositor de trilhas musicais de filmes dirigidos por Ruy Guerra, Nelson Pereira dos Santos e Júlio Bressane, entre obras de outros diretores considera que ou a música age como forma expressiva e articulada no cinema, ou deve ser silenciada,

Na tradição do cinema ocidental, a música é um segundo fator, muitas vezes desprezado, e por isso mesmo desprezível. Noventa por cento das músicas do cinema ocidental têm mais papel de estorvo à tensão dramática, ou de pura entropia linguística ou artística, do que propriamente de um elemento de grande expressão (VAZ, 2001, 2002 apud GUERRINI JÚNIOR, 2009, p. 237).

\footnotetext{
${ }^{30}$ O cineasta moçambicano Ruy Guerra estudou no Institut des Hautes Études Cinématographiques (IDHEC) de Paris, a partir de 1952. Atuou como assistente de direção até 1958, quando veio para o Brasil, onde dirigiu seu primeiro filme, Os cafajestes (1962). Dentre as obras de destaque como diretor (16 filmes), figuram ainda Os fuzis (1964), A queda (1976), Ópera do malandro (1986), Kuarup (1989), Estorvo (2000), Casa de areia (2005) e Quase memória (2015).

${ }^{31}$ Um dos pioneiros da arte sonora no Brasil, o compositor e maestro Guilherme Vaz é autor das trilhas musicais de Fome de amor (1968), Azyllo muito louco (1970) e Como era gostoso o meu francês (1971), todos dirigidos por Nelson Pereira dos Santos; A rainha diaba (Antonio Carlos da Fontoura, 1974), Feminino plural (Vera de Figueiredo, 1976), além de filmes de Júlio Bressane, tais como Tabu (1982), Miramar (1997) e Filme de amor (2003), entre outros.
} 
Imbuído deste pensamento, o maestro, ao compor a música para Fome de amor (Nelson Pereira dos Santos, 1968), criou os conceitos de 'volume de força' - quando a música deixa de assumir funções tradicionais de suporte narrativo, psicológico ou emocional, para se tornar “"[...] um meteoro que passa através do filme e sai do outro lado sem nenhuma ligação tradicional com o que acontece na imagem” (VAZ, 2001, 2002 apud GUERRINI JÚNIOR, 2009, p. 158), e de 'pigmentos sonoros' - metáfora pictórica que consiste na 'explosão', em maior ou menor intensidade, de pequenos pontos sonoros gotejados ao longo da narrativa. Tais se conceitos tornam possíveis a partir da ideia aqui articulada de que a música tem o poder de transformar e expandir os limites do simulacro e, caso ela não seja essencial, que seja valorizada pela ausência, por meio do silêncio.

É notável o esforço de compositores como Guilherme Vaz, que introduz a música concreta no cinema brasileiro e assina peças musicais de filmes do final da década de 1960 e posteriores, em criar novas possibilidades musicais para a linguagem cinematográfica mesmo em meio à escassez de recursos. Precariedade esta que historicamente justifica a quantidade pouco expressiva de filmes da época com música original, em detrimento do uso recorrente de canções e gravações preexistentes de obras sinfônicas, como as do compositor Heitor VillaLobos.

Ao analisar a música dos filmes do Cinema Novo, movimento que ajudou a construir, Cacá Diegues $^{32}$ aponta a confluência entre a vontade de ruptura com a estética pomposa e pretensamente hollywoodiana da Vera Cruz - o que inclui a música de cinema, tradicionalmente utilizada como grifo ou reforço da imagem -, a precariedade das condições de produção e o esforço em representar a diversidade cultural do Brasil e as ideias de seus cineastas-autores como um possível estímulo a tal esforço criativo.

\footnotetext{
Num momento imediatamente anterior ao Cinema Novo e que chega a conviver com o Cinema Novo, você tem uma tradição de Guerra Peixe, que fazia muita música para cinema, Radamés Gnatalli, [...] mas que era uma coisa meio tradicional, de sublinhar a narração. Já o Cinema Novo, mesmo quando a música tem um caráter sinfônico, orquestral, ela é muito mais detonadora de um universo cultural a que aquele filme pertence do que propriamente um suplemento da narração. [...] De certo modo, a gente deixa de fazer a música que corresponde à imagem do filme e passa a fazer a música que corresponde aos sentimentos do personagem ou até mesmo as ideias do autor (DIEGUES, 2001 apud GUERRINI JÚNIOR, 2009, p. 36, grifos do autor).
}

32 Entre os filmes de destaque realizados pelo diretor Cacá Diegues estão os premiados: Ganga Zumba (1964), Xica da Silva (1976), Bye bye Brasil (1979), Dias melhores virão (1989), Veja esta canção (1994), Tieta do Agreste (1996) e Orfeu (1999). 
A revelação, por meios musicais, do universo cultural que localiza o filme consiste em uma das formas de expandir a própria obra, podendo se tornar um canal de evidências não apenas dos sentimentos dos personagens, mas do contexto da produção e das circunstâncias diversas - políticas, econômicas, artísticas, emocionais etc. - que contribuem para as escolhas musicais do diretor e do compositor em cada sequência.

A própria função assumida pela música de promover, em conjunto com outros componentes, a unidade sonora da narrativa fílmica, depende, em muitos casos, da articulação das formas fragmentárias e 'inacabadas' que assume, como aponta o compositor Remo Usai: “A trilha sonora não é uma sinfonia, não é uma peça de concerto. É uma série de retalhos, de formas de curta duração, fragmentos musicais, trechos inacabados, músicas sem começo nem fim, aberturas sensacionais e finais grandiosos" (USAI, 1981 apud BERNARDET et al., 1981, p. 12). Matos (2014), entretanto, atenta para o fato de que a música que entra, sai, vai e volta com variações ao longo do filme não é necessariamente fragmentada, mas apresenta flexibilidade e certa "liberdade" de criação ${ }^{33}$; ao mesmo tempo em que precisa estabelecer, com o filme, uma relação de coerência, pode ser apreciada mesmo longe da banda visual.

Inspirado nos estudos de Gorbman $(1987)^{34}$, Matos (2014) considera didaticamente as funções da música no cinema em três grandes categorias: físicas, psicológicas e técnicas. As funções físicas dizem respeito à relação direta e de reforço da imagem pela música, por meio da ênfase da ação - cujo nível máximo é o mickeymousing ${ }^{35}$-, de referências espaciais ou cronológicas. As funções psicológicas constituem um refinamento da linguagem, a partir da revelação mais ou menos sutil de novas informações narrativas acrescidas à imagem: ambientação psicológica, emoção subliminar, comentário, 'alarme falso' (falsa expectativa criada pela música). As funções técnicas se baseiam na promoção da continuidade e/ou do contraste entre a música e a imagem, com o suporte das transições (cross-fades, fades ou dissolves).

\footnotetext{
${ }^{33}$ Essa "liberdade" é limitada, já que a composição é concebida e aprovada conforme as observações do diretor, em negociação com o compositor - a não ser que aquele deixe a criação completamente nas mãos deste, o que ocorre em parcerias consagradas entre diretores e compositores. Antes disso, é importante lembrar que todo artista tem sua expressão criativa limitada pelos artifícios tecnológicos de seu tempo.

${ }^{34}$ Gorbman (1987) observou a presença de diversas características da música nos filmes clássico-narrativos: ela pode ser inaudível, se não percebida de maneira consciente pelo espectador, subordinada a imagens e diálogos; pista narrativa, se fornece informações importantes para a compreensão da narrativa pelo espectador - como a indicação de pontos de vista e a caracterização de lugares e personagens. A música também pode promover a unidade de um filme, por meio do desenvolvimento de temas musicais e suas variações, e ser 'invisível', quando a fonte de música é extradiegética, não constando na imagem.

${ }^{35}$ Exagero na ênfase da ação: a música acentua todos os movimentos e gestos dos personagens.
} 
A partir de sua experiência como compositor, Matos (2014, p. 77-78) revela ideias convergentes com as do diretor Ruy Guerra, ao observar que a criação musical para filmes precisa encontrar seu ponto de equilíbrio entre os limites da sobrecarga sonora e do silêncio. Um filme com excesso de música se torna cansativo aos ouvidos do espectador e pode desviar sua atenção; ao mesmo tempo, um filme com muito silêncio musical deixa de aproveitar as potencialidades da música para criar situações emocionais e pistas narrativas para despertar sensações e a compreensão do público.

A trilha musical [...] não pode se exceder em seu papel de dar suporte às várias situações dramatizadas. Via de regra, ela deve se limitar à sua função de ator sutil e bem comportado, que só se manifesta nos momentos certos, da maneira e com a intensidade esperados pelo diretor, de acordo com sua concepção do filme (MATOS, 2014, p. 51).

A fluidez, a imaterialidade e as consequentes flexibilidade e adaptabilidade da música possibilitam a diversidade de significados, o que faz dela um valioso e expressivo recurso cinematográfico, considera também o compositor e professor Mauro Giorgetti ${ }^{36}$. Devido à dificuldade em precisar funções gerais da música no cinema, o autor sugere dois princípios estéticos gerais, com base em suas experiências de composição, já abordados aqui: que a música se limite ao estritamente necessário e que não se constitua uma obra de arte independente. Também inspirado em Gorbman (1987), Giorgetti (2008) elabora ainda algumas classificações para diferenciar os modos mais comuns de utilização da música no cinema, conforme a importância que ela assume e os resultados a que conduz: música de fundo (background); de preenchimento (destinada a preencher os vazios do filme, como normalmente ocorre nos créditos iniciais e finais); incidental (acompanha ou comenta, sem profundidade, o movimento ou a emoção de uma cena); música-tema (sustentáculo musical do filme, confere-lhe unidade); artística (expressiva, aquela cuja supressão prejudica o resultado final do trabalho); música como elemento unificador psicoemocional (aparece em momentos estratégicos, envolvendo o filme em um tom psicológico); e música como personagem (quando ela se comporta como agente narrativo).

É preciso lembrar ainda por quem e para quem os filmes são realizados. Em primeira instância, a música serve ao filme visando contribuir para a sua concretização estético-narrativa. Matos (2014) observa, porém, que, para atingir a satisfação/superação das expectativas do

\footnotetext{
${ }^{36}$ Irmão do diretor Ugo Giorgetti, Mauro Giorgetti é compositor e professor de trilha sonora do curso de Cinema da Fundação Armando Álvares Penteado (FAAP). Criou as músicas de O menino da porteira (Jeremias Moreira Filho, 1976), e as dos filmes do irmão, dentre as quais as de Jogo duro (1985), Festa (1989), Boleiros - era uma vez o futebol... (1998), O príncipe (2002) e Boleiros 2 - vencedores e vencidos (2006).
} 
público, tendo em vista objetivos comerciais, muitas vezes o compositor, a pedido do produtor ou do diretor, sacrifica parte de sua originalidade criativa para aderir a modelos consagrados de composição musical para cinema.

\footnotetext{
Os diretores e, em especial, os produtores, sabem que o público tem já uma cultura do cinema, o que inclui a forma como a música participa - ou não - da ação. Originalidade não é tão bem-vinda na grande tela quanto se poderia desejar. Com algumas poucas exceções, a música do cinema tende a seguir certos modelos que já provaram ser eficazes, e os compositores, em geral, acabam não tendo muita liberdade para distanciar-se de tais modelos (MATOS, 2014, p. 48).
}

Apesar da importância dos padrões composicionais de música para filmes para a aceleração do processo industrial de realização cinematográfica, para o crescimento da bilheteria e para o próprio estudo e identificação das funções exercidas pela música ao longo da história do cinema, é preciso tensionar esses modelos em busca de novas possibilidades narrativas e da diversidade de relações entre som e imagem, filme e espectador.

\section{3 ‘EQUALIZAÇÃO’ DE EXPECTATIVAS: PROCESSOS DIALÓGICOS ENTRE COMPOSITOR E DIRETOR}

Matos (2014) observa que as dificuldades se iniciam na escolha do compositor adequado para o filme. Mesmo o diretor que já tenha consolidado alguma parceria com um compositor provavelmente já viveu tal situação. Geralmente, relata Berchmans (2006, p. 33), o compositor é escolhido “[...] por suas qualidades musicais e por seu potencial de contribuição artística ao filme", o que reforça a necessidade de um conhecimento/repertório mínimo em música e de como ela pode afetar o filme, por parte do diretor.

Assim se consolidaram as parcerias entre Alfred Hitchcock e Bernard Herrmann; Sergio Leone e Ennio Morricone; Blake Edwards e Henry Mancini; Fellini e Nino Rota; Steven Spielberg e John Williams; Joel e Ethan Coen e o compositor Carter Burwell; Krzysztof Kieslowski e Zbigniew Preisner; Spike Lee e Terence Blanchard; Sam Mendes e Thomas Newman; Tim Burton e Danny Elfman (FIGURA 31).

No Brasil, são conhecidas as parcerias entre Ruy Guerra e Egberto Gismonti; Júlio Bressane e Guilherme Vaz; Walter Salles e o compositor Antônio Pinto; entre os diretores Beto Brant, Aluízio Abranches, Ricardo Elias, Marcelo Masagão, Anna Muylaert e o compositor André Abujamra, entre outras. 
Figura 31 - Tim Burton e Danny Elfman: mais de 30 anos de parceria

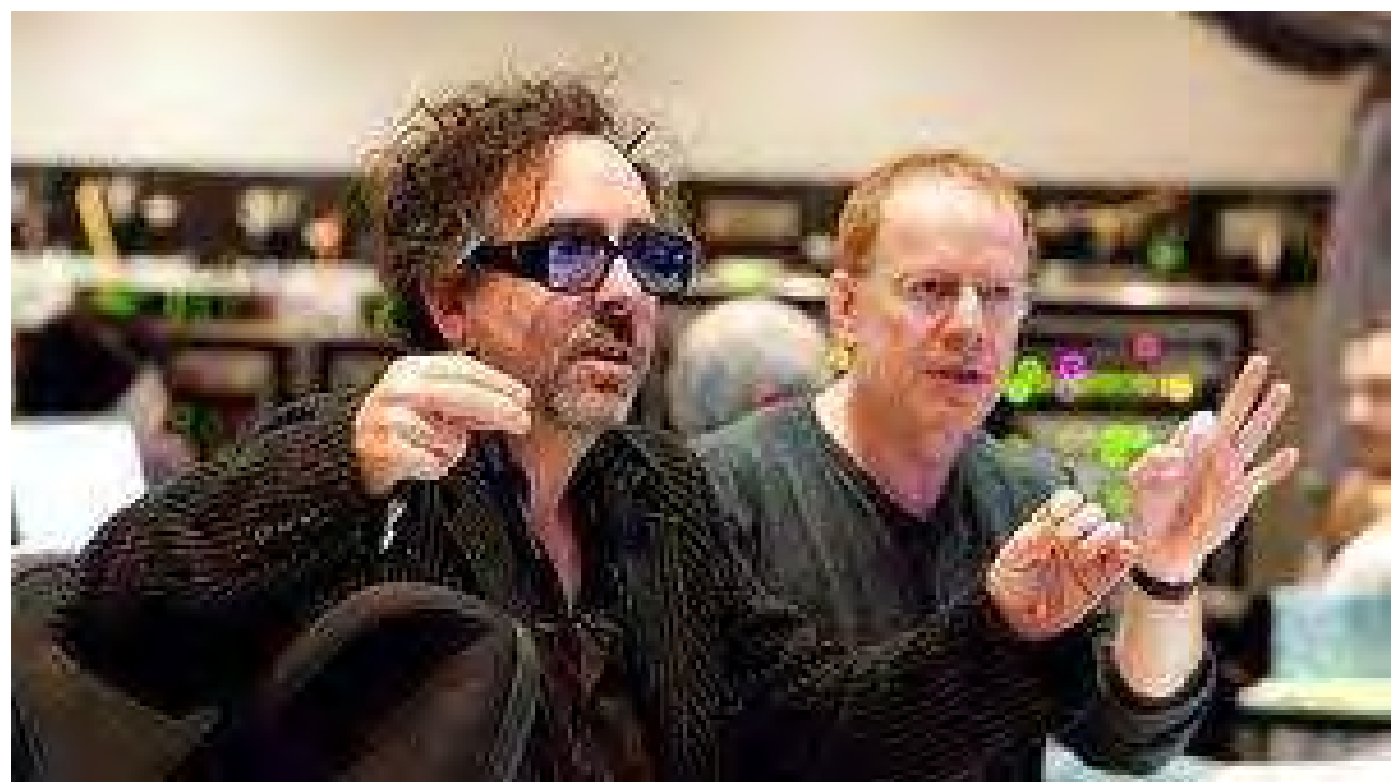

Fonte: NPR Music / Anderson Group. Disponível em: <https://www.npr.org/2015/07/04/419643892/fordanny-elfman-the-strange-worlds-of-tim-burton-just-make-sense>. Acesso em: 21 jan. 2018.

De acordo com o professor e compositor Carrasco (2012 apud NASCIMENTO, 2013), para facilitar a comunicação com o músico, o diretor precisa trabalhar a percepção musical de um filme, compreendendo a razão de a música existir ali; além de apurar a audição e estar em constante ampliação de seu repertório musical e sonoro, buscando localizá-lo temporal e esteticamente. Outra característica desejável é que o diretor consiga expressar suas ideias para o compositor o mais claramente possível.

\footnotetext{
"Frequentemente eu digo que a parte fácil de compor uma trilha sonora é escrever a música. A parte difícil é entender o diretor. E você quase tem que ser tanto um psicólogo quanto um compositor pra fazer a composição de um filme". São as palavras do compositor Danny Elfman (CASSIDY; HALPERIN, 2012).
}

Por outro lado, o perfil do compositor musical para cinema também extrapola o do músico convencional: este, mais do que um vasto conhecimento em teoria musical e orquestração - que pode ser contemplado com as presenças de um assistente e um orquestrador, por exemplo -, precisa ter sensibilidade e a compreensão da linguagem cinematográfica e, portanto, das dinâmicas entre música e imagem em movimento, para que sua criação cumpra as funções demandadas pelo filme com a economia e beleza esperadas; além de experiência em gravação e edição em estúdio; capacidade de comunicação e socialização no ambiente cinematográfico; uma rede de relacionamentos que ateste sua competência e/ou execute suas 
composições; flexibilidade e desapego para lidar com retrabalho - já que a música aqui não funciona como obra de arte autônoma; e uma visão empreendedora marcada pela busca constante por atualização tecnológica e de repertório de sonoridades.

No Brasil o perfil de compositor musical para cinema em geral é desenvolvido durante o próprio processo de realização do filme, no enfrentamento dos desafios à medida que estes aparecem e na comunicação com o diretor. Portanto, além das lacunas na formação dos cineastas, Matos (2014) aponta também a ausência de formação específica em música no audiovisual no ensino musical, reforçando o que mencionamos no início deste capítulo:

Muitos são os talentos musicais que se veem perdidos diante de um trabalho para filmes, e isso porque essa interação envolve um know-how específico, geralmente não contemplados pelos programas de música das universidades e escolas de música de nosso país. [...] Já os raros profissionais experientes nessa área vêm seguindo uma trajetória autodidata, desbravando, pela sua própria experiência, essa mata tão pouco compreendida pela indústria cinematográfica do Brasil (MATOS, 2014, p. 8).

Muitas vezes, é em meio à prática profissional que o compositor aprende a compreender o ritmo do filme para poder criar conforme o tempo e o movimento da imagem. Em geral, a trilha começa a ser criada com o filme em montagem/primeiro corte, em consonância, muitas vezes, com a música de referência sugerida e inserida previamente pelo editor para realizar a montagem, em conjunto com o diretor. Se o corte muda, o lugar de inserção de um trecho musical é alterado, o que interfere em toda a música do filme. Daí a aproximação do ofício do músico com o do montador e a necessidade de alinhamento na comunicação entre estes dois profissionais. Antônio Pinto ${ }^{37}$, um dos compositores brasileiros de maior reconhecimento no Brasil e no exterior, valoriza o contato entre compositor e montador.

Quando você faz trilha, você é um montador. Você tem a mesma relação de ritmo, porque o filme é ritmo. Então, o montador é um cara que é ele muito envolvido com ritmo, e o que ele faz, de certa forma, é uma coisa bem musical. Porque, o corte, o andamento do corte, quanto tempo leva um corte pro outro, isso tudo dá uma batida. A relação mais próxima que eu tenho é com montador e diretor. E, aqui não tanto, mas nos Estados Unidos muito com o produtor [...] mas o negócio é diretor e montador (PINTO, 2010 apud NASCIMENTO, 2013, p. 37-38).

\footnotetext{
37 Filho do cartunista Ziraldo e irmão da diretora cinematográfica Daniela Thomas, Antônio Pinto teve sua primeira experiência como compositor de trilha musical em Menino maluquinho: o filme (Helvécio Ratton, 1994). É reconhecido pela música de filmes importantes, tais como os dirigidos pelo cineasta Walter Salles (o qual já realizada trabalhos com Daniela Thomas) - Central do Brasil (1998) e Abril despedaçado (2001) - além do aclamado Cidade de Deus (Fernando Meirelles e Kátia Lund, 2002) e de filmes internacionais hollywoodianos como Collateral (Michael Mann, 2004), Lord of war (Andrew Niccol, 2005), Love in the time of cholera (Mike Newell, 2007), The host (Stephenie Meyer, 2008), além do premiado documentário Amy (Asif Kapadia, 2015), entre outros. Atuou na publicidade por meio de sua produtora, Super Sônica, e como compositor e baterista da banda Pequeno Cidadão, voltada para o público infantil. Atualmente, o compositor reside e atua em Hollywood.
} 
A harmonia entre os trabalhos do compositor, do editor de som e do mixador do filme também se faz importante, uma vez que todos integram a etapa de pós-produção com funções, objetivos e resultados sonoros interdependentes. O editor é quem trata e dispõe os sons nas pistas de áudio do filme, inserindo a música em um contexto também composto por diálogos, som ambiente, foley e outros efeitos; já o mixador hierarquiza os sons, dando a eles o volume e a equalização finais, além de organizá-los para que soem em diferentes espaços de uma sala de exibição, no caso de uma mixagem em 5.1, por exemplo, sempre buscando a inteligibilidade sonora em conjunto com a compreensão da narrativa. O diálogo entre eles e o compositor tem como eixo o diretor, como explica o cineasta brasileiro José Joffily ${ }^{38}$ :

\begin{abstract}
Simultaneamente à criação da música, o editor de som também faz o serviço dele e é importantíssimo que os dois se entendam. Cabe ao diretor fazer essa ponte fundamental. Muitas vezes é recomendável que um som ou que um efeito sugerido pelo editor de som finalize com o início de uma música. Ou ao contrário. Ou seja, músico e editor de som devem fazer uma dupla inseparável. [...] Também é imprescindível a parceria com o mixador. Muitas vezes, só durante a mixagem ouvimos todas as pistas. Nesse momento, em algumas passagens, a música, quando ouvida junto com o som ambiente ou um efeito sonoro qualquer, pode-se mostrar desnecessária. Ou vice-versa (JOFFILY, 2014) ${ }^{39}$.
\end{abstract}

No entanto, a relação com o montador, o editor de som e o mixador não consegue solucionar as frequentes limitações técnicas no diálogo entre diretor e compositor. Para sanar esse problema, a conversa costuma ser pautada sobre os aspectos dramáticos e poéticos gerais do filme, de modo a facilitar a compreensão do ponto de vista do diretor. A partir de então, o compositor 'traduz' as demandas e sugestões apresentadas para a linguagem musical. Sobre esse processo de diálogo, Ruy Guerra observa a importância da sensibilidade e criatividade do compositor diante da ausência de um vocabulário compartilhado com o diretor:

Quando dialogamos com o universo da música, dialogamos com uma abstração. E
quando encomendamos uma música a um compositor, o diálogo com ele é
referenciando ideias e emoções, mas no fundo é uma conversa de extrema e profunda
banalidade. O seu interlocutor/compositor tem de ter um universo próprio, tem de
tentar entender o que é que pode ser a emoção naquele filme, aquilo que você quer
traduzir, tem que ler entre linhas, ou ouvir entre palavras. Sempre que eu converso
com um compositor tenho um sentimento de impotência muito grande. Quando a
pergunta que ele me faz é mais concreta, eu digo, se eu soubesse fazer isso eu mesmo
faria a música. [...] Eu trabalho com referências musicais, de instrumentos ou de sons,

38 José Joffily é diretor, roteirista e produtor cinematográfico. Estreou na direção com Urubus e papagaios (1985), tendo dirigido também os filmes A maldição do Sanpaku (1992) e Quem matou Pixote? (1996) - dos quais também é roteirista -, 2 perdidos numa noite suja (2002), Achados e perdidos (2005) e Olhos azuis (2009).

39 Entrevista concedida pelo diretor José Joffily a esta pesquisa. Ele dirigiu o filme Achados e perdidos (2007), no qual trabalhou com André Abujamra. 
mas ao mesmo tempo é muito difícil traduzir o que é a música, uma música que você pressupõe que sirva para aquela cena, que não sabe qual é, e ao mesmo tempo pode induzir o compositor a falsas pistas. É dos diálogos mais difíceis em cinema. (GUERRA, 2001 apud GUERRINI JÚNIOR, 2009, p. 201).

Ao desafio de se construir um vocabulário musical e cinematográfico comuns a diretor e compositor, acrescente-se o prazo normalmente reduzido para o trabalho deste último, em decorrência do desequilíbrio na gestão de recursos financeiros e/ou de tempo para as diferentes etapas de realização cinematográfica no Brasil - com ênfase de investimento em produção e a falta dele na pós-produção. Uma trilha musical leva, em média, três meses para ser criada, gravada, mixada e entregue para ser misturada aos demais sons do filme, período que varia conforme o compositor, sua experiência com cinema, a qualidade de seu diálogo com o diretor, "liberdade", recursos e tempo disponíveis.

\subsubsection{Primeiro encontro entre músico e cineasta: o início do processo}

Em geral, o compositor entra no processo de realização cinematográfica durante a pósprodução, quando o filme começa a ser montado. É raro ele participar da pré-produção ou das filmagens, tendo mais tempo para elaborar a música e preparar sua estrutura de trabalho - o que pode acontecer quando há uma parceria consolidada com o diretor, ou simplesmente se se trata de uma demanda do projeto. Nascimento (2013) explica que o ingresso do compositor na etapa da pós-produção tem razões históricas, vinculadas ao modo de produção de filmes no período pré-som sincronizado.

De certa forma, o cinema havia aprendido a fazer película para depois colocar o som. E, simplesmente, quando surge o som sincronizado, deixa-se de fazer o som em uma etapa posterior (ao vivo), passando-se a também fazê-lo industrializado. Porém, a lógica aparentemente permanece (NASCIMENTO, 2013, p. 23).

Após a conclusão do primeiro corte, diretor e compositor se reúnem para definir o conceito do filme. Este chega até aquele geralmente por meio de indicações, ou por ter assistido e gostado de filmes com músicas do compositor almejado. De qualquer forma, como afirma o diretor José Joffily, esse primeiro encontro é uma incógnita: “O primeiro trabalho com um colaborador importante no processo de um filme é sempre cercado de mistério e desconfiança" (JOFFILY, 2014). 
O diretor revela suas expectativas e entrega ao compositor o primeiro corte, o qual normalmente vem com músicas preexistentes de referência (temp tracks ou trilhas temporárias), utilizadas para que a primeira versão do filme seja montada no ritmo mais próximo do definitivo, e para que o compositor compreenda e se inspire nas referências musicais sugeridas pelo diretor, facilitando a comunicação entre eles. Isto significa que, antes que diretor e compositor se encontrem, um integrante da equipe do filme - em geral, o montador com o diretor $^{40}$ - já definiu as trilhas temporárias para a realização da primeira montagem.

\begin{abstract}
A referência pode ser uma excelente ferramenta de auxílio na composição, ou pode ser um terrível limitador do processo de criação musical. Por um lado, quando o diretor está claramente consciente de que as temp tracks são apenas referências para estudo de sensações e funções cinematográficas, elas são ótimo recurso auxiliar. Analisando-se corretamente uma sequência com música temporária pode-se avaliar melhor a decupagem da música no filme [...]. Pode-se ainda estudar caminhos criativos e estabelecer as funções que a música definitiva a ser composta deve assumir (BERCHMANS, 2006, p. 29).
\end{abstract}

O estabelecimento do conceito do filme - "[...] a essência, o assunto ou ideia central da estória" e toda a lógica interna e conjunto de valores envolvidos e transmitidos no processo de desenvolvimento narrativo (MATOS, 2014, p. 50) - conceito este do qual as trilhas temporárias participam, auxilia no recorte de opções para a composição musical e, consequentemente, na escolha conjunta do 'tom' da obra. Este tom pode ser considerado um conjunto de características que evidenciam o 'humor', a 'personalidade' da obra, composto pela coloração da imagem, ritmo da montagem, densidade da atuação dos personagens, tipos de enquadramento etc. Conforme Matos (2014, p. 50), o 'tom' “[...] condiciona (é condicionado por) todos os seus aspectos plásticos, bem como pelo próprio conceito, ou seja, o conceito influi no tom do filme e está nele contido".

Como cada diretor e compositor ter suas subjetividades e seus processos particulares de criação, esta fase de definição do conceito e do tom do filme é, ao mesmo tempo, complexa e crucial, pois gera um planejamento criativo compartilhado, uma 'paleta de sensações' desejadas com a presença da música no filme, e, assim, um roteiro colaborativo a ser seguido pelo compositor, com a anuência do diretor.

\footnotetext{
${ }^{40} \mathrm{Na}$ indústria hollywoodiana são atribuídos, ao editor musical, os papéis de selecionar músicas preexistentes para o filme e ser um elo entre o diretor e o compositor. No Brasil, até o momento, não se observa a existência de tal função no cinema.
} 


\subsubsection{Decupagem, composição e apresentação das ideias ao diretor}

A decupagem musical (spotting) é a etapa em que diretor e compositor definem onde há e onde não há música no filme, apontando seus pontos de entrada e saída (cues) e definindo a função da inserção musical em cada trecho. É a partir desse planejamento que o compositor inicia o processo de criação e escrita da música (FIGURA 32).

Figura 32 - Codiretor Dan Quitério e o compositor Jay Rothman durante a sessão de spotting do filme In-Kind

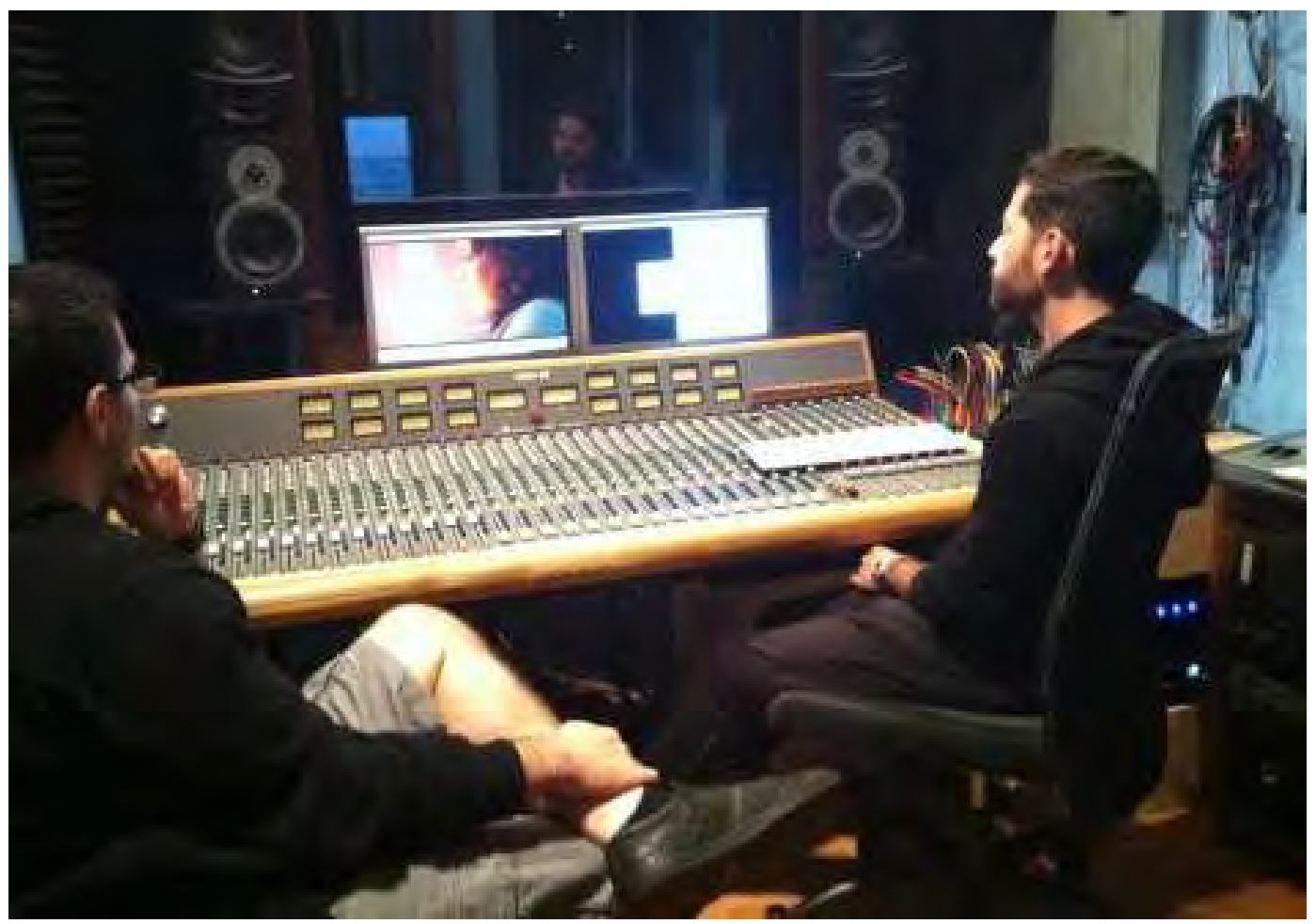

Fonte: The 170. Disponível em: <https://the170.com/tag/music/>. Acesso em: 21 jan. 2018.

Cada compositor possui um processo criativo particular e um modo singular de transformá-lo em música para cinema. De acordo com Berchmans (2006), Bernard Herrmann, por exemplo, pesquisava em profundidade a personalidade dos personagens do roteiro e a forma como eles interagiam, buscando compreender a psicologia dessas relações. Assim, buscava explorar o estado psicológico dos personagens em sua música. No Brasil o maestro Radamés Gnattali criava temas orquestrais que tivessem o poder de narrar a cena, descrevendo os sentimentos dos personagens e realçando suas ações - enfatizava, assim, o papel dramático da música no filme, seguindo a tradição do cinema clássico americano.

Independentemente do método empregado para a composição de uma trilha musical, é necessário, esclarece Matos (2014), que o compositor recorra repetidamente às ferramentas 
cinematográficas de que dispõe, como o roteiro e os próprios cortes provisórios do filme. Essa recorrência demanda uma atenção extra do compositor, para que ele não dê pistas demais sobre o enredo na música.

Tudo o que foi cuidadosamente pensado e preparado pelo roteirista e pelo diretor, além dos trabalhos do fotógrafo e do montador - incluindo-se a escolha e a ordem das tomadas, os diálogos, a performance dos atores e tudo e todos envolvidos na produção com o objetivo de prender a atenção e o interesse dos espectadores - tende a ser, para o compositor, algo cada vez mais normal, sem surpresas, cada vez "menos interessante". Nessa situação, não é difícil se distrair um pouco e, através da música, “entregar" [o enredo] (MATOS, 2014, p. 48).

Outro ponto destacado por Matos (2014) é a necessidade de equilíbrio entre a vontade de inovação do compositor e a expectativa por uma 'eficácia' da música na imagem por parte do diretor e/ou do produtor. Se a música existe em função do filme, ela precisa seguir determinados caminhos, a partir das orientações do diretor e do produtor e do que eles esperam como resultado em termos de produção e circulação. Além disso, mesmo para romper com os códigos historicamente estabelecidos pela indústria hollywoodiana quanto à música no cinema, é preciso conhecê-los em profundidade e, o que é ainda mais desafiador, persuadir diretor e produtor a trilhar os caminhos da experimentação (GORBMAN, 1987). Isto nem sempre acontece, tanto por questões artísticas quanto administrativas e orçamentárias.

\footnotetext{
Na composição para o cinema, nem sempre a originalidade é desejável pelo diretor e, principalmente, pelos produtores... Como já vimos, a trilha musical existe para dar suporte ao filme em todas as suas nuances e, nesse sentido, deve seguir algumas linhas mestras já exaustivamente testadas e aprovadas pelos executivos dessa indústria. [...] Mas, seja como for, a liberdade do compositor é sempre limitada, e a música - como tudo no cinema - deve adaptar-se a formatos mais ou menos padronizados. Assim os riscos são minimizados e a indústria pode continuar prosperando. [...] É necessário desapegar-se um pouco do instinto criador, sendo mais flexível e aprendendo a abrir mão de algumas ideias, quando o trabalho assim exigir (MATOS, 2014, p. 281).
}

Concluída a elaboração e o rascunho da partitura da música, o compositor apresenta suas ideias ao diretor. Berchmans (2006) conta que essa apresentação tradicionalmente ocorria ao vivo, com o compositor tocando ou regendo um pequeno grupo de músicos, em sincronia com as imagens. A tecnologia digital permite que hoje a qualidade da música apresentada inicialmente ao diretor seja muito próxima da música finalizada. Assim, além ou agregados à opção ao vivo, o compositor pode dispor de loops e samples de instrumentos variados para simular arranjos para orquestras inteiras, antes que mobilize músicos reais para a gravação final, barateando os custos de pré-produção com o uso de softwares, bancos de áudio e bibliotecas de timbres. 


\subsubsection{Gravação e mixagem}

Quando a peça é aprovada pelo diretor, o compositor passa a se ocupar com a gravação da música. Esta etapa envolve, além de questões artísticas - refinamento e escrita de arranjos, por exemplo -, questões logísticas e executivas, como locação de estúdio, contratação de músicos, ensaios e a gravação musical propriamente dita, cena a cena - se possível, com a imagem sendo exibida em uma tela em sincronia (FIGURA 33).

Em geral, todos os custos com a gravação e finalização da música são previstos no orçamento da trilha musical proposto pelo compositor ao diretor/produtor, e a maior ou menor utilização de recursos eletrônicos em substituição à execução por músicos reais depende do orçamento disponível e da proposta musical do filme.

Apesar de facultativa, a presença do diretor nas sessões de gravação da trilha musical o aproxima de um alinhamento de ideias com o compositor e facilita tomadas de decisão em casos de alterações na peça, momentos antes de ser registrada. A presença do produtor do filme nessa etapa pode significar também a supervisão do emprego dos recursos financeiros, em casos de filmes produzidos em escala industrial e com grandes montantes/interesses mercadológicos envolvidos.

Esse investimento teve um papel importante desde o início do som sincronizado no cinema, já que o processo de gravação do som (e da música) era uma empreitada muito mais cara e complexa tecnicamente do que pode ser hoje.

Isto significa que atores, luz, cenografia, figurino, câmeras etc. tinham que conviver pacífica e ordenadamente com grandes orquestras que interpretavam os arranjos musicais ao vivo, acompanhando a cena. Qualquer deslize poderia ser fatal e um plano longo poderia demorar até 3 dias para ser rodado (BERCHMANS, 2006, p. 105) ${ }^{41}$.

\footnotetext{
${ }^{41}$ Menção ao single system, sistema cuja adoção foi muito pontual nos processos de pós-produção de som cinematográfico, não tendo perdurado por muito tempo.
} 
Figura 33 - Compositor John Williams grava a trilha musical de Star Wars - O despertar da força (J. J. Abrams, 2015)

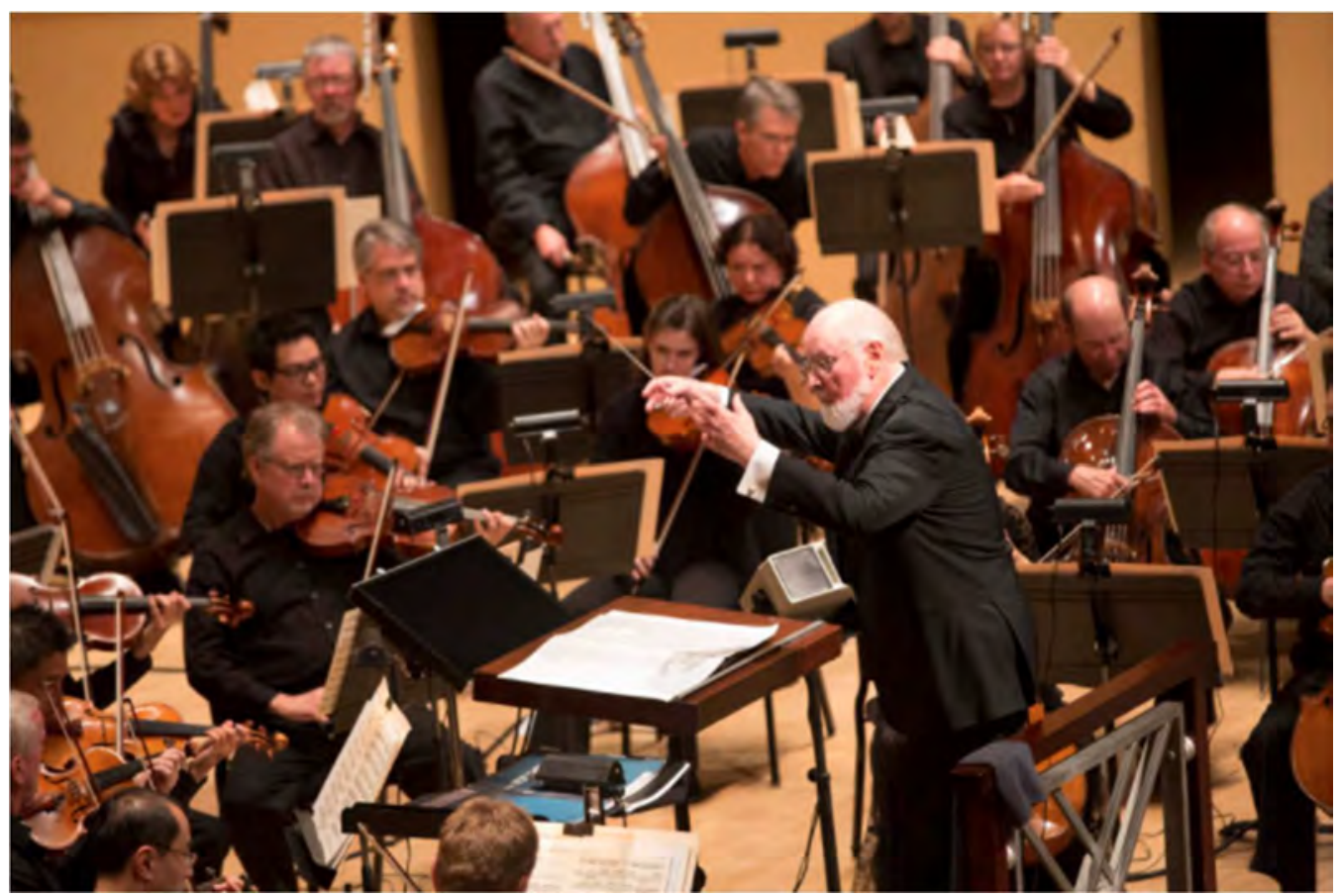

Fonte: Projector and Orchestra. Disponível em: $<$ http://projectorandorchestra.com/john-williams-onthe-force-awakens-and-the-legacy-of-star-wars/>. Acesso em: 21 jan. 2018.

De acordo com Berchmans (2006), até os anos de 1950 compositores e engenheiros de gravação lidavam constantemente com limitações técnicas básicas, como a presença de ruídos em decorrência do suporte, inconstância nas respostas de frequência e o reduzido espectro dinâmico das gravações. Com o desenvolvimento das tecnologias de produção e reprodução sonoras, houve um aumento das possibilidades de recursos a serem utilizados artisticamente por estes profissionais, como a gravação multipista, o maior controle sobre o ruído, a flexibilidade na realização de alterações e o alargamento da dinâmica musical gravável.

Como vimos no capítulo 2, os avanços tecnológicos possibilitaram o surgimento das estações de trabalho de áudio digital (DAW ou digital audio workstation). Para os processos que envolvem a produção musical em cinema e audiovisual - gravação, edição e mixagem -, as DAW oferecem a possibilidade de sincronização entre som e imagem por meio da inserção do arquivo do filme ou vídeo no projeto, permitindo maior exatidão e otimização do tempo de trabalho pelo compositor (FIGURA 34). 
Figura 34 - Exemplo de DAW: Pro Tools 11

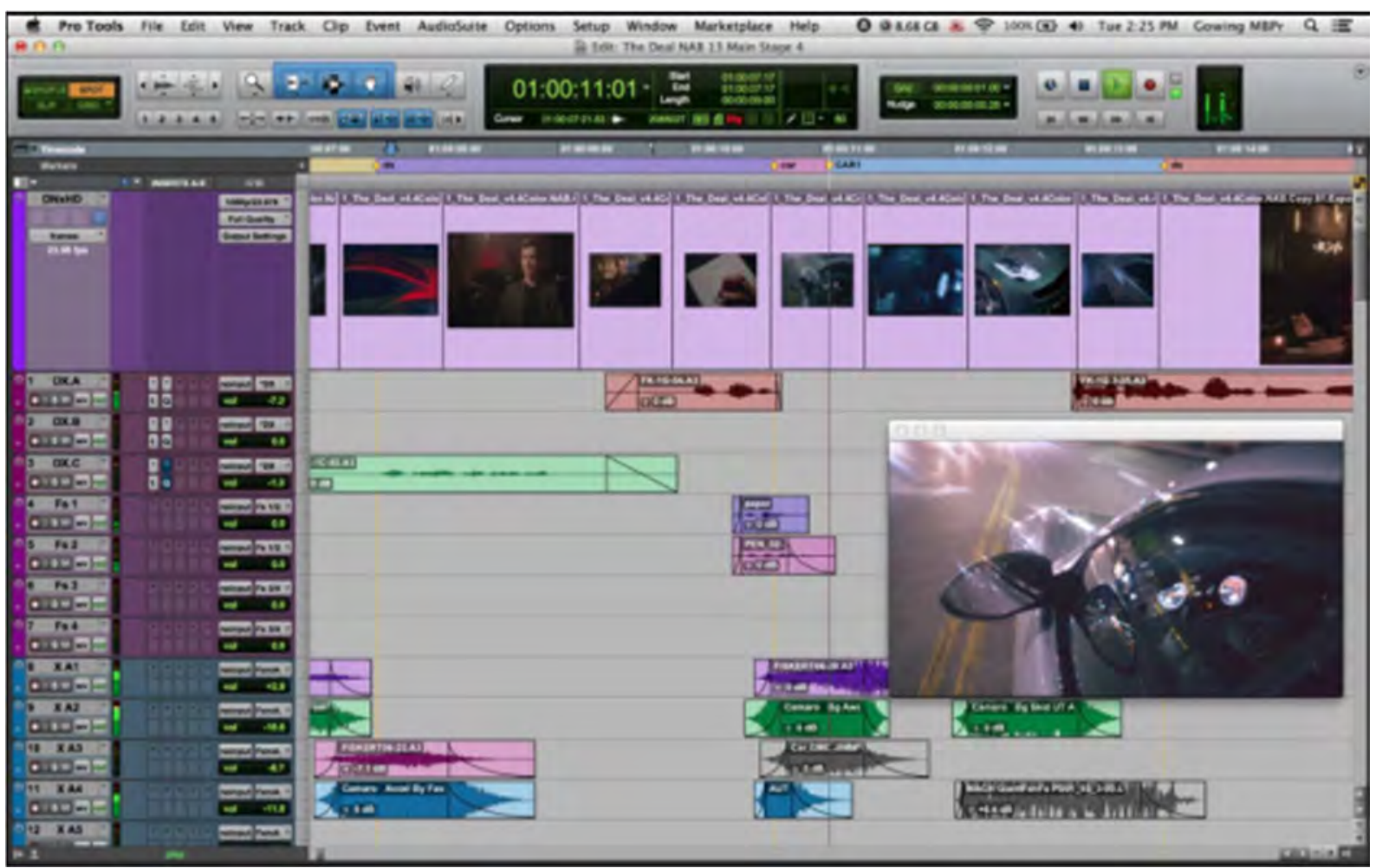

Fonte: Amazon. Disponível em: <https://www.amazon.com/Avid-Tools-Channel-AudioSoftware/dp/B00CFFB0DO>. Acesso em: 21 jan. 2018.

Outro dos fatores de praticidade e otimização de tempo dentro da DAW é o uso de MIDI, interface digital para instrumentos musicais que consiste em um protocolo de comunicação entre um equipamento master ou controlador - que envia instruções codificadas em bytes (conjuntos de oito bits) para a execução a partir de outros equipamentos, chamados 'escravos'. Assim, é possível, ao compositor, recorrer a diferentes instrumentos virtuais manuseando poucos equipamentos e gravar diretamente na DAW, podendo alterar os timbres gravados (FIGURA 35).

Por outro lado, é importante que, no caso de transferência via MIDI para outro computador que não o do compositor, a máquina de destino tenha, em sua memória, os mesmos timbres utilizados na produção, sob o risco de substituir os originais escolhidos por timbres aleatórios - daí a necessidade de exportar o material como áudio para apresentação. "O resultado final, em termos sonoros, está condicionado à qualidade tímbrica dos instrumentos controlados" (MATOS, 2014, p. 189). 
Figura 35 - Gravação MIDI no Pro Tools

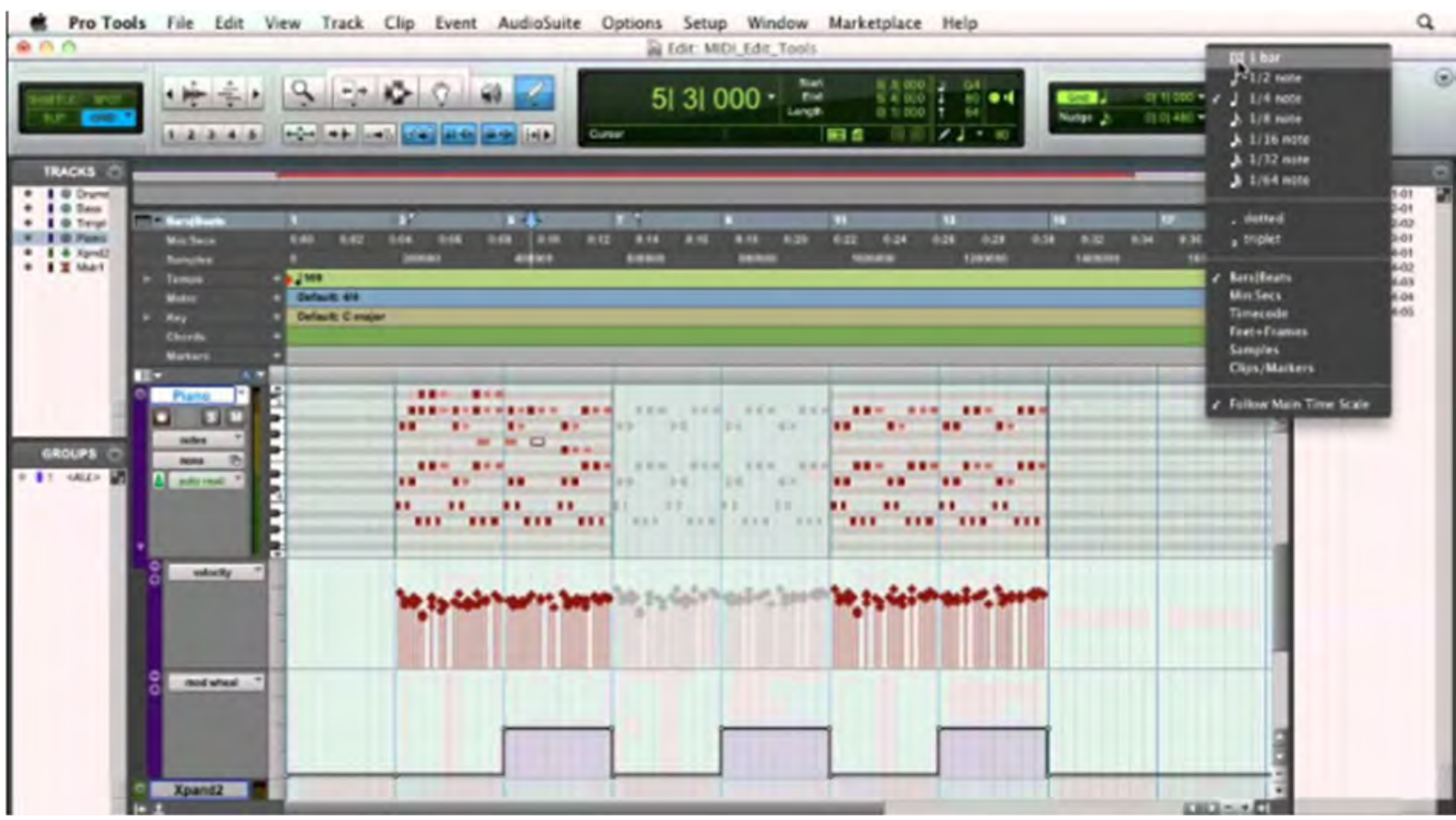

Fonte: Frame do tutorial Pro Tools 10: editing MIDI data. Disponível em:

$<$ https://www.youtube.com/watch?v=uKLg2MAD34I>. Acesso em: 21 jan. 2018.

A estação de trabalho virtual também trouxe a possibilidade de criação de timbres pelo próprio compositor, por meio dos sintetizadores (FIGURA 36). Estes consistem em instrumentos compostos por diversos circuitos, tais como osciladores - que criam as ondas geradoras do som; filtros - circuitos atuantes no timbre, por meio da filtragem de harmônicos; amplificadores - responsáveis pelo aumento do nível do sinal até o mínimo exigido para que o som percorra todos os circuitos pertinentes à síntese; envelopes - que criam variações programadas dos parâmetros sonoros (timbre, altura, intensidade e duração); e osciladores de baixa frequência (low frequency oscilators ou LFOs) - geradores de variações periódicas na afinação (vibratos), intensidade (trêmulos) e timbre (como no efeito wa-wa na guitarra) como consequência da alteração em baixas frequências. 
Figura 36 - Exemplo de sintetizador digital: Arturia CS 80

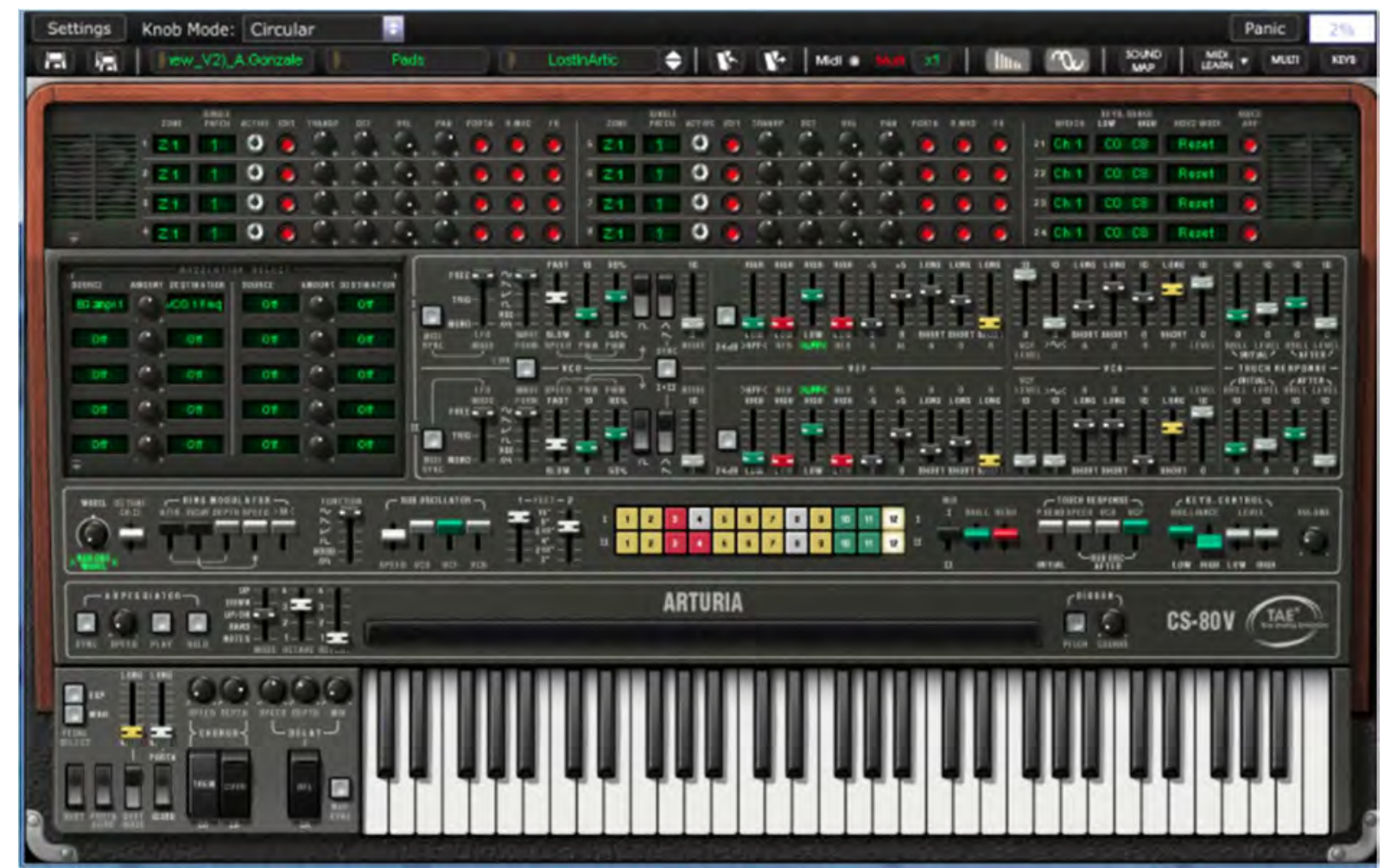

Fonte: Site Ossia. Disponível em: < http://ossia.com.br/5-incriveis-sintetizadores-digitais/>. Acesso em: 21 jan. 2018.

As ondas geradas por osciladores, ao sofrerem alterações na passagem por diferentes circuitos, transformam-se em um som com novas características, elaborado por síntese. Matos (2014, p. 198) considera a aproximação timbrística cada vez maior entre sintetizadores de qualidade e instrumentos reais uma vantagem do uso deste recurso: "O uso de algumas cordas sintetizadas, por exemplo, pode conferir uma base 'confortável' aos arranjos. Por causa disso, tais timbres são também conhecidos como 'pads' (almofadas ou 'camas')".

Os sons de instrumentos acústicos podem ser simulados por sintetizadores, mas também buscados por samplers, softwares que digitalizam ('fotografam') as formas de onda acústicas e as guardam em um padrão digital denominado samples (amostras), reproduzem esses sons em alta resolução (medida por taxa de amostragem ou sample rate) e os organizam e disponibilizam para o uso do compositor (FIGURA 37). 
Figura 37 - Exemplo de sampler digital: Steinberg HALion

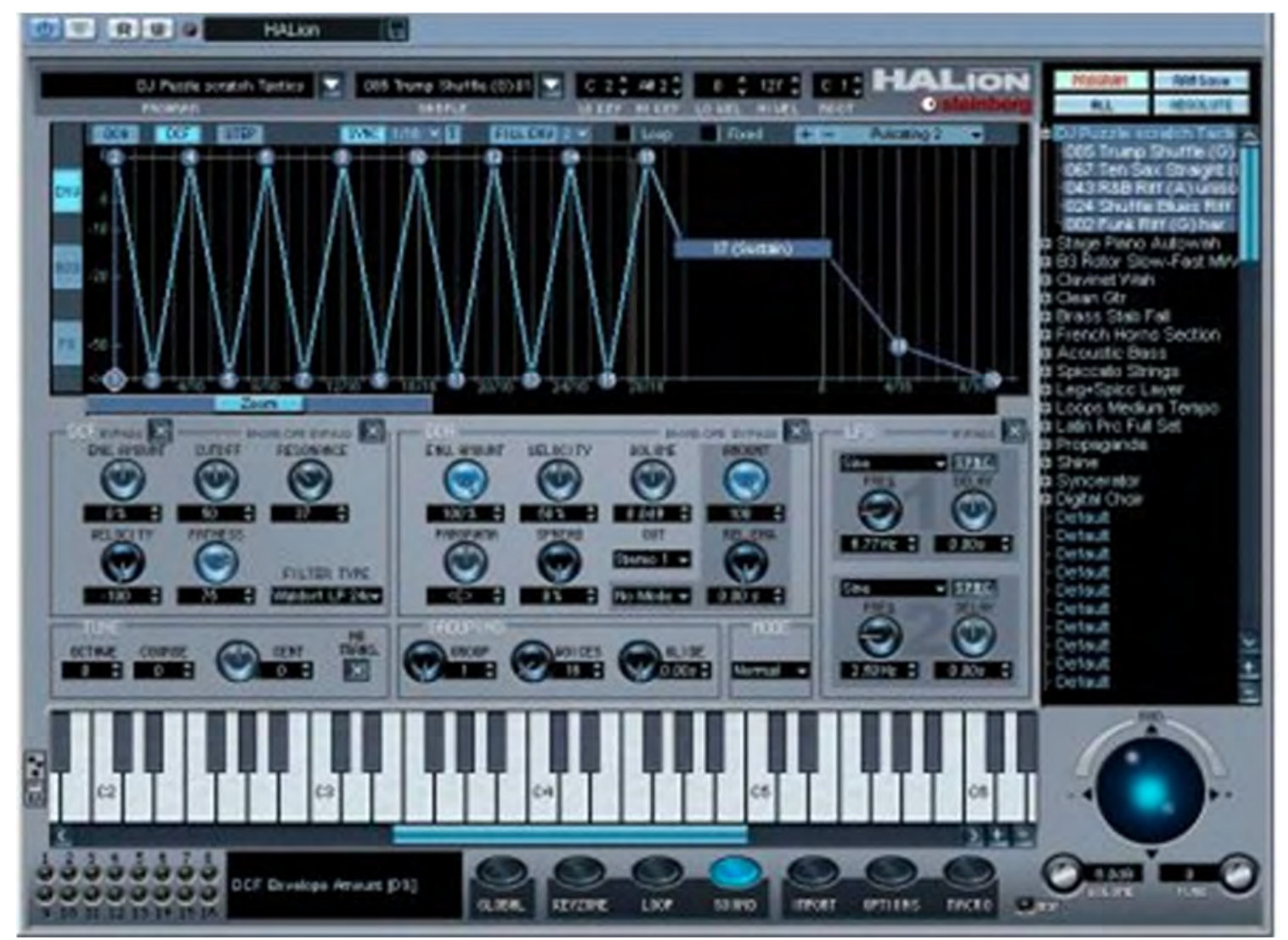

Fonte: Site ZZounds. Disponível em: <https://www.zzounds.com/item--STEHALION>. Acesso em: 21 jan. 2018.

Os sons digitalizados podem ser manuseados e disparados via MIDI por meio do controlador (em geral, um teclado), algo útil ao compositor no momento de apresentação do tema de uma trilha musical ao diretor cinematográfico, por exemplo.

Uma grande vantagem dos samples, apontada por Gallo (2015, p. 93), é o acesso a timbres com qualidade compatível com os das grandes produções cinematográficas hollywoodianas, como "[...] a orquestra sinfônica, os taikos e outras percussões de grande impacto, os instrumentos exóticos e étnicos, bem como as sonoridades de instrumentos da música pop ou de sons eletrônicos e texturas de sound design”. O investimento na aquisição de samples de alta qualidade se torna mais atraente para o compositor-empreendedor do que a onerosa contratação de uma orquestra (e suas implicações, como aluguel de sala de concerto, contratação de técnico qualificado etc.) ou de músicos especialistas em instrumentos não muito usuais no Brasil, pertencentes a culturas musicais distantes.

Daí a praticidade dos instrumentos virtuais, plug-ins inseridos nas DAWs definidos por Matos (MATOS, 2014, p. 200) como “[...] versões em software de sintetizadores, samplers e 
quaisquer outros instrumentos elétricos, eletrônicos ou acústicos". Além da redução de custos, seu uso substitui os cabos por alterações na configuração do programa, por serem instalados diretamente nas DAWs e acionados por MIDI, vantagem técnica que minimiza, portanto, a possibilidade de falhas por conexão externa.

Apesar da aproximação qualitativa entre instrumentos virtuais e reais utilizados em grandes produções, é importante lembrar que, por mais semelhantes que sejam, há nuances apresentadas apenas pelos instrumentos reais. Além disso, por mais que o custo de produção com o uso dos virtuais seja reduzido, ainda existe um grande investimento de tempo e recursos em timbres e equipamentos de alta qualidade e na obtenção de conhecimento técnico por parte de compositores profissionais que criam trilhas para cinema e audiovisual como fonte de renda, em sua rotina de trabalho.

Em entrevista a Gallo (2015), o compositor profissional Ed Côrtes analisa a questão das nuances que se 'perdem' na opção por instrumentos virtuais, revelando a solução que emprega nesses casos - mesclar sons digitais a instrumentos gravados - e os timbres a que mais recorre em suas livrarias, no caso de uma trilha orquestral, por exemplo.

Principalmente graves, que dão menos bandeira. Agudos são muito difíceis. Violino de sampler, nenhum fica bom, então é muito difícil. Mas grave rola; contrabaixos, assim: "bãn, bãn" [imita o som dos instrumentos com a boca], você dobrar com baixos de samplers. Às vezes você não tem a quantidade - aqui no Brasil, principalmente de músicos que você gostaria. E aí os estúdios não são grandes, não tem a quantidade de músicos, a gravação não é perfeita, você não pega aquele "timbrão" de graves que poderia vir. Então você adiciona um sampler: "bããn" [imita som com a boca, dando ênfase], bota bastante reverb ${ }^{42}$, e aí você fica com uma orquestra mais "encorpadona" (CÔRTES, 2014 apud GALLO, 2015, p. 92-93).

Graças aos processadores de efeitos e ao uso de instrumentos virtuais nas estações de trabalho de áudio digital é possível produzir, além de músicas com estruturas melódica, harmônica e rítmica convencionais - com tonalidade, tema, harmonia, compassos e frases estabelecidos -, trilhas sem estrutura definida ('texturas'), cada vez mais utilizadas por compositores de música para cinema. Nestas, as camadas de sonoridades não correspondem

\footnotetext{
42 Processadores de efeitos como o reverb, citado por Côrtes, são componentes muito usados nas DAWs em combinação com instrumentos virtuais. Disponíveis em valores acessíveis ou mesmo em versões gratuitas, eles consistem em superfícies de controle digitais ('racks de efeito') cujos algoritmos internos (normas e padrões de funcionamento) para a criação de efeitos podem ser (re)programados e comandados a distância, por MIDI, integrados à estação de trabalho de áudio digital em diferentes canais da música em produção. Entre os efeitos mais comuns estão o delay - atraso do sinal somado ao original, para um som mais 'encorpado'; phase - defasagem do sinal que gera interferências nas oscilações periódicas de onda; flange - semelhante ao phase, mas com frequências atenuadas ou reforçadas em intervalos de tempo regulares; atuação destacada nas frequências; chorus - 'encorpa' os sons por meio de pequenas variações de afinação por delay; reverb - efeito que simula o espaço acústico de produção do som.
} 
necessariamente a um instrumento conhecido; as durações podem ser constantes ou ter ocorrências irregulares e esparsas, não estabelecendo frases e cadências; caracterizam-se mais pela união de camadas na formação de 'massas sonoras' que por uma harmonia composta por graus verificáveis de uma escala. Segundo Gallo (2015):

\begin{abstract}
Muito do trabalho criativo dos compositores contemporâneos - e dos sound designers - é dedicado a criar essas massas sonoras, as quais diluem as fronteiras entre a música, muitas vezes minimalista, e o sound design, muitas vezes mais expressivo do que apenas realista. [...] Ainda que a matéria-prima sonora seja um instrumento gravado, dificilmente uma "textura" pode ser criada sem o largo uso de efeitos. Com novas "texturas" surgindo a cada dia, o gosto dos cineastas e do público também parece se atrair por essas ferramentas, criando um ciclo que incentiva sua reinvenção (GALLO, 2015, p. 97).
\end{abstract}

Essa massa sonora, como vimos, é resultante da conjunção de diferentes camadas, adicionadas a outras já existentes por meio de um processo denominado 'gravação de overdubs'. Este procedimento, utilizado não apenas na criação de texturas, mas em qualquer produção musical, permite que, com a adição de novas faixas gravadas, o intérprete acrescente vocais e novos instrumentos ou corrija a execução de partes do arranjo, por exemplo. Muitas vezes a gravação de overdubs coincide com o próprio processo de composição, quando as camadas são criadas no momento do registro, e outras, compostas em seguida, são acrescentadas às primeiras. "A gravação de diferentes camadas, criadas na hora muitas vezes, é ao mesmo tempo a composição, a edição, a gravação e a orquestração" (GALLO, 2015, p. $73)$.

Concluída a gravação, a música passa pela mixagem (FIGURA 38), processo em que todos os instrumentos gravados em pistas independentes são equalizados, têm seus volumes relativos ajustados e são reunidos na gravação final da trilha, que é subdividida em stems, 'grupos' (cordas, sopros, percussão), para o caso de qualquer alteração pontual na música durante a mixagem final do som completo do filme. O agrupamento em stems também facilita a distribuição dos componentes da trilha musical, preparando-os para soar de forma independente (diferentes stems em diferentes canais) na exibição, em situações de mixagem para sistemas estereofônicos ou 5.1, que têm o poder de recriar espacialmente o som, de modo a envolver ainda mais o espectador na experiência cinematográfica. 
Figura 38 - Exemplo de sessão de mixagem de trilha musical

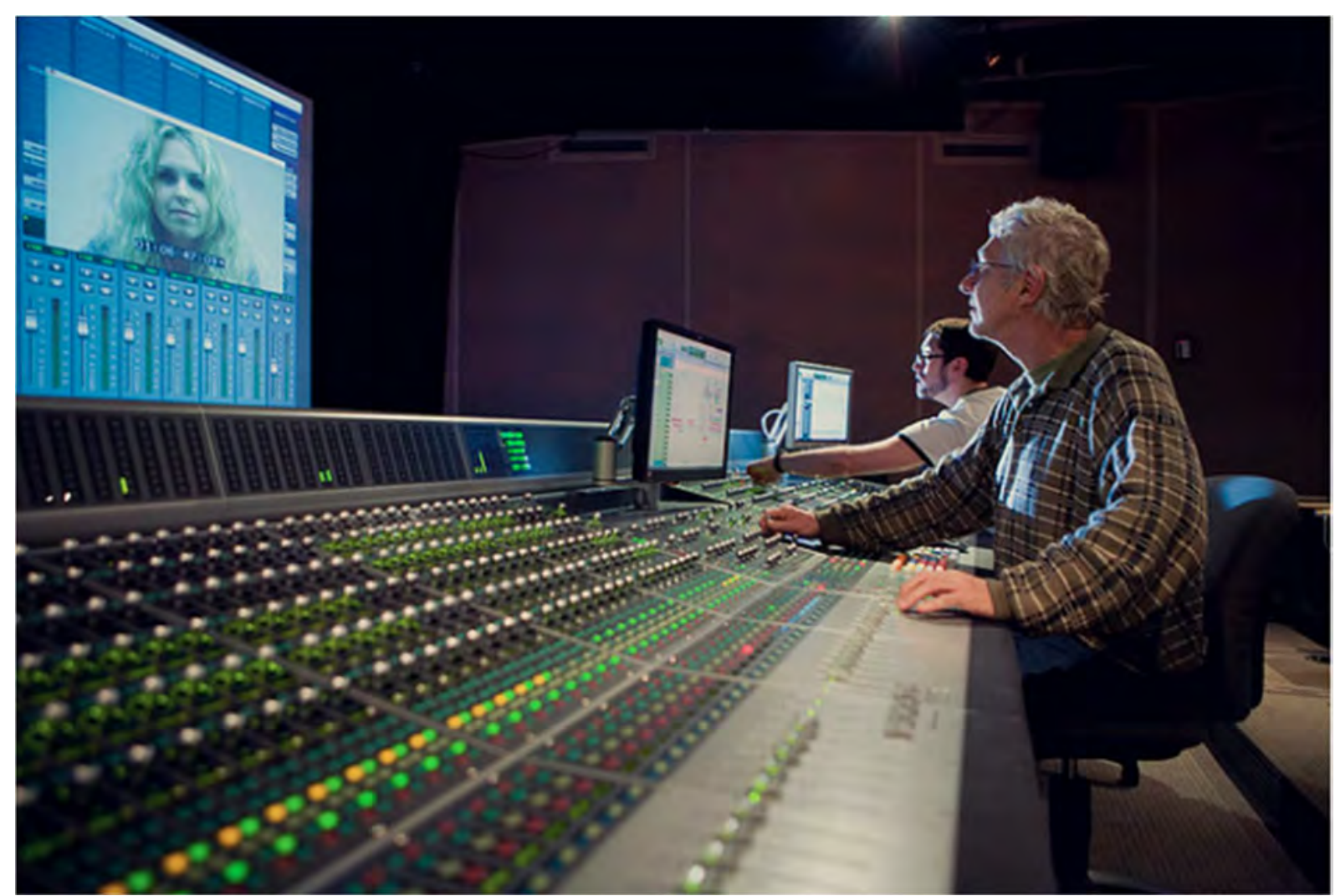

Fonte: Site Free Stock Music. Disponível em: < https://www.freestockmusic.com/article/diegetic-non-diegetic/>. Acesso em: 21 jan. 2018.

Ocorre que, como a montagem do filme ainda pode sofrer mudanças, a trilha musical também pode ser alterada para garantir a sincronização entre a imagem e os efeitos desejados. A mixagem final das peças musicais é, então, enviada à equipe de finalização, responsável por essa sincronização e pela mixagem do som final do filme - quando a música é misturada aos diálogos, ruídos, efeitos sonoros etc. Nesse momento, os diferentes sons têm sua relação de volume definida, normalmente tendo as vozes dos personagens como prioridade - o que comprova a tradição vococentrista (som centrado na voz) e verbocentrista (som centrado na palavra) do cinema apontada por Chion (1993).

Atualmente, a maior parte dos filmes é mixada em sistemas surround de, no mínimo, seis canais (sistema 5.1), endereçados para caixas de som amplificadas e dispostas em diferentes locais de uma sala de exibição (cinema ou home theater): um canal central (para onde vão os diálogos, som direto, ruídos de sala ou foley e os efeitos realistas conhecidos como hard effects); dois canais frontais laterais (esquerdo e direito, para onde vão a música e o som ambiente); dois canais traseiros laterais (esquerdo e direito, idem frontais); e um canal especial para os sons 
muito graves (subwoofer). Uma vez que o som mixado desta forma é gravado na cópia da imagem em película ${ }^{43}$, o filme está pronto para a exibição.

Outra etapa da finalização da trilha sonora audiovisual é a geração da banda internacional (music and effects ou M\&E), que consiste na versão mixada da trilha sem as vozes (diálogos, falas e vozerio). O agrupamento de música e efeitos (sons de ambiente, foley e outros) na banda internacional favorece a exportação do produto audiovisual, de modo a prepará-lo para receber a dublagem na língua do país de destino, garantindo a acessibilidade do público estrangeiro à obra.

Todo esse processo - iniciado pelo convite feito ao compositor pelo produtor e/ou diretor do filme e finalizado com a mixagem da música e sua junção aos demais elementos sonoros na mixagem final - é conhecido pelos compositores atualmente em atividade no Brasil, já citados neste trabalho. Como vimos no capítulo 2, algumas características comuns a essa geração de compositores que teve sua carreira em cinema iniciada/consolidada no Brasil a partir dos anos de 1990 é a lida constante com a tecnologia no processo de composição; a centralização da responsabilidade pela música original em todas as etapas de sua produção diferentemente dos filmes hollywoodianos, que dispõem de departamentos musicais com vários profissionais para desempenhar funções específicas; e o desdobramento em diversas atividades além do cinema - como composição de músicas para publicidade, televisão e teatro - para garantir o sustento como compositor e músico. André Abujamra, artista estudado neste trabalho, apresenta esse perfil, tendo iniciado sua carreira no cinema em 1988 (curtas-metragens) e participado, com a criação de música original, de cerca de 50 produções audiovisuais para cinema e televisão (INTERNET MOVIES DATABASE, (C1990).

\footnotetext{
43 Este processo não é necessário quando o filme é exibido em suporte digital. Nesse caso, um potente aparelho reprodutor de som é acionado pelo projecionista, que aciona também o software que reproduz o filme.
} 


\section{ENTRE A “LIBERDADE” E O DESAPEGO: O PERCURSO DE ANDRÉ ABUJAMRA COMO COMPOSITOR DE MÚSICA PARA FILMES}

Como vimos, André Abujamra compõe música para publicidade, televisão, teatro e cinema, além de manter seus projetos musicais solo ou em grupos. A construção de sua versatilidade e inventividade como compositor acompanha suas experiências em família no teatro e na televisão, a coleta de diferentes sonoridades em suas viagens, seus saberes formais e informais, sua própria carreira e círculos de convivência - tudo isso ao longo da evolução tecnológica das ferramentas de produção e reprodução sonoras, do analógico ao digital.

Neste capítulo apresentamos uma investigação sobre o processo criativo do compositor, bem como suas ferramentas de trabalho, desde o início da carreira até a atualidade. Buscamos compreender o que ocorre quando seu processo particular de criação encontra condições, limitações ou potencialidades quando colocado em contato ou sob avaliação de outros artistas - aqui, especificamente, diretores cinematográficos -, materializado em música a serviço de uma linguagem híbrida, fragmentada e complexa: o cinema. A partir de informações coletadas em entrevistas com diretores, parceiros e com o próprio artista, investigamos como a música de cinema leva Abujamra a outros tipos de colaboração, como a atuação em filmes, por exemplo.

\subsection{SONS EM IMAGENS E IMAGENS EM SONS: PROCESSO CRIATIVO E MÚSICA PARA CINEMA}

"Eu sou músico desde os três anos de idade. Então, se eu escuto uma mosca, eu sei que essa mosca tá em si bemol" (ABUJAMRA, 2013). A declaração de Abujamra a Miguel de Almeida no programa Sala de Cinema, veiculado pelo SESC TV, indica não apenas uma postura de autovalorização do artista, mas seu perfil intuitivo e uma apurada percepção, materializados, entre outros aspectos de sua trajetória e experiências, em um fenômeno chamado ouvido absoluto - capacidade de qualquer pessoa, independentemente de se dedicar à música, de identificar uma nota musical em qualquer tipo de som (solo de violino, catraca de ônibus), sem um tom de referência (BIOSOM, C2017). Com o discernimento de que tem um 'dom', o artista está consciente de que a música alimenta o seu estar-no-mundo, sendo, portanto, uma matéria fundamental, e não um objeto de pesquisa. 
las dentro de mim. Porque a música pra mim é sentido. Então eu não chamaria isso de pesquisa. Eu chamaria isso de fome de viver. Não de conhecimento, fome de sentir bem. Porque como eu nasci músico, todo som que eu escuto - esse ar condicionado que a gente está ouvindo aqui -, todo som pra mim é música (ABUJAMRA, 2016).

Ao embaralhar os significados de 'sensação' e 'sentido' em seu discurso, o compositor parece reafirmar a prioridade da primeira sobre o segundo, mesmo sabendo que, em seu ofício de compositor de música para cinema, por exemplo, é necessário atingir a sensação do espectador ao mesmo tempo em que alinha sua criação ao sentido do todo cinematográfico que o diretor, em primeira instância, busca alcançar.

O processo criativo intuitivo de Abujamra é afetado pela sua prática religiosa, o candomblé, a começar pelo seu nome dentro da religião - 'Xiriã', que, segundo ele, significa 'um barulho'. Filho de pais ateus, ele conta que sua curiosidade o levou a buscar diferentes práticas religiosas, como budismo, espiritismo, umbanda, catolicismo, Kabbalah e islamismo.

Eu tocava piano com três anos. Não era brincadeira, eu tocava! Então eu sempre tive essa intuição de que a gente já era. [...] Desde sempre a gente já era alguma coisa. [...] Eu acho que a gente não morre, a gente só... Eu sou espírita, eu acredito, né. E eu caí no candomblé (ABUJAMRA, 2016).

Atraído pelo som, pelas frequências e confluências de vibrações entre matéria e espírito que, repetidas de forma intensa, desencadeiam o transe ${ }^{44}$, o compositor encontrou, no candomblé, um aporte para sua espiritualidade.

Existem frequências que você não escuta. [...] Então, se existe frequência, e a gente tem células e a gente também é frequência, então deve existir gente que a gente não enxerga. [...] Agora, eu não levanto uma bandeira, porque eu nem posso levantar. Porque existem tantos tipos de comida, tantos tipos de religião, tantos tipos de espiritualidade que... é isso, mas a minha religião me ajuda muito no meu processo de criação (ABUJAMRA, 2016).

Crente no poder que seu nome no candomblé, Xiriã ('um barulho'), carrega, o artista reafirma a música como: a) todo e qualquer som, independentemente de sua organização e intenção, incluindo ruídos, idiomas desconhecidos e outros sons não tradicionalmente considerados música (com uma estrutura e intenção definidas); e b) uma necessidade básica em

\footnotetext{
${ }^{44}$ Conforme minha própria experiência em um terreiro de candomblé, em Recife (PE), em outubro de 2017, para que pudesse melhor compreender a relação entre o som e a religião praticada pelo compositor. Na reunião de que participei, especificamente, não havia instrumentos percussivos; os cantos eram entoados pelo pai-de-santo e toda a comunidade respondia de forma veemente, batendo palmas com toda a força. À medida que a intensidade dos sons das vozes e das palmas crescia, alguns dos presentes incorporavam espíritos e começavam a se relacionar com os demais, oferecendo bebidas, conselhos, abraços e danças.
} 
sua existência - "como beber água, como respirar [...] chega a ser matéria" -, antes de se configurar como um ofício ou sustento.

No entanto, as paisagens sonoras do cotidiano de Abujamra não o atraem tanto quanto sonoridades longínquas ou não tão familiares aos ouvidos brasileiros, americanos, ocidentais. O gosto por timbres cultural e geograficamente distantes levou o compositor, desde a adolescência, a viajar mundo afora - ocasiões em que ele coletava e coleta sons, sem objetivos previamente definidos. Ao mesmo tempo, a tecnologia digital de produção e reprodução sonora permitiu o acesso dele aos mais variados timbres sampleados, do koto japonês à mbira africana, por meio das bibliotecas virtuais de som.

\footnotetext{
As coisas que eu escuto que já são muito comuns ao meu ouvido eu não gosto de ouvir muito. Eu não escuto música. Eu escuto assim, uma flauta indiana da década de 1920 , um negócio assim que me incomoda, mas não que me incomoda porque eu acho ruim, me incomoda porque me alimenta. É uma inquietação do som, é como você precisasse desse alimento (ABUJAMRA, 2016).
}

Assim como pela possibilidade de acessar timbres não usuais, as viagens, de forma mais abrangente, alimentam o processo criativo do artista pela imersão em outras culturas, abarcando diferentes costumes, comportamentos, sabores e outras linguagens artísticas. O compositor conta que sua primeira viagem sozinho ao exterior ocorreu aos 17 anos, quando foi morar no estado de Oklahoma, Estados Unidos, por 12 meses. Imerso em country music, ele também conheceu o rock norte-americano, que, segundo ele, é uma de suas fortes referências musicais - o que se comprova na opção pela guitarra como um dos principais instrumentos em todos os seus projetos musicais e também nas distorções presentes em diversas músicas d'Os Mulheres Negras e do Karnak - como Método (Música e ciência, Os Mulheres Negras, 1988) e Sosereiseuseforso - Nuvem passageira (Estamos adorando Tokio, Karnak, 2000) - e trilhas musicais para filmes, como em Bicho de sete cabeças (Laís Bodanzky, 2001) e Encarnação do demônio (José Mojica Marins, 2008).

Outras viagens marcantes na memória do compositor foram a que realizou ao Egito, em 1991 - quando conheceu o templo de Karnak, o que o motivou a criar a banda homônima no retorno ao Brasil; uma turnê pela Europa com Maurício Pereira na dupla Os Mulheres Negras; o tempo em que morou na Cidade do México realizando a trilha musical para o filme Vozes inocentes (Luis Mandoki, 2004); a viagem para o Zimbábue, país africano, onde ele compôs o disco solo Mafaro (2010); e duas incursões à China, onde apresentou Mafaro com um baterista nativo. "Amo viajar, acho que isso me alimenta. E a coisa da inquietação do som estranho, 
sabe? Ou uma desafinação, ou um instrumento exótico, você viu a minha balalaika ${ }^{45}$ aqui [no estúdio onde ele trabalha]" (ABUJAMRA, 2016).

Quando Abujamra fala em 'instrumento exótico' há o risco de ele mesmo pastichizar as sonoridades que coleta, retirando-as de seu local de origem para colá-las, sem grandes propósitos ou reflexões, a outros sons de outros lugares em sua música feita no Brasil. O caráter intuitivo do processo criativo do artista, e o acesso facilitado a esses sons pelas tecnologias digitais de comunicação e som, o levam a essa possibilidade. Ao ser perguntado sobre como administra tantos projetos - Os Mulheres Negras, Karnak, Fat Marley, carreira solo, música para filmes, Abujamra explica ser justamente graças a essas tecnologias relacionadas à mobilidade e à comunicação: "Com o advento da internet e do avião dá pra fazer tudo" (ABUJAMRA, 2016).

\subsubsection{A criação musical no cinema}

A forma como Abujamra trabalha, sua formação e experiência, os profissionais que agrega, as diferentes ou recorrentes estruturas que utiliza para a produção musical para cinema interferem diretamente em seu processo criativo e na compreensão do papel da música em uma narrativa fílmica.

Quando ele é apresentado a um novo projeto cinematográfico, busca sentir livre e inteiramente a proposta narrativa em seus sons e imagens, buscando, dentro de seu repertório cultural e em eventos aleatórios do cotidiano, suas ideias iniciais, sem compromisso com uma estrutura ou estilo de composição. Em entrevista para o dvblog, o artista comenta sobre seu processo composicional, de referências múltiplas e casuais:

\footnotetext{
Meu processo criativo de trilha sonora pra cinema é o seguinte: eu ir pra uma praia ou eu andar de metrô, eu andar na rua e começar a imaginar não a música do filme, mas o quê que aquele filme tá trazendo pra mim (ABUJAMRA, 2007).
}

A vivência do artista, uma vez processada e reorganizados seus diversos elementos sob a forma de obras musicais para cinema, pode desempenhar uma série de papéis no filme.

Alguns falam que o som é $50 \%$ do filme. Eu acho que é mais. Eu acho que se você
pegar um filme de ação, ou um filme de terror, ou mesmo uma comédia romântica e
você não tiver música, o filme não vai existir. E mais: mesmo o filme que não tenha

45 Instrumento musical russo em madeira, de formato triangular, composto por três cordas. 
música e tenha som, tem música.

O Beto Brant [diretor] é um grande amigo e eu trabalhei com ele em dois filmes, o Ação entre amigos [1998] e Os matadores [1997]. E ele falava pra mim: 'Eu não vou te chamar pro meu próximo filme porque o meu próximo filme não vai ter música'. Eu falei assim: 'Cara, mesmo que não tenha música, tem que ter um músico pra não fazer a música'. Mesmo que não tenha música, tem que ter música! E o silêncio é música! (ABUJAMRA, 2016).

O compositor, além do encantamento por timbres incomuns, percebe o silêncio como detentor de uma musicalidade capaz de maximizar os efeitos dramáticos de uma cena e o impacto das entradas de música vindas antes ou depois dele. Além disso, a ausência planejada de música, vozes e outros sons na trilha contribui para o aumento da dinâmica sonora e audiovisual do filme. Foi o que ocorreu em Vozes inocentes (Luis Mandoki, México, 2004). Quando a obra chegou para a composição da trilha, havia, segundo ele, mais entradas de música - pontuadas por trilhas-referência - que o necessário, inclusive no clímax do filme, a morte do protagonista. O compositor, então, interveio em favor do silêncio.

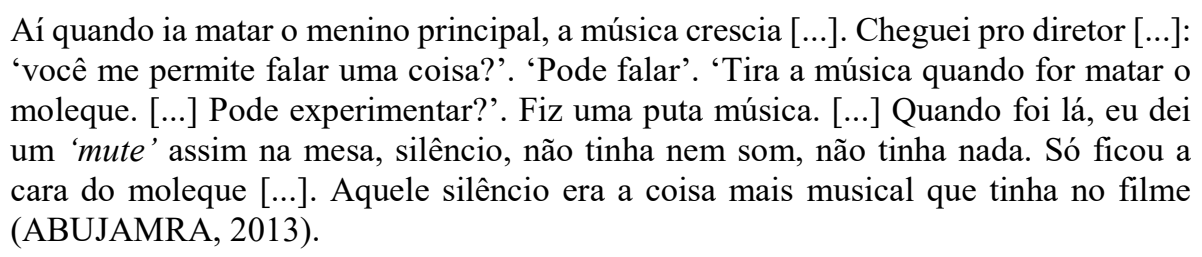

O mesmo ocorreu em Ação entre amigos (Beto Brant, 1998), também no momento da morte de um personagem.

Quando o cara vai matar o torturador no meio da floresta, aquele "puta" som, eu, na mixagem, falei: "meu tira, tira tudo, tira passarinho, tira som, tira tudo, tira tudo". Cara, dá uma tensão, aquilo é uma música, né, é o silêncio mais musical. Eu sempre busco (ABUJAMRA, 2016).

Para compor uma trilha musical, diz Abujamra, é preciso compreender e ser sensível à experiência e à linguagem do cinema, a ponto de o compositor se tornar uma espécie de 'personagem extra-fílmico' que transita entre os ambientes espaço-temporais, sentimentos e ações dos personagens do filme e as expectativas do diretor, sua equipe e o público.

Música pra cinema, ou fotografia pra cinema, você tem que ser um ator. [...] Pra você fazer música você tem que ser um personagem. A arte do cinema [...] são todas as artes reunidas pra um ideal, o grande maestro é o diretor. [...] Então não adianta você ser um "puta" músico e não entender o metabolismo do ator, a respiração do ator, a "respiração" da luz [...]. Tem que entender o timing do ator, o timing da cabeça do diretor (ABUJAMRA, 2013). 
Segundo o artista, o compositor de música para cinema, além de entender a atuação, precisa ter ritmo - o qual ele associa diretamente à 'musicalidade' -, e nessa característica ele se aproxima de um requisito necessário também ao montador das imagens: “'Qualquer músico tem ritmo': não é verdade. Um bom editor de filme eu sei que conhece música quando eu vejo a edição sem nada e eu consigo ver quando o cara entende de música. Porque a imagem tem ritmo. O ritmo é o timing da coisa, o ritmo é tudo" (ABUJAMRA, 2016).

Além de ser sensível ao ritmo dos sons e das imagens, o compositor defende que a criação musical de um filme precisa ser autoral, ou seja, a assinatura da trilha, bem como a da fotografia e as de outros elementos que compõem o filme, deve evidenciar a contribuição estética de seus respectivos criadores, sem estar relacionada a qualquer sonoridade sugerida como referência prévia.

Existem filmes ruins com trilhas boas que tornam o filme menos ruim; isso, pra mim, é ruim. Existem filmes maravilhosos em que você não lembra da trilha, mas a trilha é contundente, mesmo sem você se lembrar dela; isso, pra mim, é a busca. E existem trilhas de filmes bons que você sai cantando a melodia: esse é o suprassumo pra mim. Eu amo você pegar um tema e esse tema estar recorrente na sua cabeça e, sabe, isso é uma coisa que eu busco muito. [...] Por exemplo, o Carandiru. O Carandiru é um filme muito violento, mas se você assiste muito e se você trabalha com isso, você sai com as três notas na cabeça, isso é o que eu busco [o reconhecimento de uma marca] (ABUJAMRA, 2016).

Percebemos, aqui, traços de uma perspectiva romântica de autoria evidenciados pela clara defesa de Abujamra, mesmo que isso signifique não ser convidado para um projeto de grande porte dentro de um grande conglomerado de comunicação, ou ter que enfrentar situações conflituosas com o diretor e outros membros da equipe cinematográfica, como veremos adiante. A afirmação destes traços não está desvinculada de sua trajetória discográfica, contexto em que os contatos mais próximos do artista com a indústria fonográfica foram, em sua opinião, desastrosos, justamente pela tentativa de interferência estética em suas músicas, na formação das bandas etc., visando a venda de discos, shows e da imagem do artista, além de um vínculo contratual com uma gravadora - algo que é de praxe nessa indústria.

Foi terrível [a relação com a indústria fonográfica]! Nada funcionou! O Poladian [produtor musical] quis contratar o Karnak. Aí ele chegou pra mim e falou assim: "O Karnak é só você e o cachorro, o resto eu 'tô pouco me fudendo"'. Não dá, cara. Pra mim, tem que fazer a coisa do coração. Não dá pra imitar ninguém, não dá pra ir atrás de referência, eu não acredito nisso. [...] Existe gente que faz isso? Existe. Existe gente que faz isso e tem talento? Existe. Existe gente que faz isso, tem talento e acredita nisso? Existe. É errado? Não é errado, mas não é a minha (ABUJAMRA, 2016). 
Apesar das diferenças entre a relação com a indústria fonográfica e a relação com a equipe cinematográfica no processo composicional - a começar pelos objetivos básicos de ambas, respectivamente, gravar e vender discos e fazer a trilha musical de um filme -, Abujamra, ao reafirmar sua defesa romantizada da autoria, revela sua preferência por romper com as regras e códigos estabelecidos pela indústria do cinema para a composição de trilhas musicais. Compreendemos que seu discurso consiste mais em uma busca da "liberdade" de criação - algo que no cinema é limitado pelo diretor e/ou produtor e que, na publicidade, outra área em que atua, é ainda mais restrito ou inexistente - que um rompimento de fato com as convenções. Por mais que ele ressalte o uso de timbres e sons 'estranhos', incômodos ou incomuns ou invista em temas marcantes como algo que o diferencie, em vários filmes com trilhas assinadas por ele, conforme veremos nas análises a seguir, a música é convergente com as funções da trilha musical no cinema clássico narrativo, apontadas por Gorbman (1987) invisível, 'inaudível', significante de emoção, pista narrativa, promoção de unidade e continuidade.

\begin{abstract}
Isso [de ser autoral] não exclui se o Spielberg me chamar pra fazer um filme Hollywoodiano. Eu faço, e eu vou te falar, eu já tenho capacidade de fazer isso. Já até pinguei ali, já fiz a trilha sonora do documentário da Harley-Davidson [Harlistas: An American Journey, Alfredo de Villa, 2011] [...]. Eu não estou dizendo não pras regras, eu só acho que existem pessoas maravilhosas que quebram as regras dentro desse mercado, né? Então, pra mim, não tem nenhum problema ter regras. Pra mim o problema é você achar que aquilo ali é a única coisa que existe no mundo (ABUJAMRA, 2016).
\end{abstract}

O artista cita, sem detalhamento, a música de John Williams para Indiana Jones Raiders of the lost ark (George Lucas, 1981) e a de Ryuichi Sakamoto para The revenant (Alejandro Iñárritu, 2016) como exemplos de rompimento de regras na trilha musical dentro da indústria holywoodiana e demonstra, apesar de se definir como 'autoral' e avesso a pensar a trilha musical tendo em vista o mercado ou o público, uma vontade de compor para a indústria americana. Pensamos que novamente ele associa, de forma precipitada ou ingênua, uma provável "liberdade" de composição - dada a notoriedade da carreira cinematográfica dos compositores citados - ao um rompimento, que, por fim, não apenas não ocorre como revela o reforço e a atualização das convenções do cinema clássico narrativo nos séculos XX e XXI.

Quanto a essas convenções, podemos elencar, citando Bordwell (2004), algumas características da estrutura narrativa hollywoodiana clássica, relacionando-as às camadas sonoras, em geral: onisciente, estável, espacial e temporalmente coerente e controlada e centrada em personagens motivados a atingir determinados objetivos, passando, para isso, por 
conflitos e chegando a resoluções. Essa estrutura demonstra uma relação de causa-efeito, já esperada pelo espectador, por meio de reforços e antecipações de informações do enredo, bem como pelo preenchimento de lacunas deixadas ao longo da trama. Aqui o som colabora com a narrativa clássica com o vococentrismo e o verbocentrismo da primazia histórica dos diálogos (CHION, 1993); por meio dos foleys desencadeados pelas ações dos personagens promovendo, com a sincronia entre som e imagem, um efeito realista; e por meio da música, que pode apresentar cada um dos personagens, suas emoções, progressos e pistas no desenvolvimento da ação, além de passagens de tempo, motivos e suas variações indicando novos elementos (leitmotiv) e unidade entre planos.

Além disso, o efeito de 'transparência' provocado pelos ocultamentos da produção e do narrador observador invisível (câmera) está diretamente ligado à ilusão audiovisual gerada pelo 'valor agregado' de que fala Chion (1993): o som acrescenta valor à imagem, de modo a fazer crer que este já estava 'naturalmente' contido nela. Assim, a decupagem clássica do campo/contracampo, com montagem de planos aproximados e de conjunto, oculta sua fragmentação também por meio de sons ambientes constantes que os unem e uma mixagem que enfatiza as informações do enredo, em geral colocadas nos diálogos, à frente de outras camadas sonoras.

O tratamento precipitado dado por Abujamra ao reforço e à atualização das convenções do cinema clássico narrativo como suposta inovação no uso da música pode estar associado a objetivos diversos do compositor como artista e profissional, que vão de compor a melhor música para um filme e ser lembrado como autor a "pagar as pensões para seus filhos", como ele mesmo repete em entrevistas concedidas a diferentes veículos de comunicação. A complexidade e as divergências de suas declarações revelam questões mais amplas e de difícil solução compartilhadas pelo cinema brasileiro atual: como ser autor e, ao mesmo tempo, garantir a distribuição eficaz de um filme; ser reconhecido, mas também remunerado pela contribuição artística? Como ter alguma "liberdade" de criação e conseguir um financiamento compatível com a realização de um projeto cinematográfico? Como viver de cinema e/ou música no Brasil?

O compositor não desvincula a busca pelo reconhecimento como autor das necessidades musicais de um projeto cinematográfico, revelando a tentativa de alinhar caminhos nem sempre convergentes. Ele utiliza a metáfora do corpo humano para falar sobre o universo complexo e particular que é um filme - um todo com diversos órgãos que funcionam interligados e em harmonia, cada qual executando uma função. Ele também fala sobre a 'alma do filme', que é 
resultado desse trabalho em conjunto. "Eu me armo do que o filme me dá, do que o diretor quer. [...] Cada filme é uma história e cada filme é um ser pra mim" (ABUJAMRA, 2013).

A compreensão da linguagem cinematográfica por Abujamra, bem como suas preferências artísticas e metodológicas para criar trilhas musicais para filmes, passa pela investigação de seu repertório de sons e procedimentos ao longo do tempo, conforme as tecnologias disponíveis e acessíveis a ele. A seguir, apresentamos a investigação acerca da relação do artista com suas ferramentas de composição e produção musical.

\subsection{FERRAMENTAS DE TRABALHO}

As ferramentas e procedimentos empregados ao longo do processo criativo da composição musical interferem diretamente na realização da obra, afirma Mannis (2012). Abujamra manipula sons desde antes do início da popularização das tecnologias digitais de produção e reprodução sonoras, utilizando-se sobretudo destas em suas produções, até a atualidade.

O Logic é principal ferramenta de trabalho do compositor ${ }^{46}$. Trata-se de um software de áudio desenvolvido originalmente pela empresa alemã de tecnologia C-Lab (depois Emagic), na década de 1980, e atualmente de propriedade da Apple. Neste software o artista rascunha suas criações, escreve partituras, grava, edita e finaliza suas trilhas musicais para cinema. Ele utiliza esta plataforma desde o final dos anos de 1980, quando a dupla Os Mulheres Negras com Maurício Pereira já estava em atividade e a tecnologia digital começava a se popularizar no Brasil.

À época, o Notator Logic (FIGURA 39) era considerado um dos mais poderosos e intuitivos programas de sequenciação e notação musical criados para o computador Atari ST. O primeiro trabalho que o compositor se lembra de ter realizado com o software foi a vinheta para o Programa Som Pop (1989-1993), da TV Cultura, apresentado por Kid Vinil, com videoclipes, entrevistas e notícias do cenário rock/underground brasileiro.

Figura 39 - Interface do Notator Logic

\footnotetext{
${ }^{46}$ Em shows e espetáculos, Abujamra utiliza o software Ableton Live, que sincroniza som e efeitos visuais em performances ao vivo.
} 


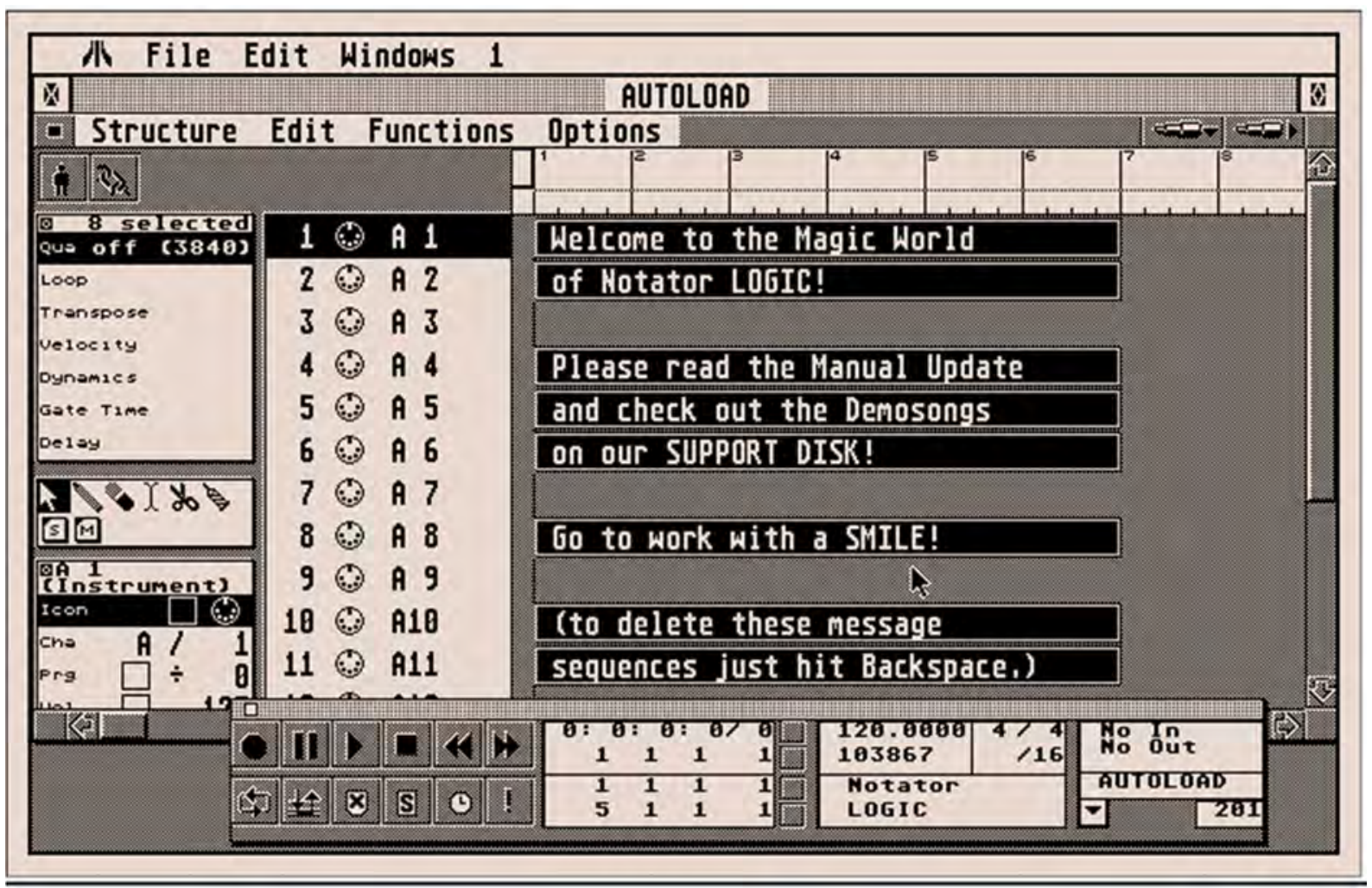

Fonte: Site Tweakheadz. Disponível em: <http://tweakheadz.com/history-of-notator-and-logic3/ >. Acesso em: 22 jan. 2018.

$\mathrm{O}$ artista atribui a si, e a outros usuários do software que se correspondiam com a empresa desenvolvedora, a iniciativa de muitas melhorias ocorridas em versões posteriores do programa.

Eu tenho os áudios sincronizados com o MIDI que vão ser partituras. Fora isso, há os plug ins que eu posso destruir, aumentar, reciclar, eu posso fazer o que eu quiser. Então a comodidade é eu poder ter tudo dentro de um lugar só, entendeu? Se eu quiser importar um diálogo, destruir ele [...] (ABUJAMRA, 2016).

Desde o início dos anos de 1990, antes mesmo da estreia da banda Karnak (1992), o compositor alimenta um acervo de sons composto por gravações dele - incluindo de registros em fitas cassete e DAT de sonoridades estrangeiras, trechos de programas de rádio, 'sons estranhos', por ele recuperados e digitalizados, a recentes gravações com telefone celular - e diferentes livrarias digitais de áudio (samplers de orquestra e outras coleções e efeitos) adquiridas por compra, download gratuito e outras formas de compartilhamento ${ }^{47}$. Ele recorre

\footnotetext{
${ }^{47}$ Dentre as livrarias mais interessantes, está a coleção Jam Pack World Music, com loops rítmicos e melódicos de instrumentos do mundo inteiro, da África à Noruega, que ele compartilhou comigo em 2006, quando ministrou uma oficina de Trilha Sonora na $6^{a}$ edição da Goiânia Mostra Curtas, mostra nacional de cinema em curtametragem realizada anualmente na cidade de Goiânia (GO). Como docente e compositora esporádica, utilizo esses arquivos e outros cedidos por ele em eventuais trilhas musicais e em laboratórios de trilha musical na Universidade Estadual de Goiás (UEG).
} 
ao acervo tanto para a produção de seus álbuns quanto para a composição de trilhas - o que, apesar do grande volume de arquivos, abre a possibilidade de trânsito de timbres marcantes entre discos e filmes - como o da gaita de fole, utilizado em fonogramas do Karnak e no filme Carlota Joaquina, princesa do Brasil (Carla Camurati, 1995), conforme rememorou o artista, em entrevista para esta tese. No entanto, ao mesmo tempo em que o compositor abastece permanentemente seu vasto repertório sonoro de arquivos das mais variadas procedências, ele não arquiva ou organiza os projetos musicais editáveis dos filmes de que participa.

Em visita ao Omin Estúdios em 7 de março de 2016, mostrando-me algumas de suas trilhas no site de compartilhamento de vídeos Youtube, Abujamra admitiu a própria desorganização na gestão de seus arquivos de trilhas musicais. A tecnologia digital possibilitou ao artista a praticidade na criação, o barateamento da produção, a acessibilidade a sons de diferentes origens, mas, ao mesmo tempo, um excesso de arquivos com o qual ele opta por lidar parcialmente, revelando, neste quesito, um perfil mais artístico/intuitivo que administrativo.

Eu não consigo mostrar nada [projetos editáveis] pra você aqui, no Youtube eu estou mostrando pra você. Eu sou muito desorganizado. Quando chegam pra mim e falam assim: 'Abu, tô precisando de uma trilha, pega alguma coisa que você já fez aí!', aí eu não aguento e faço e mando, entendeu? É muita informação (ABUJAMRA, 2016).

$\mathrm{Na}$ fala do artista, é perceptível o pouco valor dado ao trabalho do compositor, quando o diretor, no cinema ou na publicidade, pede para 'pegar qualquer coisa' que o compositor já tenha feito, para que se 'encaixe', sem elaboração conceitual e estética aprofundada, a uma peça audiovisual. Na área publicitária esse tipo de postura é ainda mais recorrente, já que os prazos para criação, produção e finalização são muito mais reduzidos/imediatos, dada a urgência de veiculação paga do produto por períodos determinados. Isso não significa que o compositor não possa reaproveitar peças não aprovadas em obras futuras; este, porém, revela ser mais fácil criar algo do início que procurar antigos projetos em seus arquivos.

No entanto, durante todo o processo de realização da música, Abujamra consegue aproveitar tanto as tecnologias digitais de produção e reprodução sonora quanto as de comunicação, buscando o alinhamento com a direção na criação, aprovação, gravação e inserção da peça musical no filme. Desse modo, se o diretor mora em outra cidade, ou se há pouco tempo disponível para a criação da trilha, o artista consegue, por meio da internet, viabilizar o trabalho.

Um exemplo dessa maleabilidade ocorreu no processo da trilha musical de O caminho das nuvens (Vicente Amorim, 2003). Entre a criação e a entrega da música, Abujamra levou 40 
dias. Como o compositor não tinha disponibilidade para ir ao Rio de Janeiro, onde estava o diretor, este enviava àquele os trechos do filme a serem musicados, que eram devolvidos com música por Abujamra e, então, aprovados à distância. Diretor e compositor se encontraram, enfim, para a gravação com os músicos (ABUJAMRA, 2003).

Sobre a decisão de utilizar músicos 'reais' ou coleções de samplers em suas trilhas, o compositor elenca como critérios o tempo de produção, o porte e o destino do projeto, o acesso e negociação com os intérpretes, enfim, tudo que dependa do orçamento disponível para a música do filme. Segundo Abujamra, é comum, no Brasil, que as filmagens comprometam grande parte do orçamento de um projeto cinematográfico, sobrando muito pouco para a finalização, distribuição e exibição. Como, via de regra, o compositor participa do projeto a partir da finalização, o orçamento para a produção da música é reduzido, o que limita as possibilidades de deslocamento para reuniões e contratação de músicos.

\begin{abstract}
A grana da finalização do filme tem que ser tão grande quanto a da realização dele antes da finalização. E eu sou um cara que eu já fiz tanta trilha que eu faço tudo por computador sampler, cordas, eu tenho sons reais. E geralmente eu uso esses sons no filme, porque não se tem dinheiro pra pagar uma orquestra. Mas hoje eu bato o pé. [...] "Ó, pessoal, eu quero uma orquestra, nem que seja de quatro cordas" (ABUJAMRA, 2013).
\end{abstract}

Foi com quatro instrumentos de cordas que Abujamra gravou a trilha musical de $\mathrm{O}$ caminho das nuvens (Vicente Amorim, 2003). O filme não tinha orçamento para a contratação de uma orquestra, mas o compositor via na narrativa essa necessidade estética. Para obter a poética e a textura densa da música do filme, o artista dobrou as cordas na edição da música, gravando os quatro instrumentistas várias vezes, em lugares diferentes do estúdio.

No primeiro longa dirigido por Beto Brant, Os matadores (1997), um problema na produção resultou no prazo estendido de um ano para que Abujamra compusesse a música. Tal intervalo garantiu um longo e aprofundado diálogo com o diretor e uma composição musical articulada com o som do lugar onde se passa a narrativa - a fronteira entre Brasil e Paraguai -, o que se tornou uma característica do compositor em outros filmes, como Bicho de sete cabeças.

O Beto e o Renato [Ciasca] foram pra fronteira do Paraguai e conheceram o Oscar e o Nino, que é [sic] um pai e um filho que tocava harpa paraguaia e o filho tocava violão. Eu trouxe os caras pra São Paulo, gravei um disco pra eles num dia, e enchi meu computador de harpa paraguaia, violão. Aí coloquei um amigo meu, Renato Lemos [maestro], tocando violoncelo. [...] E a sonoridade, eu fiz tudo meio pro grave, misturando harpa paraguaia, misturando o som daquele lugar. Eu usei muito o som ambiente pra fazer a música (ABUJAMRA, 2013). 
No entanto, mesmo que opte pela interpretação por outros músicos, esta é frequentemente combinada ao uso de seu acervo digital - combinação compreendida por ele como "uma soma de suas próprias loucuras", demonstrando, assim, que não se trata de uma escolha excludente.

\begin{abstract}
Às vezes eu usei um violino chinês, quem vai tocar um violino chinês aqui? A não ser que a produção me pague pra eu ir pra China gravar o cara lá, ou mande por mp3, hoje em dia já dá, né? Quando eu tenho isso, eu prefiro usar a orquestra, e o resto eu faço mesmo, porque eu gosto de 'meter a mão'. [...] Eu só uso músicos de verdade há muitos anos já. Mas eu somo com as minhas loucuras. E quando não tem dinheiro... Deixa eu te mostrar uma trilha pra Globo [procura nos arquivos uma vinheta musical com cordas sintetizadas]. Você não fala que isso não é uma orquestra, né? Fui eu que toquei. Agora eu não vou gastar pra fazer uma vinhetinha da Globo pra botar uma orquestra, entendeu? (ABUJAMRA, 2016).
\end{abstract}

Em alguns casos, a restrição orçamentária leva a composição a outros rumos que não o dos samplers, como na vinheta para a TV Globo. Foi o que ocorreu no filme Domésticas (Fernando Meirelles e Nando Olival, 2001), conforme o relato do compositor:

\begin{abstract}
A gente não tinha dinheiro pra fazer orquestra, né. Aí eu peguei eu, o Marcos Bowie (o vocalista do Karnak), o Mano Bapi (que é o baixista também) e um amigo da gente, o Edson Montenegro, que tem um vozeirão, fiz um quarteto de voz e peguei utensílios de empregada doméstica: vassoura, panela, tudo, pra fazer a trilha. Então essa pesquisa - isso eu acho que não é pesquisa, é brincadeira, você tentar usar essas coisas em seu favor (ABUJAMRA, 2016).
\end{abstract}

Abujamra frequentou aulas de música erudita, estudou ópera, clarinete e, motivado a compreender o que, de acordo com ele, "já tinha dentro de si”, cursou Regência na Faculdade de Artes Alcântara Machado (FAAM) por 12 anos, tendo sido jubilado após este período. "Eu tive várias desventuras, várias brigas na faculdade, com vários professores. Muitas leis, muitas regras de música [...]. Foram boas as brigas, porque hoje eu vejo a música de um jeito muito bonito", justifica o compositor (ABUJAMRA, 2016). Apesar dos conflitos, ele considera que sua passagem pelo ensino superior foi importante para que se sentisse seguro para desenvolver sua própria trajetória musical e qualificado para escrever e reger uma orquestra.

No entanto, sua formação não o livrou de cometer deslizes em sua primeira experiência à frente de uma orquestra com 25 músicos, na gravação da trilha musical de Castelo Rá-TimBum, o filme (Cao Hamburger, 1999), com orquestração do maestro Renato Lemos: 
gente usa 440 hertz, e a orquestra usa 445 ou... eu me esqueci ${ }^{48}$. Não é a mesma frequência, mas é tipo... "um palito" [de diferença]. Então, na hora que eu fui colocar os meus teclados, as minhas coisas eletrônicas, estava desafinado. Muito pouco desafinado. Então eu tive que desafinar todos os meus MIDIs pra acertar. Mas aí eu aprendi: aí, agora quando eu vou gravar eu peço pra orquestra gravar em 440, porque daí fica mais fácil pra eu usar minhas [sonoridades eletrônicas] (ABUJAMRA, 2016).

O compositor alega que, assim que se sentiu seguro para fazer, ele mesmo, a orquestração de suas músicas, deixou de trabalhar em parceria com Lemos, que colaborou com as orquestrações das trilhas musicais de Abujamra também em Carlota Joaquina, princesa do Brasil (Carla Camurati, 1995), Um copo de cólera (Aluizio Abranches, 1999), As três Marias (Aluizio Abranches, 2002) (FIGURAS 40 e 41), Carandiru (Hector Babenco, 2003), e na película mexicana Vozes inocentes (Luis Mandoki, 2005). Após as experiências em parceria com o maestro, porém, o compositor assinou como 'Orquestração e regência' trilhas com uma formação bem menor de músicos. É o caso de Achados e perdidos (José Joffily, 2005), com quatro músicos de orquestra; Encarnação do demônio (José Mojica Marins, 2008), com três; Do começo ao fim (Aluizio Abranches, 2009), com dez; O contador de histórias (Luiz Villaça, 2009), com seis instrumentistas.

Figura 40 - Renato Lemos rege músicos na gravação da trilha de As três Marias

\footnotetext{
48 Conforme explicado no website de música <www.quintaessentia.com.br> (FLAUTADOCEBR, C2015), a maioria dos instrumentos tem a nota 'lá' (diapasão, referência de afinação) calibrada em $440 \mathrm{~Hz}$ ou 440 ciclos por segundo - convenção acordada após a Segunda Guerra Mundial. Algumas orquestras, porém afinam os instrumentos em $442 \mathrm{~Hz}$, podendo chegar a $445 \mathrm{~Hz}$. Na música barroca, conforme informações dos músicos que alimentam a página, usa-se o diapasão calibrado em $415 \mathrm{~Hz}$, meio tom abaixo da convenção moderna.
} 


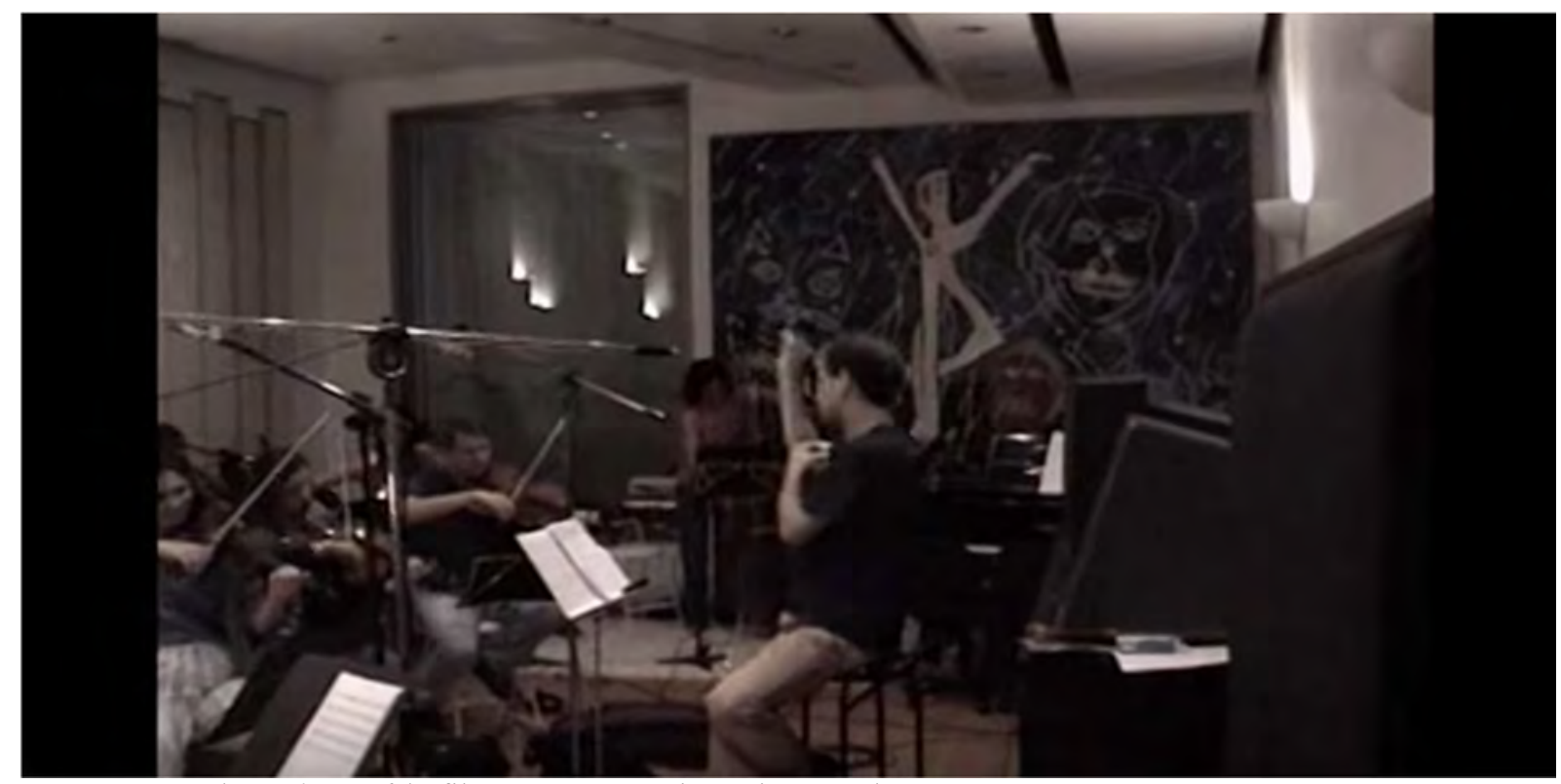

Fonte: Frame do making of do filme As três Marias. Disponível em:

$<$ https://www.youtube.com/watch?v=_jBNnXFB0aQ>. Acesso em: 22 jan. 2018.

Figura 41 - André Abujamra acompanha a gravação da música de As três Marias

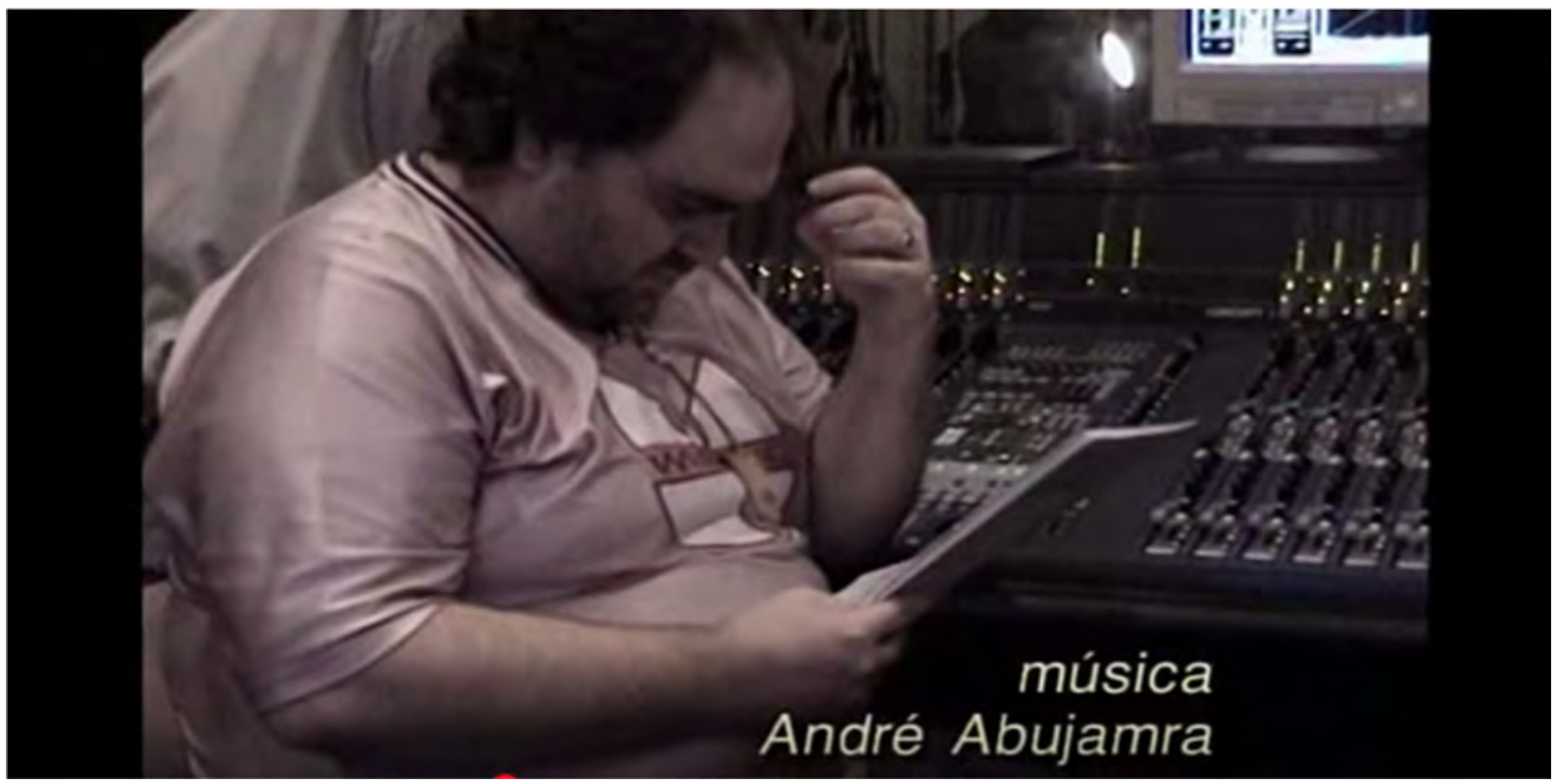

Fonte: Frame do making of do filme As três Marias. Disponível em:

$<\mathrm{https}: / /$ www.youtube.com/watch? $\mathrm{v}=$ jBNnXFB0aQ>. Acesso em: 22 jan. 2018.

A exceção é Trinta (Paulo Machline, 2014), quando o compositor liderou 20 músicos para a gravação da música orquestral. Para este tipo de trilha Abujamra delega a escolha dos músicos a algum parceiro de confiança, como ocorreu com o violista Fábio Tagliaferri nesse filme. O conjunto é construído conforme a demanda de cada projeto, sendo os músicos selecionados provenientes de diferentes orquestras.

No caso da gravação da música original de Carlota Joaquina, princesa do Brasil (Carla 
Camurati, 1999), porém, não foi isso que ocorreu. Abujamra conta que tinha, à disposição, a orquestra da Petrobras, que, à época, não tinha a qualidade desejada pelo compositor. Esse tipo de dificuldade é confirmado por Matos (2014) como um sintoma do tímido investimento em música sinfônica no país e pode ajudar na compreensão da tradicional convivência de timbres orquestrais 'reais' ou análogos, simulados por computador, com a instrumentação popular, o que também é observado nas músicas de Abujamra.

Nosso país tem talento de sobra para produzir trilhas musicais de alto nível, não deixando nada a desejar às produções estrangeiras. $\mathrm{O}$ mesmo, infelizmente, não poderíamos dizer sobre a disponibilidade de boas orquestras, o que limita bastante nossa produção musical em relação aos quesitos expressividade e colorido tímbrico (MATOS, 2014, p. 37).

O uso de instrumentação sinfônica e/ou popular depende das demandas conceituais de cada produção cinematográfica, o que demanda uma versatilidade apresentada pelo artista, independentemente de seus gostos particulares.

Eu, fazendo trilha, eu não posso falar 'eu não gosto de música sertaneja'. Eu não posso, porque, e se tiver um filme que seja sobre a vida de um sertanejo, sabe? Vai conhecer, meu, às vezes os músicos são bons pra caramba [...]. Tem umas duplas sertanejas que têm umas músicas lindas! Não tem que ter preconceito, nem com timbre nem com nada. (ABUJAMRA, 2016).

Em Cafundó (Paulo Betti e Clovis Bueno, 2005), por exemplo - cuja trilha, devido à prática de candomblé por Abujamra e à "liberdade" concedida para a função, foi uma das que o compositor mais teve prazer em fazer -, ele mistura viola caipira (executada por Théo Werneck), timbres sintetizados que lembram orquestra, percussão gravada ao vivo (James Muller), o hang (Kuki Stolarski, baterista do Karnak) e as vozes de Gilberto Gil (FIGURA 42).

Por fim, para a finalização das trilhas musicais - mixagem da música, na qual os arquivos são preparados para a mixagem final do filme -, o compositor conta que, antes que sua estrutura de trabalho comportasse esta etapa, ele investia muito dinheiro e muitas vezes não conseguia resultados satisfatórios. A partir do momento em que equipou seu estúdio com uma monitoração 5.1, ele começou a inserir uma cláusula contratual em seus trabalhos na qual ele se responsabilizava por enviar a trilha musical mixada (além dos stems separados, quando solicitado). Além disso, ele costuma acompanhar a mixagem final dos filmes, para checar o resultado da mistura de sua música aos demais sons, indicando, em alguns casos, profissionais para esta função. "[Para efeitos] Eu trabalho muito com a Miriam Biderman, [...] com o Beto Ferraz. [...] E pra mixar, o Ariel [...] [Ariel Henrique, Cinecolor Digital], ou mesmo o 
Armandinho [...]. Eu trabalho com uma molecada, um pessoal muito forte" (ABUJAMRA, 2016).

Figura 42 - Gilberto Gil gravando vozes para trilha de Cafundó

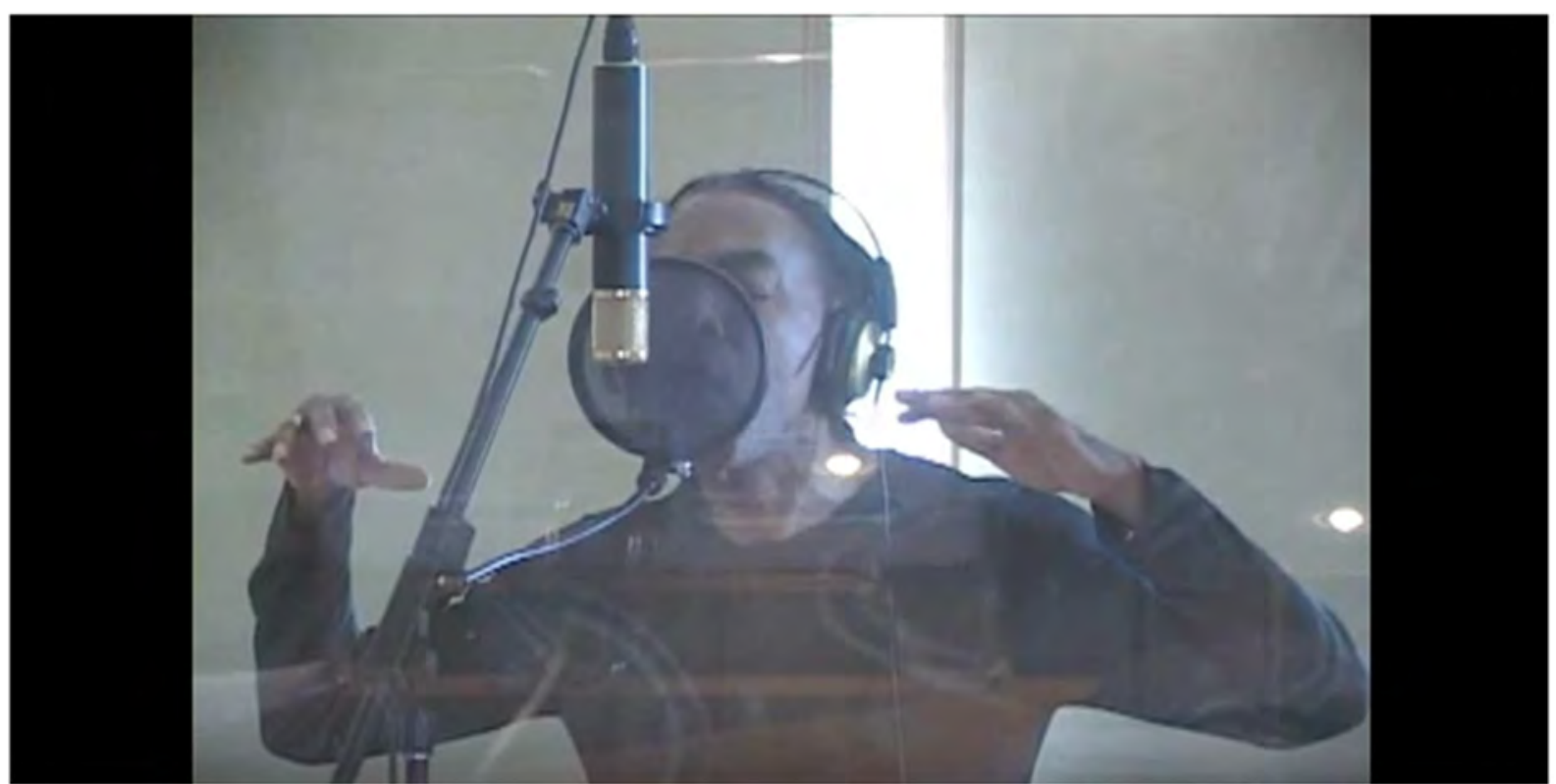

Fonte: Frame do making of do filme Cafundó. Disponível em:

$<$ https://www.youtube.com/watch? $v=g L V E 80 b t N W g ~>$. Acesso em: 22 jan 2018.

A partir da compreensão e apropriação das ferramentas pelo artista, e de como isso se reflete em seu processo composicional, estudamos o relacionamento de Abujamra com alguns diretores brasileiros ${ }^{49}$ para demonstrar os desafios ao lidar com as dificuldades técnicas e estéticas de diálogo sobre a música no cinema e com as tensões implicadas na defesa das ideias do compositor perante as de outros artistas do cinema, com seus diferentes perfis, capacidade de argumentação, repertórios e níveis de disponibilidade para negociação.

\subsection{ABUJAMRA E DIRETORES}

Tendo em vista que "cada filme é um ser único", Abujamra explica que tanto o diálogo com o diretor e a equipe quanto o processo de composição musical para cinema variam de projeto para projeto, a princípio em função do compartilhamento ou não de um vocabulário musical entre compositor e diretor. Ao longo de sua trajetória no cinema brasileiro recente, ele considera que, na maioria dos casos, não havia esse vocabulário comum, e a saída era buscar

\footnotetext{
${ }^{49}$ Em filmes de ficção em longa-metragem.
} 
de metáforas para tentar estabelecer uma comunicação que resultasse na compreensão das demandas musicais do filme e das expectativas de ambos acerca da trilha.

\begin{abstract}
A primeira coisa que é complexa com um diretor que não entende de música é a não linearidade do que a gente faz. Hoje em dia, a gente não vai gravar uma orquestra antes de ser aprovada a trilha, então você faz tudo pelo computador. Então, a primeira coisa que tem que explicar pra uma pessoa que não conhece música - e são muitos os diretores que não conhecem - é que aquele som não vai ser aquele. Então é uma coisa muito "esotérica" pra quem não entende. Você fala: "Olha, isso aqui não vai ser isso, é um esqueleto do que vai ser". Isso já é uma coisa complexa. Outra coisa que é complexa é quando tem muita referência e você tem que fazer uma coisa original, e aí o diretor já se acostumou com a referência [...] (ABUJAMRA, 2016).
\end{abstract}

O compositor procura garantir sua "liberdade" de criação na música, evitando a utilização das trilhas musicais temporárias de referência (temp tracks), procedimento comum na publicidade que também é observado no cinema: o diretor, juntamente com o montador, seleciona músicas preexistentes para auxiliar tanto na montagem do filme quanto na comunicação com o compositor sobre o que se espera da música original. Abujamra, entretanto, prefere estudar, juntamente com o diretor, as necessidades dramáticas de cada cena, sem referências pré-estabelecidas.

O que é lindo em montador é quando ele te dá a coisa em silêncio. Hoje $98 \%$ dos montadores te dão o filme com referência, pra poder montar melhor o filme. [...] Aí o diretor se vicia naquela referência, isso tem muito em publicidade. [...] Porque publicidade é um negócio rápido, 30 segundos, tem que vender. [...] Um longametragem é um trabalho artístico. [...] Deviam acabar com referência no cinema (ABUJAMRA, 2013).

Abujamra cita Marcelo Masagão como um diretor que costuma trabalhar com trilhareferência em seus documentários. Apesar de sua preferência pelo não uso da temp tracks, o compositor possui uma parceria de alguns longas-metragens com o diretor.

\footnotetext{
O Masagão é aquele cara que já vem com a referência mesmo. Nós que aqui estamos por vós esperamos, eu fiz o som do filme. Porque a música ele contratou um francês [...]. E aí eu fiz uma música ou outra música do filme. E ele fez um filme também, [...] ele chegou com a música pronta também pra mim... O Nem gravata nem honra. [...] E tem o 1,99 que eu fiz o som também, em alguns momentos eu fiz uma musiquinha ou outra. Eu odeio referência, eu quero enforcar o Masagão, sempre. [...] Existe uma coisa mais perfeita que uma colher pra tomar uma sopa? Não existe! Você vai reinventar uma colher? Usa a colher! (ABUJAMRA, 2013).
}

De acordo com o compositor, muitas vezes ele recebe o filme editado para criar; mas prefere quando é dada a ele a opção de compor a música antes das gravações, para que, além de ter otimizado o tempo de trabalho na trilha, ela seja mais uma ferramenta do diretor nos 
processos de pré, produção e pós-produção. Em Castelo Rá-Tim-Bum, o filme (Cao Hamburger, 1999), por exemplo, Abujamra, em parceria com Lulu Camargo, compôs o tema principal da família Stradivarius antes das filmagens, não devido à preferência do músico, mas por uma demanda do próprio roteiro, que previa um baile e uma ópera que seria cantada pelos atores Sérgio Mamberti e Rosi Campos.

A relação com o diretor Cao Hamburger, consolidada na produção da trilha musical em parceria com o compositor Hélio Ziskind para o programa infantil homônimo - criado por Hamburger e pelo roteirista Flávio Souza, dirigido por Hamburger e exibido pela TV Cultura entre 1994 e 1997 -, e as próprias características de linguagem do filme, que guardam aproximações com o seriado televisivo - roteiro com começo, meio e fim bem marcados e estáveis, repetições da trilha, aparição de alguns atores do seriado no filme etc. ${ }^{50}$ provavelmente facilitaram o diálogo sobre a música, conforme relatado pelo compositor:

\begin{abstract}
Quando eu fui fazer o longa, o Cao Hamburger falou: "cara, a gente tem que mudar essa abertura, tem que ser outra coisa". Aí eu: "pô, cara, como é que eu vou inventar?". Aí eu resolvi fazer tudo ao contrário. E tudo ao contrário parecia russo, então, por exemplo: "muB-miT-áR oletsaC" [canta] é "Castelo Rá-Tim-Bum"! E parece um russo arcaico, alguma coisa assim. "Ópera arepó", e tem os anagramas... E aí era uma brincadeira. Engraçado que no Castelo Rá-Tim-Bum as crianças sacam que é ao contrário, e os pais acham que eu inventei qualquer coisa. Eu invento qualquer coisa, às vezes, mas o Castelo não é inventado (ABUJAMRA, 2016).
\end{abstract}

A simplicidade da solução proposta por Abujamra - que não deixa de ser uma espécie de 'tradução literal às avessas' do pedido do diretor - aliada aos arranjos orquestrais de Renato Lemos e à parceria com o compositor Lulu Camargo, garantem o ar pomposo daquela tradicional dinastia de bruxos, e, ao mesmo tempo, mágico/lúdico/infantil da narrativa, conferindo, às palavras que nomeiam filme e série televisiva, novos valores em termos de sonoridade, para além da descoberta de seu significado pela inversão da ordem das letras.

Também em O contador de histórias (Luiz Villaça, 2009), a partir do roteiro, Abujamra criou uma peça musical e enviou ao diretor, que a utilizou como referência para as filmagens e edição. O artista definiu esta música como um 'storyboard de áudio'. A definição deste termo - que, em nossa compreensão, estaria mais próxima de um planejamento de todo o projeto sonoro do filme, realizado por um sound designer -, para Abujamra nada mais é do que uma trilha de referência criada pelo próprio compositor, utilizada para a montagem, evitando a inserção de quaisquer temp tracks pelo editor.

\footnotetext{
${ }^{50}$ A ser detalhado na análise do filme, no capítulo 5 desta tese.
} 
O que sempre me incomodou nos filmes que eu vou trabalhar é que o filme chega editado com a trilha referência, assim, Sakamoto com a Orquestra de Londres, ou aquele cara do Oingo Boingo, o Danny Elfman. Então não tem como competir com os caras. Então eu tenho pego os roteiros e tenho feito o "story audio". Eu faço a trilha antes deles filmarem e eu mando pros diretores, isso é muito legal. Porque, mesmo que eles não usem, pelo menos eles usam pra poder editar. No caso de $O$ contador de histórias eu fiz uma melodia maravilhosa, o Luiz ficou emocionadíssimo, e a gente tem uma relação muito boa, então isso ajudou muito (ABUJAMRA, 2016).

Diferentemente de Castelo Rá-Tim-Bum, o filme e O contador de histórias, na maior parte dos processos de realização cinematográfica o filme já está montado quando o compositor entra no processo. Nesses casos, Abujamra não costuma apegar-se tanto ao roteiro, devido às mudanças que este necessariamente sofre durante as gravações e após, até o corte final. Então, ele busca assistir ao filme editado com o diretor, acordando com ele, nesse processo de spotting, as cues - pontos de entrada e saída da música ao longo do filme - e ter um canal aberto de comunicação com o montador, para o estabelecimento da consonância entre o ritmo da montagem e o musical. "Com a minha experiência, tiro muito do que o diretor pôs [cues] e coloco muito onde ele nem viu", valoriza o compositor (ABUJAMRA, 2016).

Ele afirma que o diálogo flui conforme a maior ou menor flexibilidade das decisões sobre a música por parte dos diretores. Ele atribui uma boa disponibilidade de negociação - e, consequentemente, uma maior possibilidade de que suas ideias musicais sejam aceitas sem que sejam solicitadas grandes alterações - aos diretores que considera 'flexíveis'; e a firmeza da decisão e a não negociação do conceito da música, a diretores que ele denomina 'autoritários'.

Entre um extremo e outro, é preciso considerar que cada artista tem o seu processo de criação, sua abordagem ao comunicar as ideias e o seu limite de estabelecer até que ponto está disposto a abrir mão delas, seja uma trilha musical ou a proposta de direção do filme. A flexibilidade mencionada por Abujamra não pode ser considerada, porém, apenas uma questão de perfil, mas também a própria demonstração da experiência de um artista, destacada e reconhecida pela compreensão das linguagens cinematográfica e musical em relação.

Tem uma cena de um filme [...] chamado Frantic [Roman Polanski, 1988]. (...) O Harrison Ford, em cima de um telhado, lutando com um cara [...]. É uma cena assim, violentíssima, de ação, e eles colocaram Vivaldi, cara. Uma trilha de... quarteto... tan tan tararan tan tan tan [cantarola Primavera, de As quatro estações]. Cara, não tinha nada a ver a música com a cena, só que dava uma tensão aquilo, é isso que eu busco. É sempre ter alguma coisa, sempre sair da casinha, assim. E aí eu tenho muito conflito com o diretor, por quê? Porque como é que o cara vai comprar uma loucura dessa, num longa-metragem de milhões de reais? (ABUJAMRA, 2016).

Abujamra toma como inovação um recurso amplamente utilizado na história do cinema, que é o de a música ir em sentido contrário à instância visual, aumentando, assim, a força da 
relação som-imagem - conforme Chion (1993), trata-se do efeito empático por meio da música em contraste. Ao mesmo tempo, confirma-se a demanda pela construção de um repertório musical cinematográfico que amplie a concepção das potencialidades da música em um filme por parte dos diretores.

O filme Amanhã nunca mais (Tadeu Jungle, 2011) é um exemplo do empenho de Abujamra em sugerir que a música agregue um sentido divergente da imagem, o que dificultou a relação com o diretor.

Foi difícil a relação porque o Tadeu já veio com um monte de ideias, um monte de referências, e eu fui mostrando outras referências pra ele. Então a primeira cena é numa praia, em Mongaguá, assim, sei lá, e tem duas "bundas" assim, meio feias... $99,99 \%$ de todos os músicos do planeta colocariam um samba e um pandeiro naquelas "bundas”, né. Aí eu falei: "Cara, vamos colocar uma música bálcã, vamos colocar um som estranho naquelas 'bundas'!”, e ele não entendia. Aí eu comecei a mostrar pra ele, entendeu? "Vamos inverter a cabeça!" (ABUJAMRA, 2016).

Na contramão do que aconteceu na produção da trilha de Amanhã nunca mais - por fim, prevaleceu o samba que queria o diretor -, Abujamra também teve dificuldades em lidar com a situação em que o cineasta gostava de todas as sugestões apresentadas pelo compositor. No processo da trilha do filme Achados e perdidos (José Joffily, 2005), a comunicação com o diretor era baseada em referências não apenas musicais, mas na busca por afinidades artísticas menos direcionadas.

\footnotetext{
A referência era mais de filmes do que especificamente de músicas. Conversávamos sobre afinidades de toda ordem, procurando interesses comuns. Especulamos, experimentamos sugestões dele e minhas. Defendíamos ou nos rendíamos à edição desta ou daquela música. Assim como não queríamos fazer uma música reiterativa, também não queríamos uma música melodiosa. [...] Algumas vezes a música deveria mesmo se contrapor à imagem (JOFFILY, 2014).
}

O relato de Joffily é consonante à defesa do contraste entre música e imagem que faz o compositor. No entanto, a indecisão de Joffily quanto à definição da música levou à insegurança de Abujamra: "E eu acho que eu não tinha tanta maturidade como eu estou tendo hoje pra chegar a uma conclusão" (ABUJAMRA, 2016).

Um caso curioso em que Abujamra teve que se submeter a uma situação limite semelhante à das trilhas-referência ocorreu em Querô (Carlos Cortez, 2007). Ao ser convidado para compor a última música do filme, o artista tinha a informação dos irmãos Gullane, os produtores, de que a trilha musical estava pronta: tratava-se de uma coleção de músicas preexistentes, brasileiras e estrangeiras. O compositor advertiu a produção do alto custo para a 
aquisição dos direitos autorais e compôs a última peça musical para o filme, aprovada sem dificuldade. Quando o filme estava pronto e em processo de finalização, os produtores contataram Abujamra para falar da fortuna cobrada para o uso de cada fonograma e pedir ao compositor que assumisse novas composições, estritamente baseadas nas músicas tidas como primeira opção.

\begin{abstract}
Querô foi um dos filmes mais difíceis da minha vida porque não só eu tive que fazer a referência como tive que fazer no mesmo andamento igual, na mesma tonalidade. $\mathrm{O}$ filme inteiro não parece que tem música. [...] Porque já estava editado, o filme estava pronto. Mesmo andamento, mesma tonalidade, tudo, e fazer igual, mudando algumas coisas pra não pagar direito autoral. Então um foi um filme muito complexo, um filme que você vê e fala: "meu, até que parece que não tem trilha sonora" (ABUJAMRA, 2013).
\end{abstract}

Por outro lado, quando o compositor tem "total liberdade" para criar, e dependendo da qualidade da comunicação que estabelece com o diretor, a música precisa ser repensada quantas vezes forem necessárias à aprovação por parte do cineasta. Em Durval Discos (Anna Muylaert, 2003), por exemplo, o alinhamento entre a diretora e o compositor foi alcançado após uma primeira tentativa dele de criar a trilha com certa autonomia em relação às imagens.

Ele fez uma primeira versão da trilha da cabeça dele que era feita de rap e sonoridades mais duras. Lembro que no dia que mostrou eu quase tive um ataque de mau humor e se não fosse o Peninha [Schmidt, produtor musical do filme], acho que teríamos brigado. Daí eu sentei no computador com ele e mostrei cena a cena quais as necessidades e desejos que eu tinha. Daí veio a segunda versão, que foi aprovada (MUYLAERT, 2014).

Mas nenhum conflito foi maior e mais determinante para a compreensão do papel da música no cinema por Abujamra que sua relação com Héctor Babenco, diretor de Carandiru (2003). Foi sobretudo a partir deste filme que o músico - para o qual Babenco é "uma das pessoas mais difíceis" com as quais já trabalhou no cinema - aprendeu a apreciar a economia musical em trilhas, além da compreensão de que a música é feita para o filme, não se constituindo, ao menos a princípio, como uma obra de arte independente. Abujamra aprendeu ainda a respeitar a autoridade do diretor sobre a obra fílmica e, por consequência, sobre a música, como um de seus elementos constitutivos.

Depois de tanta trilha que eu fiz, no Carandiru eu aprendi a não achar que a minha música era mais importante que o filme. A minha música fazia parte do filme, o que é muito louco num filme bom. Num filme bom, você nem percebe a música, nem percebe o figurino, nem percebe nada. Isso é uma coisa maravilhosa que eu descobri no Carandiru (ABUJAMRA, 2013). 
Eu aprendi a ser dirigido. E aprender a ser dirigido é você aprender a dirigir também. [...] Por mais que eu faça uma composição linda, quem manda é o diretor. [...]. Em relação ao Héctor, eu aprendi a respeitá-lo (ABUJAMRA, 2016).

As primeiras composições de Abujamra para Carandiru tinham, como base, hip hop e orquestra $^{51}$ e, segundo o compositor, eram tão grandiosas, pesadas e longas quanto o enredo do filme, cujo primeiro corte tinha mais de três horas de duração.

Ele [Héctor Babenco] ouviu dez segundos, eu tinha feito três horas de trilha. Ele olhou pra mim, ele não me conhecia, falou assim pra mim: "Que merda de música" [imitando sotaque argentino]. Então começar uma relação assim... e eu estava ganhando uma grana, quase bati a cabeça na parede. Começa assim a história, mas eu fui lá, fui até o fim (ABUJAMRA, 2016).

A agressividade e o peso não deveriam estar na música, como apontava a reprovação de Babenco às cinco primeiras peças apresentadas pelo compositor; esteve, sim, no processo, que, até a definição da música, durou cerca de cinco meses. Este período foi considerado longo para a composição, segundo Abujamra, que costuma criar, arranjar, gravar (FIGURAS 43 e 44) e finalizar a música de um filme no intervalo de um mês e meio a três meses.

Confirmando a aleatoriedade do processo criativo do compositor, Abujamra conta que essas idas e vindas com o diretor Héctor Babenco aconteceram até que, em mais uma situação de tentar compor a música do filme, ele ouviu um sabiá-laranjeira - um pássaro, um símbolo de liberdade, segundo ele - gorjear as notas fá, mi e ré - as quais se tornaram o cerne da música que o cineasta aprovou.

Eu estava fazendo, eu já estava quase "morrendo" pra achar o tema do Carandiru. E aí eu estava na minha casa antiga e acabou a luz. Aí eu desci e fui pro piano, e tinha um jardim na frente da minha casa. Eu estava tentando compor uma música, aí tinha um sabiá-laranjeira cantando muito forte, estava me incomodando aquele canto dele. Eu não conseguia tocar piano porque o sabiá estava cantando. Aí eu comecei a ouvir e achei a melodia bonita, falei: “[...] que melodia legal pra... fá, mi, ré [cantarola e assobia, imitando o pássaro]. Peraí, será que eu faço uma trilha só com três notas? Ah, vou fazer". Aí o Héctor começou a gostar (ABUJAMRA, 2016).

Figura 43 - Ao lado de Renato Lemos, André Abujamra conversa com os músicos durante sessão de gravação da trilha de Carandiru

\footnotetext{
51 As versões reprovadas da trilha de Carandiru foram cedidas por Abujamra ao pai, que, segundo o compositor, as utilizou em peças teatrais.
} 


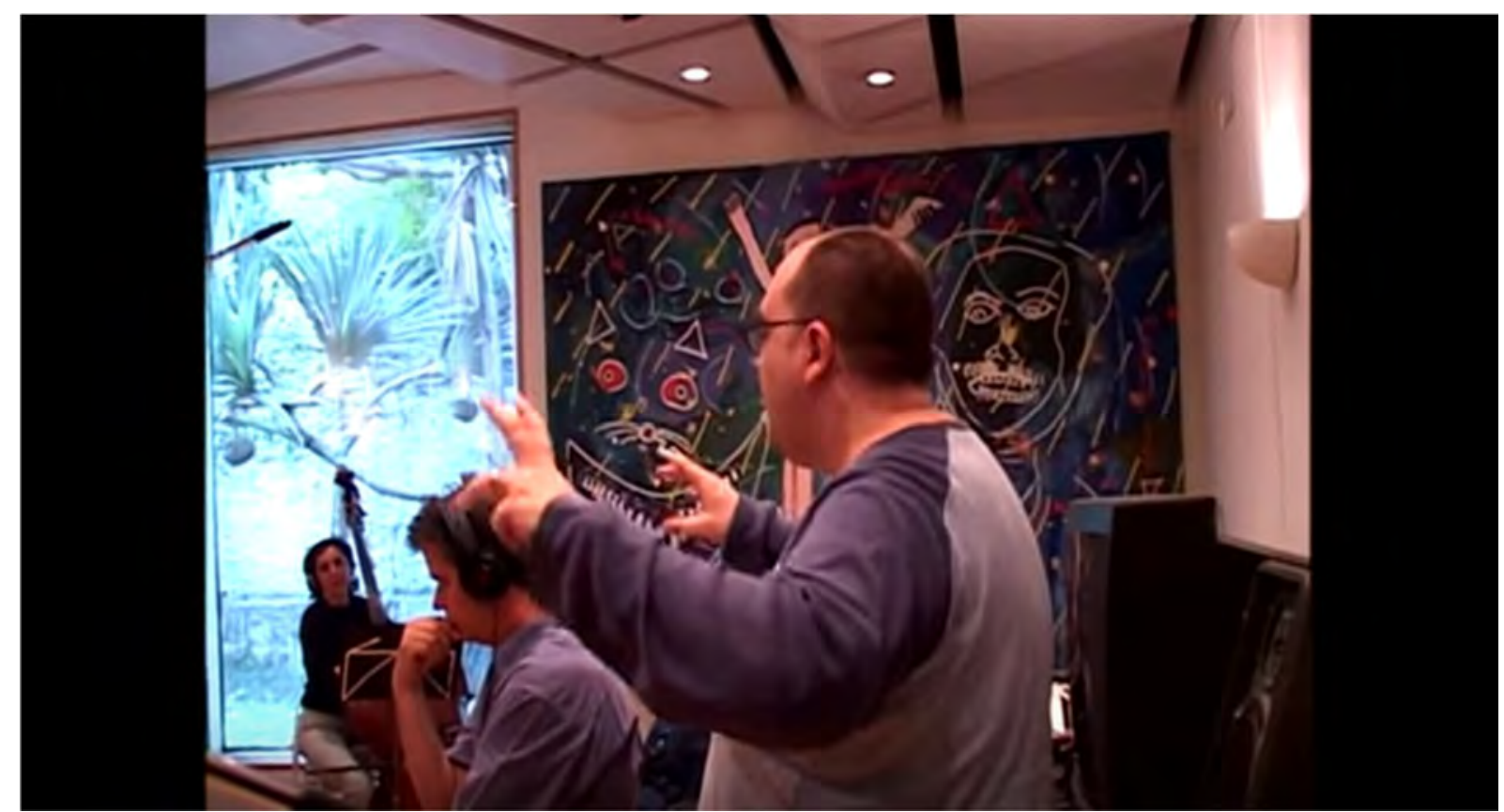

Fonte: Frame do making of do filme Carandiru. Disponível em:

$<$ https://www.youtube.com/watch?v=6o3O9jkcS2I >. Acesso em: 22 jan 2018.

Figura 44 - Renato Lemos rege os músicos na gravação da trilha de Carandiru

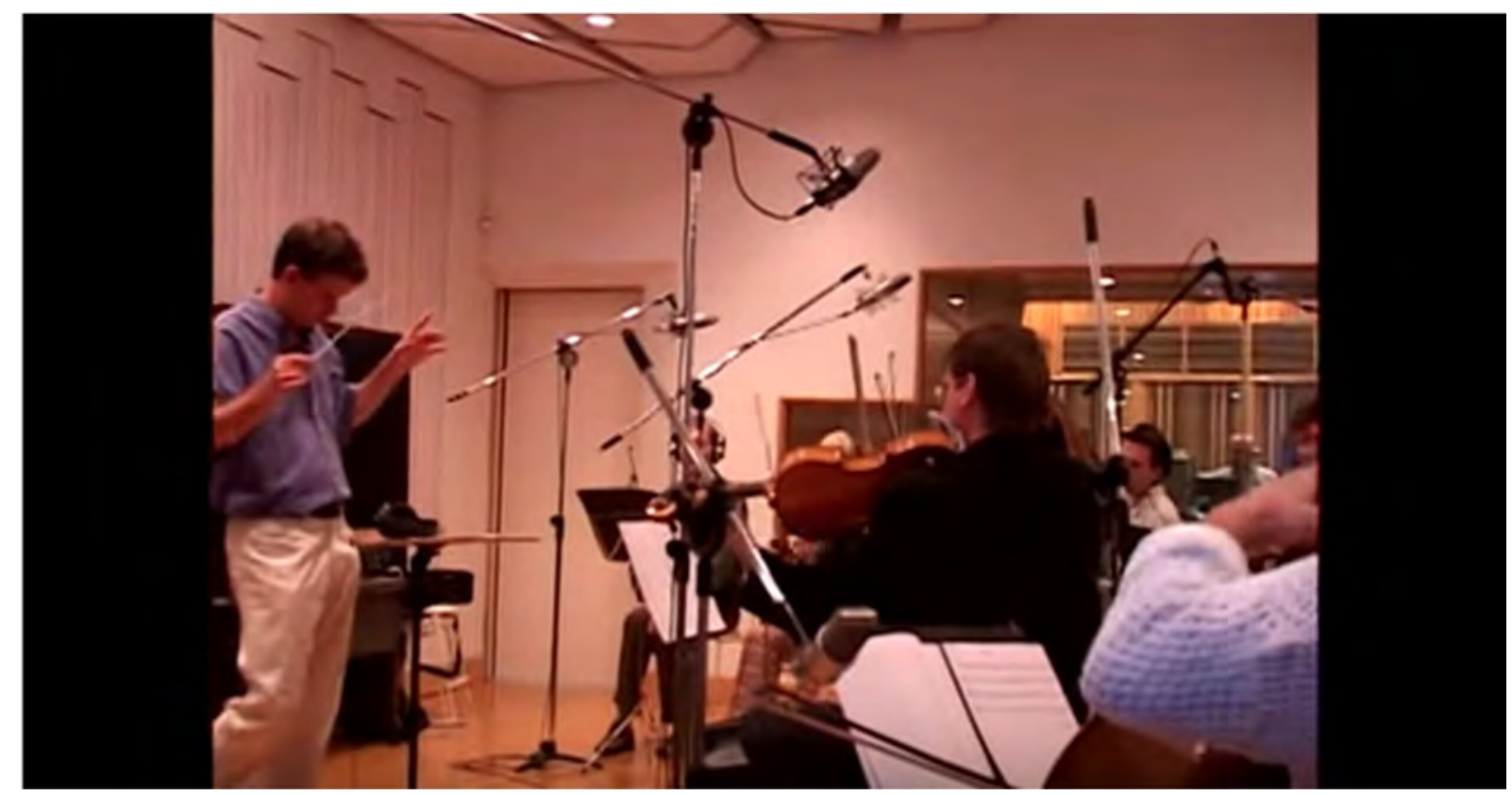

Fonte: Frame do making of do filme Carandiru. Disponível em:

$<$ https://www.youtube.com/watch?v=6o3O9jkcS2I $>$. Acesso em: 22 jan. 2018.

Apesar de expressar sua gratidão ao sabiá-laranjeira nos créditos finais de agradecimentos de Carandiru (FIGURA 45), Abujamra não se considera satisfeito com o resultado da trilha - menos por sua efetiva contribuição à narrativa fílmica e mais pelo fato de a música ter sido mixada em volume menos intenso que o esperado pelo compositor, além do desgaste profissional e emocional gerado ao longo do processo. Mesmo assim, o artista 
reconhece as consequências da música de Carandiru para sua carreira, atribuindo os posteriores convites para compor trilhas no exterior à sua participação no filme.

Figura 45 - Agradecimento ao Sabiá Laranjeira, último nome da segunda coluna da esquerda para a direita, nos créditos finais de Carandiru

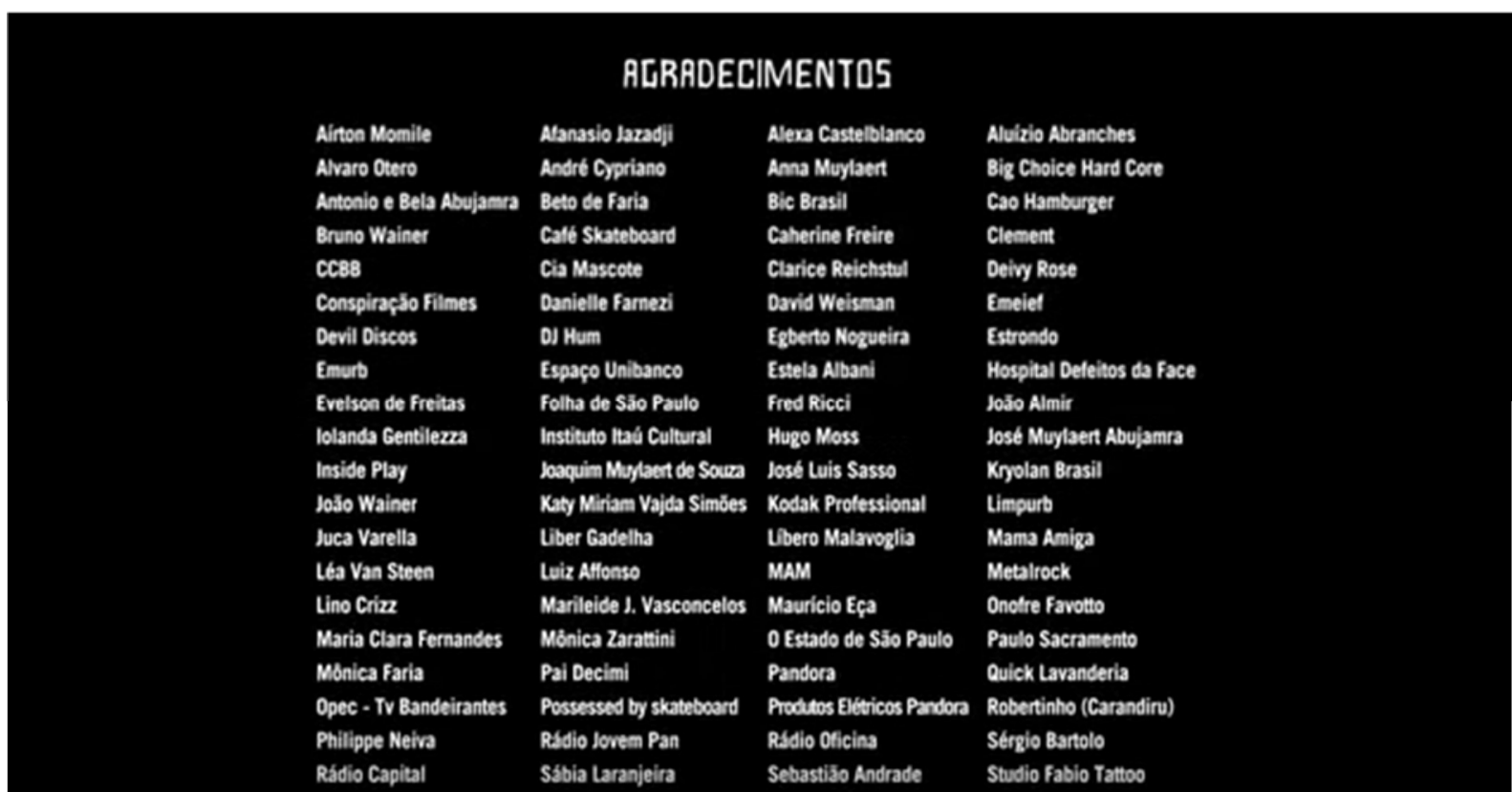

Fonte: Frame do filme Carandiru (2003). Disponível em: $<$ https://www.youtube.com/watch?v=I7EV8sRfHSw>. Acesso em: 22 jan. 2018.

Hoje, 21 anos após a sua primeira experiência compondo para um filme de ficção em longa-metragem, Abujamra avalia que a margem de negociação de suas ideias com os diretores foi ampliada. Seu crescimento como compositor é atestado pela diretora Anna Muylaert, sua parceira de mais tempo no cinema: "A música dele é de qualidade e funciona para os filmes. Ajuda a contar as histórias, sem ser óbvio. Hoje em dia, o André entende bastante de cinema, pode ajudar um filme em vários níveis” (MUYLAERT, 2014).

Foi o que constatou durante o processo de criação da trilha de 2 coelhos, primeiro longametragem dirigido por Afonso Poyart (2012):

O Afonso Poyart, que fez o 2 Coelhos; pra mim eu já estava fazendo o meu $47^{\circ}$ filme, sei lá, e o dele era o primeiro. Então existe um respeito, né, já. Existe um respeito pela minha experiência, tal. E não é uma coisa de egocentrismo, é uma coisa de estofo, da construção da sua carreira (ABUJAMRA, 2016).

A construção desta carreira no cinema abre cada vez mais espaço - respeitadas as demandas específicas de cada projeto - para a relação entre a criação da trilha musical e os diferentes momentos da vida do compositor. Abujamra cita, como exemplo, Bicho de sete 
cabeças (Laís Bodanzky, 2001), filme para o qual compôs uma trilha que considera pesada, tal como o período em que foi composta.

O Bicho de sete cabeças foi um filme muito difícil pra mim, porque pessoalmente eu estava numa fase muito difícil. Então o filme era muito pesado. [...] Então eu resolvi fazer uma trilha muito feia. [...] Eu tinha acabado de fazer o Castelo Rá-Tim-Bum, que era com orquestra [...]. Primeiro que eu passei tudo no distorcedor: bateria, baixo. Eu tava distorcido (ABUJAMRA, 2013).

Com os prêmios de Melhor Trilha Sonora concedidos a Abujamra pela música de Bicho de sete cabeças no $5^{\circ}$ Festival de Recife (2001) e no Grande Prêmio Cinema Brasil (2002), o compositor passou a suspeitar de que as melhores trilhas musicais que compunha para cinema muitas vezes eram as que apresentavam as sonoridades tidas como mais incomuns. Assim ocorreu com a música de Encarnação do demônio (José Mojica Marins, 2008), que o artista fez com Márcio Nigro. Abujamra conta que, após tentativas de apresentar a Mojica músicas com estrutura tonal - 'convencionais', mais 'palatáveis' aos ouvidos ocidentais - passou a pesquisar texturas e timbres distorcidos, obtendo, então, a aprovação da trilha.

\footnotetext{
Eu estava bem, minha vida estava boa -, e tudo que eu fazia "musical" no filme, ele [José Mojica Marins] não gostava. Eu e o [Márcio] Nigro. Aí eu comecei a ver os filmes antigos dele, em que ele fazia a música, e era tudo "wréeeeeeee prrrrrrrrr crrr shhh" [faz ruídos graves com a boca] e não era música, era ruído. E eu comecei a entender que não era que ele não estava gostando da música, ele não queria música. Então eu peguei os instrumentos e a gente fez ruído com os instrumentos, aí ele começou a amar. Foi um pouco diferente, eu não estava mal, no Encarnação eu tive que entender a cabeça do diretor (ABUJAMRA, 2016).
}

Conforme a liberdade de participação do compositor no projeto cinematográfico, a composição da trilha por Abujamra vem acompanhada de outros tipos de colaboração por parte do artista, solicitadas ou não pela produção, negociadas ou não com o diretor. Analisaremos, a seguir, como e se tais intervenções interferem tanto no diálogo com o diretor e com a equipe quanto na própria criação da trilha musical.

\subsection{A COLABORAÇÃO QUE EXTRAPOLA A MÚSICA}

Em alguns projetos a intervenção do compositor vai além da música: quando, ao assistir ao filme, percebe algum elemento destoante - luz, corte, continuidade, marcação de atores e outros -, ele procura, dentro da liberdade na relação estabelecida com o diretor, dar sugestões em outros aspectos da obra. Sendo Abujamra, um dos compositores de música para cinema 
mais ativos no Brasil, pode-se constatar que este é um processo esperado, já que o artista aprendeu sobre cinema assistindo muitas vezes a cada filme que trilhou e que, durante mais de 20 anos, logrou estabelecer relações que permitissem tais intervenções.

Quando você faz muito [filme] [...] - e olha que eu já assisti a muito filme pra poder fazer música -, que eu vejo um corte errado, ou uma luz errada, quando eu sou muito amigo do diretor, eu falo [...]. Eu me meto no filme, eu entro no filme de cabeça. Tem muito diretor que deixa. [...] Eu sinto o clima: quando eu posso, eu falo (ABUJAMRA, 2013).

Da mesma forma começou sua carreira de ator. Desde o início de sua trajetória como compositor no cinema, Abujamra negocia com diretores cinematográficos uma aparição sua como personagem: "Eu chego pra todos os diretores - às vezes eu consigo, às vezes não -, e falo: 'Eu faço a música. Mas me deixa aparecer no filme, nem que eu faça uma pontinha?"' (ABUJAMRA, 2013). Assim, o compositor começou a aparecer creditado, também como personagem, em filmes e telenovelas (FIGURA 46). Quando perguntado sobre os motivos dessa negociação, o artista é direto: “Eu adoro aparecer! Eu sou egocêntrico, eu sou artista, eu gosto de me exibir!" (ABUJAMRA, 2016).

Figura 46 - André Abujamra como recepcionista de hotel em Castelo Rá-Tim-Bum, o filme 


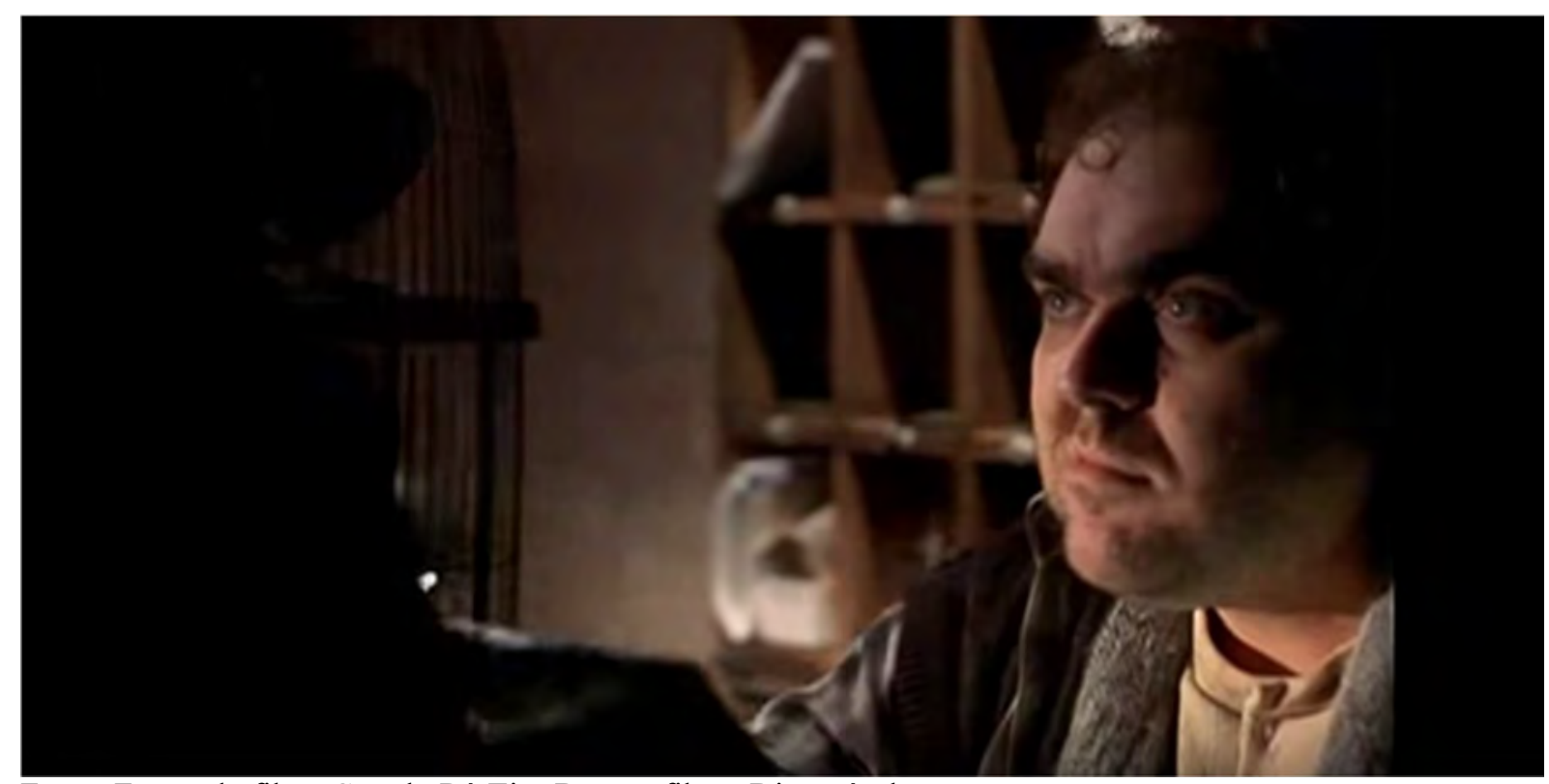

Fonte: Frame do filme Castelo Rá-Tim-Bum, o filme. Disponível em:

$<$ https://www.youtube.com/watch?v=pFCkVf3aiOI $>$. Acesso em: 22 jan. 2018.

Dentre os personagens interpretados por ele no cinema, um se destaca por ter saído da ficção e ganho vida própria, chegando, inclusive, a gravar discos e assinar músicas integrantes de trilhas sonoras de várias obras cinematográficas. Trata-se de Fat Marley (FIGURA 47), personagem ‘batizado' por Abujamra e criado por Anna Muylaert para Durval Discos (Anna Muylaert, 2003).

\begin{abstract}
Na verdade era uma ponta, em que eu era o amigo do Théo Werneck, que faz o Théo Werneck mesmo, e ia comprar o Racional do Tim Maia com o Ary França que era o Durval. E a gente não sabia o nome do personagem. Aí eu estava na casa dela, estava escutando reggae lá, o José [filho dos dois] pequenininho, dançando reggae lá, eu estava escutando Bob Marley, né? E eu estava bem gordo na época. Aí eu falei: 'Olha só, Anna, descobri um nome, vamos botar o nome do personagem de Fat Marley? A gente põe um cara gordão com um dreadlock, o cara é fanático por Bob Marley'. Foi aí que nasceu o personagem, né? Aí, quando a gente foi fazer a cena, fomos fazer um ensaio, tinha um disco do Bob Marley e eu estava com uma peruca de rastafari assim, gordo, com a camisa do Brasil. Aí eu pegava: 'Rastaman!' [interpreta, lembrando o personagem] (ABUJAMRA, 2016).
\end{abstract}

Aproveitando a evidência da figura do DJ no Brasil no final dos anos de 1990 e início dos 2000, Abujamra viu em Fat Marley a possibilidade de ingressar nessa área, com um perfil musical mais eletrônico e dançante, aproveitando ao máximo, dentro da ascensão da 'cultura do remix', seu conhecimento e experiência em tecnologia digital de áudio e sua estrutura de trabalho (livrarias de samplers, coleções de loops, software e hardware).

Figura 47 - Fat Marley em Durval Discos 


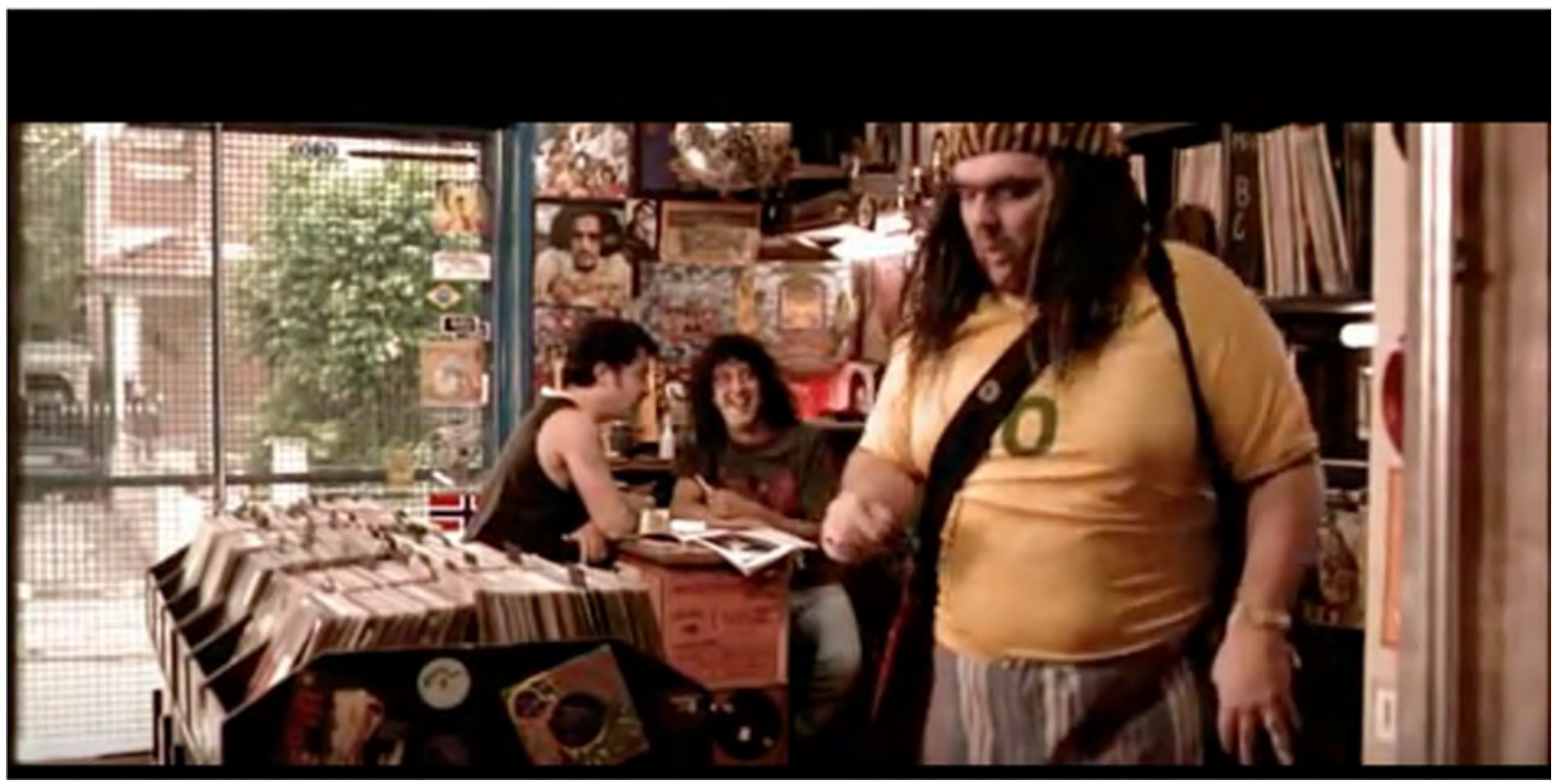

Fonte: Frame do filme Durval Discos. Disponível em: <https:/www.youtube.com/watch?v=vJ5Ka0c1mIY>. Acesso em: 22 jan. 2018.

Desde então Fat Marley passou a ter uma carreira fora da ficção, compondo, gravando discos - New old world / Future sun (Outros Discos, 2002) e Fat Marley is dead / Ceratoconnected (independente, 2007). Fazendo videoclipes e emprestando algumas de suas criações para os filmes Durval Discos (Anna Muylaert, 2003) - remix da versão de Os Mulheres Negras para Mestre Jonas (Sá, Rodrix e Guarabyra, 1973), Querô (Carlos Cortez, 2007) - This is my kingdom e I can remember you - e Do começo ao fim (Aluizio Abranches, 2009) - Fat is dead e Trim trim trim (Fat Marley is dead / Ceratoconnected, independente, 2007) ${ }^{52}$.

A construção da carreira de Fat Marley, bem como a negociação para figuração e a participação de fonogramas de seus discos em filmes, leva-nos a crer que Abujamra, mesmo que de forma não intencional, busca uma visibilidade que em sua função de compositor de trilha musical para cinema é inviável, uma vez que a música, não sendo a obra final, não pode chamar a atenção do espectador a ponto de desconectá-lo da experiência cinematográfica.

Neste capítulo buscamos compreender a trajetória de André Abujamra como compositor de música de filmes, compreendendo seu processo criativo, como ele utiliza as ferramentas de que dispõe e como se relaciona com outros profissionais envolvidos na realização cinematográfica, com destaque para os diretores. Há décadas compondo para filmes de vários

\footnotetext{
52 Outras canções de Abujamra não assinadas por Fat Marley aparecem em filmes: Sósereiseuseforsó / Nuvem passageira (Karnak, Estamos adorando Tóquio, 2000) em De passagem (Ricardo Elias, 2003); Elevador (André Abujamra, O infinito de pé, 2004) em Do começo ao fim (Aluizio Abranches, 2009). Sobre esse outro tipo de inserção musical no filme - como compositor popular de música preexistente -, o artista afirma que não há remuneração envolvida; ele cede fonogramas para filmes de amigos, quando o projeto não tem muitos recursos e/ou ele avalia que algum fonograma seu cabe em algum momento do filme.
} 
gêneros, estilos, tamanhos e orçamentos, podemos afirmar que o compositor se especializou nessa função, apreendendo, ao longo de sua prática profissional, as características específicas que a música adquire quando inserida em um filme. De obra de arte independente, ela passa a ser funcional, a servir à narrativa fílmica, à obra final e híbrida - o 'corpo humano' em toda a sua complexidade, como na metáfora do próprio compositor.

Ao estabelecer relações com vários diretores, cada qual com seu perfil e metodologias de trabalho, o compositor aliou repertório e sensibilidade musicais de uma vida ao aprendizado sobre a linguagem cinematográfica e ao desenvolvimento de sua capacidade de adaptação e proposição de soluções sonoras para situações narrativas audiovisuais particulares. As experiências de Abujamra em tantos filmes e na lida com diferentes equipes em processos tão diversos faz do artista um compositor versátil, que compõe, à sua maneira, para uma orquestra, ao mesmo tempo em que a mistura a um rap, a trilhas com sonoridades populares do Leste Europeu ou do Oriente Médio, ou a ruídos e sons gravados durante as filmagens, de forma presencial ou à distância, utilizando músicos reais - caso haja recursos - ou sua vasta coleção de samplers.

A recorrência do nome do artista nos créditos de longas-metragens brasileiros a partir da segunda metade da década de 1990 e a consequente visibilidade adquirida pelo seu trabalho face a outros diretores em atividade no País fizeram surgir parcerias entre Abujamra e alguns cineastas importantes além de Anna Muylaert, como Beto Brant, Marcelo Masagão, Aluizio Abranches e Ricardo Elias - com os quais o compositor trabalhou em dois ou mais longasmetragens. O estabelecimento dessas parcerias, aliado ao reconhecimento da crítica por meio dos diversos prêmios recebidos por ele, também contribuiu para a carreira do compositor no sentido de demonstrar sua credibilidade e permanência no ambiente cinematográfico nacional.

Uma vez descrito e analisado o processo do compositor, passamos, a seguir, às análises de filmes cujas músicas originais tenham sido compostas por Abujamra, com ou sem a colaboração de parceiros. 


\section{MÚSICA DE CINEMA E MÚSICA DE DISCO: EM BUSCA DE UMA ASSINATURA MUSICAL CINEMATOGRÁFICA DE ANDRÉ ABUJAMRA}

Após contextualizar e esmiuçar o processo composicional e de produção musical de André Abujamra para cinema, apresentamos, neste capítulo, os caminhos metodológicos percorridos para a realização deste estudo, desde a escolha da obra de Abujamra como objeto à seleção dos filmes integrantes do corpus de análise. Justificamos ainda a opção pela análise fílmica como método principal, por meio qual nos debruçamos sobre alguns dos longasmetragens de ficção cuja música original é creditada ao artista. Por meio da análise revelamos, para além da importância narrativa que a música adquire em cada caso, como o artista lida com a presença de compositores parceiros, notadamente Márcio Nigro e Lulu Camargo.

\subsection{CAMINHOS METODOLÓGICOS E COMPOSIÇÃO DO CORPUS DE ANÁLISE}

A eleição da obra de André Abujamra como objeto de estudo se justifica pela constância de seu trabalho no cinema brasileiro a partir da Retomada. Ele está entre os compositores mais recorrentes do período, assinando a trilha musical de 26 longas-metragens de ficção: um lançado em 1995 - Carlota Joaquina, princesa do Brasil (Carla Camurati); um em 1997 - Os matadores (Beto Brant); um em 1998 - Ação entre amigos (Beto Brant); dois em 1999 - Um copo de cólera (Aluizio Abranches) e Castelo Rá-Tim-Bum, o filme (Cao Hamburger); dois em 2001 - Bicho de sete cabeças (Laís Bodanzky) e Domésticas (Fernando Meirelles e Nando Olival); um em 2002 - As três Marias (Aluizio Abranches); quatro em 2003 - Carandiru (Hector Babenco), De passagem (Ricardo Elias), Durval Discos (Anna Muylaert) e O caminho das nuvens (Vicente Amorim); um em 2005 - Cafundó (Paulo Betti e Clovis Bueno); um em 2006 - Os 12 trabalhos (Ricardo Elias); dois em 2007 - Achados e perdidos (José Joffily) e Querô (Carlos Cortez); dois em 2008 - Caixa preta (Marcelo Izidoro) e Encarnação do demônio (José Mojica Marins); dois em 2009 - Do começo ao fim (Aluizio Abranches) e O contador de histórias (Luiz Villaça); um em 2011 - Amanhã nunca mais (Tadeu Jungle); um em 2012 - 2 coelhos (Afonso Poyart); um em 2013 - Corpo presente (Paolo Gregori e Marcelo Toledo); três em 2014 - Até que a Sbórnia nos separe (Otto Guerra e Ennio Terrisan), Minutos atrás (Caio 
Sóh) e Trinta (Paulo Machline); e um em 2017 - Praça Paris (Lúcia Murat) ${ }^{53}$.

A opção pelo trabalho musical de Abujamra no cinema também se deu pelo reconhecimento do público e da crítica e pelo perfil multifacetado do artista, que, do final dos anos 1980 ao início dos 1990, lançou dois discos com Os Mulheres Negras - Música e Ciência (WEA, 1988) e Música serve pra isso (WEA, 1990). E que, desde 1995, concilia seu trabalho no cinema com a televisão, o teatro, a publicidade e uma intensa carreira discográfica: lançou quatro discos com a banda Karnak - Karnak (Tinitus, 1995), Universo Umbigo (Velas, 1997), Estamos adorando Tóquio (Net Records, 2000) e o disco duplo Os piratas do Karnak - Ao vivo (Spin Music, 2003); dois como Fat Marley - New Old World / Future Sun (Outros Discos, 2002) e Fat Marley is dead / Ceratoconnected (Spin Music, 2007); um com a banda punk Gork - Tomorow tecnik (Unimar Music, 2010); quatro discos solo - O Infinito de Pé (Spin Music, 2004), Retransformafrikando (independente, 2007), Mafaro (Spin Music, 2010), O Homem Bruxa (Spin Music, 2015) e Omindá (Spin Music, 2018).

Importante destacar que a delimitação do corpus de análise em longas-metragens de ficção tem em vista tanto a maior atuação do compositor neste formato e gênero cinematográficos quanto uma estrutura mais profissional (no sentido de padronização) e robusta de produção - ou, ao menos, a estrutura de produção cinematográfica mais próxima da apresentada por uma 'indústria' -, dentro da qual é possível perceber a articulação e consolidação de relações entre artistas de diferentes áreas e procedimentos de maior complexidade e/ou duração mais ou menos comuns a vários filmes. Neste caso, interessa-nos os procedimentos concernentes à composição musical para cinema, do primeiro contato com o diretor à mixagem final. Desse modo, acomodar curtas-metragens e documentários com trilhas musicais de Abujamra no conjunto de filmes analisados significaria agregar um pequeno número de produções muito diversas em termos de organização processual, estrutural e orçamentária e com relações profissionais e artísticas menos estáveis/duradouras ${ }^{54}$.

Dentre os 27 longas-metragens ficcionais com trilha musical do compositor, elegemos cinco que, ao mesmo tempo em que apresentam elementos condizentes com os parâmetros

\footnotetext{
53 As trilhas musicais de Abujamra em coautoria com outros artistas estão especificadas no Apêndice A deste trabalho.

54 Os documentários brasileiros que contam com trilha musical de Abujamra são: Nós que aqui estamos por vós esperamos (Marcelo Masagão, 1999); Nem gravata, nem honra (Marcelo Masagão, 2001); Bem-vindo a São Paulo (Leon Cakoff et al., 2004); O livro multicolorido de Karnak (Marcel Izidoro, 2006); A raça síntese de Joãosinho Trinta (Giuliano Cedroni e Paulo Machline, 2009); Alphaville - do lado de dentro do muro (Luiza Campos e Gustavo Ribeiro, 2009) e Música serve pra isso (Bel Bechara e Sandro Serpa, 2013). O artista também assina a música do documentário norte-americano Harlistas - an american journey (Alfredo de Villa, 2011). Os curtasmetragens cujas músicas são assinadas pelo compositor se encontram citados no capítulo 2 deste trabalho.
} 
fílmicos estabelecidos para a análise, abarcam um período que vai desde o início da Retomada do cinema brasileiro até os dias atuais, têm seus processos revelados com algum detalhamento por André Abujamra por meio de depoimentos, compreendem parcerias dele com outros compositores ou composições solo e/ou figuram entre os mais acessíveis ao público (por aquisição de DVD/blue-ray ou disponíveis em sites de armazenamento de vídeo e plataformas VOD - video on demand). São eles (em ordem cronológica de lançamento): Carlota Joaquina, princesa do Brasil (Carla Camurati, 1995), Um copo de cólera (Aluizio Abranches, 1999), Castelo Rá-Tim-Bum, o filme (Cao Hamburger, 1999), Bicho de sete cabeças (Laís Bodanzky, 2001) e O contador de histórias (Luiz Villaça, 2009).

A análise de Carlota Joaquina, princesa do Brasil (Carla Camurati, 1995) no capítulo 2, além de demonstrar a irreverência e ironia contidas na relação som-imagem, contextualizou a estreia de Abujamra na composição de trilha musical para longas-metragens no início da chamada Retomada do cinema brasileiro. Tanto a trama do filme quanto seu contexto revelam um desencantamento sarcástico e questionador das identidades nacionais em uma época de globalização econômica, mundialização cultural e de uma nova relação entre os realizadores de cinema e o estado.

Também no capítulo 2, a análise de Bicho de sete cabeças (Laís Bodanzky, 2001) evidencia as potencialidades da manipulação sonora da trilha musical pelo compositor, tanto para a criação da música original quanto na relação desta com canções preexistentes, em um contexto em que as fronteiras entre música e ruído se tornam fluidas por meio da popularização das tecnologias digitais de produção e reprodução sonora.

Neste capítulo apresentamos as análises dos filmes Um copo de cólera (Aluizio Abranches, 1999), Castelo Rá-Tim-Bum, o filme (Cao Hamburger, 1999) e O contador de histórias (Luiz Villaça, 2009), em uma tentativa de verificar diferentes modos de produção, processos de composição e resultados na relação som-imagem quando Abujamra é o único compositor responsável - caso de Um copo de cólera, e quando ele trabalha em coautoria com Lulu Camargo - em Castelo Rá-Tim-Bum, o filme, e com Márcio Nigro - em O contador de histórias; Lulu Camargo e Márcio Nigro são os únicos compositores que compartilham com ele autorias de trilhas musicais para filmes ao longo de quase 20 anos.

A análise fílmica é o principal procedimento metodológico utilizado para este estudo. Por meio dele, os filmes foram dissecados em seus múltiplos elementos sonoros e visuais, em busca dos mecanismos da linguagem cinematográfica. Desse modo, a partir da compreensão de cada um desses elementos em relação aos demais, foi possível compreender e apreciar a obra em sua totalidade. 
Ao apontar a inexistência de uma teoria do cinema que abarque plenamente as potencialidades da linguagem, os teóricos franceses Jacques Aumont e Michel Marie afirmam, por consequência, a inexistência de um método universal de análise fílmica. A autonomia e as singularidades da obra fílmica exigem, do analista, um método próprio a ser construído, conforme os recortes, conexões ou eixos apresentados ou sugeridos por cada objeto de análise em particular: "Até certo ponto não existem senão análises singulares, inteiramente adequadas no seu método, extensão e objecto, ao filme particular de que se ocupam" (AUMONT; MARIE, 2004, p. 14).

Preocupados, ao mesmo tempo, com a liberdade do analista e a preservação da análise fílmica como método verificável e, portanto, válido cientificamente, os autores valorizam sua face descritiva, por meio da qual são verificados tanto os elementos da obra quanto a abordagem do analista. Ressaltamos, portanto, que, também conforme o teórico norte-americano David Bordwell, compreendemos a descrição neste trabalho, bem como qualquer outro processo de transcodificação, como uma dentre várias descrições possíveis, ou seja, como um primeiro nível da interpretação fílmica.

Instead of positing an inductivist separation of theory and criticism, perhaps we should think of the critic's interpretation as deductively deriving from the theory. According to this line of argument, no description of anything is conceptually innocent; it is shot through with presuppositions and received categories (BORDWELL, 1991, p. 4) ${ }^{55}$.

Logo, a descrição para nós consiste em um trampolim para a interpretação, em um elemento de ligação entre o que a obra efetivamente apresenta e suas possíveis leituras, a depender das chaves interpretativas, da bagagem cultural-cinematográfica e do momento mesmo da análise por quem a realiza. As fronteiras estabelecidas pelo filme para o desenvolvimento da análise permitem, assim, sua validade: não é possível falar qualquer coisa sobre qualquer obra, mas sim desenvolver uma interpretação a partir da descrição dos elementos nela disponíveis.

\footnotetext{
Seria uma atitude mais franca admitir que a análise tem efectivamente a ver com a interpretação; que esta será, por assim dizer, o "motor" imaginativo e inventivo da análise; e que a análise bem sucedida será a que consegue utilizar essa faculdade interpretativa, mas que a mantém num quadro tão estritamente verificável quanto possível (AUMONT; MARIE, 2004, p. 15-16).
}

\footnotetext{
55 “Ao invés de colocar uma separação indutivista entre teoria e crítica, talvez nós devamos pensar na interpretação do crítico como dedutivamente derivada da teoria. De acordo com essa premissa, nenhuma descrição é conceitualmente inocente; ela é lançada a partir de pressuposições e categorias preexistentes" (tradução nossa).
} 
Único e inesgotável até os limites estabelecidos pela própria obra, o processo de análise demanda adaptações, em método, abrangência e objetivos, para que se adeque aos filmes dos quais o analista se ocupa - ajuste este que possibilita a proposição das análises tais como as contidas neste trabalho.

A estratégia consiste em partir da presença da música de Abujamra nos filmes do corpus de análise, articulando-a - por meio de instrumentos descritivos, citacionais e documentais aos demais elementos sonoros e visuais, para que se possa propor uma interpretação que contemple os universos de cada obra e demonstre aproximações e particularidades. Cada filme analisado se torna um modelo construído pelo analista, a partir de sua apropriação e da estruturação do texto fílmico, adaptado sob chaves de pensamento que sejam coerentes com o recorte proposto, afirmando sua liberdade frente às intenções de seus autores.

Como instrumentos citacionais, utilizamos transcrições de trechos dos roteiros (diálogos), letras de canções, frames dos filmes. Os instrumentos documentais compreendem citações textuais a respeito do contexto histórico de composição e produção das músicas, trechos transcritos de making of dos filmes, entrevistas publicadas ou registros de comunicações pessoais com André Abujamra e produtores musicais membros das equipes de realização, dissertações e/ou artigos científicos publicados sobre as obras ou que as abranjam em recortes mais amplos.

Em relação à trilha sonora, os diálogos, as entradas e saídas de música (original de Abujamra e/ou pré-existente), a presença de ruídos e efeito-silêncio, as propriedades sonoras (timbre, duração, intensidade e altura), a localização da fonte sonora dentro ou fora da diegese (extradiegética ou diegética), a sincronia com o visual e a simultaneidade ou sucessividade de elementos sonoros entre si e em relação à imagem constituem parâmetros específicos desta análise e, portanto, passíveis de identificação, descrição e interpretação. Entretanto, “[...] um dos principais problemas na análise da banda sonora é que ela veicula funções múltiplas ao mesmo tempo, e sem que às vezes seja possível fazer distinções claras" (AUMONT; MARIE, 2004, p. 133). Por isso, é necessária a contextualização da música em cada obra e em cada sequência fílmica como resultado dessas múltiplas conexões para se pensar sobre o papel dela na narrativa cinematográfica.

Importante frisar que a análise da música de Abujamra não teve como eixo suas características formais por si mesmas - por meio de descrições harmônicas e melódicas, de andamento, entre outras, transcritas em partituras, mas sim as articulações narrativas e 
dramáticas travadas com os demais elementos sonoros e visuais ao longo dos filmes, caso a caso, conforme propõe Carrasco (1993):

\begin{abstract}
Se partimos do princípio que a trilha musical faz parte dos recursos articulatórios característicos à dramaturgia do cinema, ela deve, também no que diz respeito à sua totalidade, ser articulada em função da unidade de ação. Ela deve possuir características que façam dela um discurso unitário, e não apenas uma sucessão de passagens musicais sem nenhuma conexão. Ao mesmo tempo, ela deve contribuir para o estabelecimento, desenvolvimento e conclusão dos conflitos contidos nesse drama. No filme, enquanto unidade complexa, fechada em si mesma, tudo o que se vê e se ouve deve estar articulado em função da lógica e da direcionalidade dramática (ou narrativa) (CARRASCO, 1993, p. 169-170).
\end{abstract}

Nas análises realizadas, inevitavelmente, deparamo-nos com o esforço de tentar comunicar, em texto escrito, articulações dramáticas não verbais entre cinema e música, o que nos leva a certas imprecisões. Apesar de estas poderem ser justificadas pelas 'perdas' esperadas no processo de tradução entre linguagens e pelo próprio processo, ora em curso - de consolidação da música de cinema como campo específico de pesquisa no Brasil, com suas especificidades metodológicas -, elas podem ser melhor compreendidas por meio do contato com as obras fílmicas. Desta maneira, buscamos nos referir à música de cinema utilizando termos pertinentes ao desenvolvimento dramático nos filmes, e não aos aspectos técnicos e formais restritos ao universo musical - o que pressuporia a música como obra autônoma e independente. As sensações e sentidos emanados da música nas obras deste corpus somente podem ser concebidos em relação à totalidade fílmica.

Além da análise das obras cinematográficas integrantes do corpus de pesquisa, atualizamos a pesquisa bibliográfica que vimos desenvolvendo sobre a música no cinema brasileiro e realizamos audições acuradas da discografia do artista. Também investigamos, por meio de entrevistas com André Abujamra, alguns dos integrantes dos grupos musicais de que fez parte e diretores dos filmes analisados, bem como o processo criativo do artista e as relações entre suas experiências de vida, sua discografia e sua obra musical para cinema (investigação biográfica) - conforme apresentamos nos capítulos anteriores e nos apêndices desta pesquisa.

\title{
5.2 A TRILHA MUSICAL DE ABUJAMRA NOS FILMES
}

Estabelecidos os métodos e as técnicas de investigação e apreciados os filmes e discos do corpus de análise, foram elaborados, conforme citado, vários parâmetros de pesquisa, divididos em fílmicos - pertencentes à composição narrativa cinematográfica; e extrafílmicos 
- elementos contextuais, composicionais e de relacionamento de André Abujamra com outras equipes de produção dos filmes. Tais parâmetros foram úteis para comparar e reunir os filmes conforme os principais papéis desempenhados pela música, em cada caso, na estruturação da análise.

Compõem o conjunto de parâmetros extrafílmicos as diversas formas como André Abujamra aparece creditado por suas participações musicais em filmes - diretor e produtor musical, trilha sonora original, música original, arranjos, orquestração, regência, execução de instrumentos musicais, autor de música preexistente, mixagem; as parcerias do artista com os músicos Márcio Nigro e Lulu Camargo; a recorrência da trilha musical de Abujamra nos filmes de alguns diretores, como Aluizio Abranches, Ricardo Elias e Anna Muylaert; e a relação de elementos musicais solo, do Karnak e dos Mulheres Negras com a composição de algumas trilhas musicais para cinema. Tratamos especialmente destes parâmetros no capítulo 4, quando analisamos a inserção do compositor em diferentes processos de realização cinematográfica, ao longo de sua carreira no cinema brasileiro.

Dentre os parâmetros fílmicos eleitos estão: a presença de música-tema (instrumental ou canção), grande elemento de unidade sonora e musical de um filme; integração da trilha original (composta e gravada para o filme) com músicas preexistentes (gravadas para outros fins e ressignificada em sua utilização no filme) e outros elementos sonoros (ruídos, diálogos, efeitos); a presença da música exercendo a função de ambientação/background em cenas; a música como elemento sonoro de transição entre sequências, a presença musical sob a forma de leitmotiv - motivo musical que sofre variações melódicas, harmônicas, rítmicas e outros. conforme os diferentes momentos narrativos, entrada e saída de personagens, entre outras possibilidades; e as características da textura musical integrada ao som do filme (presença de percussão, efeitos, ruídos e vozes - não-palavras - na trilha musical).

Apresentamos, a seguir, as análises das obras conforme a metodologia e os parâmetros apresentados. A ordem das análises segue a cronologia de lançamento dos filmes.

\subsubsection{Um copo de cólera (Aluizio Abranches, 1999)}

A adaptação para cinema do livro homônimo de Raduan Nassar conta com a presença da música composta por André Abujamra em duas frentes: a sinfônica em cordas - orquestrada e regida por Renato Lemos, que representa a harmonia/reconciliação dos corpos no ato sexual 
- e a que utiliza a voz feminina como gesto sonoro e recurso musical, acompanhada de percussão - associada ao instinto ou à perda da razão que conduz ao transe.

A gravação e reprodução da voz, conjugada à imagem cinematográfica, remonta ao advento do som sincronizado, no final dos anos 1920. No entanto, a possibilidade de direcionar para a fala de personagens informações importantes da narrativa cinematográfica provocou, conforme Chion (2004), o esquecimento do gesto vocal. A voz no cinema representava, então, não uma vibração sonora, uma presença em si, mas um canal para a transmissão de conteúdo verbal inteligível: "La voz está ahí para que la olvidemos en su materialidad, y ése es el precio que paga por desempeñar su principal oficio" (CHION, 2004, p. 14) ${ }^{56}$.

O autor destaca a grandeza da voz no cinema em relação aos corpos que a emitem justamente pela necessidade estética criada com o cinema sonoro de total inteligibilidade do texto falado, dada a hierarquização da percepção do ouvido humano - acostumado, antes mesmo do nascimento, a ter/buscar a voz como principal meio estruturador da escuta e de transmissão de informação. Isso levou à busca pela total clareza/audibilidade das falas nas gravações e à hierarquização dos elementos sonoros na mixagem, com a voz em primeiro plano.

Essa construção foi consolidada na linguagem cinematográfica a ponto de provocar o receio, por parte dos editores de som, de que qualquer inovação na banda sonora que comprometesse a clareza dos diálogos fosse interpretada como falha técnica e o reforço da busca 'automática' e prioritária, por parte do espectador, pela compreensão do que é falado no filme.

Desde que el mundo es mundo, son las voces las que muestran las imágenes y confieren al mundo un orden de las cosas, dándole vida y nombre. La primera presentadora de imágenes es la Madre, cuya voz, antes del aprendizaje (eventual) de los signos escritos, hace que las cosas se destaquen dentro de una temporalidad viva y simbólica. Tanto en la función de charlatán y de narrador de historias como en la tradicional voz en off del comentario, subsiste siempre algo de aquella función original $^{57}$ (CHION, 2004, p. 58).

Essa função de destacar a imagem se relaciona à orientação imediata do espectador por meio da sincronia com o som. Assim, diálogos e ruídos cuja fonte se encontra visível na tela colaboram para a manutenção da ilusão de profundidade na imagem bidimensional, enquanto a

\footnotetext{
56 “A voz está aí para que a esqueçamos em sua materialidade, e esse é o preço que paga por desempenhar sua principal função" (tradução nossa).

57 "Desde que o mundo é mundo, são as vozes que mostram as imagens e conferem ao mundo uma ordem das coisas, dando-lhes vida e nome. A primeira apresentadora de imagens é a Mãe, cuja voz, antes da aprendizagem (eventual) dos signos escritos, faz com que as coisas se destaquem dentro de uma temporalidade viva e simbólica. Tanto na função de charlatão e de narrador de histórias como na tradicional voz off do comentário subsiste sempre algo daquela função original" (tradução nossa).
} 
música extradiegética ${ }^{58}$ e a voz over de comentário se orientam para um lugar imaginário, fora de campo.

Os sons fora da diegese tendem a despertar a atenção e a crença, dadas a clareza, a intensidade/proximidade/intimidade com o espectador, a ausência de reverberação/espacialidade e o destaque frente aos demais elementos sonoros do filme, enquanto os sons sincronizados em cena costumam ser considerados redundantes em relação à imagem. Entre uns e outros, sons e vozes 'errantes' entre o campo e o fora de campo - os sons acusmáticos, segundo Chion (2004) - apresentam-se como específicos do cinema, porque perceptíveis apenas no movimento e no curso do tempo.

Fora de campo e para além do comentário em voz over, o som vocal também pode estar na música de cinema sob a forma de canto, seja na forma de canções preexistentes ${ }^{59}$ emuladoras de uma memória extrafílmica, veiculadoras de mensagens verbais envoltas em música de determinada configuração harmônica e melódica e ressignificadas no contexto da narrativa, conforme vimos no capítulo 2; seja na música original instrumental (score). Enquanto nas canções o que em geral se destaca é o conteúdo verbal e seu significado - 'coloridos', como vimos em Castelo Rá-Tim-Bum, o filme, com a incorporação da música, no score sem conteúdo verbal ela pode se consagrar, de forma mais perceptível, como gesto sonoro.

Presente no cinema brasileiro desde o início do século XX, antes do advento do som sincronizado, a canção perdura até hoje. Graças à tecnologia digital, trilhas instrumentais convivem com diferentes vozes, cada vez mais em trânsito entre ruídos, efeitos e diálogos. Em Um copo de cólera a voz adquire possibilidades que, ao mesmo tempo, superam ou elevam a simples entoação da palavra, na música ou fora dela.

Havia muitas referências pessoais que ligavam o diretor Aluizio Abranches a André Abujamra: este e a atriz Júlia Lemmertz cresceram juntos por causa da amizade entre as famílias e o músico já era amigo do ator Alexandre Borges por causa do relacionamento deste com Júlia. Além disso, Abranches é amigo da diretora Anna Muylaert; ou seja, havia um círculo social em comum. Na época de produção do filme Abranches morava em São Paulo. "Eu era fã das bandas dele na época. É um músico multiinstrumentista, multifacetado, e foi mais ou menos seguindo minha intuição que eu achei q ia dar certo" (ABRANCHES, 2014).

\footnotetext{
58 Música extradiegética é aquela que não participa da cena, não sendo, portanto, ouvida pelos personagens; é inserida sobre a imagem, vinda de outro lugar.

59 Além da inserção de canções preexistentes, há ainda a possibilidade de haver uma canção-tema composta para o filme, recurso comum no gênero musical.
} 
Já nos créditos iniciais do filme surge a trilha musical de Abujamra: vozes agudas femininas que reverberam em um ritual que lembra uma saudação tribal, sobre uma base percussiva que combina palmas, sons graves e agudos. O canto de densa textura de vozes femininas é colocado sobre um plano-detalhe de saúvas que se movimentam freneticamente dentro e fora do formigueiro (FIGURA 48).

Figura 48 - Plano-detalhe das saúvas, durante os créditos iniciais

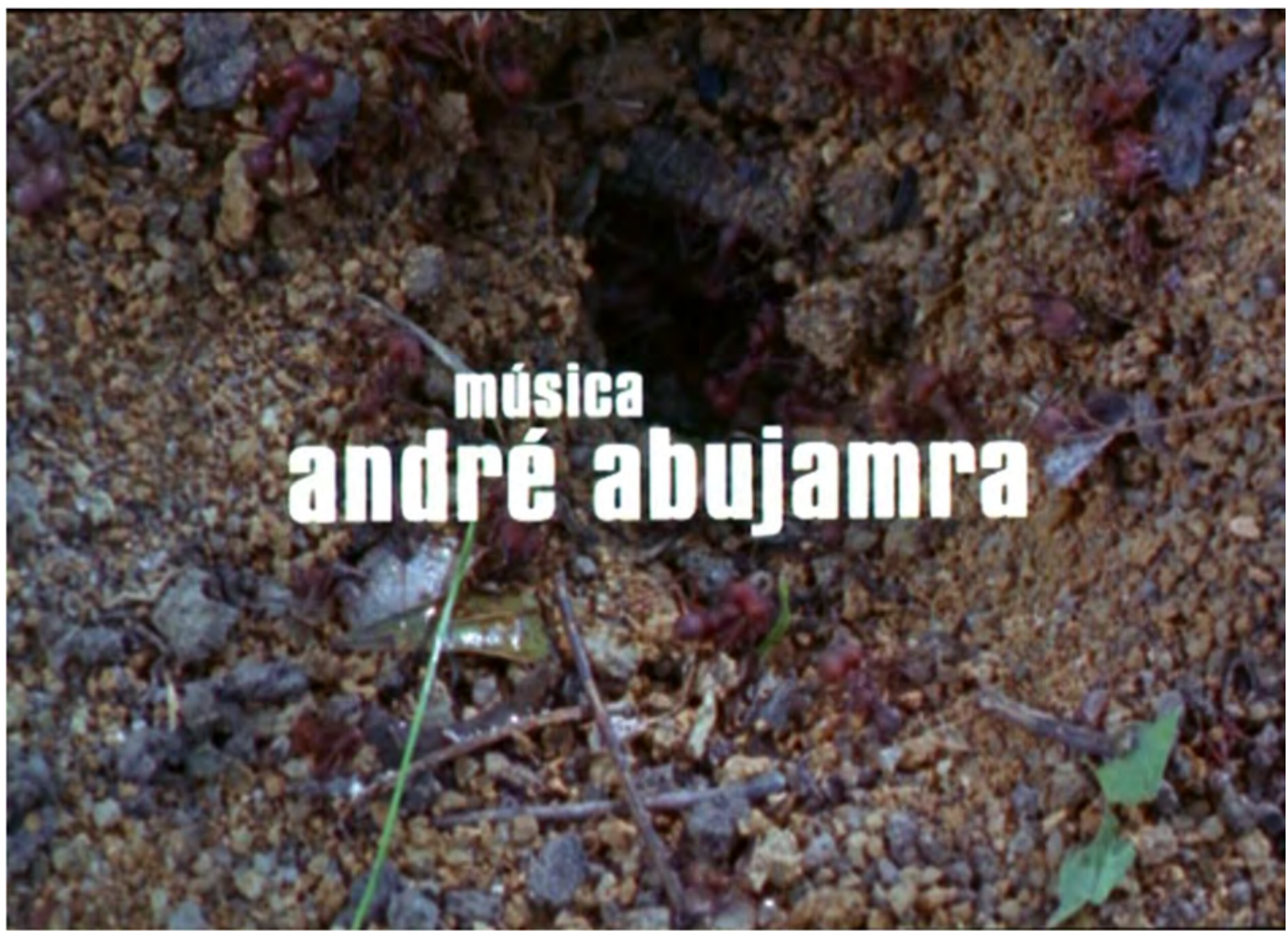

Fonte: Frame do filme Um copo de cólera (1999).

A movimentação das saúvas está associada ao ritmo das vozes. À trilha são adicionadas percussão, palmas e uma voz feminina aguda que entoa um canto solado, com melismas orientais. As letras do título do filme surgem em sincronia com o ritmo da percussão: músicatema e nome do filme são apresentados, com muitas texturas imagéticas e vocais não verbais, enfatizando o trabalho e o movimento intuitivo das formigas.

A voz é o eixo da 'dança' estabelecida entre o homem (Alexandre Borges) - ex-ativista e proprietário de uma chácara no interior de São Paulo, onde constrói seu mundo particular - e a jornalista politizada interpretada por Júlia Lemmertz, e é conjugada à expressão corporal dos atores e aos paralelismos da montagem. 
À sequência inicial das saúvas, sucede outra de vozes silenciadas, em que predominam o som ambiente da estrada, dos pássaros e os ruídos dos carros que ali passam em sequência, o da mulher e o do homem, em direção à chácara. Há um paralelismo nas ações de um e de outro até que ambos cheguem ao destino, o que sugere um descompasso entre os personagens. Este é amenizado pela fotografia dourada do entardecer e pelo som dos pássaros e insetos.

O homem passa pela mulher carregando latas de tinta sem trocar olhares ou palavras; eles se comunicam pela respiração. O homem a olha primeiro, mas é a mulher quem quebra o silêncio, perguntando o que ele tem; ao que ele responde perguntando se ela já jantou. Existe uma tensão no ar, evidenciada pelas longas pausas entre as falas, pela ausência de música, com efeito silêncio dado pela tranquilidade e textura pouco densa dos sons ambientais da chácara. Ele pega um tomate na cozinha, tempera com sal e o devora, lentamente, em close up. A mulher o observa com desejo, enfatizado pelos ruídos e enquadramentos fechados de uma erótica mastigação.

A primeira fala do homem ocorre em over, em maior intensidade e proximidade com o espectador, e, portanto, em posição de superioridade em relação à voz feminina da diegese: “É como se fosse um ritual silencioso. Quanto mais indiferente eu me parecesse, mais a ela apetecia" (ABRANCHES, 1999). Aqui o over mantém a tradicional característica explicativa, ironicamente justificando o silêncio com palavras, explicitando algumas 'regras' do jogo de sedução entre os personagens e confirmando a ideia de ritual antecipada pelas vozes-gesto femininas da música associada à sequência das saúvas.

O homem caminha à frente da mulher em quadro, na voz over, na explicação das regras do jogo. O silêncio das falas a caminho do quarto (som ambiente evidenciado) é quebrado novamente pelo homem, que, novamente em over, descreve redundantemente suas ações na imagem, a não ser pelo texto sincronizado ao encanto estampado no rosto da mulher: "[...] deixando os pés descalços, que um dia ela comparou com dois lírios brancos" (ABRANCHES, 1999). Quando ele a toca no sexo e tira sua saia (FIGURA 49), ressurge o som agudo de percussão, seguido das vozes femininas dos créditos iniciais sobre a imagem dos olhares de desejo da mulher e, a seguir, do homem. A primeira aproximação de fato entre os dois é corporal e instintiva e ocorre sobre a trilha musical já associada a este ímpeto. 
Figura 49 - Homem tira a saia da mulher ao som da mesma trilha associada às saúvas

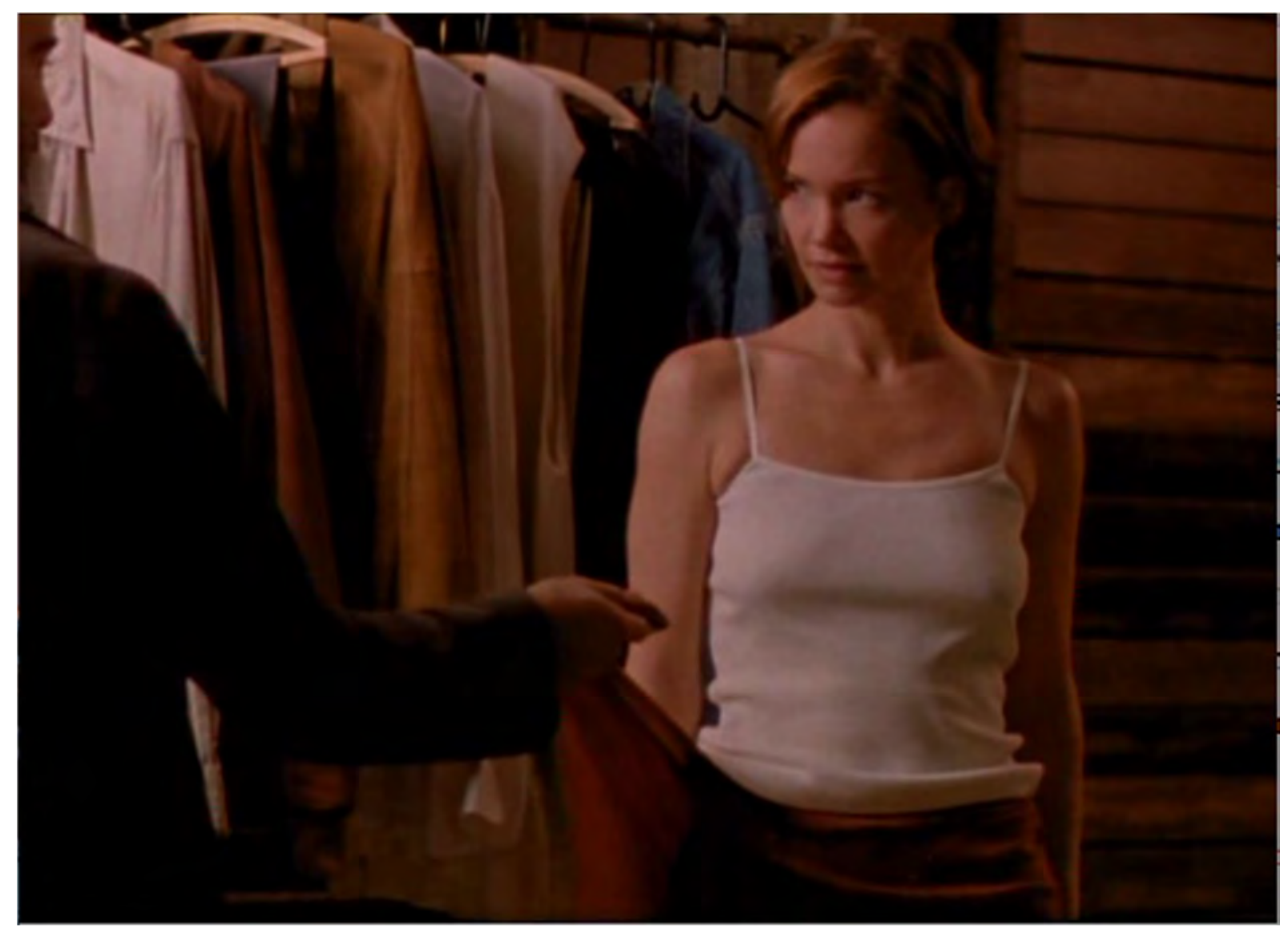

Fonte: Frame do filme Um copo de cólera (1999).

Ele segura a saia enquanto ela se aproxima, o que é pontuado pela sineta aguda da percussão. Os dois se tocam e se cheiram, em um ritual de acasalamento. Ressurge a voz feminina solo em canto não verbal, sobre a base harmônico-percussiva. Ela pega a saia e cobre a cabeça, como em uma imagem sagrada, reforçando a ideia do transe. Os dois sorriem, ele pega novamente a saia, enquanto ela sai de quadro - momento em que a música desaparece.

Fica evidente o contraponto entre as vozes masculina e feminina no filme: esta se apresenta primeiro, sobre a imagem das formigas, como uma voz-gesto ancestral - a 'voz da Mãe', a primeira voz que se ouve e se reconhece, como nos lembra Chion (2004), o que é reforçado pela quebra emocional do silêncio pela mulher. A voz masculina, em contraponto, apresenta-se como a voz da razão, da estratégia e do controle, e se destaca pelo conteúdo verbal que carrega.

Enquanto a mulher se prepara fora de quadro, as ações rápidas do homem - despir-se, deitar-se, cobrir-se com o tecido transparente da saia da mulher - são enfatizadas pelos foleys, som ambiente de pouco densa textura e ausência de música e palavras. Na espera também há prazer, como mostra a expressão do homem, que fuma, deitado. A saia erguida pelo homem se 
torna a tela na qual são exibidas as imagens de sexo (flashback - FIGURA 50) sobre uma música orquestral extradiegética, que sugere um vínculo maior que o carnal ora demonstrado pela música vocal percussiva anterior.

Figura 50 - Flashback sobre a saia transparente, ao som de trilha orquestral

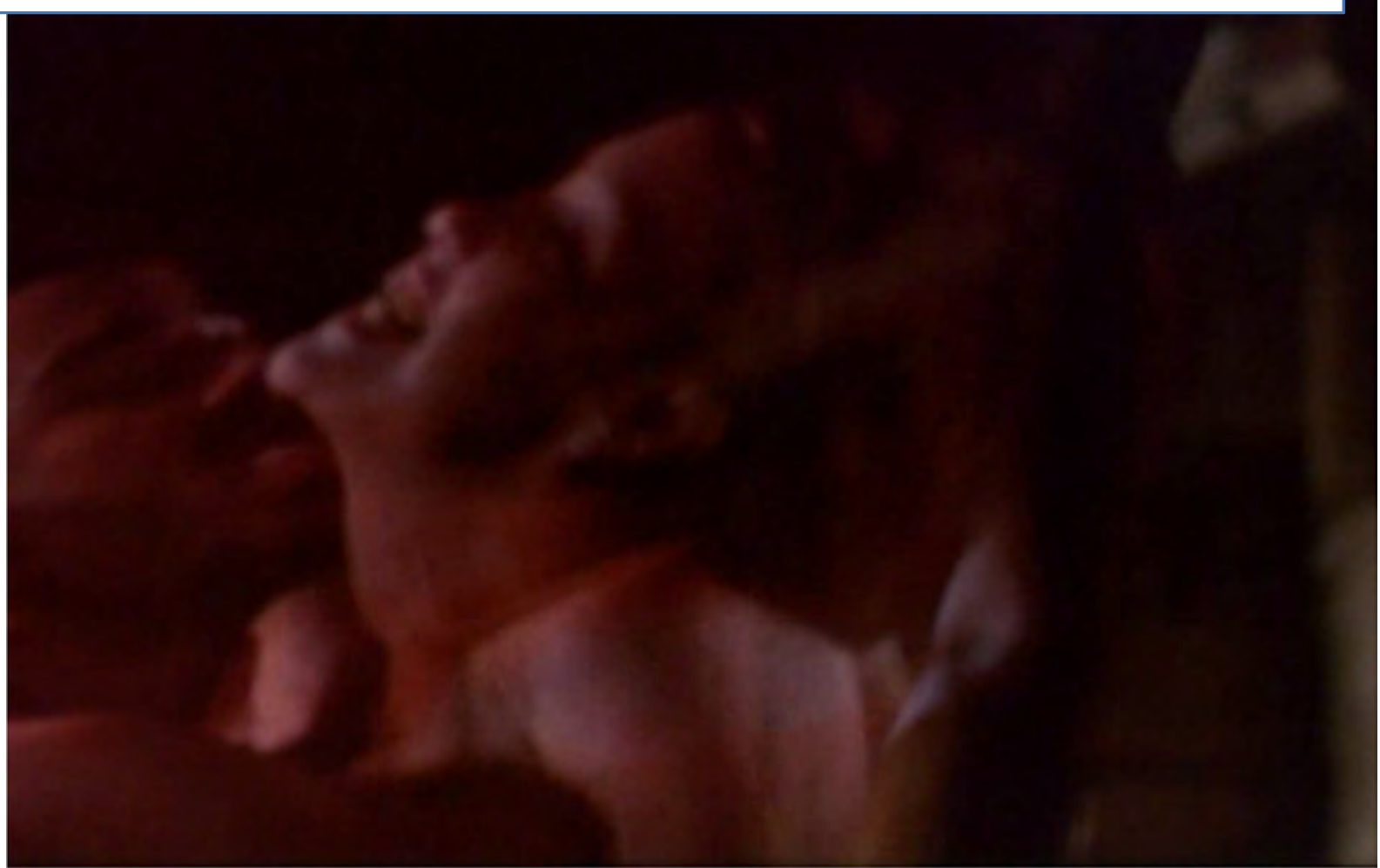

Fonte: Frame do filme Um copo de cólera (1999).

A trilha sinfônica de Abujamra, de densa textura de cordas e melodia, ao mesmo tempo, romântica e melancólica, é o único elemento do plano sonoro neste trecho, e, com o auxílio da câmera lenta e das fusões entre planos, imprime suavidade e delicadeza (amor) ao sexo animalesco na imagem, em contraponto à música vocal do desejo de possessão dos corpos.

Dadas as condições de realização desta cena - relação sexual de fato -, o diretor do filme revela a opção pela não gravação de som direto. A total valorização da música nesta cena crucial, além da proximidade geográfica, levou diretor e compositor a um trabalho em conjunto.

Um Copo de Cólera tem cenas de sexo que eu filmei sem som direto, porque era uma experiência limítrofe, então tinha muito pouca gente no set, já sabendo que o que me interessava ali de som era a música. (...) O sexo de Um Copo de Cólera é todo lembrado pelo personagem do homem, não acontece na hora ali, sabia mais ou menos o que eu queria e eu relaxei. Quando o André começou a compor, eu acompanhei, eu 
ficava sentado perto dele, e na hora que eu não conseguia me expressar em palavras eu cantava, e o André ficava olhando pra mim, e eu achava que estava quase compondo com ele. Depois ele me disse que não entendia nada do que eu falava (risos). Ele me deixou ficar próximo, ele no fim estava entendendo o que eu queria, era muito sentimento. E naquele caso a música dá toda a emoção. A musica é importantíssima até nos créditos. Então foi um processo muito criativo e colaborativo e bem-sucedido (ABRANCHES, 2014).

Quando os dois personagens atingem o orgasmo, a percussão se une às cordas na música modulada, enquanto, na imagem, são mostrados, alternadamente, os rostos de um e de outro, em close up. No fim do ato a percussão desaparece, enquanto se vê a mulher se lambuzando com o gozo em movimentos sinuosos, os quais conduzem ao retorno da música ao seu estado original e da imagem do tecido da saia estendida pelo homem nu sobre si.

O solo de violino, alternado com a maior densidade de textura da trilha musical, dá o tom da memória do homem, que passa da projeção na saia ao seu próprio ‘solo', ocupando toda a tela. O carnal e o espiritual se alimentam mutuamente por meio de lentos gestos e expressões de prazer solene, assim como música e imagem: durante um novo orgasmo - mostrado em 24 quadros por segundo -, a música instrumental original soa em notas lentas e ascendentes, 'suavizando/humanizando' o gozo da mulher e os gestos agressivos do homem, que a puxa pelo colar e aperta seus mamilos (FIGURA 51).

A música recua quando a cena volta à 'tela' (saia transparente) e o casal sai do quarto. Seu jogo/ritual sexual continua na areia, em meio a risadas e ao som dos insetos do lugar, por entre o sugestivo jogo de luz e sombra das estruturas de madeira, ora iluminando, ora escondendo os corpos nus que persistem em se perseguir em dança.

Eles retornam ao sexo, e, após um longo intervalo não verbal, a mulher diz, em meio aos gemidos: "Magnífico! Magnífico! Você é especial". O tom emocional da fala feminina é confirmado pelo tema sinfônico que ressurge a seguir, em segundo plano sonoro (atrás de respirações, gemidos e som ambiente). A imagem se funde à do homem deitado na cama, segurando a saia da mulher, com a qual se cobre por inteiro, marcando o fím da música e da sequência.

Figura 51 - Ato sexual sobre música orquestral 


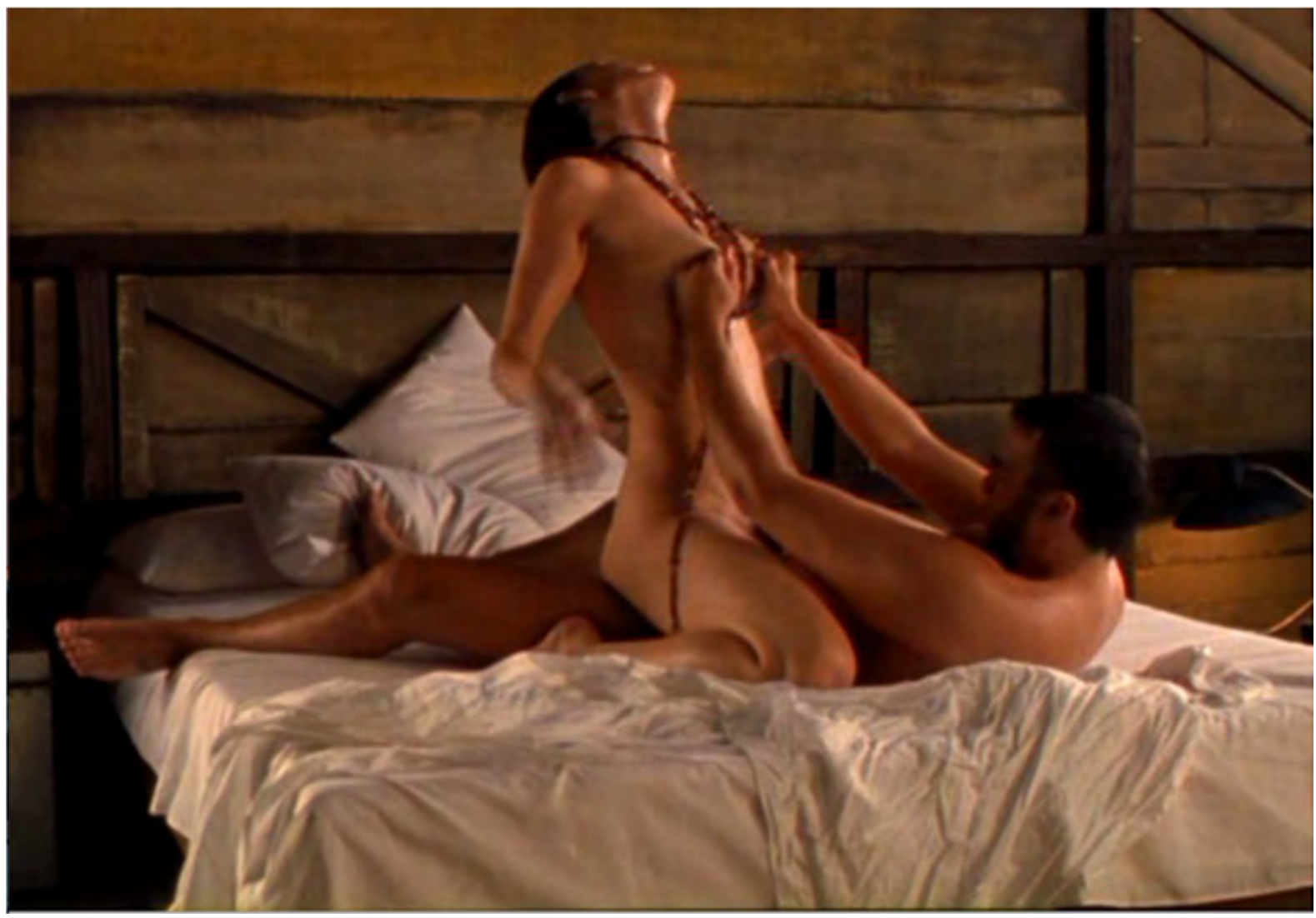

Fonte: Frame do filme Um copo de cólera (1999).

Ao amanhecer a voz masculina em over retorna para reafirmar o seu controle e o do personagem, que se assume superior à parceira. A entonação suave do texto contrasta com seu conteúdo agressivo em relação à mulher, bem como com os delicados sons ambientais da chácara ao amanhecer. No banho os planos fechados enquadram a mulher, que se abaixa para lavar o homem. Quando ela se levanta e o beija, ele pede a ela, em tom solene e distante:. Ela obedece, enquanto a voz descreve o prazer masculino, em primeira pessoa. O“Me lave a cabeça. Eu tenho pressa disso" prazer do homem está tanto em sua expressão quanto no texto proferido por sua voz over. Enquanto o som da água prevalece na trilha, a câmera desce, mostrando os sexos, e enquadra os pés de ambos, que se tocam.

Nua e ajoelhada no quarto (plano geral), ela lhe calça os sapatos (FIGURA 52), demonstrando a submissão dela como parte consentida do jogo. A seguir, na varanda, ele nota a bolsa da mulher sobre a mesa e, incomodado, coloca-a onde, para ele, deveria estar pendurada na cadeira -, indicando o quanto a sua própria ordem das coisas lhe é cara em seu mundo particular.

Figura 52 - Mulher calça o homem, em postura servil 


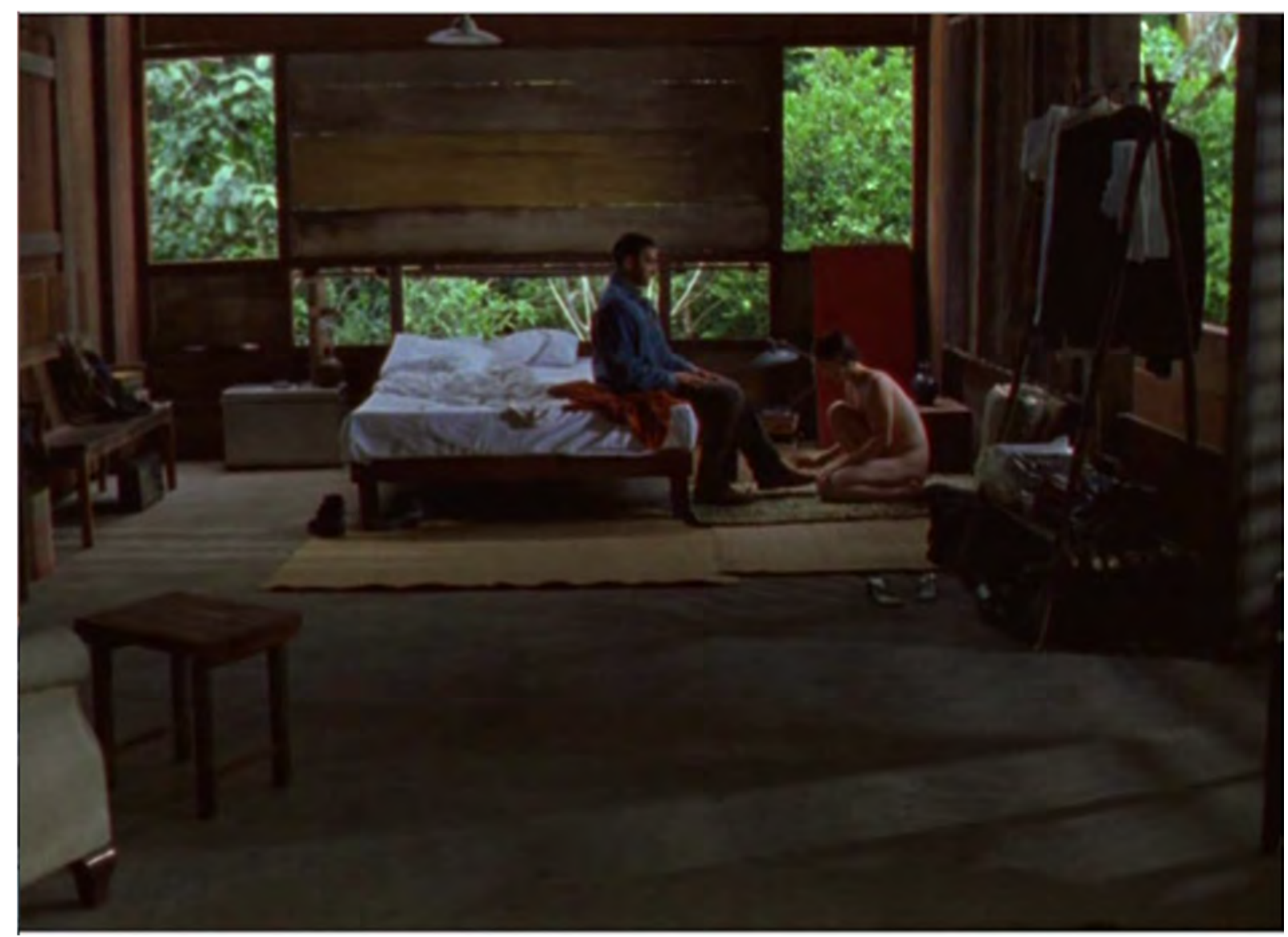

Fonte: Frame do filme Um copo de cólera (1999).

Chega a empregada, Dona Mariana, mais uma figura feminina em condição de serviçal, tratada com rispidez pelo patrão, o qual continua reclamando e propagando sua indiferença à funcionária em over, enquanto esta prepara o café. O ritmo das falas à mesa é lento e irregular, ressaltando a paisagem sonora rural e as expressões de mau-humor do patrão.

Seguem-se planos alternados dos rostos ensimesmados: ela passa um batom; ele fuma um cigarro (ênfase nos foleys). O rosto deste, então, é tomado de cólera, acentuada pela trilha percussiva e de vozes femininas que ressurgem. Diante da cerca viva, ele vê o estrago feito pelas saúvas (em close up) - sobre as quais ele não detém controle, e as vozes rituais femininas da música voltam a soar com intensidade. O homem perde o próprio prumo, gritando impropérios contra as formigas - que, como a mulher, seguem seus instintos, independentemente das vontades do personagem -, corre até elas, xinga-as, borrifando veneno em sôfregos movimentos masturbatórios (FIGURA 53) e pisando com violência contra o formigueiro. O som da sequência mistura os gritos femininos da música, os latidos constantes do cachorro e a voz agressiva do homem, que, pela primeira vez, é revelada em quadro pela violência, destacando-a como gesto sonoro. 
Figura 53 - Homem perde a razão diante da visão das saúvas



Fonte: Frame do filme Um copo de cólera (1999).

Com a mulher encostada no carro, ele se queixa (em over) da postura tranquila dela diante do ocorrido, de seu posicionamento político, de sua falta de iniciativa no sexo, demonstrando, ainda, a superioridade do conteúdo carregado pela voz em relação ao gesto apagado pela palavra e pela brutalidade na imagem. É como se a presença das saúvas 'destravasse' a voz emocional do homem, ainda que dependente da palavra. A voz over retoma a razão com agressividade, enquanto, na imagem, vemos o homem na despensa, repondo o recipiente do veneno com um líquido leitoso - o que confirma a associação com o sêmen no momento do gozo. O mau-humor masculino contrasta com o som ambiente de tranquilidade natural e com os coelhinhos que assistem a tudo da janela. A mulher, então, começa a provocálo com sarcasmo, assim que ele sai da despensa: "Não é pra tanto, mocinho que usa a razão".

Paralisado pela raiva - enfatizada pelo efeito sonoro de sopro breve e intenso, como o suspiro de uma fera raivosa -, ele se volta lentamente para ela. A partir daí há uma alternância recorrente entre planos de ação do homem na diegese e planos metanarrativos em que ele, dentro da casa e fora da ação, olha diretamente para a câmera (espectador) e explica, com 
irritação, meticulosidade e ironia, os motivos e reações decorrentes de sua ira, cujos picos são demonstrados em 'sopros sonoros', efeitos ouvidos nos diversos momentos em que a mulher consegue atingi-lo em seu brio (FIGURA 54).

Figura 54 - Homem dirige-se à câmera em plano 'metanarrativo'

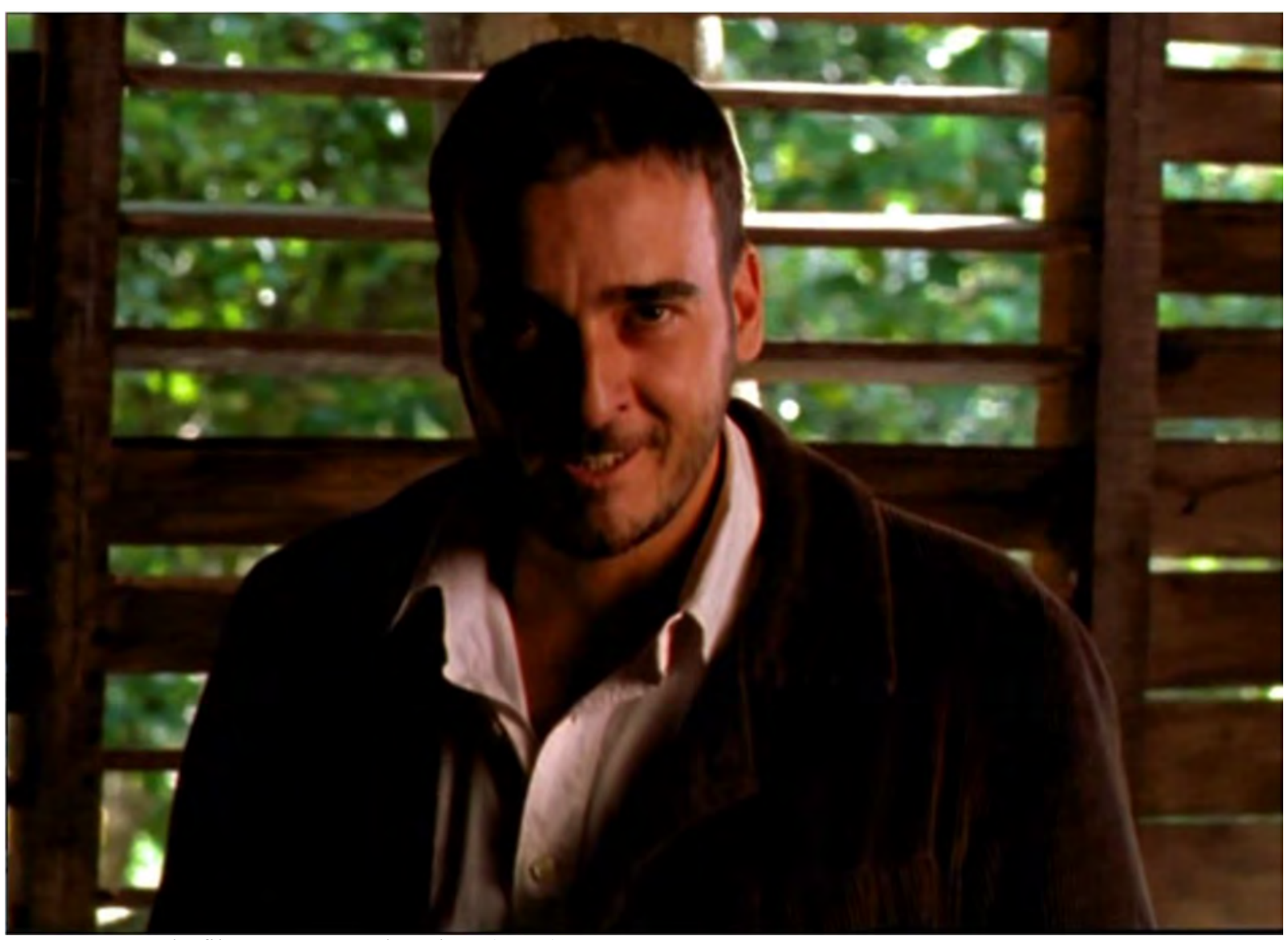

Fonte: Frame do filme Um copo de cólera (1999).

$\mathrm{Na}$ voz over, ele supõe que a mulher se queixa que ao sexo faltara a agressividade com que ele lidou com as formigas. A voz interliga os planos de modo a superpor ou transitar, com o poder que lhe é conferido, entre o over durante a interação com os demais personagens e o on nos planos explicativos: "Mas eu não falei nada. Não disse um isto. Tranquei-me a palavra. Ela não teve o bastante; só o suficiente", diz ele, olhando para a câmera.

À mulher cabe, em seu reduzido espaço verbal e imagético em comparação com o masculino, provocar e defender-se da agressividade. Vale ressaltar que, durante a discussão que evolui ao longo de todo o filme, o homem é acompanhado pela câmera a cada movimento, enquanto a mulher é revelada de forma estática, o que demonstra, também na imagem, a supremacia masculina. 
Todo o contexto - o atraso do caseiro, a falta de explicações de Dona Mariana diante do atraso do marido - alimenta a ira do homem, que é chamado de fascista pela mulher. A voz over, mais uma vez, supõe que a mulher deseja 'uma boa porretada'. Ele a chama de pilantra e profere impropérios, enquanto joga água na bacia, lava seu próprio rosto e despeja a água na terra.

A interação com a música vocal, que se torna o espaço representativo legítimo da voz da mulher na narrativa, ocorre também sobre os planos explicativos do homem, quando este cita as saúvas como provocadoras do seu ímpeto. A associação da imagem dos insetos à trilha musical de vozes femininas e à personagem de Júlia Lemmertz coloca tais elementos como responsáveis pela interferência não quista no mundo ordenado construído pelo personagem masculino, porque fora do seu controle e dos caminhos da razão: “e as malditas insetas [a feminização da palavra 'inseto' é uma pista para nossa interpretação] me tinham entrado em tudo quanto era olheiro, pela vista, pelas narinas, pelas orelhas, pelos buracos das orelhas especialmente. E alguém tinha de pagar. [...] É esse o suporte espontâneo da cólera”. Quem pagaria seria a provocadora e sarcástica mulher, em mais um ímpeto animalesco do homem. Ela, destemida, repete palavras em refrão: "Demoníaco!".

Esse sentimento é reforçado sonoramente com os latidos do cachorro, combinados, posteriormente, aos guinchos dos macacos. Os sons intensos dos animais, além da função dramática de aumentar a tensão e fazer coro à crescente animosidade entre os personagens também acompanhada pela crescente instabilidade dos movimentos de câmera, destacam-se no som ambiente. Tal importância é provada pela inserção de um plano do cachorro na sequência.

Vale ressaltar que o texto em linguagem literária, culta, em combinação com a atuação teatral dos atores, intensifica o tom agressivo da crescente discussão - que perdura por demorados minutos, em planos fechados de um e de outro - e, ao mesmo tempo, imprime um lirismo que não se espera em uma briga de casal, na qual ambos buscam diminuir o outro em seus desempenhos sexuais, valores, ideais, moral e ego.

A agressividade e o sarcasmo perduram e crescem diante dos empregados da chácara, Mariana e Antônio, enquanto este auxilia o homem na tarefa de vacinar os filhotes de coelho ação de cuidado que contrasta com as palavras de violência (FIGURA 55).

Figura 55 - Simultaneidade da discussão com os cuidados com os animais 


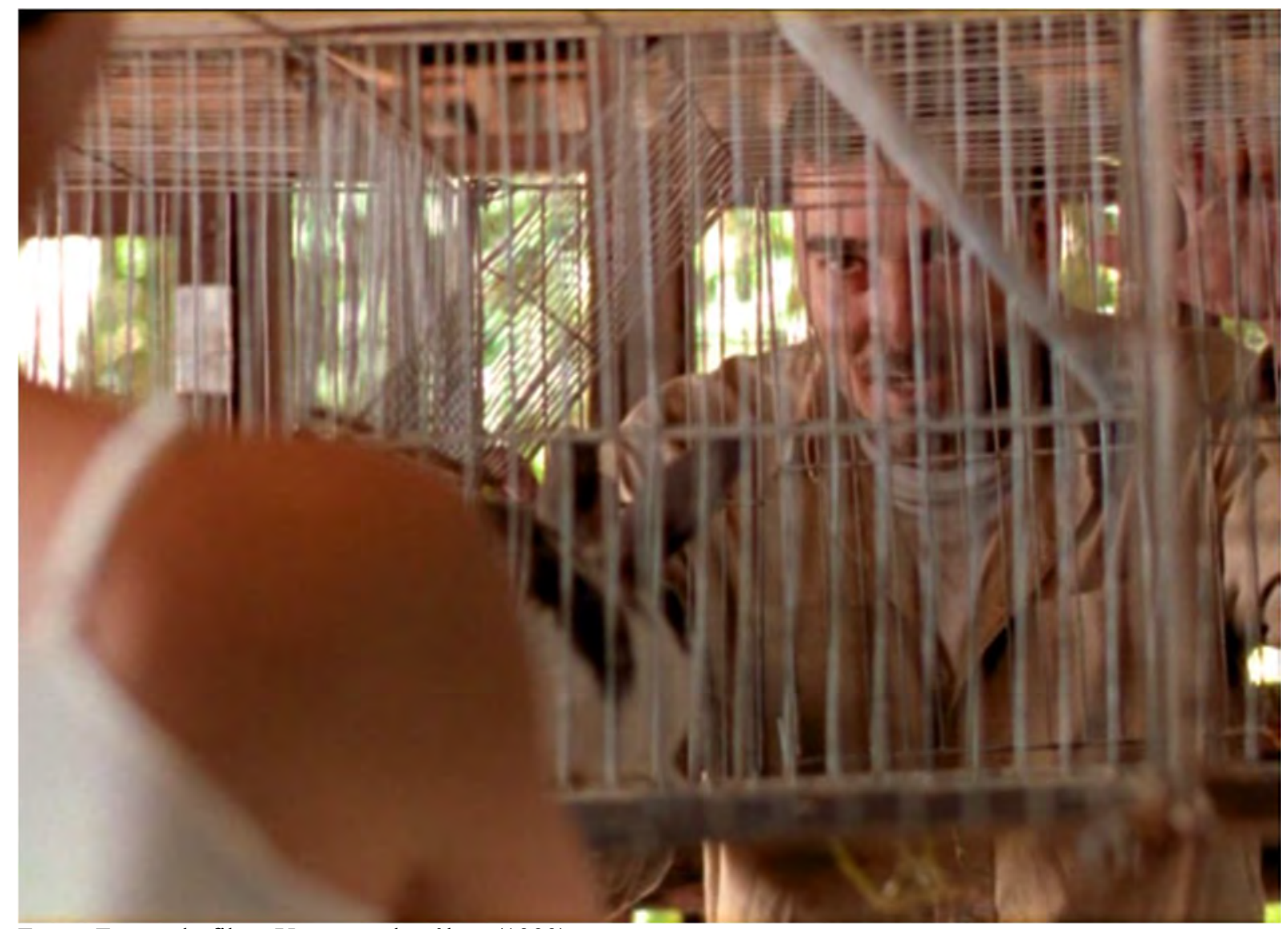

Fonte: Frame do filme Um copo de cólera (1999).

As vozes exaltadas do casal em cólera se destacam ante a docilidade dos serviçais e dos bichos (à exceção do cachorro e dos macacos) que atuam sobre o ambiente bucólico. A continuidade da discussão é revelada, em um dos planos, através das gaiolas dos filhotes, como se estas, ao mesmo tempo, delimitassem a arena dos ataqueis verbais e os lembrassem da inevitabilidade destes, conforme as 'regras do jogo'.

As palavras sarcásticas da mulher parecem enfurecer ainda mais o homem, que a todo instante tenta afirmar seu poder pela força e pela voz, em intensidade e vocabulário (on e over), ora bradando impropérios em alta intensidade em câmera na mão, ora explicando ao espectador, em tom ironicamente didático, os motivos de sua cólera. A agressão verbal - quando a mulher diz: "Bicha!" - é combinada à violência física, tapas e, depois, lambidas, ao que a mulher responde com desejo e uma declaração de amor, confirmando a cólera e a violência como componentes do ritual.

A respiração, a incitação do prazer e a aproximação da câmera dão a entender que uma reconciliação por meio do sexo vai acontecer. Quando ele sente a vulnerabilidade dela, o jogo é quebrado pela recusa do homem, que, dissimulado, não cede à sedução e humilha a mulher, expulsando-a de seu paraíso forjado. O grito feminino de dentro do carro ("Brocha!") antes de 
ela acelerar e partir põe fim à discussão, mas reverbera no orgulho do homem que, gritando, vira-se do avesso, como descrito simultaneamente pelo over: "Um ator em carne viva, em absoluta solidão, às voltas com uma zoeira de sangue e vozes”, em plano geral (FIGURA 56).

Figura 56 - Homem em posição fetal, após partida da mulher

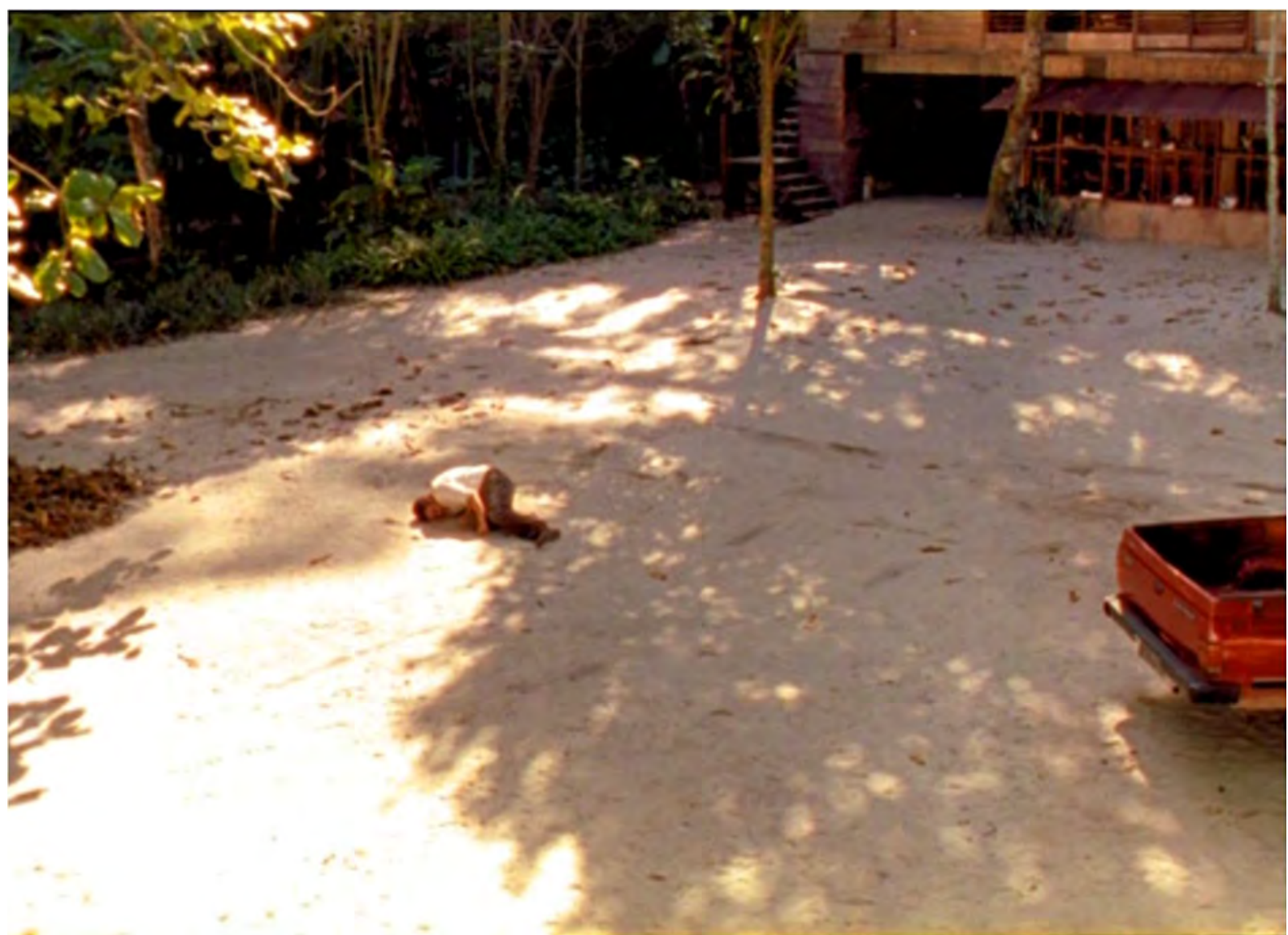

Fonte: Frame do filme Um copo de cólera (1999).

A voz over perdura sobre as imagens da infância do personagem naquele mesmo lugar: o menino, sob a mesa, espia as pernas das mulheres através das saias, remetendo à roupa que, tirada da parceira pelo homem adulto, serve de superfície/faísca para a projeção de suas lembranças. Neste momento soam os instrumentos agudos de percussão do tema musical das saúvas, em um prenúncio das consequências do desejo daquela criança no futuro. A ideia da 'profecia' é confirmada pela intensa reverberação do motivo musical percussivo nos planos seguintes (famílias sendo fotografadas e, depois, à mesa para a refeição, batendo palmas e cantando uma música que o espectador não ouve, em câmera lenta), a ponto de o tema ser descaracterizado ritmicamente, em concomitância à voz masculina adulta, em over. A música continua ressoando após o corte seco na imagem, ao que sucede o plano-detalhe da mãe dizendo ao filho: "o amor é a única razão da vida" (FIGURA 57). 
Figura 57 - Voz e imagem da mãe embalam as lembranças do homem

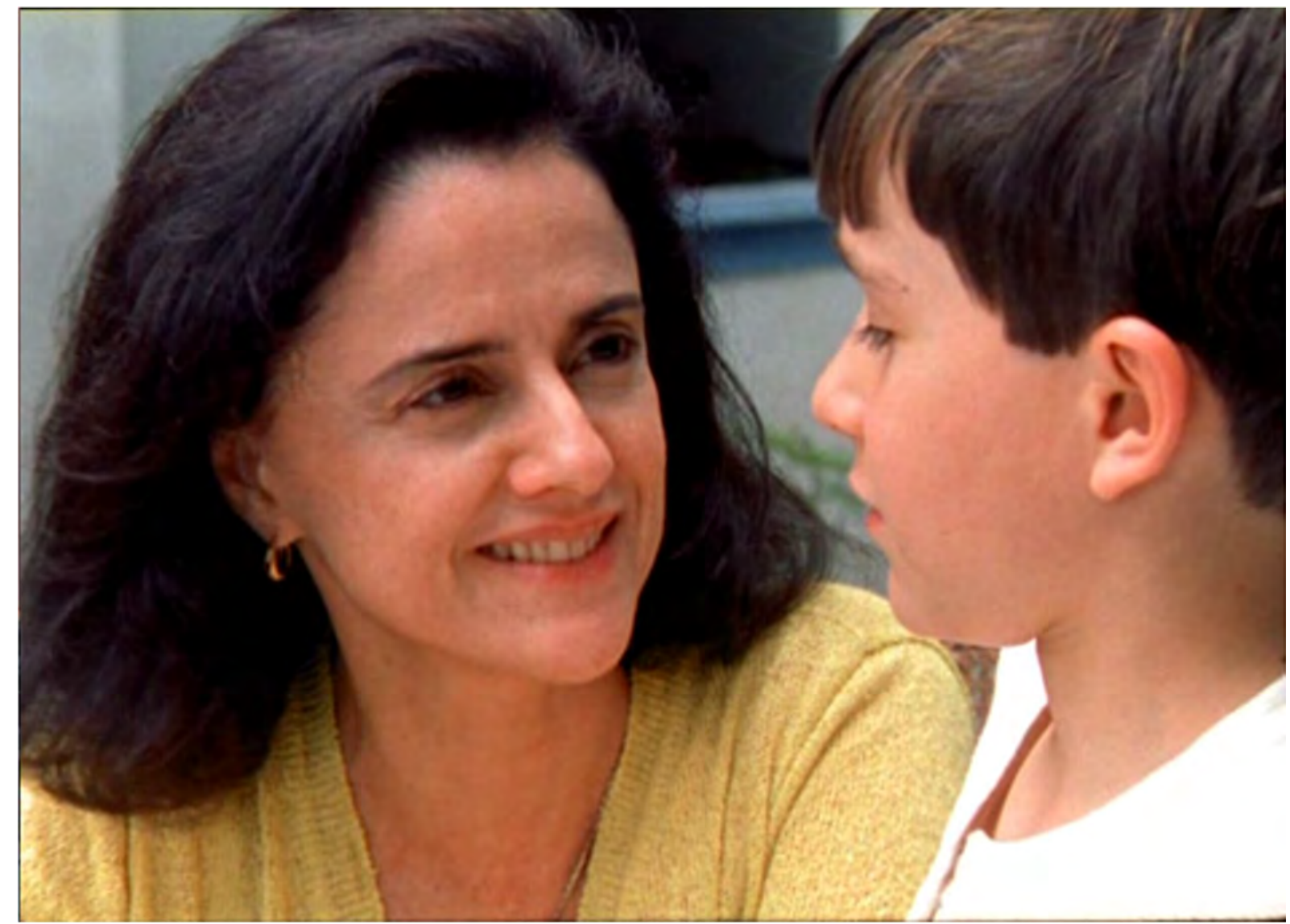

Fonte: Frame do filme Um copo de cólera (1999).

A frase é repetida pelo homem após o transe de cólera, confirmando a autoridade e a importância emocional e simbólica da 'voz da mãe'. Deitado sozinho na areia em posição fetal, ele chora, demonstrando, finalmente, sua voz em puro gesto sonoro, desprovido de qualquer significação racional. O som ambiente ganha intensidade, enquanto os empregados se aproximam para erguê-lo. Nada constrangida, Dona Mariana comenta sobre a ninhada de 13 filhotes de um dos coelhos, destacando, por meio da palavra, a continuidade da vida e a circularidade do jogo que a gera e por ela é gerado.

Depois de um fade out de som e imagem, à mulher é concedida, pela primeira vez, a oportunidade (poder) da voz over, sobre imagens de seu carro passando pelo portão da chácara, em um fim de tarde. Também pela primeira vez ela olha e fala diretamente para a câmera (FIGURA 58), contanto ao espectador sobre o momento em que o homem a esperava no quarto. É revelado o ponto de vista feminino do ato sexual, com o retorno do tema sinfônico de André Abujamra combinado à voz da mulher. 
Figura 58 - Mulher se dirige à câmera, em plano 'metanarrativo'

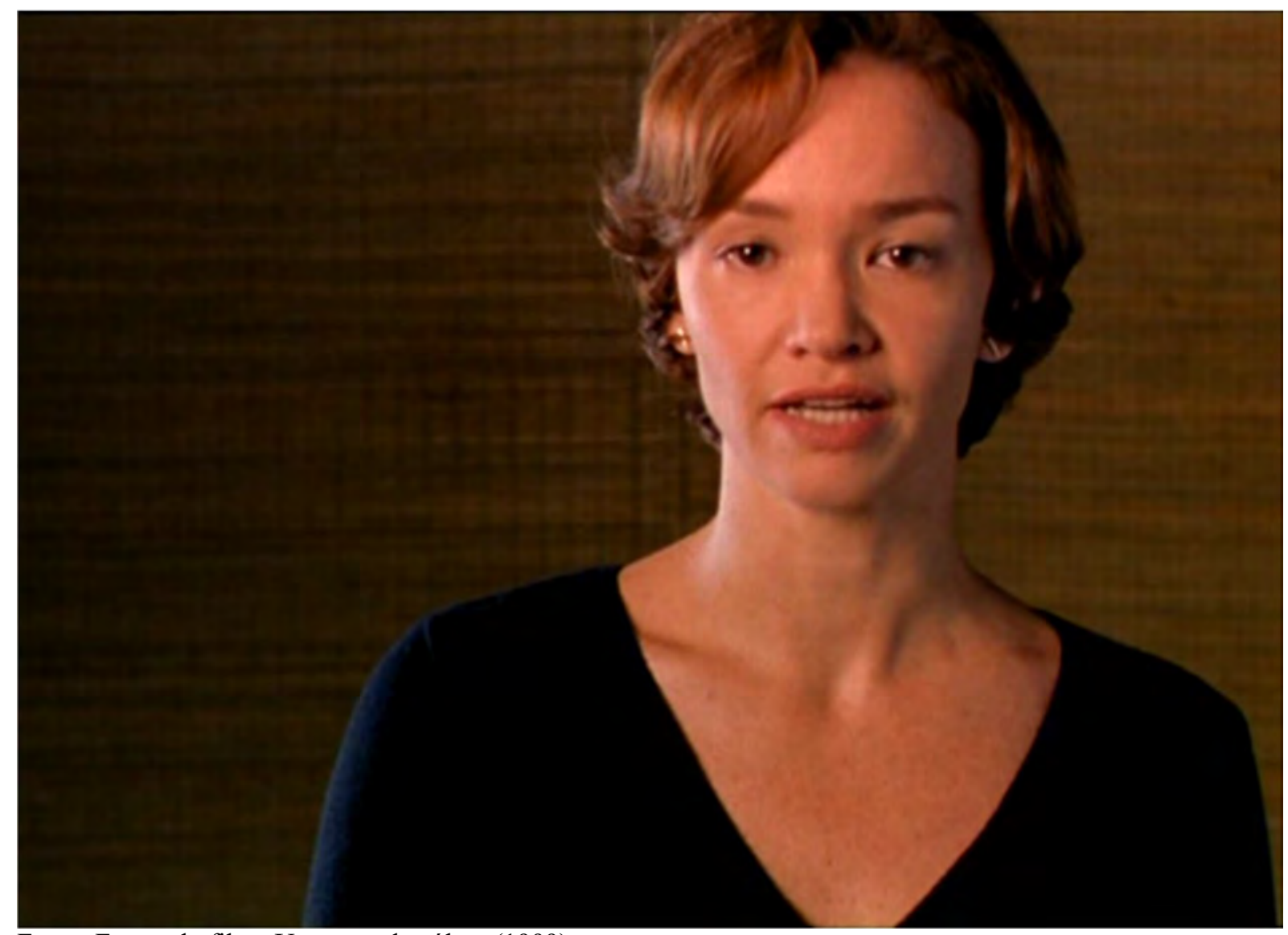

Fonte: Frame do filme Um copo de cólera (1999).

A câmera revela o homem nu, dormindo na posição fetal que lembra seu estado póstranse. A ternura e o tom maternal da voz over feminina que cobre a imagem cede lugar à intensidade da música em cordas médias e agudas, confirmando o caráter emocional de ambos os elementos sonoros. Sobre a imagem da mulher de pé diante do homem deitado na cama (inversão da posição de fragilidade), surge, na música, o solo de um violino, seguido da melodia de um segundo violino. O dueto-solo coroa a transformação das vozes dos personagens nas melodias consonantes e simultâneas que embalam o ritual do sexo, acrescido de mais e mais texturas ao longo dos créditos, confirmando a circularidade do ritual e a voz da mãe como a voz da verdade (“o amor é a única razão da vida”).

Em Um copo de cólera (1999) a voz opera em camadas de percepção e significação que interagem entre si, demonstrando o jogo entre a razão e o desejo feminino e masculino por meio da adaptação da poética verbal de Raduan Nassar, da interpretação dos atores e das composições musicais de Abujamra. Em uma peça a voz opera como provocadora da desordem que mina a razão; na outra, restabelece, transformada em melodias, a harmonia dos corpos na consumação amorosa do desejo. 
A adaptação para cinema do livro homônimo de Nassar se aproxima de Castelo Rá-TimBum, o filme (Cao Hamburger, 1999) quanto à presença da música sinfônica composta por André Abujamra - orquestrada e regida por Renato Lemos, em ambos os casos -, e distanciase dele pelo uso musical da voz. Diferentemente da carga gestual (sonora, instintiva) e semântica (racional, verbal) colocadas em oposição nas vozes ouvidas no filme de Aluizio Abranches, no longa-metragem de Cao Hamburger as vozes cantadas apresentam empostação lírica na canção-tema e entoação popular em outras músicas, além da inflexão fantasiosa/infantil nos diálogos.

\subsubsection{Castelo Rá-Tim-Bum, o filme (Cao Hamburger, 1999)}

Após som de vento em cartelas sobre preto, surge a narração em over de Nino, seguida pelo tema musical do pequeno bruxo - uma melodia inicial em madeiras (fagote e oboé). Esta logo se torna uma peça sinfônica alegre em ré maior - o 'tema de Nino', música principal do filme, com a entrada de percussão, cordas e flauta, sobre imagens de uma pipa vermelha e amarela que passeia, em primeiro plano e em tomadas de vários ângulos, por diversos pontos da cidade de São Paulo, ao entardecer, acompanhada dos créditos iniciais do filme (FIGURA $59)$.

A narração de Nino retorna sobre a imagem da pipa caindo, ao anoitecer, nos jardins do castelo da família Stradivarius - quando a música ralenta e acompanha a queda em harmonias descendentes, indo para o modo menor. Diante dos portões imponentes da entrada do castelo, Cacau, João e Ronaldo, que brincavam com a pipa nas proximidades, se perguntam como farão para recuperá-la - momento em que a música recua em textura, é combinada ao som ambiente noturno (insetos) e segue, então, enfatizando o clima de mistério, com notas muito graves e lentas sobre outras agudas executadas pelas cordas, espaçadas e sem ritmo regular. Quando as crianças entram no jardim, à trilha se unem sons agudos de caixinha de música e de oboé, dando um tom de encanto e magia combinado ao mistério das cordas.

Figura 59 - Pipa sobrevoa São Paulo, na primeira ocorrência do 'tema de Nino' 


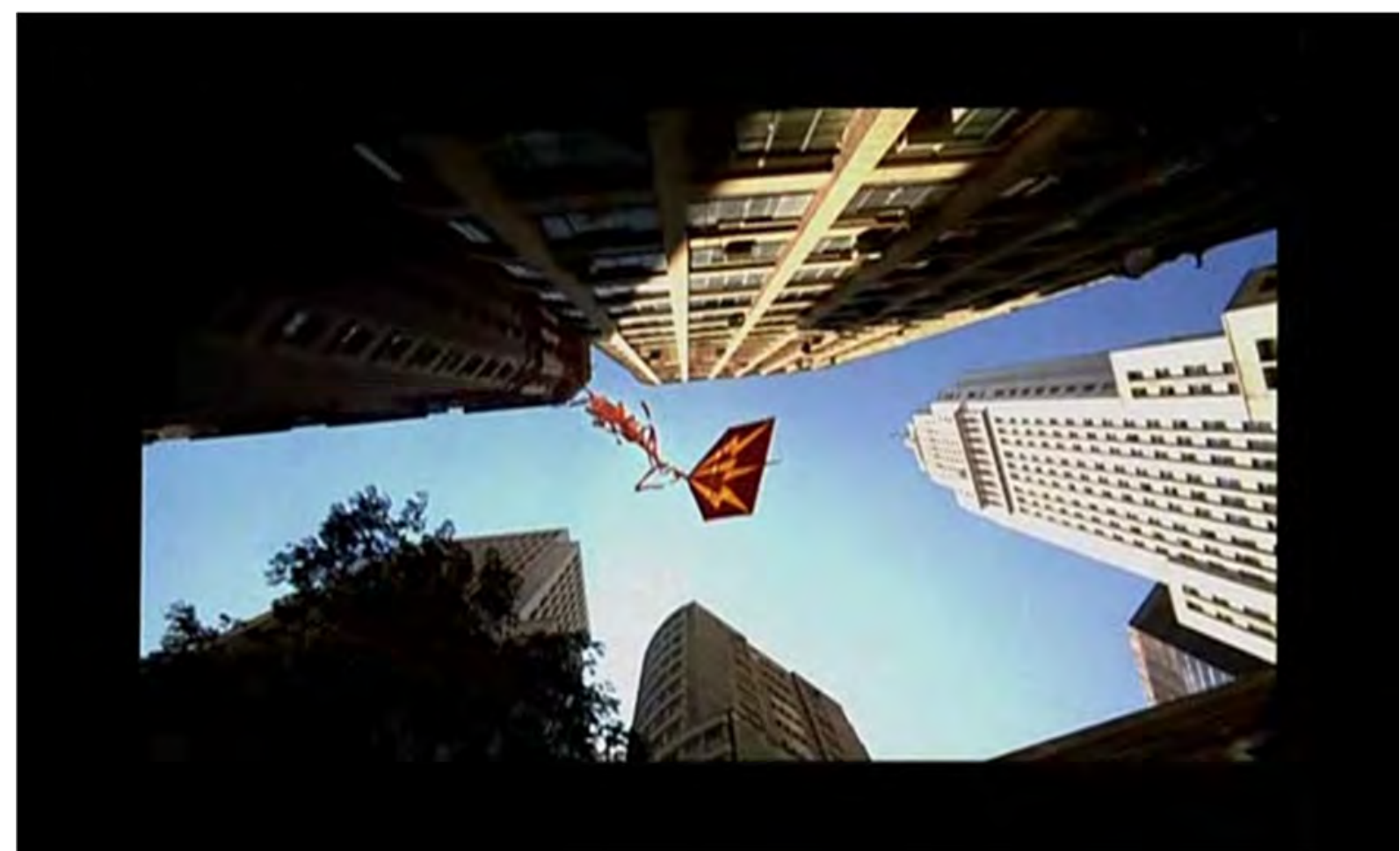

Fonte: Frame do filme Castelo Rá-Tim-Bum, o filme (1999).

Uma das crianças, ao chegar no alpendre, diz: “Maneiro esse castelo, hein!”. Nesse momento a atmosfera soturna sugerida pela música, em combinação com os sons de ambiente noturno e a fotografia azulada, transforma-se, e a música, ao modificar sua melodia e acelerar e regularizar seu ritmo, adquire um clima imponente de realeza, sobre a imagem do castelo em plano geral, sugerindo a tradição familiar dos moradores daquele lugar suntuoso e carregado de mistério. Trata-se do 'tema do castelo', a Ópera Arepó, iniciada por um coro de vozes - entre as quais, a de Abujamra - cantando o refrão, sobre uma base de cordas e madeiras, em dó menor: "muB-miT-áR oletsaC" (Castelo Rá-Tim-Bum dito ao contrário).

$\mathrm{Na}$ versão cantada da música, a inversão das palavras revela o senso de humor de Abujamra na interpretação literal do pedido de Cao Hamburger - que queria uma música diferente daquela do seriado televisivo homônimo. As palavras invertidas - de ópera para 'arepó', de Castelo Rá-Tim-Bum para 'mubmitar oletsac' - soam como um idioma estrangeiro e são misturadas a palavras em português e/ou de origem indígena, remetendo à realeza excêntrica e às origens tradicionais da família milenar de bruxos em convivência com a pluralidade cultural brasileira.

A sonoridade das palavras existentes ou inventadas e o caráter pomposo da música conferido pela empostação das vozes cantadas e pela densidade dos arranjos orquestrais do maestro Renato Lemos fazem referência à erudição da família de Nino: "stradivarius dras 
trubufu! / vrais angu! / stradivarius dras trubufu! / vrais angu! / macacos me mordam / das micus leão! / duns livrum abertum / caído do chão! / [...] mubmitar oletsac / mubmitar oletsac".

Enquanto o coro canta o refrão invertido, em plongée são reveladas as sombras dos bruxos se dirigindo ao banho de lua no jardim. Quanto eles notam a presença das crianças, o coro da música faz um glissando ${ }^{60}$ descendente e os gritos e fuga das crianças desencadeiam a batida eletrônica sobre a mesma 'ópera', na qual o coro então canta: "Bum, bum-bum-bum... Rá-Tim-Bum!", facilitando, assim, a associação com o título do filme, a série televisiva - cuja trilha já estava na memória das crianças brasileiras desde 1994 - e a própria canção-tema do castelo, com refrão principal cantando ao contrário. Sobre essa variação eletrônica do tema a câmera se aproxima da família de bruxos no alpendre e apresenta os protagonistas, associandoos também ao tema (FIGURA 60).

Figura 60 - Família Stradivarius é apresentada ao som da Ópera Arepó

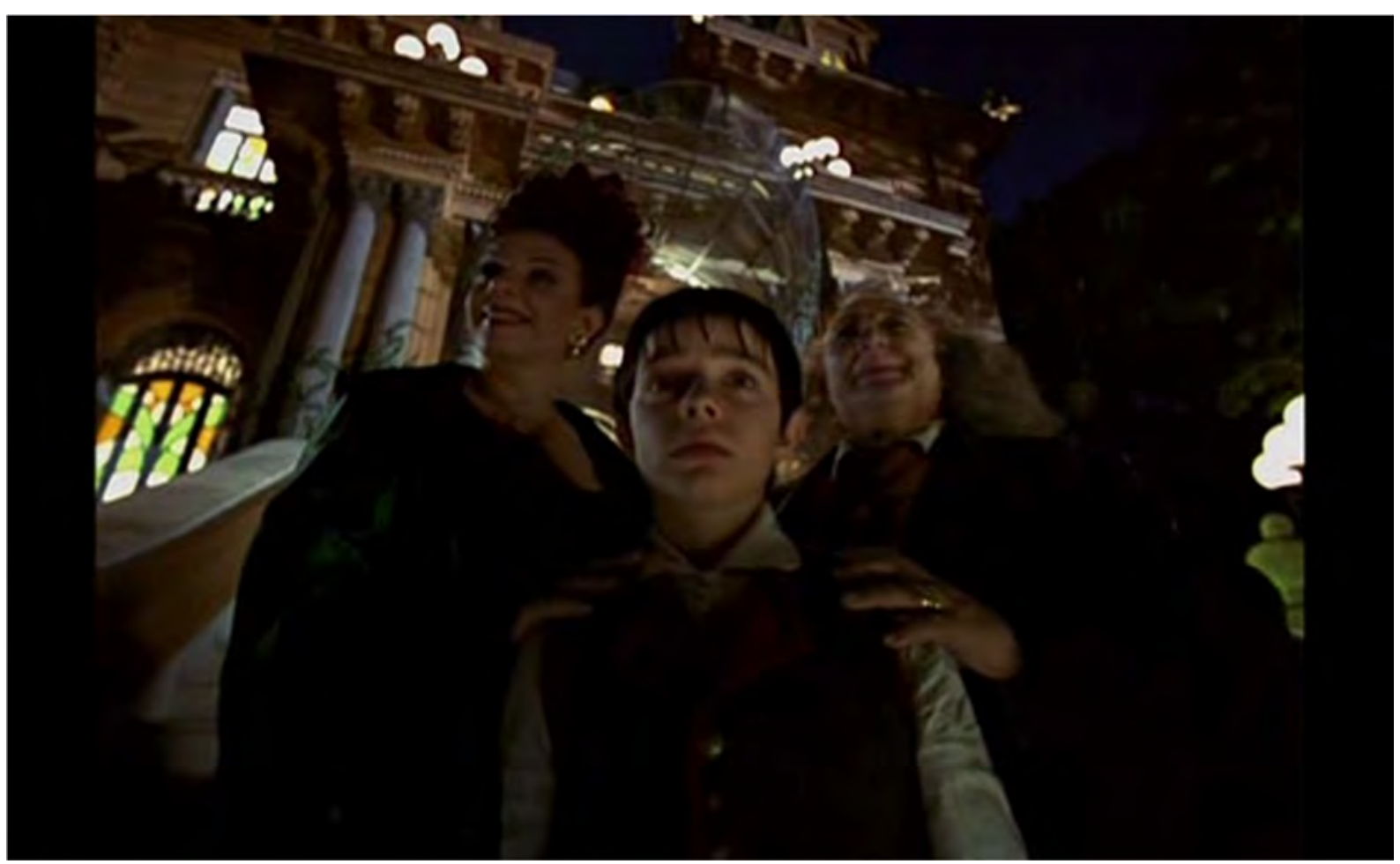

Fonte: Frame do filme Castelo Rá-Tim-Bum, o filme (1999).

A versão eletrônica do tema sinfônico do castelo evidencia a relação de estranheza entre o lar dos Stradivarius e a cidade, a família de bruxos e os habitantes da metrópole, os timbres digitais e batidas eletrônicas e a formação sinfônica da música gravada e orquestrada pelo

\footnotetext{
60 Termo italiano que designa uma passagem suave por diferentes alturas sonoras.
} 
maestro Renato Lemos, a expressão de susto de Nino com a fuga das crianças e o riso dos bruxos mais velhos, acostumados a esse tipo de reação.

Em Castelo Rá-Tim-Bum, o filme, o tema instrumental principal - 'tema de Nino', apresentado logo no início do filme - foi composto por André Abujamra e Lulu Camargo antes das gravações em decorrência da necessidade de coreografar os atores para o 'baile do alinhamento dos planetas' previsto no roteiro - conforme processo revelado no capítulo 4 (ABUJAMRA, 2016). A trilha musical se desdobra em diversas variações sinfônicas (leitmotive) para ambientar a história da tradicional família de bruxos Stradivarius, que mora em um castelo no meio da cidade de São Paulo. Morgana (Rosi Campos), Victor (Sérgio Mamberti) e seu sobrinho e aprendiz Antonino/Nino (Diegho Kozievitch) aguardam o alinhamento dos planetas, evento celeste que fortalece os poderes dos feiticeiros. Às vésperas desse acontecimento, Losângela (Marieta Severo), membro da família Stradivarius banida pelo Conselho de Bruxos por suas maldades, volta à cidade e, com a ajuda de Dr. Abobrinha (Pascoal da Conceição) - cujo maior desejo é derrubar o castelo para construir um empreendimento imobiliário - e seu capanga Rato (Matheus Nachtergaele), rouba o livro de Morgana, fazendo com que esta e Victor percam seus poderes.

Cabe ao protagonista Nino não apenas escrever seu próprio livro - tarefa que ele protela o quanto pode, apesar das cobranças de Victor -, mas também salvar sua família, recuperando o livro de Morgana, os poderes de seus tios e o castelo ocupado por Losângela. Para cumprir essa missão Nino precisa lidar com o fato de ser uma criança diferente das demais - o que é evidenciado pelo figurino, pela maquiagem, fotografia e interpretação dos atores.

Apesar das diferentes melodias e harmonias - compostas a pedido do diretor do filme, Cao Hamburger -, a obra conserva as características narrativas presentes na trilha sonora da série televisiva na qual se baseia, Castelo Rá-Tim-Bum, criada por Flávio Souza e Cao Hamburger (diretor do filme) e exibida na TV Cultura (1994-1997): associação a personagens específicos, presença de leitmotiv, acréscimo de informação à história, conforme antecipado no capítulo anterior.

A comunicação com o Cao era bem tranquila, já que trabalhávamos com ele desde o seriado para TV, Castelo Rá-Tim-Bum. Tínhamos muito pouco tempo para fazer a trilha do filme, uns dois meses, da primeira reunião até a entrega da música. Então, se a comunicação com ele não fosse boa - até porque ele queria toda a música diferente, a trilha não era pra lembrar a música do seriado -, não teríamos conseguido realizar a composição em tão pouco tempo (CAMARGO, 2016). 
Os compositores André Abujamra e Lulu Camargo já se conheciam desde antes de trabalharem juntos na trilha musical da série: foram colegas de turma no curso de Música da Faculdade de Artes Alcântara Machado (FAAM), onde iniciaram uma relação de afinidade pessoal e musical. Na década de 1980 Camargo foi morar nos Estados Unidos, onde cursou Film Scoring, na Berklee College of Music. Quando voltou ao Brasil integrou o Karnak como tecladista até os anos 2000. Sua atuação no cinema, conforme seu próprio depoimento para este trabalho, é pontual; ele trabalha sobretudo no mercado publicitário. "Sou mais cerebral e o André, mais intuitivo. Trabalhamos muito bem juntos, afinal, a gente já se conhecia de muitos anos e trabalhamos por muito tempo na música. Mas, no cinema, posso dizer que não atuo" (CAMARGO, 2016).

Era fim da década de 1990 e a tecnologia digital já permitia aos compositores comparecer às reuniões com o diretor apresentando a música já rascunhada em computador. Conforme relato de Camargo, nessas ocasiões, quando havia algum conflito de ideias entre Hamburger e Abujamra, o produtor musical Pena Schmidt mediava a relação.

Uma vez alinhados com o pensamento do diretor, Abujamra dava as instruções sobre as características gerais da música em cada trecho do filme e ele e Camargo dividiam as sequências entre si; cada um compunha sua parte e, juntos, reuniam, definiam e tratavam as composições.

\footnotetext{
Eu fiz a sequência da transformação da Morgana, por exemplo [...]. Como eu tinha mais experiência com orquestração, eu fazia mais essa parte também. O André não era tanto de escrever partitura e orquestrar. Ele era mais da impetuosidade criativa. Ele trabalha com orquestrador, trabalhava muito com o Renato Lemos, não sei se ainda continua. Mas foi o Renato Lemos que regeu a gravação da trilha musical do Castelo Rá-Tim-Bum, o Filme, feita com músicos de verdade, em formação camerística [músicos da OSESP gravados ao vivo no estudio Vice Versa, com produção de Pena Schmidt]. Foram poucos músicos, mas dobrávamos os instrumentos gravando várias vezes e ficou essa impressão de preenchimento. Poderíamos ter conseguido esse efeito inserindo samplers sobre a gravação original, mas fizemos tudo com músicos de verdade (CAMARGO, 2016).
}

A criatividade de Abujamra, combinada às ideias e arranjos de Camargo, deu origem às diferentes músicas originais ouvidas ao longo do filme: 'tema de Nino', Ópera Arepó, a música sinistra de Losângela, o tema cômico dos vilões Dr. Abobrinha e Rato, o tema dos monstros do encanamento, Mau, Sujo e Feio; além de breves e pontuais passagens musicais de transição. A principal, à qual atribuímos o nome 'tema de Nino', é a mais recorrente, surgindo em diversas situações narrativas além da sequência de abertura, sob as mais diferentes formas musicais (leitmotive), que, a seguir, elencamos.

Quando Victor, ao explicar sobre o alinhamento dos planetas, pergunta sobre o livro de poderes de Nino, o tema musical retorna em solo de oboé, lento e triste, pelo fato de o pequeno 
bruxo ainda não ter começado a escrevê-lo, e é interrompido pelo conhecido jargão reverberado "Raios e trovões!" proferido pelo tio, em reação.

O ensaio do minueto com Morgana traz mais uma versão do 'tema de Nino', iniciado com a pianola mágica, que toca sozinha e cujas dissonâncias pontuam a comicidade dos movimentos da dança e a diferença de humores entre Nino (emburrado) e sua tia (empolgada). A seguir, a música cresce em intensidade e textura com a entrada de cordas, madeiras, metais e percussão. A textura e dinâmica aumentam na medida em que Nino, a princípio sem vontade, começa a se divertir (FIGURA 61).

Figura 61 - Ensaio do baile do alinhamento dos planetas, ao som do 'tema de Nino'

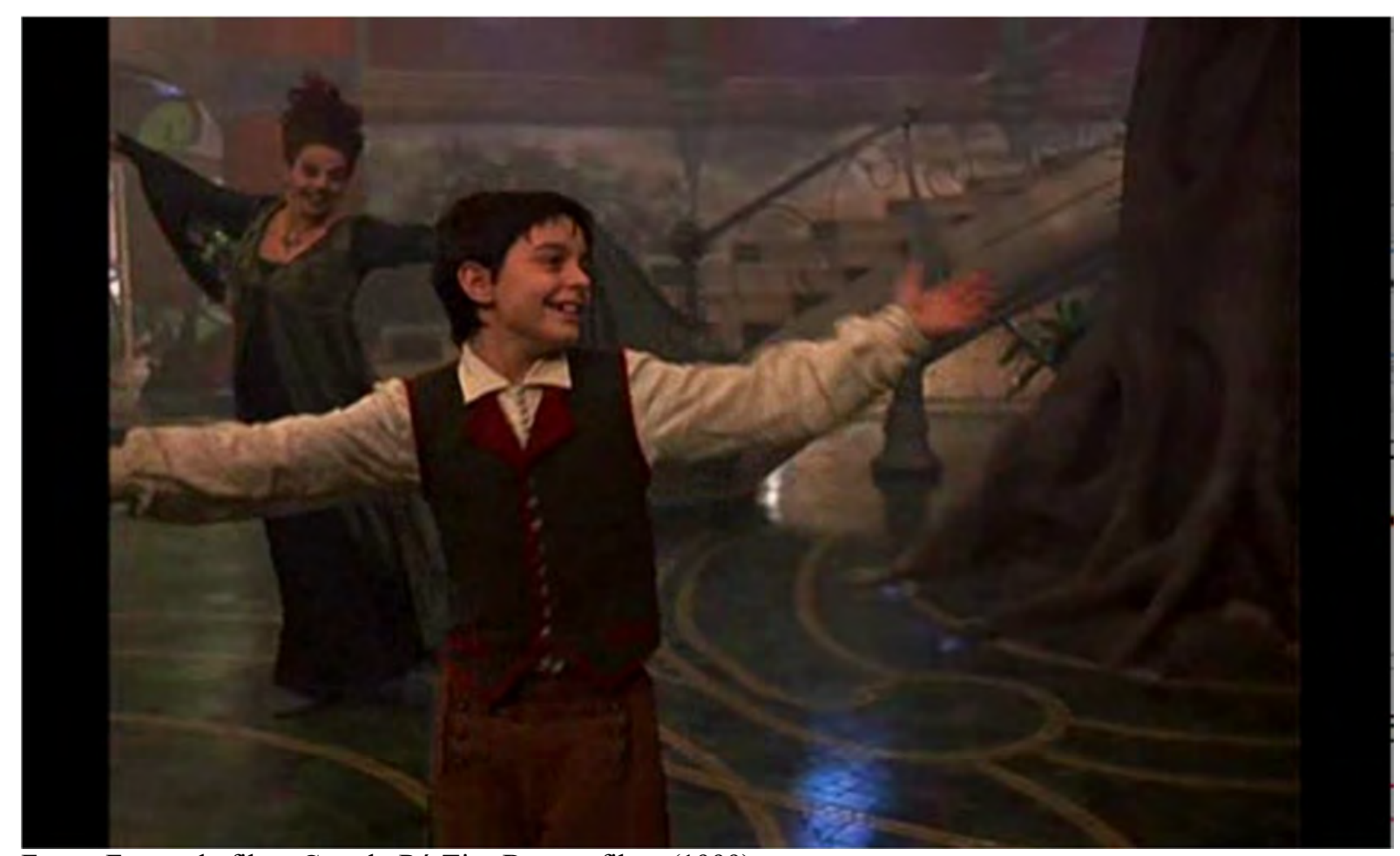

Fonte: Frame do filme Castelo Rá-Tim-Bum, o filme (1999).

A música para quando Morgana lembra que o alinhamento está próximo. A marcação grave dos passos lentos de Nino, em consonância com o tique-taque do relógio, lembra o bruxo de sua tarefa. Quando ele encontra o livro em seu quarto, nova e breve versão da música é ouvida, em fagote e oboé. O efeito de silêncio que se segue enfatiza a expectativa da escrita do livro por Nino.

As cordas do tema ficam mais graves quando, em um trecho mais à frente, Nino vai para o jardim, irritado com a tarefa de escrever seu livro e desejando ser uma criança normal. Ele então vê a pipa presa na árvore e o tema de abertura começa a adquirir as características do 
início do filme. Nino resgata a pipa, conserta-a e a devolve às crianças, e empina sua própria pipa para se aproximar delas. As pipas se emparelham e a música acompanha, em cordas em melodia descendente, a queda delas. As crianças e Nino se conhecem, percebem suas diferenças - ao que a música responde, adquirindo melodias mais graves em madeiras - e a alegria das cordas em golpes de arco volta no clipe musical de quando as crianças o convidam para andar de bicicleta. Após um dia de brincadeiras, Nino volta para casa e a música de abertura retorna em harmonias descendentes, prenunciando o diálogo gradativamente conflituoso de Nino com os tios sobre seus novos amigos, o desejo de ir à escola e a cobrança de Victor pela escrita do livro do pequeno bruxo.

Outras passagens em que o 'tema de Nino' é ouvido compreendem os momentos em que a voz da tia má Losângela descreve o livro a ser roubado pelo Dr. Abobrinha, enquanto na imagem vemos alguém (câmera subjetiva) se aproximando do livro, que se fecha, findando a música - mas é Nino, conforme anunciado pela trilha, que vai pedir conselho ao livro de Morgana; quando esta tenta consertar a mágica desastrada de Nino e o desprende do teto; quando os tios saem para uma conferência e Nino experimenta roupas 'normais' para se disfarçar.

A música adquire um caráter melancólico, com cordas graves e modo menor, no momento em que os tios, percebendo que Losângela roubara o livro de Morgana e seus poderes, encontram o castelo aberto, escuro e abandonado; no momento em que Nino, refugiado em uma árvore, sente-se sozinho, como destaca a lenta melodia de seu tema ouvida em um solo de saxofone; quando seus tios são transformados em marionetes e as crianças os levam para a casa de um deles; no instante em que, no telejornal, a repórter Penélope noticia a proximidade do alinhamento dos planetas. A saudade dos tios diante da fotografia da família o motiva a abrir seu livro e a trilha, com a entrada das madeiras, vai se transformando em uma música mais alegre, que contrasta com o silêncio de quando Nino, enfim, começa a escrever (FIGURA 62).

Figura 62 - Nino escreve em seu livro, motivado a salvar os tios Victor e Morgana 


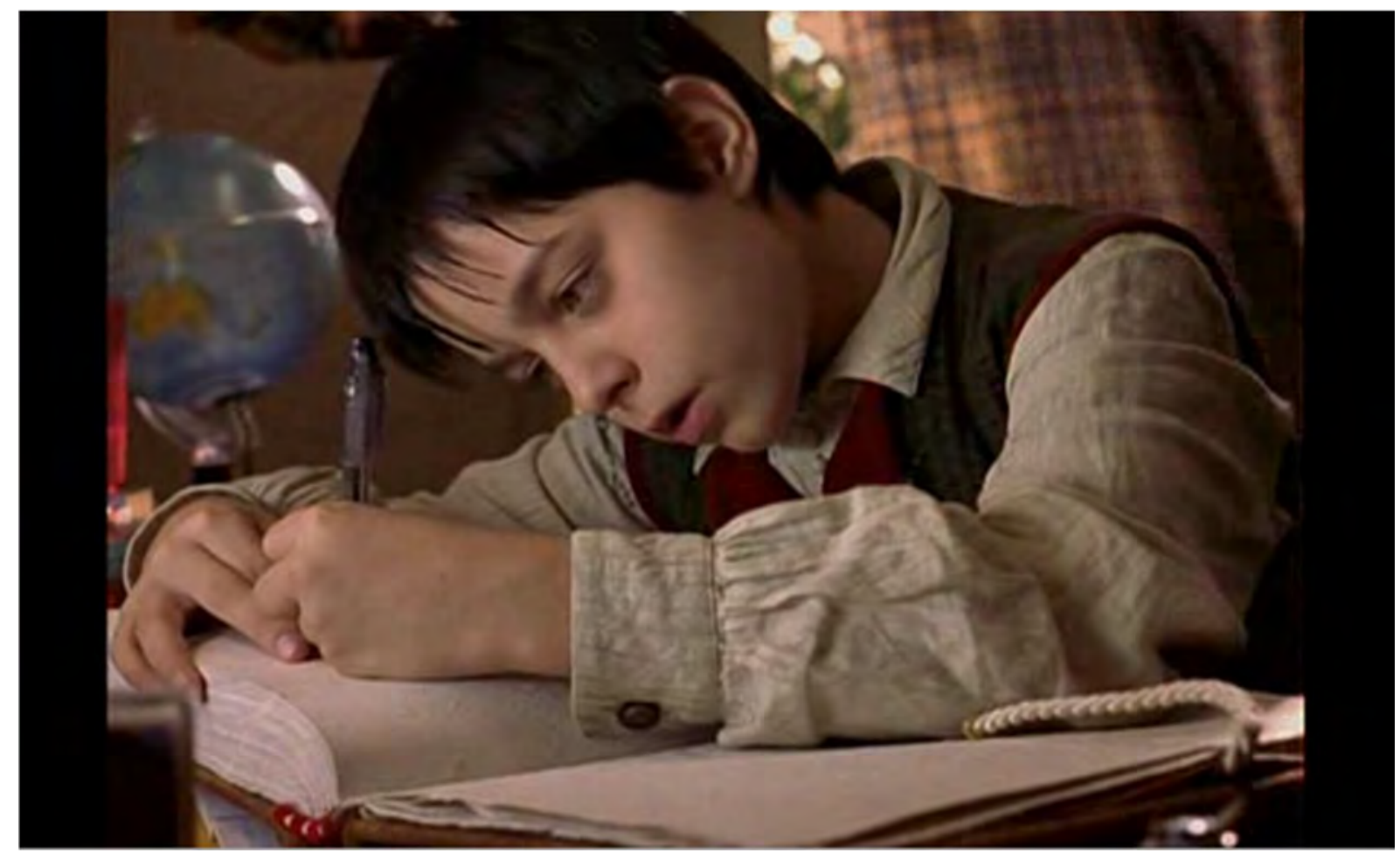

Fonte: Frame do filme Castelo Rá-Tim-Bum, o filme (1999).

A trilha cresce em tensão e dinâmica - cordas graves e agudas em contraponto, que são somadas às madeiras - quando as crianças, com o plano de recuperar o livro de Morgana e desfazer o feitiço de Losângela sobre os tios de Nino, pedalam rumo ao castelo. A melodia reaparece com batidas eletrônicas e harmonia em modo menor no instante em que Losângela faz a lareira onde estão os tios-marionetes queimar, e Nino tenta salvá-los. As batidas cessam quando Dr. Abobrinha consegue segurar o pequeno bruxo.

Novamente suave e executado em cordas agudas e madeiras, o 'tema de Nino' sinaliza, no final do filme, o restabelecimento da harmonia no castelo e a recuperação dos poderes de Victor e Morgana. A música cessa quando Victor pede o livro de Nino - que nele escrevera sem perceber - e volta quando os três bruxos, sob efeitos visuais e sonoros, fazem sua mágica durante o tão esperado alinhamento dos planetas.

Tal como no ensaio do início do filme, a pianola mágica começa a tocar o 'tema de Nino', com a diferença de que todos os convidados do baile fazem a coreografia (FIGURA 63) e a música cresce e reverbera.

Figura 63 - Baile do alinhamento dos planetas, ao som do 'tema de Nino' 


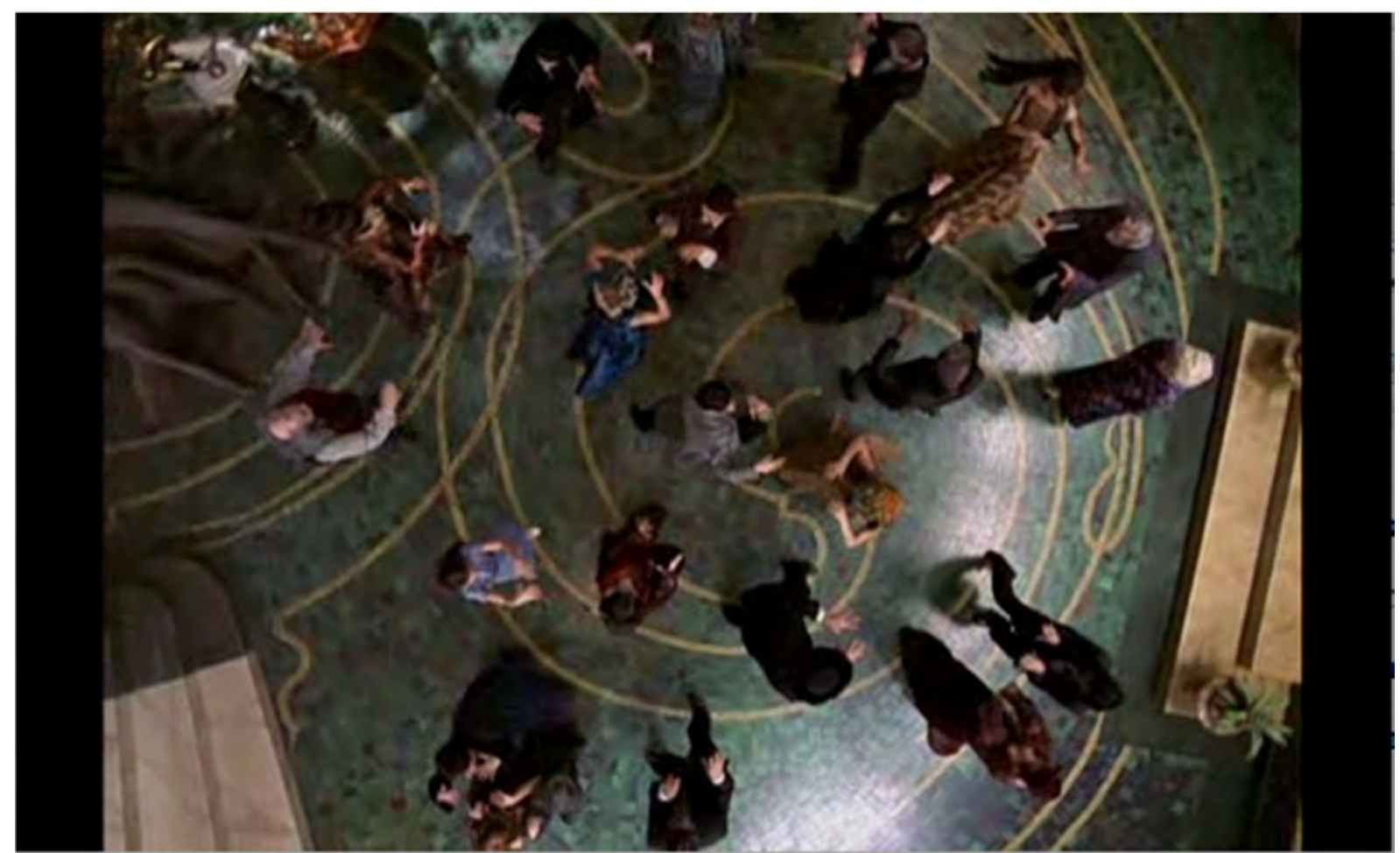

Fonte: Frame do filme Castelo Rá-Tim-Bum, o filme (1999).

A música recua quando a voz over de Nino entra, finalizando a história, e cresce em textura e dinâmica e modulação até o plano geral final do castelo cheio e sua última nota. Nos créditos finais, em novo tom, com batidas eletrônicas e efeitos de sintetizadores, o tema do bruxo soa novamente, com o refrão da Ópera Arepó, mas com as vozes das crianças cantando outras estrofes e falando trechos da letra em rap. Finda a canção, outra música cantada, derivada do 'tema de Nino', é iniciada com cordas, mas se desenvolve em teclados e batida eletrônica, com vozes infantis versando sobre amizade, até o fade out e fim dos créditos.

Outro tema importante do filme, a Ópera Arepó, ou ‘tema do castelo', também é ouvida - em sua versão cantada ou em variações instrumentais - em vários trechos do filme além da sequência de abertura, lembrando-nos da tradição centenária daquela família, de suas peculiaridades e dos mistérios que a envolvem. A música em coro solene soa quando Nino tenta usar seus poderes e cessa com uma explosão, que indica a falha de seu intento, ao ficar preso no teto - o que é consertado pelos poderes da pedra preta de Morgana. Ou quando, após o momento silencioso em que o bruxo aprendiz, refugiado na casa do amigo João, começa a escrever em seu livro (“Como posso salvar meus tios?”), momento em que ouvimos o refrão invertido "muB-miT-áR oletsaC" simultaneamente a efeitos sonoros e visuais de ventania, que fazem com que uma pequena pedra preta caia sobre o livro, revelando a resposta à pergunta.

Nino, com rosto em close up, concentra-se para pegar a pedra preta dentro do espelho. Uma variação da Ópera Arepó em cordas acompanha a progressão de sua ação. Quando ele 
percebe que pode conseguir e sua mão atravessa o espelho, o coro é ouvido novamente e a trilha musical cresce em textura e dinâmica. No instante em que o bruxo, enfim, pega a pedra do outro lado do espelho, ouvimos o coro cantar novamente o refrão invertido e a música modula (FIGURA 64), pontuando um objetivo alcançado pelas crianças em seu plano de salvar os tios do amigo bruxo.

Figura 64 - O primeiro feito de Nino como bruxo é destacado pela Ópera Arepó

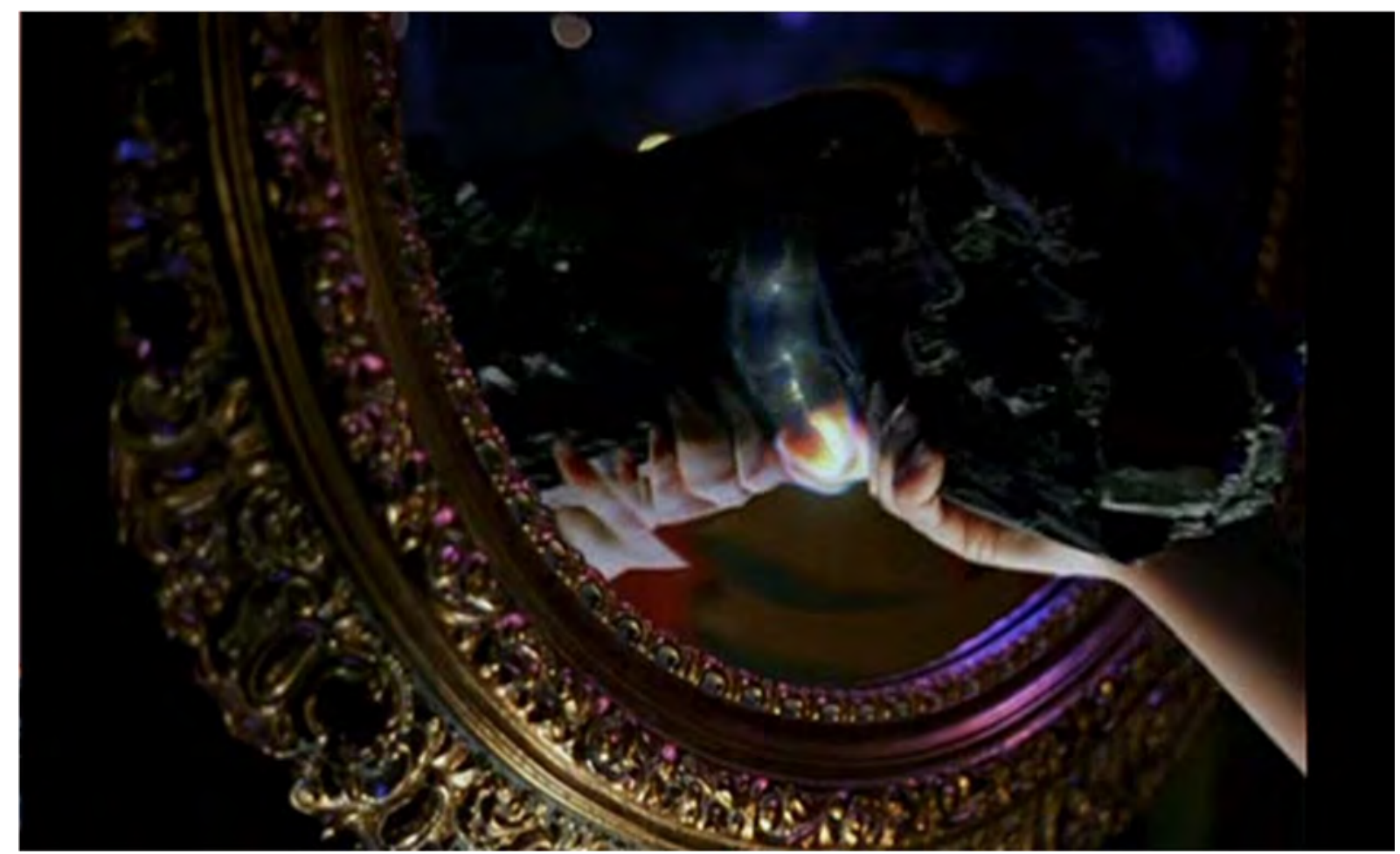

Fonte: Frame do filme Castelo Rá-Tim-Bum, o filme (1999).

Com o tema reduzido a cordas, as curtas notas agudas e as graves contínuas conferem unidade às ações das crianças, que despistam os cachorros de Losângela e conseguem entrar no castelo tomado pela bruxa. Eles se aproximam e o refrão instrumental da música aparece, pontuando mais uma conquista.

A íntegra da canção-tema do castelo coroa o paralelismo da montagem quando Morgana e Victor, transformados em marionetes por Losângela, cantam na lareira (FIGURA 65), como que em um espetáculo, para despistar o distraído Dr. Abobrinha, enquanto Cacau, a amiga de Nino, escreve o feitiço no livro de Morgana para que os poderes de Losângela sejam eliminados.

Figura 65 - Da lareira, Morgana e Victor, transformados em marionetes, cantam a Ópera Arepó e distraem Dr. Abobrinha 


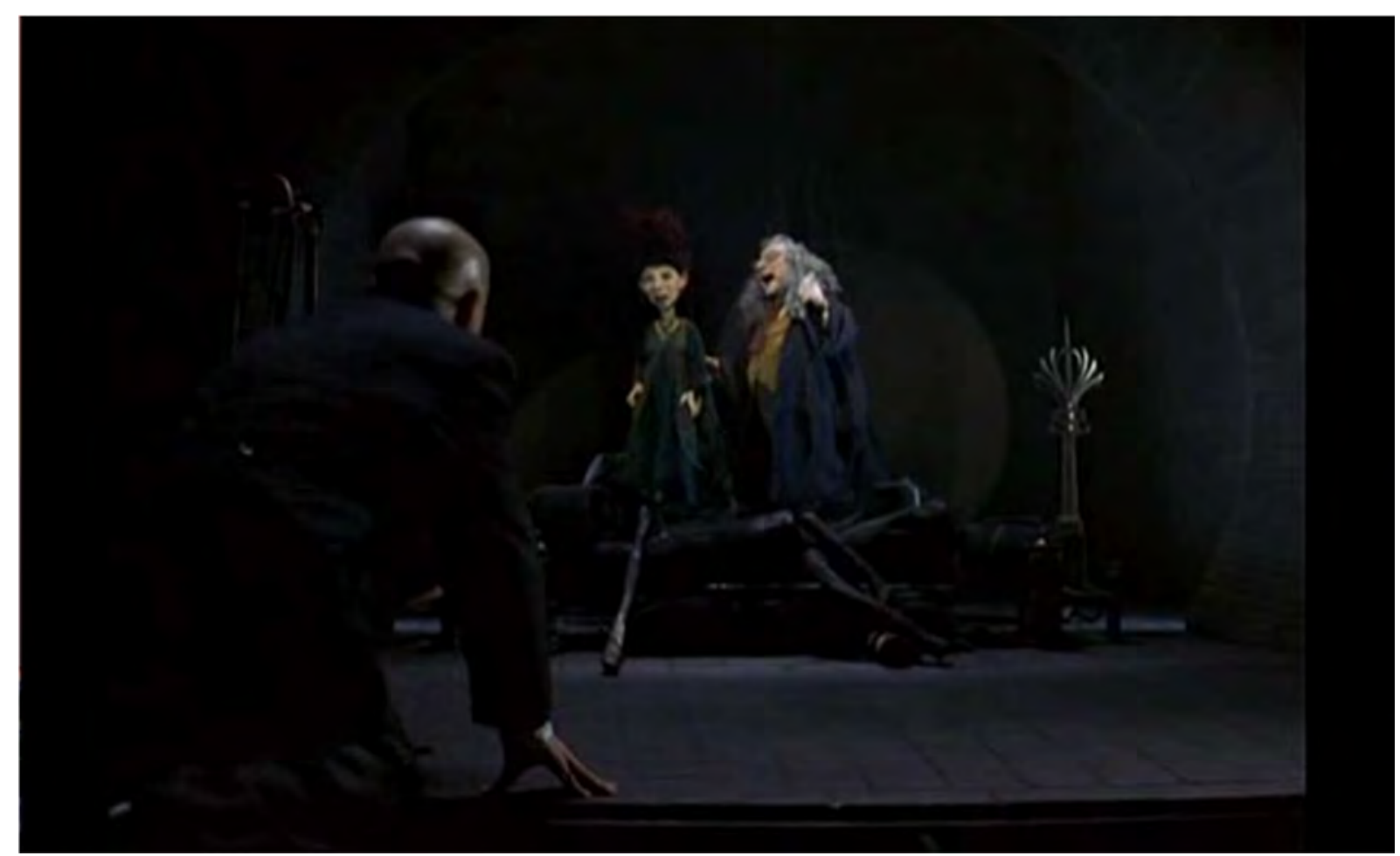

Fonte: Frame do filme Castelo Rá-Tim-Bum, o filme (1999).

Do andar superior, após levar um escorregão, Losângela observa os bonecos cantando e Nino se esconde. A música cessa com a magia de Losângela, que faz a lareira queimar, colocando em risco a 'vida' das marionetes.

Os temas musicais dos vilões Losângela e a dupla Dr. Abobrinha e Rato guardam, entre si, uma diferença crucial: o primeiro é pesado e basicamente composto de notas contínuas, graves e semitonadas ${ }^{61}$ - enfatizando o poder maligno que ela quer recuperar e os traços vingativos da personagem, prima de Morgana banida da família Stradivarius -, enquanto o segundo, leve, cômico e feito de notas curtas e agudas em instrumentos de sopro, demonstram o caráter verborrágico e irritante de suas sempre fracassadas iniciativas. Quando os vilões se aliam ou se encontram, os temas se misturam em instrumentação e arranjos, reforçando a união de forças contra a família Stradivarius e, ao mesmo tempo, os diferentes objetivos (e timbres) de reaver os poderes mágicos (Losângela) e derrubar o castelo para construir o edifício Pompeu Tower Center (Dr. Abobrinha).

As quatro notas do tema de Losângela - si bemol, si bemol, lá, dó bemol, si bemol - são reveladas em cordas, madeiras e anunciadas com grave percussão, quando os sapatos da bruxa tocam, em close up, o chão da cidade (FIGURA 66).

\footnotetext{
${ }^{61}$ Nas escalas tonais ocidentais, o intervalo de um tom é dividido em dois semitons. Assim, entre as notas dó e ré temos o dó sustenido. O intervalo entre o dó e o dó sustenido é de um semitom - o mesmo verificado entre o dó sustenido e o ré, guardada a diferença das alturas das notas.
} 
Figura 66 - Tema de Losângela é apresentado antes que ela revele sua face

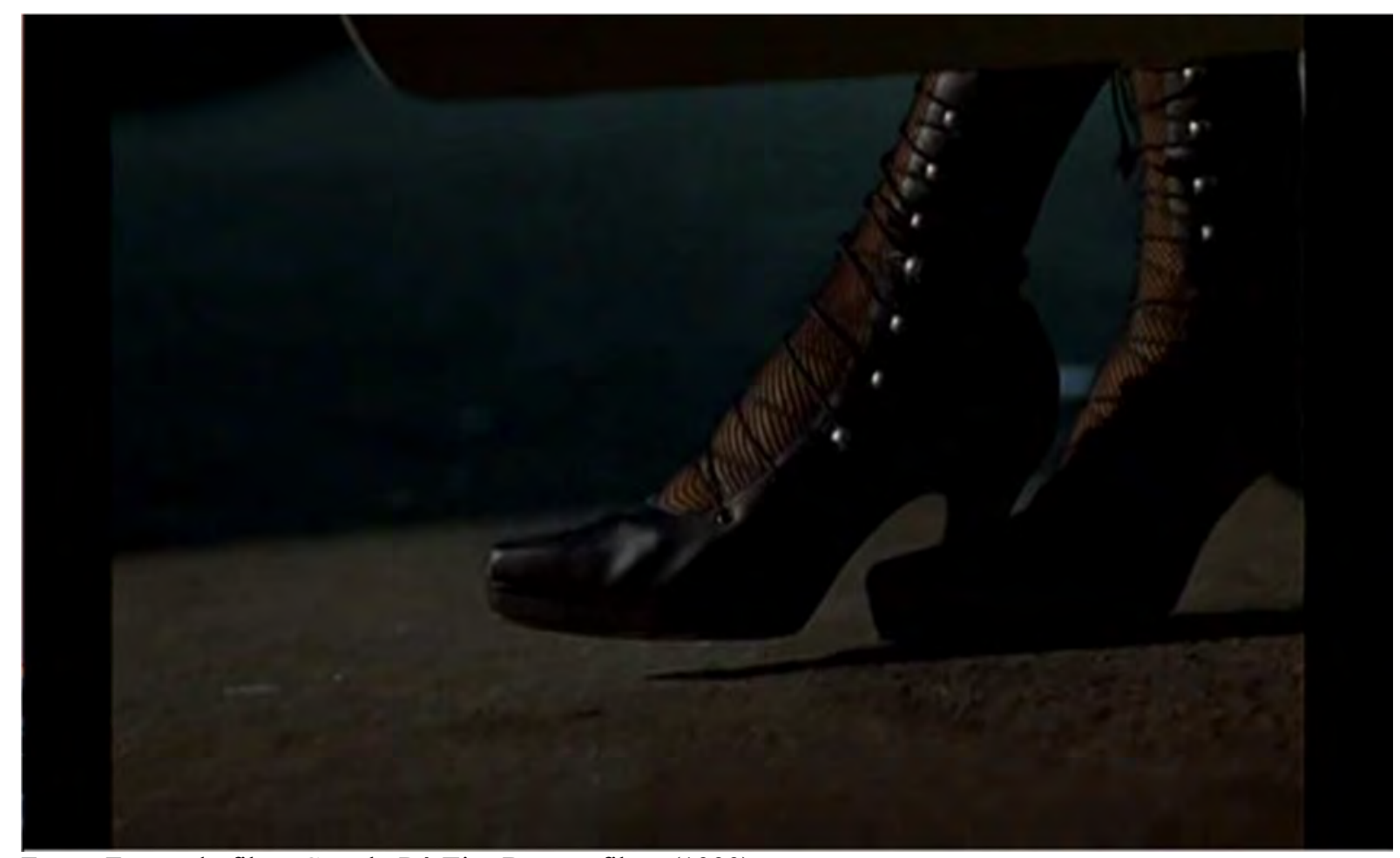

Fonte: Frame do filme Castelo Rá-Tim-Bum, o filme (1999).

Ao peso da música e da entonação grave, lenta e misteriosa da voz da bruxa - seu rosto não é revelado - contrapõem-se os latidos estridentes e agudos de seus pequeninos cachorros pinscher, os recorrentes e familiares grasnados de sua gralha e o sotaque brejeiro e carregado do recepcionista do hotel de qualidade duvidosa onde ela se hospeda, interpretado por André Abujamra.

A presença da bruxa, interpretada por Marieta Severo, na cidade é informada ou substituída pelo seu tema musical em vários momentos da trama: quando algum personagem menciona o nome dela, as quatro notas de seu tema são ouvidas. Ou quando, por exemplo, Morgana, bruxa de poderosa intuição, diz a Victor que está sentindo aquela "coceirinha na orelhinha esquerda", a melodia grave do tema é ouvida. Victor, que estava de partida, para no final da escada, preocupado. Em close up, os dois se olham, e, ao pronunciarem, ao mesmo tempo, o nome da bruxa má, ouve-se um grito reverberado, ao passo que o fogo sobe na lareira, confirmando suas suspeitas. Aqui os efeitos sonoros e visuais contribuem para potencializar o peso da trilha e demonstrar as maldades de que Losângela é capaz. 
Quando a bruxa má revela seu rosto a Dr. Abobrinha e Rato, na primeira reunião dos vilões no quarto do hotel, a aproximação da câmera é acompanhada por arpejos ascendentes em cordas, pontuando a revelação da identidade da bruxa (FIGURA 67).

Figura 67 - Arpejos enfatizam a revelação da identidade de Losângela

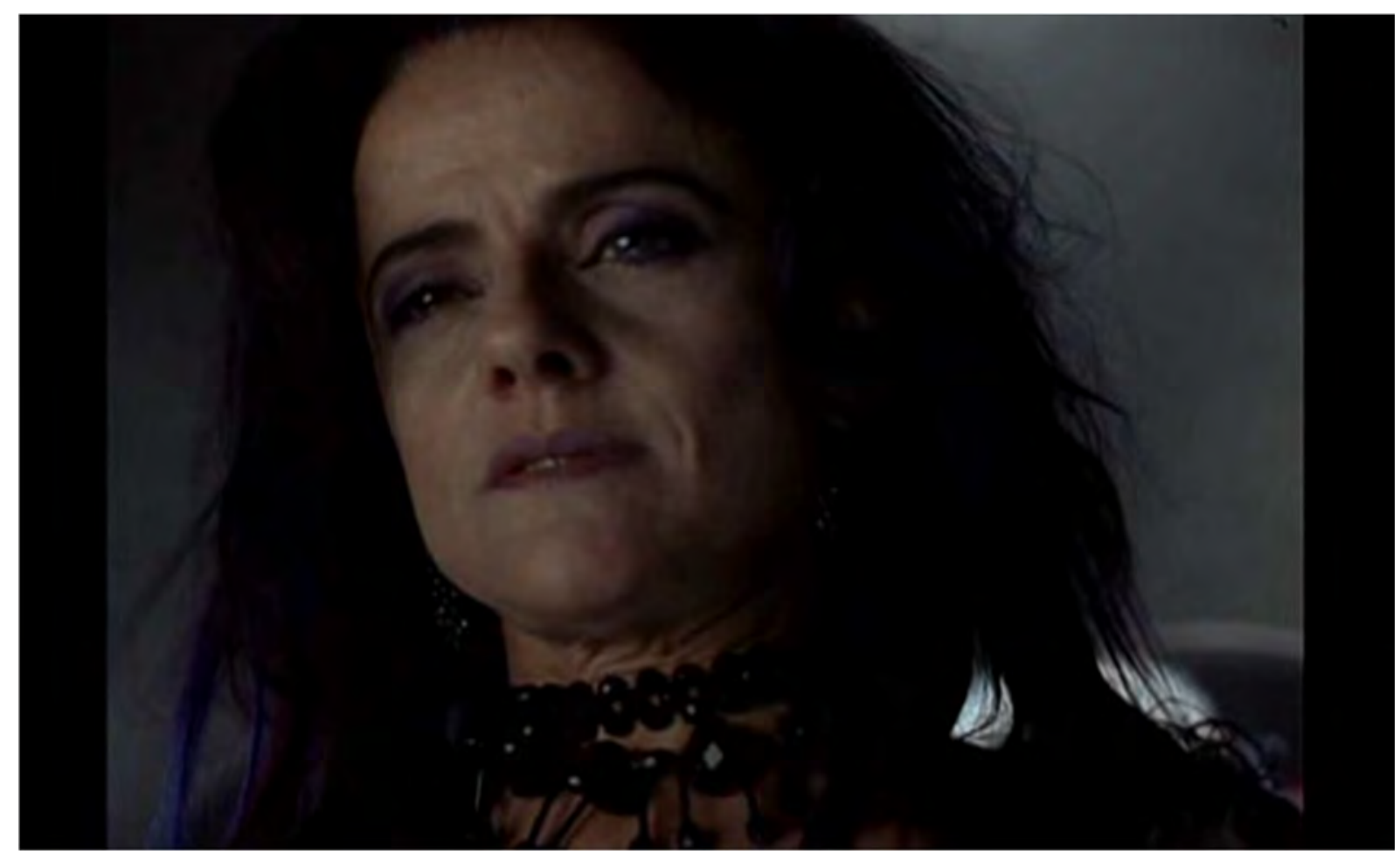

Fonte: Frame do filme Castelo Rá-Tim-Bum, o filme (1999).

Ela profere seu sobrenome e a melodia do tema é novamente ouvida, sob as manifestações sonoras da gralha, pinschers e trovões. O tema da bruxa é repetido pelo fagote, pelo oboé e pela flauta, instrumentos usados no tema de Pompeu e Rato, que ouvem sua história e proposta: ela lhes promete o castelo e o cargo de prefeito a Dr. Abobrinha, em troca do livro de poderes de Morgana. O pacto é firmado com os três fincando a faca nas cartas sobre a mesa, sob o som intenso e grave de trovões.

O tema da bruxa soa em madeiras quando Losângela está com o livro de Morgana em mãos. Ela abre o livro, esquece algumas palavras, a magia não dá certo e a música é interrompida em som e imagem por um problema no encanamento do banheiro (humor). Os efeitos sonoros, visuais, sua voz reverberada e o crescimento do tema em dinâmica e altura demonstram que, na segunda tentativa, ela recupera seus poderes. A cena mistura o humor provocado pelo pânico dos vilões cômicos, pela atenção dos bichos de estimação da bruxa ao fenômeno, pelo cabelo armado de Losângela e o suspense ocasionado pela atuação grandiosa e 
malévola da bruxa, enfatizada pela entrada de um coro na música. A conclusão da magia é marcada por uma melodia descendente das madeiras e se finaliza com as cinco notas de seu tema (FIGURA 68).

Figura 68 - Losângela reouve seus poderes ao som de seu tema musical

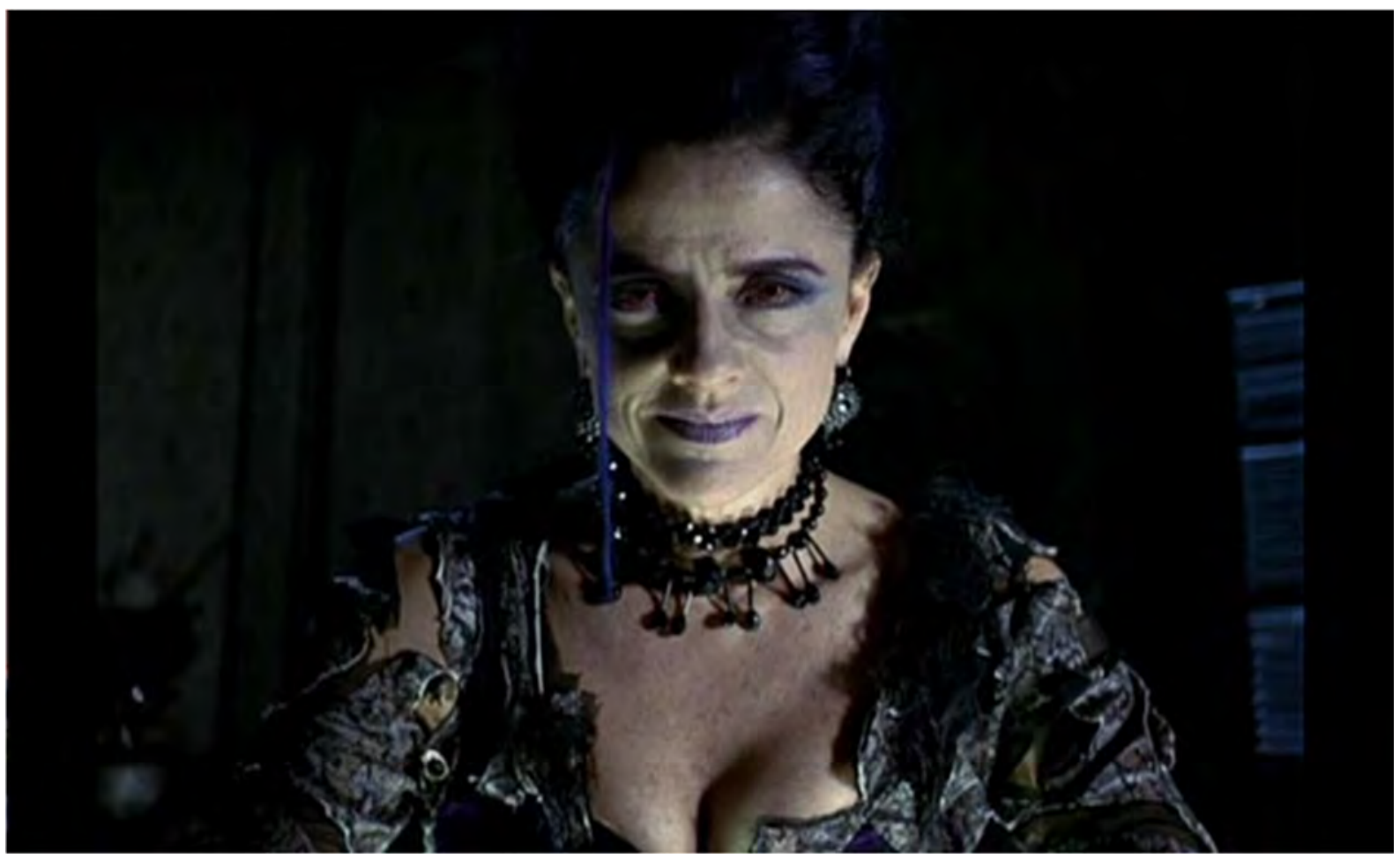

Fonte: Frame do filme Castelo Rá-Tim-Bum, o filme (1999).

Estas precedem também a entrada de Losângela no castelo, onde estão Morgana e Victor, sem poderes. O encontro das primas é marcado por uma música de violinos e flautas em suspensão. Cordas graves acompanham Losângela em sua análise pejorativa do castelo. As bruxas discutem, mostrando seus ressentimentos. A música é interrompida quando todos os personagens da cena mandam Dr. Abobrinha se calar (humor). Nino observa tudo do andar superior, o que é revelado em planos curtos em close up.

Há comicidade também enquanto Losângela, cantarolando com voz esganiçada, observa o relógio e se prepara para o alinhamento dos planetas, enquanto as marionetes de Morgana e Victor observam, da lareira, as crianças atuando para recuperar o castelo. O naipe de madeiras é ouvido no tema combinado às cordas quando o ratinho de brinquedo de uma das crianças assusta a bruxa e ela começa a gritar, mas acaba quando Dr. Abobrinha mostra que ele é inofensivo. Uma das crianças se revela, ao som do tema da bruxa, que ganha progressões melódicas em cordas e madeiras e um ritmo de aventura (dinâmica e textura), retornando, sem 
o caráter cômico, enquanto ela transforma a criança em rato. A bruxa escorrega quando consegue se aproximar de Nino e seu tema é novamente ouvido, em madeiras (humor). Ao final, a expulsão da descabelada e desempoderada Losângela, Dr. Abobrinha e Rato do castelo ocorre sob as batidas eletrônicas novamente incorporadas à música.

Já o tema cômico de Dr. Abobrinha (Pompeu Pomílio Pomposo) e seu capacho Rato representados, respectivamente pelo fagote e pela flauta executando notas curtas em contraponto - aparece pela primeira vez no filme quando, ainda nas sequências iniciais, eles vão ao castelo e são recebidos com formal hostilidade pelos porteiros (estátuas mágicas). Ouvindo que o castelo não está à venda, Rato desiste e vai saindo, mas Pompeu insiste. As estátuas falantes ativam magicamente o sistema de irrigação do jardim e, ao som do tema da dupla de vilões, são acrescidas dinâmica e textura com a inserção de uma rápida batida eletrônica que os acompanha em retirada, sob os risos graves e estrondosos das estátuas. Cordas em escalas descendentes e ascendentes e percussão grave, também adicionadas ao tema, marcam a queda dos vilões na fonte do jardim. O tema retoma seu original caráter soturno e cômico quando, já fora das dependências Stradivarius, Pompeu promete voltar ("Este castelo será meu!") (FIGURA 69).

A música dos vilões aparece conjugada à sua aparição na imagem: quando estes, assistindo, escondidos, Nino se despedir de seus amigos, descobrem que ele quer estudar na mesma escola que as demais crianças, por exemplo. Disfarçados de diretor e inspetor de escola, Dr. Abobrinha e Rato esperam Nino ficar sozinho no castelo e o visitam, também ao som do tema, sob o pretexto de verificar se ele pode estudar com seus amigos, para roubar o livro de Morgana. Sob os gritos inconformados da capa do livro indefeso - Nino fora despistado -, os ladrões o levam enquanto a música prossegue.

Figura 69 - Ao som de seu tema, Dr. Abobrinha é expulso do castelo no início do filme 


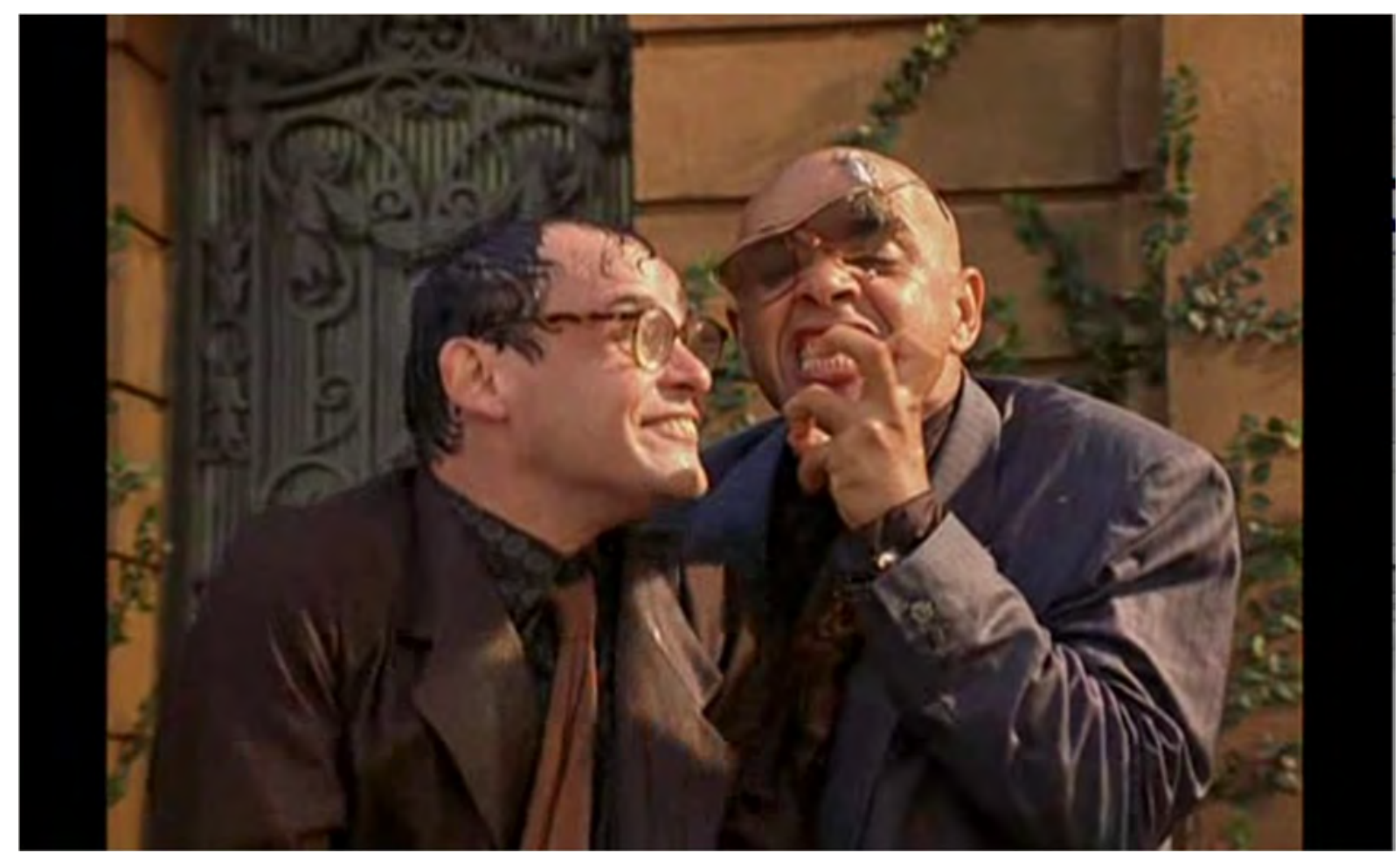

Fonte: Frame do filme Castelo Rá-Tim-Bum, o filme (1999).

No jornal a manchete anuncia Dr. Pompeu como o novo prefeito da cidade, ao som do mesmo tema. Victor e Morgana, sem poderes e sem música para embalar suas ações no castelo, são surpreendidos pela presença do novo prefeito, cuja entrada, acompanhada do assessor Rato e de seus seguranças, é tão brusca quanto a de sua trilha, momentaneamente vigorosa e séria, digna do cargo assumido (FIGURA 70).

Eles entregam uma ação de despejo a Victor: a música se reduz a cordas e ralenta para demonstrar a impotência dos Stradivarius ante a perda do castelo. Quando Losângela volta atrás na promessa de dar o imóvel a Pompeu, ouvimos o tema da bruxa; quando ela sobe para seus novos aposentos às gargalhadas, volta o tema cômico dos vilões, que continuam sonhando com a impossível tomada do castelo.

O tema retorna quando Dr. Abobrinha verifica o telescópio, aguardando o alinhamento dos planetas no castelo. As cordas que pontuam as ações das crianças continuam por toda a sequência e são simultâneas às breves intervenções de outros temas à medida que os vilões aparecem ou saem de quadro. No momento em que Pompeu sobe as escadas, por exemplo, as crianças se escondem, enquanto se ouve o tema dos vilões.

Figura 70 - Novo prefeito Dr. Abobrinha surpreende bruxos sem poderes 


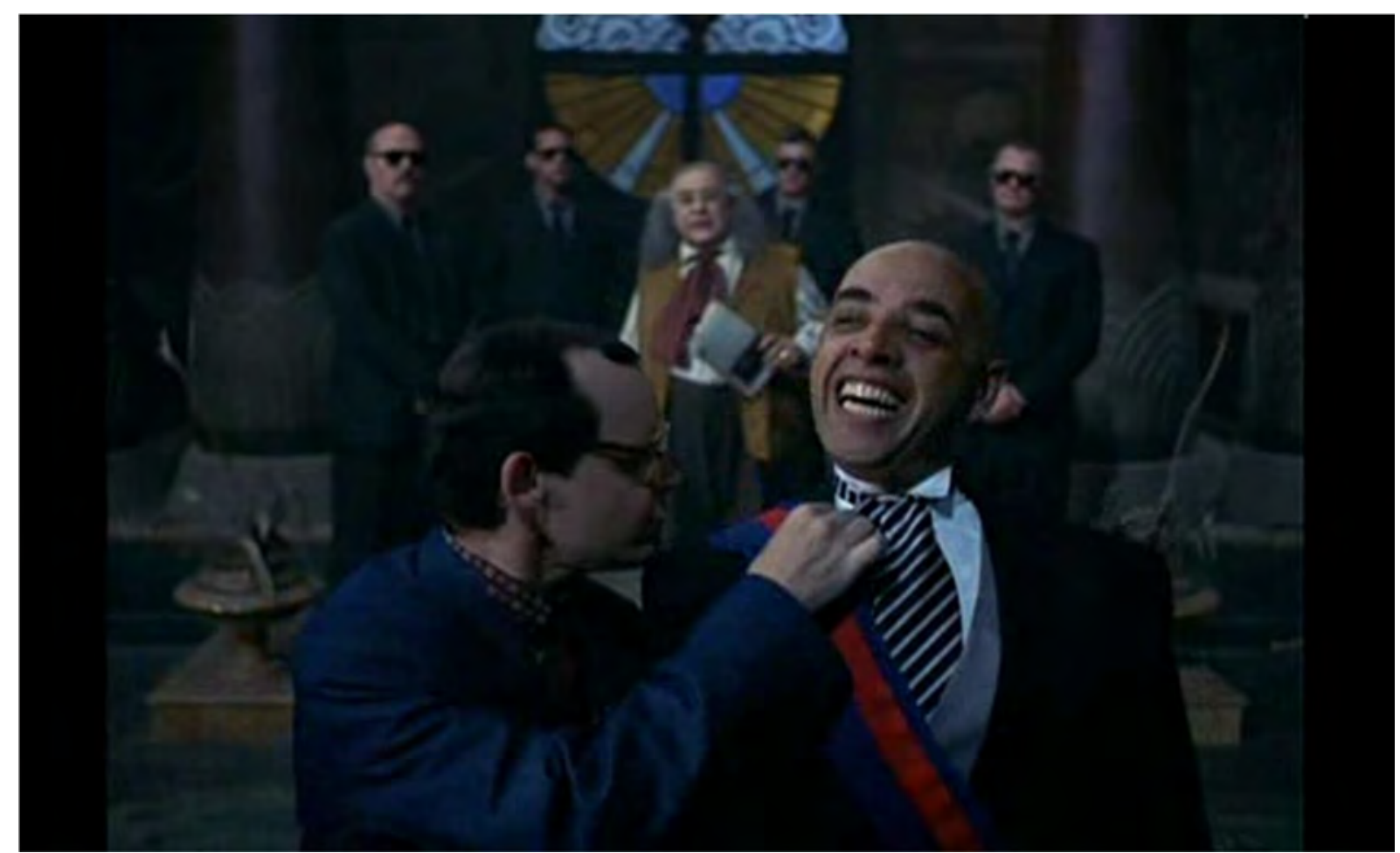

Fonte: Frame do filme Castelo Rá-Tim-Bum, o filme (1999).

Três personagens coadjuvantes também possuem um tema musical. São Mau, Sujo e Feio, os monstros que vivem no encanamento do castelo. Do quarto, Nino, ensaiando escrever seu livro de poderes, ouve o som dos monstros chegando pela tubulação, fora de quadro. A chegada dos monstros é acompanhada, fora da diegese, de um misto de jazz e funk com guitarra, contrabaixo elétrico e bateria acelerados, além de alguns efeitos vocais roucos de black music (FIGURA 71). Eles incentivam Nino a escrever seu livro e o pequeno bruxo os fecha na tubulação, o que faz cair uma vassoura - segundo os monstros, sinal de mau presságio e da chegada de alguém (Losângela).

Breves passagens musicais pontuam ações específicas ou colaboram na transição entre sequências. Um “Ooooh" cantado em notas constantes de um coro pontua as imagens do título do filme e o nome do diretor Cao Hamburger, lembrando o espectador que, apesar da familiaridade com a série televisiva, há um caráter misterioso e até sombrio na história que está por vir. O mesmo recurso aparece na abertura, na fuga das crianças cuja presença no jardim é notada pelos bruxos; ou quando a câmera enquadra a manchete do jornal que Losângela tem em mãos, sobre a construção da torre mais alta do mundo na cidade.

Figura 71 - Mau, Sujo e Feio conversam com Nino, ao som de seu próprio tema 


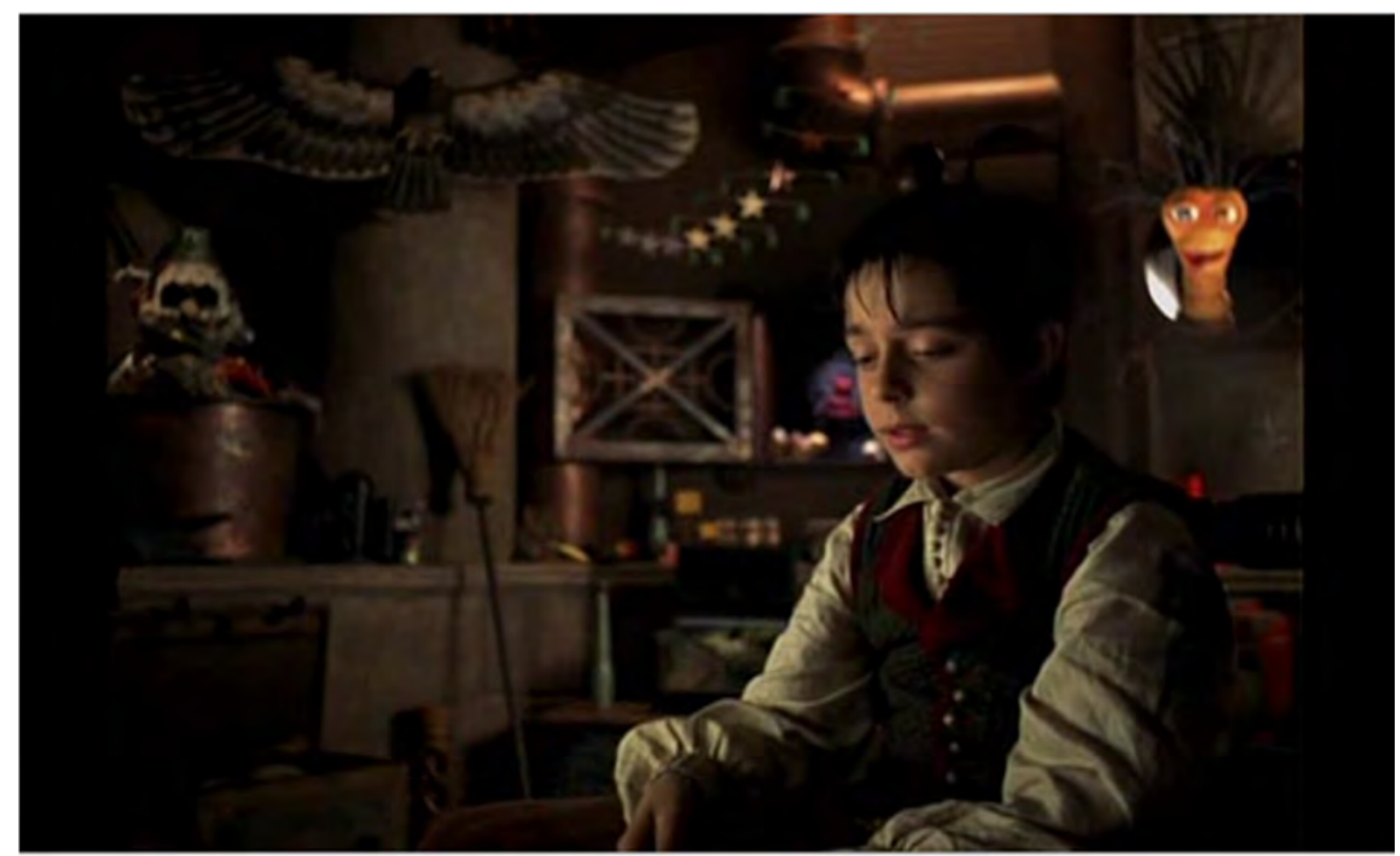

Fonte: Frame do filme Castelo Rá-Tim-Bum, o filme (1999).

Em outra passagem Victor explica o fenômeno do alinhamento dos planetas a Nino, quando se ouve uma valsa leve, em fagote e cordas mais graves. À medida que os efeitos visuais acontecem - os planetas da maquete se descolam e sobrevoam a sala -, a música cresce em altura e textura (FIGURA 72), sendo interrompida quando Victor pergunta a Nino sobre seu livro.

A intuição de Morgana, materializada na "coceirinha na orelhinha esquerda", é pontuada por cordas graves e arritmadas, tanto quando a bruxa está no castelo e sente a presença da prima má na cidade - momento em que ouvimos também o som da gralha ressoar dentro do castelo - quanto na cena da conferência de Victor, momento em que Morgana sente a mesma coceira e a passagem musical é novamente ouvida. A música adquire novas texturas - ora teclados, ora percussão - conforme o incômodo de Morgana cresce.

A pedido dos tios, já transformados em marionetes, Nino foge com seu livro, em nova passagem musical de suspense em golpes de cordas espaçados e notas graves constantes em madeira. Na perseguição que sofre dos cães de Losângela - pinschers transformados em rottweilers (humor) -, a música se torna veloz e mais intensa, aumentando o suspense. Quando ele consegue fugir, as notas altas pontuam este feito.

Figura 72 - Victor explica o alinhamento dos planetas a Nino 


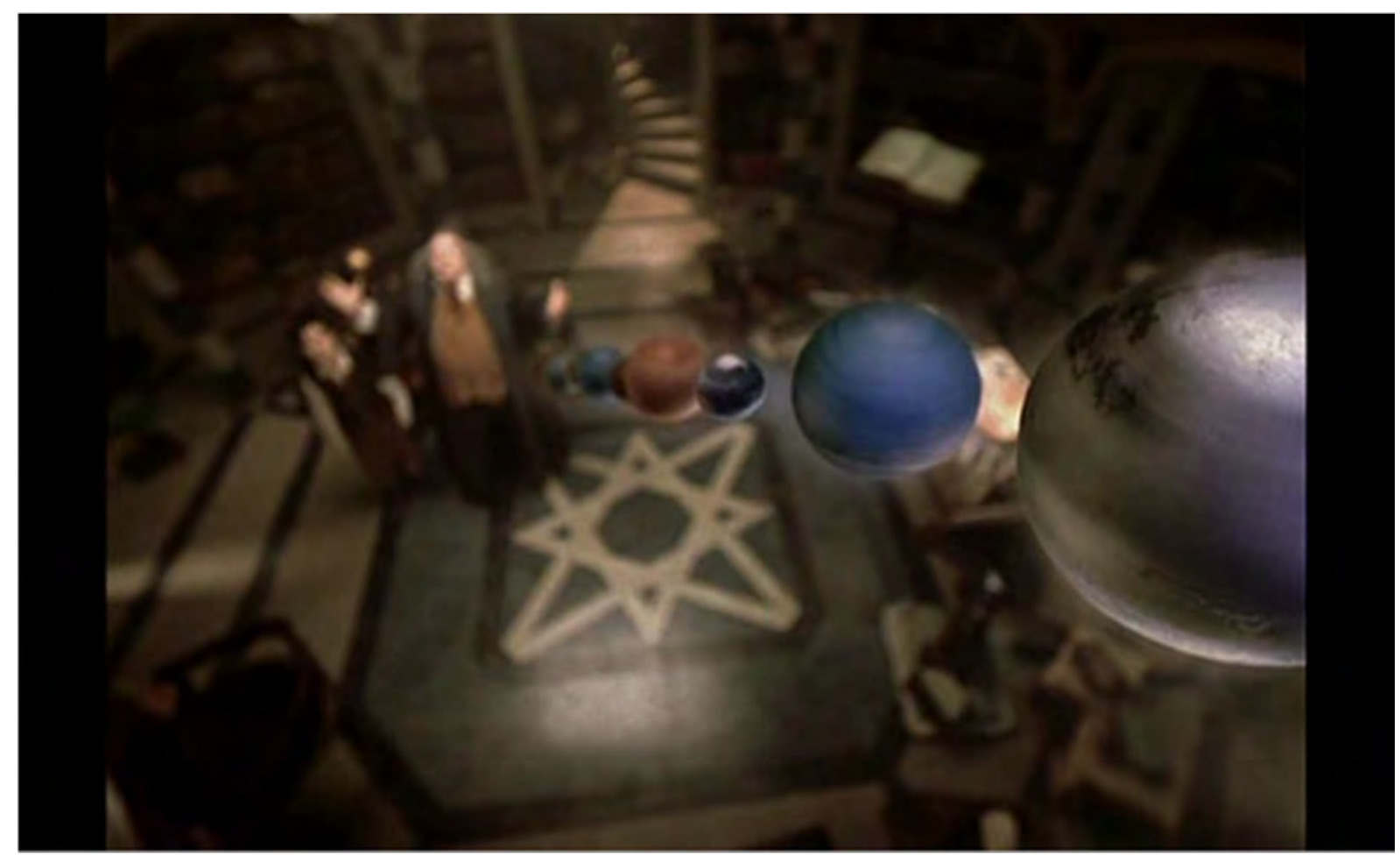

Fonte: Frame do filme Castelo Rá-Tim-Bum, o filme (1999).

Também ganham breves passagens musicais instrumentais o dia de Nino como uma criança 'normal', na casa de João - quando uma trilha frenética de notas curtas em madeiras pontua a cena acelerada e termina com a notícia do alinhamento dos planetas no telejornal; o plano de salvamento dos tios do bruxo e do castelo pelas crianças - quando cordas e madeiras graves e agudas se unem à caixa percussiva ('plano de combate'), à medida que as ideias se desenvolvem.

Como uma extensão dos diálogos, os temas vinculados a personagens se misturam à medida que os encontros entre eles acontecem, evidenciando não apenas as características de cada um para além da imagem, mas como eles se relacionam para além dos gestos visuais e das falas. Na biblioteca do castelo, por exemplo, o 'tema de Nino' e o dos vilões cômicos se misturam em melodia e instrumentação, em ritmo mais acelerado, à medida que a busca pelo livro de Morgana pelos ladrões se torna frenética.

No momento do alinhamento dos planetas, os temas de Nino e do castelo (Ópera Arepó) também se alinham (FIGURA 73), com a entrada do coro e o aumento da dinâmica e da textura musical, que passa a misturar as letras da ópera à harmonia e melodia do 'tema do bruxo aprendiz'.

Figura 73 - Alinhamento dos planetas e dos temas de Nino e do castelo (Ópera Arepó) 


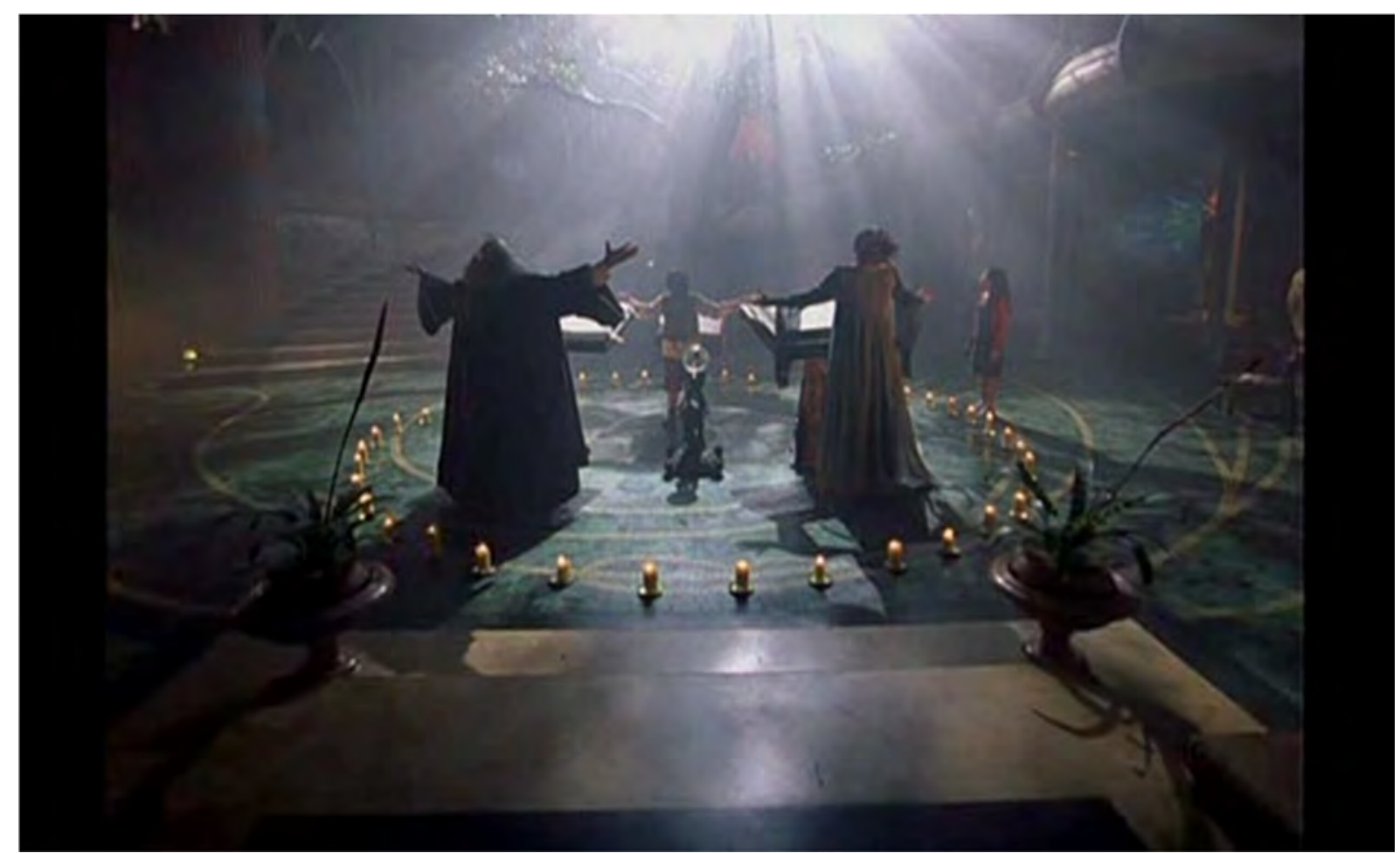

Fonte: Frame do filme Castelo Rá-Tim-Bum, o filme (1999).

Cordas graves e sinos enfatizam o alinhamento acontecendo, a música ganha sopros agudos, enquanto os bruxos olham para o céu, de braços abertos, sob o encanto das crianças humanas. O coro volta com o refrão do 'tema do castelo' sobre o 'tema de Nino', peça fundamental para a vitória do Bem e restabelecimento da harmonia inicial da trama.

A música recua em volume e continua, dando espaço para a continuidade da voz over de Nino, que conta sua história e a escreve no livro. A trilha musical cessa com Nino terminando a escrita. Ao se despedir do livro, a música do castelo, em madeiras graves, é ouvida simultaneamente às cordas, com a melodia do 'tema de Nino'.

Os efeitos sonoros se relacionam diretamente com a trilha musical: no final do filme o som de ventania marca o retorno do tema do castelo, de forma mais lenta, mostrando a suntuosidade do lugar, a nobreza da família que o habita e pontuando a conclusão da história, sob as danças, em câmera lenta, dos convidados, enquadrados ora em close, ora em planos gerais aéreos.

A gralha também possui uma importante função narrativa no som. Em meio a sons de trovões e sirenes de polícia, o som acusmático da ave confirma o endereço da vidente (Losângela disfarçada) para Pompeu e Rato, que buscam o hotel indicado pelo panfleto deixado pela mesma gralha. O pássaro aparece na sacada (FIGURA 74), em primeiro plano, tendo a cidade embaixo de si. Os vilões entram no edifício e sobem ao encontro da bruxa má, sob o som do ambiente urbano misturado a cordas agudas descendentes (submundo onde os violões 
se encontram). Em outro momento a aparição sonora da gralha reverberando no interior do castelo indica a preocupação de Morgana, que intui que algo terrível está para acontecer.

Figura 74 - Gralha, cujo som sinaliza a chegada de Losângela

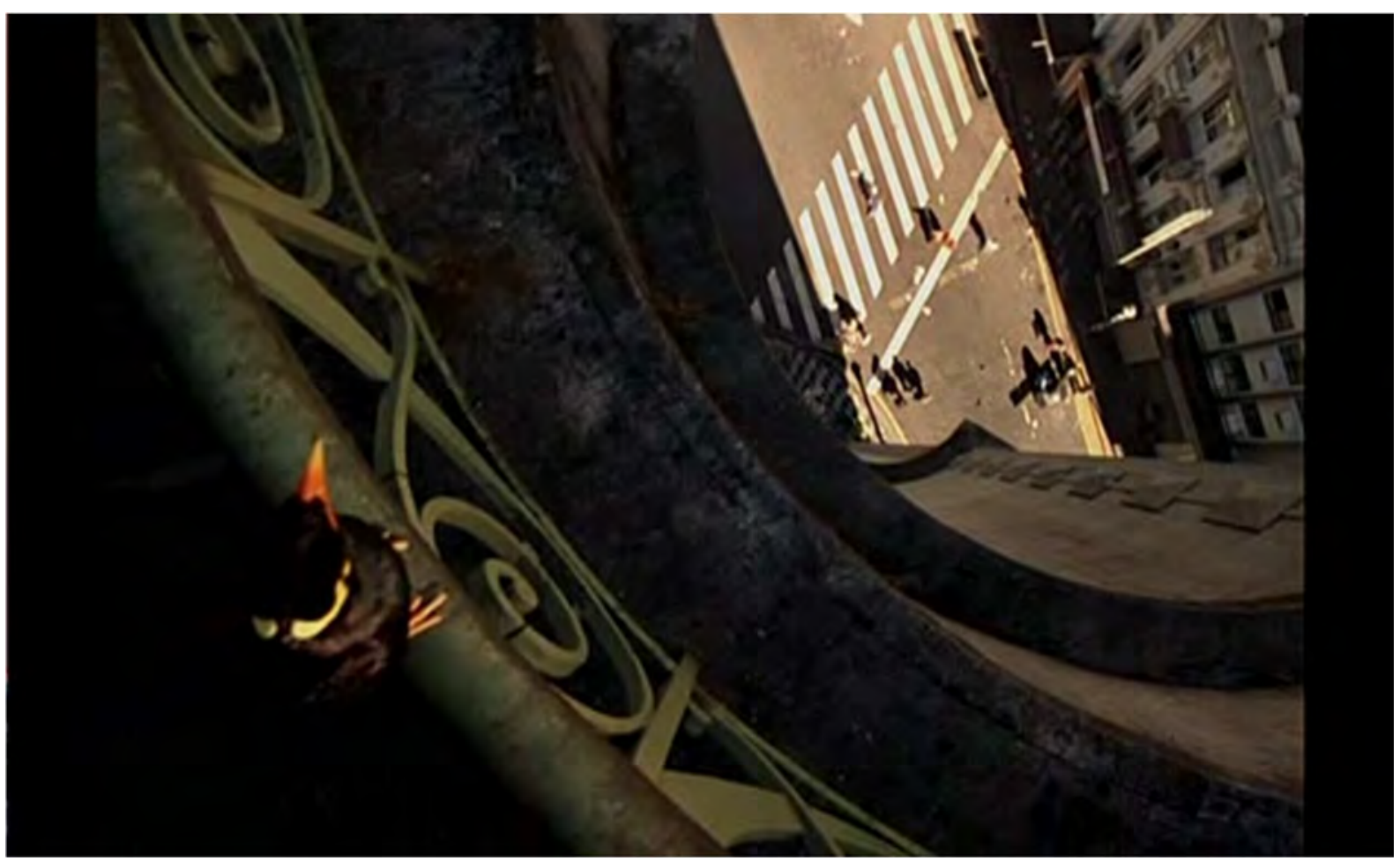

Fonte: Frame do filme Castelo Rá-Tim-Bum, o filme (1999).

Com pouco espaço na trama, os efeitos de silêncio ou de grande diminuição de textura sonora (com a ausência de música e/ou efeitos) ocorrem em pequenos instantes que antecedem falas cruciais para a compreensão da história. Isso acontece, por exemplo, para criar expectativa no momento em que Nino abre o livro para escrever, mas não sabe por onde começar; ou quando ele vai ao encontro dos tios transformados em marionetes, que recomendam que ele fuja; ou para enfatizar o estranhamento da família de um dos seus amigos quando o pequeno bruxo surge para tomar o café da manhã. A música e os efeitos também estão ausentes quando Losângela constata sua vitória sobre os bruxos-marionetes, no momento em que as crianças elaboram o plano para tirar os poderes da feiticeira má e quando Victor, no final do filme, pede para ver o livro de Nino.

Ainda sobre silêncio, Camargo avalia o resultado da composição dele e de Abujamra:

Hoje eu penso que no Castelo tem muita música; hoje eu colocaria menos música no filme, eu batalharia por isso nas reuniões de briefing. Penso hoje que o silêncio também é muito importante. Mas, ao mesmo tempo, quando ouço a trilha do filme, 
fico satisfeito, penso: "como eu fui capaz de fazer isso, fui eu mesmo?" (CAMARGO, 2016).

Presente durante quase a totalidade da obra, a trilha musical respeita as convenções do cinema clássico narrativo, sendo vinculada a personagens, apresentando protagonistas e antagonistas, antecipando informações ou substituindo elementos visuais, além de se configurar como um significante de emoções - frequências agudas e ritmo veloz em momentos de alegria ou ação; notas graves e ritmo lento acompanhando os momentos de medo e mistério.

A música também sofre diversas variações de textura e 'humor' no decorrer da narrativa (leitmotiv) e, em combinação com efeitos e foley, pontua cada movimento dos personagens em situações específicas (mickeymousing, quando Nino tenta abrir o livro de Morgana, fazendo cócegas na capa); imprime dinâmica às passagens de tempo (quando as crianças brincam na rua) e às ações dos personagens - acrescidas de ritmos eletrônicos nas cenas de fuga ou expulsão do castelo. Ela também respeita a supremacia da voz over de Nino - que abre e fecha o filme e dos diálogos entre os personagens humanos e não humanos, o que demonstra a busca pela clareza narrativa, não apenas por meio da linguagem cinematográfica, mas, sobretudo, da palavra - cujo conteúdo provavelmente supõe uma melhor compreensão pelo público infantil -; e todas as demandas gestuais (criativas e interpretativas) de entonação, combinadas à direção de arte (figurino, maquiagem), de uma narrativa fantasiosa.

Muitas vozes diferentes de personagens humanos e não humanos, principais e secundários, convivem com os diversos efeitos sonoros decorrentes tanto dos feitiços realizados pelos bruxos dentro do castelo quanto das estratégias narrativas para a sinalização da chegada de novas informações, conforme analisado. Assim, diálogos e efeitos sonoros colaboram com a música em várias ocasiões e, em decorrência das múltiplas ênfases dadas ao caráter fantástico da narrativa tanto em âmbito imagético quanto sonoro não-musical, os papéis de 'ornamento' ou 'música invisível' se sobrepõem à função de pista narrativa (GORBMAN, 1987) exercida pela trilha musical.

O papel de ornamento é percebido nos momentos de realização dos feitiços - quando contextualiza os efeitos sonoros decorrentes da ação dos bruxos e suas vozes reverberadas -, a cada vez que o livro de Morgana é aberto (tom religioso) e também sob uma forma de pontuação, como quando alguns personagens proferem seus jargões ("Raios e trovões", de Victor Stradivarius, "Este castelo será meu”, do Dr. Abobrinha, ou quando Losângela revela seu rosto para a câmera, gritando o próprio nome e repetindo-o).

Além da Ópera Arepó presente ao longo do filme, outras canções aparecem nos créditos finais, com arranjos eletrônicos e urbanos (rap) substituindo ou se acoplando à orquestração em 
melodias já ouvidas no decorrer da narrativa e letras que lembram situações e emoções vividas pelos personagens. Estranho não, diferente, gravada pelo Karnak para o filme, mostra o conflito de Nino diante de sua condição de aprendiz de feiticeiro, diferente das outras crianças, unindo a orquestração que remete às origens de Nino ao rap familiar e ao repertório infantil no espaço urbano: "Eu disse pra minha tia: "Tia eu quero ser igual" / Ela achou meio esquisito, mas eu não falei por mal/ Ser igual aos outros garotos / Porque às vezes a magia, me faz sentir tão só".

Na canção Amigos normais, também gravada pelo Karnak, o mesmo tema é abordado, celebrando as amizades feitas por Nino, que não se sente mais sozinho: "Um amigo tem com quem conversar / Um amigo sempre é bom, muito bom / Quando o amigo vem é pra aproximar diferentes corações". Aqui, André Abujamra alia as composições originais para o filme ("tema de Nino’ e Ópera Arepó) à sua banda Karnak, cuja discografia é marcada pela densidade de texturas, simplicidade das letras e pelo uso criativo dos recursos eletrônicos em misturas musicais não convencionais.

\subsubsection{O contador de histórias (Luiz Villaça, 2009)}

O drama de Luiz Villaça narra a história de amor filial/maternal entre Roberto Carlos Ramos - menino negro, pobre, de 13 anos, ex-interno da Febem e considerado irrecuperável e Margueritte - pedagoga francesa que vem ao Brasil pesquisar sobre as crianças da instituição e acaba adotando o garoto, que tem uma imaginação fértil e um dom incomum para contar histórias.

Econômico em termos musicais, o filme apresenta uma estrutura narrativa que estabelece uma relação direta entre a ausência de música e a dura realidade da ausência da infância de Roberto na Febem e/ou na rua. Tal realidade é demonstrada pela fotografia acinzentada, fria; e pela arte em tons neutros e apagados. Já a trilha musical de André Abujamra e Márcio Nigro é associada à infância sonhada do menino, que conhece a sensação de liberdade por meio de sua imaginação e do conhecimento propiciado a ele por Margueritte, quando esta o alfabetiza - evidenciada na fotografia e arte em cores vivas, quentes e alegres.

Grande parte do filme é marcada por ruídos, sons ambientais urbanos e a voz over de Roberto adulto contando a própria história, iniciada no passado, na Belo Horizonte de 1978. As cenas iniciais trazem os passos de um Roberto deitado na brita, ao lado da linha de trem. Ele se deita nos trilhos e ouvimos o trem se aproximar (FIGURA 75). O surgimento da cartela com o 
título do filme sobre preto no momento em que o trem está mais evidente na trilha sonora não deixa saber se o suicídio ocorreu.

Figura 75 - Roberto tenta se suicidar

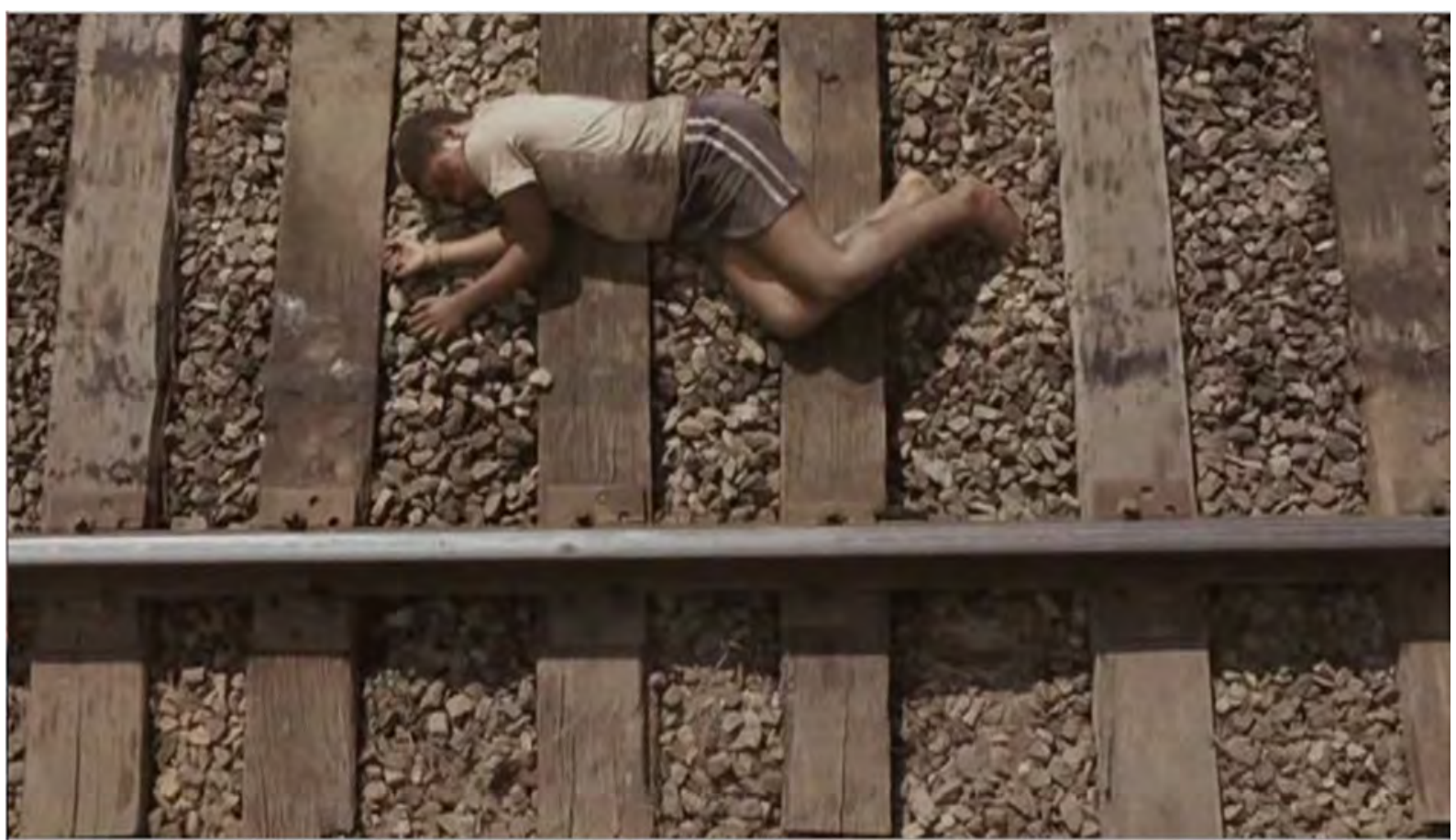

Fonte: Frame do filme O contador de histórias (2009).

No pátio da Febem conhecemos Margueritte, a pedagoga francesa. A câmera lenta destaca o primeiro olhar de Margueritte lançado a Roberto, quando este fora recapturado, e o primeiro olhar dele para ela (FIGURA 76). A ausência de música, a predominância de ruídos (gritaria, risadas, passos, correria e burburinho de meninos), sons ambientais (rua, pátio da Febem) e as pausas entre Margueritte com suas várias perguntas e as respostas curtas e agressivas de Roberto evidenciam os mecanismos de defesa e a dificuldade do menino em se relacionar.

Figura 76 - Roberto conhece Margueritte 


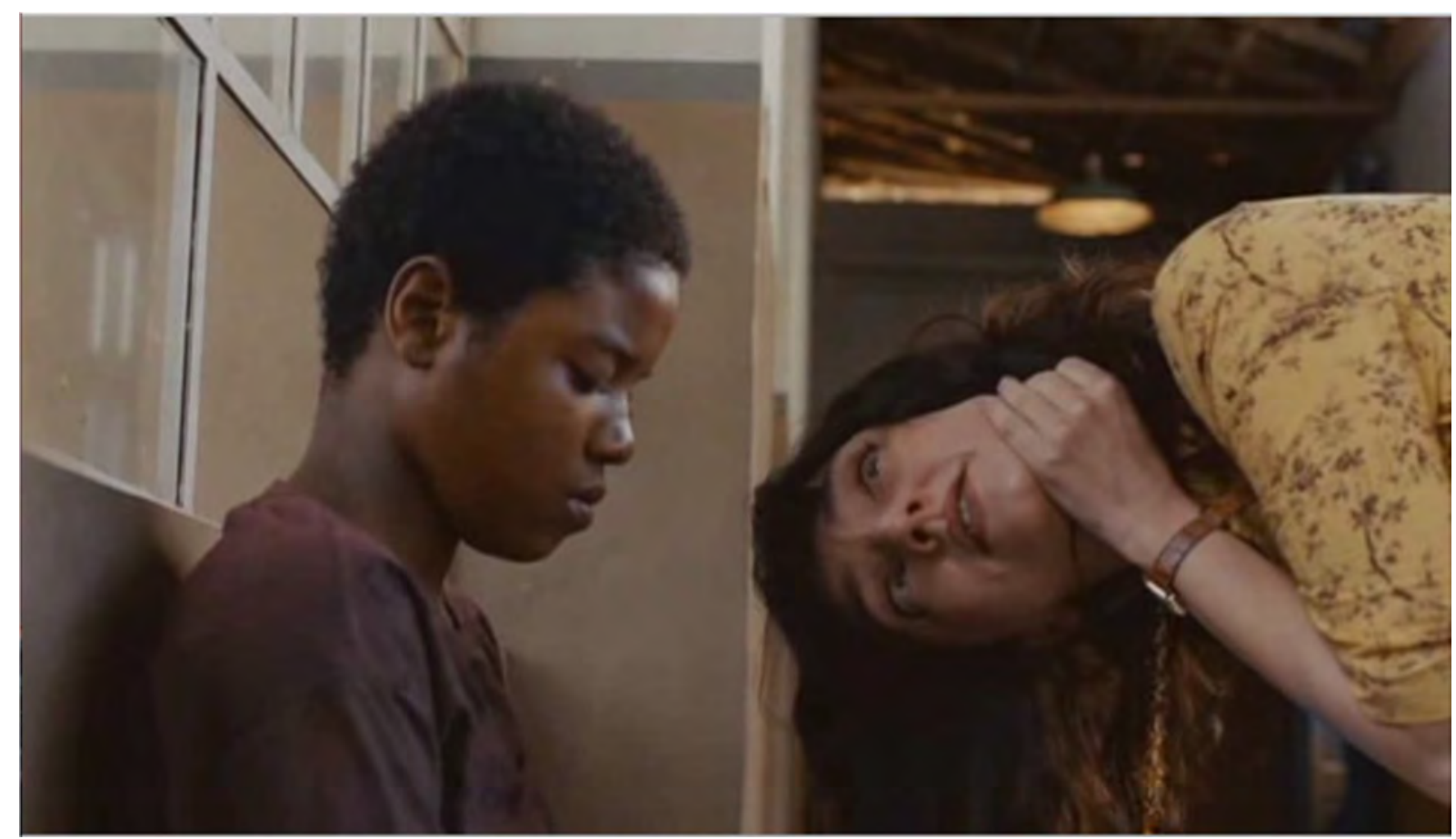

Fonte: Frame do filme O contador de histórias (2009).

Ela registra as respostas de Roberto em um gravador que chama a atenção do menino, pela capacidade de registrar a voz. Ele então conta, do jeito dele, como foi parar na Febem, com uma expressão animada, em close up. Temos, então, a primeira inserção de música original do filme: uma bateria ritmada sobre harmonias, melodias e instrumentação de funk/black music/disco music extradiegética soa sobre a imagem do menino.

A voz do menino prossegue sobre cenas que parecem fotografadas na década de 1970 (cores quentes, tom amarronzado) (FIGURA 77), narrando, em flashback, o assalto realizado por uma família negra cujo figurino parece o dos Jackson Five em início de carreira - visual colorido, calças xadrez, boca de sino, camisa justa, cabelos black power.

À bateria são acrescidas cordas agudas, contrabaixo, guitarra, metais e vozes cantando em inglês. A mãe da família dá voz de assalto ao banco, enquanto Roberto, vestido como Michael Jackson criança, grita, com uma arma de brinquedo em mãos. Com a chegada da polícia, a família foge e deixa Roberto para trás, com o argumento da mãe de que, ele, sendo menor de idade, seria levado para a Febem "e se tornaria doutor". A música setentista dá unidade à alternância entre o flashback fantasioso de Roberto e os planos dele contando a história à Margueritte em um dos corredores da Febem.

Figura 77 - Em flashback, Roberto conta, à sua maneira, como foi parar na Febem 


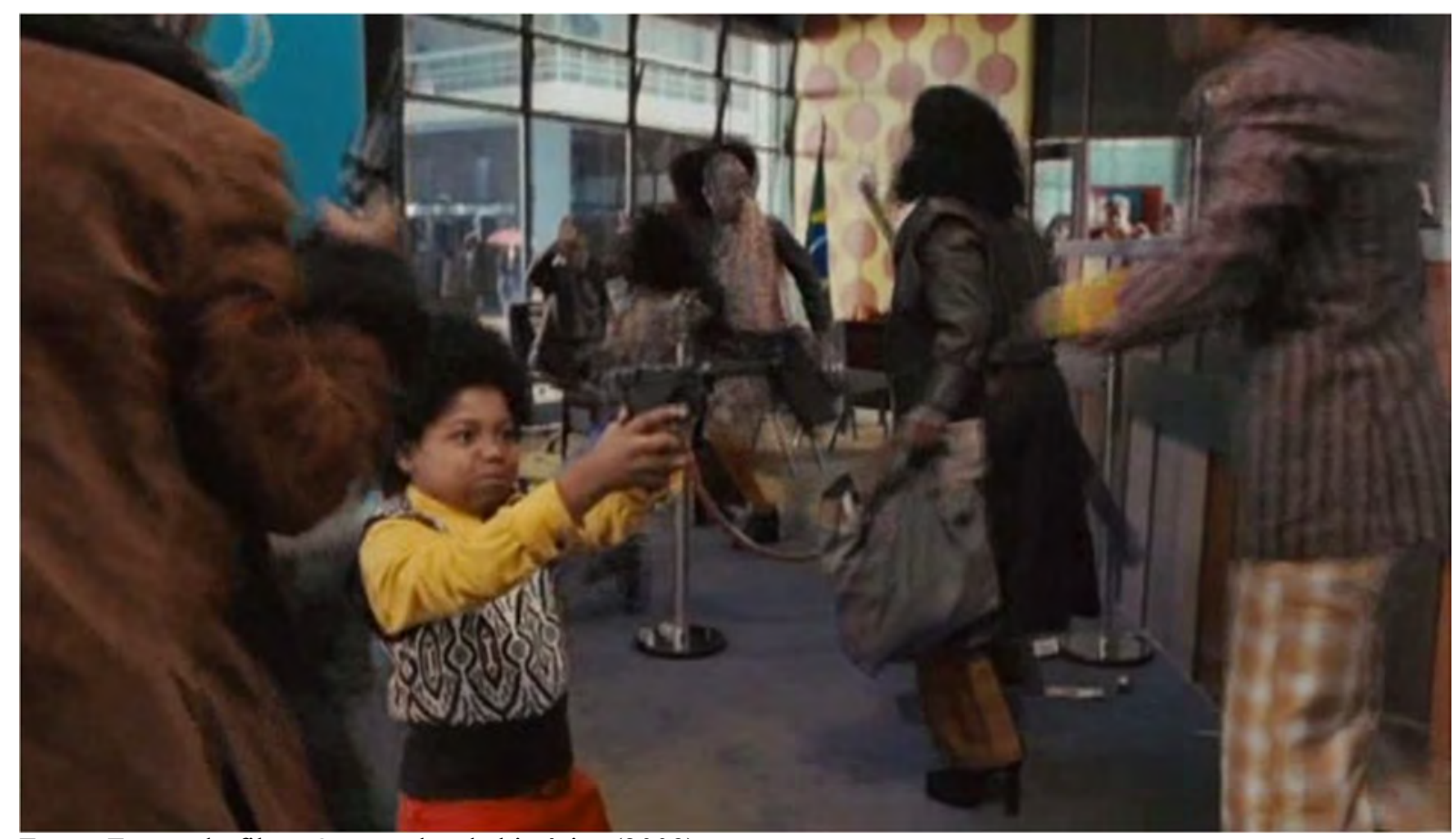

Fonte: Frame do filme O contador de histórias (2009).

A segunda inserção de trilha musical se dá logo após o soar do sino da igreja, quando, em câmera lenta, o menino de rua mais velho, Cabelinho de Fogo, vestido de rei (com coroa brilhante), e seus seguidores, trajados com elegância, são mostrados, em câmera lenta, descendo as escadas, enquanto as pessoas que passam lhes entregam suas coisas de valor, como se fosse algo completamente natural (humor) (FIGURA 78).

Aqui, enquanto a fotografia dourada realça a ideia de riqueza fácil pela sedução, a música começa com uma guitarra distorcida e evolui para uma balada rock, com bateria, contrabaixo e guitarra, em tom menor, demonstrando a visão idealizada que Roberto nutre de Cabelinho, jovem rapaz agressivo e ameaçador.

A música termina quando Roberto 'ousa' se aproximar da turma para dizer que quer fazer parte do grupo. De volta à realidade, Cabelinho e seu grupo estão vestidos como meninos de rua. Fazendo troça da criança, os meninos mais velhos o levam para a linha de trem, onde o espancam e estupram. Há ênfase nos ruídos de respiração, golpes e gritos de dor, além dos impropérios ditos por todos a Roberto. O ruído intenso do trem abafa os gritos do menino no momento do estupro - o que nos leva às cenas iniciais do filme, com ele ajoelhado na linha do trem, que passa no trilho paralelo à frente. Assim, a cena inicial adquire novos significados, por meio da montagem e da ausência de música.

Figura 78 - Visão idealizada de Cabelinho de Fogo por Roberto 


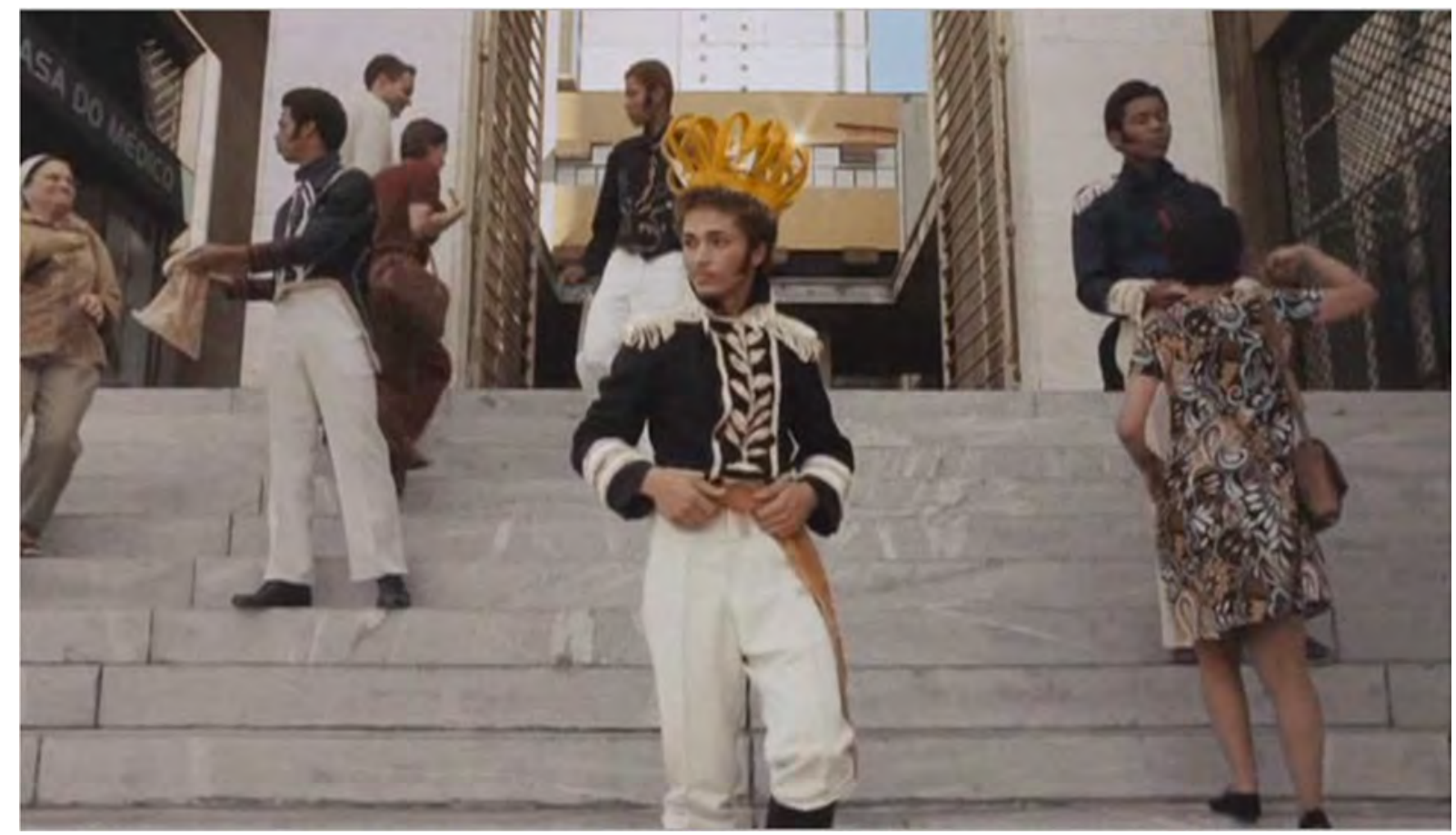

Fonte: Frame do filme O contador de histórias (2009).

Após o suicídio frustrado, a câmera subjetiva mostra os passos trôpegos de Roberto nos trilhos. Até que, na cena seguinte, vemos Margueritte abrir a porta de sua casa e Roberto entrar correndo, trancando-se no banheiro. Trata-se da segunda vez em que ele se dirige à casa da pedagoga, que um dia o convidara para um café, para que ele continuasse sua história. A textura pouco densa do som da casa enfatiza os ruídos, que ainda demonstram a distância existente entre os mundos de Roberto e Margueritte, inclusive em relação aos conceitos que cada um tem acerca de violência. Sem que as palavras consigam persuadi-lo a sair do banheiro, ela começa a agir, deixando comida e roupas diante da porta trancada. O som reverberado e a câmera com velocidade reduzida destacam a cena, bem como quando, ao acordar, ela tenta abrir a porta pela maçaneta e esta continua trancada.

Angústias e solidões paralelas em dois universos completamente diferentes acontecem na casa que hospeda Margueritte em sua passagem pelo Brasil. A ausência de música, o destaque dos foleys, o efeito-silêncio da casa (a partir do som do motor da geladeira) evidenciam a continuidade da distância entre os personagens, mesmo que a pedagoga tente se aproximar, porém, ainda com medo do menino (facas sob o travesseiro).

Mesmo que a vontade de morrer persista, a primeira abertura do menino à realidade de Margueritte ocorre quando, enfim, Roberto resolve tomar um banho. Boiando em sujeira e sangue, ele prende a respiração na banheira e, ao se levantar, começa a chorar. O tempo dilatado da cena e a ausência de música respeitam os sentimentos do personagem, cujo choro e respiração são destacados em combinação com os foleys: Roberto começa a brincar com o 
secador e a mexer nos objetos do banheiro; coloca os óculos de Margueritte, em uma possível metáfora de tentar enxergar o mundo por outro ângulo.

Em um segundo movimento de Roberto em direção à francesa ele deixa os óculos dela do lado de fora do banheiro. À noite a câmera revela Margueritte vendo TV; o som revela Roberto descendo as escadas e assistindo à TV degraus acima. Ela permite que ele durma no quarto - onde ele, acostumado à agressividade, logo provoca ruído arrastando grosseiramente os móveis para que ninguém abra a porta. Ouvindo o barulho, ela grava em francês suas impressões sobre ele.

Ele chega, tímido e calado, para o café na cozinha. Em mais uma cena silenciosa que destaca os foleys, a câmera enquadra a mão dele em close up pegando a faca, e ela também (defesa); mas ele só vai passar a manteiga no pão, e ela recua (quebra de expectativa). Até que, Margueritte, quebrando o silêncio, faz perguntas que não são respondidas. Ela começa a contar sua própria história a ele. Ele deixa escapar um olhar de curiosidade em direção a ela quando ouve sobre as uvas da Champagne e o coq au vin (galinha cozida no vinho), a comida preferida dela - sonoridades estranhas ao menino.

Até então os diálogos apenas demonstravam o abismo entre os personagens. Mas Roberto rompe o silêncio, respondendo-a com a linguagem dos meninos na rua. Ela propõe que cada um ensine ao outro sua língua. E, assim, começam a se relacionar de forma mais próxima. Ele aponta para os objetos e ela responde com as palavras em francês (FIGURA 79). A velocidade com a qual o menino pergunta demonstra sua abertura e curiosidade em relação ao mundo. Ela propõe que ele fique lá por uma semana, em troca de contar sua história para que ela registre no gravador (revelado em close up).

Figura 79 - Roberto pergunta pelo nome dos objetos em francês 


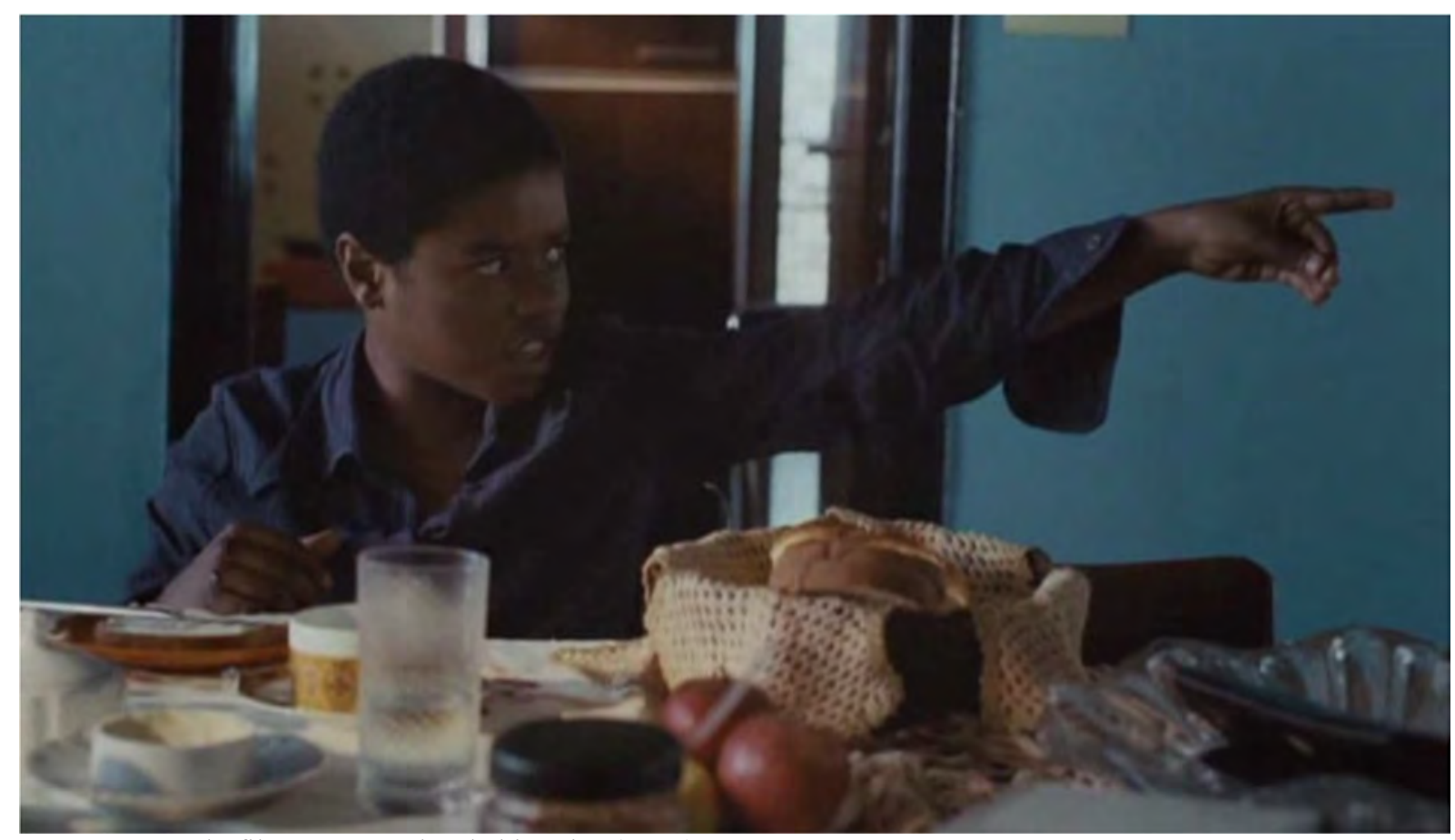

Fonte: Frame do filme O contador de histórias (2009).

Roberto adulto conta, em voz over, que ele havia aceito a proposta, sobre a imagem de uma pipa colorida no céu (ênfase no ruído do vento). As cores vivas indicam a história dele sendo iniciada. A terceira inserção de trilha musical - agora, apresentando a música-tema do filme - ocorre enquanto Roberto empina a pipa: são cordas em notas agudas, arpejadas e golpeadas sobre uma base em dó maior, com inserção de notas médias e agudas ao piano, em um ritmo andante, delicado.

A fotografia colorida, a alta intensidade dos ruídos e a alegria da música sublinham e aumentam as características da memória do menino sobre seu bairro e as pessoas do lugar: Seu Jorge e suas garrafas coloridas no bar; Vilma, vendedora de beiju, e suas longas pernas (ruído do tabuleiro) (FIGURA 80); Seu Artur e sua "bicicleta que cospe fogo" (brilho e ruído intensos da faca sendo afiada); e Seu Batista, pregador do fim do mundo, em seu tom apocalíptico.

Figura 80 - Relato ‘colorido’ de Roberto acerca dos personagens de sua infância 


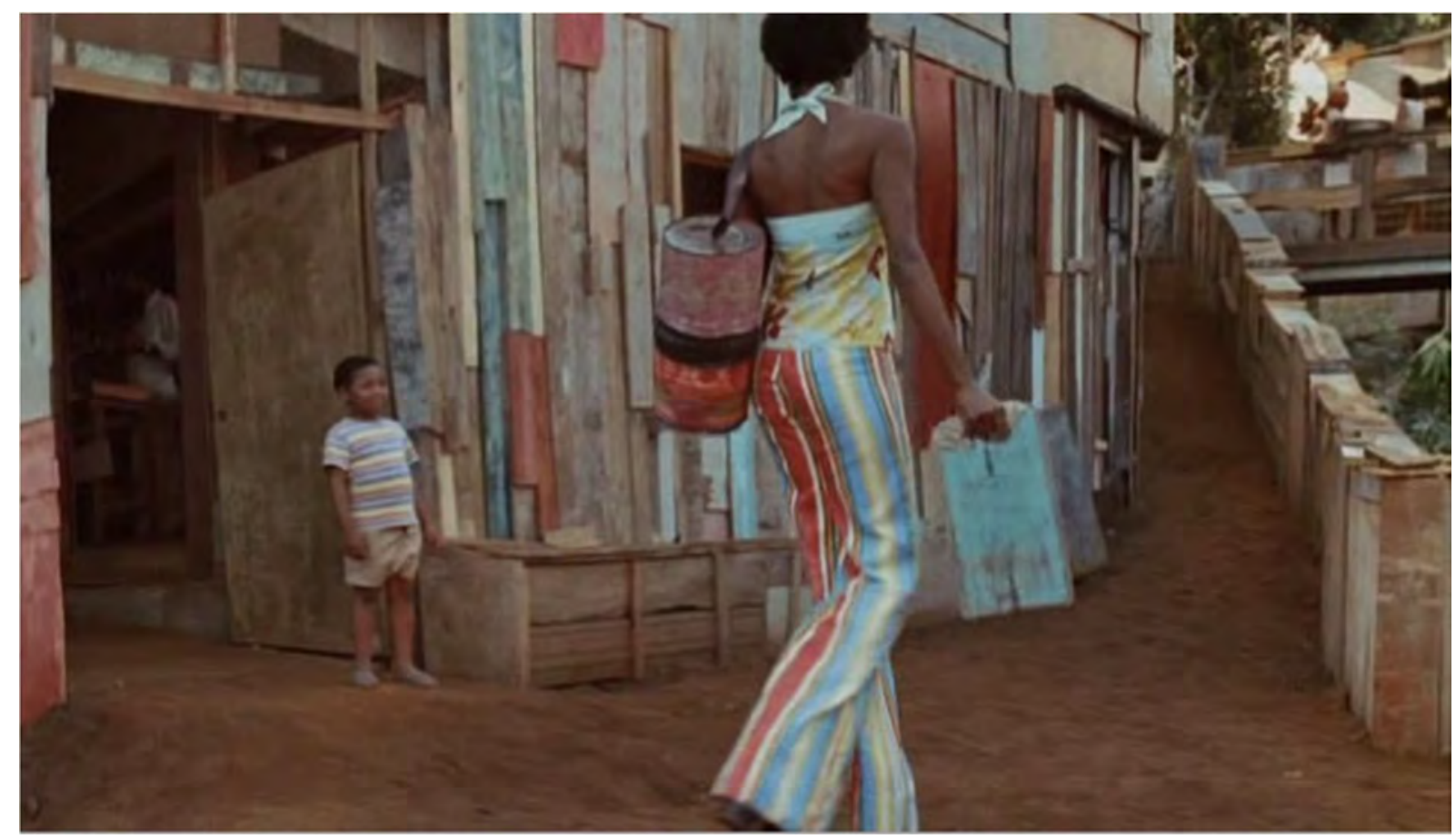

Fonte: Frame do filme O contador de histórias (2009).

Aqui o som do vento e apenas as notas arpejadas ao piano tornam mais delicado e suave o momento em que Roberto apresenta sua mãe, que estende as roupas brancas no varal. As cordas voltam quando ele apresenta toda a família. Movimentos sinuosos de câmera e a progressão das ações são embalados pelo tema musical do filme, que, por sua vez, é acompanhada da voz over de Roberto adulto.

Como vimos no capítulo anterior, Abujamra criara uma música a partir do roteiro do filme e esta, com a aprovação do diretor, serviu de referência para a montagem e para o próprio trabalho de composição posterior, com Márcio Nigro. "Ele [Abujamra] já tinha um tema que eles já tinham gostado, que era um teminha muito simples que acabou permeando praticamente toda a trilha, que era o mote. O resto foi nascendo disso" (NIGRO, 2016).

O músico e produtor musical conheceu Abujamra quando foi entrevistá-lo para um trabalho da faculdade em seu primeiro ano de Jornalismo, ocasião em que este mostrou várias gravações do Karnak, banda da qual Nigro já era admirador. Tempos depois, trabalhando como jornalista da revista de tecnologia Mac Mania, ele entrevistou Abujamra novamente, e a revista lançou uma coletânea do artista em mp3. Próximo ao universo da tecnologia digital, Nigro passou a prestar suporte em informática para Macintosh, inclusive para músicos como Luiz Tatit - até então a Apple não tinha suporte autorizado no Brasil - e só tempos depois se profissionalizou na música, montando seu próprio estúdio e iniciando a produção de trilhas comerciais. "Eu nunca tive preconceito em relação a isso [trilha de referência] e eu sempre tive 
facilidade nessa 'mimetização', tentar pegar aquilo e querer traduzir da forma que eu acho mais adequada" (NIGRO, 2016).

Jornalista de formação, Márcio Nigro iniciou sua carreira como produtor musical no começo dos anos de 2010. Produziu discos de artistas como Carlos Careqa, Marcos Bowie (Karnak) e Gláucia Nasser. Ultimamente tenta desenvolver trabalhos pessoais, como lançar, em disco, as trilhas feitas em parceria com Abu - seu sócio na produtora Mondo - e suas próprias, além de projetos como o Rock Pauleirinha (rock pesado para crianças). Como instrumentista ele acompanhou e/ou acompanha o espetáculo Show da Luna e os artistas Hélio Ziskind, Paulo Tatit, Fortuna, entre outros ligados a Abujamra. Ministrou aulas no curso de Trilha Sonora da Universidade Anhembi Morumbi e assistiu a algumas aulas da professora e pesquisadora Suzana Reck Miranda, com quem também dialogava sobre música de cinema. Seu início no longa-metragem foi com Encarnação do demônio, que ele fez em coautoria com Abujamra, momento em que demonstrou um perfil complementar ao do artista, ao ponto de um interferir nas criações do outro no processo de composição.

\begin{abstract}
Desde o começo sempre foi muito dividido, a gente dividia as cenas, ou [...] um vem, "mete a mão no [trabalho do] outro". Desde o começo ficou claro que seria fácil de se trabalhar, porque o Abu tem uma coisa bacana: ele é muito apegado às ideias, mas nem tanto à forma. Então ele lança uma ideia, você dá uma continuidade [...]. Já chega num estágio em que ele não se incomoda em nada em geral que eu... ah, sofisticar a trilha, mudar alguma coisa: sempre tem algumas coisas que a gente não concorda, mas é tudo a nossa visão artística [...] Como em todo trabalho de parceria. Mas não rola muito isso, porque ele tem muita experiência com cinema - eu tenho menos, mas, de 2008 pra cá, tenho trabalhado e sempre tive pra mim que é uma coisa natural, essa compreensão. Eu acho que vai se aprimorando, mas desde o começo eu senti uma facilidade. E, da dupla, eu sou o mais "cdf" $[\ldots]$ porque eu sou um cara muito mais metódico [...] Ele, mais intuitivo (NIGRO, 2016).
\end{abstract}

$\mathrm{Na}$ cena da pipa, em O contador de histórias, quando Roberto narra sua história para Margueritte, Nigro imaginava uma música diferente da aprovada. Prevaleceu a vontade do diretor por uma música mais discreta, em cordas e piano.

Eu queria uma trilha muito mais mágica, muito mais “Tim Burton”. O Luiz não queria. E eu achava que - e o Abu também, a gente fez juntos a trilha - foi uma trilha que eu comecei, o menino parecia que estava dançando uma valsa, que era toda comentada, porque era uma cena longa. Mas ele [diretor] queria uma coisa mais que pavimentasse, uma música menos comercial, nesse sentido. [...] Aí o Abu: "Deixa comigo". Ele foi lá e fez, e rolou. Então, você pode estar certo; mas vai estar errado de alguma forma, porque [sua composição] não foi [escolhida], entendeu? [...] A gente não pode se agarrar com unhas e dentes a uma ideia porque, no fundo, o trabalho é nosso até a parte de trilha sonora; o todo não é nosso (NIGRO, 2016). 
Na continuidade da cena, Roberto prossegue sua narração. Quando toda a comunidade aparece na casa de Seu José, a música modula para mi bemol maior, enfatizando a novidade e a expressão de contentamento das pessoas diante do único aparelho de TV da rua. A música recua para enfatizar a propaganda da Febem, que promete cuidar e garantir o futuro das crianças das famílias carentes. O piano agudo, arpejado e suave retorna em dó maior, diante da expressão da mãe de Roberto (FIGURA 81), que sonha com um futuro melhor para o filho, e cessa quando ela, já em casa, acorda o menino para levá-lo à Febem antes do amanhecer.

Figura 81 - Propaganda da Febem acalenta sonho da mãe de que Roberto se torne doutor

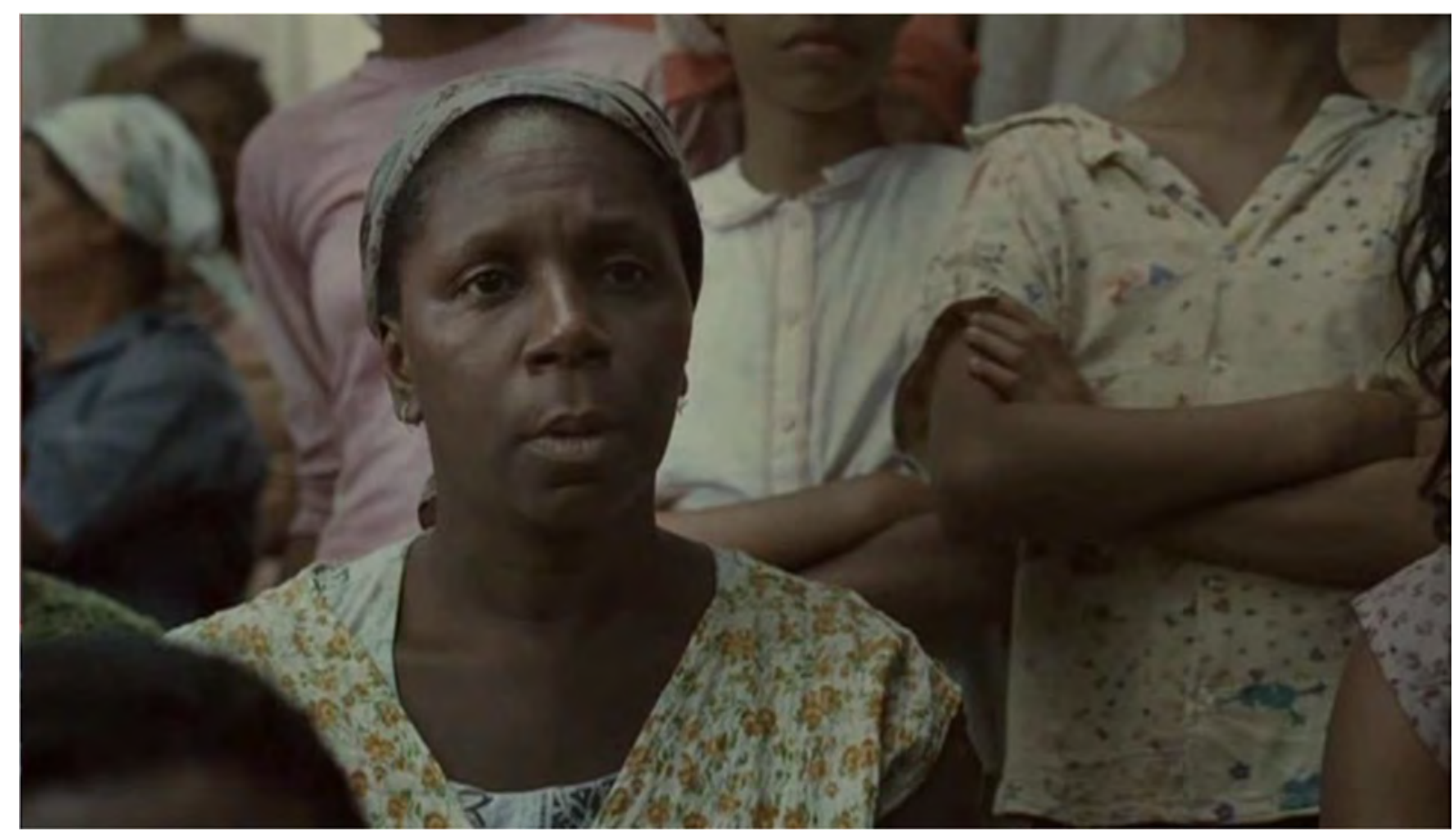

Fonte: Frame do filme O contador de histórias (2009).

Quando, no ônibus, ele pergunta o que tem na Febem e a mãe responde "um monte de coisa boa", a expressão dele através da janela do veículo se funde às imagens e aos sons de malabaristas, perna-de-pau, trapezistas, cuspidora de fogo, palhaços, animais e outros artistas de circo, que ele imagina que vão recepcioná-lo na instituição (FIGURA 82). 
Figura 82 - Febem, na imaginação de Roberto

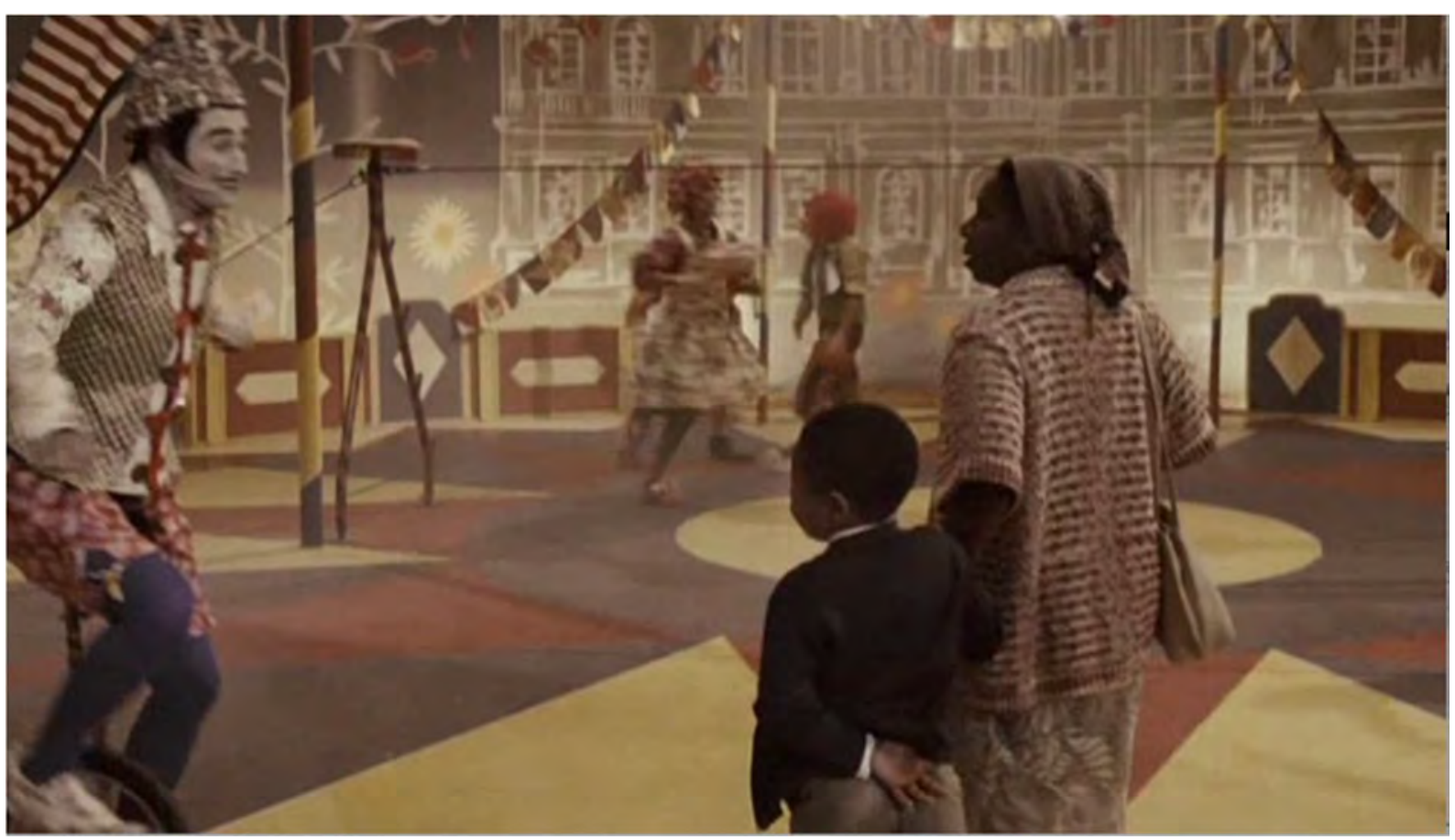

Fonte: Frame do filme O contador de histórias (2009).

É quando volta a música em dó maior, agora com metais agudos (trombone) e graves (trombone e tuba), com bateria marcada, que, com os sons das ações dos artistas e das reações (“oh!!”) de uma plateia imaginária, enfatizam o ar circense da recepção idealizada pelo menino. O fogo cuspido pela artista é colocado em movimento reverso na montagem, indicando a volta de Roberto à realidade: aqui, a música entra em fade out e cessa quando o porteiro os recebe na Febem, de uma forma impessoal, em imagem acinzentada.

Roberto narra, em voz over, sua entrada no lugar, com educadores brigando e crianças gritando. A mãe de Roberto assina os papéis para deixá-lo lá, fala dos planos para o caçula de seus nove filhos para amenizar sua própria culpa e é impedida pela diretora de se despedir do filho. A ênfase no som dos papéis revela a burocracia da ação e a desumanização das crianças, transformadas em estatística. O som reverberado da voz do menino gritando pelos corredores a mãe que vai embora começa a se misturar ao som das crianças no pátio, seguido da cena de sua primeira noite no lugar, chorando, sob a reprimenda do bedel - momentos em que a ausência de música é crucial para demonstrar a infância e a inocência perdidas.

De manhã as crianças esperam no pátio a aula de educação física. Roberto adulto narra, em voz over, a expectativa do menino sobre sua primeira aula - quebrada pela entrada de uma professora gorda e grosseira, que ele imagina ser um hipopótamo: a câmera muda de velocidade 
quando o hipopótamo de pano aparece, com um som grave de água balançando em um recipiente (FIGURA 83).

Figura 83 - Dona Judith, a professora de Educação Física da Febem, na visão de Roberto

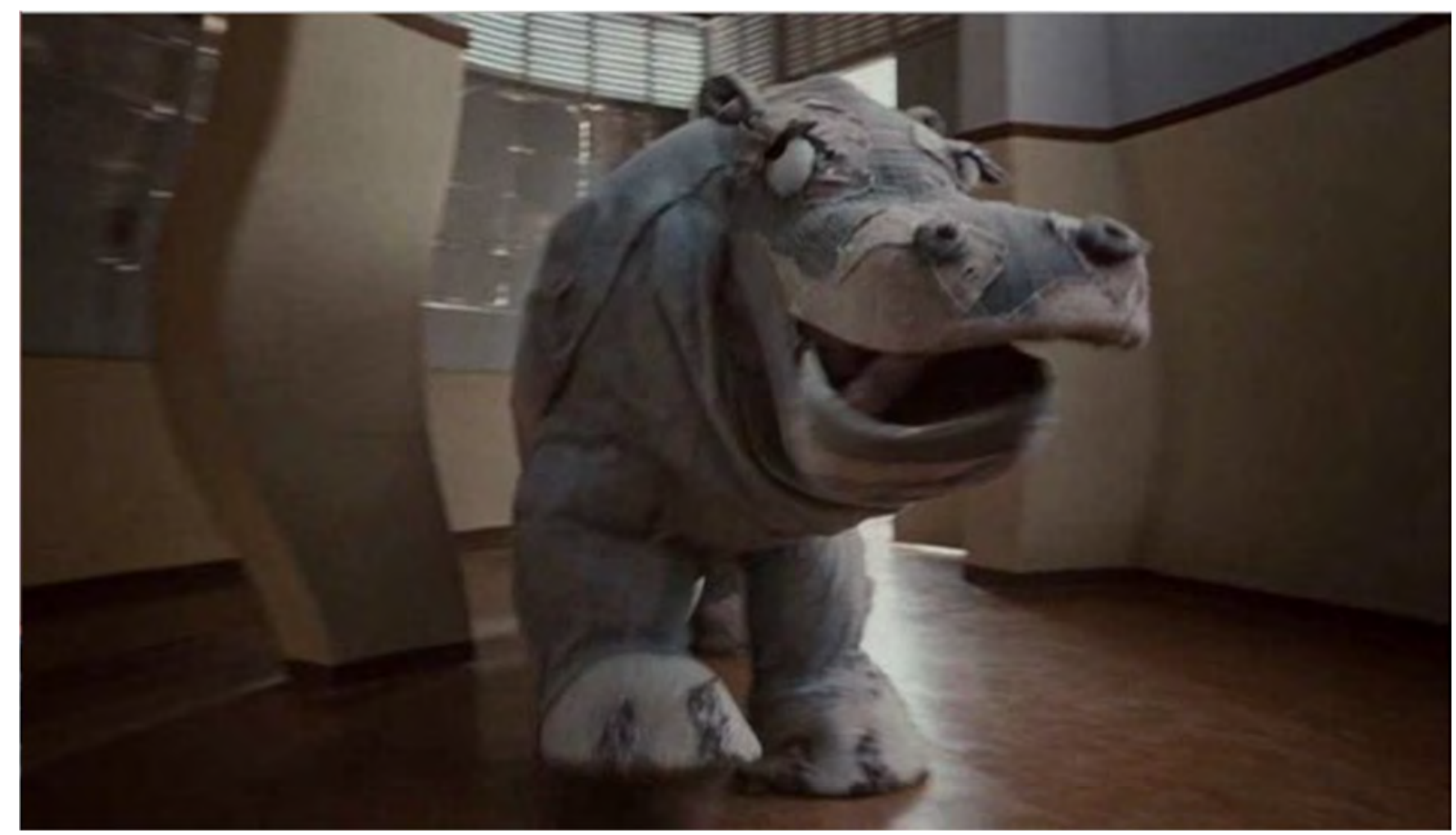

Fonte: Frame do filme O contador de histórias (2009).

Por meio de Dona Judith - que deixa as crianças fazendo polichinelo e vai ler o jornal, com voz grave e distorcida e som de água acompanhando o balanço de seus peitos enormes e das psicólogas da Febem - que diagnosticavam precocemente os problemas das crianças - o filme critica a postura dos pedagogos na Febem. E, mais do que isso, critica a desmotivação, o despreparo e a falta de suporte a eles pela própria instituição. Enquanto isso, a distância entre Roberto e sua mãe biológica aumenta. A cada cena de visita, Roberto presta mais atenção às brincadeiras no pátio, destacadas acima do diálogo, em imagem e som.

Uma trilha de caixinha de música é brevemente ouvida sobre imagens de um cartão de Natal da árvore que, na imaginação de Roberto, é animado e mostra o bom velhinho em seu trenó, demonstrando a grande expectativa das crianças para o Natal. Mas o Papai Noel é Dona Judith, a professora de educação física, e o destaque do burburinho das crianças revela sua indignação.

Roberto sofre ainda mais na Febem quando muda para a ala dos meninos maiores, já que passa a apanhar dos mais velhos. A postura impessoal da diretora contrasta com a confusão ruidosa dos meninos. Ali ele conhece o Cabelinho de Fogo, para a turma do qual ele gostaria 
de entrar. No pátio os novatos na ala mais velha ensaiam seus primeiros palavrões, enquanto os demais jogam futebol (humor).

$\mathrm{Na}$ cena da primeira fuga de Roberto a câmera revela os meninos acordando e correndo pela Febem, com imagem em baixa velocidade. A música tema em dó maior retorna, com pianos arpejados mais graves e violinos em pizzicato $^{62}$, que embalam a ilusão de liberdade dos meninos. A música é conjugada à voz over de Roberto adulto e adquire mais texturas e oitavas em cordas mais graves quando os meninos alcançam a rua. Dinâmica e textura se adensam quando eles aparecem correndo (FIGURA 84).

Figura 84 - Meninos correm em sua primeira fuga da Febem

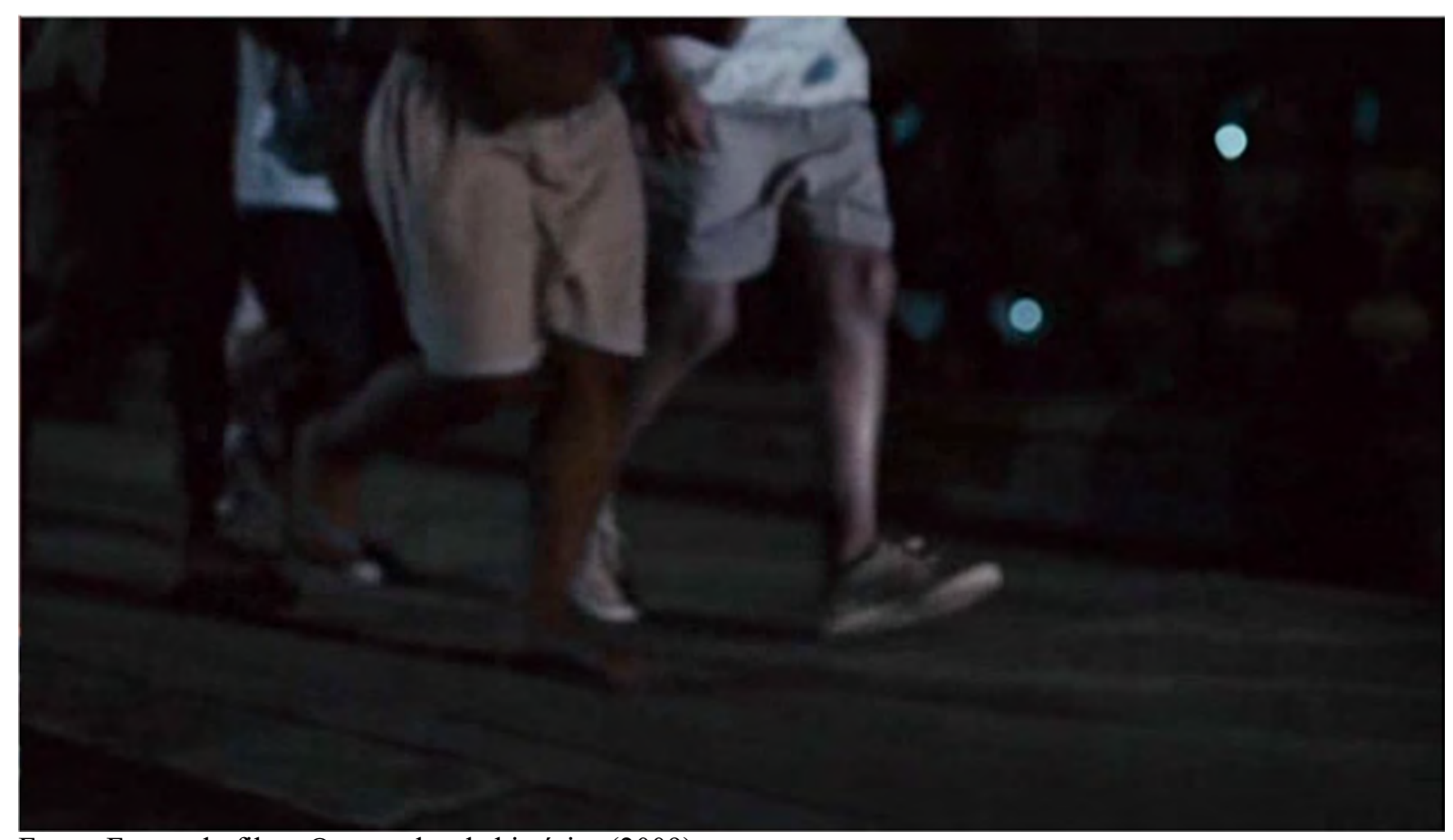

Fonte: Frame do filme O contador de histórias (2009).

Sobre a música em ritmo alegre, o adulto relembra suas diversas fugas. Pianos agudos ressurgem na música para assinalar a passagem de tempo: as pernas correndo se modificam e a câmera abre o enquadramento para revelar os meninos mais velhos. A música adquire um tom levemente irônico e também cômico quando o Roberto adulto rememora o que a Febem oferecia: companheirismo (imagem do menino apanhando); comida de primeira (gororoba em close); natação (bedel enfiando sua cabeça na água); orientação pedagógica (professor batendo no rosto e gritando com ele); quarto privativo (solitária). Esse clipe reforça a motivação dos

\footnotetext{
62 Técnica em que as cordas são pinçadas com os dedos e não friccionadas com o arco.
} 
meninos para a fuga, o que conserva a leveza da música em relação à violência das imagens da sequência.

De dia, quando eles dobram a esquina da rua, a voz over de Roberto compara a turma a um time de futebol. É quando começa a versão instrumental da canção Na cadência do samba (Que bonito é), composta por Luis Bandeira (1956), com metais, percussão e piano, em sua versão eternizada sobre imagens de futebol nos cinejornais do Canal 100. A música acompanha a narração e o som dos meninos assaltando os passantes (FIGURA 85), em câmera lenta e fotografia brilhante, clara, quente e colorida. Quando os policiais o pegam, o som de uma torcida imaginária reage (“Uhhh!”), como se estivessem em uma partida de futebol, imprimindo comicidade à cena.

Figura 85 - Roberto fala sobre sua turma como se fosse um time de futebol

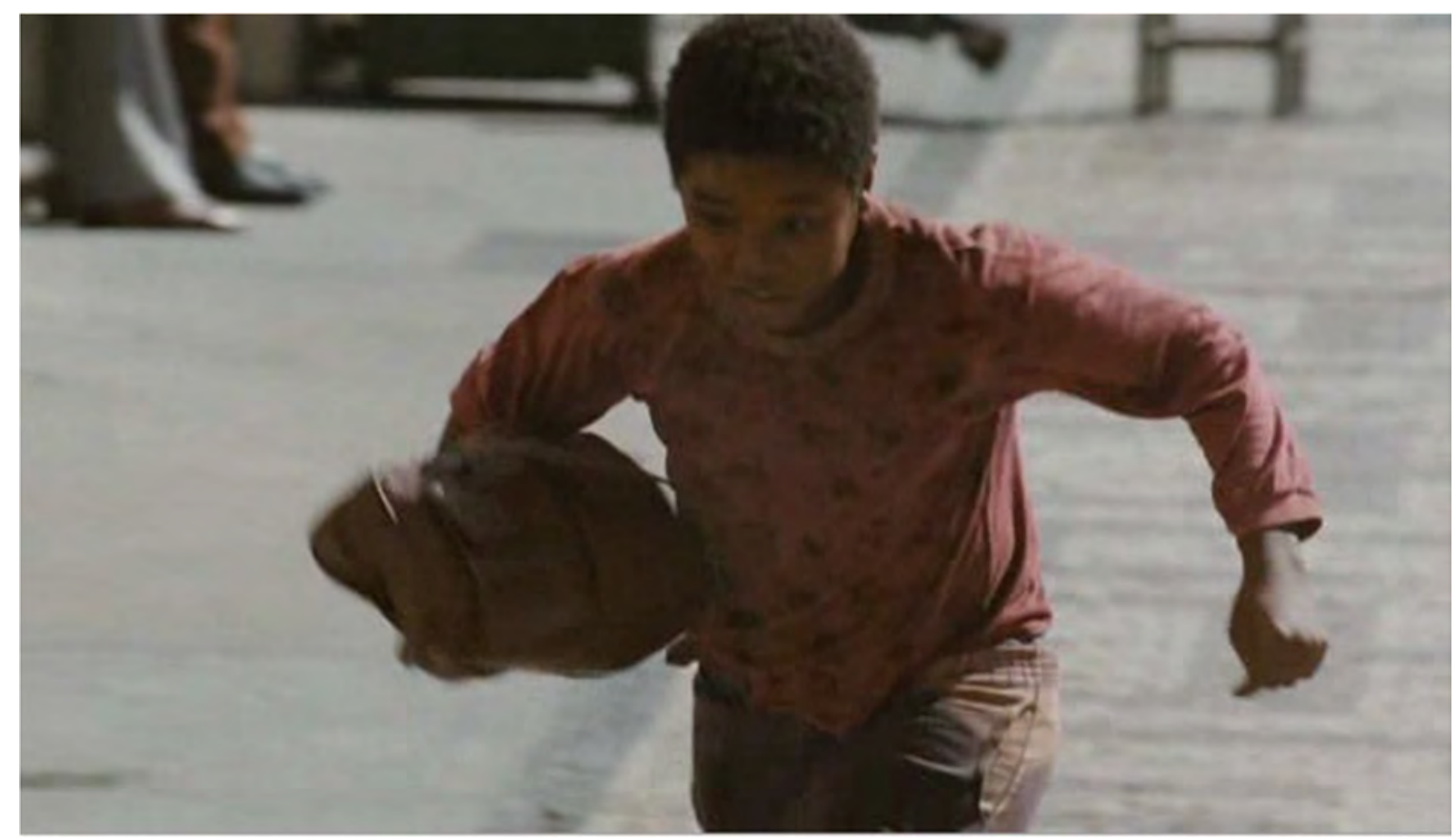

Fonte: Frame do filme O contador de histórias (2009).

Na sequência seguinte, de volta ao presente, a diretora da Febem entrega a Margueritte o dossiê de Roberto, recomendando cuidado e temendo por ela, apesar da postura neutra e contida. No diálogo no restaurante a francesa conta à amiga o relato de Roberto sobre os maus tratos, e a diretora, em tom irritado, confirma, dizendo que nada daquilo consta no dossiê e justificando a violência dos bedéis com a falta de recursos da instituição.

Em casa Margueritte ensina Roberto a andar de cabeça erguida, colocando um livro em sua cabeça. Na voz over, o adulto compara os métodos da francesa aos da Febem, dizendo que 
lá eles aprendiam a andar de cabeça baixa. Quando o livro 20 mil léguas submarinas cai no chão, Roberto se interessa e ela lê parte da história, ao que ele responde sorrindo. Há uma fusão para as imagens inventadas pelo Roberto criança, enquanto o adulto diz, em over: "Parecia que eu tinha cheirado thinner". Começa, então, uma trilha lisérgica, com guitarras distorcidas, teclados, baixo e bateria, em dó menor, sobre uma animação que simula o efeito alucinógeno da substância (FIGURA 86).

Figura 86 - Imaginação de Roberto, sob efeito do thinner

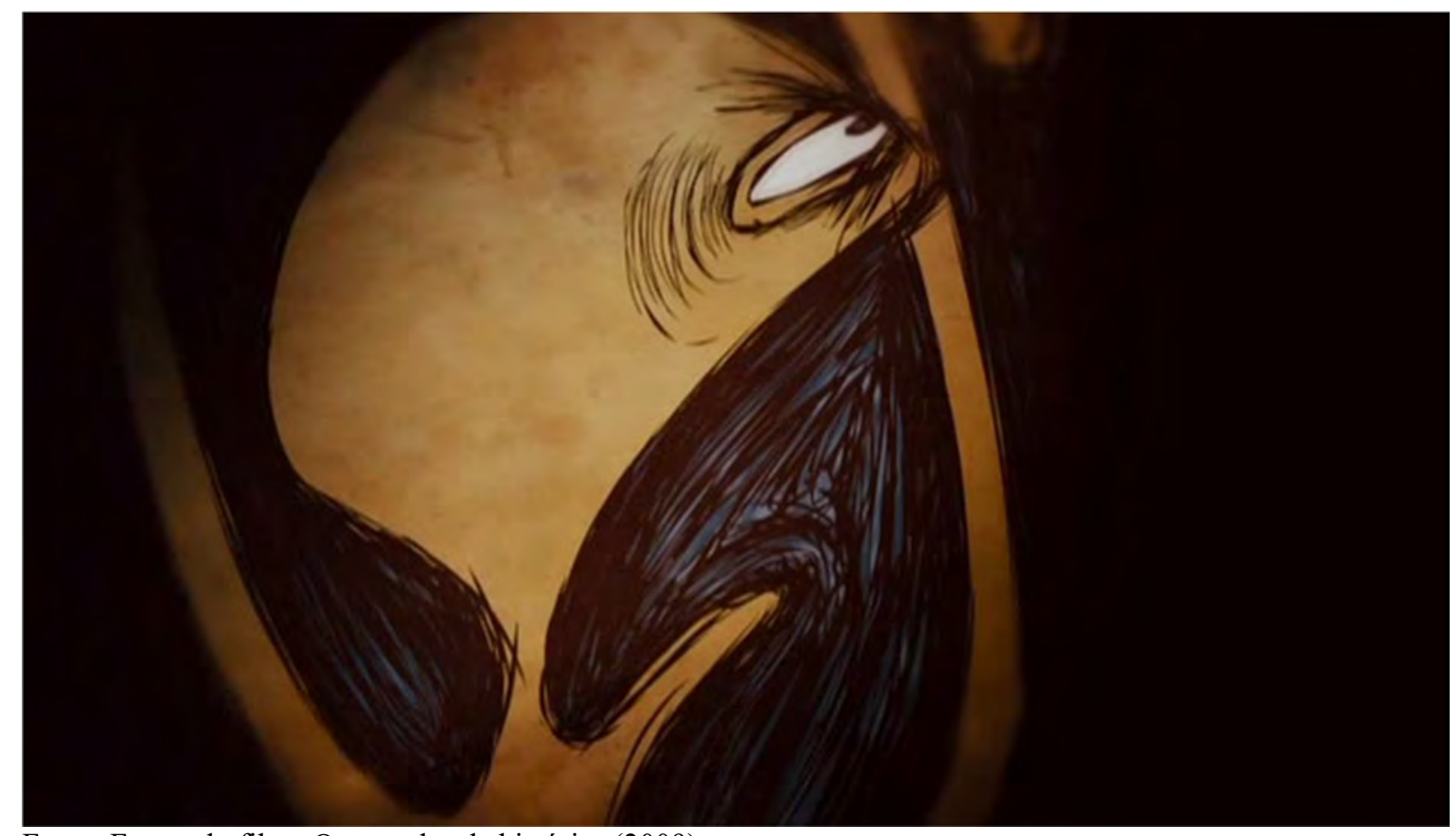

Fonte: Frame do filme O contador de histórias (2009).

Quando a animação acaba, temos Roberto dopado, cheirando uma lata de thinner na despensa da casa onde mora Margueritte. A música cessa quando ela o flagra e sai da dispensa falando sozinha em francês, irritada e ansiosa, pega o gravador e um cigarro, começa a relatar o ocorrido, mas não termina.

Ela discute com Roberto com voz alterada quando ele, ainda dopado, altera e diz que não quer ficar. Ela o convence a aceitar as regras dela quando lhe promete o coq au vin. $\mathrm{Na}$ cena seguinte, Roberto está sentando e sorri vendo TV - música ao piano e efeitos de desenho animado parecem sair do aparelho -, sobre voz over do adulto falando que faziam três coqs au vin que ele estava lá (humor com a unidade incomum de passagem de tempo). Margueritte coloca um disco de vinil na vitrola: soa a canção Sá Marina, de Wilson Simonal (1970), cuja inserção alude às histórias contadas por Roberto e à própria história narrada no filme: 
“Descendo a rua da ladeira / Só quem viu, que pode contar...". A canção cobre o intervalo de um mês na passagem para a cena seguinte, quando Roberto lê na sala e a francesa o chama para o almoço.

Na cena seguinte, os dois vão ao mercado, quando está em evidência o som do ambiente da feira. Ao ver Cabelinho de Fogo, Roberto se esconde (câmera e som em velocidade mais lenta). No retorno à casa, a voz over destaca a parada na praça. Um malandro conta a um grupo de pessoas uma história mirabolante para que comprem a caneta que supostamente foi utilizada para assinar a Lei Áurea. O moço diz que a história é mais importante que o ouro e que a mágica. A plateia ri, enquanto o moço atua. Por dez cruzeiros, Margueritte compra a caneta, mas pede a de cor marrom. Ao ser questionada por Roberto pelo fato de ter sido enganada, a francesa retruca, dizendo que pagou pela história. A caneta marrom, da Independência, é mais cara que a da Lei Áurea (humor). Roberto, desde pequeno dono de si, escolhe a da Independência.

Os dois guardam as compras. A campainha toca e, da janela, Roberto vê Cabelinho de Fogo abrindo o portão. O rapaz se apresenta como amigo dele, a câmera desacelera a imagem para enfatizar a ameaça; ele repara em tudo. O clima pesa; Margueritte prepara algo pra comer e Cabelinho se aproveita do lugar para fazer pequenos furtos. Uma discreta trilha musical ao fundo, com sons atonais e metálicos esparsos, aumentam a tensão no diálogo entre os dois meninos. Cabelinho diz que o autoriza a participar da turma, começando por um grande assalto àquela casa. Pressentindo algo, Margueritte o chama, enquanto o rapaz sobe as escadas e deita na cama da francesa. O rapaz confronta Roberto, lembrando-o do seu lugar de menino negro e pobre. Quando Cabelinho pega o gravador, Roberto reage, e o rapaz foge com o aparelho. Roberto demonstra valentia ao tentar recuperar o gravador, o que consegue, mas à custa de uma surra. Sons metálicos da trilha extradiegética se misturam aos sons da briga e da rua.

Quando ele chega ferido, Margueritte o trata como mãe, escondendo sua dor, repreendendo-o pela briga e mandando-o tomar um banho - ao que ele obedece. Na cena seguinte, no ônibus - em um paralelo com a cena da mãe biológica, quando esta o levou para a Febem - o menino, entediado e impaciente, pergunta a Margueritte sobre o destino daquela viagem, omitido pela francesa. Ela conta histórias para Roberto sobre sua infância e revela a ele o fato de não poder engravidar.

Próximo ao destino, ela usa um lenço para vendar os olhos do menino. Os violinos agudos em pizzicato executam o tema do filme quando Roberto, de olhos vendados, sente o cheiro de 'peixe podre'. Ao tirar a venda, ele vê o mar pela primeira vez. O menino corre e profere os palavrões aprendidos na Febem, demonstrando sua felicidade, enquanto a trilha cresce em textura, com cordas contínuas e agudas (FIGURA 87). A música cessa para enfatizar, 
na cena seguinte, o menino aprendendo a ler com 20 mil léguas submarinas. A passagem de tempo ocorre por meio da leitura mais fluente do menino, que conclui o livro.

Figura 87 - Roberto corre em direção ao mar pela primeira vez, ao som da música-tema do filme

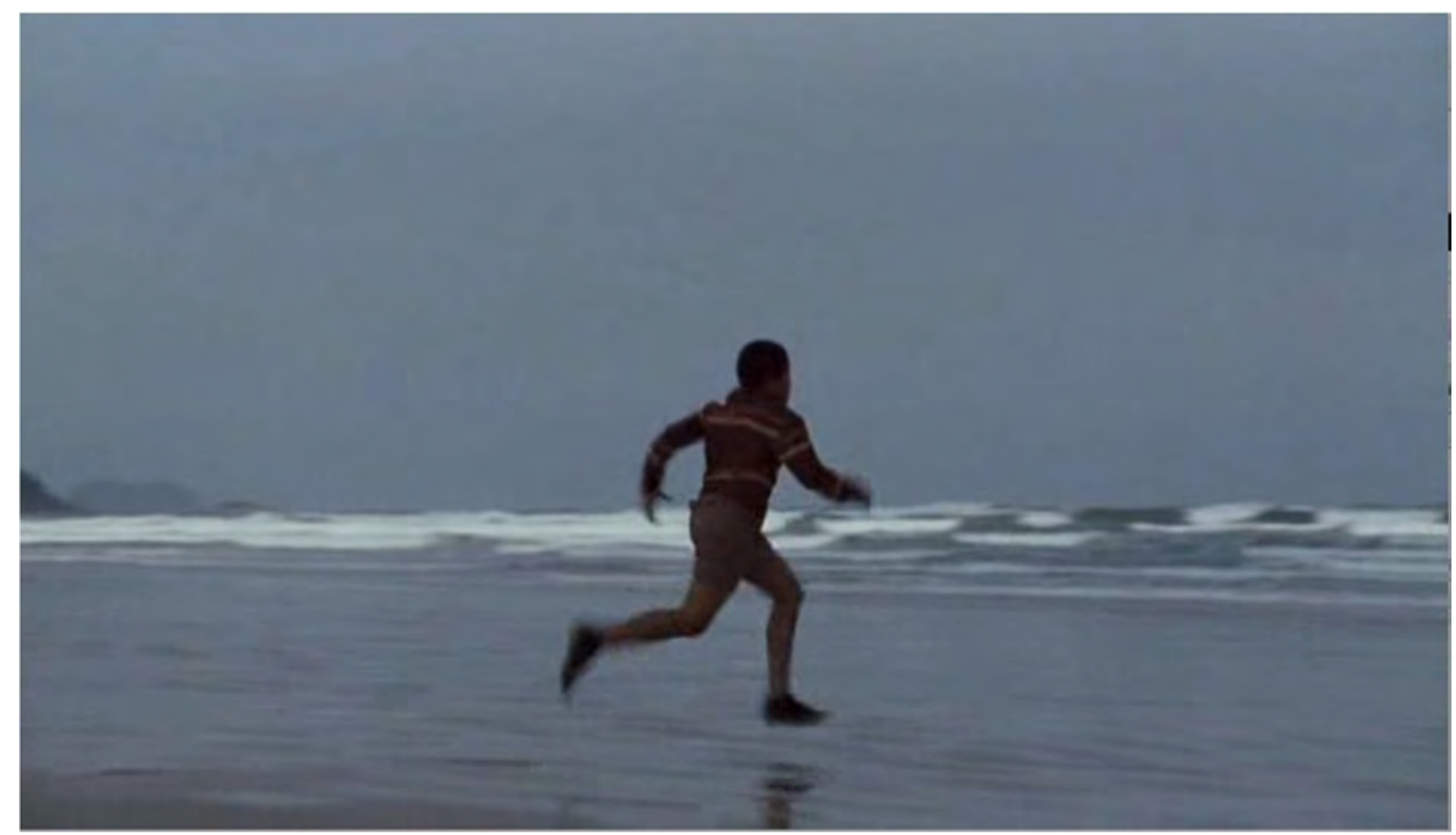

Fonte: Frame do filme O contador de histórias (2009).

Quando os dois vão ao estádio, o som reverberado das catracas revelam a perspectiva do medo do menino, e a revista pelos guardas o amedronta. No banheiro masculino, diante do espelho, Margueritte diz a ele sobre não ter vergonha de ser quem ele é, assumindo sua nova vida. Ela faz piada com sua brancura, ao que Roberto ri: começa o hino do Atlético Mineiro, falando sobre vitória ("Vencer, vencer, vencer / Este é o nosso ideal”), enquanto Roberto passa por todas as revistas que pode, pela novidade da sensação de ser liberado.

O hino entra em fade out para a cena seguinte, em que Roberto está aprendendo a escrever e pede que a francesa prepare um coq au vin. Ela revela o fim de sua pesquisa e o almoço com o cônsul da França para, supostamente, tratar de seu visto de estrangeira - na realidade, ela trata da adoção de Roberto sem que ele saiba. Uma semana antes de partir a francesa conversa com a diretora da Febem: o diálogo é suave, mas duro; as duas debatem sobre o tratamento dado aos meninos na instituição, a falta da família, as dificuldades de cuidar de muitas crianças por meio de políticas públicas. Esse debate é entrecortado de cenas de Roberto ofegante e com raiva, preparando o banheiro para uma enchente dentro da casa. 
O tema do filme volta ao piano quando as amigas ficam sem palavras, dando a entender que o problema das crianças de rua está longe de uma solução. A lentidão da música e a execução por um piano meio ‘abluesado’ reforça a melancolia da cena, acrescida do violoncelo, enquanto as duas fumam um último cigarro. A música, acrescida também de violinos, une as duas cenas paralelas, em que as amigas se despedem e Roberto destrói as fitas e alaga a casa, sem saber que vai para a França com Margueritte.

Na cena seguinte, o intenso som da água é sincrônico ao alagamento do banheiro. A água toma a casa, demonstrando também o transbordamento de Roberto pela provável perda de sua figura materna. Ao chegar, Margueritte corre para fechar as torneiras, gritando pela preocupação com Roberto. Declarando seu amor, ela conta a ele que os dois partirão juntos. A emoção da cena dada pela ausência de música se transforma em humor quando, pela voz over, sabemos que ela o fizera enxugar a casa toda, como uma mãe faria.

Em um vinhedo na França, Margueritte mostra a uva da Champagne que uma vez chamara a atenção de Roberto em uma história dela. O plano se fecha quando ele pega a fruta e, ao se dirigir ao rosto dele, a câmera revela um Roberto jovem adulto, mantendo sua mesma opinião sobre a uva ("gostosinha"). Os dois caminham pelo vinhedo, em plano geral. Ele a convida a voltar ao Brasil. Ela, com cabelos mais curtos e ar mais maduro, recusa e lhe presenteia com o endereço de sua mãe biológica, em um envelope a ser aberto em seu retorno.

Quando Margueritte lhe beija a testa, o piano com o tema do filme retorna, ligando esta cena às seguintes, quando ele volta ao seu bairro, 12 anos depois: a continuidade da fotografia revela antigos personagens antes idealizados pelo menino, demonstrando uma visão amadurecida e nostálgica de Roberto, reforçada pelos violinos e piano do tema musical (FIGURA 88).

Figura 88 - Visão amadurecida do jovem Roberto, que reencontra seu antigo bairro, ao som do tema do filme 


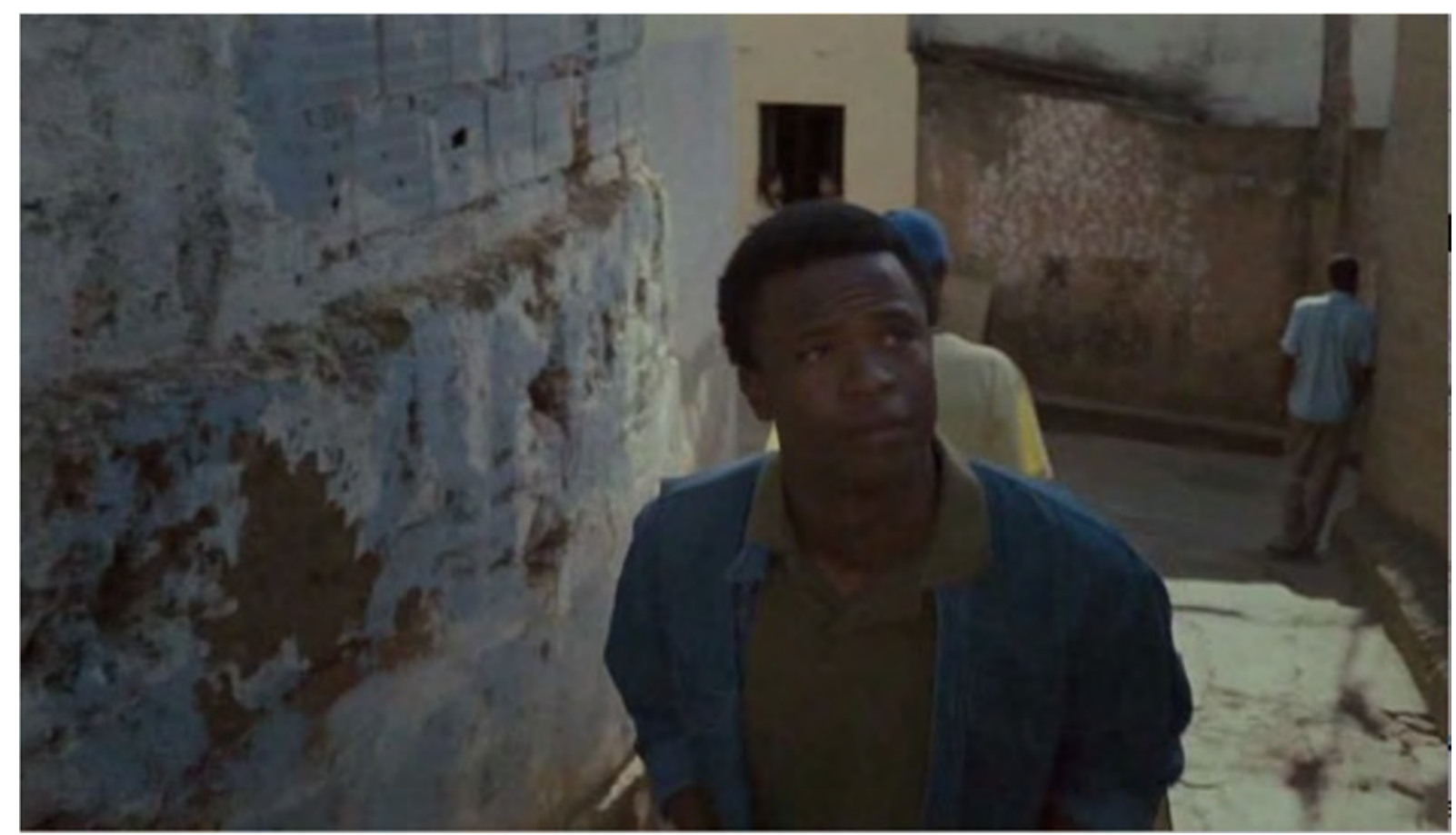

Fonte: Frame do filme O contador de histórias (2009).

O andamento lento ao piano e a voz over do adulto embalam a caminhada do personagem à sua antiga casa, quando avista a mãe, em câmera subjetiva. Ele sai do enquadramento e aparece ao lado dela. Em silêncio, os dois se olham. Ele diz que será professor e ela, reconhecendo-o apesar do tempo, conclui que tudo deu certo - provavelmente não pelos motivos que ela acredita. Os dois se abraçam e o tema musical volta a soar com violino e violoncelos, acrescido do piano, quando a música aumenta sua intensidade (FIGURA 89).

Pela voz over, sabemos que Margueritte morrera em sua cidade natal e que Roberto voltara à Febem como estagiário em docência. Sob o olhar desconfiado das crianças, ele, empolgado, começa a contar a história de 20 mil léguas submarinas. A ausência de música destaca o dom de Roberto para contar histórias. Assim, o jovem aspirante a professor encerra, na imagem simultânea às camadas sonoras diegética e extradiegética (over), sua própria história transformada em filme.

Figura 89 - Reencontro de Roberto com sua mãe biológica 


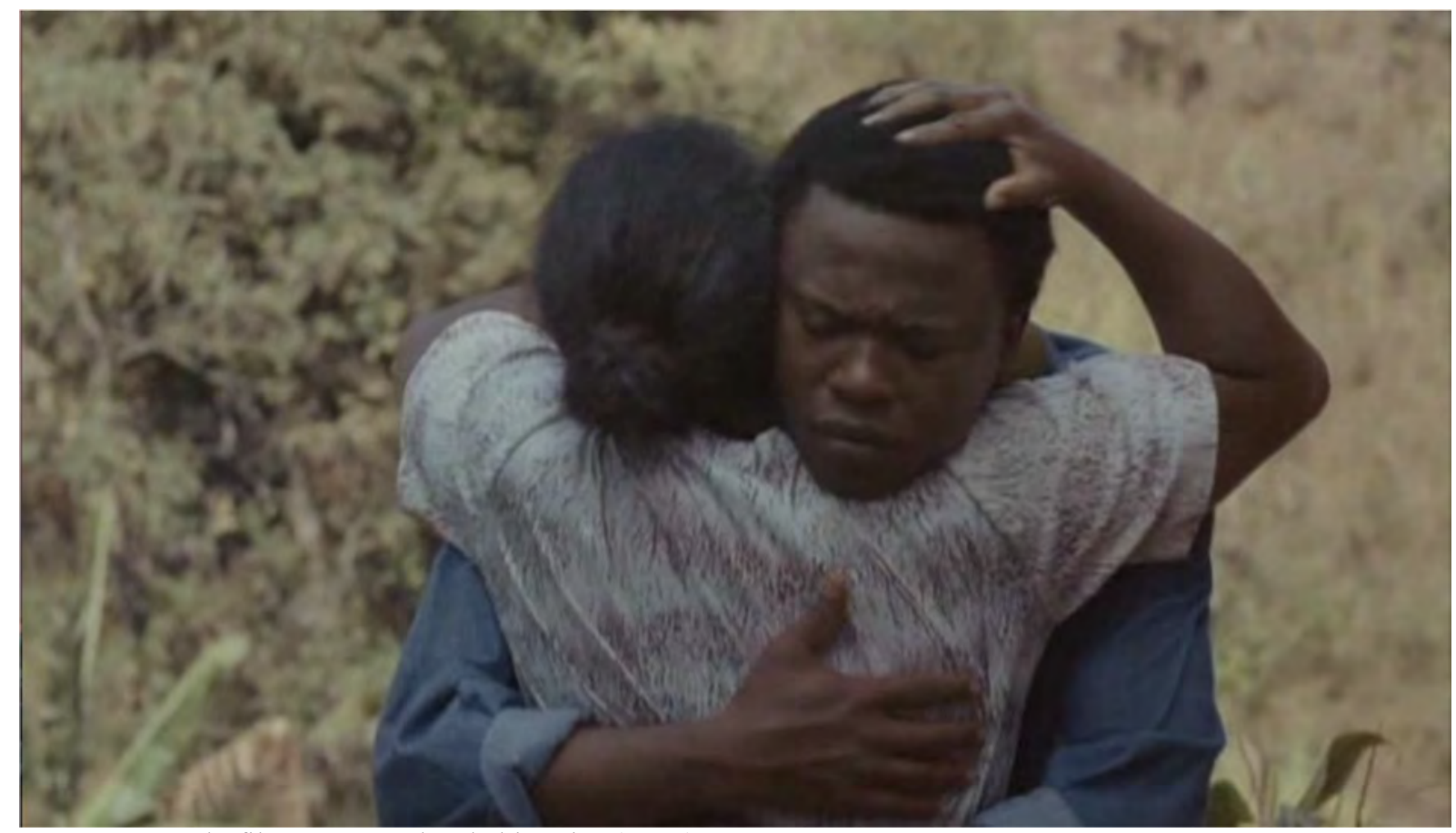

Fonte: Frame do filme O contador de histórias (2009).

O silêncio embala as cartelas sobre preto que revelam, em texto, o destino de Roberto, personagem real que inspirou o filme, seguidas dos créditos finais. Em caráter documental, a voz do professor surge nos créditos, seguida de sua imagem, contando história para desconhecidos em uma praça (FIGURA 90).

Sua voz permanece nos créditos, enquanto imagens dele e da plateia se alternam. Com os créditos do elenco, a música-tema retorna, com cordas em contraponto (violinos e violoncelo), e harmonia e melodia em dó maior. A suavidade das notas contínuas confere ao final do filme um caráter otimista, enfatizado pela modulação da música para mi bemol maior e pela existência, de fato, daquele personagem no mundo.

Pela atmosfera emocional e pelo risco de o filme se tornar mais uma história de superação de uma criança pobre - pauta recorrente em telejornais - podemos compreender o uso econômico da música em $\mathrm{O}$ contador de histórias. A economia, por fim, valoriza e fortalece o tema composto por Nigro e Abujamra, bem como a inserção de outras músicas, originais ou preexistentes, vinculadas à imaginação ou às oportunidades aproveitadas pelo menino para construir seu presente e futuro. A ausência de música, por sua vez, demonstra a realidade violenta das crianças em situação de rua e a impotência de instituições fadadas à má gestão e à escassez de recursos duramente obtidos por meio de políticas públicas.

Figura 90 - Roberto, personagem que inspirou o filme, conta histórias na rua 


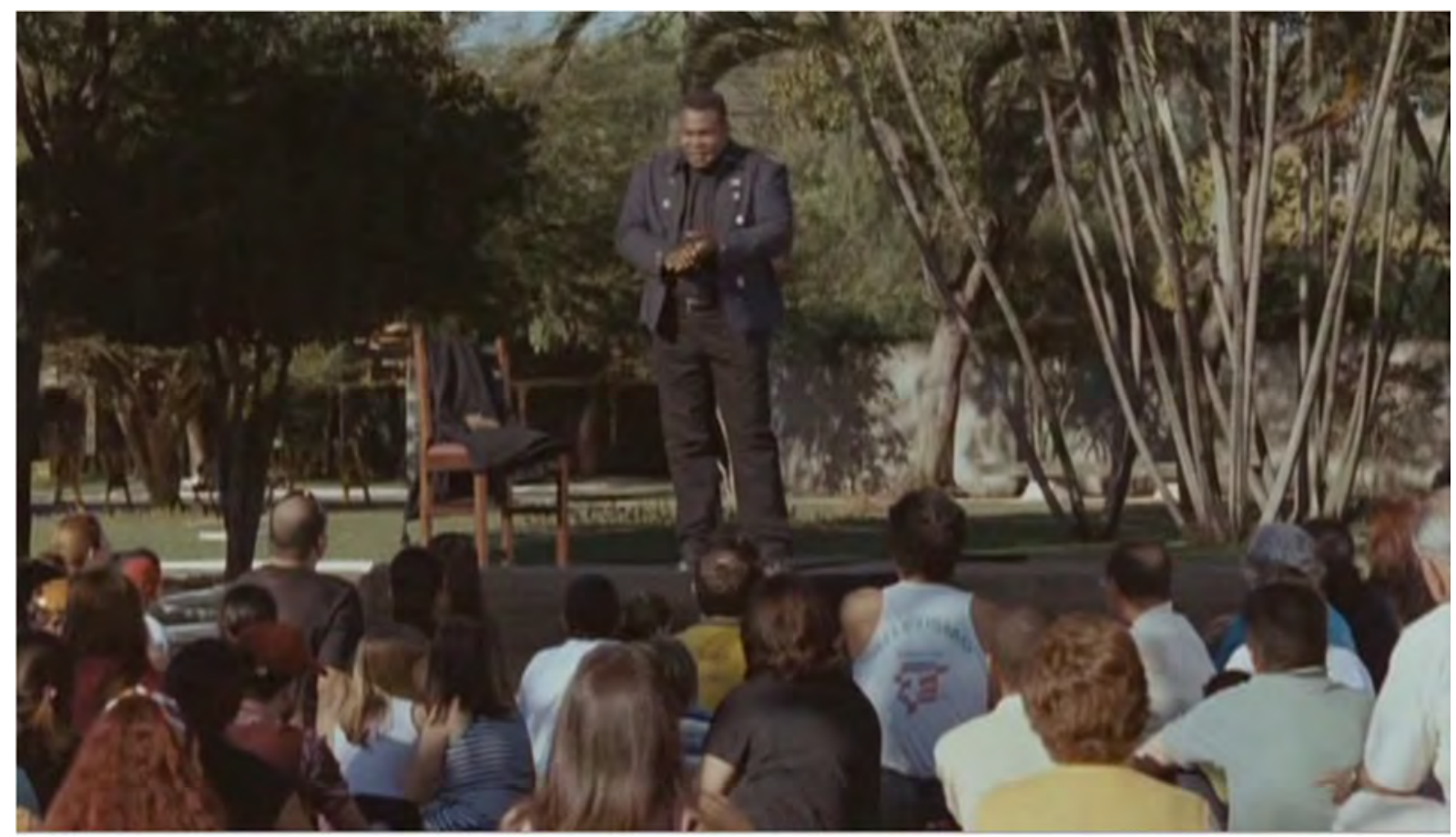

Fonte: Frame do filme O contador de histórias (2009).

Nigro e Abujamra possuem opiniões convergentes a respeito do silêncio na trilha sonora cinematográfica:

Não precisa ter música o tempo todo, porque o silêncio é dramático também, tem que lembrar dessas coisas. O músico tem que lembrar, o diretor tem que lembrar. Porque, às vezes, a função dele não é botar música o tempo todo no filme; às vezes é o contrário, falar "Olha, aqui é melhor não" (NIGRO, 2016).

Digna de nota é também a coexistência, no filme, de diferentes vozes de personagens vindos de universos distintos, em diferentes tempos: Margueritte fala português com paixão e sotaque carregado; por vezes, se expressa em francês. O menino Roberto revela o código falado nas ruas, aprende a ler e a escrever em português com uma francesa, muda de país e tem toda a sua história contada por ele mesmo, na fase adulta. Vozes de universos muito distantes se encontram na Febem e eternizam-se em espaço e tempo nas fitas do gravador de Margueritte, objeto que seduz o menino e a partir do qual uma ponte entre os mundos do filho e da mãe adotiva é construída.

Neste capítulo analisamos três longas-metragens de ficção em busca da verificação da importância narrativa da trilha musical de Abujamra, almejando também relacioná-la aos demais elementos sonoros presentes em cada filme. Para além da presença da música em cada caso, a composição em parceria com Lulu Camargo, em Castelo Rá-Tim-Bum, o filme, e com Márcio Nigro, em O contador de histórias, revela, em comparação à composição solo, em Um 
copo de cólera, uma simbiose entre as competências dos diferentes músicos, possível não apenas pela capacidade e formação técnica, mas também por uma longa convivência com Abujamra. Camargo e Nigro se definem como mais metódicos e 'cerebrais', enquanto definem Abujamra como mais 'intuitivo' - características confirmadas pelo próprio compositor em entrevista para esta pesquisa (ABUJAMRA, 2016).

Pensamos que as composições em parceria contribuíram para o amadurecimento de Abujamra como compositor de música para cinema, a partir do momento em que ele precisa negociar suas ideias não apenas com o diretor, mas submetê-las, sem apego, às opiniões e novas ideias de seus parceiros. Para um artista de palco que aprendeu a compor música para cinema na lida profissional e, muitas vezes, em conflito de ideias com o diretor, a convivência e a experiência de dividir a composição com amigos suavizou, com a cumplicidade construída nessas relações, o doloroso processo de compreender a trilha musical não como fim, mas como parte de algo maior; não como o 'projeto da vida', e sim como 'um projeto a mais'. 


\section{NARRATIVAS DIVERSAS, TRAÇOS COMPARTILHADOS}

Neste trabalho investigamos a obra musical do compositor André Abujamra para cinema, tanto analisando alguns dos longas-metragens de ficção que contam com sua assinatura na trilha musical - Carlota Joaquina , princesa do Brasil (Carla Camurati, 1995), Um copo de cólera (Aluizio Abranches, 1999), Castelo Rá-Tim-Bum, o filme (Cao Hamburger, 1999), Bicho de sete cabeças (Laís Bodanzky, 2001) e O contador de histórias (Luiz Villaça, 2009) -, como evidenciando, por meio de pesquisa biográfica e entrevistas, seu processo criativo, estrutura e métodos de trabalho e parceiros - aspectos compartilhados com sua carreira musical em disco.

O estabelecimento do elemento musical de autoria de Abujamra como eixo das análises fílmicas nos permitiu perceber, a partir do deslocamento da tradicional ênfase na imagem, a fluida relação entre as composições do artista e os demais elementos sonoros presentes nos filmes - diálogos, som ambiente, foleys, ruídos e outros efeitos, além de músicas preexistentes. Se "música é qualquer som" e também silêncio, como considera o compositor, esta fluidez é esperada e configura uma das marcas de seu trabalho no cinema.

O diálogo da trilha musical de Abujamra com outros elementos sonoros fílmicos acontece de forma menos previsível em filmes como Durval Discos (Anna Muylaert, 2003) e Bicho de sete cabeças (Laís Bodanzky, 2001). Algumas composições originais para esses filmes, se ouvidas fora do contexto, podem parecer muito sutis; no entanto, combinadas a outros elementos sonoros, têm papel fundamental na ligação deles entre si e com a imagem.

Em Durval Discos a versão de uma música preexistente foi rearranjada e tornada canção-tema. Mestre Jonas, composta por Sá, Rodrix e Guarabyra, ganhou não apenas uma, mas duas versões do compositor: uma interpretada pelo Os Mulheres Negras, na voz de Maurício Pereira, com ares de surf music; e outra por Fat Marley, personagem de Abujamra no filme (e fora dele), esta uma 'versão da versão' d'Os Mulheres Negras, eletrônica, com beat acelerado e inserções de falas dos personagens. As duas versões são simétricas em suas inserções no filme: a primeira, d'Os Mulheres Negras, abre Durval Discos, anunciando, de início, a parábola bíblica de Jonas - que vive preso na baleia, vinculada ao protagonista Durval - que vive preso no passado, na ligação infantil com a mãe Carmita e na paixão por discos de vinil. A segunda versão de Mestre Jonas, por sua vez, aparece depois de metade dos créditos finais: o remix eletrônico de Fat Marley coroa a obsolescência do familiar (e do vinil, do som analógico) diante das múltiplas possibilidades do novo (e do som digital). 
A trilha musical do filme de Anna Muylaert é percebida em dois momentos análogos aos lados de um disco de vinil: no lado A temos um festival de músicas brasileiras, canções eternizadas nas vozes de Tim Maia (Que beleza), Elis Regina (Madalena), Sá, Rodrix e Guarabyra (Mestre Jonas, que aparece em sua gravação original, além das outras versões elaboradas para o filme), Gilberto Gil (Maracatu atômico, Back in Bahia), Toquinho e Vinícius (A Tonga da Mironga do Kabuletê), Novos Baianos (Besta é tu) - além das referências visuais (capas de discos, figurino e caracterização de Durval). No lado B, com o conflito instalado na narrativa, surge então a trilha musical original de Abujamra, a princípio discretamente, em plano sonoro de fundo, em composição tonal, harmônica e melódica com as canções preexistentes já apresentadas no 'lado A', elevando-se gradualmente até o clímax, quando a música original vai para o primeiro plano sonoro, sobrepondo-se, inclusive, aos diálogos.

Nesse momento, as vozes que se unem em cantos, gritos e percussão lembram as ideias de ritual empregadas nas trilhas compostas pelo artista para a morte de Dona Maria, a rainha louca, em Carlota Joaquina, princesa do Brasil (Carla Camurati, 1995) e para as cenas de fúria e invasão das saúvas em Um copo de cólera (Aluízio Abranches, 1999). Neste filme de Abranches, a voz opera em camadas de percepção e significação, demonstrando o jogo entre as razões e os desejos feminino e masculino por meio da adaptação da poética verbal de Raduan Nassar, da interpretação dos atores e das composições musicais de Abujamra. Em uma peça, a voz opera como provocadora da desordem que mina a razão; na outra, restabelece a harmonia dos corpos na consumação amorosa do desejo.

Em outro filme, Domésticas (Fernando Meirelles e Nando Olival, 2001), a fala e o canto se misturam não somente nas canções que demonstram as emoções e posicionam cultural e socialmente as personagens (o rap e o romântico/brega), mas nos próprios diálogos, repletos de ritmo e musicalidade. As vozes musicais das domésticas são atravessadas pela trilha vocal composta por Abujamra, responsável pela desconstrução da palavra e pela reciclagem de sílabas, vogais e consoantes, juntas ou separadas, em ritmo, melodia e harmonia, em gestos vocais cujo significado transcende a palavra e só é possível em sua relação com os demais elementos sonoros e com a imagem. Nestes filmes, portanto, voz é poder, como afirma Chion (2004), tanto em verbo quanto em gesto. O empoderamento pela voz, no entanto, não está apenas na supremacia da palavra, mas também no uso criativo do gesto vocal.

Assim como em Domésticas e em Durval Discos, várias canções, desta vez de Arnaldo Antunes, compõem a trilha musical de Bicho de sete cabeças. O buraco do espelho, Fora de si, O seu olhar e outras composições de Antunes se conectam ao filme com o suporte da música original de Abujamra, que utiliza o eletrônico, o atonal, diversas alturas e texturas sonoras, e 
até falas do próprio filme tratadas de forma distinta dos diálogos, para dar, ao conjunto sonoro, coesão e unidade. A voz grave de Antunes, combinada à inesperada 'sujeira sonora' das composições de Abujamra, entra em consonância com os ruídos ensurdecedores da metrópole e das lembranças do protagonista Neto (Rodrigo Santoro). E todo esse conjunto entra em conexão com a 'sujeira da imagem', o cinza da cidade, os muros pichados, a poluição, o cotidiano automático no seio familiar. Toda essa poluição sonora e visual clama por respiração por meio da canção preexistente e homônima Bicho de sete cabeças (composta por Geraldo Azevedo em parceria com Zé Ramalho), em versão cantada por Zeca Baleiro.

Além das relações fluidas entre a música de Abujamra e os demais elementos sonoros em filmes, percebemos também aproximações entre estas trilhas, compostas em diferentes contextos e condições de realização para atender a demandas narrativas específicas, e aspectos de sua obra discográfica, desde a negação, no caso desta última, a se curvar às exigências de lucro da indústria - alterar integrantes de banda, sua sonoridade e a própria imagem para aumentar a visibilidade ante a um público massivo - até aspectos estético-musicais, como a mistura de timbres de sonoridades distantes acumulados em suas livrarias digitais, a densidade de texturas, as batidas eletrônicas, o gosto pela música sinfônica, a valorização do caráter gestual da voz - tornada ritmo, ruído e/ou idioma estrangeiro.

Tal como nos versos da Ópera Arepó, canção-tema de Castelo-Rá-Tim-Bum, o filme, o humor decorrente das combinações silábicas é uma característica das composições de Abujamra na maior parte de seus discos. Da economia à densidade de texturas, as composições de Abujamra demonstram a flexibilidade das canções na incorporação de novos gestos vocais. O humor trazido pela simplicidade das letras (quando há), por suas combinações silábicas, pelo encadeamento das palavras ou expressões vocais de outra ordem, pela métrica e pelos arranjos musicais também é uma característica de grande parte das composições do artista. A canção Mediócritas, do Karnak (Estamos adorando Tokio, 2000), é um exemplo: "Ninguém quer te ver feliz / Todo mundo quer que você quebre o nariz / Ninguém quer te ver contente / Todo mundo quer que você quebre os dentes".

O recurso de mistura de palavras simulando ou reproduzindo idiomas diferentes também é encontrado nas discografias de Abujamra. Em Estamos adorando Tokio (disco homônimo, 2000), temos o espanhol, o inglês e o português na mesma estrofe, mistura que revela o tratamento de gesto sonoro dado à voz e a identidade multifacetada do grupo: "Mira los karnako, me gusta Tokio / When you get out please take a passaporto / Mira los karnako, estamos adorando Tokio". 
Também em Castelo Rá-Tim-Bum, o filme, conforme analisado, a música orquestral de Abujamra e Lulu Camargo segue as convenções já consagradas na série televisiva homônima, o que acarreta a previsibilidade das composições em sua relação permanente com os diálogos e efeitos sonoros empregados largamente na narrativa fantástica. Também aqui as canções (originais, gravadas pelo Karnak) dialogam com o filme de maneira ornamental, reforçando o que já se encontra na trama sob a forma de linguagem cinematográfica.

Abujamra, quando não conta com um orquestrador ao seu lado - como em O caminho das nuvens, Do começo ao fim e O contador de histórias, tende ao pastiche em suas composições - entendendo pastiche como uma colagem e/ou recombinação de práticas criativas preexistentes, relacionado ainda à substituição da sonoridade orquestral (instrumentos reais gravados por músicos reais em formação de orquestra) ou outra, com menos elementos, por instrumentos virtuais. Já em Carandiru, no qual o compositor declara ter aprendido que o filme é mais importante que sua música, temos as presenças decisivas de Renato Lemos - presente também em Castelo Rá-Tim-Bum, o filme e outros, como orquestrador e regente, e de Hector Babenco, como diretor e orientador incisivo da trilha musical.

Uma vez que o artista compreende que o filme é mais importante e é para este que a música trabalha, ele começa a buscar formas de se tornar 'visível' enquanto autor, quando negocia, por exemplo, fazer figuração como ator (Fat Marley em Durval Discos, o recepcionista do hotel em Castelo Rá-Tim-Bum, o filme), ou quando cede as próprias canções de sua discografia para filmes de amigos (Elevador, do disco O infinito de pé, de 2004, presente em Do começo ao fim). Tais estratégias tensionam o lugar do compositor musical de cinema, uma vez que colocam em discussão os limites de interferência não apenas da música, mas de seu compositor, no filme. Nossa compreensão até aqui é a de que a música pode ser audível, desde que não desvie o espectador/ouvinte da narrativa fílmica, e o mesmo precisa ser aplicado à figura do compositor.

Eu não vejo muito a ligação do meu trabalho como artista pop e/ou artista do que seja com a trilha de cinema. Trilha sonora, pra mim, é uma coisa mais egocêntrica, mais egoísta, mais... eu, aqui, dentro da minha espaçonavezinha aqui, criando, entendeu? Acho que a coisa do artista é um pouco mais banda [...]. Eu não vejo muita ligação, são coisas díspares (ABUJAMRA, 2016).

Mesmo que em seu discurso Abujamra consiga discernir os limites entre suas trajetórias no cinema - invisível, para que o filme se torne visível - e como artista pop - necessariamente visível -, o caráter intuitivo e impetuoso de seu processo composicional - declarado pelos parceiros Márcio Nigro, Lulu Camargo e por ele mesmo, em entrevistas para esta tese (2016) - 
o conduz a uma tendência de encurtar as distâncias entre essas diferentes direções - o que o coloca, em Durval Discos, Castelo Rá-Tim-Bum, o filme e Do começo ao fim em camadas superpostas de atuação: música original, música preexistente e ator coadjuvante, em voz e corpo, som e imagem. A visibilidade e invisibilidade do artista se alternam, tal como ocorre com sua própria música no cinema.

Samples de cordas, piano e outros timbres sintetizados de formação sinfônica são recorrentes na discografia do artista, o que é justificado por ele como uma influência de sua carreira como compositor de música para filmes: "Eu acho que eu trago mais a minha linguagem de cinema pro meu trabalho pop do que o meu trabalho pop pro cinema" (ABUJAMRA, 2016). Dos sete discos ouvidos para este trabalho - Música e ciência (Os Mulheres Negras, 1988), Música serve para isso (Os Mulheres Negras, 1990), Karnak (Karnak, 1995), Estamos adorando Tóquio (Karnak, 2000), O infinito de pé (2004), Retransformafrikando (Abujamra, 2007) e Mafaro (Abujamra, 2010) -, cinco deles - todos, a partir de 1995, ano de lançamento de Carlota Joaquina, princesa do Brasil - apresentam sonoridades de cordas e piano que se aproximam do pastiche. Nestes cinco discos, 17 faixas apresentam cordas sintetizadas em sua composição. A faixa O amor é difícil (Mafaro, 2010), por exemplo, mistura cordas sintéticas com música andina, para, então se aproximar do eletrônico drum'n'bass.

A sonoridade de muitos destes instrumentos tensiona a singularidade timbrística em relação aos seus correspondentes reais e seu difundido uso no cinema brasileiro desde o final dos anos de 1990 evidencia, em vários casos, uma gestão de recursos de produção, de modo a não contemplar satisfatoriamente os processos sonoros de pós-produção. Por outro lado, a síntese eletrônica de sonoridades originalmente componentes da orquestra tradicional, misturadas a elementos de outras fontes, demonstram as infinitas possibilidades do som digital, reconfigurando não apenas a música em sua qualidade sonora, mas seus processos de produção - não apenas no cinema - e o próprio perfil dos compositores em atividade no século XXI, que promovem a convivência e o diálogo entre processos tradicionais e inovadores de criação.

De acordo com Berchmans (2006), os compositores de música para cinema parecem concordar que trabalhar em um filme criativo, que tenha um roteiro de qualidade, apresente uma utilização satisfatória da gramática cinematográfica executada por uma equipe técnica e artisticamente alinhada a uma direção segura contribui para a composição de uma trilha musical que atenda às demandas da narrativa, do diretor e do público. No entanto, um filme que não consegue solucionar seus problemas narrativos, estéticos e técnicos não pode depositar na música a esperança ou a responsabilidade de 'salvar' a obra. 
É muito comum produtores e diretores colocarem um excesso de responsabilidade artística na criação musical, numa tentativa desesperada de resolver algum problema que o filme traz ou ainda tentar contar uma história que o filme não conseguiu (BERCHMANS, 2006, p. 24).

$\mathrm{Na}$ trajetória de Abujamra compreendemos que o compositor soube aproveitar as oportunidades que teve de trabalhar em grandes filmes, superando, para isso, eventuais conflitos com diretores, refazendo músicas, trabalhando com Márcio Nigro e eventualmente com Lulu Camargo, adaptando-se a condições orçamentárias nem sempre ideais, utilizando todos os recursos de seu home studio em benefício de seu trabalho e do êxito dos filmes, em cada caso. O aprendizado do artista no cinema, eminentemente da ordem da atuação profissional, beneficiou-se de sua larga formação musical, mesmo que 'formalmente incompleta', além de sua bagagem cultural e experiência como músico de palco, que lhe garantem uma versatilidade musical desejável ao ofício.

Eu sou meio um "Exu” nessa história, porque eu transito entre todos. Já fiz trilha de música eletrônica, já fiz trilha só orquestral, do Castelo Rá-Tim-Bum, já fiz orquestral com rock, já fiz só rock. E já trabalhei com profissionais muito legais, já trabalhei com profissionais muito chatos, mas consegui terminar bem as coisas, sempre consegui terminar (ABUJAMRA, 2016).

Ao mesmo tempo, a estreia em longas-metragens, a partir da Retomada do cinema brasileiro, de muitos diretores hoje renomados, propiciou um aprendizado mútuo: Anna Muylaert, Carla Camurati, Aluizio Abranches e outros diretores então em início de carreira e amadureceram, juntamente com o compositor, adquirindo a segurança da habilidade em seus papéis, a partir das experiências compartilhadas nos complexos processos estéticos, técnicos, comunicacionais, econômicos e políticos que envolvem a realização de um longa-metragem de ficção no Brasil.

Quando perguntado sobre sua assinatura musical, Abujamra confirma que possui, mas que, por se tratar de sua própria vida e experiência, não consegue discernir suas características:

Muita gente fala pra mim: “Ah, eu ouvi uma música lá que parecia sua”. E geralmente era minha mesmo, ou geralmente alguém que se inspirou em mim. Eu acho que eu tenho um estilo, agora é uma coisa que está tão distante de eu te responder porque faz muitos anos que eu faço isso. Na verdade, desde pequenininho eu já faço isso, né? Então eu não sei explicar. Eu me defino como um profissional que faz arte, que faz arte em todos os sentidos, inclusive que faz arte na vida, faço muita besteira também. Eu não sou um músico que faz trilha sonora, eu acho que eu som um arquiteto do som que faz arte (ABUJAMRA 2016). 
Márcio Nigro, seu parceiro em Encarnação do demônio (José Mojica Marins, 2008), O contador de histórias (Luiz Villaça, 2009), Amanhã nunca mais (Tadeu Jungle, 2011), 2 coelhos (Afonso Poyart, 2012) e Praça Paris (Lúcia Murat, 2017), também considera Abujamra um artista para além do ofício de compositor: "Ele gosta de ser um artista e ele gosta de se meter em tudo, ser ator, ser diretor. Ele é músico, ele também é ator e ele gosta de aparecer! Então, ele quer aparecer, ele quer se divulgar como artista" (NIGRO, 2016).

A definiç̧ão das características autorais de Abujamra, considerando a abrangência de seu perfil como artista, não se torna mais fácil quando restringimos esta tarefa ao universo musical cinematográfico em que o compositor atua, como foi o grande objetivo deste trabalho. Nigro nos dá uma pista:

Todo mundo quer ter uma assinatura, mas o Abu já tem; tem uma identidade estética e musical que é dele, e que obviamente ele quer imprimir. Depende muito do estilo do filme; ele gosta muito das coisas orquestrais. Tem algumas coisas que são assinaturas dele, eu já reconheço. O arranjo de cordas dele, eu já escuto e já sei que é dele. É o modo de composição, né? (NIGRO, 2016).

Concluímos, conforme o que foi apresentado no quarto capítulo deste trabalho, que há um tensionamento entre uma postura ainda romântica de Abujamra em relação às suas criações e o desapego necessário ao ofício de compor música para filmes - que é totalmente compreendido por ele -, consequência da proximidade com que ele mesmo conduz suas carreiras na música (discos) e no cinema. Se ser compositor de trilhas para filmes é, em alguma medida, compartilhar a autoria com o diretor, como conciliar este papel com a extrema atenção dada ao artista em suas performances no palco?

Tendo tal tensionamento em vista, consideramos, por fim, que a assinatura de Abujamra é construída com base em alguns fatores fundamentais: o momento pessoal da vida do artistaque inspirou as distorções da ruidosa música para Bicho de sete cabeças; sua religiosidade uma vez que o vínculo com o candomblé o acompanha em trilhas de caráter ritualístico, com vozes, palmas e percussão, em Carlota Joaquina, princesa do Brasil, Um copo de cólera, Durval Discos, Cafundó; suas viagens e projetos discográficos - por meio dos quais conhece, acumula e experimenta combinações entre diferentes timbres; a existência de parceiros para a composição - já que os perfis mais metódicos de Márcio Nigro e Lulu Camargo equilibram seu ímpeto criativo e contribuem na estruturação das ideias; a existência de um orquestrador Renato Lemos garante uma maior complexidade de arranjos em Castelo Rá-Tim-Bum, o filme (juntamente com Lulu Camargo), Um copo de cólera e Carandiru, por exemplo. Outros fatores importantes são, como em qualquer processo de composição musical para cinema, a relação 
com o diretor do filme, o orçamento disponível e as demandas estéticas e narrativas específicas de cada projeto.

Considerando todas as informações levantadas neste estudo e os fatores fundamentais na construção da marca musical cinematográfica de André Abujamra, elencamos, por fim, os traços desta assinatura. A combinação inesperada de timbres de diferentes origens, principal marca de Abujamra, demonstra seu multiculturalismo musical e o gosto pela experimentação de sonoridades diversas, tonais ou atonais, do ocidente ou do oriente, em todos os seus projetos; ao mesmo tempo em que o coloca em proximidade com o pastiche, a partir do momento em que tais combinações resultam antes do ímpeto criativo - ponto-chave de autoria do artista do que da reflexão sobre a função da música, em cada caso - uma vez que a música dele segue as convenções do cinema clássico narrativo, conforme exposto e analisado nos capítulos anteriores deste trabalho.

Outro traço da música de Abujamra aqui reforçado é a fluidez entre suas composições e os demais elementos sonoros fílmicos, sejam eles ruídos, som da locação (ambiente), diálogos ou silêncio, o que demonstra o interesse do compositor pelo projeto sonoro do filme, pelo lugar onde ele é gravado e por como sua música pode contribuir para este universo maior.

A presença de sua música e figura em camadas sonoras e visuais - quando permitido pelos filmes, por meio de canções preexistentes e convites para atuação - comprova seu interesse pela visibilidade, mesmo que sua música, em determinada cena, precise ser invisível para que se obtenha o efeito narrativo esperado.

O gosto pela orquestração também compõe a assinatura musical de Abujamra no cinema, sendo explorado em diferentes complexidades, dependendo da presença de um orquestrador mais experiente que ele ou de orçamento disponível para a gravação de músicos em estúdio, em conjunto ou em detrimento do uso de samplers de instrumentos de formação sinfônica.

Finalizamos este trabalho com a confirmação da autoria camaleônica de André Abujamra, que, por outro lado, desde o início dos anos 2000, com o Karnak e em carreira solo, utiliza sistematicamente a linguagem audiovisual em seus projetos discográficos. Omindá - A união das almas pelo mundo da água, seu último trabalho recentemente lançado (2018), foi feito em 14 países. Fruto do amadurecimento de suas ideias há mais de uma década, Omindá reforça sua paixão por percorrer o mundo em busca de novas sonoridades, coroando a música dos sons e das imagens como matéria-prima de vida, condição de sua plena existência. 


\section{REFERÊNCIAS}

ABRANCHES, Aluizio. Aluizio Abranches: depoimento [mar. 2014]. Entrevistadora: Geórgia Cynara. São Paulo: entrevista inédita concedida para a pesquisa, 2014.

ABUJAMRA, André. André Abujamra: depoimento [maio 2003]. Entrevistadores: Dafne Sampaio, Daniel Almeida, Flávio Rosselli, Max Eluard, Ricardo Tacioli. São Paulo: Site Gafieiras, 2003. Disponível em: <http:/gafieiras.com.br/entrevistas/andre-abujamra/1>. Acesso em: 15 abr. 2015.

André Abujamra: depoimento [maio 2007]. Entrevistador: Denis Von Brasche. São Paulo: dvblog, 2007. Disponível em: <https://devebe.wordpress.com/2007/05/30/entrevistacom-andre-abujamra/>. Acesso em: 13 set. 2013.

André Abujamra: depoimento [mar. 2013]. Entrevistador: Miguel de Almeida. São Paulo: SESC TV, 2013. Entrevista concedida ao Programa Sala de Cinema. Disponível em: $<$ https://www.youtube.com/watch?v=JkOy9V69aJQ>. Acesso em: 15 abr. 2015.

André Abujamra: depoimento [mar. 2016]. Entrevistadora: Geórgia Cynara. São Paulo: entrevista inédita concedida para a pesquisa, 2016.

AUMONT, Jacques; MARIE, Michel. A análise do filme. Lisboa: Edições Texto \& Grafia, 2004.

BALLERINI, Franthiesco. Cinema brasileiro no século 21: reflexões de cineastas, produtores, distribuidores, exibidores, artistas, críticos e legisladores sobre os rumos da cinematografia nacional. São Paulo: Summus, 2012.

BENTES, Ivana. Sertões e favelas no cinema brasileiro contemporâneo: estética e cosmética da fome. In: . Ecos do cinema: de Lumière ao digital. Rio de Janeiro: UFRJ, 2007. p. 191-224.

BERCHMANS, Tony. A música do filme: tudo o que você gostaria de saber sobre a música de cinema. São Paulo: Escrituras, 2006.

BERNARDET, Jean-Claude et al. O som no cinema brasileiro. Filme e Cultura, Rio de Janeiro, Embrafilme, v. 14, n. 37, p. 2-7, jan./fev./mar. 1981.

BICHO de Sete Cabeças. Direção: Laís Bodanzky. Fotografia Hugo Kovensky. [S.1.]:

Columbia Pictures do Brasil, 2001 (84 min). NTSC, color. Disponível

em: $<$ https://www.youtube.com/watch?v=F6Yky54edpo>. Acesso em: 6 fev. 2018.

BIOSOM. Saiba tudo sobre ouvido absoluto. (C2017. Disponível em:

$<$ https://biosom.com.br/blog/curiosidades/saiba-tudo-sobre-ouvido-absoluto/>. Acesso em: 26 dez. 2017.

BORDWELL, David. Making meaning: inference and rhetoric in the interpretation of cinema. USA: Harvard University Press, 1991. 
O cinema clássico hollywoodiano: normas e princípios narrativos. In: RAMOS, Fernão (Org.). Teoria contemporânea do cinema: documentário e narratividade ficcional. São Paulo: SENAC, 2004. v. 2. p. 277-301.

Poetics of cinema. New York: Routledge, 2008.

BORDWELL, David; THOMPSON, Kristin. A arte do cinema: uma introdução. Campinas/São Paulo: Editora da Unicamp/Edusp, 2013.

BRASIL. Presidência da República. Casa Civil. Subchefia para Assuntos Jurídicos. Lei n. 9610, de 19 de fevereiro de 1998. Altera, atualiza e consolida a legislação sobre direitos autorais e dá outras providências. Disponível em:

$<$ http://www.planalto.gov.br/ccivil_03/leis/L9610.htm>. Acesso em: 11 abr. 2016.

Presidência da República. Casa Civil. Subchefia para Assuntos Jurídicos. Lei n.

12.853, de 14 de agosto de 2013. Altera os arts. $5^{\circ}, 68,97,98,99$ e 100 , acrescenta arts. 98A, 98-B, 98-C, 99-A, 99-B, 100-A, 100-B e 109-A e revoga o art. 94 da Lei n 9.610, de 19 de fevereiro de 1998, para dispor sobre a gestão coletiva de direitos autorais, e dá outras providências. Disponível em: <http://www.planalto.gov.br/ccivil_03/_Ato20112014/2013/Lei/L12853.htm>. Acesso em: 22 dez. 2017.

BUSCOMBE, Edward. Ideias de autoria. In: RAMOS, Fernão (Org.). Teoria contemporânea do cinema: pós-estruturalismo e filosofia analítica. São Paulo: SENAC, 2004. v. 1. p. 281-294.

CAMARGO, Lulu. Lulu Camargo: depoimento [set. 2016]. Entrevistadora: Geórgia Cynara. São Paulo: entrevista inédita concedida para a pesquisa, 2016.

CARLOTA JOAQUINA, princesa do Brasil. Direção: Carla Camurati. Fotografia Breno Silveira. [S.1.]: Europa Filmes, 1995 (101 min). NTSC, color. Disponível em: <https://www.youtube.com/watch?v=wk9ZE7C9P58>. Acesso em: 6 fev. 2018.

CARRASCO, Claudiney. Trilha musical: música e articulação fílmica. 1993. $221 \mathrm{f}$. Dissertação (Mestrado em Cinema) - Universidade de São Paulo, São Paulo, 1993.

CARRASCO, Ney. Cidade oculta: o jogo entre tradição e ruptura no campo de sonhos dos anos 1980. In: FREIRE, Rafael de Luna (Org.). Nas trilhas do cinema brasileiro. Rio de Janeiro: Tela Brasilis, 2009. p. 96-118.

CARVALHO, Marcia. Anos 1970: o desenlace da polifonia tropical e a marginália na música de cinema. In: FREIRE, Rafael de Luna (Org.). Nas trilhas do cinema brasileiro. Rio de Janeiro: Tela Brasilis, 2009. p. 84-95.

CASSIDY, Kevin; HALPERIN, Shirley. THR's composer roundtable: 6 movie maestros on severed heads, stubborn directors and feeling 'like Frankenstein'. The Hollywood Reporter, 20 dez. 2012. Disponível em: $<$ http://www.hollywoodreporter.com/news/zero-dark-thirty-lifepi-404029>. Acesso em: 6 set. 2016. 
CASTELO Rá-Tim-Bum, o filme. Direção: Cao Hamburger. Fotografia Marcelo Durst. [S.1.]: Columbia Tristar Home Entertainment, 1999 (105 min). NTSC, color. Disponível em: $<$ https://www.youtube.com/watch?v=pFCkVf3aiOI $>$. Acesso em: 6 fev. 2018.

CAZNOK, Iara Borges. Música: entre o audível e o visível. 2. ed. Campinas: Unesp, 2008.

CHION, Michel. La audiovisión: introducción a un análisis conjunto de la imagen y el sonido. Barcelona: Ediciones Paidos, 1993.

La voz en el cine. Madrid: Ediciones Cátedra, 2004.

COSTA, Fernando Morais. O som no cinema brasileiro. Rio de Janeiro: 7Letras, 2008.

DA-RIN, Silvio. Entrevista (técnicos). In: CAETANO, Daniel (Org.). Cinema brasileiro 1995-2005: ensaios sobre uma década. Rio de Janeiro: Azougue, 2005. p. 255-260.

EIKMEIER, Martin. A música de Remo Usai no cinema brasileiro. 2010. 249 f. Tese (Doutorado em Multimeios) - Instituto de Artes, Universidade de Campinas, Campinas, 2010.

FLAUTADOCEBR. Afinação: acabando com os mitos. C2015. Disponível em: $<$ http://quintaessentia.com.br/afinacao-acabando-com-os-mitos/>. Acesso em: $31 \mathrm{dez} .2017$.

FREIRE, Rafael de Luna (Org.). Nas trilhas do cinema brasileiro. Rio de Janeiro: Tela Brasilis, 2009.

GALLO, Rafael Eduardo. As trilhas musicais originais do cinema brasileiro após a Retomada: os compositores e seus processos de criação e produção. 2015. 405 f. Dissertação (Mestrado) - Escola de Comunicações e Artes, Universidade de São Paulo, São Paulo, 2015.

GIORGETTI, Mauro. Da natureza e possíveis funções da música no cinema. 2008.

Disponível em: <http://www.mnemocine.com.br/index.php/cinema-categoria/29somcinema/161-funcoes-musica-cinema>. Acesso em: 19 jul. 2014.

GORBMAN, Claudia. Unheard melodies: narrative film music. Bloomington: Indiana University Press, 1987.

GUERRINI JÚNIOR, Irineu. A música no cinema brasileiro: os inovadores anos sessenta. São Paulo: Terceira Margem, 2009.

INTERNET MOVIES DATABASE. André Abujamra. C1990. Disponível em: $<$ http://www.imdb.com/name/nm0009494/>. Acesso em: 8 jun. 2015.

JOFFILY, José. José Joffily: depoimento [mar. 2014]. Entrevistadora: Geórgia Cynara. São Paulo: entrevista inédita concedida para a pesquisa, 2014.

JOST, François. O autor nas suas obras. In: SERAFIM, José Francisco (Org.). Autor e autoria no cinema e na televisão. Salvador: EDUFBA, 2009. p. 11-31.

LUCENTINI, Vanderlei Baeza. Incursões da música eletroacústica no cinema. Revista Novos Olhares, São Paulo, v. 3, n. 2, p. 212-225, 2014. 
MACARIO, Leonardo Côrtes. Canções para o carnaval. In: FREIRE, Rafael de Luna (Org.). Nas trilhas do cinema brasileiro. Rio de Janeiro: Tela Brasilis, 2009. p. 23-34.

MANNIS, José Augusto. Ensaio sobre a expansão de atividades derivadas ou relacionadas à composição musical. In: TRAGTENBERG, Lívio (Org.). O ofício do compositor hoje. São Paulo: Perspectiva, 2012. p. 199-207.

MARSON, Melina Izar. Cinema e políticas de estado. São Paulo: Escrituras Editora, 2009.

MARTIN, Marcel. A linguagem cinematográfica. São Paulo: Brasiliense, 2003.

MATOS, Eugênio. A arte de compor música para o cinema. Brasília: Senac, 2014.

MIRANDA, Suzana Reck. Anos 1990-2000: Bicho de sete cabeças contado pelas canções. In: FREIRE, Rafael de Luna. Nas trilhas do cinema brasileiro. Rio de Janeiro: Tela Brasilis, 2009. p. 119-130.

MUYLAERT, Anna. Anna Muylaert: depoimento [mar. 2014]. Entrevistadora: Geórgia Cynara. São Paulo: entrevista inédita concedida para a pesquisa, 2014.

NAGIB, Lúcia. O cinema da Retomada: depoimentos de 90 cineastas dos anos 90 . São Paulo: Editora 34, 2002.

NASCIMENTO, Anselmo Mancini do. A experiência prática no diálogo entre a produção cinematográfica e a musical. 2013. 162 f. Dissertação (Mestrado) - Escola de Comunicações e Artes, Universidade de São Paulo, São Paulo, 2013.

NIGRO, Márcio. Márcio Nigro: depoimento [set. 2016]. Entrevistadora: Geórgia Cynara. São Paulo: entrevista inédita concedida para a pesquisa, 2016.

O CONTADOR de histórias. Direção: Luiz Villaça. Fotografia Lauro Escorel. [S.1.]: Warner Brothers, 2009 (106 min). NTSC, color. Disponível

em: <https://www.youtube.com/watch?v=kRJwQg-oavc $>$. Acesso em: 6 fev. 2018.

ORICCHIO, Luiz Zanin. Cinema de novo: um balanço crítico da Retomada. São Paulo:

Estação Liberdade, 2003.

ORTIZ, Renato. Mundialização e cultura. São Paulo: Brasiliense, 1994.

RODRÍGUEZ, Angel. A dimensão sonora da linguagem audiovisual. São Paulo: Senac, 2006.

SANTANA, Geórgia Cynara Coelho de Souza. Riso, desespero, exílio e loucura: a canção popular brasileira em "Terra Estrangeira" e "Durval Discos". 2012. 162 f. Dissertação (Mestrado em Comunicação) - Universidade Federal de Goiás, Goiânia, 2012.

SCHAFER, Murray. O ouvido pensante. São Paulo: Edunesp, 1992. 
SILVA, Márcia Regina Carvalho. A canção popular na história do cinema brasileiro. 2009. 340 f. Tese (Doutorado em Multimeios) - Instituto de Artes, Universidade de Campinas, Campinas, 2009.

TATIT, Luiz. Musicando a semiótica: ensaios. São Paulo: Annablume, 1997.

UM COPO de cólera. Direção: Aluizio Abranches. Pedro Farkas. [S.1.]: Seleções, 1999. 1 DVD (72 min), NTSC, color.

VALVERDE, Monclar. Mistérios e encantos da canção. In: MATOS, Cláudia Neiva; MEDEIROS, Fernanda Teixeira; TRAVASSOS, Elizabeth (Org.). Palavra cantada: ensaios sobre poesia, música e voz. Rio de Janeiro: 7Letras, 2008. p. 268-277.

VICENTE, Eduardo. Da vitrola ao iPod: uma história da indústria fonográfica no Brasil. São Paulo: Alameda, 2014.

VIEIRA, João Luiz. O (cinema) brasileiro tem memória? Revista Contracampo, Rio de Janeiro, n. 26, 2001. Disponível em:

$<\mathrm{http}: / /$ www.contracampo.com.br/26especial/memoria.htm>. Acesso em: 6 set. 2016.

WIERZBICKI, James. Film music: a history. New York: Routledge, 2009.

WISNIK, José Miguel. Sem receita: ensaios e canções. São Paulo: Publifolha, 2004.

XAVIER, Ismail. Figuras do ressentimento no cinema brasileiro dos anos 90. In: RAMOS, Fernão Pessoa. Estudos Socine de Cinema. Porto Alegre: Sulina, 2000. p. 78-98.

Cinema brasileiro moderno. São Paulo: Paz e Terra, 2001.

O olhar e a cena. São Paulo: Cosac \& Naify, 2003. 
ANEXO 


\section{ANEXO A - Pendrive com discos e filmes com músicas de André Abujamra}

Estão listados aqui os discos com músicas de André Abujamra (Os Mulheres Negras, Karnak e carreira solo) e os filmes ficcionais em longa-metragem analisados neste trabalho, que contam com trilha musical original do compositor.

Abaixo, a lista de discos e filmes, cujos arquivos se encontram no pendrive.

Discos:

- Música e ciência (Os Mulheres Negras, 1988)

- Música serve para isso (Os Mulheres Negras, 1990)

- Karnak (Karnak, 1995)

- Universo umbigo (Karnak, 1997)

- Estamos adorando Tokio (Karnak, 2000)

- O infinito de pé (André Abujamra, 2004)

- Retransformafrikando (André Abujamra, 2007)

- Mafaro (André Abujamra, 2010)

- O homem bruxa (André Abujamra, 2015)

Filmes:

- Carlota Joaquina - princesa do Brasil (Carla Camurati, 1995)

- Castelo Rá-Tim-Bum, o filme (Cao Hamburger, 1999)

- Um copo de cólera (Aluizio Abranches, 1999)

- Bicho de sete cabeças (Laís Bodanzky, 2001)

- O contador de histórias (Luiz Villaça, 2009) 
APÊNDICES 


\section{APÊNDICE A - Lista de filmes brasileiros de ficção em longa-metragem com trilhas musicais de André Abujamra, por ordem cronológica}

Estão listados aqui os filmes ficcionais em longa-metragem que contam com trilha musical original de André Abujamra. Estas obras foram produzidas e lançadas no Brasil a partir de 1995 e estão organizadas em ordem cronológica (ano de lançamento). As obras lançadas em um mesmo ano estão dispostas em ordem alfabética.

As informações contidas aqui foram buscadas em diversas fontes, tais como as cartelas iniciais e finais dos filmes analisados, websites da Agência Nacional do Cinema (ANCINE), da Cinemateca Brasileira, da Academia Brasileira de Cinema, do Internet Movie Database (IMDb), do Filme B, além de revistas de crítica de cinema e websites oficiais de filmes e produtoras. Abaixo, a lista de filmes:

- Carlota Joaquina, princesa do Brasil (Carla Camurati, 1995)

- Os matadores (Beto Brant, 1997)

- Ação entre amigos (Beto Brant, 1998)

- Castelo Rá-Tim-Bum, o filme (Cao Hamburger, 1999) ${ }^{63}$

- Um copo de cólera (Aluizio Abranches, 1999)

- Bicho de sete cabeças (Laís Bodanzky, 2001)

- Domésticas (Fernando Meirelles e Nando Olival, 2001)

- As três Marias (Aluizio Abranches, 2002)

- Carandiru (Hector Babenco, 2003)

- De passagem (Ricardo Elias, 2003)

- Durval Discos (Anna Muylaert, 2003)

- O caminho das nuvens (Vicente Amorim, 2003)

- Cafundó (Paulo Betti e Clovis Bueno, 2005)

- Os 12 trabalhos (Ricardo Elias, 2006)

- Achados e perdidos (José Joffily, 2007)

- Querô (Carlos Cortez, 2007)

- Caixa preta (Marcelo Izidoro, 2008)

- Encarnação do demônio (José Mojica Marins, 2008) ${ }^{64}$

- Do começo ao fim (Aluizio Abranches, 2009)

- O contador de histórias (Luiz Villaça, 2009) ${ }^{65}$

- Amanhã nunca mais (Tadeu Jungle, 2011) ${ }^{66}$

- 2 coelhos (Afonso Poyart, 2012) 67 $^{6}$

- Corpo presente (Paolo Gregori e Marcelo Toledo, 2013) ${ }^{68}$

- Até que a sbórnia nos separe (Otto Guerra e Ennio Terrisan, 2014) ${ }^{69}$

- Minutos atrás (Caio Sóh, 2014) ${ }^{70}$

- Trinta (Paulo Machline, 2014)

- Bem casados (Aluizio Abranches, 2015) $)^{71}$

\footnotetext{
63 Trilha musical em coautoria com Lulu Camargo.

64 Trilha musical em coautoria com Márcio Nigro.

65 Trilha musical em coautoria com Márcio Nigro.

66 Trilha musical em coautoria com Márcio Nigro.

67 Trilha musical em coautoria com Márcio Nigro.

68 Trilha musical em coautoria com Rafael Cavalcanti e André Moraes.

69 Trilha musical em coautoria com Hique Gomez e Nico Nicolaiewsky.

70 Trilha musical em coautoria com Paulinho Moska.

${ }^{71}$ Trilha musical em coautoria com Márcio Nigro e Meno Del Picchia.
} 
- Praça Paris (Lúcia Murat, 2017) 72 $^{72}$

${ }^{72}$ Trilha musical em coautoria com Márcio Nigro. 


\section{APÊNDICE B - Entrevista com o compositor André Abujamra, presencialmente, em 07/03/2016, das 11h às 13h30, no Omin Estúdios, em São Paulo-SP}

\section{Como você se define como compositor de música para cinema?}

Eu acho que eu tenho um estilo. Muita gente fala pra mim: "Ah, eu ouvi uma música lá que parecia sua". E geralmente era minha mesmo, ou geralmente alguém que se inspirou em mim. Eu acho que eu tenho um estilo, agora é uma coisa que está tão distante de eu te responder porque faz muitos anos que eu faço isso. Na verdade, desde pequenininho eu já faço isso, né? Então eu não sei explicar. Eu me defino como um profissional que faz arte, que faz arte em todos os sentidos, inclusive que faz arte na vida, faço muita besteira também. Eu não sou um músico que faz trilha sonora, eu acho que eu som um arquiteto do som que faz arte.

\section{Como você começou no cinema?}

Eu tenho uma banda chamada Os Mulheres Negras, que fez 30 anos esse ano [2016]. E a gente fazia muito show num lugar aqui em São Paulo, chamado Espaço Off. No longa-metragem, em comecei quando a Carla Camurati foi num show dos Mulheres Negras, e ela me viu tocando, e ela já sabia que eu fazia trilha de cinema de curta-metragem porque eu fui casado com a Anna Muylaert, que está fazendo um sucesso incrível.

Como eu era namorado da Anna na época e ela fazia faculdade de cinema na USP, eu fiz todas as trilhas de curtas dela e dos amigos dela que se tornaram Beto Brant, Chiquinho [Francisco César Filho], um montão de gente. E aí a Carla Camurati viu aquele show e ela me convidou pra fazer o Carlota Joaquina, que foi o meu primeiro longa, e que de certa forma foi o primeiro longa do ‘renascimento' do cinema brasileiro, em 1995. Então foi aí que eu vim com um longa.

Mas antes disso tem a história dos meus curtas. Então eu fiz milhões de curtas, ganhei um prêmio em Gramado [Melhor Música, 1992] com o filme da Anna As rosas não calam [1992], fiz muita trilha sonora de curta. Foi daí que veio a minha história com o cinema.

Só que, também antes disso, tem a história de que eu nasci no teatro. A minha mãe me dava de mamar na coxia do teatro. Então, como eu já nasci músico, eu fiz muita trilha de teatro, peça infantil, de espetáculos grandes. E aí, partir para a televisão foi uma coisa super natural.

Eu tinha três medos quando eu era pequenininho, eu falava pra minha mãe: eu tinha medo de não casar, medo de não fazer trilha sonora e medo de morrer. Casar eu já casei e trilha sonora eu já faço, agora morrer eu não morri.

3. As suas viagens parecem afetar muito você como artista, enquanto pesquisador de sons. Dos países que você já visitou, quais te chamaram mais a atenção em termos de sonoridade?

É óbvio que eu escuto de tudo, né, escuto vozes búlgaras, China, tal. Mas eu não sou um cara que vou escutar essas coisas do mundo e vou estudá-las, não. Eu vou senti-las dentro de mim. Porque a música pra mim é sentido. Então eu não chamaria isso de pesquisa. Eu chamaria isso de fome de viver. Não de conhecimento, fome de sentir bem. Porque como eu nasci músico, todo som que eu escuto - esse ar condicionado que a gente está ouvindo aqui -, todo som pra mim é música. Eu sou do candomblé. No candomblé, cada um tem um nome e cada um tem um significado. O meu nome no candomblé é Xiriã. Xiriã quer dizer 'um barulho'. Eu sou um barulho. Então, quer dizer, pra mim tudo é som, tudo é música. Então quando as pessoas falam "Ah, você pesquisa música", não, eu não pesquiso música, eu me alimento de som, de ruído, né? 
Eu gosto muito de viajar, porque a música pra mim é como beber água, é como respirar, fazer xixi, cocô. Pra mim, música não é uma coisa complexa, é uma coisa muito palpável, ela chega a ser matéria pra mim. Chega a ser matéria de pegar! Então, tudo que escuto que me incomoda é o que eu gosto. As coisas que eu escuto que já são muito comuns ao meu ouvido eu não gosto de ouvir muito. Eu não escuto música. Eu escuto assim, uma flauta indiana da década de 1920, um negócio assim que me incomoda, mas não que me incomoda porque eu acho ruim, me incomoda porque me alimenta. É uma inquietação do som, é como se você precisasse desse alimento. Então eu não acho que seja pesquisa, eu acho que é um alimento pra minha alma.

Eu já fiz várias viagens malucas. Eu já fui, pra começar, pro Egito, em 1991, quando eu conheci o templo de Karnak e montei minha banda Karnak.

\section{Essa foi sua primeira viagem sozinho?}

Não. Minha primeira viagem sozinho eu tinha 17 anos. Eu fui morar nos Estados Unidos, em Oklahoma. Fiquei um ano lá, na country music mesmo. Eu gosto muito de country. E ali que eu conheci o rock, também, o ZZ Top, essas coisas, que também têm influência no meu trabalho. Se for ver, tem essa coisa orquestral, mas tem a coisa do rock também.

Aí fui pro Egito; aí, das viagens malucas que eu fiz, fui pra Europa com Os Mulheres Negras; aí morei no México fazendo uma trilha [filme Vozes Inocentes, Luis Mandoki, 2004], morei lá pra fazer esse filme. Uma das viagens mais lindas que eu fiz foi pro Zimbábue, na África, onde eu fiz o Mafaro [2010], meu disco. Depois, graças à Anna eu ao nosso filho José, eu fui duas vezes pra China, né, num festival de cinema de lá, e levei o Mafaro sozinho. Toquei com um baterista chinês que não falava português. Amo viajar, acho que isso me alimenta. E a coisa da inquietação do som estranho, sabe? Ou uma desafinação, ou um instrumento exótico, você viu a minha balalaika ${ }^{73}$ aqui [no estúdio onde ele trabalha]. Então isso me agrada muito. Mas o que não me agrada muito é falar que eu sou um pesquisador, eu não sou um pesquisador.

Lá na China eu peguei um táxi, e o motorista do táxi se perdeu, e ele não sabia falar nada de inglês, e eu, muito menos de chinês. Aí eu peguei o Google Translator e coloquei: "Você está perdido?", aí mostrei pra ele aqueles caracteres e ele: "nõaiaõ" [imitando a fala do chinês com voz aguda]. Ele estava perdido sim, fazia assim com a mãozinha [gesto de "mais ou menos"]. Pra mim é música, sabe, qualquer som é música, motor de caminhão é música.

5. É daí que vem, por exemplo - quando você fala da sonoridade do idioma, da palavra como som/música, o artifício de usar a voz e inventar palavras no Karnak, nos Mulheres Negras, e em alguns filmes, como Castelo Rá-Tim-Bum, o filme [Cao Hamburger, 1999], Domésticas [Fernando Meirelles e Nando Olival, 2003]?

Domésticas foi muito legal, porque eu dei a ideia pro Fernando Meirelles de a gente usar os... Porque a gente não tinha dinheiro pra fazer orquestra, né. Aí eu peguei eu, o Marcos Bowie (o vocalista do Karnak), o Mano Bapi (que é o baixista também) e um amigo da gente, o Edson Montenegro, que tem um vozeirão, fiz um quarteto de vozes e peguei utensílios de empregada doméstica: vassoura, panela, tudo, pra fazer a trilha. Então essa pesquisa - isso eu acho que não é pesquisa, é brincadeira, você tentar usar essas coisas em seu favor.

No Castelo Rá-Tim-Bum tem uma coisa muito legal, no filme. Eu fiz o Castelo Rá-Tim-Bum na televisão, foi um sucesso, né, o "bum bum bum [Castelo Rá-Tim-Bum - cantarola]”. Quando

\footnotetext{
${ }^{73}$ Instrumento musical russo em madeira, de formato triangular, composto por três cordas.
} 
eu fui fazer o longa, o Cao Hamburger falou: "cara, a gente tem que mudar essa abertura, tem que ser outra coisa". Aí eu: "pô, cara, como é que eu vou inventar?". Aí eu resolvi fazer tudo ao contrário. E tudo ao contrário parecia russo, então, por exemplo: "muB-miT-áR oletsaC" [canta] é "Castelo Rá-Tim-Bum"! E parece um russo arcaico, alguma coisa assim. "Ópera arepó", e tem os anagramas... E aí era uma brincadeira. Engraçado que no Castelo Rá-Tim-Bum as crianças sacam que é ao contrário, e os pais acham que eu inventei qualquer coisa. Eu invento qualquer coisa, às vezes, mas o Castelo não é inventado. Se você pegar toda a trilha, mesmo quando tem a Losângela, a bruxa [imita um feitiço]... tudo ao contrário. Fica uma linguagem muito bonitinha, eu gostei muito. Eu uso muito essa coisa de som, né? Eu imagino que som é música. E silêncio também.

Nesse filme mexicano Vozes Inocentes, uma das coisas mais legais que eu já fiz em trilha: não fazer trilha. Tem duas vezes que eu consegui fazer isso. Nesse filme mexicano e no filme do Beto Brant, que é o Ação entre amigos [1998]. E justamente nessa hora da morte. No Vozes Inocentes, os caras vão matar o moleque, aquela "puta" trilha hollywoodiana [imita uma trilha grandiosa], "pá, pum", tiro pra todo lado. Na hora quando os caras vão colocar o revólver na cabeça do moleque, estava aquela "puta" trilha, aí eu falei assim: "tira tudo, pelo amor de Deus, tira, tira. É muito pesado". E aí tira o som de tudo. E aí na hora que ele vai matar o menino, ele toma um tiro de outro cara, o policial, e aí vem o som. Aquilo é um dos momentos que eu mais acho legais, é uma trilha sonora minha que não tem som, é o lugar que eu mais amo, é o não ter som.

E no Ação entre amigos também, quando o cara vai matar o torturador no meio da floresta, aquele "puta" som, eu, na mixagem, falei: "meu tira, tira tudo, tira passarinho, tira som, tira tudo, tira tudo". Cara, dá uma tensão, aquilo é uma música, né, é o silêncio mais musical. Eu sempre busco. Então eu sempre falo pros diretores: "cara, vamos colocar o mínimo de música possível".

\section{Você costuma acompanhar as mixagens dos filmes, da sua música com o som do filme?} Como é esse processo?

É delicado. Eu já fiz 50 filmes. Então hoje eu já tenho "cacife", vamos supor, eu tenho a... Hoje, geralmente, as pessoas me pedem, até. No começo era meio difícil, né, no Carandiru [Héctor Babenco, 2003] mesmo, a minha música está muito baixa na mixagem, mas aí é conceito do diretor, então não tem muito problema. Mas hoje em dia eu acompanho. E além de acompanhar, eu já indico pessoas pra trabalhar comigo, ou mesmo fazer efeitos sonoros, né? Eu trabalho muito com a Miriam Biderman, trabalho muito com o Beto Ferraz. Quando me pedem pra falar: "quem você indica?", eu indico sempre esses dois, e pra mixar o Ariel, que você conheceu [Ariel Henrique, Cinecolor Digital], ou mesmo o Armandinho, você conhece o Armandinho? Esse cara é demais, ele é muito bom também. Tudo moleque, né? Eu trabalho com uma molecada, um pessoal muito forte. Então pra mim é muito importante essa coisa da mixagem.

Algumas coisas que eu aprendi. Você vê nesse estúdio aqui, ele é 5.1. Eu tenho o centro, o L e $\mathrm{R}$ [left e right, canais da esquerda e da direita], o sub [subwoofer] ali, aqui atrás, e as minhas duas caixinhas [esquerda e direita de trás]. Então, no começo, eu gastava muito dinheiro pra mixar a música, a pré [pré-mixagem] da música, em 5.1. E aí eu mandava pros caras e os caras faziam a print master com a minha música mixada e mais a mixagem do som, diálogos e tudo. Aí eu comecei a ver que estava muito ruim, não era aquilo que eu imaginava. Aí tinha que ser homologado pela Dolby, e não sei o quê. Aí eu comprei minhas caixinhas e coloco no contrato que a mixagem 5.1 eu mando. Eu mando os stems também, mas eu sempre mando a minha 5.1. E, geralmente, quando é no Brasil, eu sempre acompanho a mixagem. Eles não gostam muito 
porque eu conto muita piada, todo mundo morre de rir, aí atrasa a mixagem, mas é legal, é bacana, eu acho uma ciência muito legal, a mixagem.

\section{Qual é o seu grau de "liberdade" pra sugerir alguma mudança na mixagem?}

Depende do diretor.

\section{Fale um pouco sobre essa relação entre você e diferentes diretores.}

Olha, eu já trabalhei com 50, né. 50 não, menos, porque alguns se repetem. Mas existe de tudo. É como comida, existem todos os tipos de comida. É como religião, existem todos os tipos de religião. Eu sou meio um Exu nessa história, porque eu transito entre todos. Já fiz trilha de música eletrônica, já fiz trilha só orquestral, do Castelo Rá-Tim-Bum, já fiz orquestral com rock, já fiz só rock. E já trabalhei com profissionais muito legais, já trabalhei com profissionais muito chatos, mas consegui terminar bem as coisas, sempre consegui terminar. E se você for entrevistar qualquer diretor que trabalhou comigo, ninguém vai falar mal de mim não, porque eu consigo terminar bem feito as coisas.

A minha relação com o diretor é assim: quem mais assiste a um filme - pelo menos no Brasil, porque aqui você tem que lavar, passar e cozinhar (eu tenho que escrever a partitura, eu tenho que fazer a cópia das partituras, eu tenho que...) - é o editor, depois o músico e depois o diretor. Então o músico - eu, no caso, o cara que faz a música - é o cara que mais conhece o filme, depois do editor. Porque a gente tem a imagem, a gente vê essa imagem oitocentas mil vezes. Não é que nem... mais até que o cara que edita o som, porque o cara que edita o som tem o passo, o cara coloca o passo e não fica voltando, ele acerta o passo e vai pra frente; eu não, eu tenho que ficar voltando: volto, "mas será que eu faço isso?", volto, volto. Então, hoje em dia, eu chego a ser um pentelho, mesmo. Porque às vezes eu vejo um erro de continuidade, às vezes eu vejo erro de marcação, eixo de câmera. Eu trabalho há tanto tempo com isso que eu começo a ver coisas dentro do filme que já não estão mais no âmbito da música. Já é o âmbito artístico. $\mathrm{E}$, dependendo do relacionamento que eu tenho com o diretor, isso é completamente legal, né? Eu também aprendi a ser produzido, né? Porque o ego da gente, o ego não, ele tem que ser grande, né? Triste é aquele artista que tem aquele "pseudo-ego", e fala "não, eu não sou egocêntrico". Não, tem que ser egocêntrico. Tem que saber lidar com o ego, mas tem que ser egocêntrico, se não você não cria, você não vai criar.

Tem várias histórias de vários relacionamentos com diretores, por exemplo, eu posso te contar umas dez, quinze, se você quiser. Vou contar uma história bonita. Tem um filme que eu amo, amo de paixão, que chama O contador de histórias [Luiz Villaça, 2009]. É muito fofo. É lindo. O filme é muito legal. E o Luiz Villaça, que é o diretor, me chamou, e eu inventei uma coisa chamada "storyboard de audio". O que sempre me incomodou nos filmes que eu vou trabalhar é que o filme chega editado com a trilha referência, assim, Sakamoto com a Orquestra de Londres, ou aquele cara do Oingo Boingo, o Danny Elfman. Então não tem como competir com os caras. Então eu tenho pego os roteiros e tenho feito o "story audio". Eu faço a trilha antes deles filmarem e eu mando pros diretores, isso é muito legal. Porque, mesmo que eles não usem, pelo menos eles usam pra poder editar. No caso de O contador de histórias eu fiz uma melodia maravilhosa, o Luiz ficou emocionadíssimo, e a gente tem uma relação muito boa, então isso ajudou muito.

Raros são os filmes em que a música já está pronta, em algumas coisas. No Castelo Rá-TimBum já estava pronta, porque ia ter a dança deles, né. Então é muito mais fácil você botar uma música no filme que já é sua. 
Mas quanto ao Luiz Villaça, aconteceu uma coisa muito louca, ele foi mostrar o corte do filme que o editor fez pra algumas pessoas, pra mim, pro Márcio [Nigro], que fez comigo, e algumas pessoas, pra ver como é que estava o filme. E eu assisti ao filme e odiei a edição. A edição estava muito ruim. Tem uma coisa que os caras usam muito, que é: quando o cara está andando na rua daqui até ali, pra cortar tempo, eles falam jump cut. Estava cheio de jump cut, cheio de efeitos na imagem. E é um filme naturalista, um filme poético, um filme que fala de coisas bonitas, e eu estava odiando o filme. Aí acabou, todo mundo gostou muito do filme, é bonito, mas eu não gostei do filme porque foi destruído pela edição. E quem fez a edição é um senhor muito famoso [Umberto Martins e Maria Altberg assinam a montagem], tem muita experiência, já fez mais filmes que eu, então a minha situação era delicada. E eu fiquei rezando pra não me perguntarem o que eu achei. Porque eu perco o emprego, mas não perco a frase. Eu sou uma pessoa muito transparente. Então não me pergunte, e o cara perguntou. E na hora que ele perguntou, todo mundo "ah, muito bom, muito bom", e eu falei, "cara, tá uma bosta esse filme agora, a edição tá uma merda". O cara me olhou com uma cara, mais vermelho que...: "você não entende nada, eu já trabalhei...". E eu: "olha, cara, eu posso não entender nada, mas isso que você fez tá errado". Aí eu fiquei mostrando, "isso tá errado, isso tá errado, isso tá errado". Quer dizer, até que ponto um músico tem que se meter? Mas me perguntaram, né? Essa é uma história.

Essa história mesmo, do filme mexicano [Vozes inocentes], o diretor é um cara de Los Angeles, o produtor é o cara do Pulp Fiction [Quentin Tarantino, 1995], entendeu? Então quando eu fui "peitar" os caras, eu era um "brasileirinho de merda", um "peidinho", ali. Então eu cheguei pros caras e falei assim: "olha, posso dar uma sugestão? [de substituir o som e a música pelo silêncio no momento em que vão matar o menino protagonista]", e os caras me olharam meio torto, já. O editor me amou, o editor do filme, ele falou: “cara, é uma coisa tão simples e tão mágica!". A hora que os caras viram, eles não tinham como... nem o ego deles se sobreporem, porque a ideia era muito boa. Então também foi uma conquista, saber falar na hora certa uma coisa certa.

A relação com o Héctor Babenco, por exemplo, no Carandiru, é um marco, por três razões. A primeira delas é que ele é uma das pessoas mais difíceis de se trabalhar que eu conheci na vida. Mas, ao mesmo tempo, eu aprendi uma coisa com o Hector Babenco que me ajudou muito nos trabalhos depois do Carandiru. Eu aprendi várias coisas com ele, uma, que eu aprendi a ser dirigido. E aprender a ser dirigido é você aprender a dirigir também. Então, quando o negócio é meu, que eu mando - como no Homem Bruxa, você viu, só estou eu no palco -, mas eu mando. Então, $100 \%$ das coisas que eu falo eu que mando. Quando a coisa não é minha, quando eu trabalho pra outra pessoa, eu não mando. Por mais que eu faça uma composição linda, quem manda é o diretor. E o bom diretor é um diretor flexível, não é um diretor autoritário. Em relação ao Héctor, eu aprendi a respeitá-lo. Se você for falar com ele, ele vai falar mil maravilhas de mim, porque realmente a trilha de Carandiru é uma experiência muito linda. Apesar de estar muito baixinha, o conceito da trilha inteira é lindo. São três notas, é um passarinho, é um conceito lindo. Mas o processo foi muito doloroso pra mim. Mas eu aprendi a respeitar. Aprendi a respeitar quem manda.

\section{Por que esse processo de Carandiru foi doloroso pra você?}

Primeiro que eu não conhecia o Héctor. O primeiro corte tinha mais de três horas, eu fiz uma trilha inteira que era hip hop com orquestra, que era "do caralho", depois dei tudo pro meu pai, pra ele fazer as peças de teatro dele. Ele [Héctor Babenco] ouviu dez segundos, eu tinha feito três horas de trilha. Ele olhou pra mim, ele não me conhecia, falou assim pra mim: "Que merda de música" [imitando sotaque argentino]. Então começar uma relação assim... e eu estava ganhando uma grana, quase bati a cabeça na parede. Começa assim a história, mas eu fui lá, fui 
até o fim. Eu comi o pão que o diabo amassou nessa história de verdade, mas eu fui até o fim. E por causa disso eu fui pro México, fiz um filme em Porto Rico...

10. E em relação ao resultado final da trilha (sem considerar a mixagem final com o som do filme), você ficou satisfeito com a composição aprovada?

Eu não fiquei satisfeito, eu fiz muita trilha antes do que foi aprovado. Tem uma história linda. Eu estava fazendo, eu já estava quase "morrendo" pra achar o tema do Carandiru. E aí eu estava na minha casa antiga e acabou a luz. Aí eu desci e fui pro piano, e tinha um jardim na frente da minha casa. Eu estava tentando compor uma música, aí tinha um sabiá-laranjeira cantando muito forte, estava me incomodando aquele canto dele. Eu não conseguia tocar piano porque o sabiá estava cantando. Aí eu comecei a ouvir e achei a melodia bonita, falei: "Caralho, que melodia legal pra... fá, mi, ré [cantarola e assobia, imitando o pássaro]. Peraí, será que eu faço uma trilha só com três notas? Ah, vou fazer". Aí o Héctor começou a gostar. Então foi daí que nasceu o tema do Carandiru. É poético, porque o passarinho fica na gaiola mas ele tá livre também, o Carandiru é uma prisão... tinha todo um conceito. Tanto é que nos créditos finais, se você for ver, tem ele [o passarinho] de agradecimento, o sabiá-laranjeira. Eu coloquei lá, fiz questão de colocar como compositor, comigo, porque a música é dele, cara! Então os direitos autorais são pra todos os sabiás-laranjeira do planeta. É bonita a ideia, a história, né? E foi isso.

Existe uma coisa no I-ching, tem dois anagramas, que é a diferença da comunidade pro exército. $\mathrm{O}$ exército é um homem forte que comanda vários homens fracos. A comunidade é um homem flexível que comanda vários homens fortes. O cinema, pra mim, é a forma de arte mais completa que tem. Tem artes plásticas, tem fotografia, tem música, tem dança, tem balé, tem ator, tem tudo. Então, os melhores diretores com quem eu trabalhei são os diretores mais flexíveis. Fernando Meirelles, por exemplo. O Fernando Meirelles é um doce de pessoa, e é como se ele não estivesse dirigindo, é como se ele estivesse cozinhando, sabe? Então ele pega o melhor fotógrafo, o melhor cara de música, pega o melhor roteirista, e vai fazendo a "moqueca de cinema" dele lá. Isso faz com que o filme fique mais orgânico e fique mais com a cara dele, porque ele é o diretor. Quando o diretor é um pouco mais inseguro e... mais "ditador" assim, que é o caso do Héctor - os filmes dele não são ruins não, tem algumas coisas muito boas, inclusive o Carandiru tem momentos muito poéticos, eu gosto e tal -, eu não acho que seja o mais legal pra um filme. O mais legal pra um filme é um cara que é mais flexível.

Tem um diretor que eu amo que é o José Joffily. Fiz Achados e perdidos (2005) com ele, com o Antônio Fagundes. Ele [Joffily] é o oposto do Héctor Babenco. Mas eu também tive problemas, não com ele, mas com conseguir fazer, porque tudo que eu mostrava ele gostava. Então, quem ficou inseguro fui eu. Então, se eu mandava uma ideia pra ele e ele gostava, se eu mandava outra ele gostava também, então eu que fiquei inseguro, foi o oposto. E eu acho que eu não tinha tanta maturidade como eu estou tendo hoje pra chegar a uma conclusão. A sonoridade desse filme é muito louca, eu fiz trombone, tuba, cello e fagote. Muito louca a sonoridade, parecia uma coisa alemã, assim. É um filme de mistério, né, então foi isso.

11. Como você se apropria dessas sonoridades no seu trabalho de composição de música para cinema? Você grava e faz loops desse material ou busca arquivos já prontos em livrarias? Eu trabalho com tecnologia há muitos anos, e eu amo tecnologia. E eu não guardo nada, mas eu guardo som. Então eu tenho bancos de sons que eu já gravei, tem coisas que eu gravei do Egito, tem coisas que eu recuperei, tem fitas DAT que eu estou passando pro computador... Tem sons que eu gravo com o Iphone hoje em dia, tem muita coisa de biblioteca, né, eu tenho bastante biblioteca de efeitos. Eu uso muito efeito como trilha também. Por isso que eu gosto 
de trabalhar muito com o Beto Ferraz, porque ele usa o som como trilha. Eu uso o som como trilha e ele usa a trilha como som.

Em Os matadores (Beto Brant, 1997) tem uma história muito legal que é: na hora do assassinato, você não sabe o que que é nem música nem som ali, é uma coisa muito casada. Então na trilha está um violoncelo que está no timbre do efeito de som do caminhão, que é o mesmo timbre, então a gente vai brincando com isso.

Eu uso muito banco de som, mas eu também gravo muita coisa. E eu gosto de usar músico verdadeiro também, né? Então isso me ajuda muito.

12. Como se decidir entre sons estranhos e músicos verdadeiros? É mais uma questão de banco de som mesmo, por uma dificuldade de execução, ou...?

Às vezes não tem nem como pegar esse instrumento, às vezes eu usei um violino chinês, quem vai tocar um violino chinês aqui? A não ser que a produção me pague pra eu ir pra China gravar o cara lá, ou mande por mp3, hoje em dia já dá, né?

13. Em termos de recursos mesmo, que filmes você se lembra de ter tido condições de ter, por exemplo, uma orquestra de verdade?

Quando eu tenho isso, eu prefiro usar a orquestra, e o resto eu faço mesmo, porque eu gosto de "meter a mão". Por exemplo, filmes grandes que eu fiz com orquestra: esse filme mexicano [Vozes inocentes] - fiz uma trilha linda, com uma orquestra grande...

\section{- Orquestra lá do México?}

Não. Tudo daqui. Eu fiz tudo daqui. O Castelo Rá-Tim-Bum foi a trilha que eu fiz com mais músicos, foram 25. Tinham uns russos tocando, foi aqui no Brasil, a coisa mais deliciosa do mundo. Agora, como o Castelo Rá-Tim-Bum foi o meu primeiro filme com orquestra grande, eu fiz uma "cagada", porque eles gravaram em 443 [hertz]. Com guitarra, baixo, teclado a gente usa 440 hertz, e a orquestra usa 445 ou... eu me esqueci. Não é a mesma frequência, mas é tipo... "um palito" [de diferença]. Então na hora que eu fui colocar os meus teclados, as minhas coisas eletrônicas, estava desafinado. Muito pouco desafinado. Então eu tive que desafinar todos os meus MIDIs pra acertar. Mas aí eu aprendi: aí, agora quando eu vou gravar eu peço pra orquestra gravar em 440, porque daí fica mais fácil pra eu usar minhas [coisas eletrônicas].

Eu só uso músicos de verdade há muitos anos já. Mas eu somo com as minhas loucuras. E quando não tem dinheiro... Deixa eu te mostrar uma trilha pra Globo [procura nos arquivos a vinheta e dá o play. Música com cordas sintetizadas]. Você não fala que isso não é uma orquestra, né? Fui eu que toquei. Agora eu não vou gastar pra fazer uma vinhetinha da Globo pra botar uma orquestra, entendeu?

Tem a ver com o conceito, também. Não pode ter preconceito. Eu, fazendo trilha, eu não posso falar "eu não gosto de música sertaneja". Eu não posso, porque, e se tiver um filme que seja sobre a vida de um sertanejo, sabe? Vai conhecer, meu, às vezes os músicos são bons pra caramba, esse Vitor e Leo... Tem umas duplas sertanejas que têm umas músicas lindas! Não tem que ter preconceito, nem com timbre nem com nada. Eu acho.

14. Agora, em relação à orquestra. Quando você grava com orquestra, existe alguma que seja da sua preferência, ou o diretor interfere nisso? 
Eu pico. Eu pico a orquestra. Ou seja, eu pego um músico que trabalha comigo há muito tempo, que se chama Fábio Tagliaferri, que toca viola, e ele escolhe os músicos pra mim. Mas não é uma orquestra pronta, a gente constrói a orquestra. É muito melhor.

\section{E o Carlota Joaquina?}

Carlota Joaquina foi o meu primeiro longa, em que eu tive uma experiência desastrosa com a orquestra da Petrobras na época. A orquestra da Petrobras na época - era 1994 - era muito ruim. Hoje é boa, mas na época era muito ruim. E as minhas coisas em MIDI da época, elas soavam mais bonitas do que a orquestra. Então foi um trabalho bem doloroso. Mas era uma orquestra gigantesca, só que não soava bem.

\section{- E como você resolveu isso? Você conciliou seus MIDIs com a orquestra?}

Não, não. Naquela época a gente não tinha a tecnologia que a gente tem hoje. Eu acho que é uma trilha bonita, tem coisas bonitas, mas teve como preço o som, né? Apesar de achar que tudo é música, tudo é música no lugar certo pra mim. Só que o lugar certo pra mim geralmente não é o lugar certo pra todos, então...

16. Voltando aos "sons estranhos": você lembra de algum filme que te marcou por você ter usado "sons estranhos"?

O filme mexicano. Eu usei muita trilha de orquestra, mas eu usei muita, muita coisa esquisita. Eu usei... tem uma história bonita, né [procura a trilha do filme no youtube] Olha esse começo... Você ouve essa flauta, essa flauta indiana? Os diretores não queriam, o diretor gostava, mas o produtor achou muito esquisito. E essa música não era a da abertura. Era a da abertura, mas eles não queriam. Que coisa linda. Agora isso é orquestra de verdade. Eu me inspirei no [Samuel] Barber, sabe o compositor americano? [soa uma melodia] Esse é o tema do filme. Eu sempre gosto de um leitmotiv, um tema, "pararaaa" [canta]. Isso é oboé... Então, essa trilha do começo eu fiz, o diretor gostou, o produtor não gostou, aí ficou, ficou, ficou, eu fiz várias versões desse começo. Aí, no final da mixagem, no final do processo do que ia ser e não ia ser, eu falei: "pessoal, eu posso mostrar a primeira [versão] de novo?" Aí eu mostrei pra um monte de gente e todo mundo ficou muito feliz. Então, o que é que acontece: essa flauta é uma flauta indiana que eu tinha em sampler no computador. E eu fui editando ela em cima e fui construindo as cordas em cima disso, com o meu tema. Então é desse jeito que eu trabalho. Porque esse não é um filme de música indiana, mas tem uma música indiana num filme mexicano, feita por um brasileiro, entendeu? Tá tudo aí disponível.

17. Como você criou seu banco de audio? Você compra livrarias prontas ou faz seus próprios sons?

Eu tenho isso desde muito tempo. Comecei em 1992, né, em fitas cassete, depois em fitas DAT, de coisas que eu gravei, de rádio que eu ouvi...

- Ou seja, contemporâneo ao Karnak?

Antes do Karnak, até. Então, o Karnak estreou em 1992, né, um pouquinho antes do Karnak. E aí, depois... bancos de áudio, de sampler, de coisas assim que eu baixo da internet mesmo. Algumas coisas eu comprei, de timbre de orquestra, algumas coisas em roubei, algumas coisas eu baixei, algumas coisas eu criei, e eu vou guardando.

18. É possível que você tenha usado sons desse banco na produção dos seus discos e também nas trilhas de filmes?

Ah, sim, muita coisa. Gaita de fole com certeza, em escocesa, no Karnak, ah sim. Só que assim. Ainda bem que existem pessoas como você pra pensar sobre a minha vida, porque eu não 
consigo mostrar nada pra você aqui, no Youtube eu estou motrando pra você. Eu sou muito desorganizado. Quando chegam pra mim e falam assim: "Abu, tô precisando de uma trilha, pega alguma coisa que você já fez aí!", aí eu não aguento e faço e mando, entendeu? É muita informação. Eu que tenho que te agradecer, por você colocar a minha vida em dia.

$\mathrm{Eu}$ acho que tá afunilando. Eu acho que antigamente as minhas trilhas sonoras e os meus trabalhos de composição eram mais isolados. Agora está afunilando. Se você for ver O homem bruxa, que é um disco em que eu não usei nenhum sampler, eu gravei tudo, eu tocando tudo, aí eu acho que tá afunilando, tá virando uma coisa só. Mas eu ainda estou descobrindo, ainda estou com 50 [anos], ainda faltam uns 30 pra morrer, quase, 40, sei lá.

O Karnak novo - estou fazendo um disco novo do Karnak, de estúdio - está tendo um pouco mais da coisa orquestral agora, sabe? Mas eu não sei te dizer, na verdade é muito difícil dizer sobre a minha composição, eu simplesmente componho, entendeu? Não tem muita sistematização, não precisa ter.

\section{Quais são suas ferramentas atuais de criação, processamento e edição de som?}

Eu trabalho com um programa chamado Logic. A Apple comprou lá o Logic X Pro, o Logic Pro, né. É a minha ferramenta de trabalho total. Tem um outro também que eu trabalho, mas é mais pra usar pra espetáculo, porque tem a projeção, que é o Live, o Ableton Live. Mas o que eu "como com farinha" mesmo é o Logic. Pra cinema, pra tudo. Pra viver eu uso o Logic. Que nem o Waze pra dirigir é o Logic pra trabalhar. Eu comecei com o Logic... o meu primeiro computador foi um Atari, que tinha o MIDI, que só tinha MIDI. E tinha um programa chamado Notator Logic, que é o Logic. Hoje o Logic já está na versão 10, e eu comecei com o Logic na versão zero ponto... antes da 1, praticamente. Muitas coisas que acontecem no Logic hoje foram coisas que eu, mesmo o Márcio Nigro, que faz as trilhas comigo, a gente mandava pra Apple, mandava pro Logic, pra Alemanha, pra consertar. Muita coisa que tem hoje, de vários artistas que usam isso, né, ou produtores... eu faço praticamente parte do Logic. Então pra mim é o Logic Audio. E todo mundo usa Pro Tools pra cá, Pro Tools pra lá... Pro Tools é legal pra finalizar, pra editar... Tem essa briga, né, de Pro Tools com Logic e tal, mas o meu negócio é Logic. Eu só uso o Logic Audio Pro, só. E eu posso te dizer que há mais de quase 30 anos já, 88 , vai, $89 \ldots 1990$ eu comecei a trabalhar com isso.

20. Você consegue se lembrar do primeiro trabalho que fez com tecnologia digital de audio? Olha, esse prêmio aqui [tira da prateleira e pega o prêmio pra eu ver] é o prêmio Molière, é o prêmio mais importante que eu ganhei na minha vida, eu tinha 23 anos. Foi com uma peça de teatro chamada Encontrar-se [Pirandello, montagem de Ulysses Cruz, 1989], com a Renata Sorrah. A história desse prêmio aqui é a seguinte, é um prêmio especial. Ganhei uma passagem pra Paris, classe executiva, e eu não fui. Eu não tinha dinheiro! Tem a história do Grande Otelo, que ganhou isso aqui, e foi tomar um café e voltou! Eu perdi a passagem, eu não tinha, eu não fui. Essa peça de teatro eu fiz com quatro canais analógicos, num Tascam, você lembra? Eu fiz a trilha com isso aí. Foi depois desse trabalho que eu comprei o Atari. Eu acho que o primeiro... putz, eu acho que não vai ter [procura no Youtube]. Eu acho que é um programa de televisão chamado Som Pop, na TV Cultura. Se tiver vai ser animal. Ó: 89 , né? Som Pop [dá o play no programa]. Mas não é esse aqui não. Vinheta [dá nova busca]... "Caralho", esse foi o primeiro trabalho que eu fiz com o Atari.

Pra cinema... Cara, eu nem lembro. Ah, no Carlota Joaquina eu já usei tecnologia, né? Computador. Sempre no Logic.

\section{- E o Logic funciona pra você como ferramenta de criação, execução, edição, tudo?}


Pra tudo. De edição, de escrever partitura...

- Então você já cria tendo esse suporte da tecnologia digital.

Sim. Tudo, já.

\section{Que inovações essas ferramentas trazem ao processo de se produzir música gravada, do início ao fim?}

Eu tenho os áudios sincronizados com o MIDI que vão ser partituras. Fora isso, há os plug ins que eu posso destruir, aumentar, reciclar, eu posso fazer o que eu quiser. Então a comodidade é eu poder ter tudo dentro de um lugar só, entendeu? Se eu quiser importar um diálogo, destruir ele...

Tem um filme, meu primeiro prêmio do "Oscar brasileiro" [Grande Prêmio do Cinema Brasileiro], que é o Bicho de sete cabeças [Laís Bodanzky, 2001], que foi logo após o Castelo Rá-Tim-Bum, que eu tinha feito com orquestra. E eu estava numa depressão "fudida" e eu quis usar... eu queria fazer um filme com uma música feia, eu ganhei tanto prêmio com uma trilha tão... nojenta, podre, distorcida. Eu distorci até a minha alma naquela trilha lá. Então tem processador de bumbo ${ }^{74}$ distorcido, tem processador na voz, tem distorção em voz. Eu usei a voz do Arnaldo Antunes em algumas coisas, eu destruía tudo! Se você vir a sessão - que eu não tenho aqui -, tudo tem distorção, até a masterização tem distorção, é "wréeeee" [faz um ruído grave com a boca], eu não sei se você se lembra disso. Bem pesado de ruidagem, muito, né? E foi graças ao Logic, né. Porque eu escutava aquele negócio, "ah, que coisa bonitinha", mas tem que ser feia, sabe? Às vezes você tem que saber colocar uma tinta a mais, assim, pra ficar... porque tem a ver com o filme, cara. Não é que eu quis fazer feio, eu estava feio, e o filme demandava isso, então foi no momento certo.

\section{Em Encarnação do demônio [José Mojica Marins, 2008] foi assim também?}

No Encarnação do demônio não. Encarnação do demônio é uma história mais engraçada que isso. O Zé do Caixão é maravilhoso. Ele é muito doidinho, muito legal. E tudo que eu fazia "musical" - e eu estava bem, minha vida estava boa -, e tudo que eu fazia "musical" no filme, ele não gostava. Eu e o [Márcio] Nigro. Aí eu comecei a ver os filmes antigos dele, em que ele fazia a música, e era tudo "wréeeeeeee prrrrrrrrr crrr shhh" [faz ruídos graves com a boca] e não era música, era ruído. E eu comecei a entender que não era que ele não estava gostando da música, ele não queria música. Então eu peguei os instrumentos e a gente fez ruído com os instrumentos, aí ele começou a amar. Foi um pouco diferente, eu não estava mal, no Encarnação eu tive que entender a cabeça do diretor, que era o Zé, que é maravilhoso, ele é muito louco. É um filme nojento, assim, eu mesmo não consigo ver ele inteiro assim não... É muita coisa que eu fiz, né?

\section{Como e quando surgiu Fat Marley?}

Ah, legal! O Fat Marley foi assim: eu estava na casa da Anna [Muylaert] - a Anna é a minha melhor amiga, né? Ela é a mãe do meu filho [José Abujamra], tal, e ela me chamou pra fazer como ator o Durval Discos [Anna Muylaert, 2003], e eu... Na verdade era uma ponta, em que eu era o amigo do Théo Werneck, que faz o Théo Werneck mesmo, e ia comprar o Racional do Tim Maia com o Ary França que era o Durval. E a gente não sabia o nome do personagem. Aí eu estava na casa dela, estava escutando reggae lá, o José pequenininho, dançando reggae lá, eu estava escutando Bob Marley, né? E eu estava bem gordo na época. Aí eu falei: "Puta, meu, olha só, Anna, descobri um nome, vamos botar o nome do personagem de Fat Marley? A gente põe um cara gordão com um dreadlock, o cara é fanático por Bob Marley". Foi aí que nasceu

\footnotetext{
${ }^{74}$ Peça que compõe uma bateria, caracterizada pelo som grave, tocada com um pedal.
} 
o personagem, né? Aí, quando a gente foi fazer a cena, fomos fazer um ensaio, tinha um disco do Bob Marley e eu estava com uma peruca de rastafari assim, gordo, com a camisa do Brasil. Aí eu pegava: "Rastaman!" [interpreta, lembrando o personagem], eu achei aquele personagem muito legal. E nessa época estava começando a pintar muita coisa de DJ, né? Os meus amigos músicos falavam: "Pô, a gente perde trabalho porque agora é DJ lá, não sei o quê...". Então: DJ, eu acho que eu vou fazer o seguinte, eu vou aproveitar esse personagem e vou fazer um trabalho de DJ. E foi aí que nasceu o Fat Marley, eu fiz um disco chamado Fat Marley, você tem? Eu tenho, eu te dou. É o primeiro, mas eu estou no terceiro disco já. É um disco muito louco, é muito louco, é um disco completamente desprovido de tudo, é meio de dança, mas tem uma coisa meio de reggae, é muito louco.

- Aquele remix da versão de Mestre Jonas [canção de Sá, Rodrix e Guarabyra interpretada pelos Mulheres Negras na abertura de Durval Discos] é do Fat Marley?

É do Fat Marley, que sou eu, mas eu finjo que não sou, entendeu?

- Mas o Fat Marley faz shows? Há uma vida do Fat Marley? Então saiu do filme?

Faz. Existe, existe. Saiu do filme.

- Agora o que é que veio primeiro: o personagem de Durval Discos ou o convite pra fazer a trilha original do mesmo filme?

Eu não me lembro mesmo. Foi tudo meio ao mesmo tempo. Porque eu já fazia as trilhas da Anna, né, depois foi que eu parei de fazer.

- Tem algum outro filme em que o Fat Marley aparece, não tem? Nos créditos?

Ah, tem. Vários. Vários. Porque eu faço o remix do Fat Marley e coloco o nome dele. No próprio Bicho de sete cabeças, nos créditos finais com o Arnaldo Antunes, é o Fat Marley que assina.

- Qual é a diferença entre assinar Fat Marley e assinar André Abujamra?

Fat Marley é uma coisa mais eletrônica, mais esquisita, mais de pista [de dança], mais... Deixa eu te mostrar o Fat Marley novo. O Fat Marley novo não é nem um disco nem um vídeo. Ele é uma mistura... eu não sei. É bem louco. [procura nos arquivos] Eu só tenho [aqui] porque eu estou fazendo agora, né? Olha que legal. [dá o play na música eletrônica, com um vídeo remixado]. É uma viagem, eu baixo os vídeos, não tem sentido, é uma coisa que... olha que legal. O Fat Marley é uma coisa que quanto mais você não sabe é melhor.

- É uma coisa meu VJ-DJ?

VJ DJ maluco, né?

- Existem planos para o Fat Marley?

Existem, mais ou menos. Eu tenho tanta coisa pra fazer, pra criar, que...

- Como você administra Karnak, Mulheres Negras, carreira solo, Fat Marley, filmes?

Mas assim, com o advento da internet e do avião dá pra fazer tudo. Dá, dá pra fazer tudo, entendeu? Os Mulheres Negras, a gente... é uma delícia, cara. Karnak é um albatroz. É aquele pássario grande, desengonçado, gordo, difícil de andar, mas quando voa é tão lindo, né, é uma delícia. Então é isso, eu administro assim. O meu próximo trabalho é muito... O Mafaro [carreira solo, 2010], você foi ver? O Mafaro é uma delícia, né, cara. É cinema, né?

O Omin, que é meu próximo trabalho, que é meu projeto do coração (quer dizer “água") é um show em que vai ter 40 músicos no palco (uma orquestra) e mais 11 atores -11 músicos do mundo inteiro projetados (um flautista da Índia, um... né?). Esse vai ser caríssimo, vai ser um show em preto e branco, vai ser um show totalmente triste, não vai ter nenhuma música alegre. Vai ser uma coisa bem poética, bem lenta. Eu vou vender dois CDs e vai ter quatro pessoas no máximo, você vai ver, mas eu vou fazer.

24. Que funções você acredita que a música exerce num filme?

Eu acho que depois que inventaram o som no cinema, o advento do som no cinema fez com que o filme, com que o áudio fosse... alguns falam que e 50\%, um filme com som é $50 \%$ do 
filme. Eu acho que é mais. Eu acho que se você pegar um filme de ação, ou um filme de terror, ou mesmo uma comédia romântica e você não tiver música, o filme não vai existir. E mais: mesmo o filme que não tenha música e tenha som, tem música. O Beto Brant é um grande amigo e eu trabalhei com ele em dois filmes, o Ação entre amigos [1998] e Os matadores [1997]. E ele falava pra mim: "Eu não vou te chamar pro meu próximo filme porque o meu próximo filme não vai ter música". Eu falei assim: "Cara, mesmo que não tenha música, tem que ter um músico pra não fazer a música. Mesmo que não tenha música, tem que ter música! E o silêncio é música! E não ter som também é música! É complexo isso que eu estou falando, mas isso pode ter ajudar aí. Porque é assim, cara, tem que ter. É mais de $50 \%$, pra mim são $67 \%$ do filme.

- O que a música faz no filme?

A música é um personagem. Porque isso que tem muito músico bom que não sabe fazer trilha sonora. Eu vou explicar. Como eu nasci numa família de artistas de teatro, né, o meu pai [Antônio Abujamra], eu acho que eu sou ator. Então eu acho que tem duas coisas que um músico que quer fazer trilha sonora tem que saber: ele não precisa ser ator, mas tem que entender de atuação e tem que ter ritmo. E quando você fala "tem que ter ritmo" e fala assim: "qualquer músico tem ritmo", não é verdade, não é verdade. Tem que ter ritmo. Um bom editor de filme eu sei que conhece música quando eu vejo a edição sem nada e eu consigo ver quando o cara entende de música. Porque a imagem tem ritmo. O ritmo é o timing da coisa, o ritmo é tudo.

Tem aquele filme Olga [Jayme Monjardin, 2004], por exemplo. Ali é um equívoco, a trilha, porque ali tem música demais, o tempo inteiro; grande o tempo inteiro! Está errado, entendeu, e é um grande músico que fez [Marcus Viana]. Não é meu amigo, mas assim, se eu encontrar com ele eu posso até dizer isso, não tem nenhum problema. Não adianta você ser um bom músico e você não fazer parte, você tem que ser um ator. A música é um ator no filme.

- Essa decisão de inserção ou não de música é compartilhada com o diretor?

Tem que ser compartilhada, sempre. Eles chamam de cue. Muitas vezes vocês faz a sessão de cue com o diretor: "vamos entrar aqui, vamos sair aqui, exatamente aqui, sai ali". Eu, com a minha experiência, tiro muito do que o diretor pôs e coloco muito que ele nem viu, então basicamente é isso.

\section{Os diretores com os quais você trabalhou entendem de música? Existe uma conversa com um vocabulário compartilhado, ou você precisa usar de metáforas pra chegar ao conceito da música?}

Boa pergunta, muito boa pergunta. Alguns sim, mas a maioria não. Então você tem que usar metáforas mesmo, né? A primeira coisa que é complexa com um diretor que não entende de música é a não linearidade do que a gente faz. Hoje em dia, a gente não vai gravar uma orquestra antes de ser aprovada a trilha, então você faz tudo pelo computador. Então, a primeira coisa que tem que explicar pra uma pessoa que não conhece música - e são muitos os diretores que não conhecem - é que aquele som não vai ser aquele. Então é uma coisa muito "esotérica" pra quem não entende. Você fala: "Olha, isso aqui não vai ser isso, é um esqueleto do que vai ser". Isso já é uma coisa complexa. Outra coisa que é complexa é quando tem muita referência e você tem que fazer uma coisa original, e aí o diretor já se acostumou com a referência e você "se fode todo". Então é complexo.

Agora tem diretor, por exemplo, o Luis Mandoki [Vozes inocentes]. Ele era preciso. Ele falava: "André, vamos entrar com a música aqui no frame 4 e vamos sair no frame 12". Eu achei que ele estava tirando sarro, mas não, ele sabia mesmo, ele tinha essa experiência, né? Ou mesmo o Tadeu Jungle [Amanhã nunca mais, 2011], o Tadeu Jungle não é músico, mas ele tem muita musicalidade.

- E o que é ter musicalidade? 
É ritmo. É ritmo, entendeu? Ritmo é ter musicalidade.

26. O que te leva a negociar figurações nos filmes em que atua como compositor?

É porque eu amo me exibir, eu amo, eu sou um "puta" ator, entendeu? Eu adoro, eu estou fazendo coisas de... eu amo ser ator. E eu gosto de me exibir. Meu pai falava que só faltava um espanador na minha "bunda", quando eu subia no palco. Eu adoro aparecer! Eu sou egocêntrico, eu sou artista, eu gosto de me exibir! Essa é a resposta: "porque eu gosto"!

27. Já houve filmes em que você atuou e não compôs trilha?

Já. Com o Ugo Giorgetti! O Sábado [Ugo Giorgetti, 1995], o Boleiros [Era uma vez o futebol, 1998], do Ugo Giorgetti. Porque o irmão dele faz a trilha [Mauro Giorgetti]. Então ele falou: [imita uma voz grave] "Eu não posso chamar você, meu irmão faz as músicas!". "Mas e eu, sou ator!". E ele gosta muito de mim como ator, né? Então eu fiz o Pai Vavá no Boleiros, eu fazia um pai de santo, e fiz um mendigo no elevador de Sábado, que é um sucesso até hoje.

- Você acha que a sua aparição como ator em filmes que você faz a trilha contribui pra visibilidade da trilha?

Eu acho que não. É uma pontinha, né? No Castelo Rá-Tim-Bum eu fiz um porteiro de um hotel capenga; Fat Marley no Durval [Discos]. No É proibido fumar, da Anna [Muylaert, 2009], eu não fiz a trilha, mas eu apareço com o José [Abujamra] e com meu pai.

28. Você acredita na invisibilidade da trilha musical original de um filme? A música de filme é pra ser invisível? Ou tem que estar audível?

É o seguinte, aí já é uma pergunta complexa. Porque existem filmes ruins com trilhas boas que tornam o filme menos ruim; isso, pra mim, é ruim. Existem filmes maravilhosos em que você não lembra da trilha, mas a trilha é contundente, mesmo sem você se lembrar dela; isso, pra mim, é a busca. E existem trilhas de filmes bons que você sai cantando a melodia: esse é o suprassumo pra mim. Eu amo você pegar um tema e esse tema estar recorrente na sua cabeça e, sabe, isso é uma coisa que eu busco muito.

Tem um filme do Aluízio Abranches, chama-se As três Marias [2002], que tem uma melodia que eu acho linda, e as pessoas saem cantando essa melodia, né? No Castelo Rá-Tim-Bum é bem rebuscada, a trilha, mas, por exemplo, o Carandiru. O Carandiru é um filme muito violento, mas se você assiste muito e se você trabalha com isso, você sai com as três notas na cabeça, isso é o que eu busco. Eu busco isso, aí, tá?

- Esse reconhecimento da trilha?

Da trilha, sim. De uma marca mesmo, né?

29. Dentre os diretores com que você já trabalhou, houve algum conflito entre você buscando essa trilha marcante e o diretor talvez questionando isso?

Claro! Vários conflitos com vários diretores!

A gente começa com o Héctor Babenco! O próprio Tadeu Jungle, assim, foi díficil, naquele filme com o Lázaro Ramos, como é que é o nome? Amanhã nunca mais. Foi difícil a relação porque o Tadeu já veio com um monte de ideias, um monte de referências, e eu fui mostrando outras referências pra ele. Então a primeira cena é numa praia, em Mongaguá, assim, sei lá, e tem duas "bundas" assim, meio feias... 99,99\% de todos os músicos do planeta colocariam um samba e um pandeiro naquelas "bundas", né. Aí eu falei: "Cara, vamos colocar uma música bálcã, vamos colocar um som estranho naquelas 'bundas'!”, e ele não entendia. Aí eu comecei a mostrar pra ele, entendeu? O "namoro", a relação minha com os diretores é muito legal. "Vamos inverter a cabeça".

Tem uma cena de um filme - eu acho até que eu mostrei naquele minicurso que eu ministrei lá em Goiânia -, que é um filme chamado Frantic [1988]. É o seguinte: é o cara que faz o Indiana 
Jones, o Harrison Ford, em cima de um telhado, lutando com um cara. $\mathrm{O}$ filme é daquele cara que "comeu" a sobrinha... Polanski. Roman Polanski! (O cara faz uns "puta" filmes e é lembrado por causa da sobrinha). Deixa eu descobrir o nome aqui [pesquisa na internet]... Busca frenética...

Ele tem uma cena nesse filme que ele está lutando com um cara em cima do telhado. É uma cena assim, violentíssima, de ação, e eles colocaram Vivaldi, cara. Uma trilha de... quarteto... "tan tan tararan tan tan tan" [cantarola Primavera, de As quatro estações]. Cara, não tinha nada a ver a música com a cena, só que dava uma tensão aquilo, é isso que eu busco. É sempre ter alguma coisa, sempre sair da casinha, assim. E aí eu tenho muito conflito com o diretor, por quê? Porque como é que o cara vai comprar uma loucura dessa, num longa-metragem de milhões de reais, entendeu? Eu busco muito "quebrar as pernas" das pessoas, assim, de propósito.

[Já tive conflito] com o Beto Brant, a própria Anna Muylaert...

- Em geral, qual é o resultado? Prevalece a vontade do diretor? Você consegue negociar? $\mathrm{Ah}$, hoje em dia a gente consegue negociar bastante, por causa da minha experiência. O Afonso Poyart, que fez o 2 coelhos [2012]; pra mim eu já estava fazendo o meu $47^{\circ}$ filme, sei lá, e o dele era o primeiro. Então existe um respeito, né, já. Existe um respeito pela minha experiência, tal. E não é uma coisa de egocentrismo, é uma coisa de estofo, da construção da sua carreira.

30. Pensando em 2 Coelhos, existem filmes para os quais você compôs a trilha musical original que têm muita canção. Como você "conversa" com essas canções?

$99 \%$ das vezes eu não converso. Teve um filme em que eu conversei, que na verdade foi o que eu ganhei mais prêmios até hoje, que é o Bicho de sete cabeças, que quem foi convidado pra fazer a trilha foi o Arnaldo Antunes. E ele falou: "cara, eu não consigo fazer trilha sonora". Mas a Laís [Bodanzky] amava as músicas dele. Então ele me indicou pra fazer e a gente já fez... eu já fiz alguns filmes em que eu usei o Arnaldo. No próprio filme do Tadeu [Jungle, Amanhã nunca mais], em que ele canta a música do final. O filme do José Joffily [Achados e perdidos], que ele canta a música final com arranjo meu... Eu peguei as masters do Arnaldo Antunes, fui pro estúdio e tirei só a voz dele. E eu fiz o remix da voz dele com a minha música, então esse [Bicho de sete cabeças] foi o único filme em que eu tive essa participação mesmo. O resto não. Em Durval Discos eu não me meti, no filme do Afonso [2 Coelhos] eu não me meti. Né, tem o Tom Waits maravilhoso lá, eu não me meti. E não quero me meter. É uma outra função. A não ser que você tenha que usar o tema; aí é um outro conceito, né. Eu nunca tive que fazer isso, eu não me lembro disso.

\section{E Querô [Carlos Cortez, 2007]?}

Querô foi um exercício maravilhoso. Foi o seguinte: Querô - essa história é muito engraçada. O pessoal me chamou pra fazer a música final do Querô, uma música, a música dos créditos finais. Falei: "Tá bom". Aí eu fui assistir ao filme e tinha assim: Celine Dion, tinha dupla sertaneja, tinha... Eu falei: "Galera, vocês 'tão fudidos', vocês vão gastar milhões de reais pra ter..." "Não, a gente já tá conversando..." E o filme ia estrear, tipo, 50 dias depois. E eles falaram: "Ah, tem 10 mil reais aqui pra você". Eu falei: "10 mil reais pra fazer uma música? Eu tocando tudo? É muito, não precisa, dá doisinho aí que eu faço". Eram uns amigos meus. Aí os produtores falaram: "Eu nunca vi alguém pedir menos dinheiro por um trabalho". Aí eu falei: "Não. É justiça, cara. Vai fazer uma música, não precisa pagar 10 pau pra mim, pelo amor de Deus, né. Aí eu vi o filme. Aí eu falei: “Olha, vocês 'tão fudidos', hein. Vocês 'tão fudidos', vocês vão ter que pagar milhões por essa trilha". "Não, não, não". Batata. Eu sou experiente, os caras me ligaram duas semanas depois, falando: "Abu, você tinha toda razão. A gente vai ter que refazer toda a trilha. Mas a trilha é só imitar!”. Cara, foi uma das trilhas mais difíceis que eu já fiz na minha vida; não parece que fui eu, porque eu imitei... Essa é a história. Aí me 
pagaram um pouquinho mais, mas... Meu, imitei até a Celine Dion lá, fiz tudo, tudo igualdiferente, pra não pagar direito autoral, entendeu? Foi um dos trabalhos mais malucos que eu já fiz na minha vida, de cópia.

- Você não gosta de trilhas temporárias, né?

Odeio. A do Querô foi um exercício, né. Não era trilha temporária, era imitação.

32. Como você negocia com a equipe do filme a inserção de canções preexistentes suas?

Eu dou. É, eu dou música. E na verdade, no filme do Aluizio [Abranches, Do começo ao fím, 2009] foi porque não tinha dinheiro mesmo, e eu chamei o Paulinho Moska, que é meu "irmão", com uma música dele [Lágrimas de diamantes] e uma música minha [Elevador], mais ou menos que tinha a ver com o filme, então...

- Mas nisso você já está envolvido com a música original?

Ah, sim.

- Daí no meio do filme você percebe o lugar que a música pode ter...?

Isso. É, mas nisso aí eu não gosto de me meter não. Nos Estados Unidos ou em outro lugar tem várias... o cara que faz a música, ele não faz a partitura, o cara que coloca a música, lá... Eu, aqui, meio lavo, passo e cozinho, mas eu gosto de fazer o scoring lá, e eu não gosto de me meter com colocar música do Caetano, agora, isso aí não é comigo. Quando o filme não tem dinheiro, quando o cara é muito amigo meu, quando ele me pede, aí eu ajudo, entendeu?

- E você acha que a inserção das suas canções te ajuda a ter visibilidade? É algo equivalente à figuração que você às vezes faz?

Não. É diferente, porque eu acho que eu não vejo muito a ligação do meu trabalho como artista pop e/ou artista do que seja com a trilha de cinema. Trilha sonora, pra mim, é uma coisa mais egocêntrica, mais egoísta, mais... eu, aqui, dentro da minha espaçonavezinha aqui, criando, entendeu? Acho que a coisa do artista é um pouco mais banda, mais... Eu não vejo muita ligação, são coisas díspares.

- Existe um autor que cita você como uma referência de composição pop e de world music no cinema brasileiro [Fernando Morais da Costa, $O$ som no cinema brasileiro]. Ele aproxima o pop ao seu trabalho de trilha, e você, na sua fala, os afasta.

Eu afasto. Eu acho que eu trago mais a minha linguagem de cinema pro meu trabalho pop do que o meu trabalho pop pro cinema. Eu acho que é invertido.

- Como?

Ah, por exemplo, se você for ver O homem bruxa (2015), ou o próprio Mafaro (2010), ou mesmo o Fat Marley, tem coisas de orquestração, de musicalidade, de sonoridade que vêm muito dos meus filmes. É muito mais ao contrário, fala pra esse cara que é ao contrário!

33. Como os prêmios ganhos por você como compositor de trilha musical no cinema afetaram seu trabalho?

De forma nenhuma. Primeiro, que eu nunca ganhei um centavo com prêmio. Nunca ganhei um centavo, nunca. Todos esses prêmios... Eu tenho sete APETESPs [Associação de Produtores de Espetáculos Teatrais do Estado de São Paulo], esses "pintos" dourados, está vendo? São sete. Pesado, não serve pra nada. Nenhum prêmio eu ganhei... o único prêmio que eu ganhei dinheiro foi aquele que tem a bolinha vermelha que é de peça infantil, da Coca Cola, "A Bruxinha não sei o quê" [não lembra o nome]. Eu ganhei, sei lá, 18 reais e 20 centavos. Nunca ganhei, não afeta em nada. Eu ganhei já três prêmios do Cinema Brasileiro [Grande Prêmio do Cinema Brasileiro], três, assim.

- $\quad O$ último foi o Trinta [Paulo Machline, 2014], né?

É, o Trinta, filme lindo. E não afeta em nada. A única coisa que afeta é que meu nome fica forte pra se alguém quiser me chamar, né? Só que hoje em dia tem tanta gente nova, e eu estou cobrando - não é que eu estou cobrando caro, eu estou cobrando o que eu mereço cobrar. Então 
fica mais árido, e o filme está, e as pessoas estão com muita crise, né? E eu adoro fazer, né, mas não têm me chamado muito. Eu tenho feito bastante, mas... não naquela quantidade que eu fazia.

34. Qual foi o último diretor jovem, estreante que te convidou pra compor e deu certo?

O Ricardo Elias. Eu fiz um curta dele, Derrube Jack [1993], um filme super bom. Aí eu fiz o filme Os doze trabalhos [2006], o De passagem [2003]... É um menino que ganhou vários prêmios, é um cara muito legal. O próprio Afonso Poyart, que agora está internacional, né? Ele está lançando um "puta" filme, né. Encontrei com ele e dei bronca, porque... não me chamou, né, chama os gringos pra fazer.

- Existe uma curiosidade da sua parte de se aproximar desses diretores estreantes?

É que eu tenho uma coisa até meio espiritual... Eu não sou a leoa que vai comer a gazela, sabe? Eu sou a gazela que espera o leão vir comer. Eu não acredito muito nessa coisa de... Eu acho que "o que é do homem o bicho não come", entendeu? Então se a pessoa pensa em mim - e vários meninos que estão começando me chamam pra fazer alguma coisa -, antigamente eu aceitava tudo. Hoje não é questão de tempo, é questão de já... Tem tanta gente boa nascendo, fazendo trilha, né, que assim, eu já estou consolidado. Então, a pessoa que está começando, faz com gente que está começando também. Não é uma coisa egocêntrica isso, é uma coisa que é bonita que eu faço. Agora, se o menino é muito bom... Que nem: eu fiz um filme com o Caio Sóh. Eu e o Moska fizemos. Ele de ator e eu fiz a trilha. É um longa, maravilhoso. [procura o filme no Youtube]. Minutos atrás [2014]. Ó, esse filme aqui, ó [dá o play no Youtube, mostra o trailer]. Minha trilha, com o Paulinho Moska. A trilha é maravilhosa, a gente fez tudo acústico. Tipo aqui dentro [do estúdio], percussão... Eu saí como produtor desse filme, ele não tinha dinheiro.

35. Existe alguma relação entre a sua religião, o candomblé, e a sua composição musical?

Existe total relação. Desde pequenininho eu sou ligado a alguma coisa espiritual, a alguma religião. Meus pais ateus, meu irmão ateu, e eu nunca tive acesso a nenhuma religião. E, por não ter acesso a nenhuma religião, eu busquei todas as religiões. Eu fui no budismo, no espiritismo, no kardecismo, na umbanda, eu fui no catolicismo, eu fui na Kabbalah, aí, cara, eu fui nos muçulmanos, enfim. Todas as religiões que você possa imaginar eu fui atrás, porque eu tinha alguma coisa, eu não acreditava. Eu tocava piano com três anos. Não era brincadeira, eu tocava! Então eu sempre tive essa intuição de que a gente já era. Aí o pessoal fala: "Já era como, já acabou?". Não, desde sempre a gente já era alguma coisa. Então, do mesmo jeito que eu acho ignorância as pessoas não acreditarem em vida fora do planeta - porque é impossível que não haja vida fora do planeta. Seria muito egoísmo a gente achar que não existe vida fora do planeta, porque... a gente é um "peido" perto do universo.

Claro que não tem como dizer que eu estou certo e você está errado. O Evangelho, por exemplo, fala que acabou, "acabou, acabou!". Mas aí vem e fala "rest in peace" [descanse em paz]. Você morre, e aí quando Jesus Cristo voltar, você volta. Mas, se acabou, como é que você vai voltar? São coisas assim, que eu sempre me perguntei desde pequenininho.

Eu acho que a gente não morre, a gente só... Eu sou espírita, eu acredito, né. E eu caí no candomblé. E eu caí no candomblé por causa do som mesmo. Não é por causa da música africana, não. É porque existe... - eu vou te falar uma explicação que eu estudo faz tempo. Uma vez um professor levou um apito de cachorro pra dentro da faculdade, que era uma frequênca que eu não ouvia. E aí existem frequências que você não escuta. As mais agudas e as mais graves também não. Então, se existe frequência, e a gente tem células e a gente também é frequência, então deve existir gente que a gente não enxerga, e aí eu comecei a viajar nessa coisa. Por isso é que eu virei espírita, por causa do som. E a minha função como artista e como músico pra fazer trilha sonora, diversas vezes - por exemplo, a história do passarinho no 
Carandiru, do sabiá-laranjeira. Pode ser uma coincidência, mas... como eu sou espírita e como eu acredito nisso, eu acredito que realmente aquele passarinho me passou aquela música. Então eu vivo assim, né? Agora, eu não levanto uma bandeira, porque eu nem posso levantar. Porque existem tantos tipos de comida, tantos tipos de religião, tantos tipos de espiritualidade que... é isso, mas a minha religião me ajuda muito no meu processo de criação.

- Na criação de imagens e de sons?

De som e de imagem também! De imagem também, mas [sobretudo] de som! E aí tem a ver com aquela história da gazela e do leão, né? O que é meu é pra ser meu. O que não é meu não é pra ser meu. Então eu não fico atrás da gazela. Eu sou a gazela, e eu espero que o leão, que o Tarantino me chame pra fazer uma trilha. Por que não, né?

\section{E Cafundó [Paulo Betti e Clovis Bueno, 2005]?}

Cafundó foi a trilha mais linda que eu fiz na minha vida. Primeiro, porque se tratava [da história] do primeiro pai de santo que apareceu no Brasil. Segundo, porque se tratava de um cara que eu amo e que faleceu agora, o Clovis Bueno, maravilhoso, um grande artista. Então foi "comer filé mignon com batata frita", né? E foi uma das trilhas mais gostosas e lindas que eu já fiz. Se eu tiver que falar assim: "qual foi a trilha que você mais gostou de fazer, que você mais está feliz da vida?", é a de Cafundó. Eu misturei tudo, né, eu misturei viola caipira - o Théo Werneck tocando comigo - com orquestra. E eu não tinha dinheiro, usei orquestra de computador, misturada com percussões tocadas ao vivo, né? Eu usei um instrumento, hang, quem tocou foi o Kuki Stolarski, o baterista do Karnak. Percussão foi o James Muller... deixa ver se eu acho aqui [procura o hang no Youtube]... Pra não falar besteira, mas eu acho que é um instrumento finlandês, um negócio assim. Ah, é esse instrumento aqui, o hang [dá o play no Youtube]. Bonito, né? Deixa ver que país que é, pra não falar besteira. Suíça! Instrumento sueco [sic], né? É uma das trilhas que eu mais amo, cara, que eu fiz.

- Ama por quê?

Porque tem a ver com a minha religião, porque foi uma liberdade muito grande que eu tive pra fazer a trilha. Eu usei um tema do Obaluayê, que é o orixá da cura... Então tem momentos lindos, né, deixa eu ver aqui, Cafundó... [pesquisa o filme no Youtube e dá o play]. Ó [passa um trecho de uma procissão]: essa música de coreto é uma música de candomblé, que é "Encontro o preto no caminho e peço a bênção, meu pai, meu pai, Atotô"... isso é meu. E aí vai, né, é o filme que eu mais amei fazer.

\section{E em relação à orquestração? Como é sua formação?}

Eu estudei 12 anos na FAAM [Faculdade de Artes Alcântara Machado], aqui em São Paulo. Eu fiz um curso particular, eu cantei ópera, fui cantor de ópera, fiz aula de ópera. Eu ia ser cantor de ópera. Estudei clarinete... Tive uma formação de músico erudito, né? Na FAAM. Mas eu não me formei, fui jubilado.

- E como você pode aproveitar essa formação?

Tudo. Tudo. Porque é assim, eu sou um compositor que sei escrever pra orquestra. Sei reger. Então... na verdade eu entrei pra faculdade porque eu tinha muita música dentro de mim, e eu queria aprender uma linguagem que fosse universal - que eu também discordo um pouco sobre como é essa linguagem. Eu tive várias desventuras, várias brigas na faculdade, com vários professores. Muitas leis, muitas regras de música, que hoje... Foram boas as brigas, porque hoje eu vejo a música de um jeito muito bonito.

Mas eu falo isso pra você: em que me ajudou a faculdade? Me ajudou a desenvolver a minha música. E a tecnologia pra que eu escreva essa música. Eu chego lá, eu sei que a clarineta é em si bemol, eu sei que eu vou escrever a parte pro clarinetista tocar. É mais usar a faculdade como uma ferramenta pra eu poder usar a música que está dentro do meu coração. Mas deixa eu tentar 
achar essa música que... é uma sinfonia que eu quero escrever quando eu estiver velhinho, que tem a ver com isso [procura a música].

38. Gostaria que você comentasse sobre quando você faz orquestração pra cinema e quando você chamava orquestrador. Você trabalhava com o Renato Lemos, às vezes, não é?

Eu parei de trabalhar com ele, é porque eu aprendi, na verdade, a fazer. Porque, na verdade, eu era muito inseguro, né? Então o Renato é um maravilhoso, e mesmo assim eu aprendi com o Renato, é que ele é "muito foda", é um cara que eu gosto muito. Mas também eu tive uma, eu comecei a... cara, eu não sei nem como é que eu vou achar isso aqui [procura a própria sinfonia]. Será que é essa aqui? É. Ó, eu vou tentar te explicar. Essa é a linha da flauta, tá vendo? Olha lá. Essa flauta é uma melodia [toca a melodia da flauta no Logic, com instrumentos virtuais]. É uma pessoa. Entra a segunda pessoa, que é o oboé, junto com o oboé, são dois oboés tocando. Olha só, não é um contraponto, são dois oboés agora [dá o play]. Não, na verdade é o seguinte: o segundo oboé está imitando a flauta, mas é uma melodia, né? [dá o play]. Se você fosse estudar a música, está cheio de erros, não condiz com as regras, não. É lindo, mas assim: cada instrumento está tocando uma música, não é uma harmonia, é o que faz a música. Se você chamar isso de harmonia, então a harmonia existe, existe uma harmonia, mas não é a harmonia que se fala, não é. Cada um tem uma música dentro de si. Entendeu? Olha que loucura [música continua], eu chamei isso de "gotas", porque eu tive um sonho com o Tom Jobim, eu posso te contar essa história, porque você vai entender melhor o que eu quis dizer [sons de caixinha de música junto com outros instrumentos virtuais de orquestra]. Já é outro tema, e aí vai... Quando eu ficar velhinho eu lanço a minha música.

- E você trabalha nela ocasionalmente...?

Não, eu me esqueci. Lembrei dela só porque você veio aqui. Eu vou retomar isso aqui. Não se enquadra em "porra" nenhuma, não tem enquadramento. É tudo fora da casinha! Por que é que a gente vai deixar dentro da casinha?

39. Como é isso, de compor pra cinema "fora da casinha", às vezes enfrentando um desgaste com o diretor, mas pensando além, pensando que existe um público, existem as convenções de música pra cinema, uma tradição clássica que vem de Hollywood, todo um estudo... Como você lida com isso? Como é a sua relação com o que é tradicional na música de cinema?

Você assistiu ao filme do Leonardo di Caprio, que ganhou o Oscar [O regresso, Alejandro Iñárritu, 2016]? Você gostou? É o melhor que eu já vi na minha vida. Se você for ver, é um filme que ganhou o Oscar, mas quebrou um monte de regras lá. Tanto a trilha do Sakamoto, que é maravilhosa, é uma trilha desconstruída, é uma trilha neurótica, porque ela começa, mas não vai, né? Eu acho que o próprio John Williams, meu, a trilha do Indiana Jones [Raiders of the Lost Ark, George Lucas, 1981] é maravilhosa! Eu não estou dizendo não pras regras, eu só acho que existem pessoas maravilhosas que quebram as regras dentro desse mercado, né? Então, pra mim, não tem nenhum problema ter regras. Pra mim o problema é você achar que aquilo ali é a única coisa que existe no mundo. E não é a única coisa que existe no mundo. Opa! Tem tanta coisa no mundo! Ir além, mas não dizer não. Porque você toma sopa com a colher, você não vai reinventar uma colher. Ou você pode tomar com a boca. São dois jeitos de tomar a sopa, não um só. Eu não digo “não”, mas eu gosto de quebrar a regra. É bom, é gostoso.

40. Quando você está compondo, você pensa no resultado que a sua música pode ter na experiência do espectador? Ou é uma coisa mais livre?

Não. É livre e tem que ser livre. Eu não penso nada. Eu não penso. E não existe o pensar sobre isso, existe a teoria do pensar sobre isso. "Vou fazer uma coisa palatável, vou fazer uma coisa pra vender...”, não, não penso nisso e não se deve pensar nisso. Você acha que o Iñárritu lá, o 
diretor de O Regresso, está pensando o quê? Não está pensando nada! Na verdade, na verdade é o seguinte: se você colocar o Frank Zappa tocando 30 vezes por dia na rádio, ele vai ser palatável. Em qualquer indústria, não adianta. Então eu não posso entrar nessa. Quando o produtor começa com esse papo pra mim, eu "cago" pra ele, entendeu? Eu "cago". Hoje, eu "cago" mais ainda. Antigamente, eu "dava a bunda", hoje eu não dou mais não.

\section{Houve alguma relação de suas bandas, Karnak, Os Mulheres Negras, você solo, com a indústria fonográfica? Como foi essa relação?}

Sim. Foi terrível! Nada funcionou! O Poladian [produtor musical] quis contratar o Karnak. Aí ele chegou pra mim e falou assim: "O Karnak é só você e o cachorro, o resto eu "tô pouco me fudendo"'. Não dá, cara. Pra mim, tem que fazer a coisa do coração. Não dá pra imitar ninguém, não dá pra ir atrás de referência, eu não acredito nisso. Eu não acredito nisso, isso não é da minha... Existe gente que faz isso? Existe. Existe gente que faz isso e tem talento? Existe. Existe gente que faz isso, tem talento e acredita nisso? Existe. É errado? Não é errado, mas não é a minha. Pra mim, tem que ser autoral. Tudo tem que ser autoral. Uma luz tem que ser autoral, um diretor tem que ser autoral. Eu já trabalhei com diretores que não são autorais. A Anna Muylaert, pra mim - não é porque é minha ex-mulher, não é porque é a minha melhor amiga , mas o filme dela é autoral! O filme dela é dela. Os nomes dos personagens dela são dela. Eu acredito nisso. Uma música minha é minha, não é do Sakamoto. Não sou eu imitando ele. Entendeu? Isso tem a ver com uma coisa que eu acredito, você tem que fazer o que é seu. "Ah, vou fazer um filme em outra rotação". É “do caralho". "Eu vou fazer uma música só com Cassio Tone". É “do caralho". Eu vou fazer! Eu não acredito em mercado. Isso não exclui se o Spielberg me chamar pra fazer um filme hollywoodiano. Eu faço, e eu vou te falar, eu já tenho capacidade de fazer isso. Já até pinguei ali, já fiz a trilha sonora do documentário da HarleyDavidson, você sabia? Chama Harlistas [Harlistas: An American Journey, Alfredo de Villa, 2011]. Aqui, ó [me mostra as informações na internet].

\section{Como essa sua não crença na indústria fonográfica vai pro cinema? Existe alguma relação} entre o seu afastamento da indústria fonográfica e sua aproximação com o cinema?

Eu acho que o meu perfil autoral me ajudou e me atrapalhou, porque muitos projetos eu deixei de fazer por causa disso. Tem muita gente que faz a coisa dentro do mercado mesmo, né, o que esse cara que faz os filmes da Globo Filmes aí, né, o Daniel Filho é o diretor. O cara que faz as trilhas é um produtor aí da Globo Filmes, faz todos os filmes. Pra mim foi ruim, pra mim é ruim, porque eu deixo de fazer muito filme grande no Brasil porque eu tenho esse caráter autoral, meio "marginalzinho", assim.

- Você acha?

Ah, sim, com certeza! Os caras pensam... Às vezes os caras me chamam pelo meu nome, mas não porque acham que a música é muito boa, não. Pô, o Aluizio [Abranches] é meu irmão, então tudo bem [em relação à entrevista que ele concedeu à autora, falando que ia fazer uma comédia romântica]. Fez uma "puta" trilha, maravilhosa, vai ver o filme, é legal "pra caralho!". O filme é muito legal. Eu consegui fazer uma trilha popular. Eu sou popular! Eu sou popular e eu sou autoral. Não me venha pedir pra fazer coisa parecida, chama alguém que saiba fazer. $\mathrm{O}$ [Márcio] Nigro, que trabalha comigo, ele é muito autoral, também, ele é muito legal, mas ele sabe copiar. Ele tem talento pra isso, tem que ter talento pra copiar. Eu não tenho. Eu não tenho. Não me peça pra fazer uma música parecida com aquilo. Se você me pedir pra eu fazer uma sinfonia, eu faço; uma ópera, eu faço, entendeu? Geralmente, os caras que se dão bem e eu me dou bem é quando o cara quer a minha ferradura ali. Eu me dou muito mal quando tenho que fazer uma coisa parecida com outra pessoa, entendeu? 
43. Estou tentando entender se as suas carreiras fonográfica e cinematográfica se aproximam ou não...

Eu acho que são muito separadas. Não tem nada a ver! Eu, como artista pop, não tenho nada a ver com trilha sonora. Trilha sonora, pra mim, é uma outra coisa, é um outro mundo, sabe? Eu até alinho elas, às vezes, mas elas não têm nada a ver comigo. Não têm nada a ver comigo... Eu não uso uma coisa pra outra, outra coisa pra uma, entendeu?

- E quando o Karnak grava a música dos créditos finais do Castelo Rá-Tim-Bum, ou quando Os Mulheres Negras fazem uma versão de Mestre Jonas pra abertura de Durval Discos?

Isso é ideia do diretor, não tem nada a ver comigo. Eles que falam. Ou o produtor, "Vamos somar, pra ganhar dinheiro, pra...". Nada dá certo. Nada pensado pra funcionar dá certo. Eu acho. Não tem dedo meu, e eu discordo, porque eu acho que não se força a arte. Não se força beijo, não se força "trepar". Não se força fama, não se força... As coisas são bem feitas, e geralmente quem criou essas coisas nem sabia que ia dar certo. É... Charles Chaplin, esse Iñárritu aí, o próprio Tarantino... Ele faz o que ele quer, na hora que ele quer, como ele quer. Ele faz pra ele! Isso é como uma dança no Maranhão, os caras fazem pra eles! A música é feita pro entretenimento? É, mas é feita pro entretenimento a partir da criação de alguém que criou! Não existe pra mim isso. Não existe e eu não quero que exista pra mim. Existe pros outros. E eu consigo fazer - porque eu sou um profissional e tenho que pagar pensão, e tenho que ganhar dinheiro -, eu consigo trabalhar nisso. Por isso é que eu trabalho com outras pessoas pra me ajudar. Mas eu sempre coloco uma pimentinha.

44. Me conta um pouco sobre a sua equipe. Tem o Márcio Nigro...

Tem algumas pessoas, o Márcio, o Meno [del Picchia], o Herom, que é o tecladista do Karnak, tem o Mano, várias pessoas que não só eu ajudo como também eles me ajudam. Então, se vai fazer uma trilha sonora de cinema que tem uma cara x ou y, eu chamo o Nigro. Se tem que fazer uma trilha mais folk, eu chamo o Meno, Meno del Picchia, eu me organizo. Mas basicamente eu gosto de fazer tudo, eu sou "meio gordinho" nessa situação.

45. Pesquisando os créditos dos filmes que você participa, percebi que alguns nomes se repetem. Por exemplo: estúdios e produtoras. A Voz do Brasil...

A Voz do Brasil é porque eu gravo muito lá, porque é um estúdio muito legal e eu sou amigo do dono. Lá tem um som bonito, nA Voz do Brasil.

- Aí tem Bell e Bull Produções Artísticas...

Essa não existe mais, que era a Bell, que era a produtora do Karnak, que trabalhou comigo. Mas a gente não está mais juntos. Era minha e dela.

- E o Omin Estúdios?

Eu. Isso aqui é o Omin [mostra o próprio estúdio onde acontece a entrevista]. Esse é o Omin.

- Aninomato Estúdios?

É um estúdio que não existe mais, onde eu mixei vários filmes em 5.1. Hoje eu mixo aqui. Lá eu contratava. Era um empreendimento meu também.

- E a Abujamra Music Station?

Era aqui, mas agora virou Omin.

- Qual o critério pras mudanças de nome?

Eu mudo de acordo com o meu humor, a minha vontade mesmo, mas já faz muitos anos que é Omin. E a minha empresa agora sou eu sozinho e eu chamo as pessoas pra trabalharem comigo.

- E é diferente da Mondo.

A Mondo é de publicidade. Mas dentro da Omin, o Márcio, que é da Mondo, trabalha comigo. É complexo, né? 
46. Que discos de que artistas você produziu em sua carreira?

Eu produzi Pato Fu, Tom Zé. Eu não gosto muito não [de produzir], mas faço. Quando eu gosto muito de uma banda, e quando eles me chamam muito, eu faço. Mas digo muito mais não que sim. Tem uma banda que chama Abayomi [Afrobeat Orquestra], já ouviu falar? É maravilhosa, é do Rio [ele procura na internet]. Eu que produzi eles [dá o play no Youtube]. Mas eu não gosto muito [de produzir] não. Agora eu já estou sabendo fazer mais, mas assim, é... é lidar com o ego, né, eu também sou artista, eu também componho... É complexo. Eu prefiro mais ser diretor de teatro do que produzir música. Mas eu produzo.

- Que discos do Pato Fu e do Tom Zé você produziu?

Tem mas acabou (1996), eu acho que é o terceiro álbum deles, segundo... E o do Tom Zé foi um disco que fez ele ficar famoso no mundo inteiro. Com defeito de fabricação (1998) fui eu que produzi. Só que ninguém sabe, né, porque o David Byrne [Talking Heads] colocou o nome dele como produtor. Mas quem produziu, mixou, fez tudo, fui eu.

- Falando nisso, a trilha de Capitalismo Selvagem é sua, como consta no IMBD? Não aparece seu nome nos créditos...

É erro. Eu já mandei e-mail, inclusive. Não fiz. [procura algo na internet] Tem um site italiano que diz que eu fiz a música do filme Gladiador (Ridley Scott, 2000). E eu não fiz, né? Eu acho que eles devem ter tirado.

47. Que autocrítica você faz do seu trabalho como compositor de trilha musical para cinema? Ai, que pergunta difícil! Cara, é tanta música! Alguma coisa que eu não gostei do meu trabalho? Olha, cara, pode ser que a pessoa me ache a pessoa mais egocêntrica, mais convencida do mundo, cara, mas... Eu não me lembro de nenhuma música que eu fiz que eu falasse que eu não faria, que eu deixei passar alguma coisa que eu não gostasse. Porque eu sou muito autocrítico. Então o que foi, eu aprovei, mais o diretor. Eu não me lembro de ter uma música: "nossa, que música feia". Tem, sim, mas não de cinema. Do Telecurso do segundo grau [Telecurso 2000], eu odeio aquela música que eu fiz.

- Talvez seja a que mais entrou na cabeça das pessoas...

É. Eu odeio. Eu não gostei, mas eu tive que fazer, eu estava de cueca, era de madrugada... E é a trilha que mais toca minha no mundo. E eu não gosto dela, mas não é de cinema. 


\section{APÊNDICE C - Entrevista com o compositor Márcio Nigro, presencialmente, em 09/09/2016, das 13h45 às 15h, no home estúdio do compositor, em São Paulo-SP}

\section{Como você se comunica com os diretores para poder compor? Você sente alguma dificuldade nessa comunicação?}

Relações profissionais, em geral, artísticas, são delicadas, principalmente quando envolvem mais de um artista. O diretor é um artista, o cenógrafo é um artista, existem muitos artistas envolvidos. E todo artista tem algum nível de ego envolvido, porque, se não, a pessoa não é artista. Se ela não tiver essa coisa de querer botar essa coisa... A menos que ela seja muito desapegada, a pessoa que faz e não liga pra nada do trabalho - existe também. Mas a pessoa que quer viver da sua arte precisa ter um ego envolvido ali, porque, se não, você não acredita realmente naquilo. Uma parte da sua imposição como credibilidade é você acreditar no que você faz. Acreditar que você faz bem, que você pode fazer o melhor, o seu melhor praquilo, colaborar de alguma forma.

O cinema aqui no Brasil é muito... é um pouco centralizado demais na figura do diretor. Eu não vou falar se isso é bom ou ruim, porque tudo depende muito. Um filme pode ser bom justamente por a pessoa ter... você pega um Woody Allen da vida... Mas existem muitos filmes americanos em que o diretor é uma peça, às vezes o produtor é mais importante. Tudo é uma questão de julgamento de valor. Mas no Brasil é fato, o diretor... muitas vezes às custas de um esforço pessoal, realmente; [o filme] é um filho dele, mais do que para os outros. O cara normalmente move montanhas, corre atrás de patrocínio, principalmente aquele que é mais independente, conta com pouco subsídio, etc. Você sabe que é uma batalha. Então nada mais natural do que ele querer ter controle sobre todos os aspectos.

Só que geralmente o aspecto que o diretor menos tem controle é a trilha sonora. Porque geralmente eles não sabem fazer, eles não são músicos; às vezes são, mas ser músico não garante que você faça trilha sonora... não existe essa relação. O cara não precisa ser um "puta" músico pra fazer uma boa trilha sonora. Quer dizer, o melhor músico do mundo não necessariamente vai fazer uma boa trilha sonora.

E, nessa hora, o embate vai se dar no plano da comunicação. Porque se comunicar é a coisa mais difícil que tem, na verdade, quando você fala de uma linguagem, inclusive, que não é palpável. No plano cinematográfico, o cara até faz um storyboard, ele faz o enquadramento, mostra exatamente pro câmera o que ele quer, o que ele imagina, ele chega pro ator... Mas se o cara não souber se comunicar direito com o compositor, e se o compositor não souber também extrair as informações necessárias, a relação pode se complicar aí, mais a expectativa do que você pode fazer ou não.

Então o primeiro desafio está aí: você saber se comunicar. O diretor não tem a obrigação de entender a linguagem musical; quer dizer, deveria entender mais, estudar mais, porque eu tenho certeza que muitos diretores não entendem muito a função narrativa da música. E isso pode ser uma falha na formação. Outros entendem muito bem, mas não entendem muito bem da linguagem musical. O compositor, por sua vez, precisa entender o máximo possível da linguagem cinematográfica. Quanto mais ele entender plano, sequência, o que envolve todas as etapas, isso vai facilitar a comunicação, porque o compositor musical pode estar envolvido desde o roteiro até a montagem, mandar a trilha antes, em cima de um esboço... Ele pode estar envolvido em qualquer etapa.

Normalmente, aqui no Brasil, ele fica na reta final, quando se tem o filme montado, o que nos leva a um outro problema: normalmente, o compositor fica numa etapa posterior da pósprodução. Quando tudo já está montado, o editor ou o diretor já botou um monte de música de referência, botou lá na tela, já se acostumou com aquelas referências - estando boas ou não, adequadas ou não, porque em questão de trilha sonora não existe isso, se a música é boa, não importa; a música pode ser linda e não ser funcional. Daí entra a questão das funções narrativas. 


\section{Como compositor, como você pensa a música de cinema? Qual é o papel dela, nos filmes para os quais compõe?}

Eu estudei um pouquinho, eu não sou acadêmico, mas quando eu dei aula lá na Anhembi [Morumbi, no curso de Trilha Sonora], eu tive a oportunidade de compartilhar algumas aulas que eram dadas por uma professora que se chama Suzana Reck Miranda - você deve conhecer -, que é uma estudiosa do assunto. Ela deu algumas aulas, e eu acabei tendo a oportunidade de adentrar um pouco mais nesse universo. Porque realmente eu comecei a fazer trilha nessa época, com Encarnação do demônio [José Mojica Marins, 2008, em parceria com André Abujamra], inclusive. Eu mostrava pra ela os primeiros cortes, e, ao mesmo tempo, eu comecei a ler mais. E tem essa questão da diegese, de criar a sensação da realidade, transportar o espectador. Então a música tem essa função narrativa, de conduzir, unificar a narrativa. Quando normalmente o diretor bota trilha de referência, a coisa tende a ficar desconectada musicalmente, porque cada coisa vem de um canto, tem uma sonoridade, tem uma intenção diferente. Embora isso possa ajudar na comunicação, porque mostra uma intenção, ao mesmo tempo pode atrapalhar, porque às vezes o motivo não é a função narrativa, é uma função psicológica, é alguma coisa que ele quer dizer lá que está na música [de referência], mas não está na narrativa musical [do filme]. O diretor já botou alguma coisa por causa da letra, porque a letra fala de liberdade; ele quer falar de liberdade, e a música não era aquilo. Muitas vezes acontece: "Olha, eu tô botando isso, mas não é isso", e eu falei: "É melhor não botar", porque tudo que "não é isso" é ruído, aí atrapalha.

Então, a música está lá; tem horas que não tem música; tem horas que a música é pra antecipar, se a intenção é antecipar. No cinema hollywoodiano, a música está te conduzindo o tempo todo; é uma fórmula. Muitas pessoas são acostumadas com isso. Quando tem um filme que não tem a condução, a pessoa fica desconfortável, porque se acostumou. Porque os filmes antigos eram menos sonorizados musicalmente, a música entrava mais em questões muito específicas. A música começou a ter essa coisa mais própria do videoclipe. A música que não para ajuda na passagem do tempo e também é tudo uma questão comercial. Não é julgamento; às vezes é legal, porque você quer fazer uma coisa comercial, faça isso. Não precisa ter música o tempo todo, porque o silêncio é dramático também, tem que lembrar dessas coisas. O músico tem que lembrar, o diretor tem que lembrar. Porque, às vezes, a função dele não é botar música o tempo todo no filme; às vezes é o contrário, falar "Olha, aqui é melhor não. Vamos segurar, segura, segura, é aqui". Muitas vezes o diretor lembra a gente disso, porque muitas vezes a gente esquece, a gente se envolve muito na música. E muitas vezes a gente tem que também falar "Opa, é hora de eu tirar a mão".

03. O Abujamra citou você quando eu perguntei a ele sobre música de referência, pela qualidade que você teria e ele não de conseguir, a partir da trilha temporária, pegar aquelas características e passar pra sua criação.

Eu comecei minha carreira de estúdio e de produção musical vinculado com essa coisa de trilha comercial. Então, qual é a verdade? Todo mundo gosta de música. Quando a gente gosta de alguma coisa, a gente acha que, de alguma forma, conhece; confunde-se reconhecer com conhecer. Quer dizer, "você conhece Beatles?" "Conheço". "Você conhece mesmo?" É diferente. Você conhece porque já você ouviu falar, você conhece porque você já ouviu algumas músicas ou você conhece muito bem? São coisas completamente diferentes. As pessoas gostam de música, todo mundo gosta de música, eu imagino - tem um ou dois que pode ser que não, mas em geral todo mundo gosta. Você tem uma afinidade, a música comunica, a música fala com as pessoas e não precisa de palavras. É justamente essa questão da comunicação: ela comunica uma coisa e você não precisa entender; mas na hora que você precisa botar a comunicação verbal naquilo, às vezes nem comunicação é. "Deixa eu fazer, eu te mostro. 
Porque se eu ficar falando, não vai falar”. Não adianta, só na hora de fazer que eu mesmo vou saber o que eu quero apresentar.

Então todo mundo gosta de música e todo mundo quer "Ah, eu gosto disso aqui". Isso é a coisa mais comum da publicidade. "Ah, Coldplay, eu gosto de estar na banda da moda" - o pessoal de marca gosta de Coldplay, eles [publicidade] botam Coldplay. "É o melhor pra coisa?" "Não". "Funciona?" "Ah, funciona." "Legal".

Eu nunca tive preconceito em relação a isso e eu sempre tive facilidade nessa mimetização, tentar pegar aquilo e querer traduzir da forma que eu acho mais adequada. Às vezes não é; às vezes você tem que falar "Olha, eu acho que não funciona", quando você tem abertura - às vezes você não tem abertura; na publicidade, muito menos. Mas os próprios diretores, muitas vezes, vêm: "Aqui, olha, é esse que eu quero, é assim..." ou não é sempre, mas "Olha, o que você acha? Faz o que você quiser, primeiro vamos ver a sua proposta". Seria uma forma de trabalhar.

Mas realmente você tem que entender que é difícil pra o editor [não usar música de referência] - ainda mais hoje, com o computador e suas possibilidades. É muito prático montar um filme e você criar um ritmo pra imagem, pra entender, porque a música ajuda a criar o ritmo da edição. Começa a virar um vício, por outro lado; muitas vezes gera problemas pra gente. Filmes de ação como 2 coelhos [Afonso Poyart, 2012] foram todos editados em sincronia com a trilha [temporária]. Então você engessa o seu trabalho, porque você é o obrigado a seguir...

Mas assim, eu não sou um cara de ficar reclamando, não. A música é quase um "líquido", mais flexível que qualquer coisa. Se eu preciso encaixar a música de qualquer forma, ela vai. Pode não ficar o melhor possível em relação ao que você imagina, mas é possível moldar. Você quer pegar música clássica com Olodum, que dá essa alquimia ali que eu não vejo que seja nada impossível. Isso é muito a cara do Abujamra, inclusive.

\section{Em que ocasião você conheceu André Abujamra?}

O trabalho dele no Karnak, a primeira vez que eu ouvi, eu fazia Jornalismo - eu me formei em Jornalismo. Eu estava no primeiro ano de faculdade, juntamos uma turma lá e fomos fazer uma revista, "pede pra entrevistar o Abujamra, conhecê-lo pessoalmente" - e eu o conheci pessoalmente muitos anos depois. Ele mostrou as primeiras demos do Karnak e têm muito a ver com o que eu acredito. Eu sempre gostei de diversidade: se eu tenho uma música, a outra vai ser diferente, eu nunca penso em fazer duas vezes a mesma coisa, da mesma forma que eu não penso em comprar duas vezes o mesmo instrumento. E a mistura, pra mim, é: se for pra fazer chorinho, vamos fazer chorinho, eu estudei um pouquinho, "vai lá e aprende". Se for fazer uma música mexicana, vamos lá, que legal, é mais repertório. Quanto mais eu aprender com um músico sobre outros tipos de música, melhor. Isso não vai me fazer um músico de jazz, ou um músico bom de chorinho, mas enriquece o repertório. Se o desafio é bom, eu não vejo problema. E tudo te ajuda a desenvolver a linguagem, porque a composição é um exercício; é uma linguagem que precisa ser exercitada. Por mais que você tenha o dom natural ou não, é uma coisa que você vai aprimorando, como em qualquer outro ofício, artístico ou não artístico.

\section{Antes de Encarnação do Demônio, você já tinha trabalhado com cinema, em curtas ou outros projetos?}

Tem um curta, está até no Youtube lá... Pouca coisa, eu ainda não tinha tido a oportunidade. Eu fiz um curta que era o WC. Era a Antônia Salazar... Desses festivais de curta, tem no meu canal no Youtube, eu te passo. É muito simpático. Eu lembro que eu mostrei até pra Suzana na época, e ela achou que era super minimalista. $\mathrm{Na}$ época, eu tinha estúdio e tinha pouco recurso, tudo foi feito basicamente no teclado - que é uma das grandes formas de aprendizado, você fazer muito com pouco. Hoje a gente tem muito e as pessoas, sabendo pouco, mesmo tendo muita disposição, às vezes não aproveitam; não têm esse aprendizado das etapas. 
06. Conte sobre seu início no longa-metragem, com Encarnação do demônio, que você fez com Abujamra, e como se desenvolveu sua carreira de compositor de música para cinema.

O Abu me chamou, a gente já tinha contato, por causa do filme mexicano [Voces inocentes, Luis Mandoki, 2005], e ficou nessa, "Ah, vamos trabalhar juntos", e lá se foram quatro anos, "Vamos montar uma produtora", e cinco anos depois a gente montou uma produtora, a Mondo. E, na verdade, ele abriu uma porta lá que eu não sei se eu conseguiria abrir sozinho, pelo menos não com o meu... eu nunca fui muito bom de marketing pessoal; eu tenho uma coisa muito do trabalho em si, do resultado do trabalho... E eu comecei a valorizar mais, investir, quer dizer, me tornar um pouco mais "marqueteiro". Mas eu sou meio avesso a essas coisas do show off [exibir-se]. Eu acredito muito em meritocracia, apesar de estar num país errado, porque eu sempre tive as pessoas de quem eu conquistei a confiança fazendo.

Antes disso, uma experiência que era pra ser muito legal e que acabou não rolando: teve um diretor que era de publicidade e que mora em Portugal agora, se chama Marcos Menescal. Ele tinha uma produtora chamada Paradiso. Ele tinha estudado Belas Artes na Noruega, tinha trabalhado com o Spike Lee em alguma função. E também tinha uns clipes que eram um filme sobre o EMA, que era a Expedição Mata Atlântica, tipo um eco-challenge aqui no Brasil. E ia ser um filme, eu cheguei a fazer umas trilhas bem bacanas, mas aí o dono do EMA pegou um parasita nesse eco-challenge, ficou paraplégico, aí acabou morrendo o projeto. Isso era 2002, por aí. Seria provavelmente a minha estreia, ainda que em documentário... Eu tenho dois clipes, e sobraram umas músicas, até hoje eu penso no que fazer lá, que foram super legais. São aquelas coisas mais "trilha sonora" mesmo que eu devo conseguir reaproveitar em uma outra coisa.

Mas enfim, quando o Abu falou do Encarnação foi genial, já começar com uma coisa tipo Zé do Caixão, independente do julgamento do filme em si, foi muito legal trabalhar, porque era extremamente livre. Tudo que era pra ser padrão era negado, então era já começar "fora da caixa".

\section{O que você fazia, o que o Abujamra fazia?}

Desde o começo sempre foi muito dividido, a gente dividia as cenas, ou, "vamos começar", um vem "mete a mão no [trabalho do] outro". Desde o começo ficou claro que seria fácil de se trabalhar, porque o Abu tem uma coisa bacana: ele é muito apegado às ideias, mas nem tanto à forma. Então ele lança uma ideia, você dá uma continuidade, "Pô, 'do caralho', mas pô, aqui, vamos só fazer mais isso, que tal tirar isso?”. Já chega num estágio em que ele não se incomoda em nada, em geral, que eu... ah, sofisticar a trilha, mudar alguma coisa: sempre tem algumas coisas que a gente não concorda, mas é tudo a nossa visão artística.

Mas foi assim a divisão, "vamos pegar, dividir, você faz tal cena" e tal, ele já tinha estabelecido uma pré-sonoridade e a partir disso a gente vai desenvolvendo. Daí eu mandava, ele falava "Olha, eu fiz mais isso aqui...", ele mandava a cena, "Olha, eu acho que fica mais legal...".

08. E essa pré-sonoridade que você diz, ela era estabelecida entre o Abujamra e o diretor, ou a três - vocês dois e ele?

Ele já sabia exatamente. Tipo, em O contador de histórias [Luiz Villaça, 2009] ele já tinha um tema que eles já tinham gostado, que era um teminha muito simples que acabou permeando praticamente toda a trilha, que era o mote. O resto foi nascendo disso. Pro Encarnação ele tinha feito o tema do Zé do Caixão [cantarola]. Mas quem intermediou muito a coisa foi o Paulo Sacramento, que "traduzia"... Às vezes era engraçado ver como é que ele [José Mojica Marins] se expressava, porque não era musical, mas dava pra sacar. Mas as primeiras tentativas de tentar fazer algo mais convencional já foram bombadas. A gente tentou botar uma guitarra e ele: "Nada a ver". E daí a gente soube que o Mojica, nos filmes antigos, quando não gostava da 
trilha, botava ao contrário. Então a gente começou a pensar: "Ah, vamos botar as coisas ao contrário, vamos botar a mão no teclado, fazer uns acordes esquisitos". Então foi uma trilha pouco cerebral e muito primitiva, cheia de instinto, que era uma coisa da estranheza. Então as percussões podiam ser cadenciadas, mas tinham que ser mais pro primal, não podia ter uma "batera", um ritmo. Não podia soar nada do tipo Hollywood. Isso é um desafio também, você pegar alguma cena como as cenas de tortura, procurar o timbre mais "perfurante", o timbre mais cortante, ali. Parecia que a gente estava lá tocando tenso, porque você tava tentando traduzir, na própria sonoridade, a tensão.

Uma trilha sonora é um trabalho grande, leva uns três meses. É possível você fazer antes, depende da evolução [do trabalho], do tipo de trilha sonora... Pode levar um mês, seis meses, mas a questão é sempre que eu acho que algumas coisas levam mais tempo pra maturar do que outras. Já ouvi falar de pintor que demorou um ano pra pintar um quadro e pode ter pintado em um dia. A obra-prima pode nascer de várias formas, pode ser fruto de muito suor, mas pode ser só da inspiração. Paul McCartney um dia acordou com Yesterday na cabeça, outras músicas dele podem ter demorado muito mais tempo.

09. É interessante que vocês dividam o filme em sequências para compor, porque não se nota uma mudança brusca de características na trilha musical, a não ser que determinada cena peça.

O começo do filme é sempre a busca da sonoridade, o que daí é mais travado com o diretor, que manda alguma cena... Você pega algumas cenas mais chave, normalmente - tem que pegar pelo que mais define o filme. Aí você manda a cena e ele: "Ah, gosto disso, não gosto daquilo". Vamos pegar tipo o Amanhã nunca mais [Tadeu Jungle, 2011]. O Tadeu Jungle estava com uma cabeça de publicitário: tinha trilha em todo canto, tudo trilha comercial. E foi um filme que, por razões pessoais dele, ele foi adiando, adiando. E foi mudando, ele foi mudando o desenho do filme. Curiosamente, ele mudou do comercial para o menos comercial, o que foi corajoso, o filme ficou melhor. Mas ficou menos comercial, ficou uma semana no cinema. $\mathrm{O}$ filme tinha muita voice over, tinha muita narração do Lázaro Ramos, e ele foi tirando, e o filme foi ficando "do caralho". E a trilha ficou muito legal, porque a nossa visão foi conquistando porque tem esse tempo, que eu falei, das referências. Tem a coisa do Pavlov: você se acostuma com aquilo. Então, quando a gente colocou a música, ele achou estranho; mas com o tempo, foi pegando. Às vezes você precisa conquistar aquilo, às vezes não tem tempo, "é isso mesmo" e tal. O Amanhã nunca mais teve essa transição, e acabou ficando com a cara que a gente imaginava.

10. Conte-me sobre as discordâncias que vocês e o Abujamra têm quando compõem juntos. Ele não tem muito problema em a gente dar uma mexida nas trilhas não. Tem horas que eu falo: “Abu, tá ruim". Nem sempre ele reage bem a isso, como eu às vezes também não. É a questão do ego, você gosta, você acredita, e às vezes leva um tempo pra você perceber, às vezes ele fala: "É mesmo, nada a ver". Então às vezes tem esse embate, e normalmente é nisso, quando você geralmente gostou da coisa e o outro fala: "acho que não é isso". Como em todo trabalho de parceria. Mas não rola muito isso, porque ele tem muita experiência com cinema - eu tenho menos, mas, de 2008 pra cá, tenho trabalhado e sempre tive pra mim que é uma coisa natural, essa compreensão. Eu acho que vai se aprimorando, mas desde o começo eu senti uma facilidade. E, da dupla, eu sou o mais "cdf”. Eu não sou tradicionalmente um "cdf", mas, no comparativo [com Abujamra] eu sou, porque eu sou um cara muito mais metódico; eu sou um cara que leio - não sou um cara que estudou profundamente, eu fugi da academia. Eu tentei fazer História e fugi; aí alguém me ofereceu pra fazer um mestrado de graça lá [na Anhembi Morumbi] e eu ia ter o segundo filho; eu queria investir meu tempo em música, e não em escrever uma tese, porque isso não iria mudar minha vida. Mas eu parei pra estudar, pra 
entender melhor o que eu estava fazendo, me comunicar melhor, fazer melhor meu trabalho. Mas, na maior parte, é intuitivo. Ele, mais intuitivo, e eu, lendo mais e também com alguma intuição.

\section{E Dois coelhos [Afonso Poyart, 2012]?}

Ele é um filme que chegou já editado e sincronizado com trilhas de referência, e era só esse o trabalho. Ele [o diretor] queria isso [música muito próxima da referência]. Também foi um filme que parou, e na fase final eu falava "Olha, Afonso, vamos mudar isso aqui? Não tá funcionando", mas nunca saía muito longe do que estava. Não havia muita liberdade de criar coisa nova, mas de aprimorar. Não que houvesse algo de errado; tinha uma pré-concepção de trilha e já chegou bem definido o que a gente teria que fazer no filme. Ele é um filme mais comercial, "institucional", num certo sentido; ele tem mais a cara do mercado, porque era a proposta. E pessoalmente não vejo nada de errado, porque é uma fórmula, e fórmulas existem pra, na ausência de uma solução, a gente ficar com a fórmula.

O que mais me incomoda num filme é quando ele é indeciso: ele aponta pra fórmula, mas luta contra a fórmula. Então, a indecisão gera um filme indeciso e que vai desagradar aqueles que querem um filme comercial e aqueles que esperavam um filme artístico. É como na política: quando você está "no meio", ali, você toma bordoada dos dois lados. Mas é pior, porque realmente o filme indeciso mostra que ou não "teve culhão" pra ser artístico mesmo, ou [o diretor] falou: "vou ser comercial porque eu quero vender". No Brasil, ser comercial é algo meio... Mas isso é no meio artístico todo, você faz sucesso e alguém vai querer te criticar por fazer sucesso. Existe o medo de ser taxado de comercial. Eu não vejo problema: você vai na música, Beatles não era nada mais que música comercial, e como música comercial, teve a possibilidade de evoluir por questões comerciais. O comercial pode ser o caminho pra você ir além do comercial. Isso se você está no começo de carreira; se você não está, ou você arrisca "vou fazer um filme", porque no Brasil é complicado, politicamente e por questões de bilheteria. O diretor fica numa situação complicada, porque é difícil conseguir dinheiro; se não for comercial não consegue dinheiro; se for muito artístico, vai ficar restrito, vai passar uma semana no cinema (se é que vai passar no cinema). Mas a minha postura em relação a isso é que o diretor tem que assumir uma postura clara em relação a isso, porque isso dificulta muito o trabalho de todo mundo. Se as pessoas não sabem onde elas estão pisando, "eu atiro um pouquinho pra lá, mas não vou", e as coisas nunca vão numa direção; elas ficam num meiotermo e isso acaba gerando um filme normalmente "morno", que não adotou uma posição clara e não vai conquistar o espectador que estava numa expectativa de uma coisa ou outra.

\section{2. É proibido fumar [Anna Muylaert, 2009] foi a sua primeira trilha solo?}

Foi. O Abujamra passou pra mim, ele me recomendou pra Anna porque achou que iria ter problemas pessoais (risos), já que ela é ex-mulher dele. Mas o É proibido fumar é um filme um pouco diferente. Ele era um filme parte coberto por fonogramas e trilha incidental. Me [sic] gerou muita publicidade, mas foi um filme em que eu fiz menos coisa, por ser uma trilha incidental, não aparece muito. Em alguns momentos e tal...

\section{E a trilha tem que aparecer?}

Sim, depende muito. A trilha não precisa ser perceptível. Se você percebe, é bom, fala "aquela trilha é "do caralho"". Mas não necessariamente; ela pode ser o elemento narrativo imperceptível. A trilha de suspense, por exemplo: às vezes só aquele agudo, aquele "gravão" dando o clima ali tá cumprindo a função dele de criar tensão. E a trilha perceptível obviamente vai ser noutro momento, que é diálogo, ou quando você quer algo mais videoclipe, em que você pensa na parte fotográfica e a música realmente completa. Mas a boa trilha não necessariamente aparece. Agora: a boa trilha pode ser salvadora, porque muitas vezes as pessoas não gostam do 
filme, mas sim da trilha. É mais ou menos quando você vai num show, você não gosta da banda, mas o baterista é "bom pra caramba". Tem um caso clássico de um filme chamado The lost weekend [Billy Wilder, 1945], que era um filme em que o ator fazia o papel de um bêbado, um alcoólatra, e ele estreou sem trilha sonora. E as pessoas riam do filme; tiraram logo ele de cartaz. Chamaram o Miklos Rózsa pra fazer a trilha, o filme reestreou, ganhou o Oscar, mas não ganhou o Oscar de Trilha Sonora. O que demonstra que - eu não vi o filme, só vi uns trechos normalmente a trilha grandiosa é a que realmente salta aos olhos. Você pega O Grande Hotel Budapeste [Wes Anderson, 2014, trilha de Alexandre Desplat]... Eu ouvi e pensei "Que trilha é essa, quem é esse cara?" e já anotei; foi um grande trabalho de pesquisa. Mas o cara fez a trilha que costurou o filme inteiro; salvou o filme. Ganhou o Oscar de Melhor Trilha, mas na verdade não importa; o que importa é que o filme funcionou, entendeu?

Então, a trilha sonora está lá pra ajudar o filme; ela tem uma função lá. Então, se é pra aparecer ou não, não importa. $\mathrm{O}$ que importa é o que é melhor pro filme. Esse eu acho que é o caso emblemático.

\section{Qual a diferença entre trabalhar sozinho e trabalhar com Abujamra no cinema? O que muda na dinâmica de criação e produção?}

Todo mundo quer ter uma assinatura, mas o Abu já tem; tem uma identidade estética e musical que é dele, e que obviamente ele quer imprimir. Depende muito do estilo do filme; ele gosta muito das coisas orquestrais. Tem algumas coisas que são assinaturas dele, eu já reconheço. $\mathrm{O}$ arranjo de cordas dele, eu já escuto e já sei que é dele. É o modo de composição, né? Você pega o Hermeto Pascoal: depois de um tempo, você vai reconhecer a assinatura da pessoa.

Eu tenho uma assinatura estilística também, com coisas mais modernas. Quando eu estou trabalhando com o Abujamra é uma coisa; quando eu trabalho só, posso tomar outras formas ali que às vezes não têm muito a ver com o Abujamra. Tipo: o Abu quase nunca pega um piano rhodes ou um órgão; ele gosta muito das coisas orquestrais, muitas vezes ele parte daí. Eu tenho uma ligação muito com o pop e com o rock, então, se eu pegar uma trilha assim... O Bem casados [Aluízio Abranches, 2015], por exemplo, ele chamou o Meno [del Picchia]. O Meno trouxe um elemento ali super legal; ficou até quase um meio-termo entre mim e o Abu, um terceiro elemento que foi super legal de trabalhar. Mas eu também amo as coisas orquestrais e

aprendi muito. $\mathrm{Eu}$ vou botar no meu site $\mathrm{e}$ vou te passar o link [http://www.marcionigro.com.br/], não sei se você chegou a ver. Tem um curta que se chama DaliVinCasso [Marcelo Castro e Marlon Tenório, 2014], que eu fiz a trilha e que ganhou vários prêmios. Uma animação genial do Marcelo Castro e do Marlon Tenório. A história lá é basicamente que o Da Vinci é o zelador do Louvre, e chega um quadro lá que é metade Picasso metade Dalí, os personagens fogem do quadro e começam a transformar o Lourve num museu de arte moderna. Aí começa uma briga entre eles lá, e o Da Vinci tentando desfazer tudo. E são 11 ou 12 minutos de música, numa narrativa estilo Tom \& Jerry, não teve nem sound design. Meu sócio fala: "você tinha que ter botado algo mais lá", mas a música era o suficiente; ela era a comentadora, a narradora. E eu a chamei de uma suíte "pseudoespanhola renascentista". Não é que eu estudei música renascentista pra fazer; eu peguei alguns elementos da minha cabeça e o resto é intuição, porque a parte acadêmica, cerebral, não é muito a minha. $\mathrm{E}$ foi muito rápido de fazer, porque quando você está fazendo só a música narrativa, "ah, é só um minuto", às vezes vai o dia todo. Fazer, num dia, 30 segundos, a parada ali. Vai, volta, comentando, tem muita coisa de mickeymousing... Mas ficou super legal. Eu fiquei super orgulhoso do trabalho, que me deu muitos prêmios em vários festivais - merecido, porque o trabalho deles [diretores] em animação é sensacional. Eu até queria que circulasse mais, mas curta [metragem] a gente sabe como é: um outro pode ser alçado a uma esfera mais alta. Mas foi um trabalho muito peculiar, uma oportunidade muito diferente e eu fiquei muito feliz com o resultado. Parece que a gente se surpreende, às vezes, com o nosso trabalho, porque não é você que diz o que a música quer; 
é a música que vai te levando, a música do filme, pra onde ela quer. Então você vai ouvindo e "Olha, que legal! Não era isso que eu estava perseguindo, mas foi pra esse lado".

\section{Falamos muito sobre a comunicação diretor-compositor. $\mathbf{E}$ a comunicação compositor- compositor?}

Olha, normalmente não é tão difícil porque existe um código comum. Mas no caso de trilha sonora existe uma coisa que, quando você está discutindo a música pela música, aí você pode falar de Stockhausen e pode falar de funk carioca. Aí, o que é melhor, ou mais bonito? Um vai achar que Stockhausen é barulho; o outro, que gosta, não vai achar que é barulho. Quando é a música pela música, é difícil de se discutir o que é melhor. Você precisa falar da música sempre em relação à função. Qual é a função da música: é entreter? Você está fazendo a música pra você, pros outros? É pra fazer sucesso, é pra não [fazer sucesso]?

No caso do audiovisual, a música tem uma finalidade; então, todo parâmetro de julgamento tem que ser baseado na questão audiovisual. Funciona ou não funciona? - é a primeira coisa. Aí, "olha, eu acho que não está funcionando por essa razão, ou pela imagem, ou porque eu acho que não é bem isso que o diretor quer. Olha, eu acho 'do caralho', mas não é isso que eles querem". E, muitas vezes - eu passei por isso também -, tem uma cena de um menino empinando uma pipa em $\mathrm{O}$ contador de histórias, em que eu batalhei pra ser uma outra trilha. Eu queria uma trilha muito mais mágica, muito mais "Tim Burton". O Luiz não queria. E eu achava que - e o Abu também, a gente fez juntos a trilha - foi uma trilha que eu comecei, o menino parecia que estava dançando uma valsa, que era toda comentada, porque era uma cena longa. Mas ele [diretor] queria uma coisa mais que pavimentasse, uma música menos comercial, nesse sentido. É uma opção. As pessoas com um olhar mais intelectual queriam [a música menos comercial] - que, no final, foi o que o $\mathrm{Abu} \mathrm{fez} \mathrm{-,} \mathrm{mas} \mathrm{as} \mathrm{outras} \mathrm{pessoas} \mathrm{queriam} \mathrm{a} \mathrm{mais}$ comercial. Então é uma questão de finalidade, “o que é melhor, pra um e pro outro?”. Eu batalhei pra ter aquela trilha lá, insistia, brigava. Mas não rolou, porque não era o que eles queriam, então... Você fica frustrado; aí tem a questão do ego. Aí o Abu: "Deixa comigo". Ele foi lá e fez, e rolou. Então, você pode estar certo; mas vai estar errado de alguma forma, porque [sua composição] não foi [escolhida], entendeu? Porque alguém do outro lado não quer aquilo, e você está prestando um serviço. No dia em que o filme for seu, você faz a trilha que você quiser.

\section{E que qualidades nessa parceria entre você e ele você ressalta como um fator de longevidade dessa relação?}

A gente trabalha juntos o tempo todo, por causa da produtora [Mondo, voltada para publicidade]. A gente fez, no ano passado, o Bem casados. É assim, tem uma química. É tipo jogo de vôlei, um levanta, o outro já corta; eu já sei fazer trilha meio que nem o Abu, às vezes ele dá umas "nigradas" na trilha também. Eu já sei muito bem como funciona a cabeça dele. Ele sabe onde estão as minhas deficiências, eu sei onde estão as deficiências dele e a gente consegue se complementar bem. É essa coisa da experiência: a gente meio que já entende, ele começa alguma coisa e, se eu acho que está faltando alguma coisa... Às vezes ele vem com uma ideia embrionária, "Ó, fiz isso"; eu gosto muito disso. Eu sou produtor musical, eu posso pegar a ideia ele e construir uma casa em torno daquela ideia.

\section{E que limitações são essas, suas e dele, que você citou?}

Ele me ensinou, por exemplo - e continua me ensinando -, a parte de orquestração. Eu não fiz faculdade, aprendi tudo sempre muito na raça. Eu tive professores de violão e guitarra, mas eu era aquele cara que estava tocando muito com a intuição. E quando eu comecei a escrever os primeiros arranjos para "O contador", ele falou, : "Olha, joga o violino pra cima, não sei o quê...". Então tem horas que você tem a deficiência, tem horas em que você não consegue 
enxergar uma saída; e às vezes é o outro que te abre, "Ó, vamos tentar isso, esquece aquilo, não tá funcionando". E nessa parte do trabalhar, de mexer, não tem um ego envolvido. Em algumas ideias você vai bater o pé, o outro; mas como sempre é em função de um terceiro, tem que ter essa balisa. "Tá funcionando pra lá? Funcionou? Rolou?".

Ele falou uma coisa pra mim logo no começo, acho que foi por causa dessa trilha aí da pipa [O contador de histórias], ele falou, "Ó, a primeira coisa que você tem que lembrar é que, pra eles, é o filme da vida deles. E pra gente, sempre vai ser mais uma trilha". Não é diminuindo o nosso trabalho, porque a gente sempre faz o nosso trabalho querendo fazer o melhor. É que a gente não pode se agarrar com unhas e dentes a uma ideia porque, no fundo, o trabalho é nosso até a parte de trilha sonora; o todo não é nosso. Sempre tem uma expectativa do outro lado, e a gente está sendo contratado pra fazer um serviço.

Então, tem horas em que o ego tem que ficar completamente de lado - pra mim não tem problema. Quando tem essa coisa de referência, tem questão de ego, porque eu acho que eu posso, às vezes, fazer melhor, ou conseguir fazer algo parecido. Depende muito do que a pessoa entrega. Teve um caso, na publicidade, em que um cara queria botar uma versão de Across the universe que não funcionava, mas "só funcionava porque era Across the universe". Aí, o Abu ligou pro diretor e falou, "Olha, não funciona por causa disso, e tal", e ele, "tudo bem". Mas tem coisas que você não vai superar: me dá uma trilha completamente orquestrada com a Royal Philharmonic [Orchestra], com Sakamoto, sabe, bota lá na trilha de referência e eu falo: "Você quer 'foder' a gente, né?"; não tem como superar aquela expectativa tecnicamente. Composição pode ser, mas tecnicamente aquilo não dá, porque você não tem orçamento. Primeiro que não é uma competição. Você acha uma coisa "massa" do Sakamoto, mas outra coisa do Sakamoto pode não ser tão legal. Mas a qualidade técnica influencia muito. Se você tem orçamento pra fazer um filme com orquestra, vai ser outra coisa, diferente de a gente fazer tudo em computador. Não tenho dúvida da gradiosidade daquilo, mas a maioria dos filmes não tem [orçamento]. Então não adianta botar a expectativa lá em cima, se não tem a condição de chegar naquilo.

\section{Qual foi o filme em que vocês mais tiveram orçamento?}

Não tem muito isso. Eu acho que só ele [Abujamra] pode falar, porque ele gravou com orquestra de verdade. A gente sempre grava com uns quartetos, quintetos, então eu não posso falar, eu nunca estive nessa situação. Ele gravou no México com orquestra, muitas coisas aqui, ele gravou. Eu não tive essa oportunidade ainda. Agora, um dia em que uma orquestra estiver tocando... - eu duvido que seja uma orquestra de verdade, tipo Hollywood - mas eu não perco a esperança de pegar algum trabalho assim, gravar em um estúdio em Los Angeles... Isso é uma "puta" responsa também. Mas é difícil, é muito pouco orçamento e é bem caro. Hoje eu acho que dá pra gravar com um orçamento menor uma orquestra nos países do Leste Europeu; eu sei que hoje é possível gravar com alguma quantia [menor]. Agora Estados Unidos, Europa, esquece, é muito caro. Só o ensaio já é caro, e tem que pagar o ensaio. O orçamento precisa ser uma boa grana, pra contemplar uma orquestra. E não é todo filme que precisa. Existe essa coisa, né, que as coisas orquestradas têm um certo "oh", mas nem todo filme precisa.

\section{O Abujamra é assumidamente desorganizado, e me chamou a atenção você dizer que é metódico.}

É, eu já penso nisso, eu gerencio tudo. Essa questão de preservar os projetos, eu sempre fíco preocupado, eu gravo em DVD, mas todas essas coisas de DVD, blue-ray, sempre "dá merda", eu vou copiar... Sempre fico preocupado sobre como é que eu vou fazer, tentar deixar na nuvem. Mas isso é um aspecto mais de preservação da memória, de ter as coisas caso você precise. Eu estou falando com ele há tempos, "Vamos sentar, vamos lançar um CD nosso com as trilhas!". Porque é necessário, né? Não se lança trilha sonora aqui. E uma coletânea, talvez de um filme 
inteiro, mas só de fazer uma coletânea - já temos vários trabalhos - vai ser “do caramba". Eu sou metódico mesmo, e o Abu acredita muito na coisa explosiva da criação. Às vezes, pra mim é muito mais uma questão de colocar camada por camada, aquela pintura mais completa, sabe? Aí passa lá depois, passa outra camada e tem a lapidação. Muitas das trilhas que eu faço é isso: tem uma primeira camada, que é a estrutura, e depois... Então, nesse sentido, talvez eu seja mais cerebral, porque é um método, mesmo, de trabalho, de lapidação - que é mais a minha cabeça de produtor. Eu estou sempre ocupado em chegar o mais próximo possível do produto final. E, às vezes, o que eu estou fazendo já é o produto final, porque não vai ter uma orquestra gravada. Hoje eu tenho essa possibilidade de ser muito autossuficiente, já gravo aqui, "pede pra alguém gravar a bateria", tal. Então, em tudo que eu faço, eu já penso no produto final e no acabamento. Quanto melhor a forma que você puder apresentar, maior a chance de a trilha ser aprovada porque um esboço, muitas vezes, não transmite; a pessoa tem que abstrair, ir além do esboço pra entender a sua intenção.

\section{Como estão esses arquivos no seu acervo?}

Você fala dos filmes inteiros? Eu tenho acho que quase todos guardados aqui, que eu baixei. Mas os filmes nem sempre são do jeito que a gente quer; tem umas coisas bem frustrantes na mixagem e tal... Muitas vezes não é bom de a gente ouvir muito também não. Tem uma cena no Encarnação lá que a música sumiu atrás do grito e era uma música extremamente narrativa, e os gritos, não. Porque os gritos não precisam aparecer pra saber que a pessoa está gritando.

\section{Você guarda as duas versões (a mixada e a que vocês enviam)?}

Eu acho que a maioria deles eu guardo os cues com a trilha mais alta ali como lembrança. Eu tenho os projetos guardados. Esses dias até o Abu precisou das músicas de créditos do Encarnação e eu achei. Por sorte, eu tinha consolidado... Sorte não, por precaução, eu tinha consolidado todos os canais. Porque a sessão é antiga, então tem essas coisas, plug ins que às vezes não abrem. Mas tenho o Encarnação, tenho o Amanhã, tenho O contador...

\section{O trabalho que vocês fazem na Mondo para publicidade é diferente da parceria que vocês têm no cinema?}

Às vezes sim, às vezes não. A publicidade é uma coisa assim que não tem beijo na boca nenhum, né? No cinema rola mais esse engajamento, no próprio curta que eu fiz, não foi um trabalho grande, em termos de orçamento e tal, mas você abraça porque é um trabalho legal e te dá a liberdade de trabalhar.

A publicidade é mais funcional: você está lá, muito pela questão comercial, você sempre está fazendo algum trabalho. Às vezes casa de ter trabalhos "mais cinematográficos", muito porque também eu mostro o portifólio e isso ressalta um pouco, não é fácil lembrar. As pessoas lembram de mim por causa das trilhas sonoras, ainda que eu tenha feito muito poucas. Meu nome já circula. Mas, ao fazer música, o trabalho começa sempre parecido [com o cinema]; é sempre pela forma e função. A questão é que, se você vai ter 30 segundos, em uma sentada você faz; uma hora e meia de filme não é a mesma relação. Não é proporcional; é desproporcional - em todos os sentidos, inclusive no custo-benefício - mas é muito mais gratificante, do ponto de vista artístico. A publicidade não: ela tem um custo-benefício muito melhor, mas a gratificação é muito menor - às vezes, é extremamente irritante, por essa demanda ser cada vez mais pasteurizada, ou então "de cima pra baixo".

\section{E como vocês se dividem na Mondo? É você, o Abujamra e o Nasa?}

Isso, e a gente tem também o Herom, que participa com a gente lá na música, mais o rapaz que faz a finalização, e por enquanto é isso. Eu e o Abu... a nossa função é a criação musical. A 
gente faz um pouquinho de tudo, mas os papéis delineados são esses, mais pra parte de fazer direção musical e tal.

\section{E fora o cinema e a publicidade, você tem projetos musicais, você produz artistas?}

Eu gosto muito de produzir disco. Dá pouquíssimo dinheiro, mas eu adoro. Eu adoro estúdio e essa coisa da alquimia de pegar o trabalho de alguém e tentar ter uma visão praquilo, sabe? Lapidar, chegar pra pessoa e falar, "vamos...?". Às vezes não bate a química; às vezes você não consegue convencer as pessoas, mas é sempre um trabalho de meio-termo. Eu produzi... agora eu estou com o Carlos Careqa, agora eu vou produzir o quinto CD dele. Eu comecei em 2009, 2010... Não, 2011, 2012. Eu comecei a produzir o primeiro disco e não parei; virou meu amigo, como o Abu. Ele também é amigo do Abu. E é um trabalho com muita liberdade. Talvez pelo meu perfil, é o trabalho pra o que as pessoas me procuram mais - porque não adianta me procurar pra produzir um disco de pagode, ou de jazz ou MPB, porque não é a minha linguagem; então ninguém me procura pra isso.

Aí, por causa do Abu, eu produzi o disco do Marcos Bowie [Karnak] - ele fez arranjos, mas eu também "meti a mão" em algumas coisas. Tem uma cantora chamada Gláucia Nasser, que acabou de sair um EP - da qual em 2010 eu produzi um outro disco, tentando ter uma ótica diferenciada. No caso dela, o disco nasceu - não necessariamente se centralizou - porque eu gosto muito de afinações diferentes no violão, então eu comecei a fazer os arranjos a partir disso. Eu gosto muito de música comercial, mas eu gosto da música comercial que tem um tempero diferente - que acaba deixando de ser ultra comercial. É o que eu mais gosto de fazer. Agora, nesse momento eu estou, pela primeira vez em muito tempo, tentando fazer trabalhos pessoais. Tenho um monte de coisa engavetada. Um deles é tirar as nossas trilhas [da gaveta]. Eu quero botar trabalhos com meu nome, eu passei muito tempo... pra falar a verdade, todo o tempo que eu tive foi basicamente trabalhando pros outros. E quando eu produzo, eu trabalho pra fazer o nome de outra pessoa, às vezes com o reconhecimento justo, às vezes não. Porque o produtor é uma pessoa que pode ser determinante, e às vezes você vê, "poxa, nem citou [no disco]". E você sabe tudo o que você fez, né? É diferente se a pessoa chega com o trabalho pronto e você só dá uma lapidada, tudo bem, é o trabalho da pessoa. Quando você sabe que o seu trabalho é seu mesmo, aí não; é, às vezes, de má fé. A fogueira da vaidade nem sempre leva à má fé.

Daí chegou um momento agora que está mais tranquilo, os filhos já estão maiores, já dá pra respirar. Tem essas coisas antigas... Tem um disco... Durante um tempo eu fiz várias músicas, estão no meu HD até hoje. Agora é tirar um tempo pra lançar de alguma forma. Tá tudo aí, só falta sentar e lapidar daquele jeito, sabe? Eu falei de maturação; hoje eu tenho certeza: se eu tivesse feito em qualquer outro momento, não ia ficar legal.

Eu tenho um projeto a ser desenvolvido com rock e música brasileira, que é diferente do Karnak, eu brinquei que é o "heavy metal popular brasileiro" - não é um heavy metal, mas eu queria fazer uma música brasileira "de pegada", uma coisa mais roqueira, mas que não seja uma simples junção. Rola de desenvolver uma linguagem. Tem uma outra música ali, mas - estou tentanto desovar os projetos mais encaminhados. Como eu toquei - quer dizer, eu toco... aliás, eu não sei se toco, porque o Hélio está parado - o Hélio Ziskind, eu acompanhei ele há muito tempo no estúdio - recentemente menos, por questões de agenda - e no palco. Eu trabalhei com o Paulo Tatit, com o Hélio Ziskind, com a Fortuna, com um monte de gente ligada ao próprio Abu. Daí comecei a fazer o show da Luna, que foi um laboratório maravilhoso.

Agora comecei um trabalho de composição pra crianças, agora eu comecei a gravar umas ideias musicais. Eu tinha dúvida se eu saberia fazer, mas, quando eu vi, eu estava fazendo um monte de coisa legal de música voltada pra criança. Aí eu estou com um projeto que é - novamente voltando ao rock - rock pesado pra criança, em que eu misturo as músicas tradicionais com as bandas emblemáticas e faço uma fusão que, quando eu lançar, eu acho que vai ser legal. O meu 
trabalho inclusive tem planos de ter audiovisual, mas eu continuo as histórias, as letras são pequenininhas, às vezes meio nonsense, às vezes eu consigo a história. Porque eu tenho uma banda - eu tenho uma banda? Eu não tenho uma banda -; eu tenho uma "entidade". Você fala Língua de Trapo, Premê [Premeditando o Breque], essas coisas: existe, mas não é sempre que tem um corpo físico.

De 1997 a 2000 e pouco, a gente tinha uma banda chamada Libera o Badaró. Hoje, na verdade, sou eu e meu amigo de ginásio, meu amigo mais antigo, e sempre fomos fãs de Premê, Língua de Trapo, Joelho de Porco, Karnak, Mulheres Negras, etc. E eu sempre tive uma veia humorística - pode não parecer, eu posso parecer um cara sério, porque quando criança eu não falava muito mas eu estava sempre fervilhando de ideias. Daí eu tive essa banda, que teve uma música chamada Jesus Negão (não sei se você já ouviu falar), circulou muito na internet. Tem uns vídeos que não foi a gente que fez - por causa da nossa inabilidade de ganhar dinheiro mas as pessoas fizeram uns clipes lá que têm mais de um milhão de views, que era uma paródia de rap, com todas as influências que a gente tinha. Não sei de você conhece uma banda argentina chamada Les Luthiers, é o que já foi feito de melhor de humor na música. Hoje tem o Youtube, que tem os shows deles; e antes a gente só conhecia os discos. Eles são muito conhecidos na Argentina. É um trabalho extremamente sofisticado, mas no palco às vezes é meio "pastelão". E a gente traduz tudo isso na música, Monty Python, todas essas referências... Isso é uma outra coisa: eu vou lançar no Spotify e nas lojas virtuais o trabalho que ficou... Tinha muito problema de direitos autorais, porque a gente fazia versão, citação, e a gente não podia lançar $\mathrm{CD}$. Eu estou começando a remixar pra lançar.

Então tem todos esses trabalhos aí que ficaram guardados por causa de questões de trabalho. E eu estou querendo agora dar um pouco de prioridade pra fazer meus trabalhos porque, se não, você nunca faz. Porque, se não, você está sempre trabalhando pros outros, os outros ganham dinheiro... Discurso de marketing, mas é isso. Eu estou trabalhando pros outros fazerem o nome deles, ganhando dinheiro ou não, porque às vezes não ganha, também. Porque fazer nome não é a mesma coisa que fazer dinheiro. Eu penso mais em agregar valor, mas o projeto pra crianças tem um intuito financeiro, mas o primeiro foco é a coisa ser boa, fazer uma coisa que as pessoas curtam "pra caralho". Se vai dar dinheiro ou não é outra questão. Os outros são diletantes, a maioria das coisas que eu falei são diletantes, que eu quero botar no mundo. Só esse das crianças que eu acredito que tenha um potencial de ter inclusive uma outra ótica sobre música infantil, entendeu? Porque muito do que existe já foi feito: música educativa, música... Eu curto mais o nonsense, a criança é nonsense. E eu quero explorar uma outra característica dela, porque nem tudo pra criança precisa ser educativo, didático. Tem gente muito melhor do que eu que faz isso.

Você pega o trabalho do Hélio, é fantástico. Eu não acho que tenha ninguém melhor do que ele. É mais complexo do que Palavra Cantada. Palavra Cantada é legal, muito mais pop. O trabalho do Hélio é especialíssimo, porque ele bota a criança num patamar acima. Ele não está preocupado em fazer um refrãozinho, ele está preocupado em enriquecer [a criança]. Como eu trabalho há muito tempo com o Hélio e o admiro muito, eu aprendi muito sobre a ótica do trabalho musical infantil. Porque o Hélio é extremamente metódico, muito intelectualizado, mas ao mesmo tempo ele tem uma musicalidade incrível. Eu fiquei horas e horas trabalhando com ele em estúdio e aprendi muito. Outro dia eu estava fazendo um jingle - que acabou não dando certo - cuja primeira versão era muito inspirada nele, nas coisas que ele trouxe da sequência do Luiz Tatit, que era do Rumo, e que ele traduziu perfeitamente pra criança. Aproveitar essa bagagem... E hoje são todos meus amigos, então, na hora de fazer um show, você pode contar com essas pessoas. E sempre fui uma pessoa muito generosa também.

Eu comecei a manter esse contato porque eu trabalhava, escrevia na revista Mac Mania, uma revista de tecnologia. Nessa época, eu entrevistei o Abujamra novamente, ele já me conhecia. Lançamos uma coletânea dele em mp3. Aí eu conhecia o Abu; na primeira vez que eu o 
entrevistei, eu ainda estava na faculdade. Inclusive saiu em uma dessas revistinhas eu falando de Logic. Mas eu estava falando isso porque eu tinha estúdio, mas eu trabalhava lá, porque quando você começa em estúdio, ele não dá dinheiro. E eu comecei a fazer suporte de mac [Macintosh], porque as pessoas ligavam pra lá, porque a Apple não tinha suporte na época [no Brasil]. Aí, de repente, os músicos começaram a me ligar, o Hélio, o Tatit. Com o Abu não foi exatamente isso, mas conheci o [Mario] Manga por causa disso, virou meu amigo - ah, eu também estou fazendo parceria com o Manga, começando agora. Você vê que eu estou com vontade de fazer rock, né? Muita saudade de fazer rock. Eu sempre lembro o discurso do Steve Jobs, aquele "connecting the dots", que é famoso, "conectar os pontos". Eu fiz um caminho meio torto na minha vida de músico. Porque minha mãe falava: "vai ser músico!", mas eu não queria. O Barba, do Barbatuques, era da minha classe; tinha um monte de músicos lá que foram pra Unicamp estudar. Mas aí eu fui prestar Filosofia e não entrei; eu ainda tinha uma coisa de querer ser meio intelectual. Depois eu fui descobrir que eu não tinha o que eles falam em inglês "what it takes", porque eu não gosto... Aí eu fui fazer História e não... A vida acadêmica não é a minha. Então eu demorei um tempo, eu não sou intelectual - eu posso até parecer ser, mas eu não sou; eu finjo bem, mas não tenho a veia. Daí o meu caminho foi tortuoso, eu fui ser jornalista, porque era uma forma de ganhar dinheiro e acabou me levando pra área de informática, que acabou me levando pra Mac Mania, que acabou me levando pra vida de estúdio, que é o que eu faço mesmo. Demorou mais, mas por uma questão de se achar, porque eu queria saber como é que eu iria trabalhar com música, mas do jeito que eu gostaria que fosse. E eu não sabia, até um dia descobrir que eu estava fazendo música no computador, etc. E acabou sendo esse caminho que acabou me levando pra conhecer essas pessoas. Eu poderia ter feito Música na Unicamp, poderia estar tocando só acompanhando outras pessoas - que até curto tocar, tem o Careqa -, mas não é o que eu penso como músico.

25. O Abujamra de vez em quando negocia umas aparições como figurante nos filmes que ele compõe trilha. $O$ que você pensa sobre isso?

O Abu não tem um perfil específico de compositor; ele tem um perfil de artista. Ele gosta de ser um artista e ele gosta de se meter em tudo, ser ator, ser diretor. Ele é músico, ele também é ator e ele gosta de aparecer! Então, ele quer aparecer, ele quer se divulgar como artista. O perfil dele é completamente diferente.

Eu gosto dos bastidores. Eu quero ser muito mais reconhecido do que conhecido. Eu não tenho muita vontade de as pessoas me reconhecerem na rua, você ouvir meu nome, eu não faço questão nenhuma. Não que eu ache errado; não é o meu trajeto, não é o meu objetivo.

\section{De todas essas diversas frentes, diversos projetos em curso, qual a frente que te dá mais prazer?}

O que me dá mais prazer é fazer música boa. Se você falar que é só uma coisa, trilha sonora é "do caralho", mas se você faz três, quatro, cinco, seis filmes por ano, você vai ficar muito [sobrecarregado]... Mas você tem que pegar as coisas. Eu quero pegar, eu sempre quero fazer trilha sonora, porque eu adoro essa relação. Você cria uma música que você jamais criaria sozinho.

\section{Algum projeto em vista?}

No momento, não. Eu terminei agora, nesse ano [2016], o filme do Toni Venturi, que eu fiz junto com o Kaká Machado, foi uma parceria. O Kaká estava começando a fazer a trilha do A Comédia Divina - com o Murilo Rosa e tal -, ia ser lançado agora, mas foi adiando pro ano que vem, o Kaká encontrou o Toni, mas aí vai ser mais um filme do ano que vem. É filme Globo Filmes. O Kaká circula nesse meio mais acadêmico. Ele é ativista, estava em Brasília fazendo 
umas reuniões, é um cara tipo o Pena Schmidt. Aí ele pediu pra eu ajudar lá e eu também boto minha assinatura.

No começo, o Toni disse que a trilha estava muito pesada, mas eu estava fazendo o que eu acreditava, e, no final das contas, foi pra onde eu tinha sugerido mesmo. Tem coisa que é experiência, e eu não queria que o filme lutasse contra justamente... seria cair na armadilha, de querer ser uma coisa que ele não é. Já botou o Murilo Rosa, botou a Mônica Iozzi, botou não sei lá mais quem, um ator que eu não me lembro - eu não assisto muito a novela e já não sei mais nomes. Então ele é comercial - porque num intelectual você já vai começar diferente, você faz uma trama, todo um roteiro que não é pra um filme comercial. Aí, no final, a trilha ficou muito legal. Mas você sempre torce pra ser bom. O Bem casados [Aluízio Abranches] vendeu relativamente bem, eu achei um filme bem feito. E ele [Abranches] fez um filme comercial, pra fazer dinheiro; então, está muito claro, foi tudo muito tranquilo. Quando essa regra está clara, o processo de trabalho fica mais fácil pra todo mundo. O Toni é um cara mais preocupado com essas questões... Eu sei das histórias do filme lá que ele abriu mão de algumas coisas que eu acho que ficariam melhores pro som porque não tinham a ver com ele. São coisas que eu entendo, foi pra achar esse foco que ele precisava. Quando sair e você assistir, você me conta. 


\section{APÊNDICE D - Entrevista com o compositor Lulu Camargo, por Skype, em 15/09/2016}

\section{Quando você começou a trabalhar com música no cinema?}

Na verdade, fiz um curso de Film Scoring na Berklee College of Music há muito tempo [19861987], mas atuo mais na publicidade. Não me considero um compositor de música para cinema, minha participação foi muito pontual.

\section{Como compositor, como você pensa a música de cinema? Qual é o papel dela, em} Castelo Rá-Tim-Bum, o filme?

Hoje eu penso que no Castelo tem muita música; hoje eu colocaria menos música no filme, eu batalharia por isso nas reuniões de briefing. Penso hoje que o silêncio também é muito importante. Mas, ao mesmo tempo, quando ouço a trilha do filme, fico satisfeito, penso: "como eu fui capaz de fazer isso, fui eu mesmo?".

\section{Como foi a comunicação com o Cao Hamburger, para a composição da trilha musical do Castelo Rá-Tim-Bum, o filme?}

A comunicação com o Cao era bem tranquila, já que trabalhávamos com ele desde o seriado para TV, Castelo Rá-Tim-Bum. Tínhamos muito pouco tempo para fazer a trilha do filme, uns dois meses, da primeira reunião até a entrega da música. Então, se a comunicação com ele não fosse boa - até porque ele queria toda a música diferente, a trilha não era pra lembrar a música do seriado -, não teríamos conseguido realizar a composição em tão pouco tempo.

Era fim dos anos 90, então a gente já chegava pras reuniões com o Cao apresentando um rascunho da música, já feito com samplers, em computador.

Pena Schmidt, que parecia um "buda", fazia o meio de campo entre Cao e André, quando o lance do ego falava mais alto.

\section{Como foi a divisão das tarefas com Abujamra nessa composição?}

Dividíamos as sequências, eu e o André; eu fíz a sequência da transformação da Morgana, por exemplo. Ele falava qual seria o clima geral da música, compúnhamos cada um a nossa parte e nos reuníamos pra juntá-las. Como eu tinha mais experiência com orquestração, eu fazia mais essa parte também. O André não era tanto de escrever partitura e orquestrar. Ele era mais da impetuosidade criativa. Ele trabalha com orquestrador, trabalhava muito com o Renato Lemos, não sei se ainda continua. Mas foi o Renato Lemos que regeu a gravação da trilha musical do Castelo Rá-Tim-Bum, o filme, feita com músicos de verdade, em formação camerística [músicos da OSESP gravados ao vivo no estudio Vice Versa, com produção de Pena Schmidt]. Foram poucos músicos, mas dobrávamos os instrumentos gravando várias vezes e ficou essa impressão de preenchimento. Poderíamos ter conseguido esse efeito inserindo samplers sobre a gravação original, mas fizemos tudo com músicos de verdade.

\section{Em que ocasião conheceu André Abujamra?}

O André eu conheci na faculdade, cursamos a FAAM juntos. Daí, logo fui morar nos Estados Unidos. Depois entrei pro Karnak, fiquei até os anos 2000, então sempre mantivemos essa afinidade pessoal e musical.

\section{Que trabalhos você desenvolveu com o Abu?}

Participei do Karnak como tecladista, fizemos muitos trabalhos pra publicidade e compus com ele a trilha do Castelo Rá-Tim-Bum, o filme. No Karnak, o André chegava com as ideias, tocava na guitarra, e a gente contribuía nos arranjos. Eu gostava muito da sonoridade do Karnak, uma música era muito diferente da outra, essa diversidade me atraía. Mas chegou um ponto em que trabalhar com o André no Karnak parecia bater em uma parede intransponível. Por fim, eu já 
não queria mais tocar aquelas músicas, uma saturação mesmo. Então eu saí, pra manter aquela coisa bonita que temos entre nós. Eu acho a impetuosidade e a intuição dele algo muito bonito.

\section{Quais as diferenças entre trabalhar sozinho e trabalhar com Abu no cinema? O que muda na dinâmica de criação e produção?}

Sou mais cerebral e o André, mais intuitivo. Trabalhamos muito bem juntos, afinal, a gente já se conhecia de muitos anos e trabalhamos por muito tempo na música. Mas no cinema posso dizer que não atuo.

\section{Que qualidades ou características de Abujamra você identifica ao longo dessa parceria?}

Nós somos muito diferentes. Quando fomos gravar Comendo uva na chuva [Karnak], por exemplo, mostrei a ele uns cantos polifônicos de uma tribo que eu tinha descoberto. Aí ele disse: "Vamos botar na música". E eu: "André, vamos ver se está no mesmo tom, mexer no pitch, pra podermos colocar...”. E ele: "Não, põe de qualquer jeito mesmo!”. 
APÊNDICE E - Entrevista com a diretora Anna Muylaert, por e-mail, em 27/03/2014

1. Nos filmes dirigidos por você com trilha musical de André Abujamra, quais foram os critérios de escolha para trabalhar com este compositor?

Eu era casada com ele (risos)! Além disso, obviamente eu era fã da musicalidade dele e pela nossa proximidade desenvolvemos muita coisa juntos. Começamos um trabalho meu que se chamava "trash video", onde ele fazia a "trash trilha", que foi o marco inicial do trabalho dele com sampler.

2. Em que etapa(s) dos filmes ocorreu um diálogo mais próximo entre você e Abujamra ao longo do processo de realização?

Eu fiz um curta chamado Kiki Cavalcanti, onde eu pedi pra ele fazer uma trilha lírica a partir de uma musiquinha que a atriz cantava em cena. Ele ficou meio bravo com isso, mas fez e a trilha e ficou um arraso.

Em 2002, trabalhei no Durval Discos, quando eu já não era mais casada com ele. A trilha foi artisticamente produzida pelo Pena Schmidt e era composta por dois lados. O lado A formado basicamente por fonogramas de MPB dos anos 70 e o lado B que era a trilha composta para a segunda parte do filme. O André foi o compositor escolhido para esta segunda parte. Ele fez uma primeira versão da trilha da cabeça dele que era feita de rap e sonoridades mais duras. Lembro que no dia que mostrou eu quase tive um ataque de mau humor e se não fosse o Peninha [Schmidt], acho que teríamos brigado. Daí eu sentei no computador com ele e mostrei cena a cena quais as necessidades e desejos que eu tinha. Daí veio a segunda versão que foi aprovada.

3. Você chegou a mencionar referências para o compositor ou deixou-o totalmente livre para criar? Como você administrou a "liberdade" criativa de Abujamra para que a trilha musical servisse aos filmes?

Eu raramente mostro referências. Eu estudava com ele as necessidades dramáticas de cada cena.

4. Que avaliação você faz da trilha musical de Abujamra em cada um dos filmes dirigidos por você que têm a participação do compositor?

Eu acho que ele é bom, ele faz parte da minha historia.

5 - Quais as maiores qualidades de Abujamra como compositor de trilhas musicais para cinema que justificam o seu convite a ele para a realização de mais de um projeto?

Ele é bom, a música dele é de qualidade e funciona para os filmes. Ajuda a contar as histórias, sem ser óbvio. Hoje em dia o André entende bastante de cinema, pode ajudar um filme em vários níveis.

6. Existe alguma limitação ou fragilidade em sua relação com o compositor?

Sim. Acho que às vezes ele faz filme demais e eles podem tender a ficarem parecidos. Às vezes acho que o "gênio" pode ficar preguiçoso (risos)...

7. Existem novos projetos em vista que devem contar com a participação de Abujamra? No momento não, mas a qualquer momento pode surgir. 


\section{APÊNDICE F - Entrevista com o diretor Aluizio Abranches, por telefone, em 20/03/2014}

\section{Nos filmes dirigidos por você com trilha musical de André Abujamra - Um copo de cólera, As três Marias e Do começo ao fim -, quais foram os critérios de escolha para trabalhar com este compositor?}

Eu conheço o André, tive muitas referências próximas que me levaram a pensar no André naturalmente, porque ele é muito próximo da Júlia [Lemmertz] e do Alexandre Borges, os pais do André e da Júlia eram muito amigos, eles foram criados juntos. E ele foi casado com a Anna Muylaert, minha amiga, então eu tinha o André por perto. Eu era fã das bandas dele na época. É um músico multiinstrumentista, multifacetado, e foi mais ou menos seguindo minha intuição que eu achei q ia dar certo.

No Um copo de cólera, dei até uma referência pra ele, de um filme que eu adoro, e ele ficou me olhando. E trabalhei muito junto com ele. Na época eu morava em São Paulo. Um copo de cólera tem cenas de sexo que eu filmei sem som direto, porque era uma experiência limítrofe, então tinha muito pouca gente no set, já sabendo que o que me interessava ali de som era a música. Eu já tinha feito contato com o André e eu só ficava pensando na música. O sexo de Um copo de cólera é todo todo lembrado pelo personagem do homem, não acontece na hora ali, sabia mais ou menos o que eu queria e eu relaxei. Quando o André começou a compor, eu acompanhei, eu ficava sentado perto dele, e na hora que eu não conseguia me expressar em palavras eu cantava, e o André ficava olhando pra mim, e eu achava q estava quase compondo com ele. Depois ele me disse que não entendia nada do que eu falava (risos). Ele me deixou ficar próximo, ele no fim estava entendendo o que eu queria, era muito sentimento. E naquele caso a música dá toda a emoção. A musica é importantíssima até nos créditos. Então foi um processo muito criativo e colaborativo e bem-sucedido.

No Do começo ao fim, a composição da música foi o processo de que eu menos participei. A gente concordou que era um filme diferente, o tema era dramático, mas a abordagem não era, eu queria uma coisa leve, menos pomposa. Foram menos cordas, que eu gosto muito, então foi uma coisa mais dele sozinho, mas os outros filmes eu queria uma coisa mais grandiosa, mais emocionante. Nesse, eu queria uma abordagem feliz, leve, ele colaborou dessa maneira. Ele estava morando em Curitiba, eu fui a Curitiba, passei dois dias lá com ele, só. Ele me mandava muito material por e-mail. Eu senti o resultado da distância do André. Comigo funciona mais essa colaboração próxima. Talvez um erro da realização do filme foi que eu o chamei no último momento. Cheguei a sentar com outros músicos, não me entendi, ele não ia fazer por problemas de agenda, mas eu corri pra ele de novo e deu certo. Foi essa pressa, até hoje eu cobro dele, no final do filme até hoje eu acho que falta uma nota e mais cinco segundos de filme pra ter "aquela" nota. Outra coisa horrível que eu fiz foi que o editor usou uma outra música pra editar o filme, ele deve ter ficado "chapado" (risos).

Uma coisa que eu quero pros meus próximos projetos é que o compositor participe desde o início. Eu já entreguei pra ele uma música de referência, com o filme já montado em cima da música - aquela "valsinha da Amélie Poulain", eu fiz tudo errado. Foi falta de experiência minha. Em As três Marias e Um copo de cólera, o que ele compôs foi executado por uma pequena orquestra muito bacana que ele tinha, foi o mesmo maestro nos dois [Renato Lemos]. No making of de As três Marias tem até a gente gravando um pedacinho da música no estúdio. Nesse filme, ele compôs uma música que não era pra créditos, era pro filme. Eu deixei o plano ali, depois do toque da Marieta. Na próxima vez eu vou pedir pra ele pra compor algo pra eu poder montar em cima, pra ouvir desde o início.

\section{Em que etapa(s) dos filmes ocorreu um diálogo mais próximo entre você e Abujamra ao longo do processo de realização?}


Nos três filmes o contato foi após as gravações, mas em As três Marias e Um copo de cólera foi antes que em Do começo ao fim, filme em que o processo aconteceu um pouco menos em conjunto. De uma certa maneira ele salvou. Ele pegou um filme praticamente pronto, montado com outra música, e ele salvou. Ele foi muito criativo. Então eu não tive o músico como eu quero ter agora (antes no processo).

3. Você chegou a mencionar referências para o compositor ou deixou-o totalmente livre para criar? Como você administrou a "liberdade" criativa de Abujamra para que a trilha musical servisse aos filmes?

Eu acho que ele foi generoso, e eu sou muito cuidadoso. Apesar de acompanhá-lo, eu não queria invadir o espaço. No Um copo de cólera eu fiquei muito ali, passava dias com ele em São Paulo. Eu acho que a gente se entendeu, teve uma comunicação, uma química que funcionou. Eu não estava fazendo exigências, ele foi generoso em concordar, e eu, muito cuidadoso em não atrapalhar.

4. Que avaliação você faz da trilha musical de Abujamra em cada um dos filmes dirigidos por você que têm a participação do compositor?

Super satisfatória. Do começo ao fim, fica faltando uma nota. Porque é uma colaboração criativa e ao mesmo tempo tem um cronograma a ser seguido.

5. Quais as maiores qualidades de Abujamra como compositor de trilhas musicais para cinema que justificam o seu convite a ele para a realização de mais de um projeto?

Criatividade, sensibilidade.

\section{Existe alguma limitação ou fragilidade em sua relação com o compositor?}

Nenhuma. Em três filmes, a gente não conseguiu se comunicar em uma nota [em Do começo ao fim], que eu nem sei qual é. Ou uma nota que durasse mais tempo. Eu não sei explicar, mas sei que faltou uma coisinha.

\section{Existem novos projetos em vista que devem contar com a participação de Abujamra?}

Eu estou preparando uma comédia romântica que vai ter que ter muita música preexistente. Eu agora eu estou mudando, vou fazer um filme mais comercial, eu comecei a conversar, e certamente ele vai ser pensado sempre, tem muita musica pré-gravada, eu não sei se eu vou pedir um tema pra ele. Eu tenho muita vontade de ter uma canção-tema no filme, que eu nunca tive. De Do começo ao fim, tem outras músicas cantadas, do Moska, do Caetano etc., mas a que eu mais gosto é a que o Abujamra canta com uma parceira dele, na cena da passagem de tempo que corta pra cena da natação, dos personagens já adultos. 


\title{
APÊNDICE G - Entrevista com o diretor José Joffily, por e-mail, em 19/03/2014
}

\author{
1. Em Achados e perdidos, quais foram os critérios de escolha para trabalhar com este \\ compositor?
}

Algum conhecimento de seu trabalho e intuições. O primeiro trabalho com um colaborador importante no processo de um filme é sempre cercado de mistério e desconfiança. Acho que esses sentimentos são de parte a parte. Mas sei que para mim e o André, a nossa aproximação resultou em coisas boas.

\section{Como diretor, você trabalhou com Abujamra em algum outro longa além de Achados e perdidos?}

Trabalhamos juntos no projeto de um musical. Escrevi as letras e o André fez as musicas. Ai de ti, Copacabana, um filme ainda não filmado.

3. Em que etapa(s) do filme ocorreu um diálogo mais próximo entre você e Abujamra ao longo do processo de realização?

Antes, durante e depois de prontas a músicas. O filme tinha umas 40 entradas de música.

\section{Como se deu esse diálogo, em termos de compreensão do projeto e de relacionamento entre vocês?}

Nossa ideia desde o início era que a música poderia ser tudo, menos reiterativa. A música não deveria ser apenas para reforçar a imagem, mas acrescentar sentimentos não evidentes. Algumas vezes a música deveria mesmo se contrapor à imagem. Acho que esse foi um acordo que firmamos ao longo de todo o processo. Já errei muito com a edição de músicas em outros filmes, não queria repetir enganos ou cair na cilada de editar muitas músicas ao longo do filme. A música é muito cativante e é frequente o realizador pensar que ela pode salvar uma cena. Mas isso é mesmo um engano.

5. Você chegou a mencionar referências para o compositor ou deixou-o totalmente livre para criar? Como você administrou a "liberdade" criativa de Abujamra para que a trilha musical servisse aos filmes?

Se não me engano a referência era mais de filmes do que especificamente de músicas. Conversávamos sobre afinidades de toda ordem, procurando interesses comuns. Especulamos, experimentamos sugestões dele e minhas. Defendíamos ou nos rendíamos à edição desta ou daquela música. Assim como não queríamos fazer uma música reiterativa, também não queríamos um música melodiosa. Esses dois conceitos iniciais nos orientavam nas escolhas. Cobrávamos um do outro esse princípio.

6. Que avaliação você faz da trilha musical de Abujamra no filme dirigido por você que tem a participação do compositor?

O Abujambra é o parceiro que todo realizador quer. Tem sempre sugestões, mas não se aferra a elas de qualquer modo, o mais importante é sempre o filme, não a música. Simultaneamente à criação da música, o editor de som também faz o serviço dele e é importantíssimo que os dois se entendam. Cabe ao diretor fazer essa ponte fundamental. Muitas vezes é recomendável que um som ou que um efeito sugerido pelo editor de som finalize com o início de uma música. Ou ao contrário. Ou seja, músico e editor de som devem fazer uma dupla inseparável. E o André sabe disso. E foi muito importante o entrosamento dele com a Miriam Biderman, editora de som do Achados e perdidos. Também é imprescindível a parceria com o mixador. Muitas vezes, só durante a mixagem ouvimos todas as pistas. Nesse momento, em algumas passagens, a música, quando ouvida junto com o som ambiente ou um efeito sonoro qualquer, pode se 
mostrar desnecessária. Ou vice-versa. O André e a Miriam tiveram sabedoria suficiente para identificar esses momentos.

7. Quais as maiores qualidades de Abujamra como compositor de trilhas musicais para cinema?

O André não é só talentoso, ele sabe ouvir e fazer parcerias. Nunca é demais entender que fazer filmes é um trabalho coletivo. Somos poucos na finalização de um filme, bem menos do que na produção, mas da mesma forma é preciso haver um entendimento entre essas 10 ou 15 pessoas que operam nesse estágio.

8. Existe alguma limitação ou fragilidade em sua relação com o compositor? Se sim, qual seria?

Acho que ele deveria se mudar para o Rio, a gente se veria mais. No mais, é só cumplicidade.

9. Existem novos projetos em vista que devem contar com a participação de Abujamra? Os filmes demoram a ser feitos e depois demoram a ser finalizados, mas voltar a trabalhar com ele será sempre uma boa aventura. 


\section{APÊNDICE H - Entrevista com o ex-integrante da banda Karnak, Juliano D'Horta Becari, por mensagem na rede social Facebook, em 29/03/2014}

\section{Quando e como você entrou no Karnak?}

Eu já conhecia os membros da banda pois alguns deles tocavam comigo na Scrutinizer, cover do Franz Zappa. Lembro como se fosse hoje quando eles disseram que teriam que se ausentar pra tocar na banda recém-montada do André. Isso foi por volta de 1990. Depois de alguns anos, soube por eles que o Lulu [Camargo] sairia e o André me chamou pra tocar no lugar dele.

2. Quais eram suas funções na banda (musicais e/ou de produção)?

Tecladista e disparador de samplers e bases.

3. Chegou a gravar algum disco com o Karnak? Se sim, qual?

Estou nas gravações ao vivo dos Piratas do Karnak. CD duplo.

4. Como era o processo de composição do grupo?

Normalmente as músicas já eram do André. Ele passava com a banda, mas já havia uma préconcepção dele.

5. Como, na sua percepção, é a atuação de André Abujamra no Karnak? Como era a relação dele com os demais integrantes do grupo, enquanto você esteve nele?

O André é uma criança grande, quer sempre do jeito dele e às vezes com uma certa impaciência. Mas ele é muito atento a tudo que todos tocam e vivia aproveitando ideias que surgiam nos ensaios. O processo sempre foi colaborativo.

6. Você já presenciou algum processo de criação de Abujamra durante alguma viagem do grupo, dentro ou fora do Brasil? Caso sim, descreva o processo (como puder) que acompanhou e cite o local onde ele ocorreu.

Na verdade não.

7. Havia, nas composições e/ou shows do Karnak, referências cinematográficas de alguma natureza? Se sim, quais e como eram buscadas?

André sempre trouxe suas influências, e elas sempre eram teatrais, mais do que cinematográficas. Poses da banda na abertura do show e vários momentos durante os shows.

8. Você, a banda ou alguns de seus outros integrantes já foi(ram) convidada(os) a participar das trilhas musicais composta por Abujamra para algum filme? Se sim, quais integrantes participaram da música para quais filmes?

Eu não, porque era um músico convidado e não fazia parte do núcleo da banda.

9. Quando e por que você deixou de integrar a banda?

Minha função foi substituída por um computador. As partes de teclado e samplers eram todas gravadas.

10. Que avaliação você faz da sua participação no Karnak?

Foi um grande aprendizado pra mim, tanto musical quanto artístico, e conviver com essas pessoas sempre influencia sua maneira de ver as coisas. Aprendi também algumas coisas chatas, como conviver durante viagens e ter que abafar sua própria opinião quando não cabem mais ideias. Às vezes são muitas ideias ao mesmo tempo. Algumas ajudam, outras atrapalham. 
11. Como você vê André Abujamra como artista?

O André tem uma grande influência no cinema, pois vem de família de teatro e já fez muitas coisas no cinema, desde trilha até atuação. Ele é um personagem dele próprio.

12. Você tem contato com alguns outros integrantes do Karnak? Caso sim, pode me passar os contatos (e-mail/fone e/ou perfil em redes sociais)?

No momento não tenho contato com nenhum deles, por questões envolvendo outras bandas e algumas pessoais mesmo. Posso te indicar o Marcos Bowie, que é muito simpático e pode te ajudar. Ou o André mesmo... Vc já é amiga dele no face? 


\section{APÊNDICE I - Entrevista com o integrante da banda Os Mulheres Negras, Maurício Pereira (saxofone, efeitos e voz), por e-mail, em 28/03/2014}

\section{Quando e como surgiu a ideia dOs Mulheres Negras?}

O Mulheres surgiu por acaso. Eu não era músico, mas gostava muito, me formei de jornalista, e já trabalhava. Conheci o André num curso de percussão africana, e a gente se entendeu logo de cara, tipo um amor musical à primeira vista. Aí ele me chamou pra tocar junto com uma banda que ele tinha com seus colegas de faculdade de música. Mas a gente tinha uma visão particular e pop das coisas, e acabamos montando o Mulheres, pra trabalhar mais livre e caoticamente.

\section{O que os motivou a parar as atividades da dupla por um tempo?}

Depois de sete anos tocando juntos, as ideias estavam muito diferentes, estávamos pensando a música de jeitos meio opostos: eu, pensando em canções; o André, dum jeito mais cênico, mais textual. A gente se desgastou um pouco. Então encerramos a banda e partimos pra carreira solo.

\section{O que os motivou a voltar à ativa?}

A vontade e o prazer de tocar junto. Mesmo nos anos em que o Mulheres não esteve ativo, a gente sempre colaborou no trabalho um do outro, e sentíamos que a química estava intacta. Chegou uma hora que resolvemos voltar pra a estrada. Realmente tem sido ótimo: estamos mais sossegados, mais experientes, mais focados.

\section{Como é o processo de composição de vocês?}

Quando estamos juntos compomos com as máquinas ligadas, improvisando, tentando e testando coisas, e as músicas acabam aparecendo, acontecendo, funciona em alta velocidade porque a gente se conhece bem, e vamos multiplicando as ideias. Mas às vezes um manda uma música ou letra pro outro, e aí funciona mais num pingue-pongue; individualmente, vamos trocando figurinha.

5. Como, na sua percepção, é a atuação de André Abujamra na "terceira menor big band do mundo"? Como tem sido a sua relação com ele ao longo de todos esses anos?

A função do André é muito a do provedor de música, no Mulheres. É ele que, no palco, faz e dispara os loopings, então as bases ficam muito na mão dele. Eu funciono muito fazendo a interface com o público e colocando melodia nas coisas, seja com o sax, seja com a voz. E na parte cênica a gente tem o nosso jeito de operar, conhecemos bem os nossos personagens. $\mathrm{O}$ André trabalha muito na pantomima, no não verbal, ele tem muita noção de palco. E entre a gente tem muito improviso, já que o show tem um roteiro básico aberto, que deixa a gente brincar, especialmente quando o público interfere. Resumindo, tanto ele quanto eu funcionamos como músicos, como atores e como diretores de cena, o tempo todo. E pessoalmente, até por a gente ter começado junto e ter experimentado muita coisa junto (na vida e na profissão), a gente tem uma irmandade muito forte, muita liberdade pra conversar um com o outro.

\section{Como é o Abujamra criando? Ele compõe em qualquer lugar/situação? Lembra de alguma situação especial de composição?}

O André é um cara muito rápido. Decididamente o processo dele não é o daquele artista que vai criando aos poucos, que deixa coisas na gaveta. Ele tem uma capacidade muito forte de tornar reais as ideias que ele tem na cabeça, não é muito de guardar as coisas, bota tudo pra fora. No Mulheres, especificamente, a gente trabalha muito de improviso durante os ensaios, pinguepongueando ideias velozmente, porque o nosso entendimento é grande e a gente pensa 
muito rápido junto. Tem uma música chamada Judith, no segundo disco, que foi feita numa passagem de som: ele fez uma base, cantou uma letra, deu certo em cima do looping, quando acabou a primeira parte ela já jogava harmônica e melodicamente pra uma segunda parte, e eu já fui cantando um letra e melodia, coube bem no looping e chegamos no fim da canção. Depois demos uma acertada final nela.

7. Há, nas composições e/ou shows dOs Mulheres Negras, referências cinematográficas de alguma natureza? Se sim, quais e como são buscadas?

Sim. Elas aparecem na sonoridade, nos temas, no jeito de contar uma história, numa associação de ideias. Tipo: Documentário Alemão é uma música que a gente imaginava que seria trilha dum documentário alemão qualquer sobre o funcionamento de máquinas, sei lá. Peter Gunn é um tema cinematográfico do Henry Mancini que a gente abraçou (e ainda boto uma cena narrada no meio); nossa versão de Summertime é bem climática, imagética, assim como a nossa Mãoscolorida; Monstros Japoneses é quase um filme; $\mathrm{Eu} \mathrm{Vi,} \mathrm{também.}$

\section{Você já foi convidado a participar das trilhas musicais composta por Abujamra para algum filme? Se sim, como foi a experiência?}

Geralmente ele me chama pra botar letras em músicas que ele fez. Foi assim no Castelo RáTim-Bum, o filme. Já no telefilme E além de tudo me deixou mudo o violão, da Anna Muylaert, ele partiu do clima de Rita, do Chico Buarque, e eu forneci pedaços de naipes de sax que ele foi editando pra fazer a trilha do filme.

\section{Que avaliação você faz da sua participação nOs Mulheres Negras?}

Bom, é um lugar onde eu me sinto bem à vontade, até mais hoje do que quando a gente surgiu. E também um trabalho onde eu posso me colocar dum jeito mais punk ou clown, já que o meu trabalho solo é muito na canção, longas letras, mais lírico, mais introvertido. Enfim, tem a eletricidade de tocar com o André, que é sempre grande, a gente tá sempre alerta, aceso, pra improvisar, ir buscar a música, o espetáculo, a gag, a poesia.

10. Como você vê a dupla hoje? Você enxerga alguma relação entre a banda e o cinema brasileiro? Se sim, por quê?

A gente tá tentando entender o nosso lugar no cenário e no mundo atual, de muita informação, de muita tecnologia. Tem coisas que a gente fez lá nos anos 80 , que ninguém mais fez ou faz, são procedimentos da gente, viagens pessoais. Então a gente tá tentando entender o nosso tamanho na cena do pop rock brasileiro. A relação da banda com o cinema vem muito pelo André, penso eu, porque ele é um trilheiro talentoso e com um vasto trabalho, e de vez em quando bota o Mulheres pra trabalhar pro cinema, como ele já faz habitualmente com seu trabalho solo.

\section{Como você vê André Abujamra como artista?}

Olha, eu não gosto de chamar ninguém de gênio, mas o André é meio que um gênio... Muito rápido, muito intuitivo, com um carisma danado pra ter o público sempre na mão dele, é um cara de ímpeto, de explosão. Por outro lado, ele tem muito conhecimento técnico e muito método, ele é muito organizado pra trabalhar. É um mix fabuloso pra um artista: a fagulha da maluquice misturada com um domínio profundo da linguagem. Já pensou? 